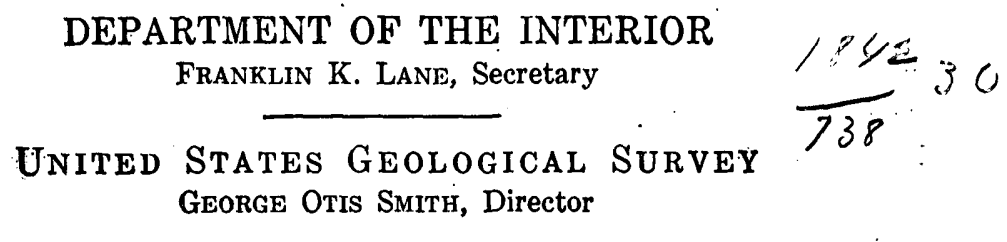

Bulletin 669

\title{
SALT RESOURCES OF THE UNITED STATES
}

BY

W. C. PHALEN

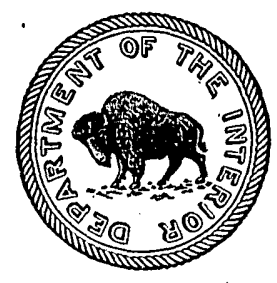

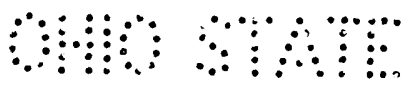

界

WASHINGTON

GOVERNMENT PRINTING OFFICE

- 1919 
Q 2505

89

1.50.669-677

copy?

צִ

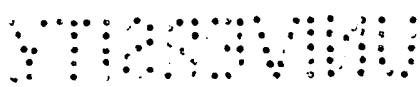




\section{CONTENTS.}

Page.

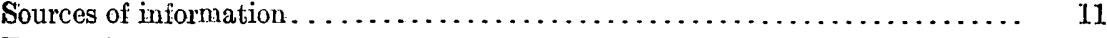

Types of occurrence........................................... 12

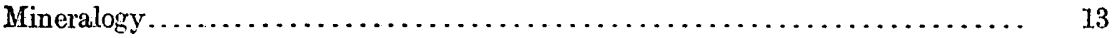

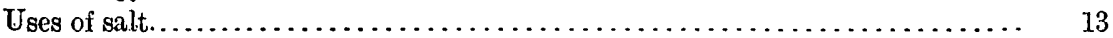

Geology of salt deposits of the United States....................... 14

General distribution and character $\ldots \ldots \ldots \ldots \ldots \ldots \ldots \ldots \ldots \ldots \ldots, 14$

New York............................................... 15

History of the salt industry $\ldots \ldots \ldots \ldots \ldots \ldots \ldots \ldots \ldots \ldots \ldots \ldots, 15$

Position of field........................................... 17

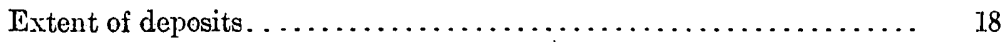

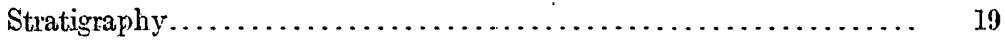

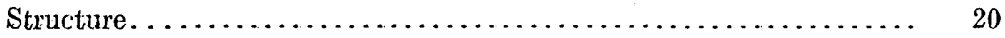

The salt beds......................................... 20

Records of salt wells and shafts. . . . . . . . . . . . . . . . . . . 23

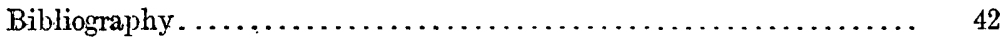

Michigan................................................... 44

Position of fields..................................... 44

Stratigraphy and structure................................ 44

Monroe group and Salina formation. . . . . . . . . .

Character and extent.................................. 45

Depth to salt beds................................ 48

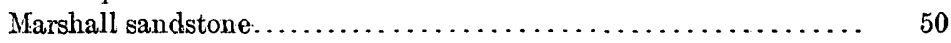

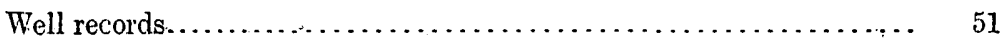

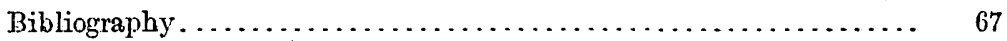

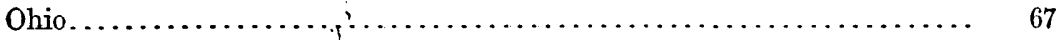

Position of fields...................................... 68

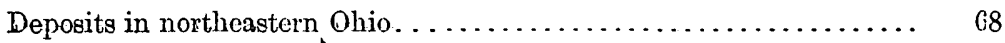

Extent............................................. 68

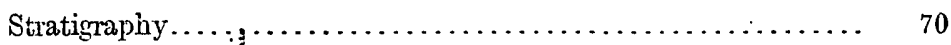

Brine horizon in southeastern Ohio..................... 71

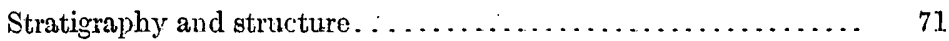

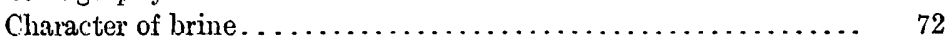

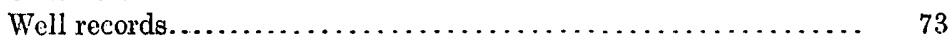

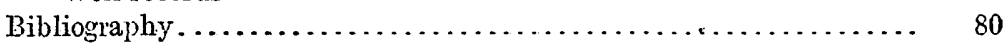

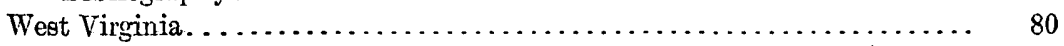

Position of fields......................................... 80

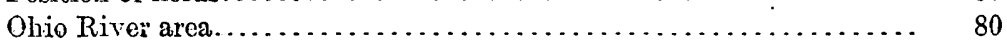

Kanawha River area. .................................. 80

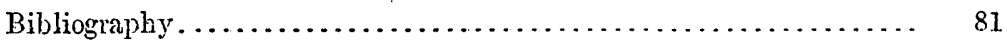

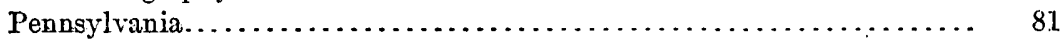

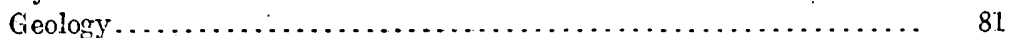

Probable southward extension of the Salina formation in Pennsylvania. $\quad 83$ 
Geology of salt deposits of the United States-Continued. $\quad \therefore \quad \ldots \quad$ Page:

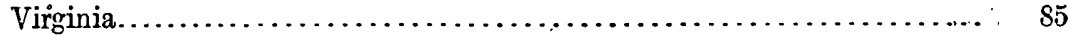

Position and extent of deposits............................ 85

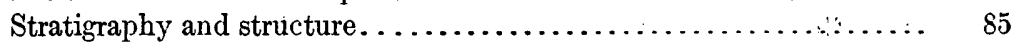

Records of deep wells near Saltville, Va..................... 86

Bibliography......................................... 89

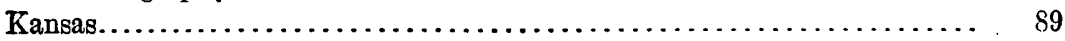

Position and extent of deposits. . . . . . . . . . . . . . . . . . 89

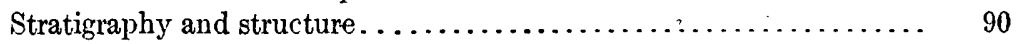

The salt-marsh area. ............................. 90

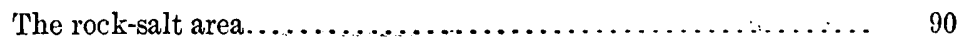

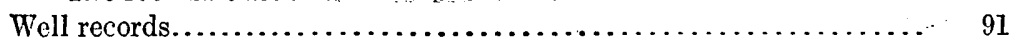

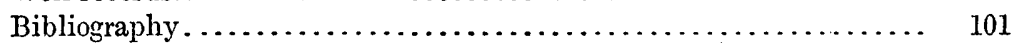

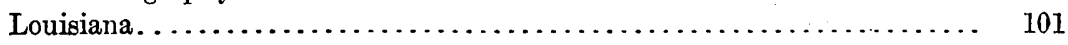

Position of deposits. . ............................... 101

Salines of northern Louisiana.......................... 101

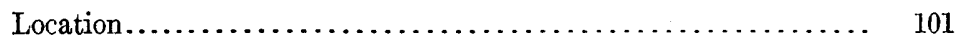

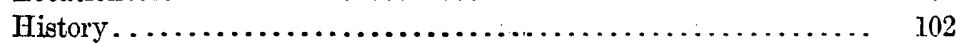

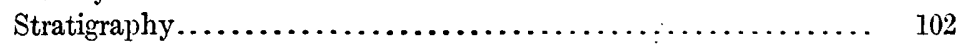

Salines of southern Louisiana......................... 103

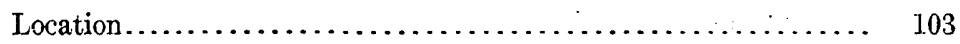

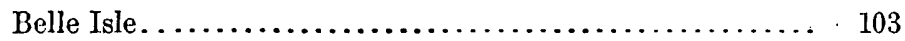

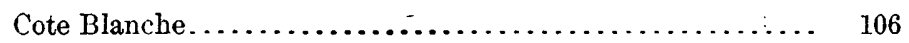

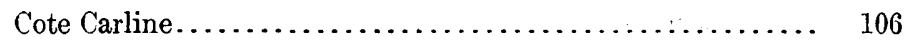

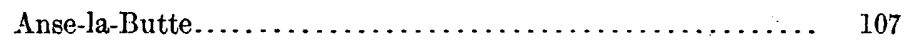

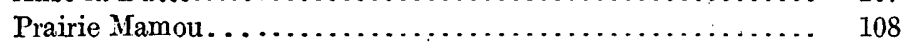

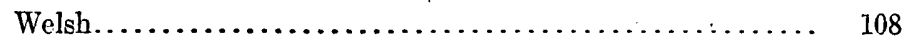

Chicot........................................ 108

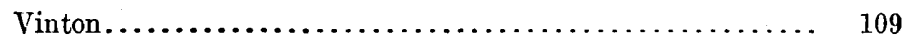

Hackberry . . . . . . . .

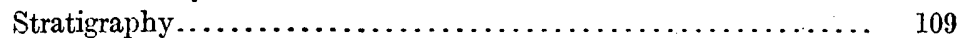

Structure and origin of salt domes..................... 109

Salt-producing localities................................. 112

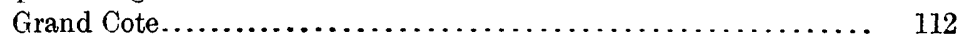

Location...................................... 112

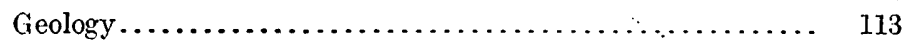

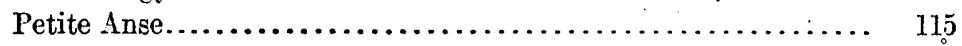

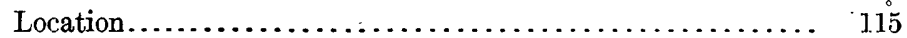

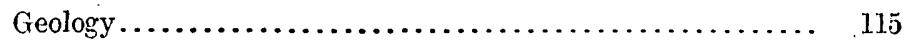

Bibliography......................................... 116

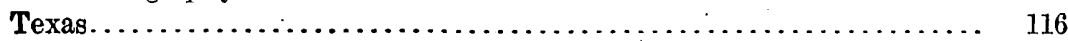

Location of salt-producing areas.......................... 116

Salt domes of eastern Texas. . . . . . . . . . . . . . . . . . . . 117

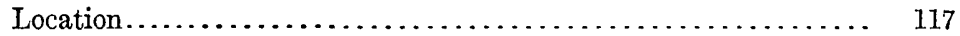

Geology .......................................... 117

Industrial development............................ 117

Salines of eastern Texas. .............................. 118

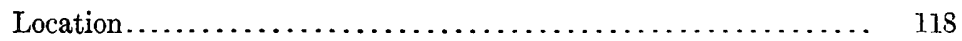

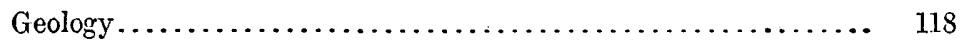

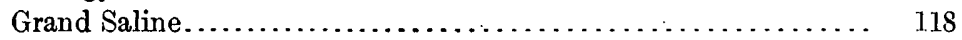

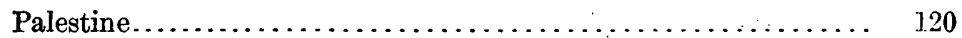

Steen Saline................................... 121

Brooks Saline.................................... 121 
Geology of salt deposits of the United States-Continued.

Texas-Continued.

Other occurrences of salt................................ 121

Northwestern Texas.............................. 121

Western Texas................................. 124

Salt basin of trans-Pecos region.................... 124

Location................................... 124

Salt deposit............................. 124

Colorado.................................... 125

Other localities.......................................... $\quad 125$

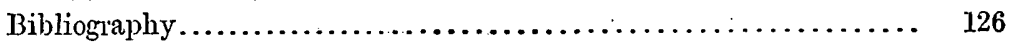

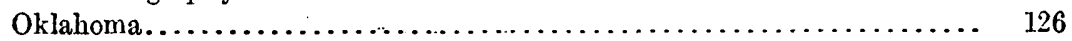

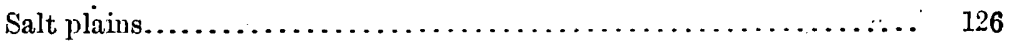

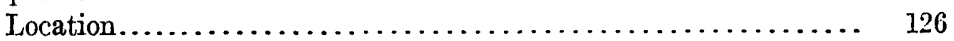

Cimarron River plains............................. 127

Harmon County plains.......................... I $\quad 127$

Alfalfa County plain........................... 128

Blaine County plain.......................... 128

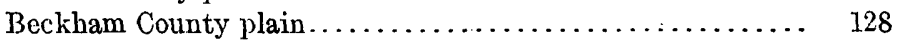

Jackson County plains........................ 129

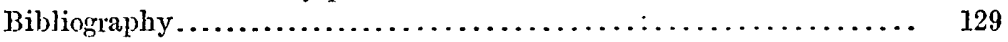

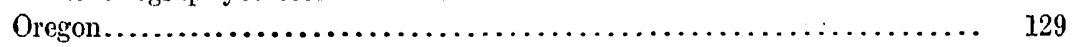

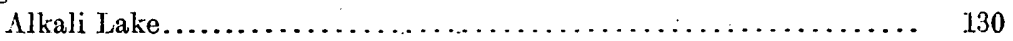

Abert and Summer lakes................................ 130

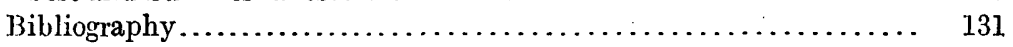

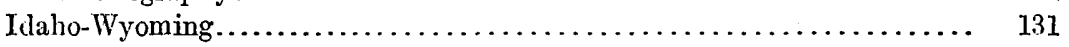

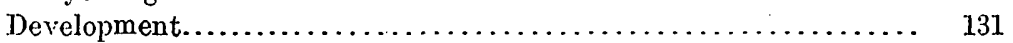

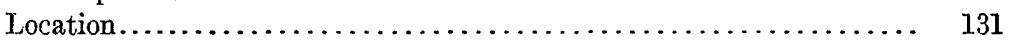

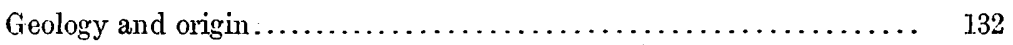

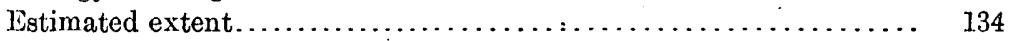

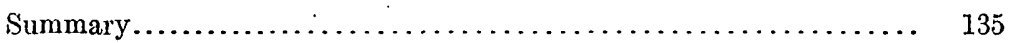

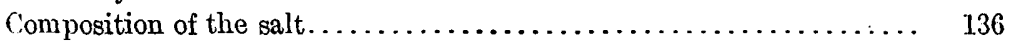

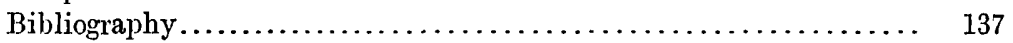

Nevada............................................. 137

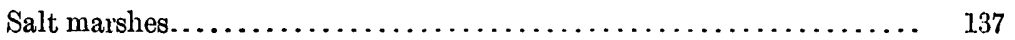

Location......................................... 137

Churchill County ............................... 137

Sand Springs............................... 137

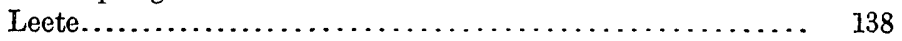

Parran...................................... 140

White Plains................................. 140

Dixie Salt Marsh............................. 140

Esmeralda and Mineral counties........................ 141

Location of deposits................................ 14.1

Rhodes Marsh............................. 141

Columbus Marsh............................. $\quad 142$

Silver Peak Marsh............................ $\quad 142$

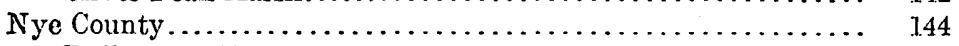

Railroad Valley........................................ 144

Elko and Eureka counties .......................... 145

West of Diamond Range............................. 145

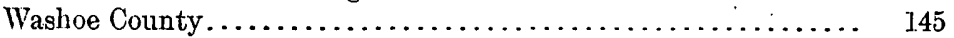

Buffalo Springs Salt Works....................... 145

Clark County ................................. 146

Virgin River salt deposits...................... 146

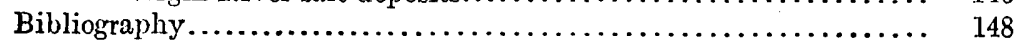


Geology of salt deposits of the United States-Continued. $\quad-\quad \therefore$ Pago.

New Mexico......................................... 148

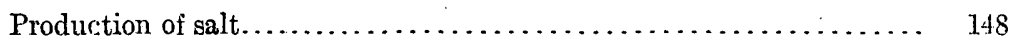

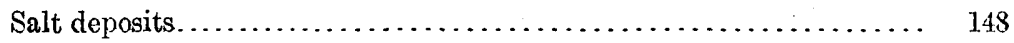

General geologic occurrence......................... 148

Estancia salt basin ................................ 149

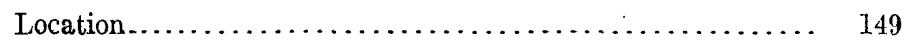

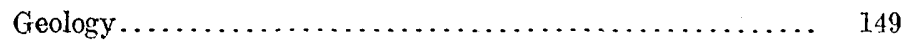

Extent of the ancient lake ....................... 149

Character and extent of the deposits ................. 149

Salt lakes of the White Sand Plains:................... 150

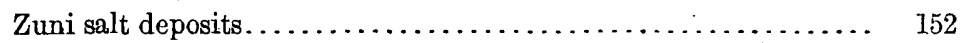

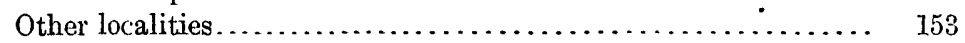

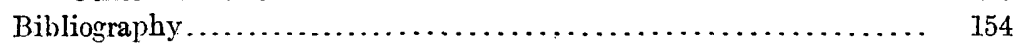

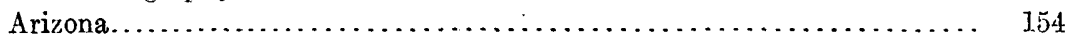

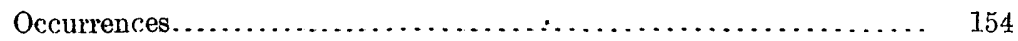

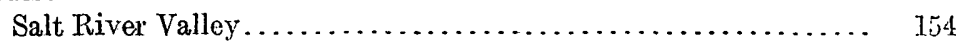

Virgin River Valley............................... 154

Other localities... . . . . . . . . . .

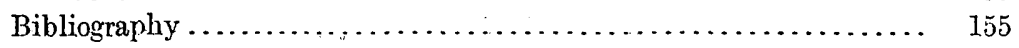

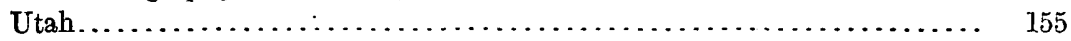

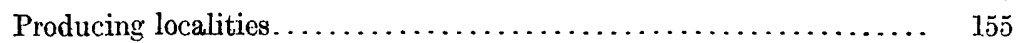

Great Salt Lake ................................. 156

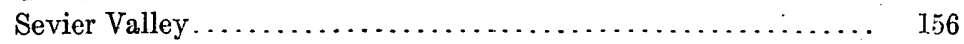

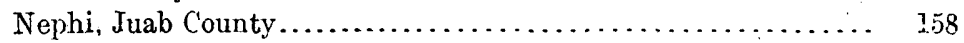

Clear Lake, Millard County........................... 158

Salduro salt marsh, Tooele County $\ldots \ldots \ldots \ldots \ldots \ldots \ldots \ldots \ldots .158$

Other occurrences.................................... 159

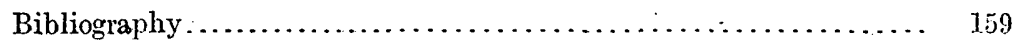

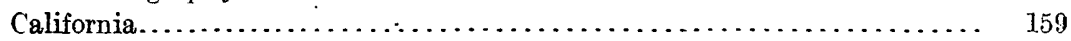

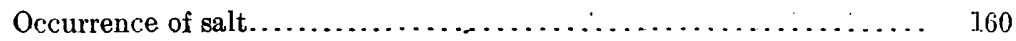

Producing localities................................. 161

Colusa County................................... 161

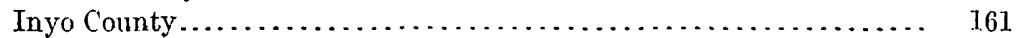

Owens Lake, by H. S. Gale........................ 162

General features............................. 162

Composition of the water . . . . . . . . . . . . . . . . 162

Total salines............................... 164

Searles Lake, by H. S. Gale......................... 164

General features................................ 164

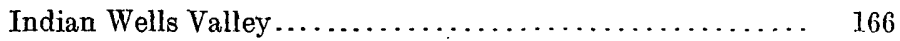

Salt Wells Valley .................................. 167

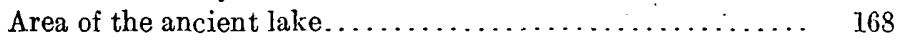

The saline deposits............................ 108

Chemical composition of the salines........................ 170

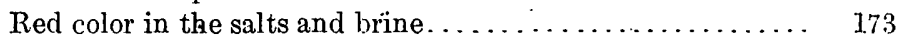

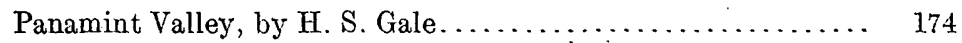

The former lake................................. 174

Salines in Panamint Valley....................... 174

Prospects for potash................................ 175

The desert basins................................ $\quad 175$

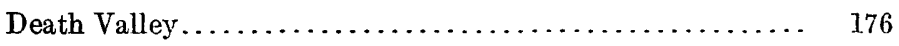

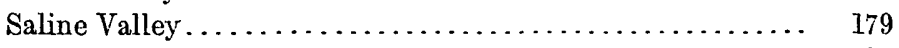

Other occurrences.......................... 181 
Geology of salt deposits of the United States-Continued.

California-Continued.

Prospects for potash-Continued. Page.

Kern County ................................. 182

Cameron Lake............................... 182

Kane Lake................................... 182

Other occurrences............................ 1.82

Mono County..................................... 183

Riverside County................................ 184

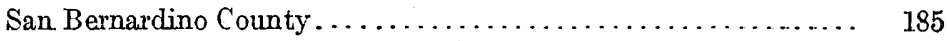

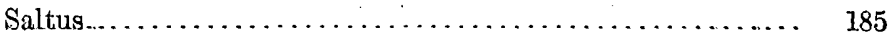

Amargosa River.............................. 185

A.vawatz Mountains............................ 186

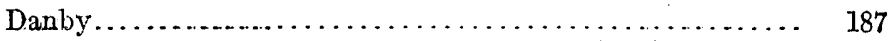

Mohave River and sink $\ldots \ldots \ldots \ldots \ldots \ldots \ldots \ldots \ldots \ldots \ldots . \quad 187$

Bitter Springs.................................... 189

Daggett................................... 189

Owl Springs...................................... 189

Other localities............................... 189

San Luis Obispo County .......................... $\quad 190$

Other counties.................................. 191

Bihliography .................................. 192

Origin and formation of saline deposits.......................... 193

Age of saline deposits. ..................................... 193

General principles of deposition ............................... 193

The bar theory of Ochsenius............................... 197

Desiccation theory $\ldots \ldots \ldots \ldots \ldots \ldots \ldots \ldots \ldots \ldots \ldots \ldots \ldots \ldots \ldots, 198$

Formation of rock salt in Michigan, New York, and Ontario........... 201

The Dead Sea........................................... 202

Karaboghaz Gult...................................... 203

The Stassfurt deposits..................................... 203

Extent and development. .............................. 203

Zechstein section........................................ 204

Mineralogy ............................................ 206

Investigations ............................................ 210

Chemical composition of saline materials......................... 210

Scope of analyses........................................... 210

Collection of samples ...................................... 211

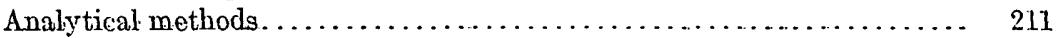

General features..................................... 211

Preparation of the solution................................. 211

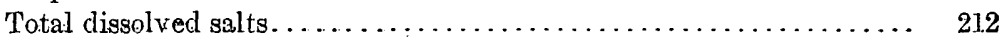

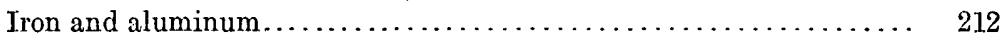

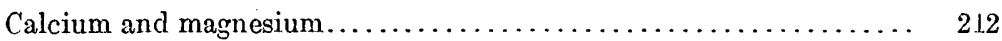

Sulphate......................................... 213

Sodium and potassium.............................. 213

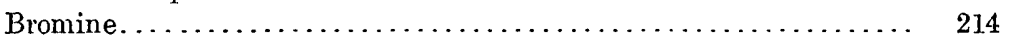

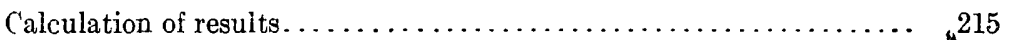

Composition of rock salt...................................

Composition of natural surface brines. . . . . . . . . . . . . . . 217

Sea water...................................... 217

Water of Great Salt Lake............................. 220 
Chemical composition of saline materials-Continued. Page.

Composition of natural and artificial underground brines........... 221

Brines and samples................................ 221

New York.................................... 222

Michigan...................................... 225

Northeastern Ohio................................. 228

Southern Ohio and West Virginia $\ldots \ldots \ldots \ldots \ldots \ldots \ldots \ldots \ldots \ldots, \quad 230$

Pennsylvania........................................ 233

Kansas. . . . . . . . . . . . . . . . . .

Louisiana........................................ ${ }^{2} 235$

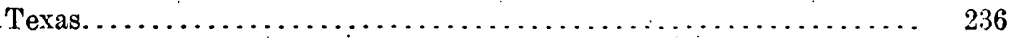

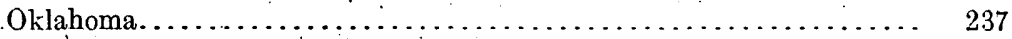

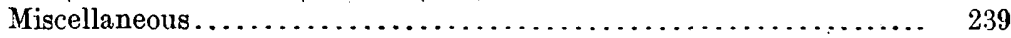

Composition of bitterns................................. $\quad 240$

New York.................................... 240

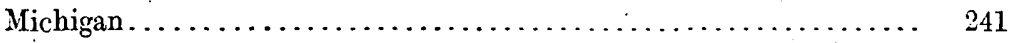

Northeastern Ohio................................ 244

Southern Ohio and West Virginia ......................... 245

Kansas.......................................... 246

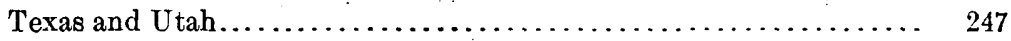

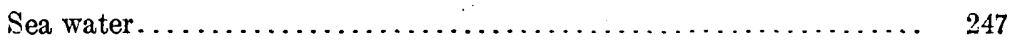

Composition of calcium chloride. .......................... 248

Composition of miscellaneous substances..................... 248

Potash from commercial brines and bitterns..................... 249

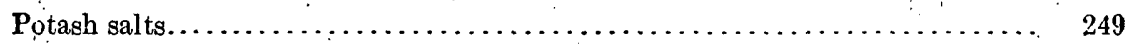

Scope of investigations. ................................. 249

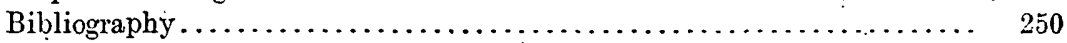

Statistics of production of salt in the United States, by A. T. Coans........ 251

Reliability of statistics..................................... 251

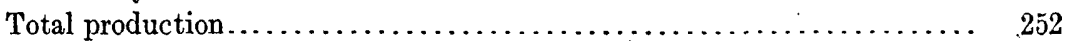

Production by grades....................................... 254

Production by States....................................... 257

Rank of States........................................ 262

Production. on the Onondaga Salt Springs Reservation, N. Y......... 263

Early production in Michigan................................ 265

Early production in West Virginia.............................. 266

Exports.............................................. 266

Imports.................................................. 267

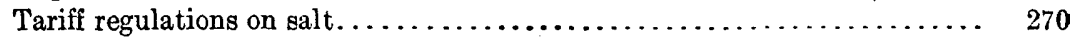

Domestic consumption.................................. 272

Useful tables and factors...................................... 274

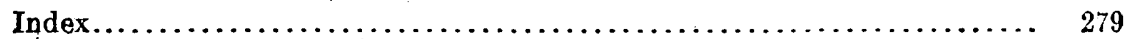




\section{ILLUSTRATIONS.}

Plate I. Map showing location of salt plants in the United States............

II. Forms of salt crystals: $A$, Rock salt including fragments of shale; $B$, Hopper-shaped crystals from the evaporating ponds of the Leslie Salt Co., Leslie, Cal.; $C$; Perfect cubes of salt from Silver Peak Marsh, Nev.; $D$, Salt crystals from Kansas; $E$, Large plate of rock salt from a mine in Genesee County, N. Y .................

III. Map of central New York, showing outcrop of the Salina formation and locations where salt or brine has been found in wells and shafts...

IV. Diagrammatic sections showing depths of rock salt below the top of the Onondaga ("Corniferous") limestone in New York..........

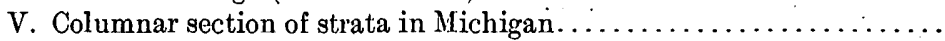

VI. Geologic map of the lower peninsula of Michigan, after $\Lambda$. C. Lane,

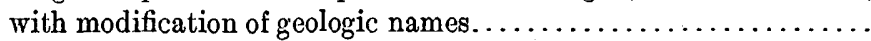

VII. Open valley at Saltville, Va., showing brine wells..............

VIII. Map of middle Kansas, showing location of salt marshes and area underlain by rock salt. . . . . . . . . . . . . . . . . . . . . . . .

IX. Geologic sections across the salt field of Kansas ................

$X$. Map of northern Louisiana, showing locations of salines...........

XI. Myles salt mine, Weeks Island, La.: $A$, Almost perpendicular strata or bands of salt lying in closely compressed folds; $B$, View in

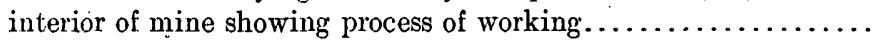

XII. View of Silver Peak Marsh, Nev., a typical playa..............

XIII. A, Salt exposed on west side of Virgin River, 5 miles south of St. Thomas, Nev.; $B$, Salt in arroyo near Virgin River bottom, 5 miles

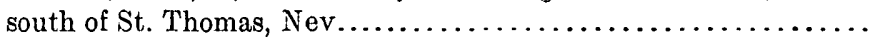

XIV. A, Panoramic view of surface mine in rock salt, Gunnison Valley Salt Co., near Redmond, Utah; $B$, Panoramic view showing gypsum and salt beds, Avawatz Salt \& Gypsum Co., Avawatz Mountains, San

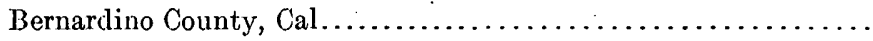

XV. Map showing the general location of the Owens-Searles-Panamint

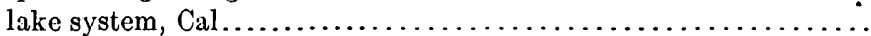

XVI. $A$, Hogback of celestite with gypsum in background, Avawatz Salt \& Gypsum Co., San Bernardino County, Cal.; B, Bedded structure in celestite, Avawatz Salt \& Gypsum Co., San Bernardino County,

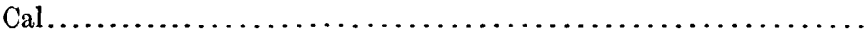

XVII. A, Bed of "mixed salt," Livonia salt mine, Livonia, N. Y.; $B$, Stratified shale and salt, Bevis Rock Salt Co.'s mine, Lyons, Kans.

Figure 1. Geologic section through the salt wells from Le Roy to Gainesville Creek, N. Y., showing structure of Onondaga ("Corniferous") limestone and underlying salt bed......................

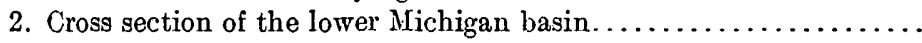

3. Map of eastern Ohio showing location of salt works and alkali works

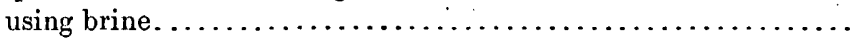

4. Map of a part of the coast of southern Louisiana, showing location of

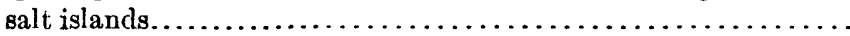

5. Topographic sketch map of Grand Cote (Weeks Island), La...... 
Frgure 6. Topographic sketch map of Avery Island (Petite Anse), La...... 114

. 7. Sketch map showing location of salt plains in Oklahoma....... 127

8. Sketch geologic map of part of Idaho-Wyoming border country.... 133

9. Section of reservoir and vats, Eagle Salt Works, Leete, Nev...... 139

10. Map showing drainage boundary and Pleistocene lakes of the.Great

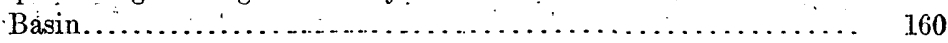

11. Map showing salt deposits in Death Valley, Cal., and location of wells drilled by the United States Geological Survey......... 177

12. Map of Saline Valley and vicinity, Cal., showing location of salt

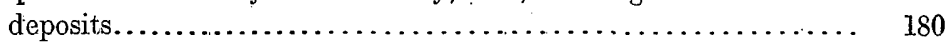

13. Map of Soda Lake, San Luis Obispo County, Cal............ 191

14. Section of shaft in German potash mine, Ludwig II, Stassfurt, Germany ................................... 205

15. Diagram showing total production of salt in the United States, by

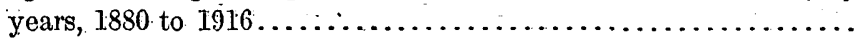

16. Diagram showing total production of salt in the United States, by

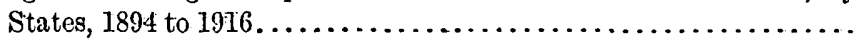




\title{
SALT RESOURCES OF THE UNITED STATES.
}

\author{
By W. C. Phalen.
}

\section{INTRODUCTION.}

In the search for deposits of soluble potash salts carried on by the Geological Survey under specific authority of Congress a great deal of important information on the salt resources of the United States has been collected. The bulletin containing this information as first prepared was divided into five parts, as follows: (1) Geology of the salt deposits of the United States; (2) theories (origin and formation) of saline deposition; (3) chemical composition of saline materials; (4) statistics of the production of salt in the United States; and (5) technology of the manufacture of salt.

The part relating to-the technology of the manufacture of salt is omitted from the Geological Survey publication as more properly connected with the work of the Bureau of Mines. That part, which complements the present bulletin, has therefore been prepared for publication as Bulletin 146 of the Bureau of Mines, to which bureau application should be made for it.

\section{SOURCES OF INFORMATION.}

- It was recognized that every known deposit of rock salt should be closely studied and tested from time to time in order to make a complete investigation of the possible occurrence of commercial deposits of potash salts in the United States; for deposits of ordinary rock salt may overlie, be included within, or underlie deposits of potash salts. A systematic study was therefore made in the summer of 1911 of the brines, bitterns, and deposits of rock salt in the States east of the Rocky Mountains and in localitics considered most promising for potash. Hundreds of samples of brines, bitterns, rock salt, and calcium chloride, many of them sent in by drillers for oil, were collected for chemical examination; the geology of the occurrences of the brines and salt was investigated; records of deep wells were examined in the hope that some of them might be more complete than those already published by the different State surveys; and samples of the rocks passed through in the deep drillings were studied. 
The field work extended over the western part of New York and included visits to the operating plants in Wyoming, Livingston, Genesee, and Tompkins counties. Every active salt plant in the Lower Peninsula of Michigan was visited. During the early part of the work the writer was accompanied by J. W. Turrentine, of the Bureau of Soils, United States Department of Agriculture. The brines of Midland, Saginaw, Bay, and Isabella counties, Mich., whose content of bromine in commercial quantity indicates partial desiccation of sea water and the occurrence of mother liquors, were sampled; also the brines of Malden, Kanawha County, and of Mason and Hartford, Mason County, W. Va.; those of Meigs County, Ohio, across Ohio River from Mason County, W. Va., and those of Pittsburgh, Pa.-all of which are or have been worked for bromine. Northern Ohio and Kansas were reviewed. As it was rumored early in 1911 that potash . salts had been found near Goderich, western Ontario, Canada, that locality was visited and samples were obtained.

Similar field work was continued by the writer during the summer of 1912, principally by visits to the salt-producing districts in the Western States. The shores of Great Salt Lake were inspected, and the salt deposits to the south, in Sevier, Sanpete, and Juab counties, Utah, were sampled: Samples of salt and brine were obtained from the solar-salt plants on San Francisco Bay, Long Beach, and San Diego Bay; and the deposits in the Avawatz Mountains, San Bernardino County, Cal., were examined.

Practically all the analyses resulting from this work are given under the heading "Chemical composition of saline materials" (pp. 270-277).

The writer takes this opportunity to thank his numerous friends in the industry who have contributed so generously both time and information. In this connection specific mention should be made of his former colleagues in the United States Geological Survey, Messrs: H. S. Gale, R. B. Dole, and R. K. Bailey. Mr. Gale examined the report critically, as did Mr. Dole, who also scrutinized the analyses thoroughly and suggested many changes that have been incorporated in the report. Mr. Bailey recalculated all the chemical analyses and brought them to a uniform basis.

\section{TYPES OF OCCURRENCE.}

Salt is widely distributed and occurs in many places in beds of sufficient size to constitute true rock masses. It is also found in solution, as in salt springs and in the water of the ocean and of inland salt lakes or seas, as Great Salt Lake and the Dead Sea: Deposits of rock salt that are interstratified with rocks of various geologic horizons (see p. 193) have been formed by the gradual evaporation of bodies of sea water cut off from the main ocean. The salt water of inland salt lakes or seas, like Great Salt Lake and the Dead Sea, has 
J. S. GEOLOGICAL SURVEY

BULLETIN 669 PLATE

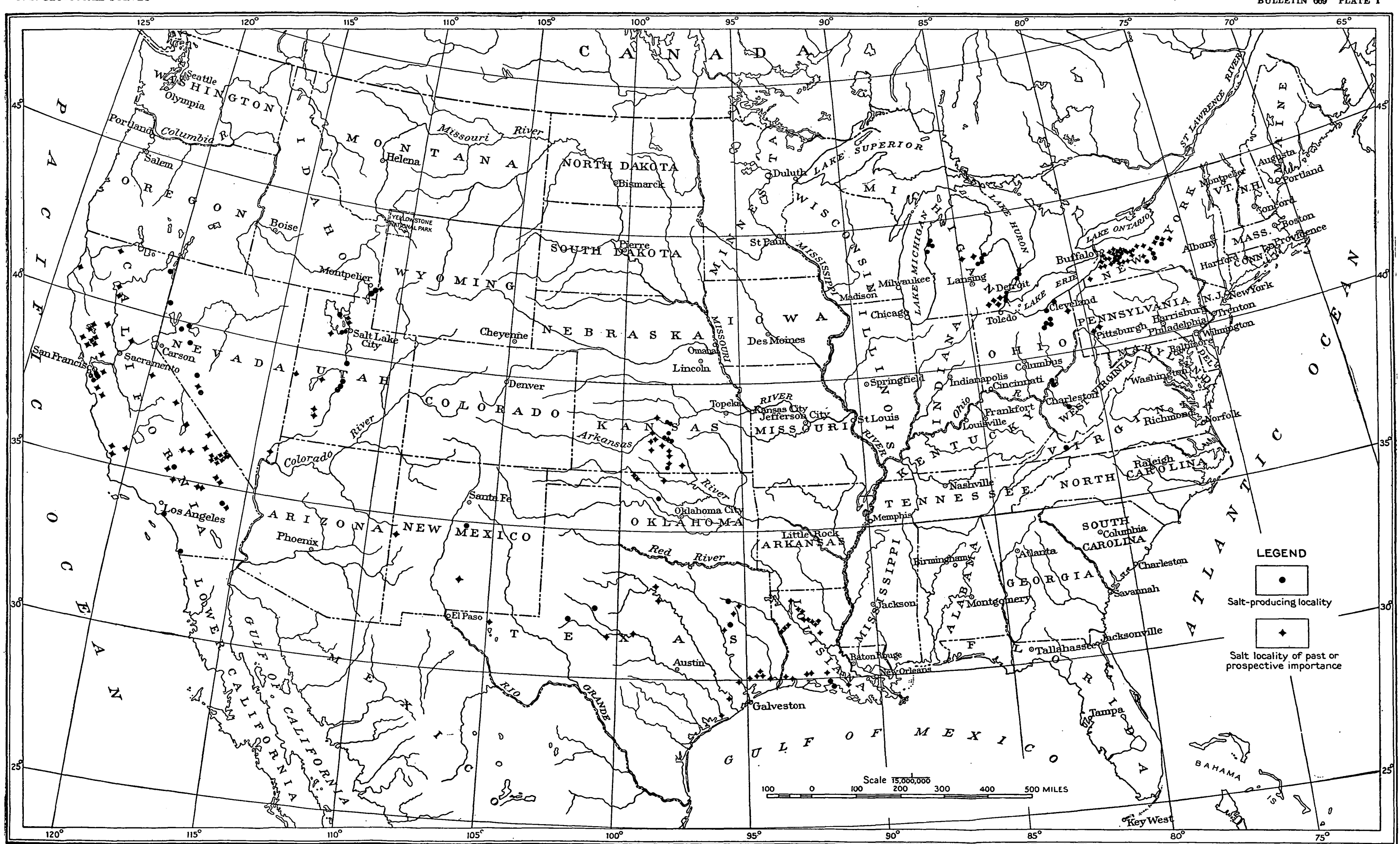

MAP SHOWING LOCATION OF SALT PLANTS IN THE UNITED STATES. 
been concentrated by evaporation through lack of an outlet. The mineral matter of such inclosed bodies of salt water in general crystallizes out in the order in which the solution becomes saturated with the various salts. This order depends partly on the relative amounts of the salts in the water and partly on their solubility.

Rock salt is of such universal occurrence that a list of the localities where it is found would include almost every country on the globe. In the United States extensive and valuable deposits of salt are found in central and western New York, in Pennsylvania; Ohio, Michigan, Virginia, Kansas, Louisiana; Texas, Nevada, Utah, Arizona, New Mexico, California, Idaho, Wyoming, and probably in several other States. Salt springs and wells abound in the neighborhood of the salt deposits, and these, as well as the waters of salt lakes and sea water, are used as sources of the commercial product.

The location of the producing salt plants in the United States is shown on the accompanying map (Pl: I).

\section{MINERALOGY.}

Common or rock salt is known mineralogically as halite. It is the chloride of sodium, composed of 39.4 per cent chlorine, which in its free state is a gas, and 60.6 per cent of the metal sodium. Halite is rather brittle and has a conchoidal fracture. Its hardness is 2.5 . Its specific gravity ranges from 2.1 to 2.6, that of pure crystals being 2.135. Its index of refraction is 1.5442 . It is highly diathermous. It seldom occurs perfectly pure, being mixed with a variety of other saline minerals, among which are gypsum, anhydrite, and (in Germany) carnallite, kiescrite, and polyhalite, or it is associated with shale and sandstone.

Halite is isometric in crystallization and usually forms cubes, which are commonly distorted or united in cavernous aggregations called hopper-shaped crystals. (See Pl. II.) It also occurs massive with granular to compact structure. Masses with perfect cubical cleavage are common as well as the fibrous rariety; which is said to be pseudomorphous after gypsum. It has a vitreous luster, and when pure it is transparent and colorless. Impurities impart to it yellow, red, brown, blue, and purple hues and are responsible for its different degrees of translucency. It is readily soluble in water. (See table on pp. 274-275.) Its characteristic saline taste is known to all.

\section{USES OF SALT.}

Salt is largely used for culinary purposes and in the meat-packing, fish-curing, dairying, and other industries to preserve the products from deterioration. It is used extensively in refrigeration. The chlorination of gold consumes some salt. - It is also used to form a

1 Dana, J. D., System of mineralogy, 6th ed., New York, pp. 154-156, 1892. 
glaze on pottery, in enameling and pipe works, for salting cattle, in curing hides, making pickles, and in clearing oleomargarine. In the form of brine it is largely used in the chemical industries in the preparation of soda ash, caustic soda, and various other chemicals containing a sodium base.

\section{GEOLOGY OF SALT DEPOSITS OF THE UNITED STATES.}

\section{GENERAL DISTRIBUTION AND CHARACTER.}

Of the useful minerals found in the United States none perhaps occurs in greater abundance or is more widely distributed than common salt. It occurs in crystalline layers interbedded with other sediments, which may have been chemically precipitated, like gypsum, or which may be classified as ordinary clastic deposits, like sandstone and shale - the whole forming hills or even mountainous masses (see Pls. XIII, XIV, XV, and XVI); in the beds of dry, or nearly dry, lakes, marshes, or alkali flats (see Pl. XII, p. 142); or in the form of dissolved salt in natural brines that issue from salt springs or are found in salt lakes or ponds or in the ocean. Examples of all these modes of occurrence will be given in the descriptions of the salt resources of the different States in which salt is of present or of prospective commercial importance.

In the eastern and southern parts of the United Stares salt deposits do not appear at the surface as they do in many parts of the West. In New York, northern Pennsylvania, Michigan, Ohio, Kansas, Virginia, Louisiana, New Mexico, and eastern and northwestern Texas salt occurs in bedded deposits well below the surface, where it is protected from the solvent action of rain and ground water by a mantle of impervious strata. In the Western States, Idaho, Wyoming, western Texas, New Mexico, Arizona, Nevada, and California, many extensive salt deposits are exposed at the surface because of arid climatic conditions. Thus the United States may be divided into eastern and western parts with reference to its salt resources, the division being not only geographic but climatic.

The greater part of Nevada, large parts of Utah and California, and small parts of Oregon, Idaho, and Wyoming are included in the Great Basin region, so called, in which are the drainage basins of Lake Lahontan and Lake Bonneville, two Pleistocene lakes. The basins of these lakes have been studied by G. K. Gilbert ${ }^{1}$ and I. C. Russell. ${ }^{2}$ The conclusions of these geologists regarding the saines deposited from the waters of these lakes, their accumulation, theip disappearance from the surface, and the possibility of finding them below the surface are discussed in subsequent pages of this bulletin.

1 Gilbert, G. K., Lake Bonneville: U. S. Geol. Survey Mon. 1, 1890.

2 Russell, I. C., Gcological history of Lake Lahontan, a Quaternary lake of northwestern Nevada: U. S. Geol. Survey Mon. 11, 1885. 


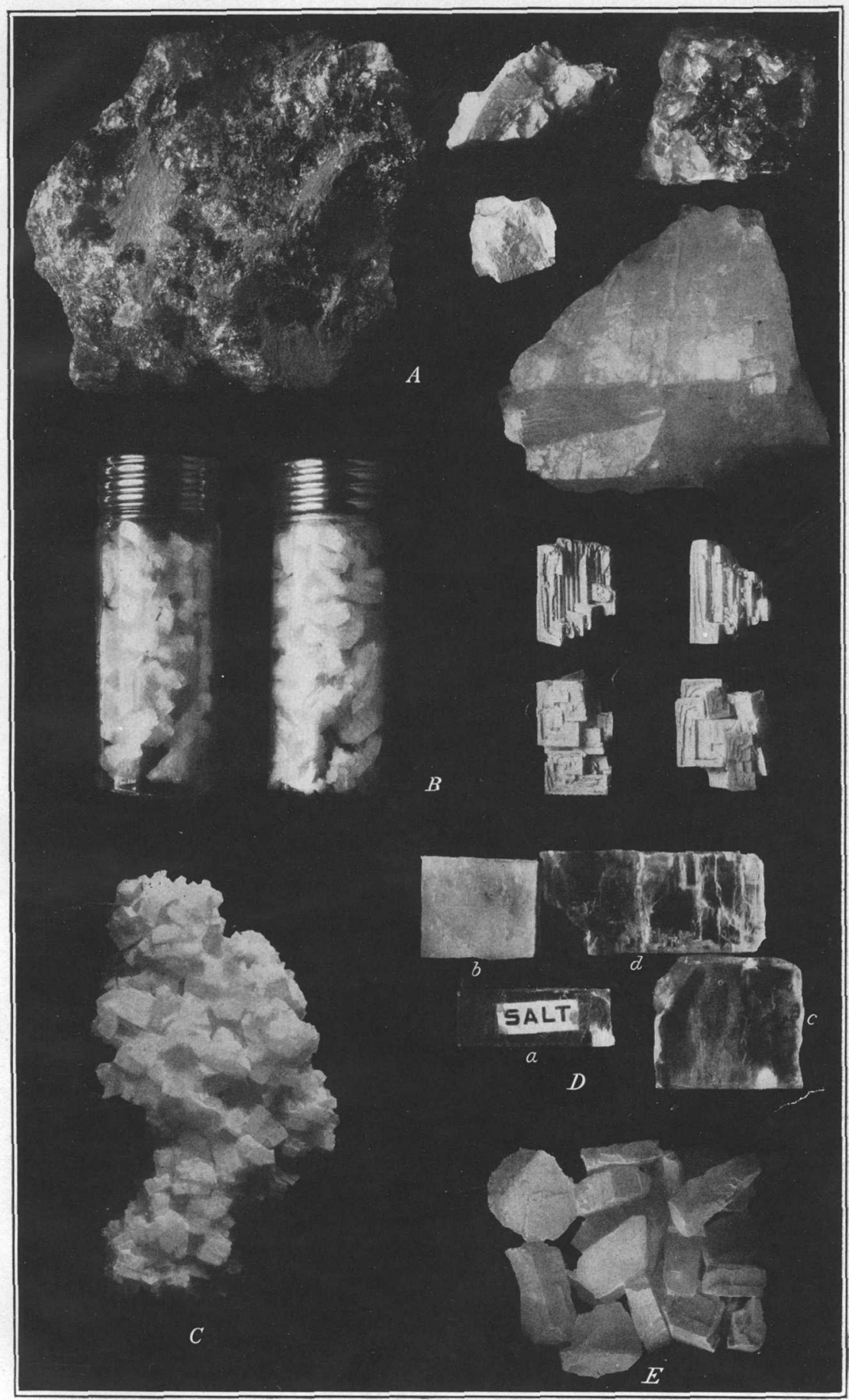

FORMS OF SALT CRYSTALS.

$A$. Rock salt including fragments of shale. $B$. Hopper-shaped crystals from the evaporating ponds of the Leslie Salt Co., Leslie, Cal. C. Perfect cubes of salt from Silver Peak Marsh, Nev. D. Salt crystals from Kansas: $a, b$, Rock salt from shaft of Standard Salt Co. Little River, Kans. $c, d$, Salt showing perfect cubical cleavage, furnished by Bevis Rock Salt Co., Lyons, Kans. . E. Large plate of rock salt from a mine in Genesee County, N. Y. 
The climatic and geologic conditions pertaining to certain of the saline deposits of Arizona and New Mexico are similar to those of the Great Basin region, and the generalizations by Gilbert and Russell for that region hold for certain occurrences of salt in the two States mentioned.

\section{NEW YORK.}

\section{MISTORY OF THE SALT INDUSTRY.}

The salt industry is older in New York than in any other salt-producing State. Salt was probably made by the Indians from brine springs, the most important of which, near Syracuse, Onondaga County, were noted by missionaries among the Indians about the middle of the seventeenth century. Le Moyne, a French Jesuit, mentions the salt springs in connection with the Indians in his journal published in 1653. The Delawares are known to have sold salt to settlers in Canada and in northern and eastern New York as early as 1670. The manufacture of salt by white people near Syracuse began about 1788 or 1789 . At first the brine was evaporated in kettles suspended over fires, but arches large enough to contain four ordinary potash kettles. were soon introduced.

In 1797 the legislature of New York set apart 15,000 acres of land, the Onondaga Salt Springs Reservation surrounding the head of Onondaga Lake, and laws were made regulating the making of salt. The area of the reservation was reduced from time to time until 1908, when the control of the lands and wells was relinquished to the Onondaga Pipe Line Co. and the Mutual Pipe line Co., of Syracuse, for the nominal sum of $\$ 15,000$. The establishment of the reservation was followed by the formation of the Federal Co., which erected the largest salt-making plant of the period-32 kettles set in blocks of four each. At first the brine was pumped by hand from shallow wells, but as the wells enlarged horsepower and subsequently water power was used to lift the brine. Since the State government took possession of the reservation and appointed a superintendent, a record has been kept of all matters pertaining to its production of salt. The whole production from 1797 to 1896 was $365,434,887$ bushels of 56 pounds.

Prior to 1846 the royalty charged the manufacturers by the State was variable, but since that year the uniform charge has been 1 cent a bushel; the net profit to the State to 1886 was $\$ 668,200$, but since then there has been a small annual deficit.

It had long been believed by the geologists of the New York survey that the Onondaga salt springs were supplied by the leaching of beds of rock salt. In 1820 explorations with a deep drill were begun on the Onondaga Reservation in search of these beds, but they resulted in failure. In 1838 the State legislature appropriated a sum large 
enough to enable the superintendent to sink a shaft or well 600 feet deep, which likewise resulted in failure. The truth of the geologists' belief was demonstrated later by accident and in a locality where salt was least expected.

Rock salt was discovered in New York in 1865 at the village of Vincent, in western Ontario County... The importance of the find was not appreciated and it was not generally known until after the salt bed had been found in other places. Early in 1878 one of several test wells sunk in western New York in a search for oil encountered a bed of rock salt 70 feet thick at a depth of 1,279 feet a mile south of Wyoming. This well became known as the Pioneer well. Three years later, in March, 1881, works with the small capacity of 40 barrels a day were erected and salt was first made from artificial brine. Shortly after this discorery successful exploration took place at Leroy, north of Wyoming, where salt was made in the spring of 1884.

In the meantime progress was made in another part of the State. In August, 1881, a company of citizens of Warsaw began to sink a well near the Buffalo, Rochester \& Pittsburgh Railway in the northern part of the town, and in October of that year a bed of salt and shale 111 feet thick was found at a depth of 1,520 feet. Eighty feet of the bed proved to be salt. An abundant supply of water with which artificial brines could be made was also encountered. It was soon shown that the artificial brine was fully saturated, of great purity, and could be produced practically in unlimited quantity. The development of the salt industry in this general locality was very rapid. In 1883, the year in which there was such a marked development in the Oatka Valley, salt was found in the Genesee Valley, where the salt bed was first reached in a well near the shaft of the Retsof salt mines, 10 miles directly east of the Pioneer well in the Oatka Valley. In September, 1885, a shaft 9 by 12 feet reached rock salt near Griegsville at a depth of 996 feet. Many wells and a few other shafts were later put down in the Genesee Valley.

The discovery of rock salt at Wyoming in 1878 revived interest in the search for the bed that geologists had asserted must exist in the higher land south of Syracuse, and in 1881 a well was sunk at Jamesville, 7 miles southeast of the head of Onondaga Lake. In 1882 another well was sunk at Cedarvale, $7 \frac{1}{2}$ miles southwest of the reservation. Rock salt was not found in either of these wells. In 1884 two wells were put down near the Onondaga salt springs, one by private parties and the other by the State. No rock salt was found in the Salina formation in either of these wells. In 1885 a test well was sunk at Ithaca to a depth of 3,185 feet in which salt was found and a careful record was made of it. (See p. 39.) The stratigraphy of the Ithaca well has been described by C. S. Prosser. ${ }^{1}$. In 1886 a well 
was sunk at Morrisville, Madison County, in which rock salt was found. The Morrisville well marks the most easterly point at which rock salt has been found in the State and also the most northerly point east of Genesee River, with possibly a single exception.

In 1888 the Solvay Process Co., of Syracuse; in searching for a larger and cheaper supply of brine for its large soda-ash plant at Syracuse began to sink a well near the middle of the south end of the valley of Onondaga Creek in the town of Tully, 17 miles south of Syracuse. The well was abandoned after it had passed through 400 feet of glacial drift,-and another was begun a quarter of a mile farther east, in which the drill encountered at a depth of 1,216 feet a bed of rock salt 45 feet thick. In 1889 ten new wells were put down; in 1890 ten more; and in 1891 nine more, all on the eastern side of the valley. In 1895 and 1896 eleven additional wells were drilled on the opposite side of the valley, making a total of 41 wells drilled to the salt bed in this locality by this company. Forty of these wells are connected by iron pipes with Tully Lakes. The water from the lakes flows by gravity to the salt and becomes saturated with it. This brine formerly flowed out through other pipes into a large main that conveyed it to Syracuse, where the works are 360 feet lower than the mouth of the lowest well, but because of the loss by this method the wells are now pumped. The geologic horizon of the mouths of these wells, all of which are close together, is the middle of the Hamilton formation.

In 1891 a well was sunk to the salt bed at Ludlowville, Tompkins County, and a second well was put down in 1892. In 1895 another well was drilled at Ithaca, north of the well put down in 1885 . In 1893,1894 , and 1896 wells were sunk at Watkins, Schuyler County, and salt is now made at that place.

During the last few years New York has ranked second among the States in both quantity and value of the salt produced. The industry includes both the mining of rock salt and the evaporation of brine by the solar, open-pan, grainer, and vacuum-pan processes.

\section{POSITION OF FIELD.}

The Salina or salt-bearing formation outcrops in a belt approximately 12 miles wide at Niagara River, extends eastward across the central tier of counties to a point a little south of Oneida Lake. The outcrop then turns to the southeast, tapering gradually, and terminates in the vicinity of Schoharie River, Schoharie County. Its greatest width, about 20 miles, is at the foot of Cayuga and Seneca lakes. Salt mining is confined to the region south of this outcropping belt-that is, in the direction of the dip of the beds-as the salt beds, by reason of their solubility, can not exist at the $40104^{\circ}-18-B u l 1.669-2$ 
surface in this region of abuudiant rainfall. These facts are brought out on the map: (Pl. IIE), which shows: the outcrop of the Salina formation and the places in the State where salt has been found in wells and shafts.

\section{EXTENT: OF DEPOSIFT.}

The district under which rock salt is known to exist comprises the corner of Genesee County south of Leroy, the eastern half of Wyoming County, nearly the whole of Livingston County, and the part of Ontario County west of Canandaigua Lake and chiefly south of the New York Central Railioad. There can be scarcely a doubt that rock salt exists west of Warsaw, but the early borings in Erie County seem to have been beyond the western limit of the salt deposits. No rock salt was found at the East Aurora well, but strong brine was obtained. At Gardenville, 7 miles from Buffalo, a well was sunk entirely through the Salina formation, but no rock salt was found. Likewise at Eden Valley and Gowanda, only brine was obtained in the early wells. Eater reports, however, state that rock salt has been found in Erie County at Eden Valley, Springville, Perry, and Gowanda ;" and in Cattaraugus County in a gas well between Cattaraugus and Gowanda.:

East of Canandiagua lake the borings put down at Dundee, Watkins, Ithaca, Ludlowville,. and Tully all reached the rock-salt beds. The area underlain by rock salt west of Canandaigua Lake is computed by I. P. Bishop ${ }^{3}$ to be 1,100 square miles in areal extent. In view of discoveries made since. Bishop's report was published, it is probable that his estimate is far too low. East of this lake the area underlain by salt must be fully as Iarge as that west of it if not larger. The northern limit can be assigned only approximately, owing to the solution of the rock salt as it approaches the surface. The southern limit is not known and may never be accurately dotermined, as the cover of the Salina formation increases in thickness in that direetion; but the salt is known to extend at least as far south as the vicinity of Pittsburgh, Pa. The persistence of the salt to the south in New York, however, is indieated by the wells at Ithaca, which reach the salt at a depth of 2,200 feet, and by test borings in northern Cattaraugus and Allegany counties, which encountered. salt below 3,000 feet. The boring at Canaseraga, Allegany County, penetrated 75 feet of rock salt, beginning at a depth of 3,050 foet. ${ }^{2}$

The northern limit, as shown by the outcropping Salina strata, is approximately defined by a line drawn from a point south of Oneida Lake westward to Buffalo. To the south of this line deposits are

1 Newland, D. H., New. Y.ork State Mus: Ball..166, p. 57, A ugust, 1913.

2. Newland, D. H., New York State Mus. Bull. 174, p. 66, December, 1914.

3 New York State Geologist Rept., vol. 5, p. 34, 1885. 


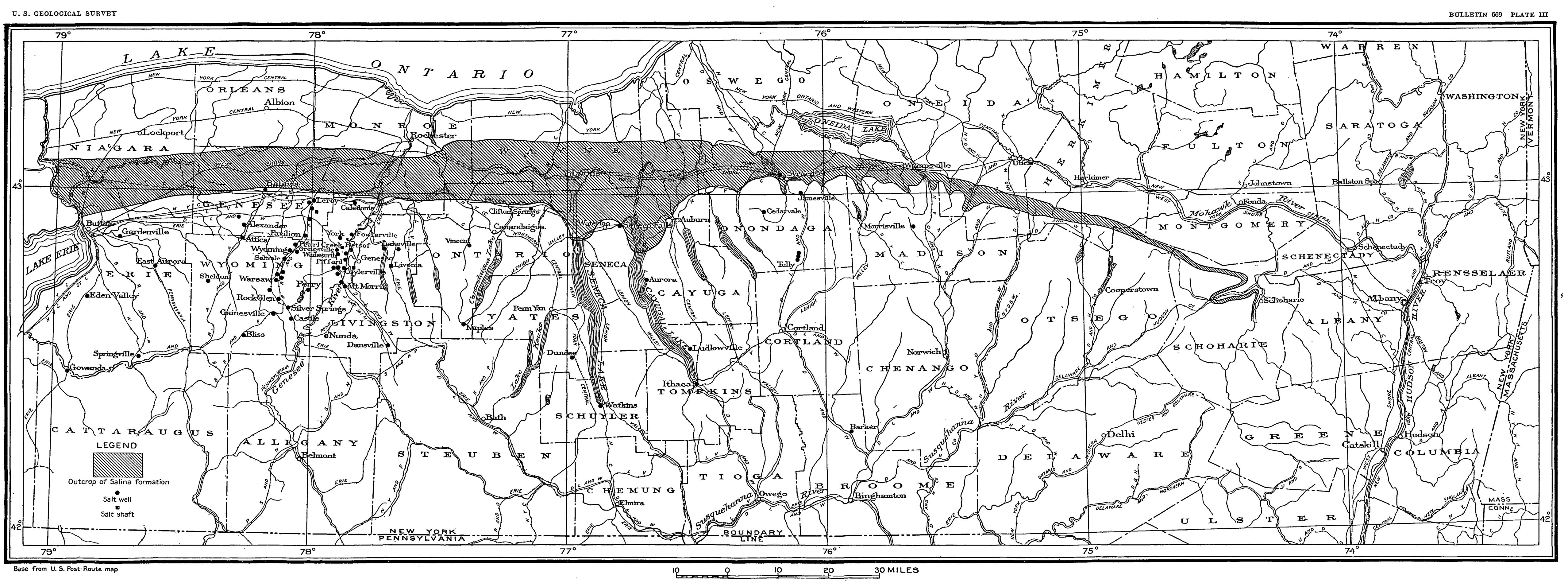


encountered at progressively increasing: deptlis. in accordance. with the: dip of the strata, which ranges: from: 40 : to 50 feet a mile. The most easterly point where salt has been found: is Morristille; Madison County. Between this: point and Lake Erio salt hos been found in: almost all the counties in the central tier of the State.

\section{STRATIGRAPHY.}

The salt beds of Now York belong in the Salina formation of the Eayuga group of roeks, which in turn are in the Silurian system: To illustrate the position of these-beds: in the geologic columnar section of New York, the section of the Devonian and Silurian rocks is given below:

Major subdivisions of the Devonian and Silurian rocks of New York, showing position of Salina formation. ${ }^{1}$

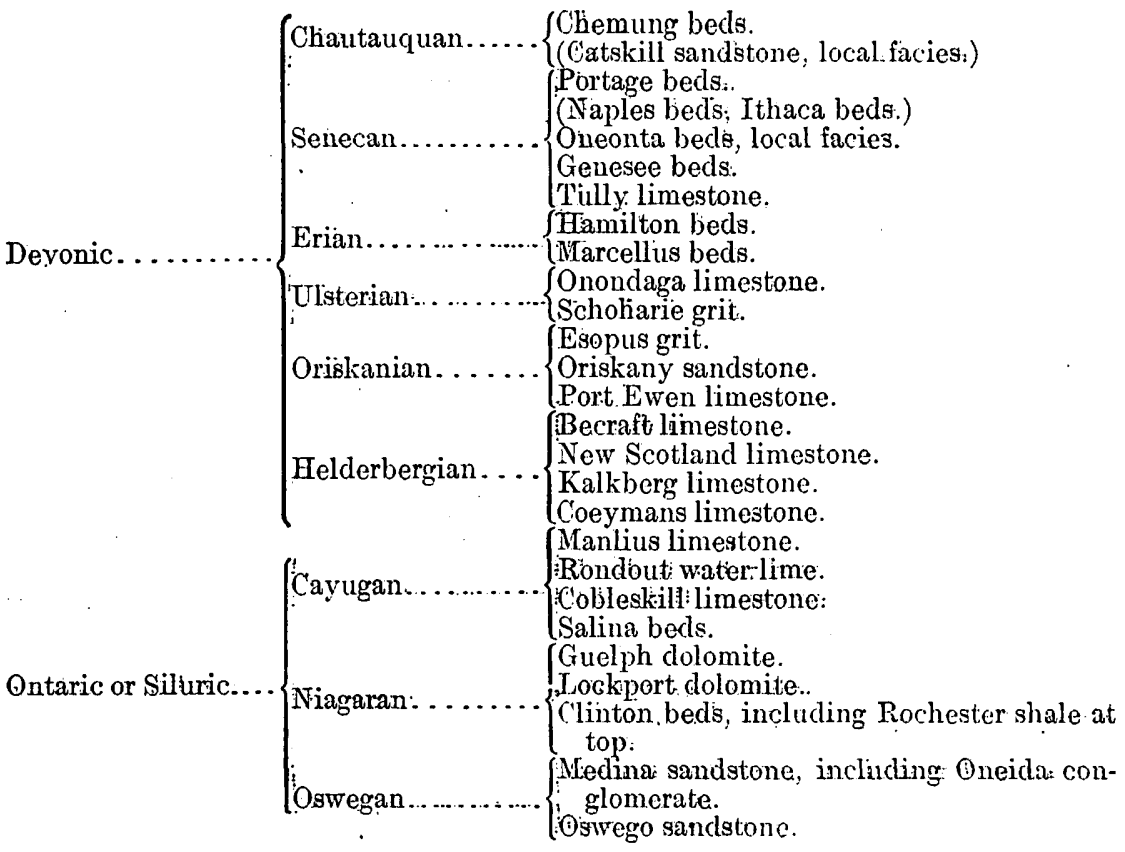

The Salina formation in central and western New York is now: subdivided in to the following members, beginning, with the highest:

1.. Bertie waten lime:: Argillaceous magnesian limestone, used for the manufacture of natural cement in Erie County. (This is the upper horizon of abundant Eurypterus.)

2. Camillus shale: Workable gypsum deposits; shale, and dolomite.

3. Syracuse salt.

4. Vernon shale: Red, gray; and green shales and thin dolomites.

5. Pittsford shale: Shale interbedded. with dolomite; contains a profusion of eurypterids.

1. Hartagel, C. $\Lambda$., Classification of the goologic formations of the State'of. New York: New Iork State Museum: Handbook No. 19, 1913, table.1, betweon pp: 24: and 25 .

2 The names here used are those in current use by the New York State Cieological Survey. 
In eastern New York the Wilbur limestone, below the cement beds of the Salina, carries a brief modified reappearance of the Niagaran fauna. ${ }^{1}$ It will be observed, therefore, that the salt beds of New York are associated with deposits of gypsum, shale, dolomite, and limestone.

\section{STRUCTURE.}

It was stated that the Salina beds in which the salt deposits occur are lens shaped. The strike or line of surface exposure of the saltbearing formation is eastward, approximately parallel with the shore

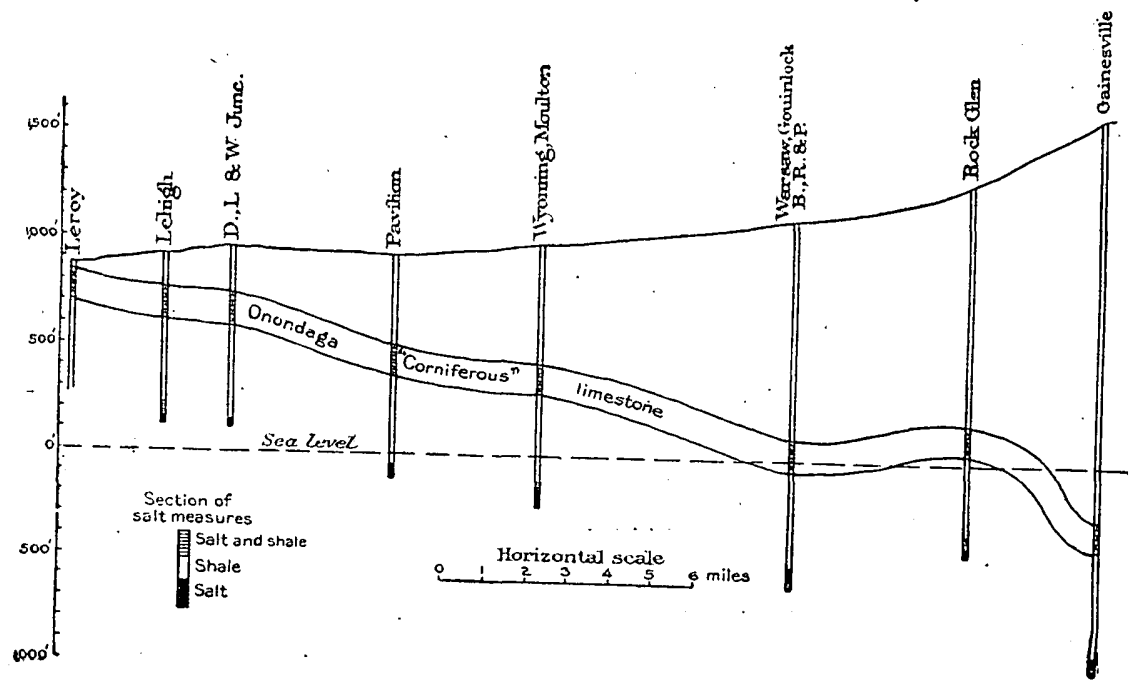

FigURE 1.-Geologic section through the salt wells from Leroy to Gainesville Creek, N. Y., showing structure of Onondaga ("Corniferous") limestone and underlying salt bed. ( $\Lambda$ fter F. J. H. Merrill, New York State Mus. Bull. 11, 1893.)

of Lake Ontario, though because of the rough topography the line of outcrop is tortuous in detail.

The beds or lenses dip to the south at a low angle. Exposures and sections of deep records show that this dip is not continuous but is reversed at intervals, with consequent dip to the north. Over a large part of the salt district 60 feet a mile is considered a fair average of the dip, but it is very irregular and ranges from 100 feet or more to the south to almost as much to the north, where reverse dips have been noted. The structure is well shown in figure 1 .

THE SALT BEDS.

The Salina formation contains not only the salt deposits of New York but also the gypsum deposits of the western part of the State. The gypsum deposits occur in the upper part of the Salina, in the

1 New York State Mus. Handbook 19, pp. S, 1S, and 19, ed. 1903; idem, pp. 51-53, ed. 1912. 
member designated Camillus shale, occurring above the salt deposits. Eridence that the rocks were deposited in water which contained salt nearly to the point of complete saturation is found in the hoppershaped forms that occur at several horizons and in the numerous carities in the porous limestones, which it is now known were filled with salt. The Salina formation rests on rocks of the upper part of the Niagara group. From the point where these rocks terminate on the east the Salina rests on the lower part of the Niagara group, the Clinton formation. East of the line at which the Clinton formation ends the Salina rests on the beds designated as Frankfort shale by the New York State Survey (lower part of Lorraine shale), on which they continue to a point near Hudson River.

There is scarcely any well-defined division between the Salina formation and the magnesian limestone which overlies it. This magnesian limestone has been used extensively in the manufacture of hydraulic cement. It is known as the Rondout limestone or water lime.

The Salina beds as a whole have the form of an irregular lens, the maximum thickness of which is found between Oneida Creek and Cayuga Lake. From this region they diminish in thickness east and west, which fact has been determined by plotting the sections revealed

- by deep drillings. The areal distribution of the formation is indicated on the map (Pl. III) taken from a geologic map of the State survey. In the earlier studies of the Salina exposed at the surface no rock salt was found simply because this soluble substance can not remain at the surface in a region where the rainfall is considerable. Our linowledge of the condition and magnitude of the salt beds has been obtained entirely from deep wells and mine shafts, more than 200 of which are distributed over the entire area in which the salt beds are ncar enough to the surface to be reached practicably by drilling. If the salt outcropped, it would in general appear along a line a short distance north of the southern boundary of the Salina; north of this line it would be useless to expect to find rock salt by drilling. The outcrop of the Marcellus shale is about as far north as salt may be found on deep drilling. The Solvay wells must be located near the edge of the salt bed, and it also seems clear that the bed does not bccome thinner toward the north and gradually "peter out," as it does west of Seneca Lake, but that it ends abruptly as though part of it had been remored.

The thickness and character of the salt deposits is essentially the same throughout the district, the only material difference being in the thickness and the number of intercala ted layers of rock. In many of the wells a thick layer of rock separates the salt bed into two parts, each of which is subdivided in turn into other and thinner layers. No one of these layers is continuous over the whole field, 
and wells only a few rods apart show marked differences in stratification.

In the Oatka Valley the total thickness of the rock salt beds, including the interstratified shales and limestones, is from 100 to 135 feet, at Silver Springs it is 145 feet, and at Castille 190 feet. The salt beds gradially thin out to the north and do not reach beyond the latitude of Batavia, Eeroy, and Caledonia. In the Genesee Valley, in a well on the Retsof mine property, the total thickness of the saltbearing strata: was 124 feet, of which 80 feet was rock salt. At the West Bloomfield and Bristel wells. in Ontario County only one bed 8. to 15 feet thick was found. At Naples the bottom of the well is in the second bed of salt 63 feet below the upper one. At Watkins several hundred feet of the salt strata were penetrated. From the top of the upper beel of salt in the Ithaca test well to the bottom of the seventh or lowest one is 470 feet, the salt in this column measuring 248: feet in thiekness. The greatest thickness in: the Solvay wells at Tully is 318 feet. At Morrisville, Madison County, it was only 12 feet.

Overlying the salt deposits are 250 to 300 feet of shales and magnesian limestones that contain the great deposits of gypsum found in Matison, Onondaga, Cayruga, Seneea, Ontario, Monroe, and Genesee counties.

The broadier features of the structure of the salt beds have been outlined. To: reeapitulate: The beds are lens shaped, strike eastwarch, and have an average dip to the south of 60 feet a mile although the dip: is reversed at initervals. Cross folding: is marked in: eertain areas, giving: strong dips east or: west; but in general elips east or west are hardly appreciable. Besides the undulations, which are low in proportion to their width, there are many small but sharp anticlinal folds in which the rocks are fractured at the apex and at botll sides of the base. In some places the sidles are inclined $45^{\circ}$, but as a rule the slant-is much less. Dislocations of the strata in overturns and vertical faults are encountered in places and also fissures and joints which penetrate to great depths, but these are common to all the formations..

In the district included in Livingston: and Wyoning: counties so many wells have been sunk to the salt beds that the data secured enable certain general statements to be made with a considerable degree of certainty. F. J. H. Merrill ${ }^{1}$ has construeted a map showing the undergrotnd contours of the salt meastres. The datum plane chosen for this map is 610 feet below the upper surface of the Onondiaga. ("Cornifereus:") limestone. This: seemingly arbitrary datum is chesen because the salt bedls. wary greatly in thicknoss and position in the Salina formation, and it is necessary to assume a horizon 

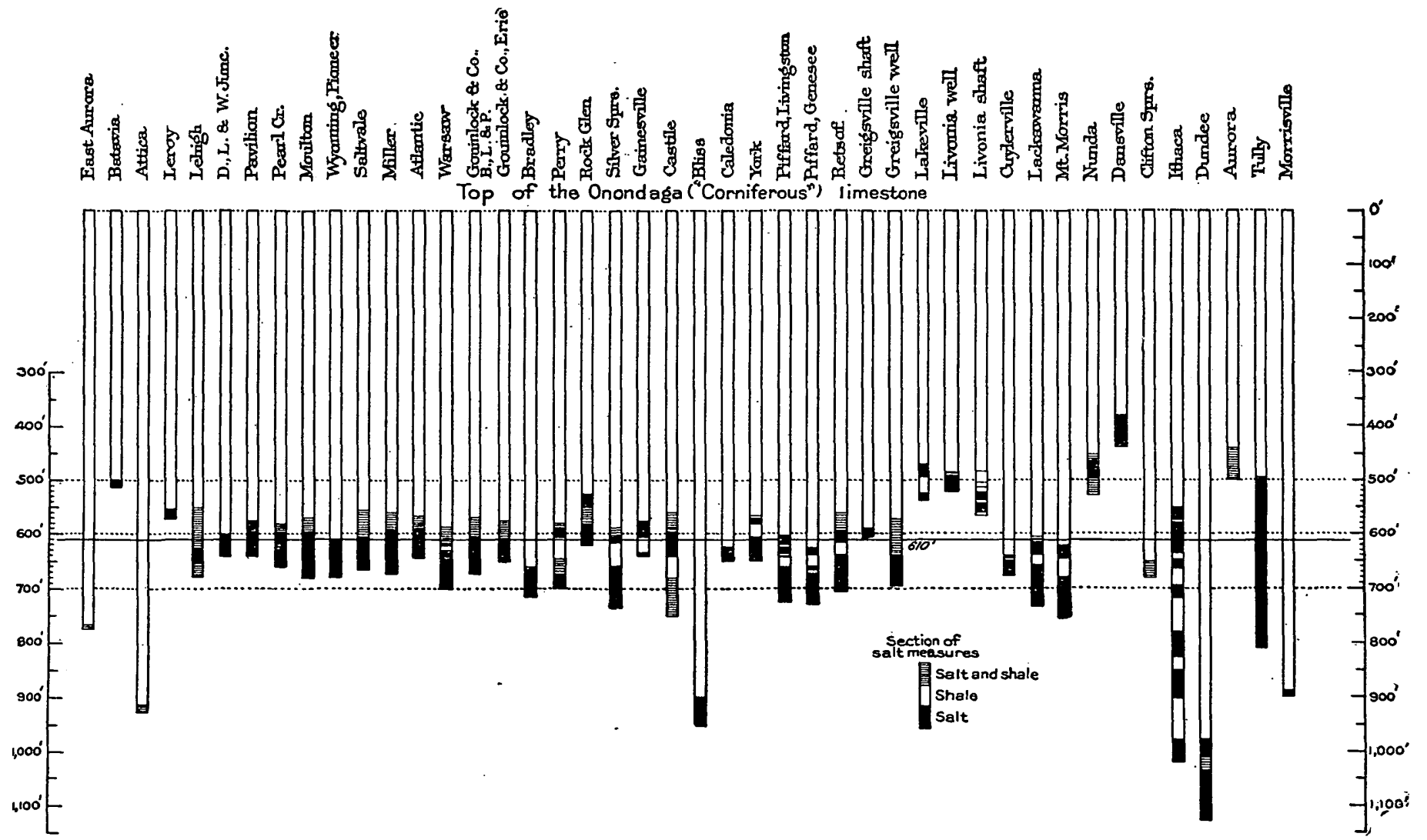

DIAGRAMMATIC SECTIONS SHOWING DEPTHS OF ROCK SALT BELOW THE TOP OF THE ONONDAGA (“CORNIFEROUS") LIMESTONE IN NEW YORK. After F. J. H. Merrill. 
at which the salt may be expected to occur. The contour line at the altitude chosen intersects the principal salt bed in nearly every well shaft. ${ }^{1}$

Throughout the Oatka-Genesee district salt is usually found at levels rarying from 550 to 750 feet' below the upper surface of the Corniferous limestone. The exceptions to this are very few; the only ones * * being the wells at Nunda and Bliss, in the former of which salt was found between 450 and 500 feet below the Corniferous, and in the latter it was first met at a depth of 900 feet. In the Ithaca well the lowest bed of rock salt was over 1,000 feet below the upper surface of the Corniferous. The testimony of the two latter wells would suggest that as a rule the wells and shafts of western New York have penetrated little more than half way through the salt measures. The upper surface of the Corniferous limestone has been taken as the datum plane from which to determine the relative positions of the salt beds, because it is invariably recognized by the driller as soon as reached. Its persistent character and the abundance of chert distributed through it form a marked contrast with the comparatively soft shales and thin limestones which overlie it. From the underground contours as shown on the map ${ }^{2}$ it will be seen that the dip of the strata in western New York is not directly to the south, but nearly southeast at the rate of about 60 feet to the mile: The section as plotted between Leroy and Gainesville Creek shows that the beds do not slope uniformly to the southeast but undulate in that direction.

\section{RECORDS OF SALT WELIS AND SHAFTS.}

The well records in the following pages have been taken from Bishop and Merrill in the references cited. Those by Bishop were obtained generally in the field; those quoted from Merrill were obtained in part in this way and in part from Englehardt and Prosser. Some of the records were obtained in the field by the writer." The arrangement in the text is geographic, from west to east. (See Pl. IV.)

Log of well at Goucanda, Catlaraugus County, N. T."

\begin{tabular}{l}
\hline \\
\hline
\end{tabular}

a Bishop, I. P., New York State Geologist Filth Ann. Rept., p. 17, 1SS5.

Note.-At 1,700 feet a vein of salt water was struck which filled the well and prevented further driliing. The brine is said to be very strong.

1 Now York State Afus: Bull. 11, vol. 3, p. 32, 1893.

2 Merrill, $F$. J. H., op. cit., map. 
Log of well at Eden Valley, Eric Countiy, N.Y.a

\begin{tabular}{|c|c|c|c|}
\hline & Material. & $\begin{array}{l}\text { Thick- } \\
\text { ness. }\end{array}$ & Depth. \\
\hline $\begin{array}{l}\text { Shale........... } \\
\text { Hard rock, blue. } \\
\text { Shale, black..... } \\
\text { Flint, lime, and } \\
\text { Brine in soft rock }\end{array}$ & 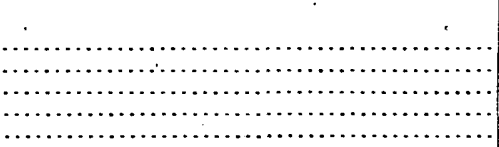 & $\begin{array}{r}\text { Fcct. } \\
125 \\
200 \\
300 \\
400 \\
50\end{array}$ & $\begin{array}{l}\text { Fct. } \\
.125 \\
325 \\
625 \\
1,025 \\
1,075\end{array}$ \\
\hline
\end{tabular}

$a$ Bishop, I. P., op. cit., p. 17.

NoTE.-Salt water was struck at 1,025 feet.

\section{Log of well at East Aurora, Erie County, N. $Y_{a}^{a}$}

\begin{tabular}{|c|c|c|}
\hline Material. & $\begin{array}{c}\text { Thick- } \\
\text { ness. }\end{array}$ & Depth. \\
\hline 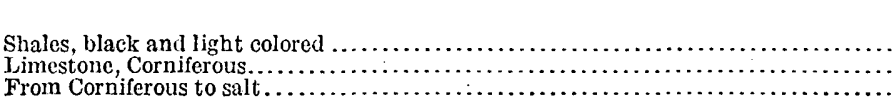 & $\begin{array}{r}\text { Fcct. } \\
695 \\
165 \\
605\end{array}$ & $\begin{array}{r}\text { Fect. } \\
695 \\
860 \\
1,465\end{array}$ \\
\hline
\end{tabular}

$a$ Bishop, I. P., op. cit., p. 18.

Note.-Strong brine was struck at 1,465 feet, which filled the well and ran out over the top.

Log of well at Gardenville, Erie County, N.Y.a

\begin{tabular}{|c|c|c|}
\hline Material. & $\begin{array}{l}\text { Thick- } \\
\text { ness. }\end{array}$ & Depth. \\
\hline 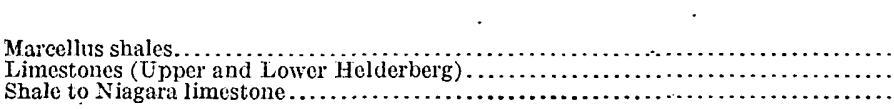 & $\begin{array}{r}\text { Fcct. } \\
60 \\
205 \\
535\end{array}$ & $\begin{array}{l}\text { Fect. } \\
60 \\
205 \\
800\end{array}$ \\
\hline
\end{tabular}

a Bishop; I. P., op. cit., p. 18.

NoTE.-Gas was found at the top of the Niagara and a few feet of shale containing brine a few feet above. No rock salt was found in the well.

Log of well of Lehigh Salt Mining Co., Lehigh, Genesee County, N.Y.a

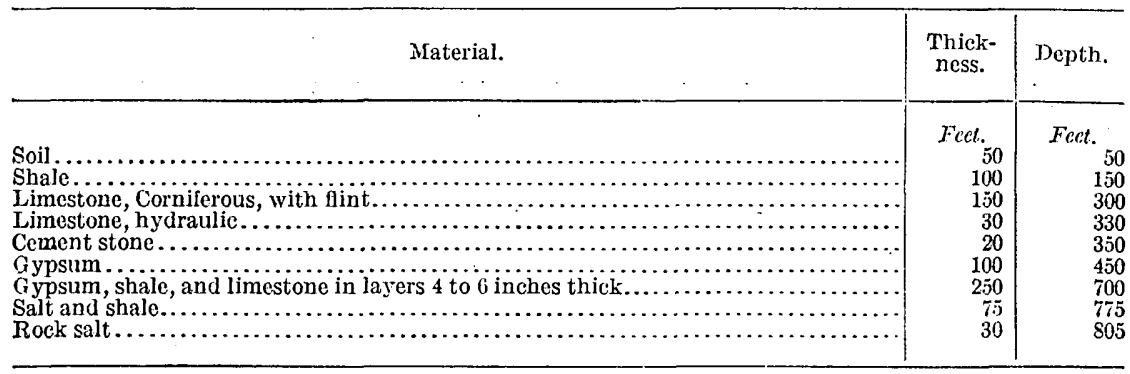

a Merrill, F. J. H., New York State Mus. Bull. 11, rol. 3, 1893. 
Log of woll at Batavia, Genesec County, N. Y.a

\begin{tabular}{|c|c|c|}
\hline Matcrial. & $\begin{array}{l}\text { Thick- } \\
\text { ness. }\end{array}$ & Depth. \\
\hline$\cdot$ & Fect. & Fect. \\
\hline 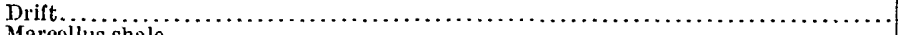 & 40 & 40 \\
\hline 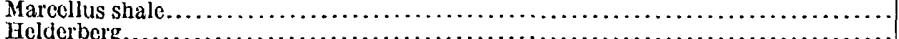 & 60 & 100 \\
\hline 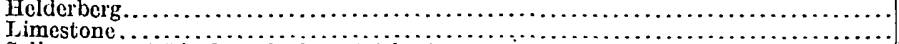 & 150 & 250 \\
\hline 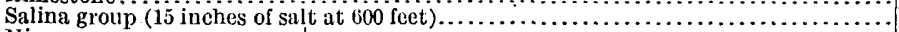 & 500 & 750 \\
\hline 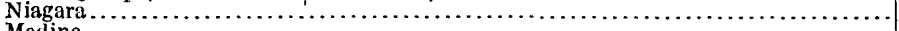 & 250 & 1,000 \\
\hline 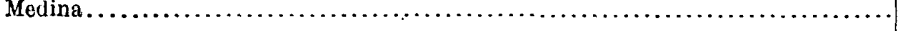 & 1,000 & 2,000 \\
\hline
\end{tabular}

a Prosser, C. S., quoted by F. J. H. Merrill, New York State Mus. Bụll. 11, vol. 3, 1893.

Logs of two wells at Lcroy, Genesee County, N.Y.

\begin{tabular}{|c|c|c|c|c|}
\hline \multirow{2}{*}{ Material. } & \multicolumn{2}{|c|}{ Well No. 1.a } & \multicolumn{2}{|c|}{ Well No. $2 . b$} \\
\hline & $\begin{array}{l}\text { Thick- } \\
\text { ness. }\end{array}$ & Depth. & $\begin{array}{l}\text { Thick- } \\
\text { ness. }\end{array}$ & Depth. \\
\hline 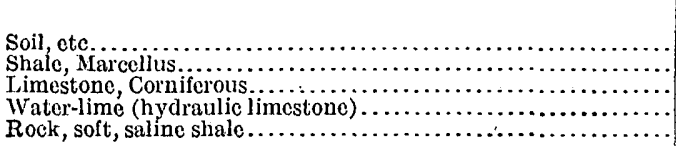 & $\begin{array}{r}\text { Fect. } \\
23 \\
10 \\
150 \\
40 \\
427\end{array}$ & $\begin{array}{r}\text { Fcet. } \\
23 \\
33 \\
183 \\
223 \\
650\end{array}$ & $\begin{array}{r}\text { Fect. } \\
22 \\
11 \\
137 \\
440\end{array}$ & $\begin{array}{r}\text { Fcct. } \\
22 \\
33 \\
170 \\
610\end{array}$ \\
\hline
\end{tabular}

a Merrill, F. J. H., op. cit.

$b$ Bishop, I. P., New J ork State Geologist Fifth Ann. Rept., p. 19, 1885.

Noтk. $-\lambda t 610$ feet in the second well saturated brine was found in shale, mixed with particles of salt.

Log of well at junction of Bufalo, Rochester \& Pittsburgh Railway with Delaware, Lackawanna \& Western Railroad, Genesee County, N. Y.a

\begin{tabular}{|c|c|c|c|}
\hline Material. & - & $\begin{array}{l}\text { Thick- } \\
\text { ness. }\end{array}$ & Depth. \\
\hline 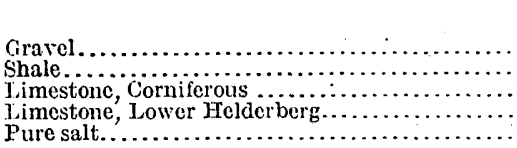 & 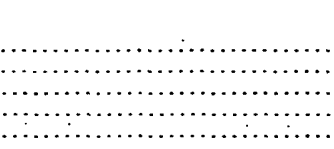 & $\begin{array}{r}\text { Fcet. } \\
46 \\
192 \\
146 \\
454 \\
40\end{array}$ & $\begin{array}{r}\text { Fcet. } \\
46 \\
238 \\
384 \\
838 \\
878\end{array}$ \\
\hline
\end{tabular}

a Bishop, J. P., op. cit., p. 20.

NoTE.-The drill passed directly from limestone to salt, there being no intervening shale, as in other wells. No salt was found in the shale below the main bed, though boring was continued with the expectation of finding it.

Log of well at Pavilion, Genesee County, N. Y.a

[Record furnished by M. E. Calkins.]

\begin{tabular}{|c|c|c|}
\hline Material. & $\begin{array}{l}\text { Thick- } \\
\text { ness. }\end{array}$ & Depth. \\
\hline 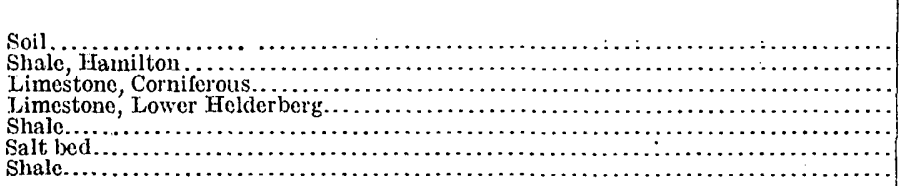 & $\begin{array}{r}\text { Fcct. } \\
51 \\
374 \\
150 \\
374 \\
50 \\
64 \\
12\end{array}$ & $\begin{array}{r}\text { Fcct. } \\
51 \\
425 \\
575 \\
949 \\
999 \\
1,063 \\
1,075\end{array}$ \\
\hline
\end{tabular}

a Bishop, Y. P., New York State Mus. Forty-fifth Ann. Rept., p. 54, 1892. 
Log of well No. 2 of Pavilion Salt Co., Pavilion, Genesee County. N. Y.a

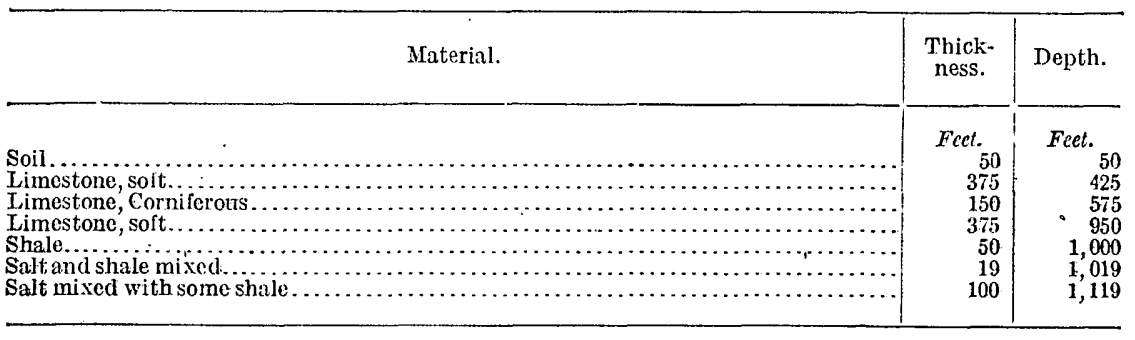

a Merrilf, F. J. H., New York State Mus. Bull. 11, vol. 3, 1893.

Note.-Bottom in shale rock.

L.g of well at Attica, Wyoming County, N. I.a

\begin{tabular}{|c|c|c|}
\hline Material. & $\begin{array}{l}\text { Thick- } \\
\text { ness. }\end{array}$ & Depth. \\
\hline 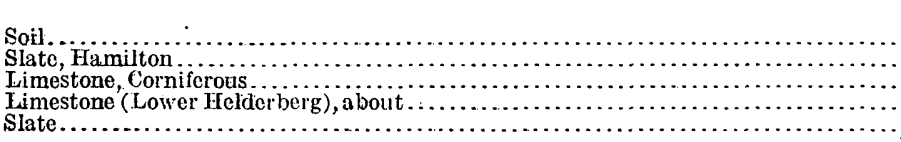 & $\begin{array}{r}\text { Feet. } \\
200 \\
375 \\
156 \\
300 \\
104\end{array}$ & $\begin{array}{r}\text { Feet. } \\
200 \\
575 \\
731 \\
1,031 \\
1,135\end{array}$ \\
\hline
\end{tabular}

a Bishop, I. P., New York State Geologist Fifth Ann. Rept., p. 18, 1885 .

Note.-At 1,490 fect some salt in rock till 1,500 feet. Tatal depth, 1,960 feet. For more details see Bishop's report.

Log of well at Peart Creek, Wyoming County, N. Y.a

[Record furnished by Otis \& Barton.]

\begin{tabular}{|c|c|c|}
\hline Material. & $\begin{array}{c}\text { Thick- } \\
\text { ness. }\end{array}$ & Depth. \\
\hline 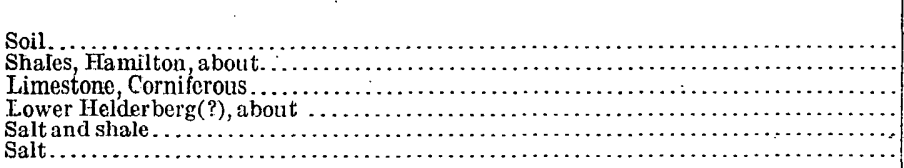 & $\begin{array}{r}\text { Feet. } \\
20 \\
500 \\
90-100 \\
600 \\
20 \\
55\end{array}$ & $\begin{array}{r}\text { Feet. } \\
20 \\
520 \\
620 \\
1,220 \\
1,240 \\
1,295\end{array}$ \\
\hline
\end{tabular}

a Bishop, I. P., New York State Mus.. Forty-fifth Ann. Rept., p. 5t, 1592.

Log of Moulton well, between Pearl Creek and Wyoming, Wyoming County, N. Y.a

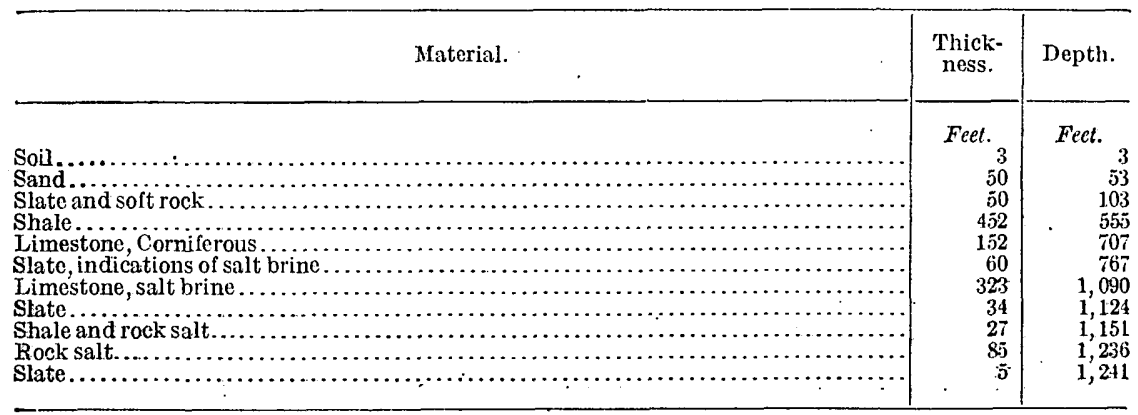

a Bishop, I. P., New York State Geologist Fifth Amn. Rept., p. 20, 18S; 
Log of Proneck wall, neat Wyoming, Wycming Counly, N. F.

\begin{tabular}{|c|c|c|}
\hline Material. & $\begin{array}{c}\text { Thick- } \\
\text { ness. }\end{array}$ & Depth. \\
\hline 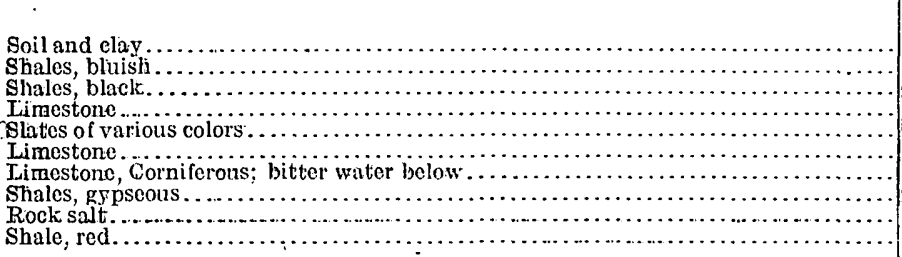 & $\begin{array}{r}\text { Fect. } \\
40 \\
40: \\
220 \\
10 \\
363 \\
100 \\
92 \\
495 \\
7.0 \\
190\end{array}$ & $\begin{array}{r}\text { Fect. } \\
40 \\
\mathrm{S0} \\
309 \\
310 \\
673 \\
5.73 \\
865 \\
1,270 \\
1,340 \\
1,530\end{array}$ \\
\hline
\end{tabular}

a Merrill, F. J.. H., New York Etate Mus. Bull. 11, vol. 3, 1893.

Log of well No. 1 of Crystal Salt Co., Saltrale; Wiyoning County, $N$. F.a

\begin{tabular}{|c|c|c|}
\hline Material. & $\begin{array}{c}\text { Thick- } \\
\text { ness. }\end{array}$ & Depth. \\
\hline 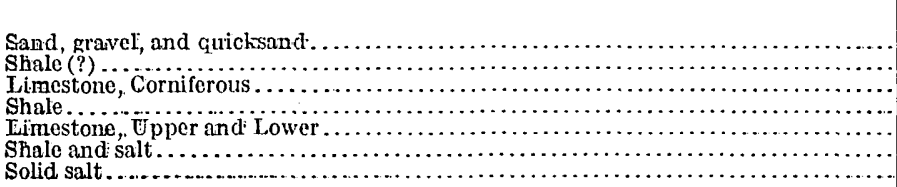 & $\begin{array}{r}\text { Feet. } \\
136 \\
634 \\
146 \\
15 \\
394 \\
50 \\
61\end{array}$ & $\begin{array}{r}\text { Feet }{ }_{136} \\
\mathbf{7 3 6} \\
\mathbf{9 1 6} \\
916 \\
931 \\
\mathbf{1}, 325 \\
\mathbf{1}, 375 \\
1,436\end{array}$ \\
\hline
\end{tabular}

a Bishop, I. P., op. cit., p. 21.

Log of Miller well, Warsan, Wiyoming County, N. Ta

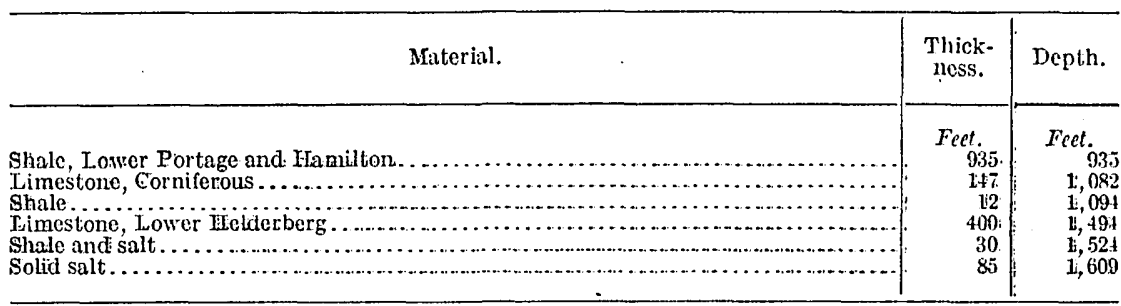

a. Bishop, I.. P., op. cit., P. 21.

Notr.-Depth to base of salt bed, 1,609: feet.

Log of well of Allantic Salt Co., Warsaw, Wyoming County, N. T.a

\begin{tabular}{|c|c|c|}
\hline Materïl: & $\begin{array}{c}\text { Thick- } \\
\text { ness. }\end{array}$ & Depth. \\
\hline 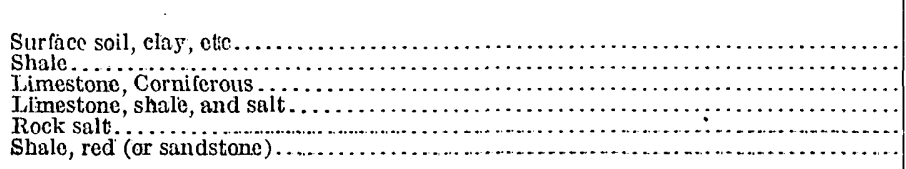 & $\begin{array}{r}\text { Feet. } \\
26 \\
874 \\
148 \\
440 \\
57 \\
104\end{array}$ & $\begin{array}{r}\text { Feet. } \\
26 \\
900 \\
1,048 \\
1,488 \\
1,545 \\
1,649\end{array}$ \\
\hline
\end{tabular}

a Bishop, I. P., op. cit., p. 21; also. Merrill, F. J. H., Table of salt wells, New York State Mus.. Bull L1, 1893. The two records disagree in description of location and thickness of strata. 
Log of well of Warsaw Salt Co., Warsaw, Wyoming County, N. Y.a

\begin{tabular}{|c|c|c|}
\hline Material. & $\begin{array}{c}\text { Thick- } \\
\text { ness. }\end{array}$ & Depth. \\
\hline 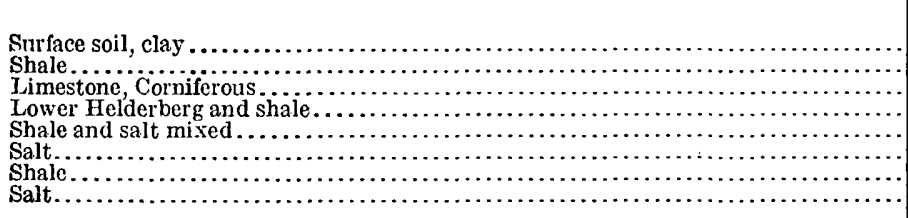 & $\begin{array}{r}\text { Feet. } \\
16 \\
940 \\
156 \\
430 \\
30 \\
6 \\
10 \\
70\end{array}$ & $\begin{array}{r}\text { Feet. } \\
16 \\
956 \\
1,112 \\
1,542 \\
1,572 \\
1,578 \\
1,588 \\
1,658\end{array}$ \\
\hline
\end{tabular}

a Merrill, F. J. H., op. cit.

Log of well of W. C. Gouinlock, Warsaw, Wyoming County, N. T.a

\begin{tabular}{|c|c|c|}
\hline Material. & $\begin{array}{l}\text { Thick- } \\
\text { ness. }\end{array}$ & Depth. \\
\hline 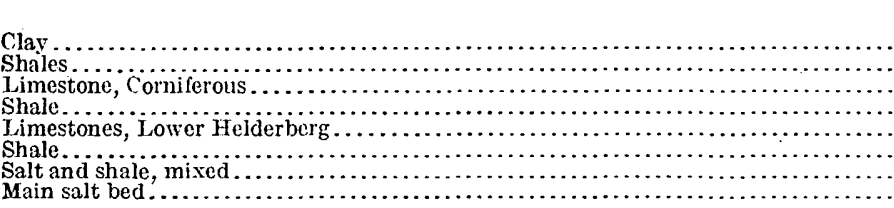 & $\begin{array}{r}\text { Feet. } \\
17 \\
1,011 \\
148 \\
75 \\
300 \\
45 \\
37 \\
68\end{array}$ & $\begin{array}{r}\text { Feet } \\
17 \\
1,028 \\
1,176 \\
1,251 \\
1,551 \\
1,596 \\
1,633 \\
1,701\end{array}$ \\
\hline
\end{tabular}

a Bishop, I. P., op. cit., p. 22 .

Log of well of Gouinlock \& Humphrey, on west side of the valley, Warsaw, Wyoming County, N. Y:a

\begin{tabular}{|c|c|c|}
\hline Material. & $\begin{array}{l}\text { Thick- } \\
\text { ness. }\end{array}$ & Depth. \\
\hline 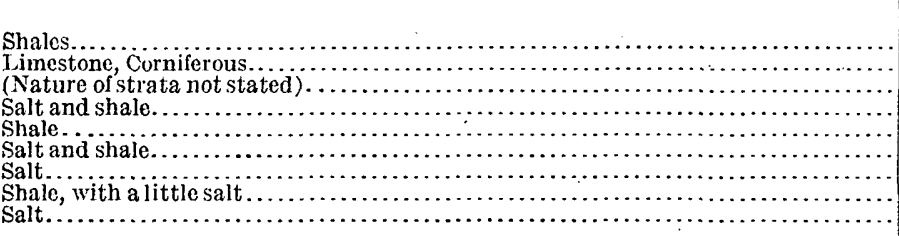 & $\begin{array}{r}\text { Fect. } \\
1,230 \\
150 \\
423 \\
19 \\
3 \\
12 \\
24 \\
2 \\
16\end{array}$ & $\begin{array}{r}\text { Feet. } \\
1,230 \\
1,380 \\
1,803 \\
1,822 \\
1,825 \\
1,837 \\
1,861 \\
1,863 \\
1,879\end{array}$ \\
\hline
\end{tabular}

$a$ Bishop, I. P., op. cit., p. 23.

Log of Bradley well, Warsaw, Wyoming County, N. Y:a

[Bishop calls this the well of the Eldridge Salt Co.; the designation here used is that of F. J. H. Merrill in New York State Mus. Bull. 11, 1893.]

\begin{tabular}{|c|c|c|}
\hline Material. & $\begin{array}{c}\text { Thicls- } \\
\text { ness. }\end{array}$ & Depth. \\
\hline 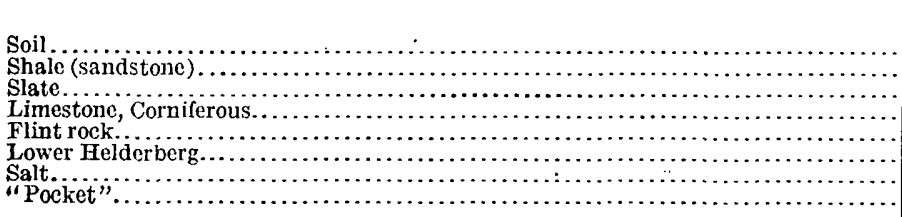 & $\begin{array}{r}\text { Feet. } \\
9 \\
450 \\
856 \\
225 \\
70 \\
365 \\
54 \\
10\end{array}$ & $\begin{array}{r}\text { Feet. } \\
9 \\
1,315 \\
1,540 \\
1,610 \\
1,975 \\
2,029 \\
2,039\end{array}$ \\
\hline
\end{tabular}

a Bishop, I. P., op. cit., p. 23. 
Log of well of Alex: Kerr, Bro. \& Co., Rock Glen, Myoming County, N. Y.a

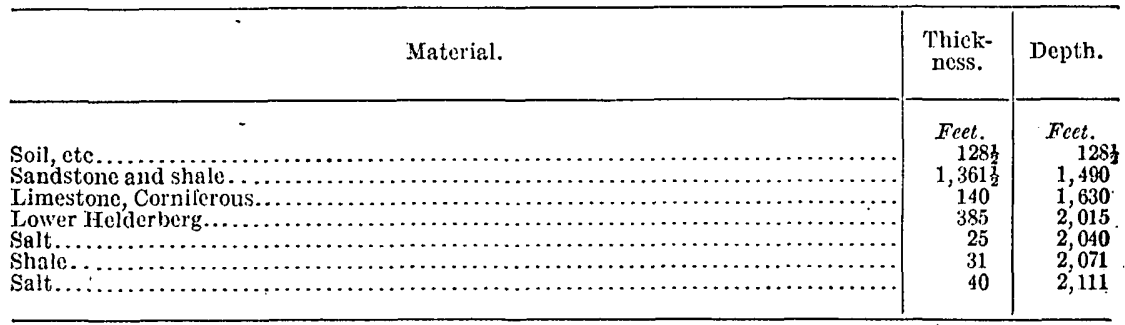

a Bishop, I. P., op. cit., p. 24.

Log of well at Perri, Wyoming County, N. Y.a.

\begin{tabular}{|c|c|c|}
\hline Material. & $\begin{array}{l}\text { Thick- } \\
\text { ness. }\end{array}$ & Depth. \\
\hline 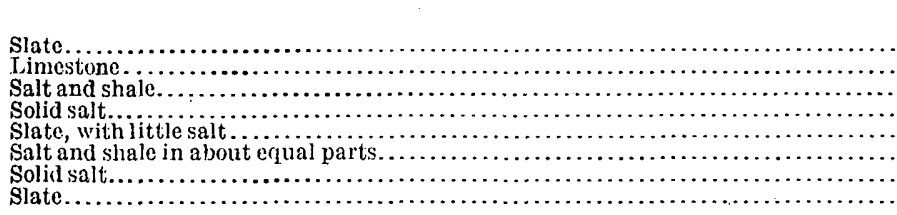 & $\begin{array}{l}\text { Feet. } \\
1,462 \frac{1}{2} \\
580 \\
10 \\
15 \\
40 \\
30 \\
25 \\
18\end{array}$ & $\begin{array}{l}\text { Feet. } \\
1,462 \frac{1}{2} \\
2,042 \frac{1}{2} \\
2,052 \frac{2}{2} \\
2,067 \frac{1}{2} \\
2,107 \frac{1}{2} \\
2,137 \frac{1}{2} \\
2,1621 \\
2,180 \frac{1}{2}\end{array}$ \\
\hline
\end{tabular}

a Bishop, I. P., op. cit., p. 24.

Log of well of Duncan Salt Co., Silver Springs, Wyoming County, N. Y.a

\begin{tabular}{|c|c|c|}
\hline Material. & $\begin{array}{l}\text { 'Thick- } \\
\text { ness. }\end{array}$ & Depth. \\
\hline 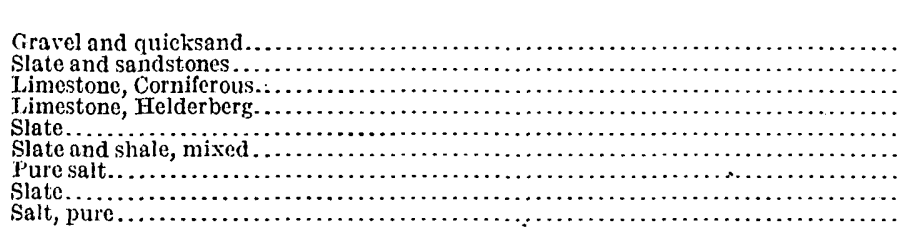 & $\begin{array}{r}\text { Feet. } \\
222 \\
1,299 \\
140 \\
320 \\
128 \\
15 \\
10 \\
45 \\
75\end{array}$ & $\begin{array}{r}\text { Fcet } . \\
222 \\
1,521 \\
1,661 \\
1,981 \\
2,109 \\
2,124 \\
2,134 \\
2,179 \\
2,254\end{array}$ \\
\hline
\end{tabular}

a Bishop, I. P., op. cit., p. 25.

Log of typical well section near Silver Springs, Wyoming County, N. Y.a

\begin{tabular}{|c|c|c|}
\hline Naterial. & $\begin{array}{l}\text { Thick- } \\
\text { ness. }\end{array}$ & Depth. \\
\hline 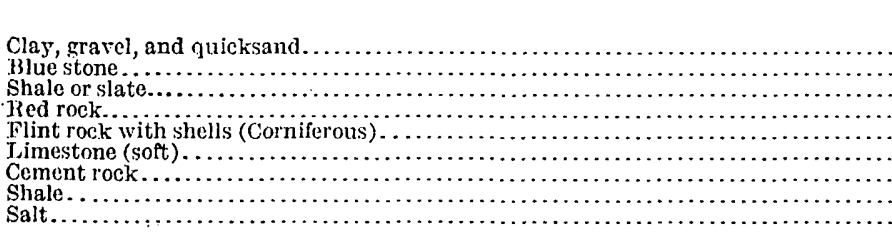 & $\begin{array}{r}\text { Fcet: } \\
200 \\
50 \\
1,200 \\
40 \\
150 \\
200 \\
250 \\
80 \\
100\end{array}$ & $\begin{array}{r}\text { Feet. } \\
200 \\
250 \\
1,450 \\
1,490 \\
1,640 \\
1,840 \\
2,090 \\
2,170 \\
2,270\end{array}$ \\
\hline
\end{tabular}

a Furnished by superintendent of Worcester Salt Co., Silver Springs, N. Y. 
Log: of well at Castite, Wyoming: County, N. Y. ${ }^{i t}$

\begin{tabular}{|c|c|c|}
\hline Material. & $\begin{array}{l}\text { Thick- } \\
\text { ness. }\end{array}$ & Depth. \\
\hline Soil: & Feet. & Feet. \\
\hline Sandstone; argiliaceous; 175 feet or..... & 180 & 229 \\
\hline Shale, blue, nearly uniform in color and hardness. & 786 & 1,015 \\
\hline Flint shell & 10 & 1,025 \\
\hline 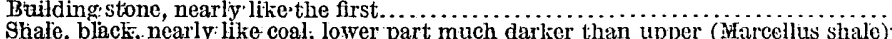 & $\begin{array}{l}650 \\
100\end{array}$ & $\begin{array}{l}1 ; 675 \\
1,775\end{array}$ \\
\hline 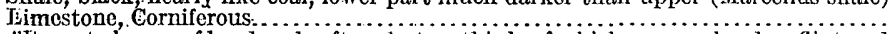 & 140 & $1 ; 915$ \\
\hline $\begin{array}{l}\text { Silternate layers of hard and soft rock, two-thirds of which was as hard as flint and } \\
\text { the rest shale }\end{array}$ & & \\
\hline 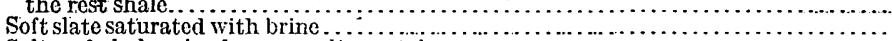 & 320 & $\begin{array}{l}2,2,235 \\
2,335\end{array}$ \\
\hline Salt and shale mixed; some salt crystals. & 35 & 2,370 \\
\hline Clear salt........................... & 4.5 & 2,415 \\
\hline Salt and slate, 5 feet of which was salt.. & 70 & $\begin{array}{l}2,455 \\
2,525\end{array}$ \\
\hline
\end{tabular}

a Bishop, I. P., op. cit., pp. 25-26.

Log of 'well of Bliss Salt \& Oil Co., Bliss, Wyoming County, N. I.a.

\begin{tabular}{|c|c|c|}
\hline Material. & $\begin{array}{l}\text { Thick- } \\
\text { ness. }\end{array}$ & Deptals. \\
\hline$\ldots$. & Fect. & Fect. ${ }_{55}$ \\
\hline To gas sand: & 580 & 035 \\
\hline 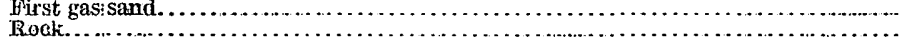 & $40:$ & $\begin{aligned} 605 \\
1.200\end{aligned}$ \\
\hline Sacond gas and oil saind & 100 & 1,300 \\
\hline Shale and black rock............. & 400 & 1,700 \\
\hline Third gas sand ......................... & 14 & 1,714 \\
\hline 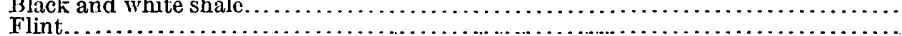 & 2260 & $\begin{array}{l}2,000 \\
2,100\end{array}$ \\
\hline Limeroch and flint (solid) .......... & 806 & 2,900 \\
\hline $\begin{array}{l}\text { Salt (very pu } \\
\text { Limenoch (so }\end{array}$ & 56 & 2,956 \\
\hline Limerock (solid & & \\
\hline
\end{tabular}

$a$ Merrill, F. J. H., New York State Mus. Bull. 11, rol. 3, 1893.

Log of well at Caledonia, Livingston County, N. Y.a

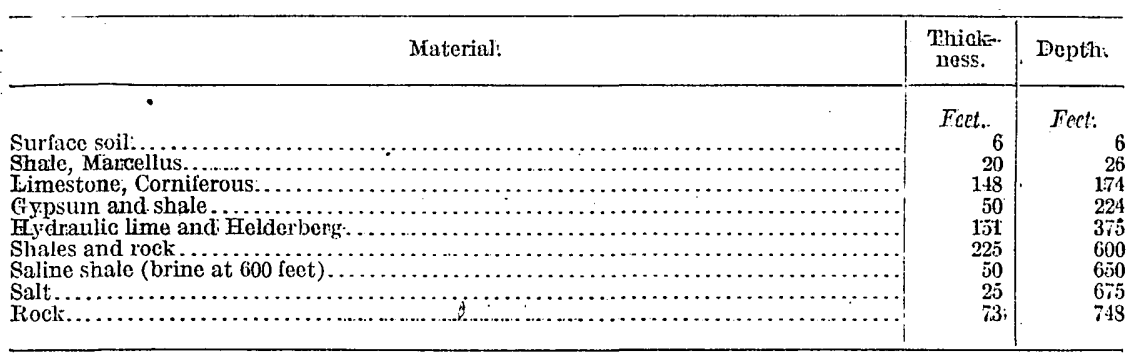

a Bishop, I. P., op. cit., pp. 26-27.

Log of well of York Salt Co., York, Livingston County, N. Y.a

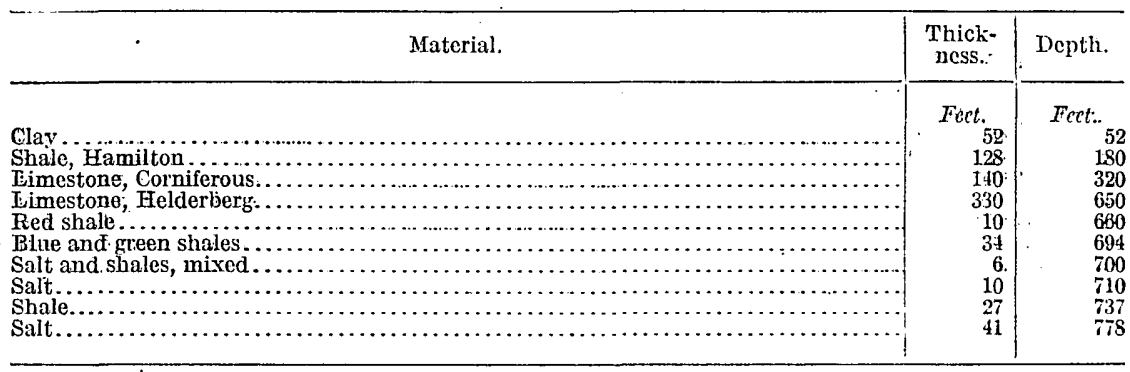


Log of well of Livingston Salt C'o., Piffard, Livingston Counity, N. Y.a

\begin{tabular}{|c|c|c|}
\hline Material. & $\begin{array}{l}\text { Thick- } \\
\text { mess. }\end{array}$ & Depth. \\
\hline 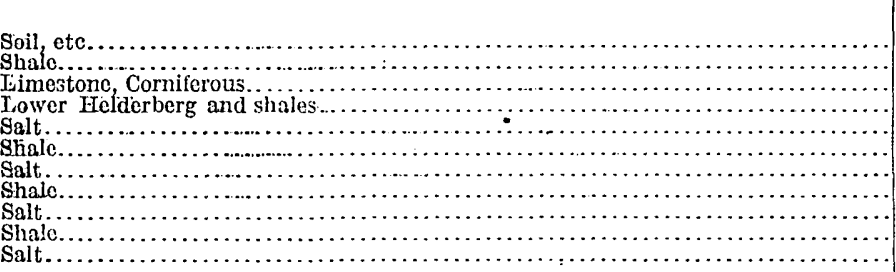 & $\begin{array}{r}\text { Fect. } \\
155 \\
77 \\
150 \\
453 \\
15 \\
6 \\
11 \\
4 \\
2 \\
20 \\
62\end{array}$ & $\begin{array}{r}158 \\
235 \\
3 \times 5 \\
838 \\
875 \\
8152 \\
873 \\
877 \\
879 \\
899 \\
961\end{array}$ \\
\hline
\end{tabular}

$a$ Bishop, I. P., op. cit., p. 27.

Log of well of Genesee Salt Co., Fiffurd, Livingston County, N. Y.a

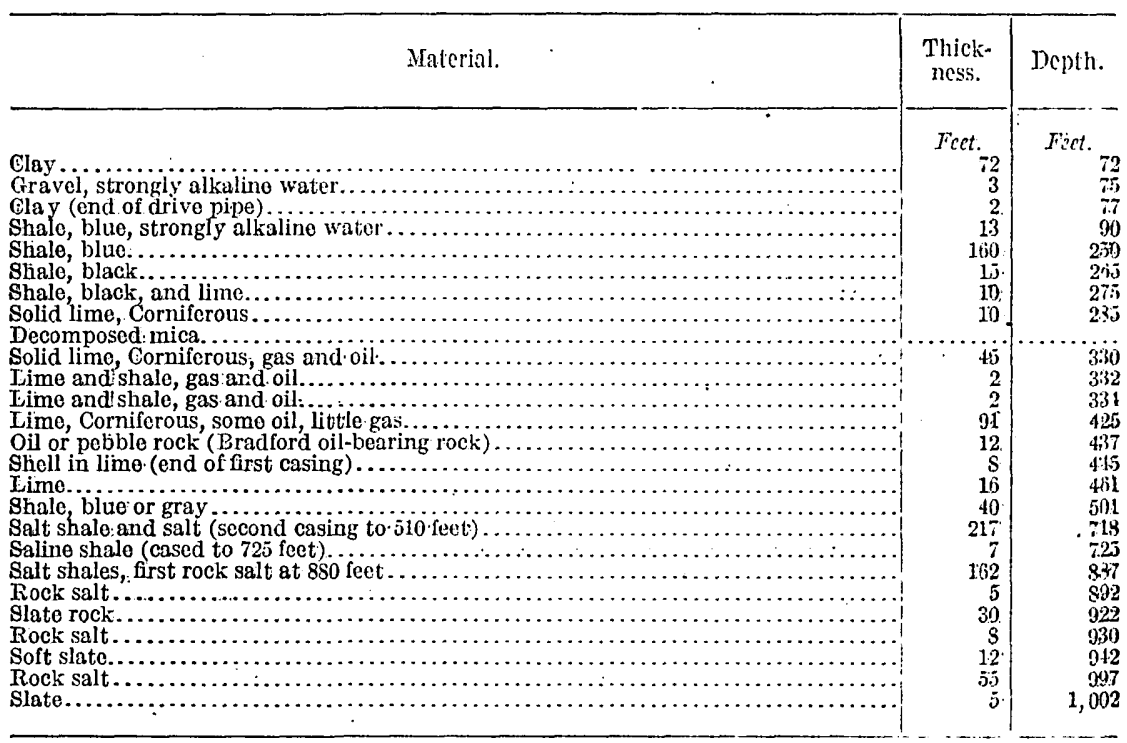

a Furnished by superintendent of company.

Note. - First flow of brine $\left(65^{\circ}\right.$ salimeter) at 718 feet rose to about 60 feet from the surface. The brine at 725 feet registered $75^{\circ}$ salimeter.

Log of well of Genesee Salt Co., Piffard, Livingston County, N. Y.a

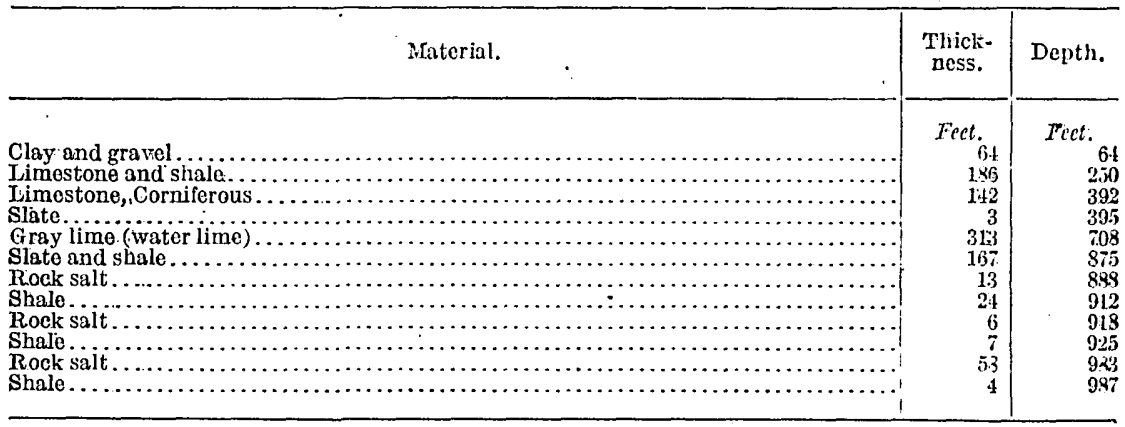

a Merrill, F. J. H., New York State Mus. Bull. 11, rol. 3, 1893.

NorE.-Brine of $68^{\circ}$ salimeter at 708 feet. 
Log of well a short distance above Genesee Co.'s works, Piffard, Livingston County, N. Y.a

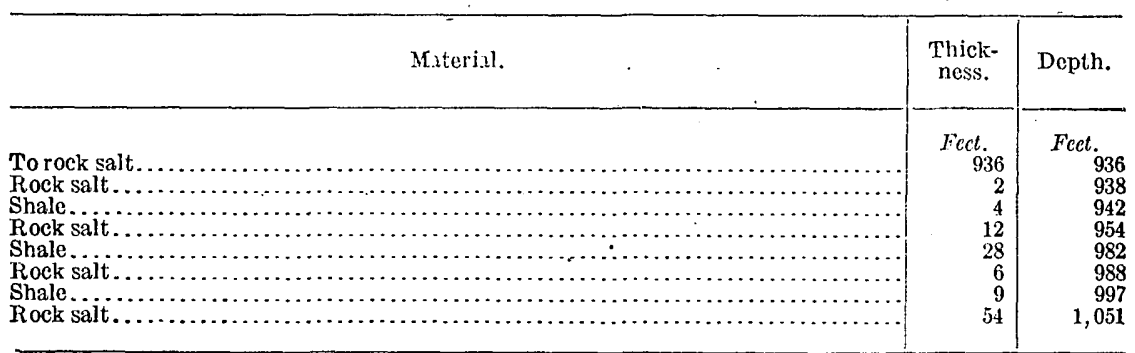

a Bishop, I. P., New York State Geologist Fifth Ann. Rept., p. 28, 1885.

Log of well of Retsof . Yining Co., Piffard, Livingston County, N. Y.a

\begin{tabular}{|c|c|c|}
\hline Material. $\quad$ & $\begin{array}{c}\text { Thick- } \\
\text { noss. }\end{array}$ & Depth. \\
\hline Fneringllimestonio & Fect. & Fect. \\
\hline 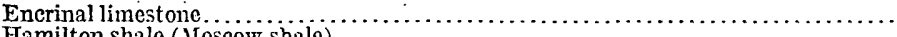 & & \\
\hline 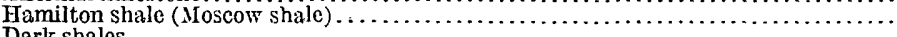 & 40 & 48 \\
\hline 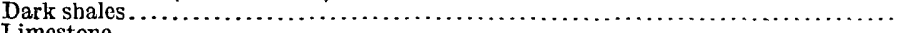 & 93 & 141 \\
\hline 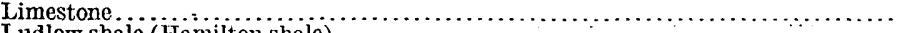 & 8 & 149 \\
\hline 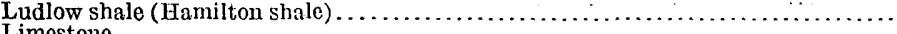 & 216 & 365 \\
\hline 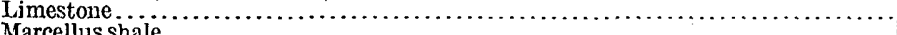 & 4 & 369 \\
\hline 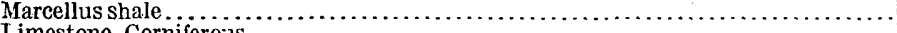 & 39 & 408 \\
\hline 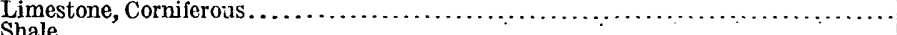 & 2 & 410 \\
\hline 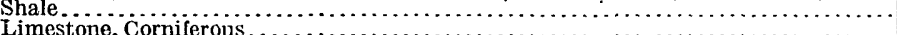 & 1 & 411 \\
\hline 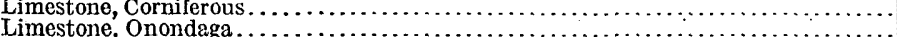 & 140 & 551 \\
\hline 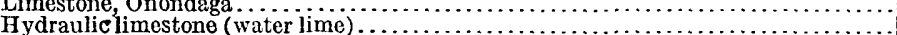 & 1 & 552 \\
\hline 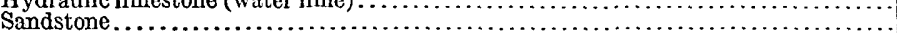 & 13 & 50 \\
\hline ................ & $\begin{array}{r}1 . t \\
4\end{array}$ & 583 \\
\hline Hydraulic limestone....... & 25 & 608 \\
\hline 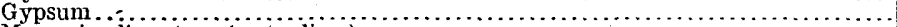 & 47 & 655 \\
\hline 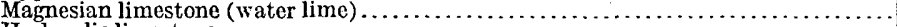 & 63 & 718 \\
\hline 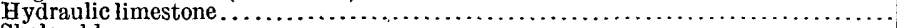 & 1.4 & 732 \\
\hline 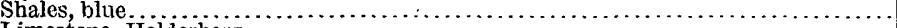 & 25 & 757 \\
\hline 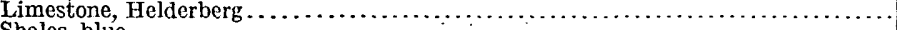 & 10 & 767 \\
\hline 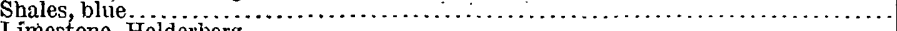 & 12 & 779 \\
\hline 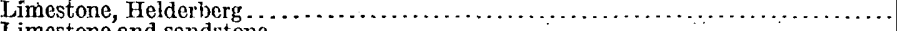 & 17 & 796 \\
\hline 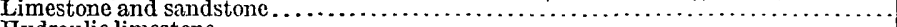 & 31 & 827 \\
\hline Hydraulic limestone .............. & 10 & 837 \\
\hline Limestone and cement....... & 15 & 852 \\
\hline Hydraulic limestone.... & 6 & 858 \\
\hline$\ldots \ldots \ldots \ldots \ldots \ldots \ldots \ldots \ldots \ldots$ & 19 & 877 \\
\hline 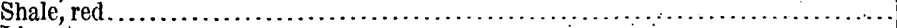 & 12 & 889 \\
\hline 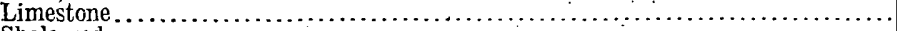 & 41 & 930 \\
\hline Shale, red $\ldots \ldots \ldots \ldots \ldots \ldots \ldots \ldots \ldots$ & -5 & 935 \\
\hline Shale, blue $\ldots \ldots \ldots \ldots \ldots \ldots \ldots \ldots \ldots$ & 12 & 947 \\
\hline Limestone $\ldots \ldots \ldots \ldots \ldots \ldots \ldots \ldots \ldots \ldots \ldots$ & 12 & 959 \\
\hline shale............... & 51 & 1,010 \\
\hline 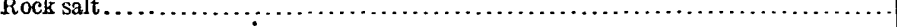 & & 1,012 \\
\hline
\end{tabular}

( Merrill, F. J. H., New York State Mus. Bull. 11, vol. 3; 1893.

Log of well of Retsof II Ining Co., Piffard, Livingston County, N. Y.a

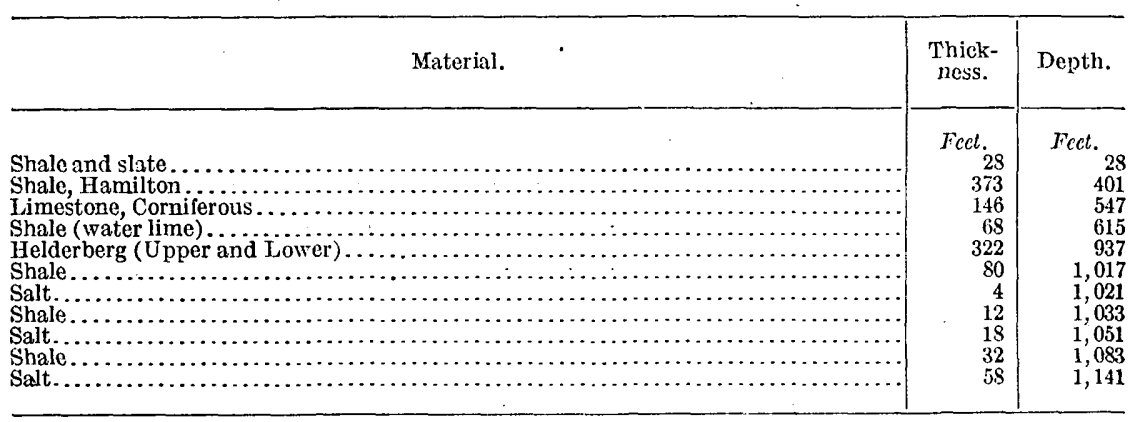

a Merrill, F. J. H., op. cit.

NoTE.-First well sunk on the property where the shaft is now. 
Log of the main hoisting shaft,-Retsof Ifining Co., Retsof, Livingston County, N. Y.a

\begin{tabular}{|c|c|c|}
\hline Material. & $\begin{array}{l}\text { Thick- } \\
\text { ness. }\end{array}$ & Depth. \\
\hline 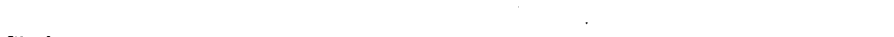 & Frct. & Fcet. \\
\hline Shalo................. & 133 & 133 \\
\hline 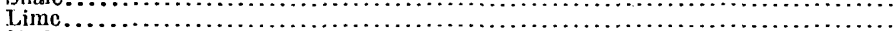 & & 141 \\
\hline 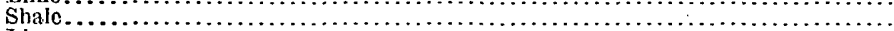 & 232 & 373 \\
\hline 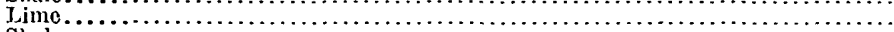 & & 377 \\
\hline 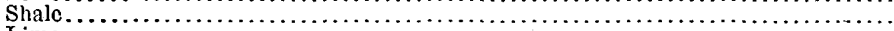 & 23 & 400 \\
\hline 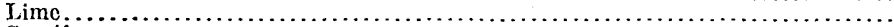 & 3 & 403 \\
\hline 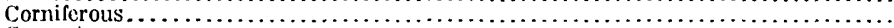 & 142 & 545 \\
\hline 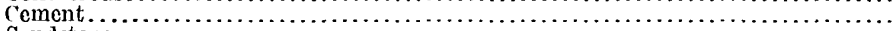 & 13 & 558 \\
\hline 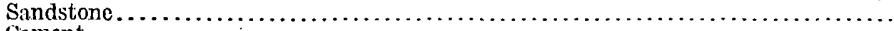 & 4 & 562 \\
\hline 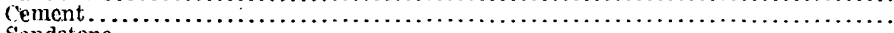 & 7 & $5 \mathrm{fig}$ \\
\hline 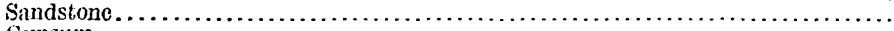 & 14 & 583 \\
\hline 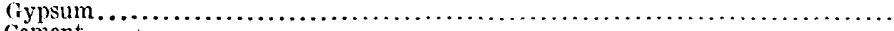 & 4 & 587 \\
\hline 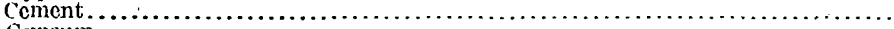 & 26 . & 613 \\
\hline 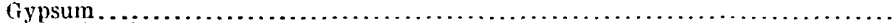 & 47 & 660 \\
\hline 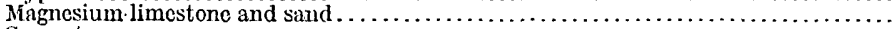 & 63 & 723 \\
\hline 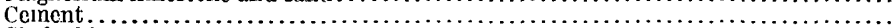 & 14 & 737 \\
\hline 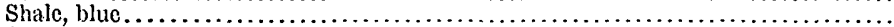 & 25 & 762 \\
\hline 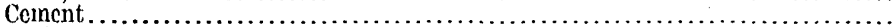 & 10 & .772 \\
\hline 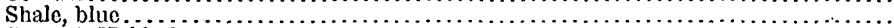 & 12 & 784 \\
\hline 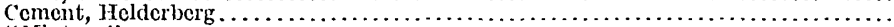 & 17 & 801 \\
\hline "Mixture"..................... & 31 & 832 \\
\hline 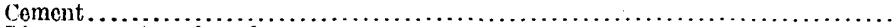 & 10 & 842 \\
\hline Lime, coment, and sand......... & 15 & 857 \\
\hline 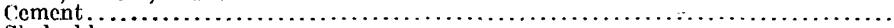 & 6 & 863 \\
\hline$\ldots \ldots \ldots \ldots \ldots \ldots \ldots$ & 19 & 882 \\
\hline Shale, red.. & 12 & 894 \\
\hline 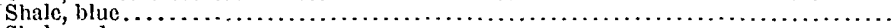 & 41 & 935 \\
\hline 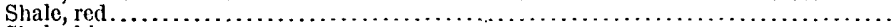 & 5 & 940 \\
\hline$\ldots \ldots \ldots \ldots \ldots \ldots$ & 12 & 952 \\
\hline .................. & 12 & 964 \\
\hline le $\ldots \ldots \ldots \ldots$ & 32 & 996 \\
\hline Foot of shaft in rock salt. .......... & 21 & $\cdot 1,017$ \\
\hline
\end{tabular}

a Obtained through the courtesy of Mr. Frank Rundio, general superintendent of Retsof Mining Co.

Log of well al Greigsville, Livingsion County, $N . Y^{\prime} \cdot a$

\begin{tabular}{|c|c|c|}
\hline Matcrial. & $\begin{array}{l}\text { Thick- } \\
\text { ness. }\end{array}$ & Depth. \\
\hline 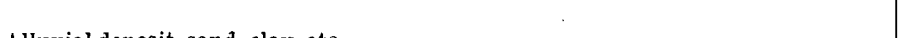 & Fect. & Fect. \\
\hline 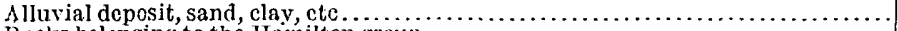 & 60 & 60 \\
\hline Rocks belonging to the Hainilton group $\ldots \ldots \ldots \ldots \ldots \ldots \ldots \ldots$ & 112 & 172 \\
\hline 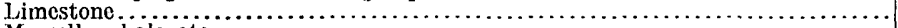 & 10 & 182 \\
\hline 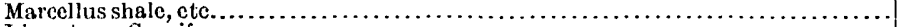 & 260 & 442 \\
\hline 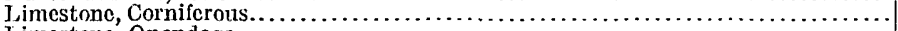 & 150 & 522 \\
\hline Limestone, Onondaga............. & 10 & 602 \\
\hline 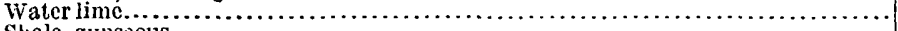 & 40 & 642 \\
\hline 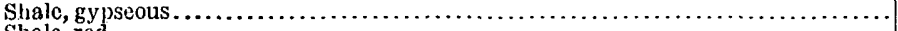 & 75 & 717 \\
\hline 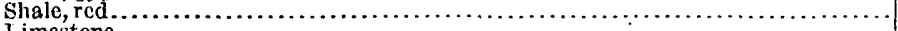 & 12 & 729 \\
\hline 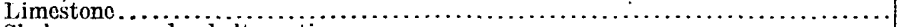 & 12 & 741 \\
\hline 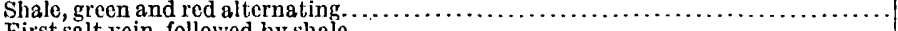 & 269 & 1,010 \\
\hline 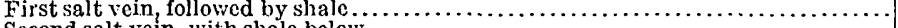 & 2 & 1,012 \\
\hline 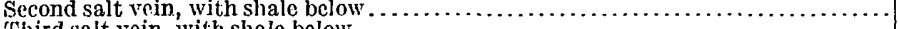 & 4 & 1,016 \\
\hline 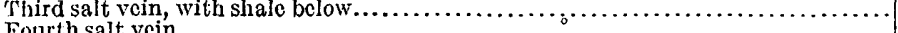 & 19 & 1,035 \\
\hline 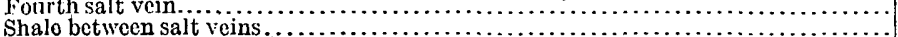 & $\begin{array}{l}58 \\
45\end{array}$ & $\begin{array}{l}1,093 \\
1,138\end{array}$ \\
\hline alo delinetesa & & \\
\hline
\end{tabular}

a Merrill, F. J. H., Now York State Mus. Bull. 11, vol. 3, 1893. $40104^{\circ}-15-$ Bull. $669-3$ 
Log oj.well three-quarlers of a mile south of Greigsville, Livingston County, N. Y.a

\begin{tabular}{|c|c|c|}
\hline Material. & $\begin{array}{l}\text { Thick- } \\
\text { ness. }\end{array}$ & Depth. \\
\hline & Feet. & Feet. \\
\hline $\begin{array}{l}\text { Alluvium }{ }_{\text {Hamilton }} \text { shales } \\
\text { Hal }\end{array}$ & 105 & $\frac{1}{2}$ \\
\hline & $\begin{array}{r}145 \\
12\end{array}$ & 2 \\
\hline 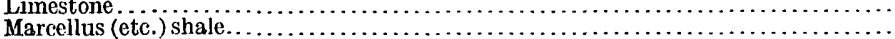 & $\begin{array}{r}12 \\
182\end{array}$ & \\
\hline 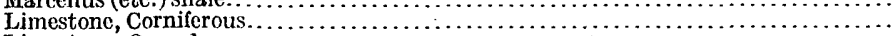 & 148 & 5 \\
\hline Iimestone, Onondaga............ & 10 & 6 \\
\hline 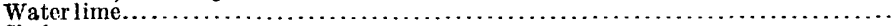 & 78 & 6 \\
\hline Shale, gypseous . . . . . . . . . . . . & $\$ 0$ & \\
\hline Shale, grecn and red......... & 275 & 1,0 \\
\hline First salt bed & 19 & 1,064 \\
\hline 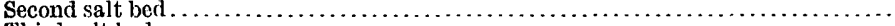 & 6 & 1,070 \\
\hline 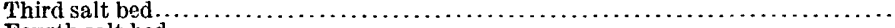 & 6 & 1,076 \\
\hline 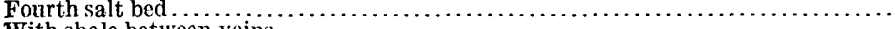 & 6 & 1,082 \\
\hline With shale between veins & 63 & \\
\hline
\end{tabular}

a Morrill, F. J. H., op. cit.

Log of well of Phoenix Salt Co., Cuylerville, Litingston County, N. Y.a

\begin{tabular}{|c|c|c|}
\hline Material. & $\begin{array}{c}\text { Thick- } \\
\text { ness. }\end{array}$ & Depth. \\
\hline 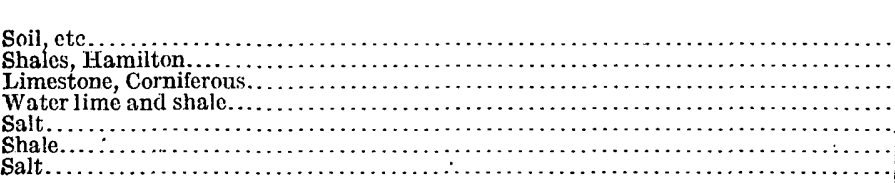 & $\begin{array}{r}\text { Feet. } \\
184 \\
286 \\
140 \\
500 \\
4 \\
3 \\
28\end{array}$ & $\begin{array}{r}\text { Feet. } \\
184 \\
470 \\
610 \\
1,110 \\
1,114 \\
1,117 \\
1,145\end{array}$ \\
\hline
\end{tabular}

a Bishop, I. I., New York State Geologist Fifth Ann. Rept., p. 30, 1885.

Log of well of Lackawanna Salt Co., Mount Morris, Livingston County, N. Ya

\begin{tabular}{|c|c|c|}
\hline Material. & $\begin{array}{l}\text { Thick- } \\
\text { ness. }\end{array}$ & Depth. \\
\hline 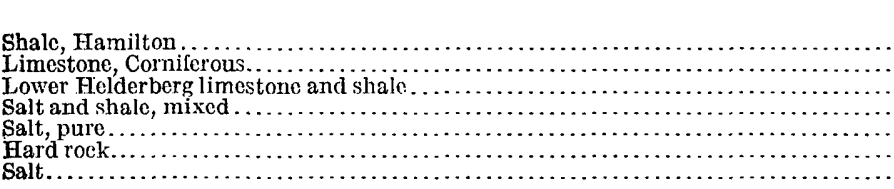 & $\begin{array}{r}\text { Fect. } \\
600 \\
140 \\
463 \\
12 \\
23 \\
20 \\
75\end{array}$ & $\begin{array}{r}\text { Feet. } \\
600 \\
740 \\
1,203 \\
1,215 \\
1,238 \\
1,258 \\
1,333\end{array}$ \\
\hline
\end{tabular}

a Bishop, I. P., op. cit., p. 30.

Log of well of Royal Salt Co., Mount Morris, Livingston County, N. Ya

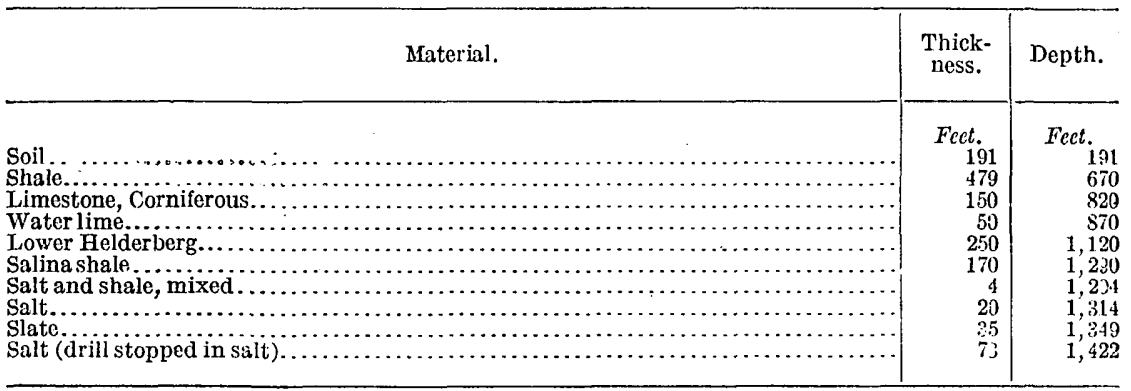


Log of well of Conesus Lake Salt \& Mining Co., Lakcrille, Livingston County, N. Fa

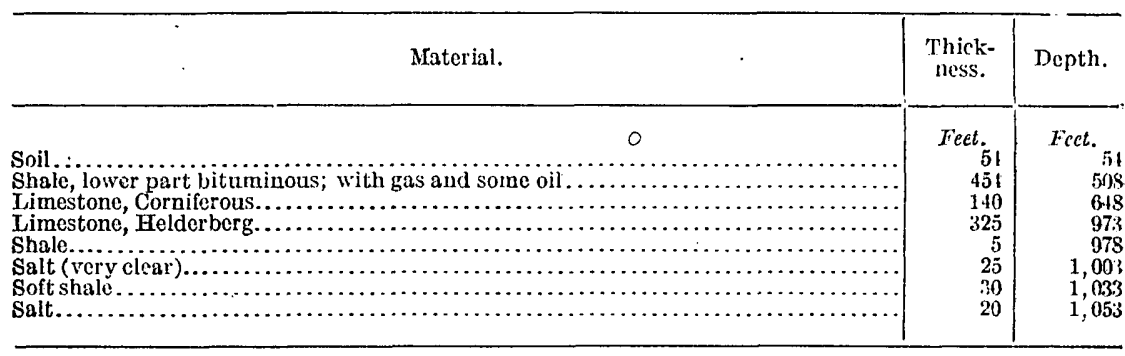

a Bishop, I. P., op. cit., p. 31 .

Log of Livonia well, bored by Ifr. Tounsend, half a mile north of Livonia, Livingston County, N. Y.a

\begin{tabular}{|c|c|c|}
\hline Material. & $\begin{array}{l}\text { Thick- } \\
\text { ness. }\end{array}$ & Depth. \\
\hline 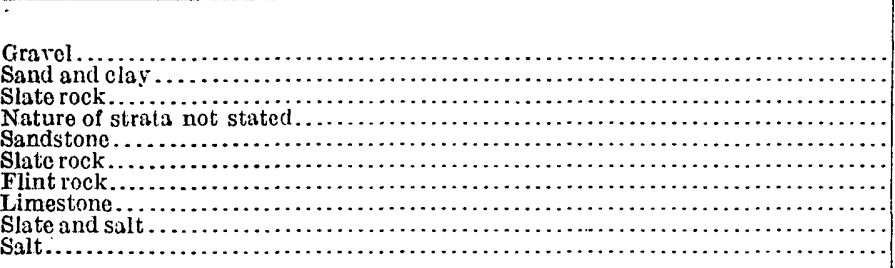 & $\begin{array}{r}\text { Fect. } \\
90 \\
250 \\
65 \\
6 \\
10 \\
284 \\
140 \\
345 \\
5 \\
32 .\end{array}$ & $\begin{array}{r}\text { Feet. } \\
39 \\
341 \\
405 \\
411 \\
121 \\
705 \\
845 \\
1,190 \\
1,197 \\
1,2275\end{array}$ \\
\hline
\end{tabular}

a Merrill, F. J. H., New York State Mus. Bull. 11, voi. 3, 1893.

Log of Livonia shaft, Livonia, Livingston County, N. Y.a

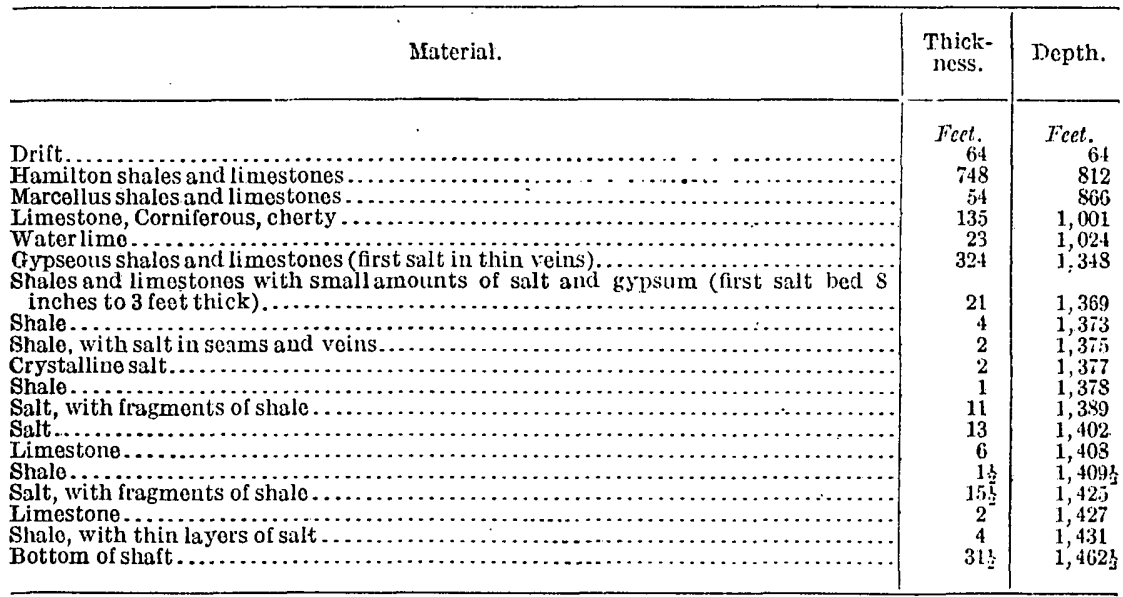

a Merrill, F. J. Ir., op. cit. 
Log of well on Reed farm, Livonia, Livingston Couniy, N. Y.a

\begin{tabular}{|c|c|c|}
\hline Material. & $\begin{array}{l}\text { Thick- } \\
\text { ness. }\end{array}$ & Depth. \\
\hline 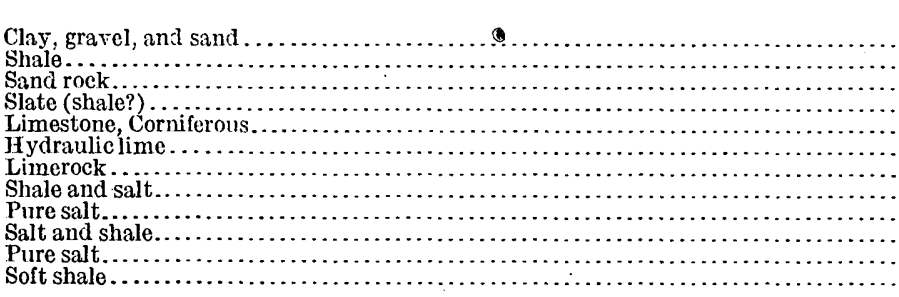 & $\begin{array}{r}\text { Fcet. } \\
56 \\
464 \\
10 \\
302 \\
133 \\
45 \\
3131 \\
11 \frac{1}{35} \\
35 \\
15 \\
114\end{array}$ & $\begin{array}{r}\text { Feet. } \\
56 \\
520 \\
530 \\
832 \\
965 \\
1,010 \\
1,3231 \\
1,335 \\
1,370 \\
1,378 \\
1,393 \\
1,507\end{array}$ \\
\hline
\end{tabular}

$a$ Bishop, I. P., New York State Mus. Forty-filth Ann. Rept., p. 57, 1892. [Furnished by D. D. Luther.] Log of wcll at Nunda, Livingston County, $N_{i}, Y{ }^{a}$

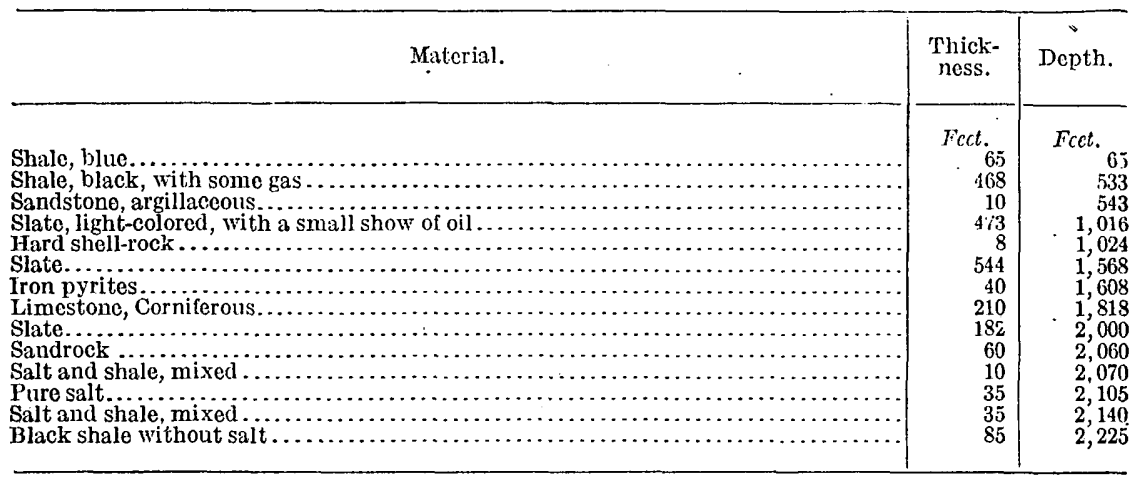

$a$ Bishop, I. P., New York State Geologist Fifth Ann. Rept., p. 26, 1885.

Log of well of Danswille Oil, Gas \& Mining Co., Dansville, Livingston County, N. Y.a

\begin{tabular}{|c|c|c|}
\hline Material. & $\begin{array}{l}\text { Thick- } \\
\text { ness. }\end{array}$ & Depth. \\
\hline 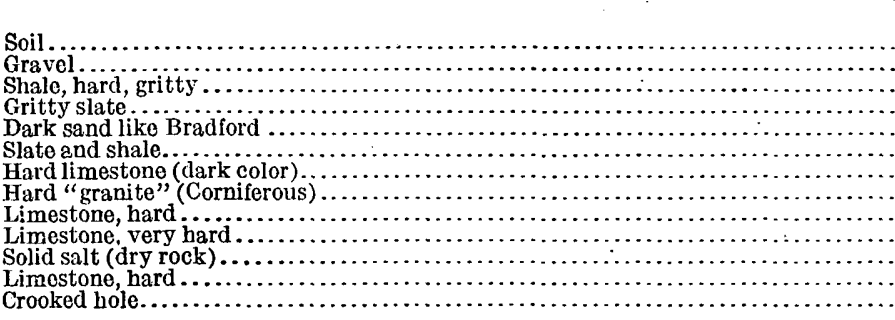 & $\begin{array}{r}\text { Feet. } \\
20 \\
10 \\
70 \\
20 \\
15 \\
1,565 \\
80 \\
80 \\
40 \\
200 \\
60 \\
70 \\
10\end{array}$ & $\begin{array}{r}\text { Fect. } \\
20 \\
30 \\
100 \\
120 \\
135 \\
1,700 \\
1,780 \\
1,860 \\
1,900 \\
2,100 \\
2,160 \\
2,230 \\
2,240\end{array}$ \\
\hline
\end{tabular}

a Merrill, F. J. H., New York State Mus. Bull. 11, vol. 3, 1883.

Log of well at Mfuttonville, near Bristol, Ontario County, N. Y.a

\begin{tabular}{|c|c|c|}
\hline Material. & $\begin{array}{l}\text { Thick- } \\
\text { ness. }\end{array}$ & Depth. \\
\hline $\begin{array}{l}\text { Shale, about } \ldots \ldots \ldots \ldots \ldots \ldots \ldots \\
\text { Limestone, about } \ldots \ldots \ldots \ldots \ldots \ldots\end{array}$ & $\begin{array}{r}\text { Fcet. } \\
550 \\
450\end{array}$ & $\begin{array}{l}\text { Feet. } \\
\quad \begin{array}{r}559 \\
b 1,000\end{array}\end{array}$ \\
\hline
\end{tabular}

a Bishop, I. P., New York State Geologist Fifth A nn. Rept., p. 32, $18 \$ 5$. $b$ Then more than 300 feet of shale and salt, with rock salt at the bottom. 
Log of well at Clifton Springs, Ontario County, N. Y.a

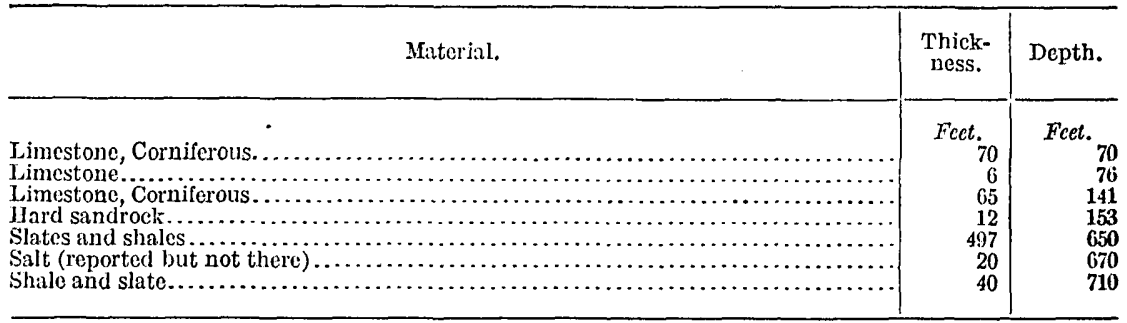

a Merrill, F. J. H., New York State Mus. Bull. 11, vol. 3, 1893.

Log of Gcorge G. Hill salt well, Watkins, Schuyler County, N. Y.a

\begin{tabular}{|c|c|c|}
\hline Matcrial. & $\begin{array}{l}\text { Thick- } \\
\text { ness. }\end{array}$ & Depth. \\
\hline 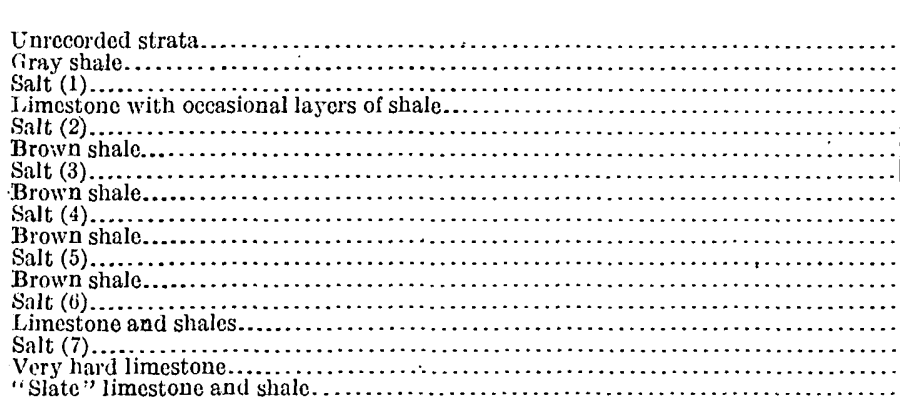 & $\begin{array}{r}\text { Feet. } \\
1,880 \\
125 \\
265 \\
10 \\
28 \\
40 \\
72 \\
57 \\
10 \\
20 \\
23 \\
70 \\
50 \\
130 \\
10 \\
100 \\
395\end{array}$ & $\begin{array}{r}\text { Feet. } \\
1,880 \\
2,005 \\
2,270 \\
2,310 \\
2,338 \\
2,378 \\
2,450 \\
2,507 \\
2,517 \\
2,537 \\
2,560 \\
2,630 \\
2,680 \\
2,810 \\
2,820 \\
2,920 \\
3,315\end{array}$ \\
\hline
\end{tabular}

a Kindle, E. M., U. S. Geol. Survey Bull. 260, p. 56 $198,1905$.

Nore.-The record at Watkins shows the salt to be distributed throughout $\$ 15$ feet of the Salina formation.

Log of well No. 6, International Salt Co., Watkins, Schuyler County, N. Y.

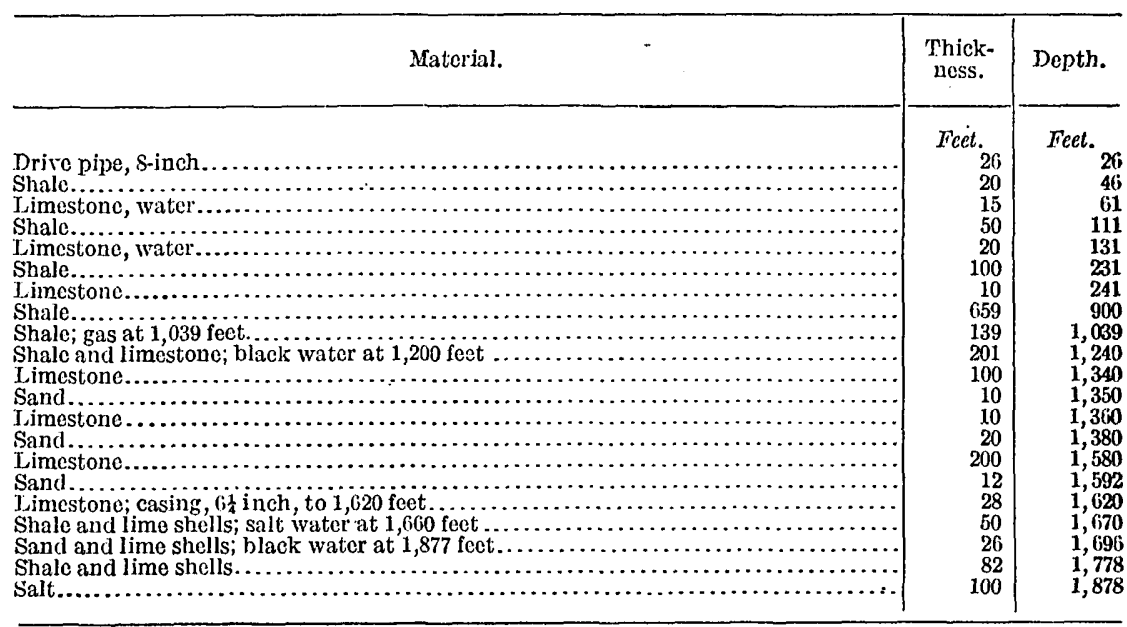

NoTE.-The International Salt Co. has seven wells from which artificial brines are obtained for the manufacture of salt. The wells are distributed alongside tho plant near the edge of Take Seneca, and are located a hundred feet or mora apart in the following order from north to sonth, Nos. 1, 7, 6, 4, 2,5, 3. The first four were drilled about 1893, No. 5 a little later, and Nos. 6 and 7 about 1908 (?). The depths of the wells are as given on page 38 . 
Log of well No. 7, International Salt Co., Watlins, Schryler County, N. Y.

\begin{tabular}{|c|c|c|}
\hline Material & $\begin{array}{c}\text { Thick- } \\
\text { ness. }\end{array}$ & Depth. \\
\hline 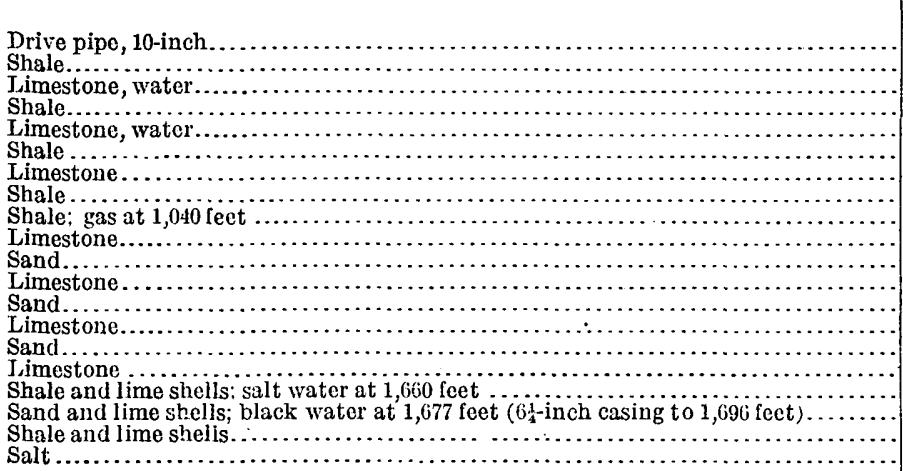 & $\begin{array}{r}\text { Feet. } \\
22 \\
24 \\
15 \\
50 \\
20 \\
100 \\
10 \\
659 \\
340 \\
100 \\
10 \\
10 \\
20 \\
200 \\
12 \\
28 \\
50 \\
26 \\
83 \\
96\end{array}$ & $\begin{array}{r}\text { Feet. } \\
22 \\
46 \\
61 \\
111 \\
131 \\
231 \\
241 \\
900 \\
1,240 \\
1,340 \\
1,350 \\
1,360 \\
1,380 \\
1,580 \\
1,592 \\
1,620 \\
1,670 \\
1,696 \\
1,779 \\
1,575\end{array}$ \\
\hline
\end{tabular}

Note.-10-inch hole to 660 feet, and 8-inch hole from 660 to 1,690 feet.

Depths of wells of International Salt Co., Watliins, N. Y.

\begin{tabular}{|c|c|c|}
\hline & $\begin{array}{l}\text { Depth } \\
\text { to salt. }\end{array}$ & $\begin{array}{l}\text { Total } \\
\text { depth. }\end{array}$ \\
\hline 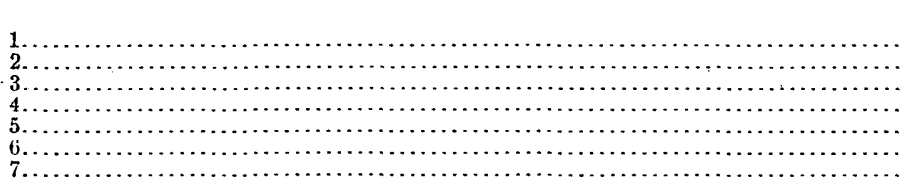 & $\begin{array}{c}\text { Fcet. } \\
1,760 \\
1,775 \\
1,780 \\
1,769 \\
1,780 \\
1,778 \\
1,779\end{array}$ & $\begin{array}{r}\text { Fect. } \\
1,854 \\
1,830 \\
1,870 \\
1,890 \\
1,883 \\
1,878 \\
1,875\end{array}$ \\
\hline
\end{tabular}

Log of well at Aurora, Cayuga County, N. Ya

\begin{tabular}{|c|c|c|}
\hline Material. & $\begin{array}{l}\text { Thick- } \\
\text { ness. }\end{array}$ & Depth. \\
\hline Soil ........ & Feet. & Feet. \\
\hline (1, & 10 & 15 \\
\hline 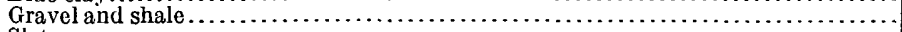 & 95 & 110 \\
\hline 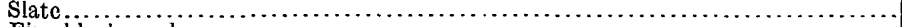 & 245 & 355 \\
\hline 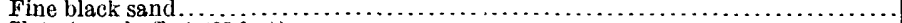 & 20 & 375 \\
\hline 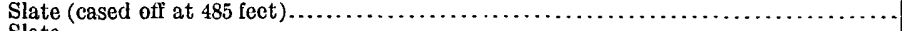 & 110 & 485 \\
\hline 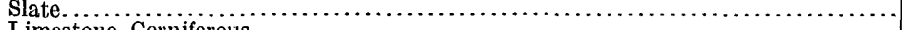 & 15 & 500 \\
\hline 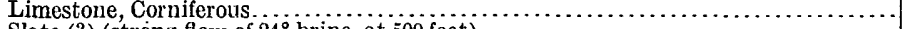 & 175 & 675 \\
\hline Slate (?) (strong flow of $24^{\circ}$ brine, at 500 feet) . . . . . . . . & 30 & 705 \\
\hline 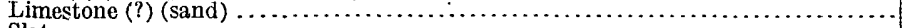 & 25 & 730 \\
\hline 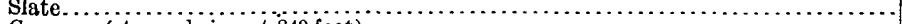 & 100 & 830 \\
\hline 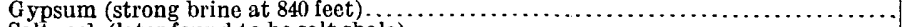 & 108 & 938 \\
\hline Salt rock (later found to be salt shale). & 60 & 998 \\
\hline 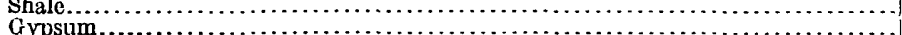 & 45 & 1,043 \\
\hline 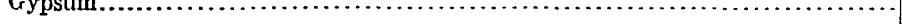 & $2 b$ & 1,008 \\
\hline
\end{tabular}

$a$ Bishop, I. P., New York State Geologist Fifth Ann. Rept., pp. 33-34, 1835. 
Log of well No. 1 of Remington Salt Co., near Ilhaca, Tomplins County, N. Y.a

\begin{tabular}{|c|c|c|}
\hline Matcrial. & $\begin{array}{l}\text { Thick- } \\
\text { ness. }\end{array}$ & Depth. \\
\hline Lime Portage & Feet. & Feet. \\
\hline 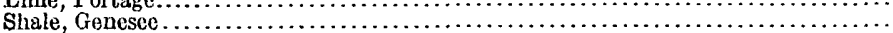 & 125 &, $25 j$ \\
\hline 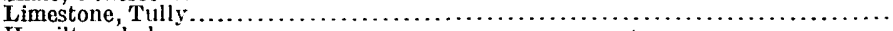 & 30 & 285 \\
\hline 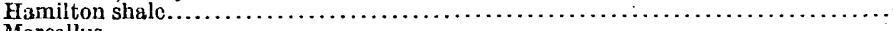 & 1,360 & 1,645 \\
\hline 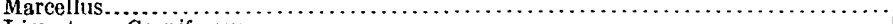 & 80 & 1., 725 \\
\hline 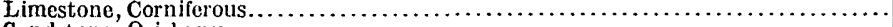 & 75 & 1,800 \\
\hline 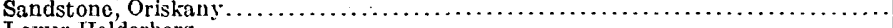 & 22 & 1,822 \\
\hline Lower Helderberg....................... & 1.25 & 1,947 \\
\hline 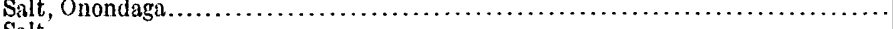 & 148 & 2,095 \\
\hline 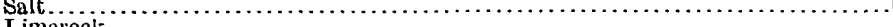 & 42 & 2,137 \\
\hline 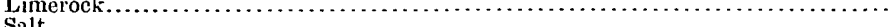 & $\begin{array}{r}8 \\
4\end{array}$ & 2,145 \\
\hline 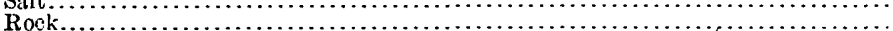 & $\begin{array}{r}44 \\
3\end{array}$ & $\begin{array}{l}2,189 \\
2,192\end{array}$ \\
\hline (n) & & \\
\hline
\end{tabular}

a Record furnished by superintendent.

Note.-Piping, 20 feet; 61 -inch casing, 452 feet; 31 -inch tubing, 2,183 fect.

Log of well at Ithaca, Tompkins County, N. Y."

\begin{tabular}{|c|c|c|}
\hline Material. & $\begin{array}{l}\text { Thick- } \\
\text { ness. }\end{array}$ & Depth. \\
\hline & Feet. & Fcet. \\
\hline 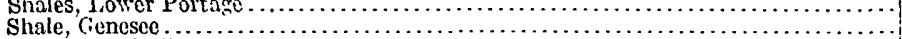 & $\begin{array}{l}340 \\
100\end{array}$ & $\begin{array}{l}3.10 \\
410\end{array}$ \\
\hline Limestone. Tully & 30 & 470 \\
\hline Hemilton gróp & 1,142 & 1.612 \\
\hline 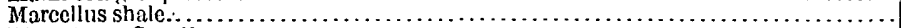 & 82 & 1.694 \\
\hline 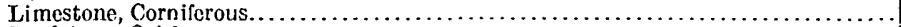 & 78 & 1.772 \\
\hline . & 13 & 1,785 \\
\hline 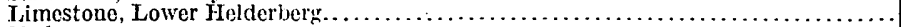 & 115 & $1,90 !$ \\
\hline 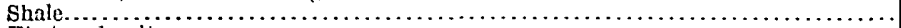 & 344 & 2.24 .4 \\
\hline 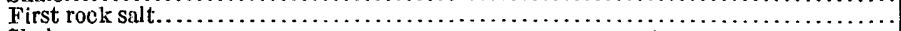 & 24 & 2,268 \\
\hline 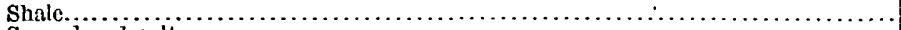 & 6 & 2.274 \\
\hline 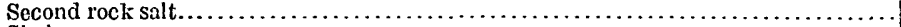 & 54 & 2.323 \\
\hline 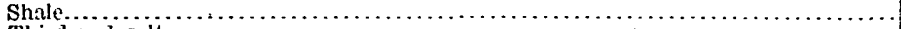 & 12 & 2.340 \\
\hline 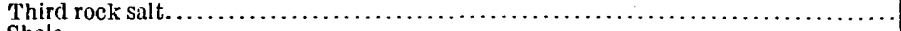 & 17 & 2,357 \\
\hline 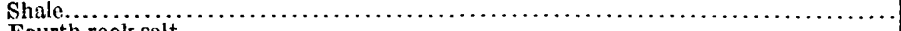 & 31 & 2,388 \\
\hline 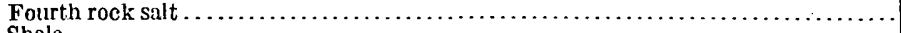 & 21 & 2,409 \\
\hline 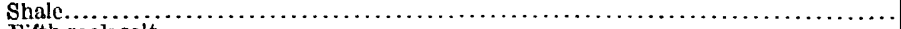 & 67 & 2,476 \\
\hline 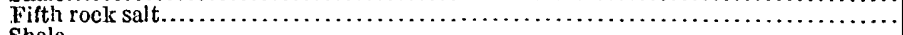 & 42 & 2,518 \\
\hline 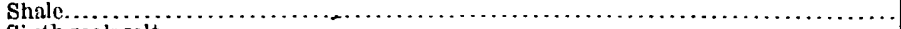 & 24 & 2,542 \\
\hline Sixth rock salt . ................... & 48 & $2.5 \% 0$ \\
\hline 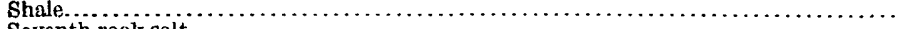 & -82 & 2,672 \\
\hline Seventh rock salt............. & 42 & 2,714 \\
\hline 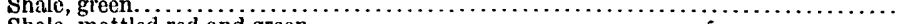 & 308 & 3.022 \\
\hline Shale, mottled red and green.. & 6 & 3,028 \\
\hline shale, green........... & 157 & 3,155 \\
\hline
\end{tabular}

a Prosser, C. S. (quoted by F. J. H. Merrill), New York State Mus. Bull. 11, vol. 3. 1893.

Log of well No. 8, International Salt Co., near Meyers, Tompkins County, N. Y.a

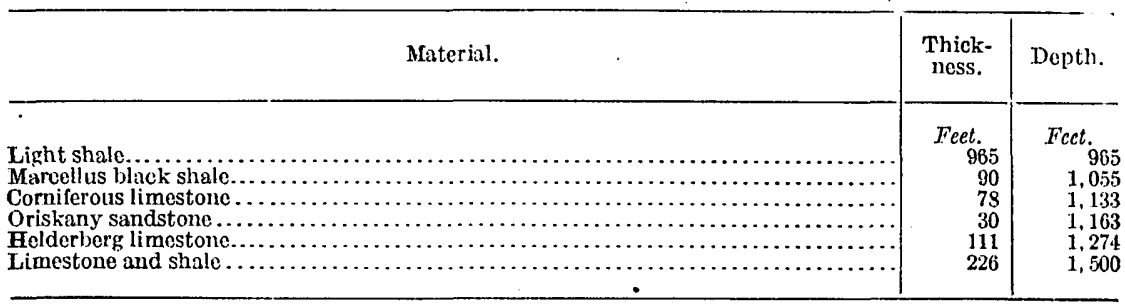

$a$ Record furnished by the superintendent of the plant, Mr, James Cooney. 
Log of well No.4[?], International Salt Co., ncar Ifoycrs, Tomplins County, N. Y.a

\begin{tabular}{|c|c|c|}
\hline \multirow[t]{3}{*}{ Materi.ll. } & & \\
\hline \multirow[b]{3}{*}{. } & & \\
\hline \multirow{3}{*}{ 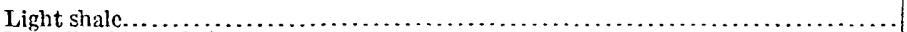 } & & \\
\hline \multirow{5}{*}{ 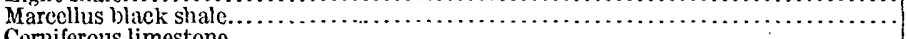 } & & \\
\hline \multirow{3}{*}{ 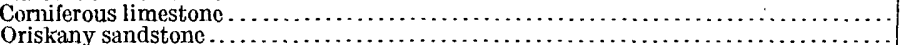 } & & \\
\hline \multirow{3}{*}{ Helderberg limestone................ } & & \\
\hline \multirow{3}{*}{ Iimestone and shale. } & & \\
\hline \multirow{3}{*}{ Salt.. } & & \\
\hline \multirow{6}{*}{$\begin{array}{l}\text { Limes } \\
\text { Salt.. }\end{array}$} & & \\
\hline & & \\
\hline & & \\
\hline & & \\
\hline & 900 & 900 \\
\hline & & \\
\hline & & \\
\hline & & \\
\hline & & \\
\hline & & \\
\hline & & \\
\hline & & \\
\hline & & \\
\hline & $\begin{array}{l}\text { Thick- } \\
\text { ness. }\end{array}$ & Depth. \\
\hline & & \\
\hline & Solo & retis \\
\hline & 105 & 1,005 \\
\hline & 55 & 1,060 \\
\hline & 32 & 1,092 \\
\hline & 108 & 1,200 \\
\hline & 230 & 1,430 \\
\hline & 30 & 1,460 \\
\hline & 30 & 1,490 \\
\hline & 63 & 1,553 \\
\hline
\end{tabular}

a Record furnished by the superintendent of the plant, Mr. James Cooney.

(Two different records were markel as from well No. 4.)

Log of well No.4 [?], International Salt Co., near Meyers, Tomplins County, N. Y.a

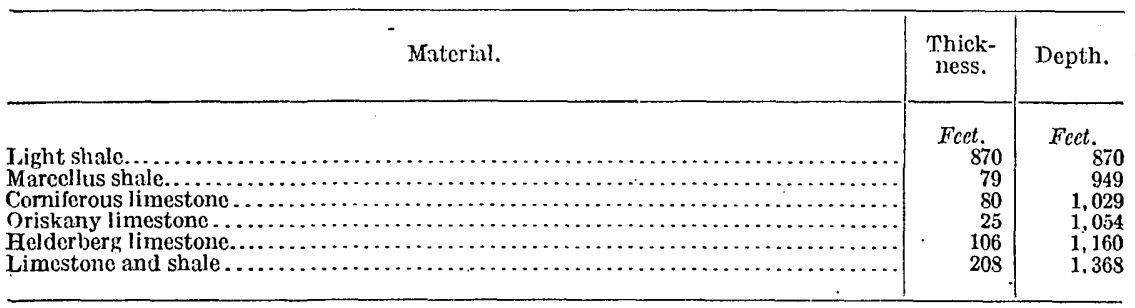

a Record furnished by the superintendent of the plant, Mr. James Cooney.

('Two different records were marked as from well No. 4.)

Log of deep State well of 18s.4, Syracuse, Onondaga County, N. Y.a

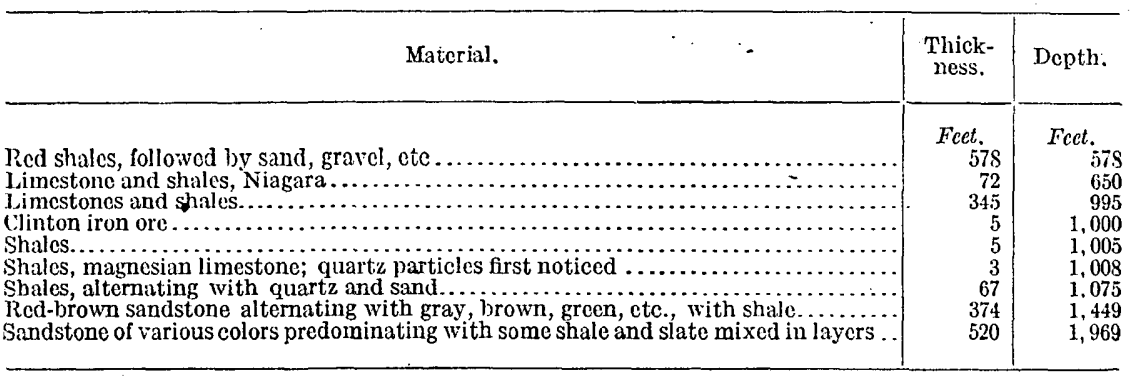

a Merrill, F. J. H., New York State Mus. Bull. 11, vol. '3, 1893.

Nore.-For details in regard to this and the Gale well (p. 41), see Now York State Ceologist Arn. Rept: for 1884 .

Log of well of Solvay Process Co., Cardiff, Onondaga County, N. Y.a

\begin{tabular}{|c|c|c|}
\hline Material. & $\begin{array}{l}\text { Thick- } \\
\text { ness. }\end{array}$ & Depth. \\
\hline 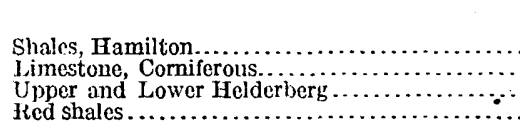 & $\begin{array}{r}\text { Fcet. } \\
244 \\
148 \\
352 \\
100\end{array}$ & $\begin{array}{r}\text { Fcet. } \\
244 \\
392 \\
744 \\
844\end{array}$ \\
\hline
\end{tabular}

a Merrill, F. J. H., op. cit. 
Log of well at Jamesville, Onondaga County, N. Y.a

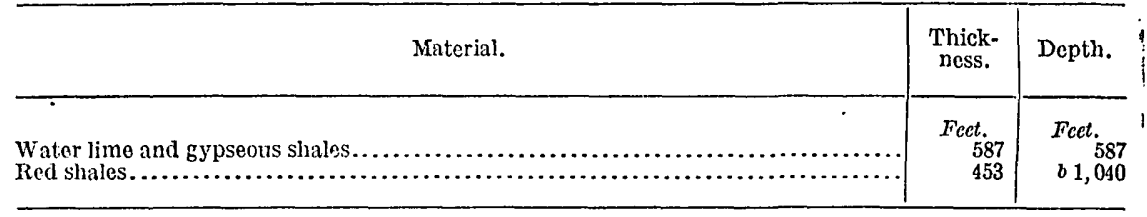

a Merrill, F. J. H., op. cit.

$b$ Stopped in red shales.

Log of well of Solvay Proccss Co., Tully, Onondaga County, N. Y.a

\begin{tabular}{|c|c|c|}
\hline Material. & $\begin{array}{c}\text { Thick- } \\
\text { ness. }\end{array}$ & Depth. \\
\hline 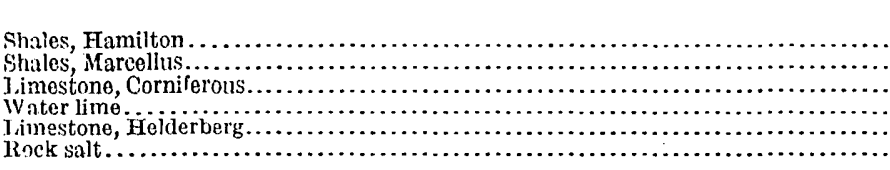 & $\begin{array}{r}\text { Feet. } \\
678 \\
40 \\
150 \\
50 \\
294 \\
47\end{array}$ & $\begin{array}{r}\text { Fect. } \\
678 \\
718 \\
868 \\
918 \\
1,212 \\
1,259\end{array}$ \\
\hline
\end{tabular}

a Merrill, F. J. H., op. cit.

Log of Gale well, Green Point, Onondaga County, N. Y.a

\begin{tabular}{|c|c|c|}
\hline Material. & $\begin{array}{l}\text { Thick- } \\
\text { ness. }\end{array}$ & Depth. \\
\hline Red shale.. & Fect. & Fect. $_{536}$ \\
\hline 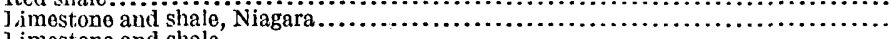 & 69 & 605 \\
\hline 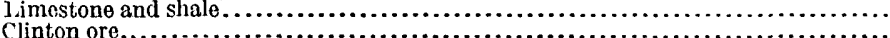 & $\begin{array}{r}371 \\
10\end{array}$ & \\
\hline Shales with some limestone & 10 & 900 \\
\hline 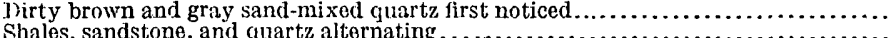 & 4 & 1,000 \\
\hline $\begin{array}{l}\text { Sandstones and sha!es of various colors nixed with quartz, etc., to bottom of well... } \\
\text { Sand }\end{array}$ & 545 & $\begin{array}{l}1,055 \\
1,600\end{array}$ \\
\hline
\end{tabular}

a Morrill, T. J. H., op. cit.

Log of well at Morrisville, Madison County, N. Y.a

\begin{tabular}{|c|c|c|}
\hline Material. & $\begin{array}{c}\text { Thick- } \\
\text { ness. }\end{array}$ & Depth. \\
\hline 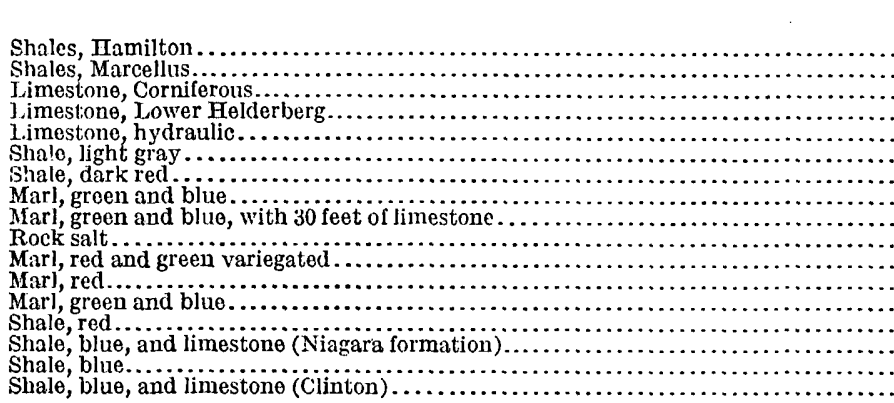 & $\begin{array}{r}\text { Feet. } \\
340 \\
31 \\
70 \\
209 \\
325 \\
43 \\
5 \\
87 \\
149 \\
10-12 \\
129 \\
60 \\
105 \\
225 \\
59 \\
22 \\
15\end{array}$ & $\begin{array}{r}\text { Fcet. } \\
340 \\
371 \\
441 \\
650 \\
975 \\
1,018 \\
1,023 \\
1,110 \\
1,259 \\
1,271 \\
1,400 \\
1,460 \\
1,565 \\
1,790 \\
1,849 \\
1,871 \\
1,886\end{array}$ \\
\hline
\end{tabular}

a Prosser, C. S., quoted by F. J. H. Merrill, op. cit. 


\section{BIBLIOGRAPHY.}

Beck, L. C., Brine springs of Onondaga: New York Geol. Survey Ann. Rept. (Mineralogy), 1837, pp. 24-36, 1838; idem, 1840, pp. 18-23, 1841; Mineralogy of New York, pp. 103-108, 110, 1842.

Brine springs or salines of the State of New York: New York Geol. Survey Ann. Rept. (Mineralogy), 1837, pp. 10-40, 1838; Mineralogy of New York, pp. 99-127, 1842; New York State Mus. Third Ann. Rept., pp. 119-123, 1850.

- Muriate of soda or common salt: New York Geol. Survey Ann. Rept. (Mineralogy), 1838, p. 17, 1839; Mineralogy of New York, pp. 198-200, 1842; New York State Mus. Third Ann. Rept., pp. 119-123, 1850.

Montezuma brine: New York Geol. Survey Ann. Rept. (Mineralogy), 1840, p. 23, 1841; Mineralogy of New York, pp. 108-110, 1842.

- Manufacture of salt and origin of brine springs: Mineralogy of New York, pp. 111-127, 1842 .

Bishop, I. P., Salt wells of western New York: New York State Geologist Fifth Rept., pp. $] 2-47,1886$.

- Report on the salt industry of central New York for the year 1891: New York State Mus. Forty-fifth Ann. Rept:, pp. 53-61, 1892. Gives several sections as shown by well borings at different localities.

Rock salt of Erie County: New York State Geologist Fifteenth Ann. Rept., pp. 391-392, 1897; New York State Mus; Forty-ninth Ann. Rept., vol. 2, pp. 391-392, 1898.

- Economic geology of western New York: New York State Mus. Fifty-sixth Ann. Rept., pp. r42-r74, 1904. Gives notes on the occurrence of economic products, particularly building stone, clays, salt, pp. r59-r62, natural gas and petroleum.

Clarke, J. M., Fossils found in the Livonia salt shaft: New York State Geologist Eleventh Ann: Rept., pp: 10-11, 54, 55, 1892; New York State Mus. Forty-fifth Ann. Rept., pp. 326-327, 370-371, 1892.

Livonia salt shaft: New York State Geologist Twelfth Ann. Rept., pp. 46-47, 1893; New York State Mus. Forty-sixth Ann. Rept., pp. 192-194, 1893.

- Succession of the fossil faunas in the section of the Livonia salt shaft: New York State Geologist Thirteenth Ann. Rept., pp. 131-158, 1894; New York State Mus. Forty-seventh Ann. Rept., pp: 325-352, 1894.

New or rare species of fossils from the horizons of the Livonia salt shaft: New York State Geologist Thirteenth Ann. Rept., pp. 159-189, 1894; New York State Mus. Forty-seventh Ann. Rept., pp. 353-383, 1894.

Conrad, T. A., Brine springs: New York Geol. Survey Ann. Rept., 1836, pp. 172-176, 1837 (2d ed., pp. 174-178, 1840).

Соoк, G. H., Communication from Prof. George H. Cook on the nature of the specimens of salt and salt water presented by him, with an analysis of most of the same: New York State Mus. Seventh Ann. Rept., pp. 79-93, 1854.

Eldrs, MARY, Index to publications of the New York State Natural History Survey and New York State Museum, 1837-1902: New York State Mus. Bull. 66, 1903.

Emmons, Ebenezer, First annual report of the second geological district of New York: New York Geol. Survey Ann. Rept., 1836, pp. 97-153, 1837. (See also succeeding reports to 1848 , inclusive.)

Gedpes, George, Salt springs of Onondaga County: New York State Agr. Soc. Trans. vol. 19 , pp. 266-286, 1860.

Goessmann, C. A., Contributions to the chemistry of the mineral springs of Onondaga, N. Y.: Am. Jour. Sci., 2d ser., vol. 42, pp. 211-218, 368-374, 1866. 
Hall, James, Salt springs of Wayne County: New York Geol. Survey Ann. Rept., 1837, pp. 317-31.8, 1838; Geology of New York, pt. 4, pp. 417-418, 1843.

- Salt springs in Orleans County: New York Geol. Survey Ann. Rept., 1837, pp. 352-353, 1838; Geology of New York, pt. 4, p. 436, 1843.

Salt springs in Niagara County: New York Geol. Survey Ann. Rept., 1837,

p. 336, 1838; Geology of New York, pt. 4, p. 446, 1843.

Salt springs of Monroe County: New York Geol. Survey Ann. Rept., 1837, p. 336, 1838; Geology of New York, pt. 4, pp. 427-428, 1843.

- Saline efflorescences: New York Geol. Survey Ann. Rept., 1838, pp. 336-337, 1839; idem, 1839 ; p. $450,1840$.

_- Brine springs or salines: Geology of New York, pt. 4, pp. 44-45, 134-136, 31.4-315, 664. 1843.

- Geological work in connection with the Livonia salt shaft: New York State Geologist Eleventh Ann. Rept., pp. 7-1.2, 1892; New York State Mus. Fortyfitth Ann. Rept., pp. 323-328, 1892.

Livonia salt shaft: New York State Geologist Twelfth Ann. Rept., p. 13, 1893; New York State Mus. Forty-sixth Ann. Rept., p. 159, 1893.

Livonia salt shaft, its history and geological relations: New York State Geologist Thirteenth Ann. Rept., pp. 11-20, 1894; New York State Mus. Forty-seventh Ann. Rept., pp. 203-214, 18940 Contain map showing area of New York covered by Onondaga salt groups; also (in Geologist Report only) map showing saltproducing district of western New York.

Hunt, T. S., On the acid springs and gypsum deposits of the Onondaga salt group: Am. Jour. Sci., 2d ser., vol. 7, pp. 175-178, 1849.

Kndef, E. M., Salt and other resources of the Watkins Glen district, N. Y.: U. S. Geol. Survey Bull. 260, pp. 567-572, 1905. Describes location of the salt deposits, the general geology of the area, and the strata penetrated in the salt wells; also the occurrence of natural gas.

Luther, D. D., Report on the geology of the Livonia salt shaft: New York State Geologist Thirteenth Ann. Rept., for 1893, pp. 21-130, 1894; New York.State Mus. Forty-seventh Ann. Rept, pp. 215-324, 1894.

The economic geology of Onondaga County, N. Y.: New York State Geologist Firteenth Ann. Rept., for 1895, vol. 1, pp. 14-16, 237-303, 1897; New York State Mus. Forty-ninth Ann. Rept., for 1895, vol. 2,.pp. 237-303, 1898.

- Brine springs and salt wells of the State of New York and the geology of the salt district: New York State Geologist Sixteenth Ann. Rept., pp. 171-226, 1899; New York State Mus. Fiftieth Ann. Rept., vol. 2, pp. 171-226, 1899.

- Geological map of salt district: New York State Geologist Sixteenth Ann. Rept., p. 172, 1899; New York State Mus. Fiftieth Ann. Rept., vol. 2, p. 172, 1899.

Mather, W. W., Salt manufacture: New York State Nat. Hist. Survey Ann. Rept., 1836, p. $87,1837$.

- Brine springs, licks, etc.: New York State Nat. Hist. Survey Ann. Rept., 1839, pp. 233-235, 1840 .

Sulphate of magnesia, muriate of soda, and muriate of lime: Geology of New York, pt. 1, pp. 86-88, 1843.

Merrill, F. J. H., Salt and gypsum industries of New York: New York State Mus. Bull. 11, 89 pp., 1893. Contains map of New York showing salt wells and gypsum quarries, map of western salt field of New York, and chart of well sections.

- Salt and gypsum industries of New York-abstract: New York State Mus. Bull. 15, pp. 545-551, 1895; New York State Mus. Forty-eighth Ann. Rept., vol. 1, pp. 545-551, 1895. 
Merrmi, F. J. H., Producers of salt in New York State: New York State Mus. Bull. 15, pp. 549-550, 1895; New York State Mus. Forty-eighth Ann. Rept., vol. 1, pp. 549-550, 1895.

- Salt: New York State Mus. Bull. 19, pp. 223-224, 1898; New York State MusFifty-first Ann. Rept., vol. 1, pp. 223-224, 1899.

Newland, D. H., The mining and quarry industry of New York State: Report of operations and production in 1904: New York State Mus. Bull. 93, pp. 946-949, 1905.

- The mining and quarry industry of New York State; Report of operations and production during 1907: New York State Mus. Bull. 120, pp. 52-55, 1908.

The mining and quarry industry of New York State; Report of operations and production during 1908: New York State Mus. Bull. 132, pp. 52-56, 1909.

The mining and quarry industry of New York State; Report of operations and production during 1909: New York State Mus. Bull. 142, pp. 64-67, 1910.

Note.-Newland has continued to prepare annual reports similar to those cited.

VANUXEm, LARdner, First annual report of the geological survey of the fourth district of New York: New York Geol. Survey Aun. Rept., 1836, pp. 187-212, 1837.

- Montezurna brine springs: New York Geol. Survey Ann. Rept., 1838, pp. 270-272, 1839.

Salt wells or borings of Onondaga: New York Geol. Survey Ann. Rept., 1838, pp. 262-270, 284-285, 1839; idem, 1840, pp. 139-147, 1841.

Hopper-shaped caritiles in Onondaga salt group; Rock salt: Geology of New York, pt. 3, pp. 102, 280-283, 287, 1842.

- Salt boring in Broome County: Geology of New York, pt. 3, pp. 295-296, 1842. Whirıock, H. P., Halite (rock salt): New York State Mus. Bull. 58, pp. 63-64, 1902.

\section{MICHIGAN.}

For some years Michigan has ranked first among the States in both quantity and value of the salt produced. The salt is derived from two distinct sources-rock salt and natural brines-and is obtained by open-pan, grainer, and vacuum-pan methods of evaporation. The industry based on rock salt is of much greater importance than that bascd on natural brine.

\section{POSITION OF FIELDS.}

Salt is produced in three distinct parts of the State. The districts (see Pl. I, p. 12) are (1) in the southeastern part of the State along Detroit and St. Clair rivers; (2) in approximately the central part of the Lower Peninsula, especially in the Saginaw Valley, and (3) along the western shore of the Lower Peninsula.

\section{STRATIGRAPHY AND STRUCTURE.}

The salt produced in the southeastern part of the State and along the western shore is derived from rock-salt beds in the Salina formation, underlying the Monroe group (Silurian); that produced in the Saginaw Valley comes from natural brines in the Marshall sandstone (Mississippian). These brines are of importance also as sources of bromine and calcium chloride, as well as of other calcium and mag- 


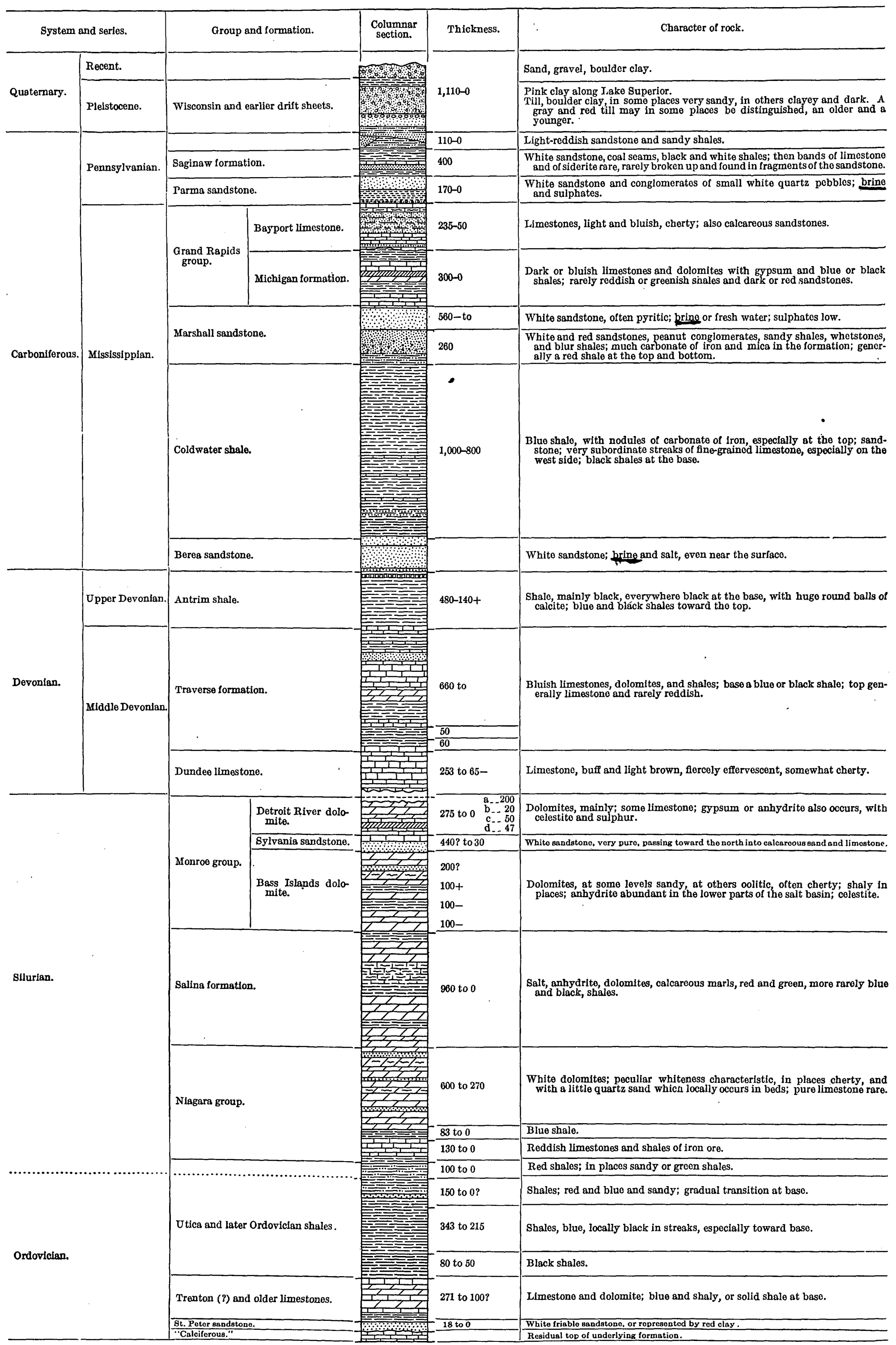


nesium compounds. The positions of the rock-salt beds and the brime-bearing horizon in the geologic column of the State and their relations to the orerlying and underlying beds are shown in Plate V.

The Lower Peninsula of Michigan is a syncline or basin. The salt beds that are worked in the southeastern part of it dip northwest toward the center of the State and outcrop again on the shore of Lake Michigan and the Strait of Mackinac. The salt beds that are worked at varying depths along Detroit and. St. Clair rivers lie very much decper in the central part of the State, but as they approach the shore of Lake Michigan they again rise and are worked by moans of deep wells in the ricinity of Manistee and Ludington. The major structural features of the Lower Peninsula are brought out in figure 2 .

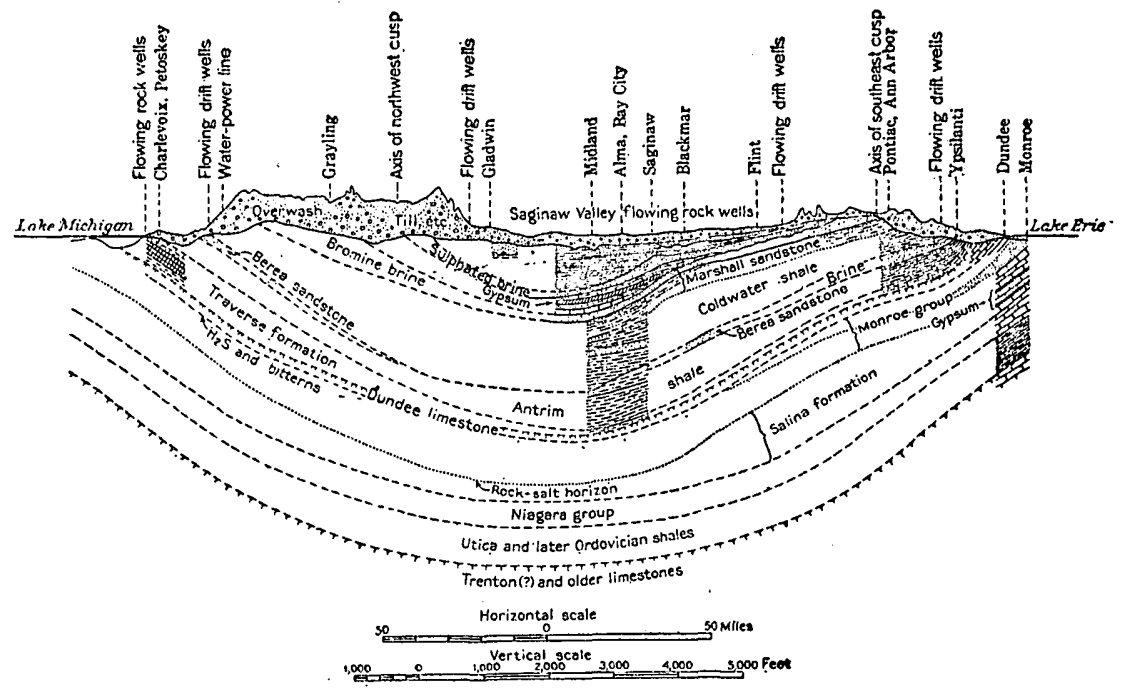

Figure 2.-Cross section of the lower Michigan basin. (After A. C. Lane, U. S. Geol. Survey WaterSupply Paper 114, 1905, with modifications.)

HONROE GROUP AIND SALINA FORMATION.

CHARACTER AND EXTENT.

The rock salt of the Lower Poninsula of Michigan is found in beds underlying the Monroe group and consisting of Silurian rocks now generally accepted as belonging to the Salina formation, although in the earlier reports they were included in the Monroe. (See Pl. VI.)

The term Monroe was introduced into geologic nomenclature in $1893^{1}$. by M. E. Wadsworth and A. C. Lane, being applied to rocks underlying the Dundee limestone and overlying (whether directly or indirectly not indicated) 650 to 2,000 feet of dolomite, salt, and anhydrite containing the fourth brine. As later defined, ${ }^{2}$ the torm

1 Wadsworth, M. E., Michigan Geol. Survey Rept. for 1891 and 1892, p. 66, 1893.

2 Lane, A. C., The geology of Lower Michigan with reference to deep borings: Michigan Ceol. Survey, vol. 5, pt. 2, pp. 26-28, 1895; Notes on the geological section of Michigan: Michigan Cieol. Survey Ann. Rept. for 1908, p. $57,1909$. 
was made to include all the Silurian rocks abovo the Niagara, as it was found difficult to separate the Salina from the beds above, owing to the fact that the latest salt bed is not always at the same horizon, and it is particularly difficult to know where to draw the line where no salt exists. The Monroe as thus defined was described" "as extending from the limestones of the overlying Dundee down to the lowest gypsiferous beds and as consisting mainly of buff dolomites and calcareous and argillaceous marls associated with anhydrite and rock salt."

The present generally accepted definition of Monroe, however, restricts the name to the rocks overlying the salt-bearing beds and underlying the Dundee limestone, including 1,200 feet or more of strictly marine strata, chiefly dolomite, divided into Detroit River dolomite (275 feet thick) at the top, Sylvania sandstone (440 feet thick) in the middle, and Bass Islands dolomite (500 feet thick) at the base; the salt-bearing deposits, which are considered by Grabau and others to be of nonmarine origin and lithologically resemble as well as occupy the stratigraphic position of the Salina formation of New York, are considered as representing the western accumulations of the Salina sea.

What Lane says regarding the Monroe beds (the name at that time being used by him to include not only the Monroe group, as now generally accepted, but the underlying Salina formation as well) is of peculiar interest with reference to the subject of salt in general, and in Michigan and Ohio in particular. It is therefore given below in full. ${ }^{2}$

The period of the Monroe beds is that of the Salina and Lower Helderberg. At that time Michigan was covered by an excessively salt sea which stretched from Wisconsin to New York, was bounded by a continent on the north and east, on the west by low land in Wisconsin (the edge of the Helderberg is found barely extending to just north of Milwaukee), and on the south by a great bar, or reef, or flat in Ohio, which seems to have been just awash. This is indicated by the prevalence in the Ohio Helderberg not only of ripple marks, but also of mud cracks and of brecciated and conglomeratic layers. If we imagine tides like those of the Bay of Fundy rushing over this flat, producing this breccia and conglomerate and bringing fresh supplies of water to the inclosed sea, and furthermore that the sea was exposed to a hot sun and received but little accession of fresh water from rivers-this latter is shown to be true by the scarcity of mud and sand-we have the conditions of the Helderberg or Monroe deposits, conditions which are evidently favorable to the formation of a sea charged with salts. ***

If a line be drawn (on the Lower Peninsula of Michigan) leaving Muskegon and Wyandotte on its northeast side and Monroe and Kalamazoo on the southwest, we may say that south of this line no rock salt has been discovered in this formation, although concentration proceeded far enough to lead to the deposition of sulphate of lime and the concentration of brines. This region then belongs with Ohio. But north of this

1 Lane, $\Lambda$. C., The geology of Lower Michigan with reference to deep borings: Michigan Geol. Survey; vol. 5 , pt. 2 , p. 27,1895 .

2 Idem, pp. $27-28$. 


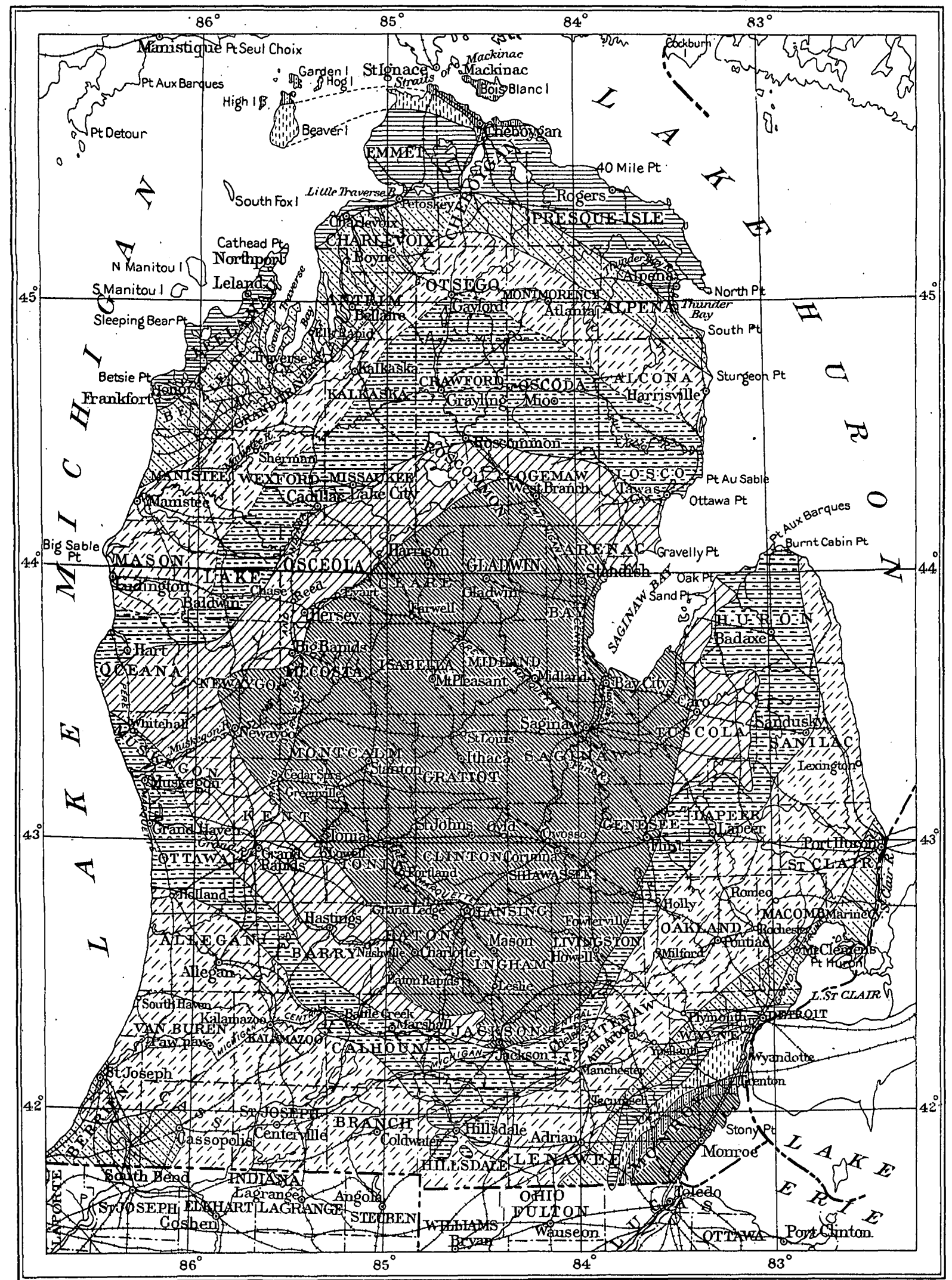

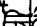

$$
\begin{aligned}
& \text { GEOLOGIC MAP OF THE LOWER PENINSULA OF MICHIGAN } \\
& \text { After A.C.Lane, with modifications }
\end{aligned}
$$

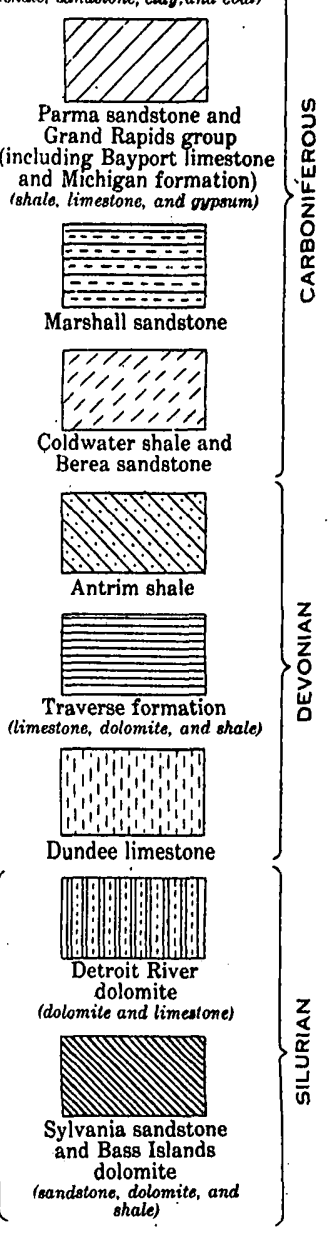

Note: The boundary between the Coldwater shale is undetermined north of coal 
line it is probable that this formation yields rock salt almost universally. The thickness of rock salt at Wyandotte and along St. (lair River is over a hundred feet, and at Royal Oak it appears to be over a thousand.

These figures need excite no incredulity, as there are vastly thicker deposits in Germany. They only excite the query whether somewhere there may be found deposits of those salts which, being most soluble, are latest to crystallize, like those deposits which have made Stassfurt the storehouse of the world's chemical industries. Such analyses as those of Sand Beach [Huron County ${ }^{1}$ ] indicate a concentration of sea water nearly to the point of precipitation of the Stassfurt salts. Such deposits, if they occurred, would be expected in the upper part of the formation.

These salt deposits should rise again, proceeding to the north, and, in fact, just north of the Strait of Mackinac gypsum beds do outcrop, while at St. Ignace a thin bed of salt is reported only 400 feet below the surface. At Alpena they are about $1 ; 200$ feet below the surface. Near Cheboygan they should be sooner reached. The salt industry will doubtless, in time, work north.

The upper beds outcropping in Monroe County are ash-colored and brecciated, in some places marked with acicular crystals (gypsum), which readily weather out and leare carities.

Thick as this formation is, we can not sharply subdivide it, although, as I have said, it doubtless includes the series called Salina in New York, as well as the Helderberg. However, in the section between Monroe and Goderich we may perhaps divide it as follows, in descending order:

At the top a series of dolomites or gypseous marls, marking a time of desiccation, underlain by limestone frequently passing into a calcareous sandstone; beneath this sandstone some more beds, gypseous or even salty, marking a second time of desiccation, and after 200 feet or more of somewhat gypsiferous dolomites, a rapid succession of thick salt beds, marking the first and greatest period of desiccation. The boundary line between this formation and the Niagara underlying it is far from well marked.

To recapitulate, the thickness of the Monroe group, as judged by borings, has been given as 1,200 feet. The beds are stated by Lane to have been deposited in an interior sea extending from New York to eastern Wisconsin and exposed to arid conditions-a hot sun and only slight accession of fresh water from rivers. Shallow-water conditions prevailed in places, especially in Ohio, where the existence of a bar, reef, or flat permitted ripple marks and mud cracks to form. In southeastern Michigan three periods of desiccation have been recognized, the first and greatest is represented by heavy beds of rock salt aggregating in thickness some 900 feet; the second, preeeding the formation of the Sylvania sandstone (the middle formation of the Monroe group) is marked by gypseous or salty dolomites; and above the Sylvania, at the top of the Monroe, is evidence of a third period of desiccation, during which there were deposited dolomites and gypseous marls.

In the records of wells in the southeastern part of the Lower Peninsula at Britton, Milan, Romulus, and Wyandotte there is an increasing thickness to the northeast between the beds of the rock salt and what is regarded as the top of the underlying Niagara group. Northward the salt beds seem to occur higher up in the geologic 
column, and gypsum often occurs above the Sylvania sandstone. Salt occurs below the Sylvania, usually within 450 feet. .

The salt-bearing formation itself, the Salina, has the following thicknesses and occurs at the indicated depths below the surface at the following places in southeastern Michigan:

Depth below surface and thickness of the Salina formation in southeastern Michigan.

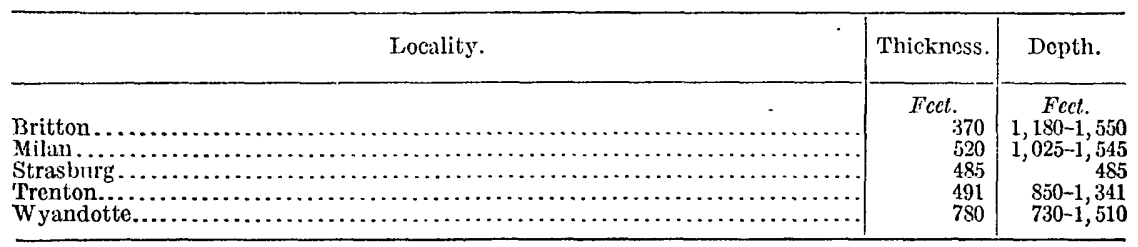

In general, it will be seen that the thickness of the formation increases to the north, which increase holds good into Canada. To the southeast the salt disappears. Thus wells drilled at Trenton show the exact edge of the salt-producing area to be there, as salt occurs in only one of them.

As already stated, it is hard to draw the line of the top of the Salina where no salt exists. There are only lithologic grounds and stratigraphic position for identifying it with the Salina of New York, and it is altogether unlikely that the top can be drawn consistently on such grounds. At present the top of the nearest salt or gypsum bed, 400 feet below the Sylvania sandstone, is regarded as the top of the Salina. This procedure gives fairly consistent results.

DEPTII TO SALT BEDS.

In the southeastern part of Michigan and to the north along St. Clair River a great many drill holes have been sunk to the saltbearing horizons. Records of these are given in the reports of the Michigan Geological Survey, chiefly in the publications already cited. The depths to the salt beds are given in the accompanying table:

Depths to salt beds in eastern Michigan.

\begin{tabular}{|c|c|c|}
\hline Iocation. & Well and formation. & Depth. \\
\hline 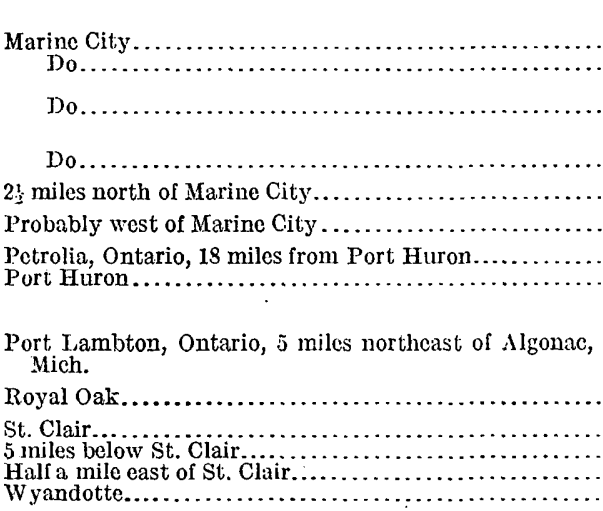 & 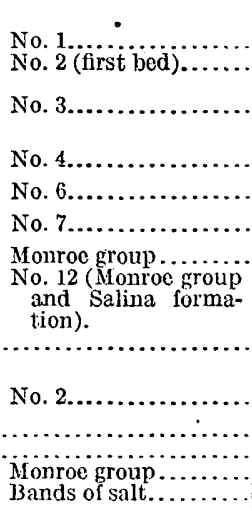 & 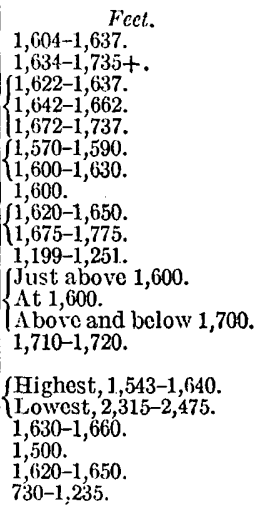 \\
\hline
\end{tabular}


In the southwestern part of the State no rock salt occurs, but to the north at Ludington and Manistee rock salt was struck. At Frankfort, still farther to the north, in Benzie County, wells have been put down deep enough to go through the Salina, but they did not strike salt and not even a very strong brine. It is very likely that the location of Frankfort was just without the borders of the Salina sea. Likewise the St. Ignace and Cheboygan wells show no salt. As showing the character of the material which a typical well goes through in this region, the following $\log$ may be given:

Log of well put down by J. S. Stearns, at Ludington, Mason County, Mich.a

\begin{tabular}{|c|c|c|}
\hline Material. & $\begin{array}{c}\text { Thick- } \\
\text { ness. }\end{array}$ & Depth. \\
\hline 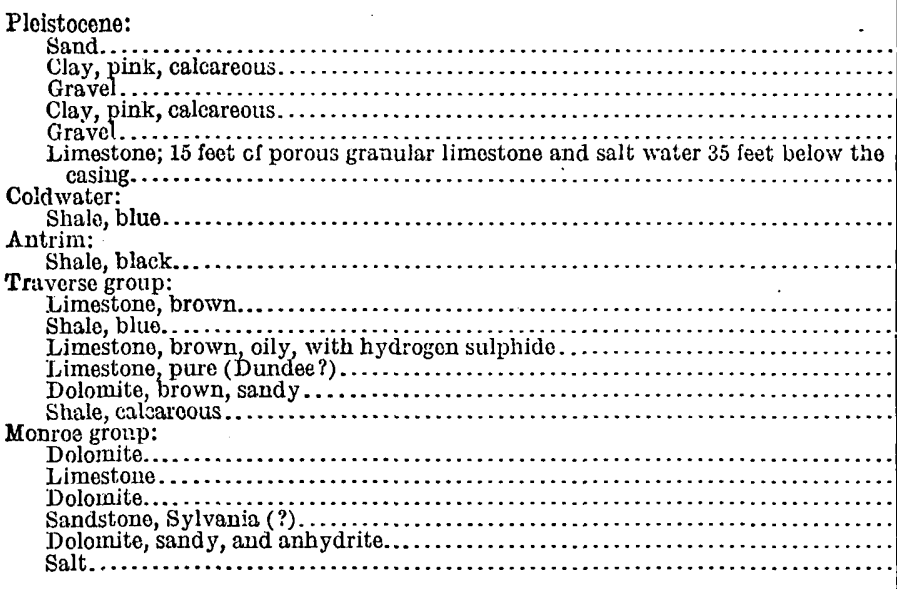 & $\begin{array}{r}\text { Feet. } \\
198 \\
68 \\
94 \\
155 \\
61 \\
74 \\
550 \\
200 \\
25 \\
35 \\
40 \\
250 \\
160 \\
20 \\
25 \\
25 \\
25 \\
100 \\
121 \\
8\end{array}$ & $\begin{array}{r}\text { Feet. } \\
198 \\
266 \\
340 \\
515 \\
576 \\
\\
650 \\
1,200 \\
1,400 \\
1,425 \\
1,460 \\
1,500 \\
1,750 \\
1,910 \\
2,000 \\
2,025 \\
2,050 \\
2,075 \\
2,175 \\
2,296 \\
2,304\end{array}$ \\
\hline
\end{tabular}

a Lane, A. C., Notes on the geological section of Michigan: Michigan Geol. Survey Ann. Rept. for 1908, p. $94,1909$.

Note.-10-inch casing, 204 fest; water (temperature, $53^{\circ}$ F.) at about 300 feet; 8 -inch casing to rock.

At Manistee there are a number of wells, the depths of which are 300 to 400 feet shallower than that of the Stearns well just given. The depth to the salt, as shown by some of the records of the Ludington and Manistee wells, are as follows:

Depths to salt at Ludington and ILanistee, Mich.

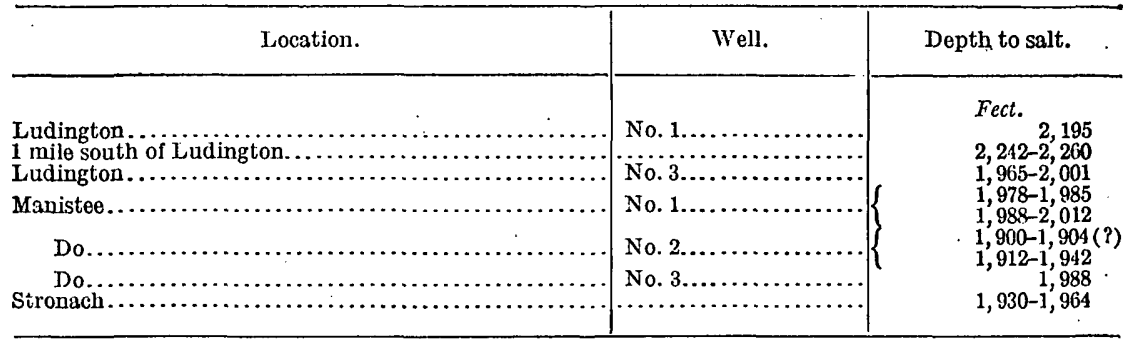


Alpena, in the northeastern part of the Lower Peninsula on the shore of Thunder Bay, an arm of Lake Huron, is another area in which rock salt has been found in some quantity but has not yet been developed. There are five beds of salt, which aggregate about 300 feet in total thickness and include streaks of gypsum and anhydrite.

\section{MARSHALL SANDSTONE.}

The brines of the Saginaw Valley occur in the Marshall sandstone of the Mississippian series, which yields the brine utilized so extensively in the manufacture of salt, bromine, and calcium and magnesium salts. Wells have been put down to the brine-bearing horizon at Bay City, Saginaw, Midland, Mount Pleasant, St. Charles, and perhaps elsewhere. The description, by Lane, of the Marshall sandstone is as follows:

Next beneath the Grand Rapids group occurs a series of sandstones usually very easy to recognize in a general way. The lower part of the formation and the beds immediately underlying it are rich in fossils. It is a fact that the Grand Rapids group is underlain by sandstone which often grades into the shales beneath. It varies in thickness, which is generally from 50 to 100 feet. It is fine grained, calcareous, friable, and gray or slightly greenish in hue, and in contrast with the Parma sandstone finer grained and darker. This appears to be its common character, but at Napoleon, Stony Point, and elsewhere it is thicker and coarser. Its upper boundary is generally sharper than the lower. It is of economic importance where it outcrops and is the source of building stone, flagstone, grindstones, and, where covered in Saginaw Valley, also the source of the brines of Saginaw, Bay City, Midland, and other places. It is the second salt horizon. ${ }^{1}$

In a later report Lane speaks of the upper Marshall or Napoleon sandstone and gives the following record of the rocks at Mount Pleasant:

Log of well at Mount Pleasant, Isabella County, Mich.a

\begin{tabular}{|c|c|c|}
\hline Material. & $\begin{array}{l}\text { Thick- } \\
\text { ness. }\end{array}$ & Depth. \\
\hline 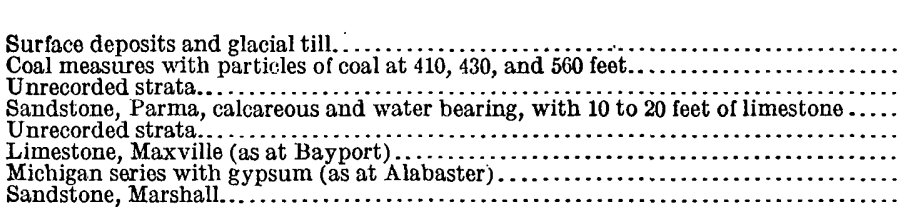 & \begin{tabular}{r|} 
Fcct. \\
400 \\
220 \\
190 \\
30 \\
130 \\
80 \\
358 \\
142
\end{tabular} & $\begin{array}{r}\text { Feet. } \\
400 \\
620 \\
810 \\
840 \\
970 \\
1,050 \\
1,408 \\
1,550\end{array}$ \\
\hline
\end{tabular}

a Michigan Geol. Survey Ann. Rept. for 1903, pp. 293-294, 1905.

A detailed description of the Marshall sandstone and its variations from place to place is also given by Lane in a later report, ${ }^{2}$ and in

\footnotetext{
1 Lane, A. C., The geology of Lower Michigan with reference to deep borings: Michigan Geol. Survey, vol. 5, pt. 2, pp. 17-19, 1895 .

${ }^{2}$ Lane, A. C., Notes on the geological section of Michigan: Michigan Geol. Survey Ann. Rept. for 1908, pp. $79-83,1909$.
} 
the geologic column accompanying that report (p. 43) the Marshall is classified as the upper and lower Marshall sandstone under the single heading Napoleon sandstone.

\section{WELI, RECORDS.}

The following are selected records of deep wells in the different salt-producing districts of Michigan, and they furnish in detail the bases of some of the general statements already made. In general, the arrangement is from north to south.

Log of well of Lewis Sands at Manistee, Manistee County, Mich. ${ }^{a}$

\begin{tabular}{|c|c|c|}
\hline Material. & $\begin{array}{l}\text { Thick- } \\
\text { ness. }\end{array}$ & Depth. \\
\hline 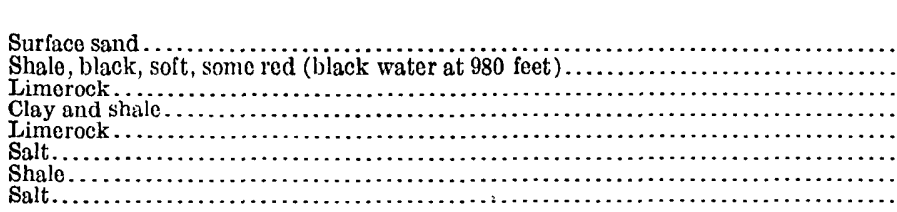 & $\begin{array}{r}\text { Feet. } \\
640 \\
340 \\
510 \\
110 \\
378 \\
7 \\
3 \\
24\end{array}$ & $\begin{array}{r}\text { Feet. } \\
640 \\
980 \\
1,490 \\
1,600 \\
1,978 \\
1,985 \\
1,988 \\
2,012\end{array}$ \\
\hline
\end{tabular}

a Lane, A. C., The geology of Lower Michigan with reference to deop borings: Michigan Cieol. Survey, vol. 5, pt. 2, pl. 30,1895 .

Log of Canfield \& Wheeler well, Manistee, Manistee County, Mich.a

\begin{tabular}{|c|c|c|}
\hline Material. & $\begin{array}{l}\text { Thick- } \\
\text { ness. }\end{array}$ & Depth. \\
\hline & Feet. & Feet. \\
\hline 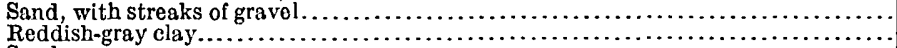 & $\begin{array}{r}93 \\
2\end{array}$ & $\begin{array}{l}93 \\
95\end{array}$ \\
\hline Sand..................... & 107 & 202 \\
\hline Gray clay .................... & 94 & 296 \\
\hline Dark-reddish clay.............. & 2 & 298 \\
\hline Quicksand.......................... & & 301 \\
\hline 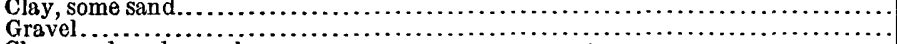 & $\begin{array}{r}54 \\
3\end{array}$ & $\begin{array}{l}355 \\
358\end{array}$ \\
\hline Clay, sand, and gravel............ & 36 & 394 \\
\hline Reddish clay, gravel, and some sand & 181 & 575 \\
\hline Dark clay and gravel................. & & 580 \\
\hline Dark shaly stuft.................... & 15 & 595 \\
\hline shaly stuff $\ldots \ldots \ldots \ldots \ldots \ldots \ldots$ & & 602 \\
\hline Shale and gravel ................................... & 113 & 815 \\
\hline $\begin{array}{l}\text { Sandrock, with streaks of shale and lime in places. } \\
\text { Shale, and streaks of hard lime..................... }\end{array}$ & 200 & 1,075 \\
\hline Blue shale..................... & 380 & 1,455 \\
\hline Sticky grayish-brown shale.... & 100 & 1,555 \\
\hline Shaly lime. & 20 & 1,575 \\
\hline ............. & 29 & 1,604 \\
\hline Shale and lime $\ldots . . . \ldots \ldots \ldots \ldots$ & 51 & 1,055 \\
\hline $\begin{array}{l}\text { Lime streaks, dark and light.......... } \\
\text { White lime....................... }\end{array}$ & $\begin{array}{l}40 \\
10\end{array}$ & $\begin{array}{l}1,695 \\
1,705\end{array}$ \\
\hline 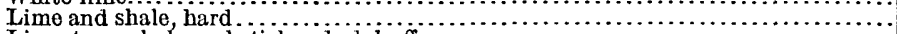 & 20 & 1,725 \\
\hline Limestone, shaly and sticky, dark buff.... & 15 & 1,740 \\
\hline $\begin{array}{l}\text { Limestono } \ldots \ldots \ldots \ldots \ldots \ldots \ldots \ldots \ldots \ldots \ldots \ldots \\
\text { Shale, limy } \ldots \ldots \ldots \ldots \ldots \ldots \ldots \ldots \ldots \\
\end{array}$ & $\begin{array}{l}5 \\
7\end{array}$ & $\begin{array}{l}1,745 \\
1,752\end{array}$ \\
\hline Very hard spots and softer streaks of lime. & 28 & 1,780 \\
\hline Very hard streaks, with streaks of softer material. & 23 & 1,803 \\
\hline Dolomite, dark gray or drab..... & & 1,835 \\
\hline Dolomite, dark drab, very hard. . & 10 & 1,845 \\
\hline Limerock, gray, with hard thin streaks & 3 & 1,848 \\
\hline $\begin{array}{l}\text { Softer material that is cut very fast... } \\
\text { Limerock, soft....................... }\end{array}$ & $\begin{array}{r}10 \\
7\end{array}$ & $\begin{array}{l}1,858 \\
1,865\end{array}$ \\
\hline Hard and soft streaks; $92^{\circ}$ brine. & 10 & 1,875 \\
\hline $\begin{array}{l}\text { Limerock, massive } 93^{\circ} \text { brine..... } \\
\text { Supposed salt: } 96^{\circ} \text { brine. }\end{array}$ & 25 & 1,900 \\
\hline $\begin{array}{l}\text { Supposed salt; } 96^{\circ} \text { brine......... } \\
\text { Unrecorded strata.............. }\end{array}$ & 8 & $\begin{array}{l}1,904 \\
1,912\end{array}$ \\
\hline Rock salt.......... & 30 & 1,942 \\
\hline Limestone, hard. & & 1,947 \\
\hline
\end{tabular}


Log of well of Wheeler, Magill \& Co., Manistee, Manistee County, Mich.a

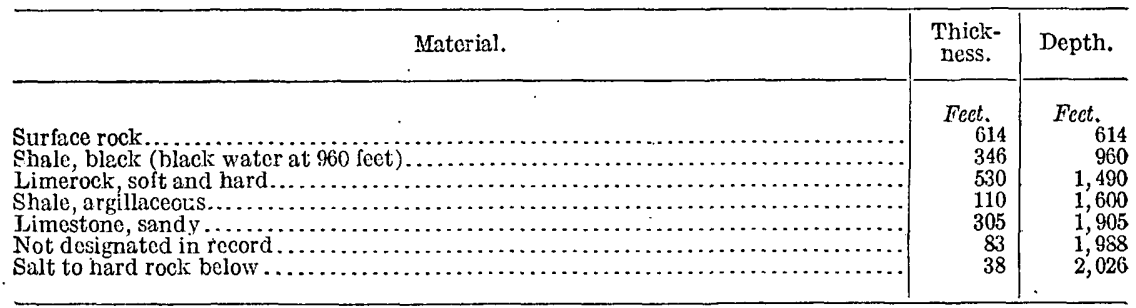

$a$ Lane, A. C., op. cit., pl. 82.

Log of well at East Lake, Manistee County, Mich.a

\begin{tabular}{|c|c|c|}
\hline Material. & $\begin{array}{l}\text { Thick- } \\
\text { ness. }\end{array}$ & Depth. \\
\hline & Fect. & Feet. \\
\hline Sand and gravel. & 104 & 104 \\
\hline 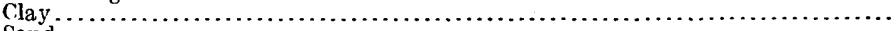 & 3 & 107 \\
\hline 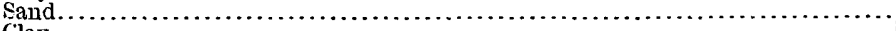 & 70 & 177 \\
\hline 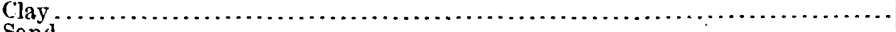 & 1 & 178 \\
\hline 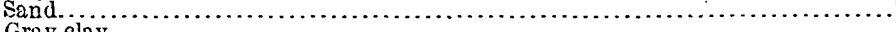 & 23 & 201 \\
\hline 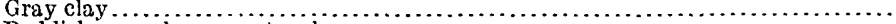 & 51 & 252 \\
\hline 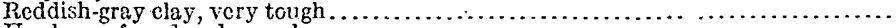 & 257 & 509 \\
\hline Hardpan of sand and gravel....... & 13 & 522 \\
\hline Sand and gravel, mostly quicksand... & 21 & 543 \\
\hline 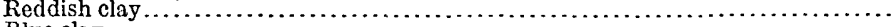 & 37 & 580 \\
\hline Blue clay & 2 & 582 \\
\hline 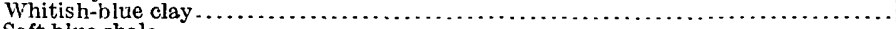 & 4 & 586 \\
\hline Soft blue shale................ & 2 & 589 \\
\hline 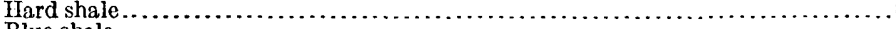 & 1 & 589 \\
\hline 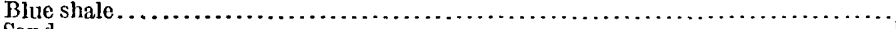 & 2 & 591 \\
\hline 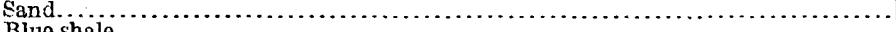 & $\dot{4}$ & 505 \\
\hline 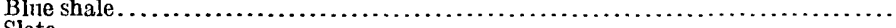 & 5 & 600 \\
\hline 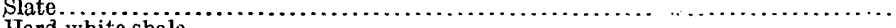 & 1 & 601 \\
\hline 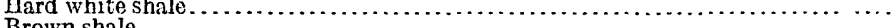 & 120 & 721 \\
\hline 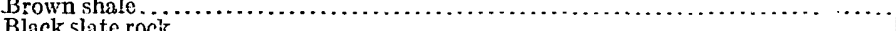 & 90 & 811 \\
\hline 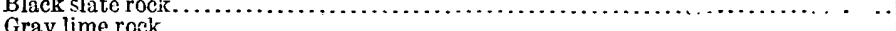 & 58 & 869 \\
\hline $\begin{array}{l}\text { Gray lime rock. } \\
\text { Hard black limerock }\end{array}$ & 10 & 879 \\
\hline $\begin{array}{l}\text { Hard black limerock }{ }_{\text {Hard }} \text { white limerock } \\
\text { Ha. }\end{array}$ & 86 & 965 \\
\hline $\begin{array}{l}\text { Hard white limerock }{ }_{\text {Br }} \text { Brown limerock } \\
.\end{array}$ & $\begin{array}{l}31 \\
80\end{array}$ & 1.076 \\
\hline Very little gypsum. & 00 & 1,0 o \\
\hline White limestone........... & 59 & 1,135 \\
\hline White limerock................... & 15 & 1,150 \\
\hline Blackish-blue limerock.............. & 132 & 1,282 \\
\hline Gypsum ..................... & 10 & 1,292 \\
\hline 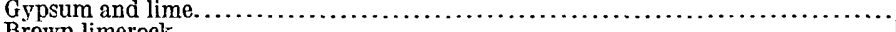 & 58 & 1,350 \\
\hline 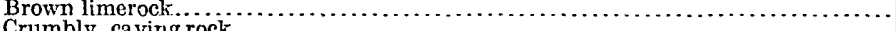 & 106 & 1,456 \\
\hline 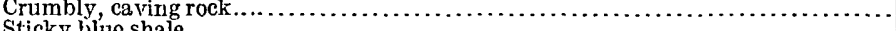 & 62 & 1,518 \\
\hline 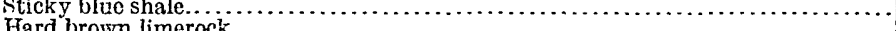 & 69 & 1,587 \\
\hline 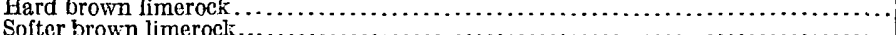 & 88 & 1,675 \\
\hline $\begin{array}{l}\text { Softer brown limerock }{ }_{1} \\
\text { Hard brown limerock }\end{array}$ & $\begin{array}{r}44 \\
4\end{array}$ & 1,719 \\
\hline 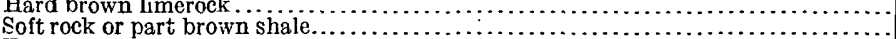 & 17 & 1,740 \\
\hline Hard limerock . . . . . . . . . . . . . . & & 1,745 \\
\hline Solt limerock.......... & 3 & 1,748 \\
\hline Flard limerock . . . . . . . . . . . . . . . . & 19 & 1,767 \\
\hline 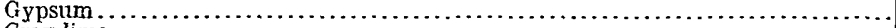 & 1 & 1,768 \\
\hline Gray lime.... & 27 & 1,79 \\
\hline Soft gray lime. & & 1,796 \\
\hline lime. & 18 & 1,814 \\
\hline Blue shale.... & 15 & 1,829 \\
\hline Hard sticky rock.................. & 3 & 1,832 \\
\hline Soft slate rock....... & 5 & 1,837 \\
\hline 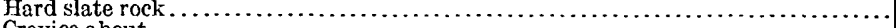 & 10 & 1,817 \\
\hline 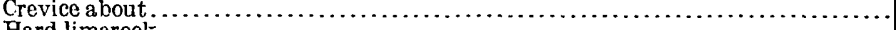 & 1 & 1,84 \\
\hline nerock $\ldots \ldots \ldots \ldots \ldots \ldots \ldots$ & 60 & 1,908 \\
\hline ombed limerock.............. & 1 & 1,909 \\
\hline nerock $\ldots \ldots \ldots \ldots \ldots \ldots \ldots \ldots$ & 27 & 1,936 \\
\hline 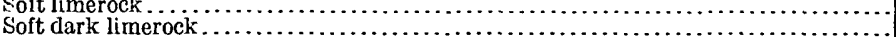 & $\begin{array}{r}14 \\
8\end{array}$ & $\begin{array}{l}1,900 \\
1,958\end{array}$ \\
\hline Solt dark limerock.... & 19 & 978 \\
\hline Shell lime and gypsum & 9 & 1,986 \\
\hline Soft blue lime........ & 2 & 1,588 \\
\hline & 20 & 2,003 \\
\hline & 1 & 2,009 \\
\hline xed with sma & b & 2,015 \\
\hline 20 & 4 & $b 2,019$ \\
\hline
\end{tabular}

a On land owned at present by R. G. Peters Co. . . Total depth given as 2,024 feet 10 inches. 
Log of well of plant of R. G. Peters Salt Co., 500 feet from East Lake station, Manistce County, Mich.a

\begin{tabular}{|c|c|c|}
\hline Material. & $\begin{array}{l}\text { Thick- } \\
\text { ness. }\end{array}$ & Depth. \\
\hline Blue calcareous shale. & Fect. & Fect. \\
\hline 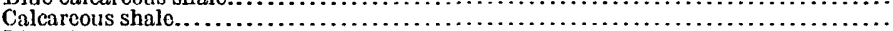 & 207 & 800 \\
\hline Limestone............. & 675 & 1,475 \\
\hline$\ldots \ldots \ldots \ldots \ldots \ldots \ldots \ldots \ldots \ldots \ldots \ldots \ldots \ldots \ldots$ & 12 & 1,487 \\
\hline 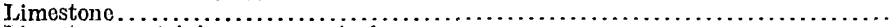 & 118 & 1,605 \\
\hline limestone contrining sponge spicules.. & 33 & 1,638 \\
\hline 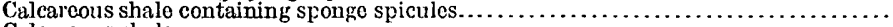 & 14 & 1,652 \\
\hline 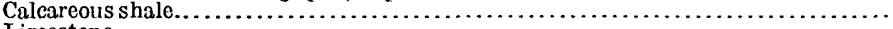 & . & 1,658 \\
\hline 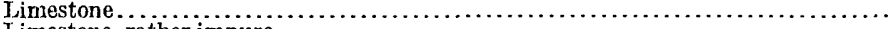 & 22 & 1,680 \\
\hline 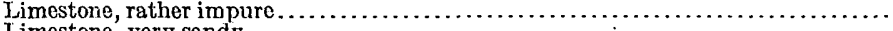 & 10 & 1,690 \\
\hline 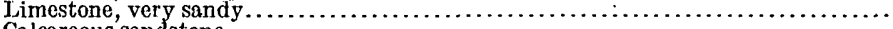 & 90 & 1,780 \\
\hline 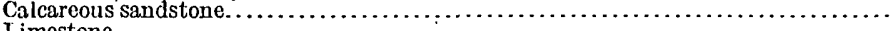 & 30 & 1,810 \\
\hline Jimestone $\ldots \ldots \ldots \ldots \ldots \ldots \ldots \ldots$ & 110 & 1,920 \\
\hline Siliccous and ferruginous limestone... & 20 & 1,940 \\
\hline Shaly limestono................... & 24 & 1,964 \\
\hline
\end{tabular}

a Petrographic examinations by W. H. Fry, U. S. Dept. Agr., Bur. Eoils.

Log of well of Stronach Lumber Co., southeast of Manistee, Manistce County, Mich.

\begin{tabular}{|c|c|c|}
\hline Material. & $\begin{array}{l}\text { Thick- } \\
\text { ness. }\end{array}$ & Depth. \\
\hline 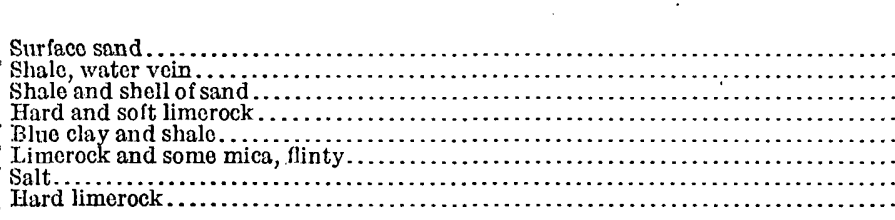 & $\begin{array}{r}\text { Fert. } \\
570 \\
380 \\
20 \\
480 \\
175 \\
305 \\
34 \\
8\end{array}$ & $\begin{array}{r}\text { Fect. } \\
570 \\
950 \\
970 \\
1,450 \\
1,625 \\
1,920 \\
1,964 \\
1,972\end{array}$ \\
\hline
\end{tabular}

a Lane, A. C., The gcology of Loncr Michigan with rcference to deep bcrings: Michigan Gcol. Survey, vol. 5 , pt. 2 , pl. 65,1895 .

Log of well of Stearns Salt \& Lumber Co., Ludington, Mason County, Mich.a

\begin{tabular}{|c|c|c|}
\hline Material. & $\begin{array}{l}\text { Thick- } \\
\text { ness. }\end{array}$ & Depth. \\
\hline & Fcet. & Fect. \\
\hline Reddish sand . ................. & 94 & 94 \\
\hline 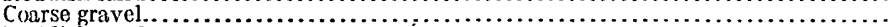 & 6 & 100 \\
\hline 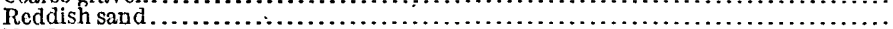 & 52 & 152 \\
\hline (1) & 35 . & 187 \\
\hline 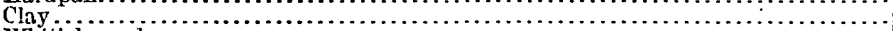 & 56 & 243 \\
\hline 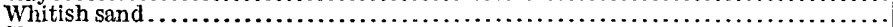 & 2 & 245 \\
\hline 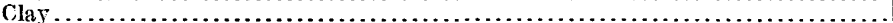 & $4 \overline{9}$ & 294 \\
\hline 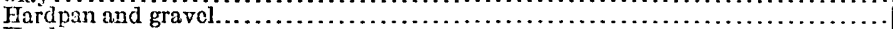 & 20 & 314 \\
\hline 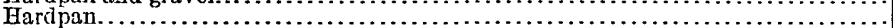 & 96 & 410 \\
\hline Fine sand.......... & 107 & a 517 \\
\hline Calcareous sandstone............ & 3 & 520 \\
\hline 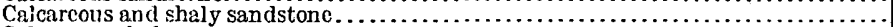 & 13 & 533 \\
\hline 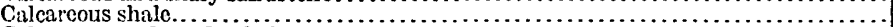 & 40 & 573 \\
\hline 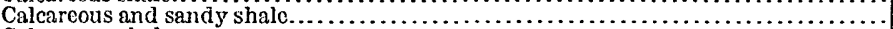 & 30 & 603 \\
\hline 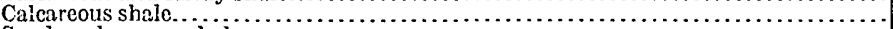 & 5 & 608 \\
\hline 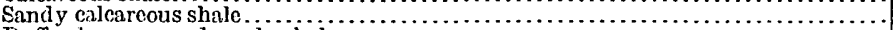 & 1 & 609 \\
\hline Buff calcarcous and sandy shale......... & 6 & 615 \\
\hline 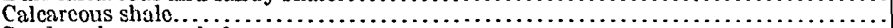 & 223 & 838 \\
\hline 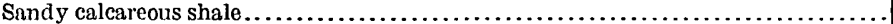 & 373 & 1,211 \\
\hline Calcareous shale.................. & 179 & 1,390 \\
\hline Limestone, impure................ & 73 & 1,463 \\
\hline Fairly pure limestone............. & 338 & 1,801 \\
\hline 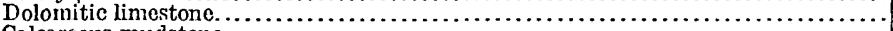 & 134 & 1,935 \\
\hline 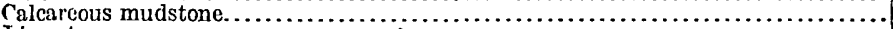 & 86 & 2,021 \\
\hline Iimestone........ & 260 & 2,281 \\
\hline 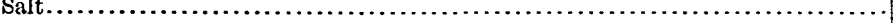 & & 2,290 \\
\hline
\end{tabular}

a Petrographic examinations of the material below 517 feet were made by W. H. Fry, Burean of Soils, United States Department of A griculture, and the notations in the record below that depth differ from those in the original draft of the record furnished the writer. 
Log of well No. t of Pere Marquette Libmber Co., Ludington, Mason County, Mich.a.

\begin{tabular}{|c|c|c|}
\hline Material. & $\begin{array}{l}\text { Thick- } \\
\text { ness. }\end{array}$ & Depth. \\
\hline Sand... & Fcct. & Fect. \\
\hline Marl, shells, and piuestieks........ & $\begin{array}{r}30 \\
5\end{array}$ & 35 \\
\hline 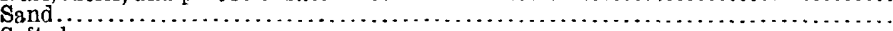 & 21 & $\begin{array}{l}35 \\
50\end{array}$ \\
\hline 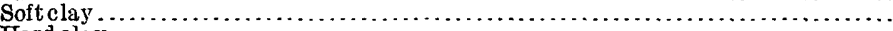 & 4 & 60 \\
\hline 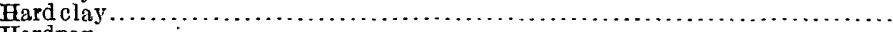 & 20 & 80 \\
\hline 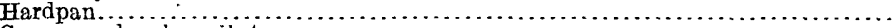 & 10 & 90 \\
\hline 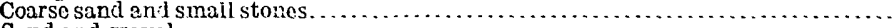 & 18 & 103 \\
\hline 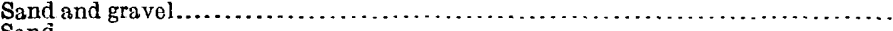 & 9 & 117 \\
\hline 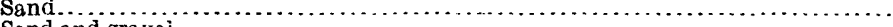 & 42 & 159 \\
\hline 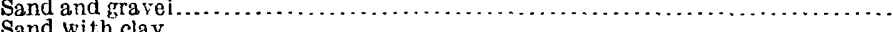 & 24 & 183 \\
\hline 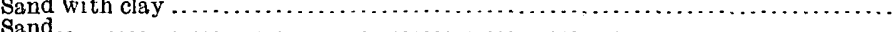 & 17 & 200 \\
\hline Sand...$\cdots \cdots$ & 5 & 205 \\
\hline Clay and gravel & & 209 \\
\hline (n. & 27 & 214 \\
\hline 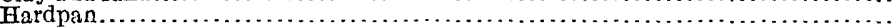 & 32 & 273 \\
\hline 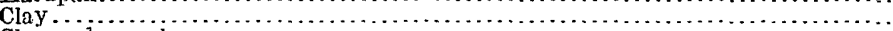 & 11 & 284 \\
\hline Clay and gravel & 8 & 292 \\
\hline Clay & 15 & 307 \\
\hline 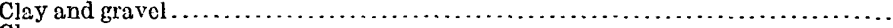 & 53 & 360 \\
\hline 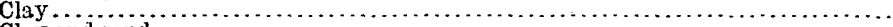 & $3 \overrightarrow{7}$ & 337 \\
\hline 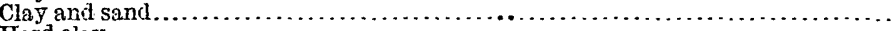 & 15 & 412 \\
\hline 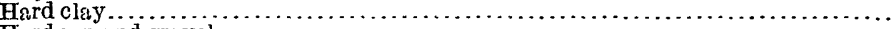 & 52 & 464 \\
\hline Hardpan and gra ${ }^{\prime}$ el.............. & 12 & 476 \\
\hline 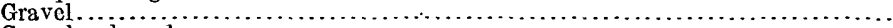 & 16 & 492 \\
\hline 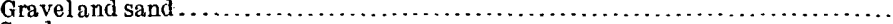 & 6 & 498 \\
\hline 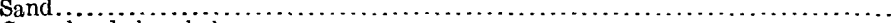 & 18 & 516 \\
\hline 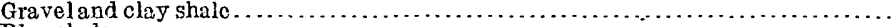 & 12 & 528 \\
\hline 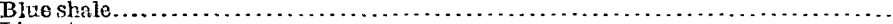 & 35 & 563 \\
\hline 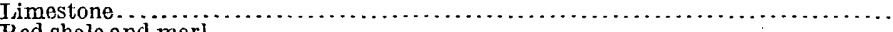 & 15 & 578 \\
\hline Red shale and marl .............. & 8 & 586 \\
\hline 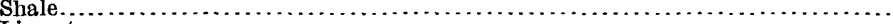 & 8 & 594 \\
\hline 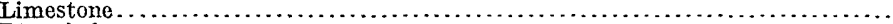 & 5 & 599 \\
\hline$\ldots \ldots \ldots \ldots$ & 601 & 1,200 \\
\hline Black slate or hard shale, with pyrite. & 165 & 1,365 \\
\hline Biue shale and limestone............. & 70 & 1,435 \\
\hline Black sandy limestone, with strata of gypsum.... & 45 & 1,480 \\
\hline 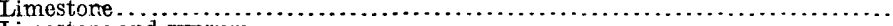 & 60 & $5+40$ \\
\hline 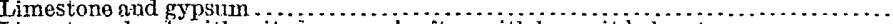 & 20 & 1,560 \\
\hline Limestone, hard, with grit above, and soiter, with less grit below.... & 240 & 1,800 \\
\hline 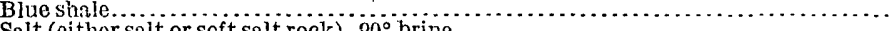 & 58 & 1,8 \\
\hline Salt (either salt or soft salt rock), $90^{\circ}$ brine $\ldots \ldots \ldots \ldots \ldots \ldots \ldots \ldots \ldots \ldots \ldots$ & & 1,862 \\
\hline 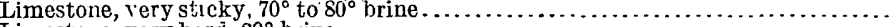 & 100 & 1,962 \\
\hline Limestone, very hard, $20^{\circ}$ brine...... & 40 & 2,002 \\
\hline Dolomite, with soft streaks, $50^{\circ}$ to $56^{\circ}$ brine & 138 & 2,140 \\
\hline Hard gray limestone. . . . . . . . . . . . . . . . . . . . . . & 55 & 2,195 \\
\hline Rock salt .. & 18 & 213 \\
\hline 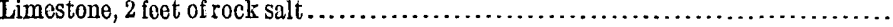 & 7 & 2,220 \\
\hline
\end{tabular}

a Lane, A. C., op. cit.. pl. 27.

Log of well No. 2, Ludington, Mason County, Mich.a

\begin{tabular}{|c|c|c|c|}
\hline ' & Material. & $\begin{array}{c}\text { Thick- } \\
\text { ness. }\end{array}$ & Depth. \\
\hline 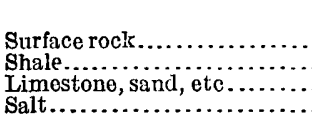 & 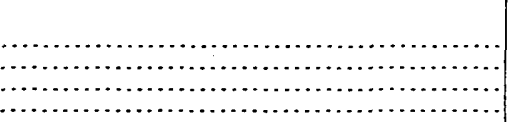 & $\begin{array}{r}\text { Fect. } \\
540 \\
950 \\
752 \\
19\end{array}$ & $\begin{array}{r}\text { Feet. } \\
540 \\
1,490 \\
2,242 \\
2,260\end{array}$ \\
\hline
\end{tabular}

a Lane, A. C., op. cit., pl. 28. 
Log of well'No. 3, Ludington, Mason County, Mich.a

\begin{tabular}{|c|c|c|}
\hline Material. & $\begin{array}{c}\text { Thick- } \\
\text { ness. }\end{array}$ & Depth. \\
\hline 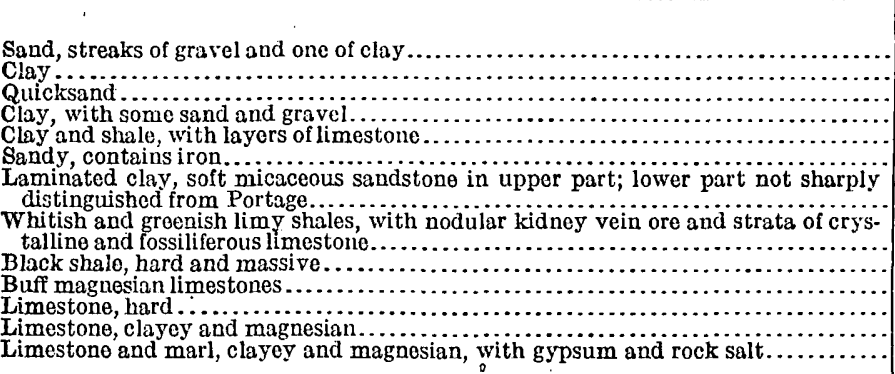 & $\begin{array}{r}\text { Feet. } \\
200 \\
97 \\
3 \\
300 \\
115 \\
160 \\
\\
200 \\
500 \\
20 \\
160 \\
150 \\
60 \\
36\end{array}$ & $\begin{array}{r}\text { Fet. } \\
200 \\
207 \\
300 \\
600 \\
715 \\
875 \\
1,075 \\
\\
1,575 \\
1,505 \\
1,755 \\
1,905 \\
1,965 \\
2,001\end{array}$ \\
\hline
\end{tabular}

a Lane, A. C., op. cit., pl. 29.

Log of well of Port Huron Salt Co., Port Huron, St. Clair County, Mich.

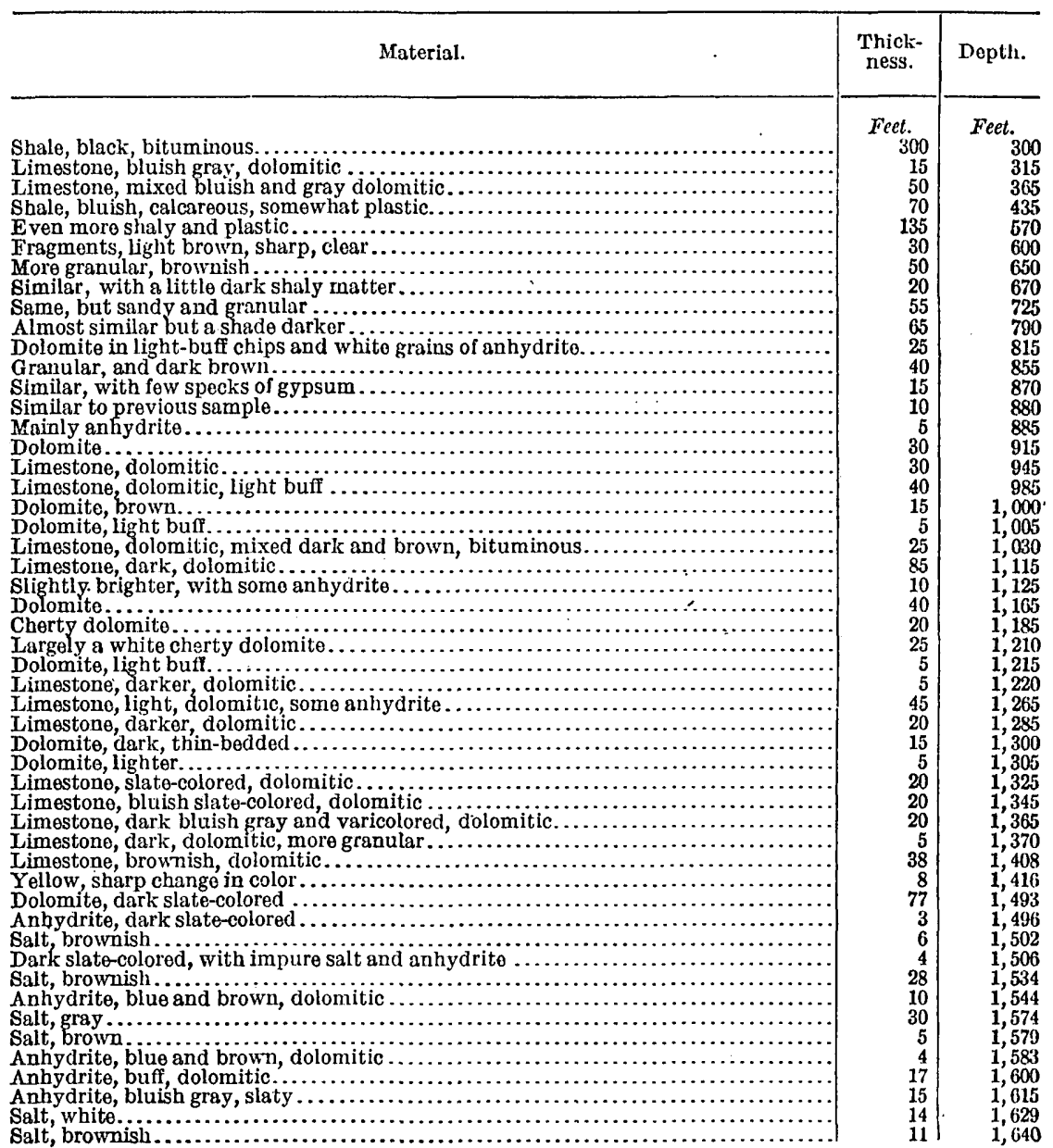


Log of well of Port Huron Salt Co., Port Huron, St. Clair County, Mich:-Contd.

\begin{tabular}{|c|c|c|}
\hline Material. & $\begin{array}{l}\text { Thick- } \\
\text { ness. }\end{array}$ & \\
\hline 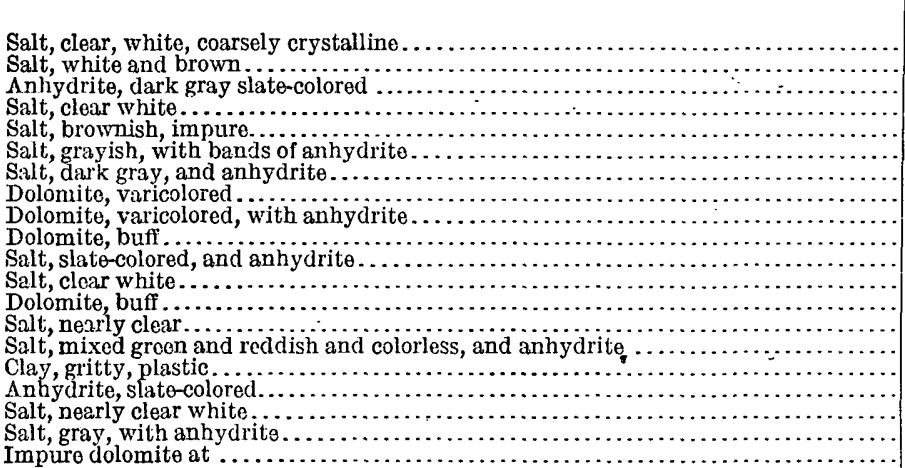 & $\begin{array}{r}\text { Fcet. } \\
26 \\
29 \\
-.5 \\
25 \\
10 \\
25 \\
20 \\
25 \\
20 \\
.30 \\
5 \\
10 \\
5 \\
10 \\
30 \\
5 \\
62 \\
66 \\
212\end{array}$ & $\begin{array}{r}\text { Fect. } \\
1,666 \\
1,695 \\
1,700 \\
1,725 \\
1,735 \\
1,760 \\
1,780 \\
1,805 \\
1,825 \\
1,855 \\
1,860 \\
1,870 \\
1,875 \\
1,885 \\
1,915 \\
1,920 \\
1,982 \\
2,048 \\
2,260 \\
2,260\end{array}$ \\
\hline
\end{tabular}

Log of well No. 12, Port Huron, St. Clair County, Mich.a

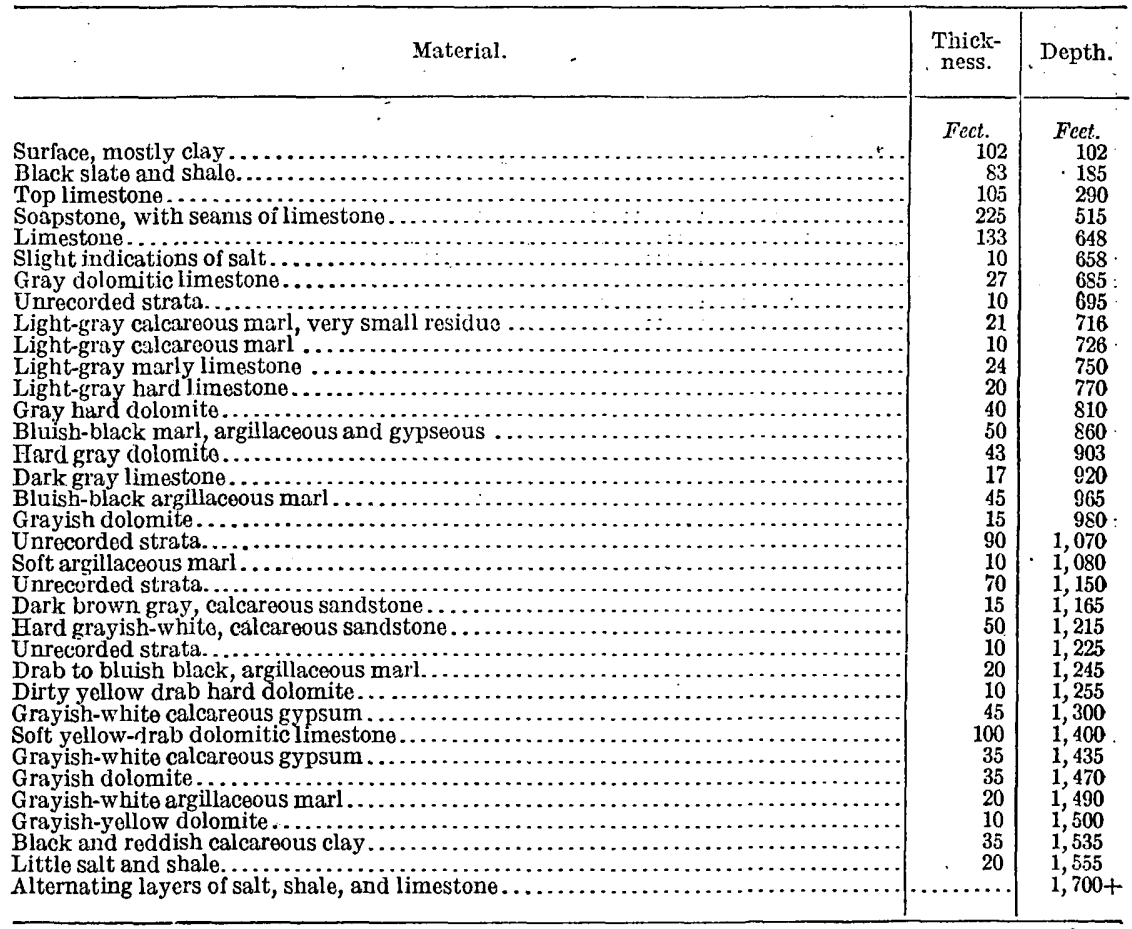

a Lane, A. C., op. cit., pl. 57. 
Log of well No. 1, Marine City, St. Clair County, Mich.a

\begin{tabular}{|c|c|c|}
\hline Material. & $\begin{array}{l}\text { Thick- } \\
\text { ness. }\end{array}$ & Depth. \\
\hline Surface rock.... & Feet. & Feet. \\
\hline Clay.......... & $\begin{array}{r}50 \\
150\end{array}$ & 50 \\
\hline Hardpan.. & 150 & \\
\hline Slate, black, bituminous, containing is & & 230 \\
\hline Slate, dark and light drab............ & 20 & 300 \\
\hline Slate, black, bituminous.... & 20 & 340 \\
\hline Shalo, dark drab, bituminou & 10 & 350 \\
\hline Shale, drab, bituminous, somowhat calcareous . . . . . . . . . . . & 10 & 360 \\
\hline Limestone, argillaceous, dolomitic............ & 50 & 410 \\
\hline Limestone, light bluish gray to drab.. & 40 & 450 \\
\hline n.................................. & 20 & 470 \\
\hline Timestone, light gray, with little talc and slate $\ldots \ldots \ldots \ldots \ldots \ldots \ldots \ldots \ldots \ldots \ldots \ldots \ldots \ldots \ldots \ldots \ldots$ & 0 & 490 \\
\hline 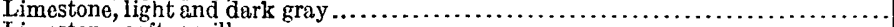 & 0 & 500 \\
\hline 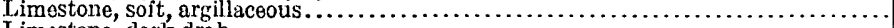 & 50 & 550 \\
\hline 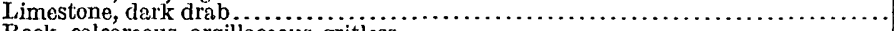 & 10 & 560 \\
\hline 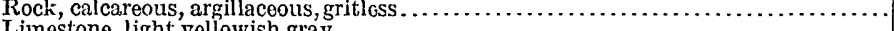 & 75 & 635 \\
\hline e, light yellowish & 95 & 730 \\
\hline$\cdots \cdots \cdots \cdots \cdots \cdots \cdots$ & $\begin{array}{l}40 \\
30\end{array}$ & 770 \\
\hline e, light bromish drab. & 30 & \\
\hline Dolomite, light gray........... & 25 & \\
\hline Dolomite, light đrab........ & 25 & 85 \\
\hline ne, hard, dolomitic, light gray & 25 & 905 \\
\hline Limestone, dolonitic, with fragments of slate, little anhydrite. & 30 & 935 \\
\hline Limestone, dolomitic.. & 30 & 965 \\
\hline Limestone, dolom & 15 & 980 \\
\hline Limestone, dolon & 10 & 990 \\
\hline tic, dark drab........ & & 1,060 \\
\hline ús... & 0 & 130 \\
\hline drab... & 30 & \\
\hline tone, li & 60 & \\
\hline Limestone, dol & 5 & \\
\hline Limestone, dolomitic, haid, light gray & 20 & \\
\hline $\begin{array}{l}\text { Limestor } \\
\text { Limestor }\end{array}$ & $\begin{array}{l}25 \\
23\end{array}$ & \\
\hline $\begin{array}{l}\text { chlight ar } \\
\text { white.... }\end{array}$ & & \\
\hline dark o & 2 & $\begin{array}{l}1,304 \\
1,330\end{array}$ \\
\hline reous, dark drab, possibly argillaceous, with anhydrite. & 35 & \\
\hline Gypsum, calcaroous, dark drab, contains anhydrite $\ldots \ldots \ldots \ldots \ldots \ldots \ldots$ & 25 & \\
\hline 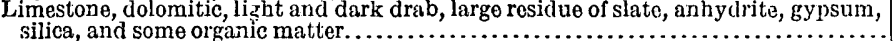 & 75 & \\
\hline Limestone, dolomitic, light drab, lirge rosiduo of gypsum & 20 & 85 \\
\hline I.imestone, gypseous, light drab, large residue of gyp & 53 & \\
\hline 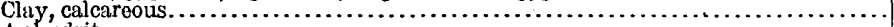 & 41 & \\
\hline Anhydrite. & 20 & \\
\hline psum, wh & 5 & \\
\hline k salt . . . ......... & 33 & \\
\hline lestone, gyps & & \\
\hline
\end{tabular}

a Lano, A. C., op. cit., pl. 33.

Notc.-The gypsum is anhydrite.

Log of well No. 2, Marine City, St. Clair County, Mich.a

\begin{tabular}{|c|c|c|}
\hline Material. & $\begin{array}{l}\text { Thick- } \\
\text { ness. }\end{array}$ & Depth. \\
\hline Surface rock. & Fect. & Feet. \\
\hline Brownish-black argiliaceou & 200 & 410 \\
\hline Hard gray limestone............ & 45 & 455 \\
\hline Hard gray limestone, with fragments of slate & 15 & 470 \\
\hline Bluish-gray argillaceous shale...... & 166 & 636 \\
\hline Bluish-gray argillaceous limestone. & 4 & 640 \\
\hline Light-gray siliceous limestone...... & 100 & 740 \\
\hline [Not named in record].... & 96 & 836 \\
\hline Gray dolomiticli & & 846 \\
\hline Dark-gray hard limestone & 34 & 880 \\
\hline Dark chocolate colored dolomitic limestone. & 10 & 890 \\
\hline [Not & 110 & 1,000 \\
\hline Dark-gray dolomitic limestone.... & 10 & 1,010 \\
\hline Dark-gray dolomitic limestone, medium residue. & 20 & 1,030 \\
\hline Hard gray dolomitic limestone............................. & 20 & 1,055 \\
\hline $\begin{array}{l}\text { Hard gray dolomitic limestone, medium siliceous residue.. } \\
\text { Hard light-gray and grap arenacoous dolomiticlimestone.. }\end{array}$ & 10 & $\begin{array}{l}1,075 \\
1,085\end{array}$ \\
\hline 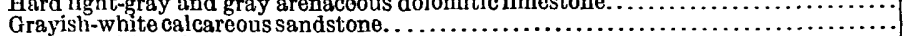 & 25 & 1,110 \\
\hline Hard grayish, calcareous sandstone... & 50 & 1,160 \\
\hline [Not named in record] & 455 & 1,615 \\
\hline Salt (stopped in salt)..... & 101 & 1,735 \\
\hline
\end{tabular}

a Lane, A. C., op. cit., pl. 34. 


\begin{tabular}{|c|c|c|}
\hline Material. & $\begin{array}{c}\text { Thick- } \\
\text { ness. }\end{array}$ & Depth. \\
\hline 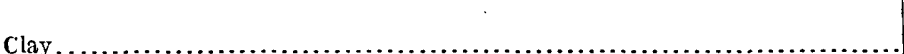 & Fect. & Feet. \\
\hline 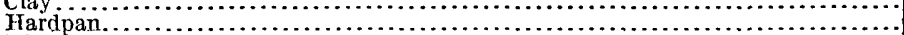 & $\begin{array}{r}155 \\
27\end{array}$ & $\begin{array}{l}155 \\
182\end{array}$ \\
\hline 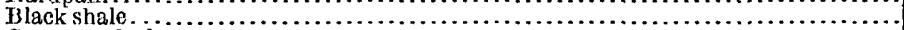 & 20 & 202 \\
\hline Gas rock, dark.............. & 10 & 212 \\
\hline [Not named in record]........ & 148 & 360 \\
\hline 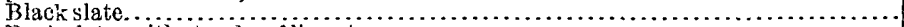 & 10 & 370 \\
\hline Dark slate, with streaks of limestone.. & 70 & 440 \\
\hline 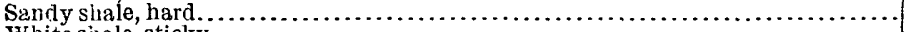 & 40 & 480 \\
\hline 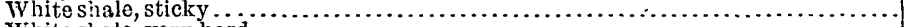 & 25 & 505 \\
\hline 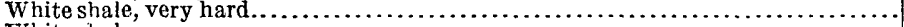 & 10 & 15 \\
\hline 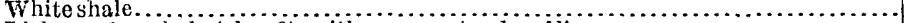 & 25 & 540 \\
\hline Light pucker shale (alum?), with narrow streaks of lime $\ldots \ldots \ldots \ldots \ldots \ldots \ldots$ & 60 & 600 \\
\hline 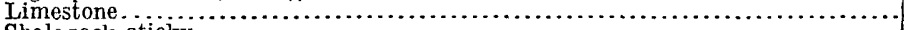 & 40 & 640 \\
\hline 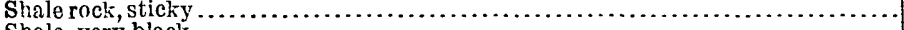 & 60 & 700 \\
\hline 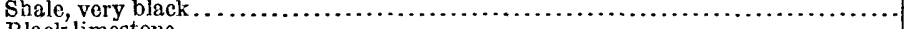 & 30 & 730 \\
\hline 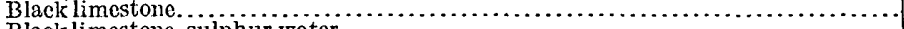 & 20 & 750 \\
\hline Black limestone, sulphur water...... . & 60 & 810 \\
\hline Hard limestone.............. & 100 & 910 \\
\hline Hard limestone. . & 82 & 992 \\
\hline Limestone with pockets of sandstone.. & 200 & 1,192 \\
\hline Limestone, some sandstone, and a showing of gypsum $\ldots \ldots \ldots \ldots \ldots \ldots \ldots \ldots$ & 33 & 1,225 \\
\hline 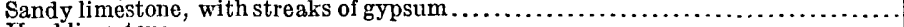 & 60 & 1,285 \\
\hline & 280 & 1,565 \\
\hline Light-colored shale (anhydrite?) . . .... & 40 & 1,605 \\
\hline Hard limestone. . ................... & 17 & 1,622 \\
\hline 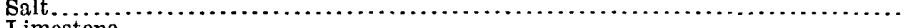 & 15 & 1,637 \\
\hline н & $\begin{array}{r}5 \\
20 \\
0\end{array}$ & 1,642 \\
\hline${ }_{1}$ & 20 & 1,602 \\
\hline Salt.............. & 65 & 1,727 \\
\hline
\end{tabular}

a Lane, A. C., op. cit., pl. 35.

Log of well No. 4, Marine City, St. Clair County, Mich.a

\begin{tabular}{|c|c|c|}
\hline Material. & $\begin{array}{l}\text { Thick- } \\
\text { ness. }\end{array}$ & Depth. \\
\hline 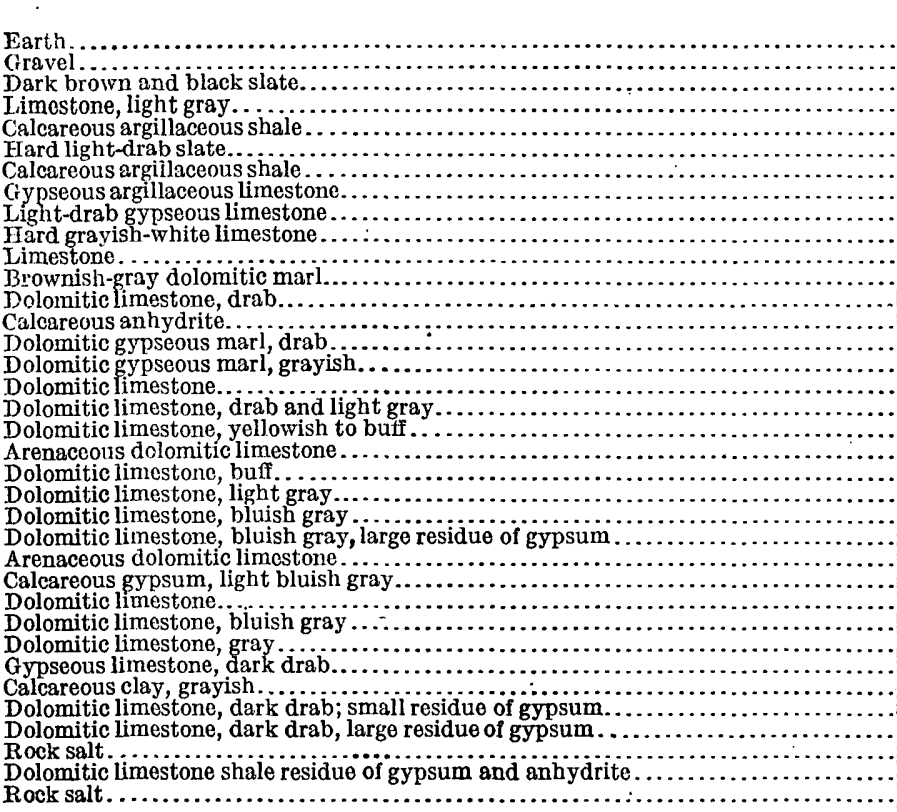 & $\begin{array}{r}\text { Feet. } \\
150 \\
50 \\
200 \\
75 \\
95 \\
15 \\
40 \\
40 \\
35 \\
25 \\
25 \\
60 \\
10 \\
30 \\
10 \\
10 \\
10 \\
90 \\
30 \\
130 \\
60 \\
30 \\
50 \\
60 \\
20 \\
50 \\
30 \\
20 \\
60 \\
10 \\
30 \\
10 \\
10 \\
20 \\
10 \\
30\end{array}$ & $\begin{array}{r}\text { Fcet. } \\
150 \\
200 \\
400 \\
475 \\
570 \\
585 \\
625 \\
665 \\
700 \\
725 \\
750 \\
810 \\
820 \\
850 \\
880 \\
870 \\
880 \\
970 \\
1,000 \\
1,130 \\
1,190 \\
1,220 \\
1,270 \\
1,330 \\
1,350 \\
1,400 \\
1,430 \\
1,450 \\
1,510 \\
1,, 520 \\
1,550 \\
1,560 \\
1,570 \\
1,590 \\
1,600 \\
1,630\end{array}$ \\
\hline
\end{tabular}


Log of well No. 5, Marine City, St. Clair County, Mich.a

\begin{tabular}{|c|c|c|}
\hline Material. & $\begin{array}{c}\text { Thick- } \\
\text { ness. }\end{array}$ & Depth. \\
\hline & Fcet. & Feet. \\
\hline 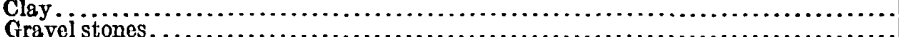 & 150 & 150 \\
\hline 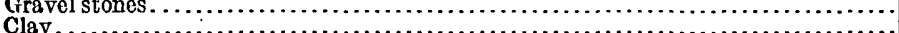 & $\begin{array}{r}5 \\
20\end{array}$ & 155 \\
\hline 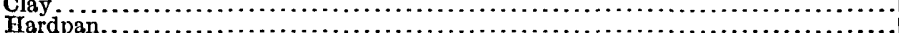 & 30 & 185 \\
\hline Brown shale & $\begin{array}{l}45 \\
70\end{array}$ & 300 \\
\hline Black slate... & 160 & 460 \\
\hline Brown calcareous slate.......... & 5 & 465 \\
\hline Flard siliceous gray limestone ............ & 45 & 510 \\
\hline 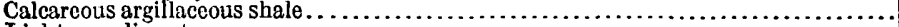 & 230 & 740 \\
\hline Light-gray limestone.............. & 50 & 790 \\
\hline 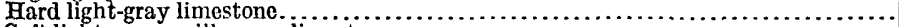 & 25 & 815 \\
\hline 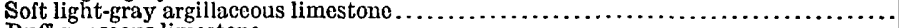 & 10 & 825 \\
\hline & 55 & 880 \\
\hline 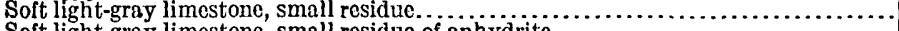 & 20 & 900 \\
\hline Soft light-gray limestone, small residue of anhydrite $\ldots \ldots \ldots \ldots \ldots \ldots \ldots \ldots \ldots \ldots \ldots$ & 30 & 930 \\
\hline 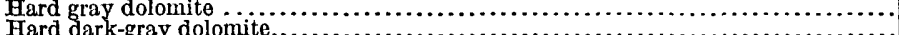 & 65 & 995 \\
\hline 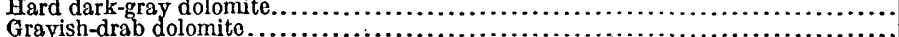 & 15 & 1,010 \\
\hline Dark-buff arenaceous limestone........ & 25 & 1,000 \\
\hline Dark-buff calcareous sandstone & 35 & 1,125 \\
\hline Dark-buft arenaceous limestone. & 82 & 1,207 \\
\hline Chocolate-bufi dolomite ........... & 93 & 1,300 \\
\hline 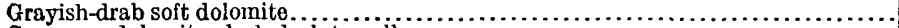 & 10 & 1,310 \\
\hline 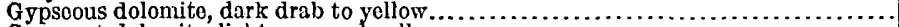 & 30 & 1,340 \\
\hline Gypseous dolomite, light gray and yellow. & 20 & 1,360 \\
\hline 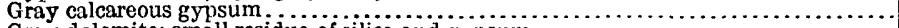 & 100 & 1,460 \\
\hline Gray dolomite; small residue of silica and gypsum........ & 10 & 1,470 \\
\hline
\end{tabular}

$a$ Lane, A. C., op. cit., pl. 37.

Log of well No. 6, 21 miles north of Marine City, St. Clair County, Mich.a

\begin{tabular}{|c|c|c|}
\hline Material. & $\begin{array}{c}\text { Thick- } \\
\text { ness. }\end{array}$ & Depth. \\
\hline Cle & Feet. & Feet. \\
\hline 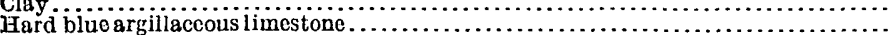 & 60 & $\begin{array}{r}40 \\
100\end{array}$ \\
\hline 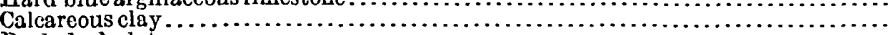 & 70 & 170 \\
\hline 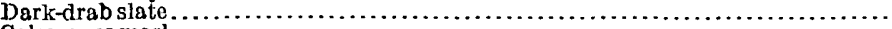 & 30 & 00 \\
\hline 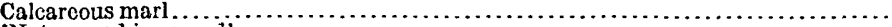 & 10 & 210 \\
\hline 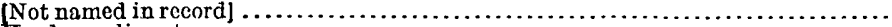 & 490 & 700 \\
\hline 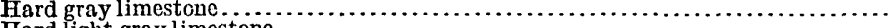 & 10 & 710 \\
\hline 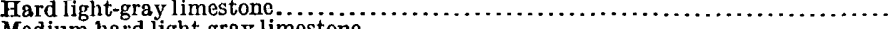 & 40 & 750 \\
\hline 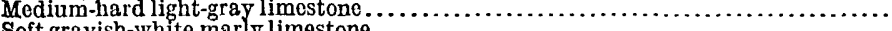 & 60 & 810 \\
\hline 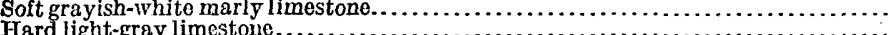 & 20 & 830 \\
\hline 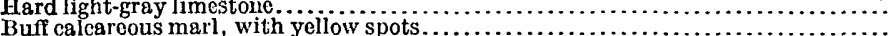 & $\begin{array}{l}50 \\
30\end{array}$ & $\begin{array}{l}880 \\
910\end{array}$ \\
\hline Medium-soft grayish-white limestone....... & 30 & 940 \\
\hline 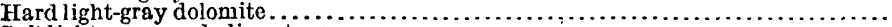 & 10 & 950 \\
\hline 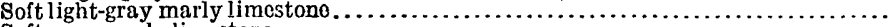 & 10 & 930 \\
\hline 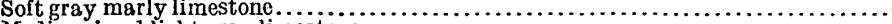 & 50 & 1,010 \\
\hline Medium-hard light-gray limestone $\ldots \ldots \ldots \ldots \ldots \ldots \ldots \ldots \ldots \ldots \ldots \ldots$ & 50 & 1,060 \\
\hline 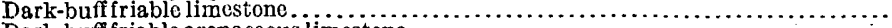 & 20 & 1,080 \\
\hline 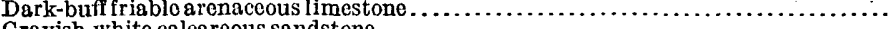 & $\dot{\Sigma} 0$ & 1,110 \\
\hline 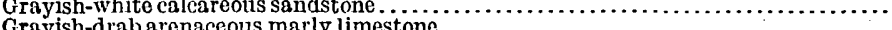 & 80 & 1,190 \\
\hline $\begin{array}{l}\text { Girayish-araw arenaceous marty } 11 m e s \\
\text { Bluish-gray calcareous clay....... }\end{array}$ & $\begin{array}{r}130 \\
80\end{array}$ & $\begin{array}{l}1,320 \\
1,400\end{array}$ \\
\hline 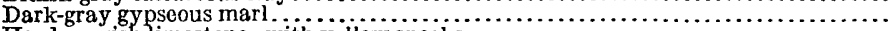 & 40 & $\overrightarrow{1}, 440$ \\
\hline Hard grayish limestone, with yellow & & 1,460 \\
\hline Dark-gray marly limestone....... & 60 & 1,520 \\
\hline $\begin{array}{l}\text { [Not namod in record] } \ldots \ldots \ldots \ldots \ldots \ldots \ldots \ldots \ldots \ldots \ldots \ldots \ldots \ldots \ldots \ldots \ldots \ldots \ldots \ldots \ldots \ldots \ldots \\
\text { Salt. }\end{array}$ & 100 & 1,620 \\
\hline
\end{tabular}

a Lane, A. C., op. cit., pl. 38. 
Log of well No. 7, Marine City, St. Clair County, Mich.a

\begin{tabular}{|c|c|c|}
\hline Material. & $\begin{array}{l}\text { Thick- } \\
\text { ness. }\end{array}$ & Depth. \\
\hline م & Feet. & Feet. \\
\hline lue clay....... & $14 j$ & 145 \\
\hline 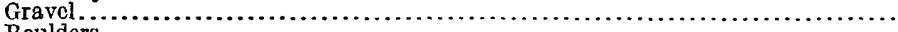 & 6 & 151 \\
\hline 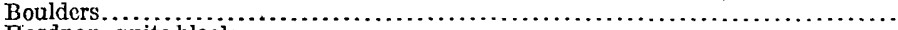 & 4 & 155 \\
\hline 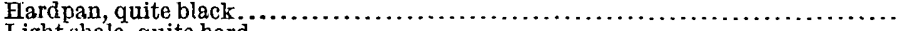 & 40 & 195 \\
\hline 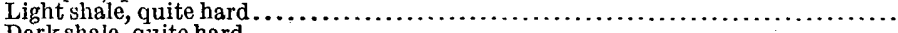 & 20 & 215 \\
\hline 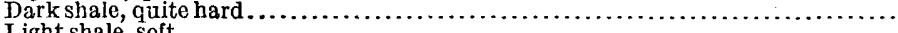 & 25 & 240 \\
\hline 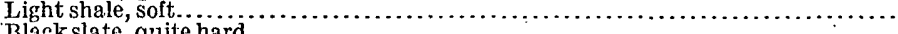 & 100 & 340 \\
\hline 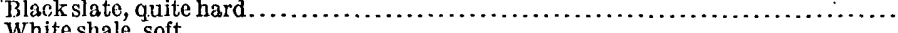 & 250 & 590 \\
\hline 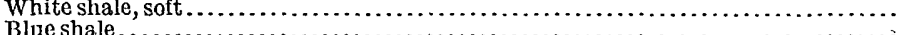 & 25 & 615 \\
\hline$\cdots \ldots \ldots \ldots \ldots \ldots \ldots \ldots \ldots \ldots \ldots \ldots$, & 50 & \\
\hline 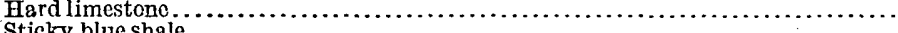 & 50 & 715 \\
\hline n............................ & 60 & 775 \\
\hline ........................ & 50 & 825 \\
\hline 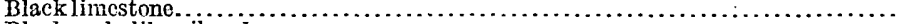 & 30 & 855 \\
\hline Black rock, like oil rock................. & 75 & 930 \\
\hline 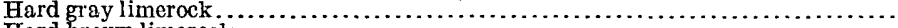 & 100 & 1,030 \\
\hline Fard brown limerock.............. & 80 & 1,110 \\
\hline White shale (anhydrite?) . ........ & 60 & 1,170 \\
\hline Sandrock, with streaks of limerock... & 200 & 1,370 \\
\hline Hard limerock, brown. & 50 & 1,420 \\
\hline Hard gray limerock. & 50 & 1,470 \\
\hline 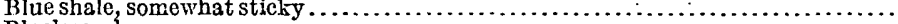 & 75 & 1,545 \\
\hline 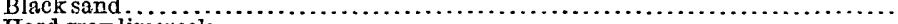 & 50 & 1,595 \\
\hline Hard gray limerock................... & 25 & 1,620 \\
\hline Solid salt . . . . . . $\ldots \ldots$ & 30 & 1,650 \\
\hline 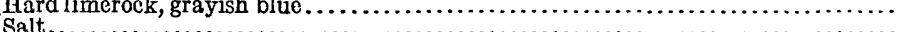 & $\begin{array}{r}25 \\
100\end{array}$ & 1,675 \\
\hline Hard limerock. & 100 & $\begin{array}{l}1,66 \\
1,777\end{array}$ \\
\hline & & \\
\hline
\end{tabular}

a I.ane, A. C., op. cit.; pl. 39.

Log of well No. 2, Royal Oak, Oakland County, Mich.a

\begin{tabular}{|c|c|c|}
\hline Material. & $\begin{array}{c}\text { Thick- } \\
\text { ness. }\end{array}$ & Depth. \\
\hline Clay. & Feet. & Feet. \\
\hline 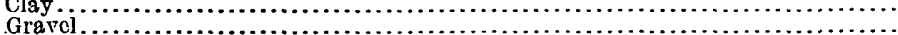 & & 40 \\
\hline 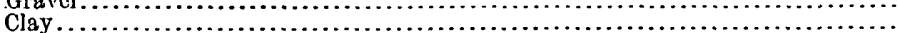 & & $\begin{array}{l}45 \\
70\end{array}$ \\
\hline 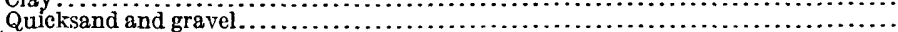 & & 164 \\
\hline 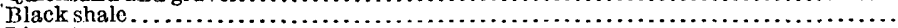 & 141 & 305 \\
\hline 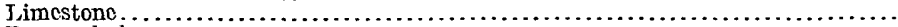 & 85 & 330 \\
\hline 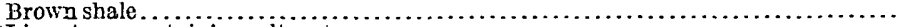 & 130 & 520 \\
\hline 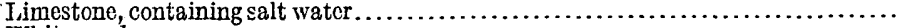 & 316 & 836 \\
\hline 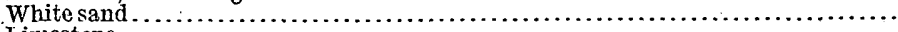 & 154 & 990 \\
\hline 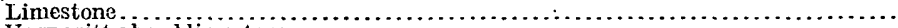 & 115 & 1,105 \\
\hline 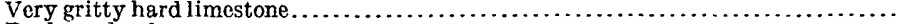 & 20 & 1,125 \\
\hline 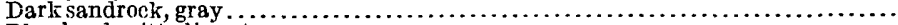 & 15 & 1,140 \\
\hline Blue hard gritty limestone............... & 35 & 1,175 \\
\hline Very soft light-colored lime.............. & 40 & 1,215 \\
\hline 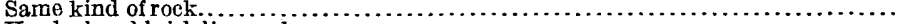 & 45 & \\
\hline 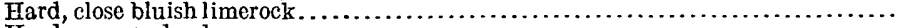 & 145 & 1,405 \\
\hline 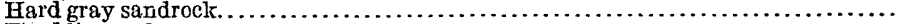 & 5 & 1,410 \\
\hline 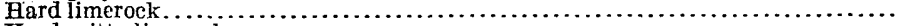 & 10 & 1,420 \\
\hline Hard gritty limerock. ................ & 45 & 1,465 \\
\hline 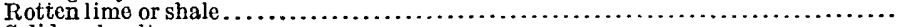 & 78 & 1,543 \\
\hline 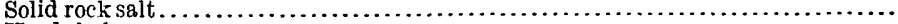 & 97 & 1,640 \\
\hline 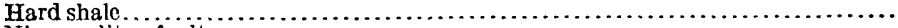 & 10 & 1,650 \\
\hline Nice quality of salt..................... & 45 & 1,695 \\
\hline Slate, rotten lime, or shale, marly ..... & 40 & 1,735 \\
\hline 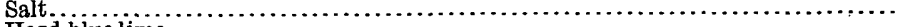 & 57 & 1,792 \\
\hline Hard bluelime.................... & 18 & 1 \\
\hline 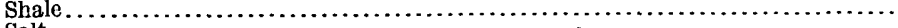 & 10 & 1 \\
\hline$\ldots \ldots \ldots \ldots \ldots \ldots \ldots$ & 80 & 1,900 \\
\hline 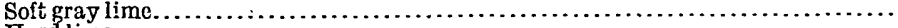 & 10 & 1,910 \\
\hline 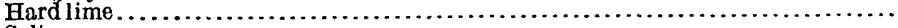 & 95 & 2,005 \\
\hline 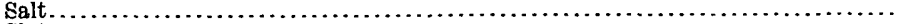 & 15 & 2,020 \\
\hline Slate. & 95 & 2,115 \\
\hline Salt. & 35 & 2,150 \\
\hline 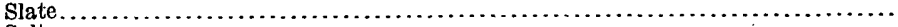 & 15 & 2,165 \\
\hline 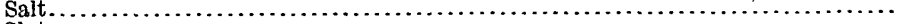 & 20 & 2,185 \\
\hline ........................ & 15 & 2,200 \\
\hline Salt. . & 100 & 2,300 \\
\hline - & 15 & 2,315 \\
\hline 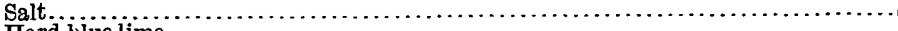 & 160 & 2,415 \\
\hline 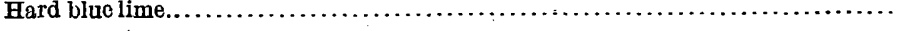 & 27 & \\
\hline
\end{tabular}


Log of well of Detroit Natural Gas Co., Detroit, Wayne County, Mich.a

\begin{tabular}{|c|c|c|}
\hline Material. & $\begin{array}{c}\text { Thick- } \\
\text { ness. }\end{array}$ & Depth. \\
\hline 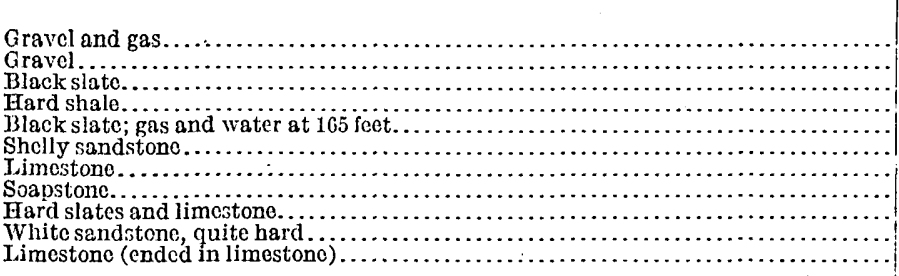 & $\begin{array}{r}\text { Fct. } \\
100 \\
25 \\
8 \\
7 \\
52 \\
34 \\
14 \\
160 \\
75 \\
105 \\
190\end{array}$ & $\begin{array}{r}\text { Fcct. } \\
100 \\
125 \\
133 \\
140 \\
192 \\
226 \\
240 \\
400 \\
475 \\
580 \\
770\end{array}$ \\
\hline
\end{tabular}

a Lane, A. C., op. cit., pl. 15.

Log of well of Morton Salt Co., Ecorse, Wayne County, Mich.a

\begin{tabular}{|c|c|c|}
\hline Material. & $\begin{array}{c}\text { Thick- } \\
\text { ness. }\end{array}$ & Depth. \\
\hline 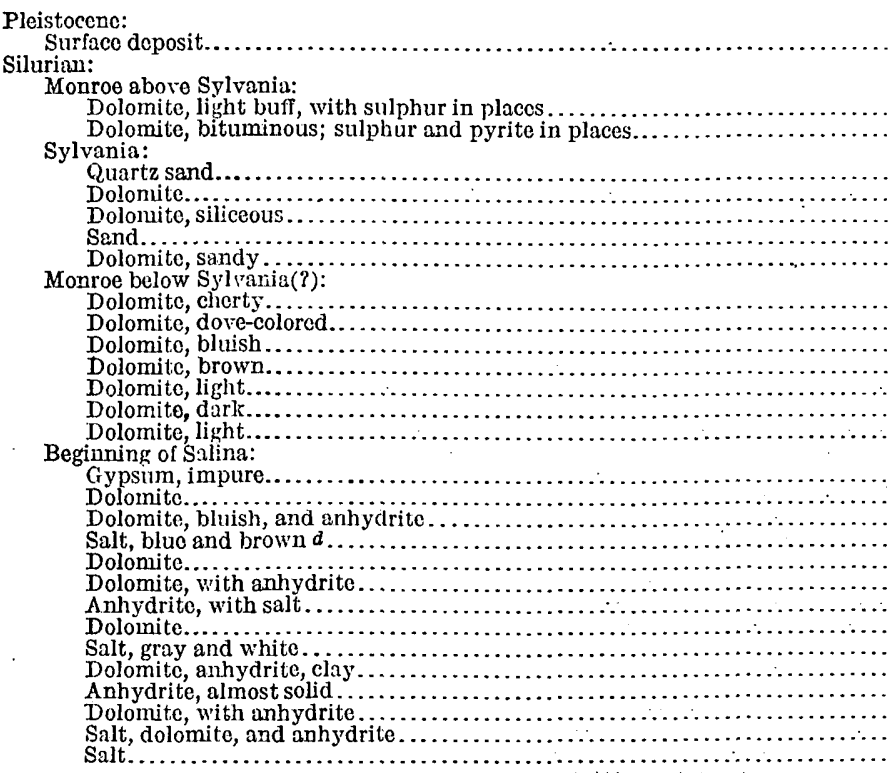 & $\begin{array}{r}65 \\
20 \\
35 \\
35 \\
10 \\
50 \\
50 \\
20 \\
30 \\
15 \\
15 \\
335 \\
25 \\
\\
45 \\
20 \\
175 \\
50 \\
80 \\
10 \\
10 \\
5 \\
15 \\
100 \\
5 \\
50 \\
5 \\
201\end{array}$ & $\begin{array}{r}412 \\
432 \\
462 \\
477 \\
492 \\
527 \\
552 \\
\\
597 \\
617 \\
c 792 \\
842 \\
922 \\
932 \\
912 \\
917 \\
962 \\
1,062 \\
1,067 \\
1,117 \\
1,122 \\
1,323\end{array}$ \\
\hline
\end{tabular}

a Lane, A. C., Notes on the geological section of Michigan: Michigan Geol. Survey Ann. Rcpt. for 190 , p. $97,1909$.

$b$ Given as 40 fect in original report.

c First salt at 730 feet.

$d$ "This is the most likely to contain potash." 
Log of well No. 9 of Pennsylvania Salt Co., Wyandotte, Wayne County, Mich.a

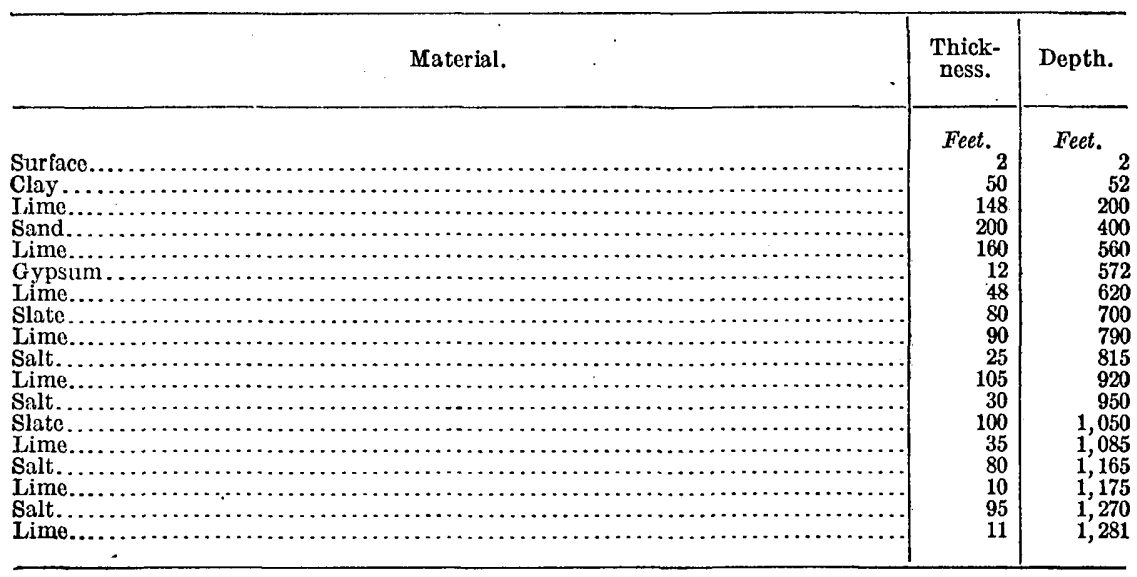

a Furnished by the Pennsylvania Salt Co.

Log of well at Wyandotte, Wayne County, Mich.a

\begin{tabular}{|c|c|c|}
\hline Material. & $\begin{array}{l}\text { Thick- } \\
\text { ness. }\end{array}$ & Depth. \\
\hline & Feet. & Feet. \\
\hline $\begin{array}{l}\text { Clay and gravel. } \\
\text { Dark limestone.. }\end{array}$ & 75 & 75 \\
\hline (n. & 15 & 90 \\
\hline 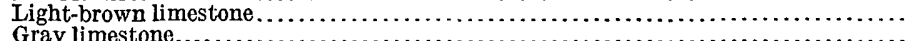 & 10 & 100 \\
\hline 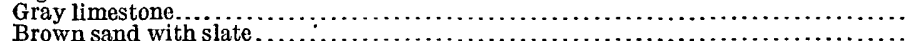 & 25 & 125 \\
\hline 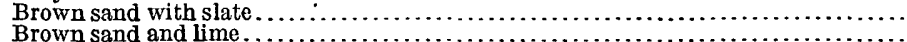 & 30 & 155 \\
\hline 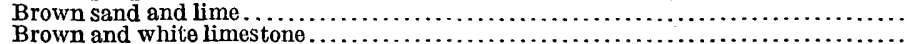 & 5 & 160 \\
\hline 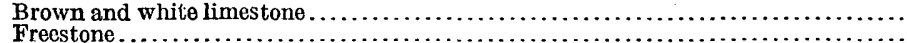 & 70 & 230 \\
\hline 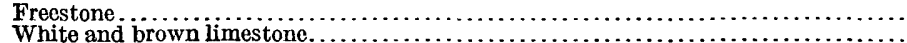 & $\begin{array}{l}60 \\
70\end{array}$ & 290 \\
\hline 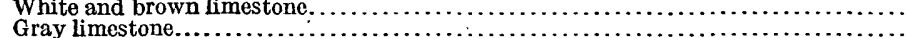 & 70 & 360 \\
\hline & 30 & 365 \\
\hline Brown limestone. & 5 & 400 \\
\hline (n. & 30 & 430 \\
\hline Very dark limestone.. & 104 & 534 \\
\hline Limestone and slate................ & 66 & 600 \\
\hline Slate and soa & 15 & 615 \\
\hline 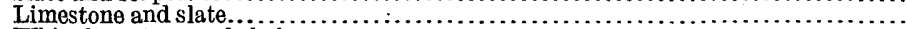 & 75 & 690 \\
\hline 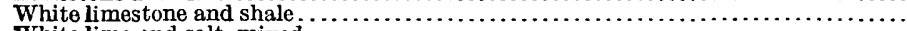 & 40 & 730 \\
\hline 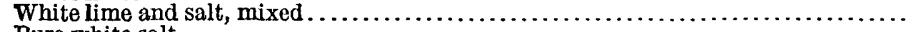 & 70 & 800 \\
\hline 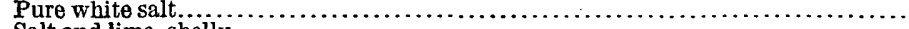 & 30 & 830 \\
\hline 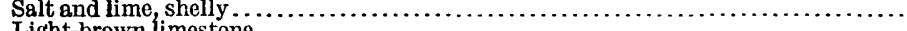 & 40 & 870 \\
\hline 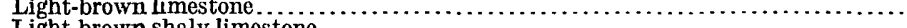 & 30 & 900 \\
\hline 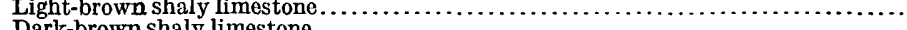 & 20 & 920 \\
\hline 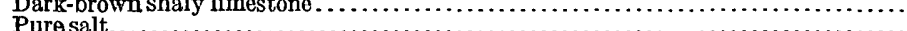 & 20 & 940 \\
\hline 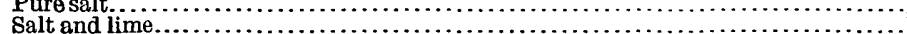 & 15 & 955 \\
\hline 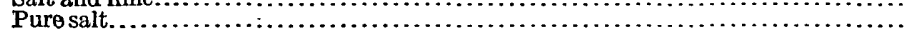 & & 960 \\
\hline SaIt and lime shell.... & 5 & 970 \\
\hline 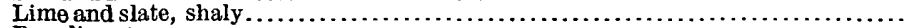 & 75 & 1,045 \\
\hline 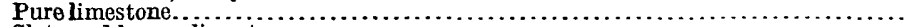 & 10 & 055 \\
\hline estone. & 5 & 1,060 \\
\hline Pure brown limestone...... & 20 & 1,080 \\
\hline 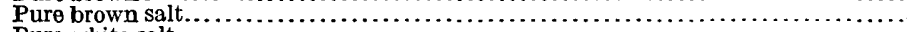 & 10 & 1,090 \\
\hline white salt... & 100 & 1,190 \\
\hline nestone...... & 45 & \\
\hline ly limestone............ & $\begin{array}{r}5 \\
90\end{array}$ & 30 \\
\hline 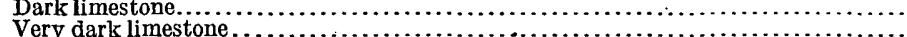 & 90 & 33 \\
\hline Brown limestone..... & 5 & 1,340 \\
\hline Blue limestone... & 10 & 350 \\
\hline Brown limestone. . & 10 & 1,360 \\
\hline Brown limestone, very hard. & 5 & 1,365 \\
\hline 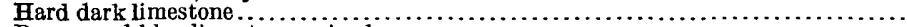 & & 1,370 \\
\hline Brown and blue limestone, & 50 & 1,375 \\
\hline blue & & \\
\hline
\end{tabular}

a Lane, A. C., The geology of lower Michigan with reference to deep borings: Michigan Geol. Survey; vol. 5 , pt. 2 , pl. 56,1895 . 
Log of well at Wyandotte, Wayne County, Mich.-Continued.

\begin{tabular}{|c|c|c|}
\hline Material. & $\begin{array}{l}\text { Thick- } \\
\text { ness. }\end{array}$ & Dopth. \\
\hline 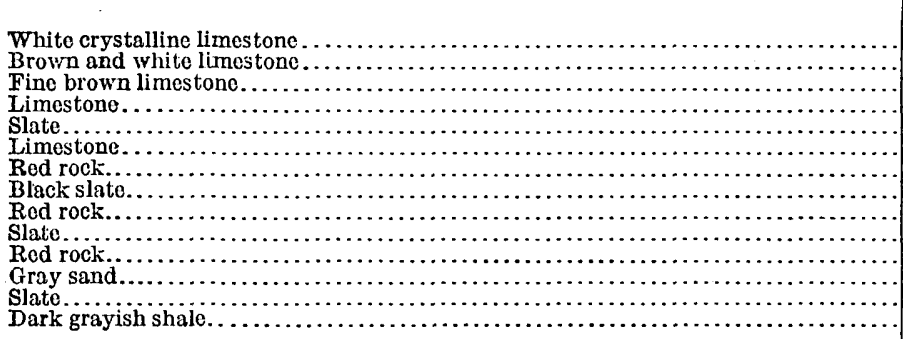 & $\begin{array}{r}\text { Feet. } \\
15 \\
35 \\
35 \\
350 \\
10 \\
20 \\
110 \\
20 \\
80 \\
95 \\
5 \\
10 \\
40 \\
250\end{array}$ & $\begin{array}{r}\text { Fcet. } \\
1,440 \\
1,475 \\
1,510 \\
1,860 \\
1,870 \\
1,890 \\
2,000 \\
2,020 \\
2,100 \\
2,195 \\
2,200 \\
2,210 \\
2,250 \\
2,500\end{array}$ \\
\hline
\end{tabular}

Note.-The strata from 730 to 1,500 feet were provisionally assigned by Lane to the Salina.

Log of well at Alpena, Alpena County, Mich.a

\begin{tabular}{|c|c|c|}
\hline Material. & $\begin{array}{l}\text { Thick- } \\
\text { ness. }\end{array}$ & Depth. \\
\hline 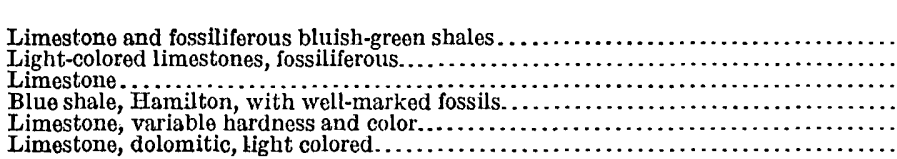 & $\begin{array}{r}\text { Feet. } \\
20 \\
60 \\
320 \\
80 \\
120 \\
425\end{array}$ & $\begin{array}{r}\text { Feet. } \\
20 \\
80 \\
400 \\
480 \\
600 \\
1,025\end{array}$ \\
\hline
\end{tabular}

a Lane, A. C., op. cit., pl. 5.

NoTE.--Salt found a little below 1,000 feet.

Log of well at Petrolia, Ontario, Canada.a

\begin{tabular}{|c|c|c|}
\hline Material. & $\begin{array}{l}\text { Thick- } \\
\text { noss. }\end{array}$ & Depth. \\
\hline 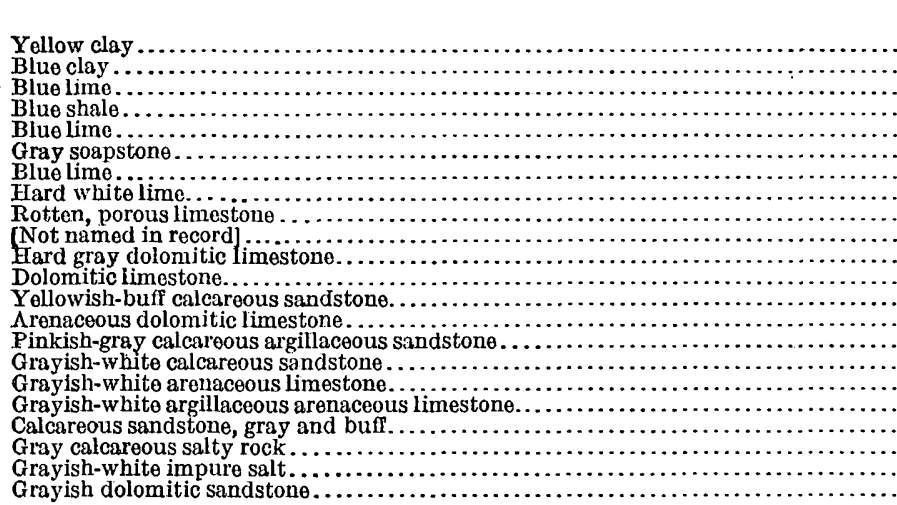 & $\begin{array}{r}\text { Feet. } \\
12 \\
108 \\
65 \\
120 \\
10 \\
30 \\
30 \\
100 \\
15 \\
578 \\
4 \\
4 \\
26 \\
5 \\
26 \\
21 \\
13 \\
10 \\
16 \\
6 \\
52 \\
63\end{array}$ & $\begin{aligned} & \text { Feet. } 12 \\
& 120 \\
& 185 \\
& 305 \\
& 315 \\
& 345 \\
& 375 \\
& 475 \\
& 490 \\
& 1,068 \\
& 1,072 \\
& 1,076 \\
& 1,102 \\
& 1,107 \\
& 1,133 \\
& 1,154 \\
& 1,167 \\
& 1,177 \\
& 1,193 \\
& 1,199 \\
& 1,251 \\
& 1,314\end{aligned}$ \\
\hline
\end{tabular}

a Lane, A. C., op. cit., pl. 46. 
Log of well at Port Lambton, Ontario, Canada.a

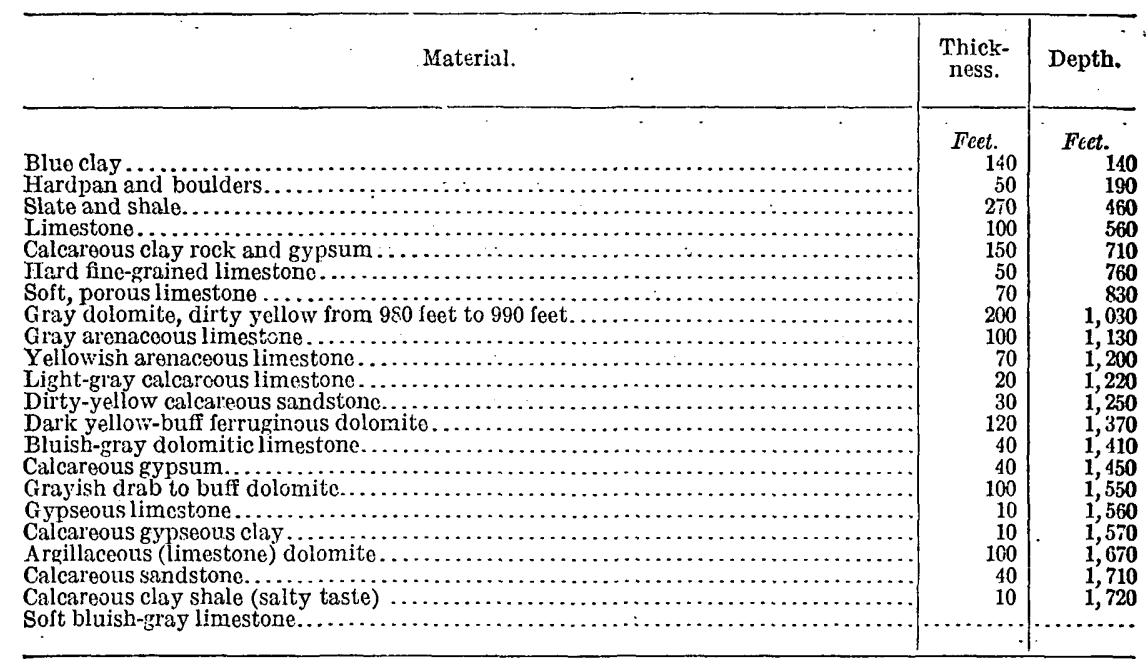

a Lano, A. C., op. cit., pl. 5 s.

Log of well of Peter MacEwan estate, Goderich, Ontario, Canada.

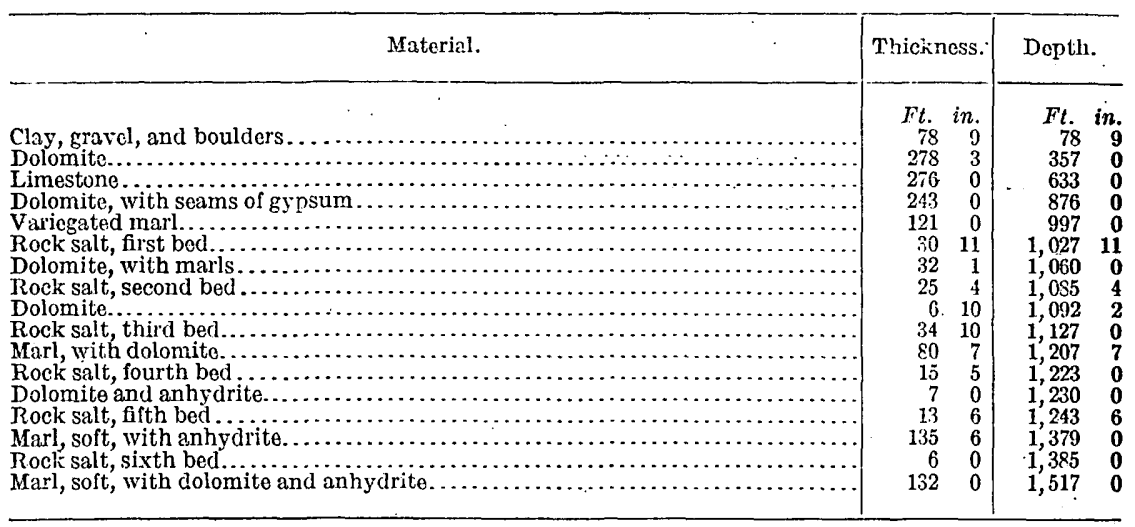

.Log of well No. 1, Bay City, Bay. County, Mich.a

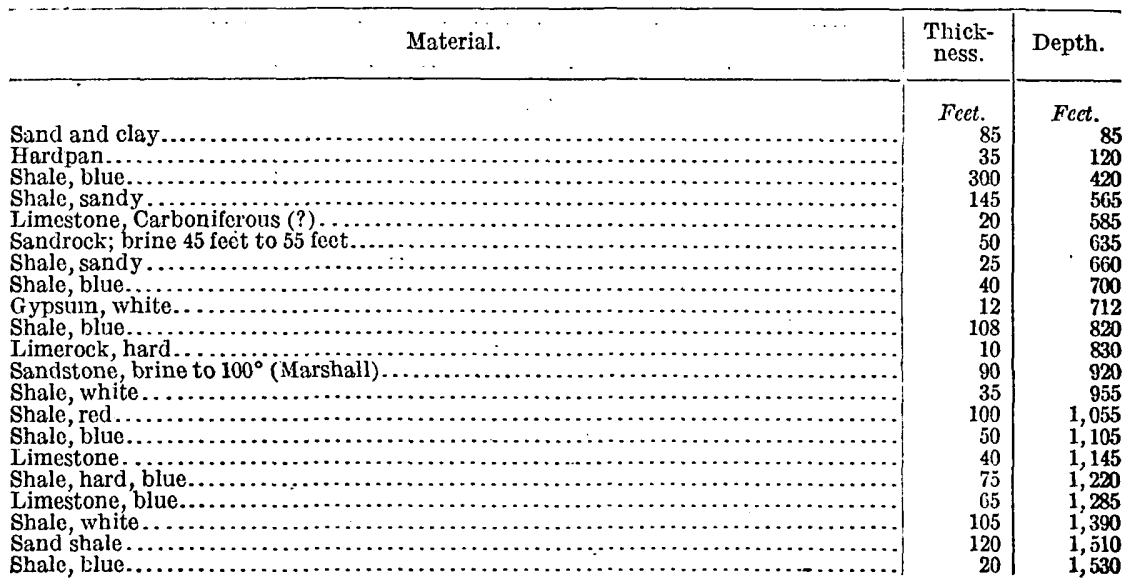


Log of well No. 1, Bay City, Bay County, Mich.-Continued.

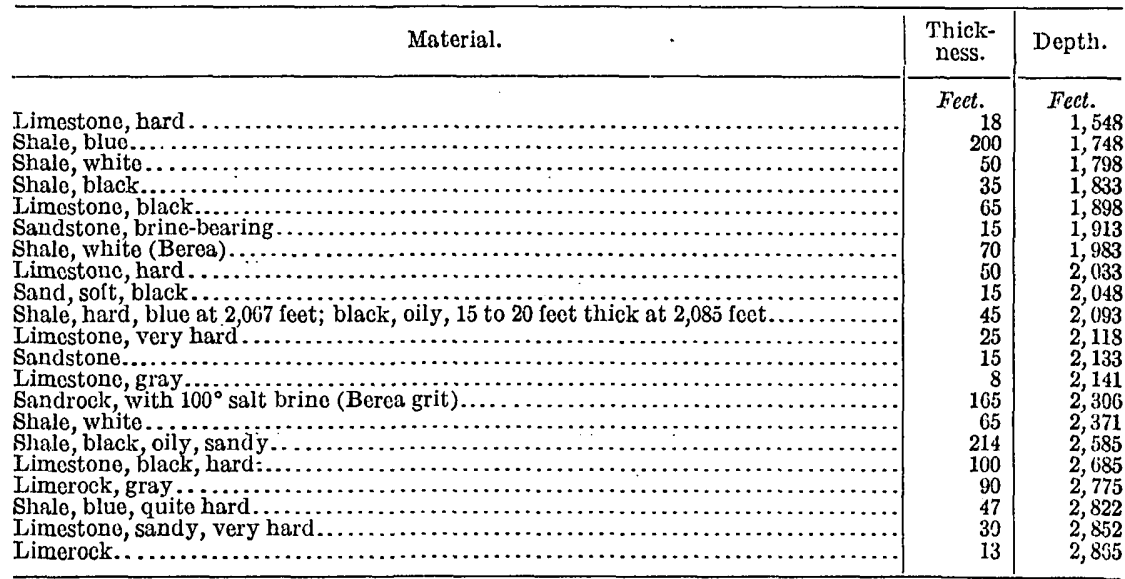

Log of well of Saginaw Plate Glass Co., West Saginaw, Saginaw County, Mich.a

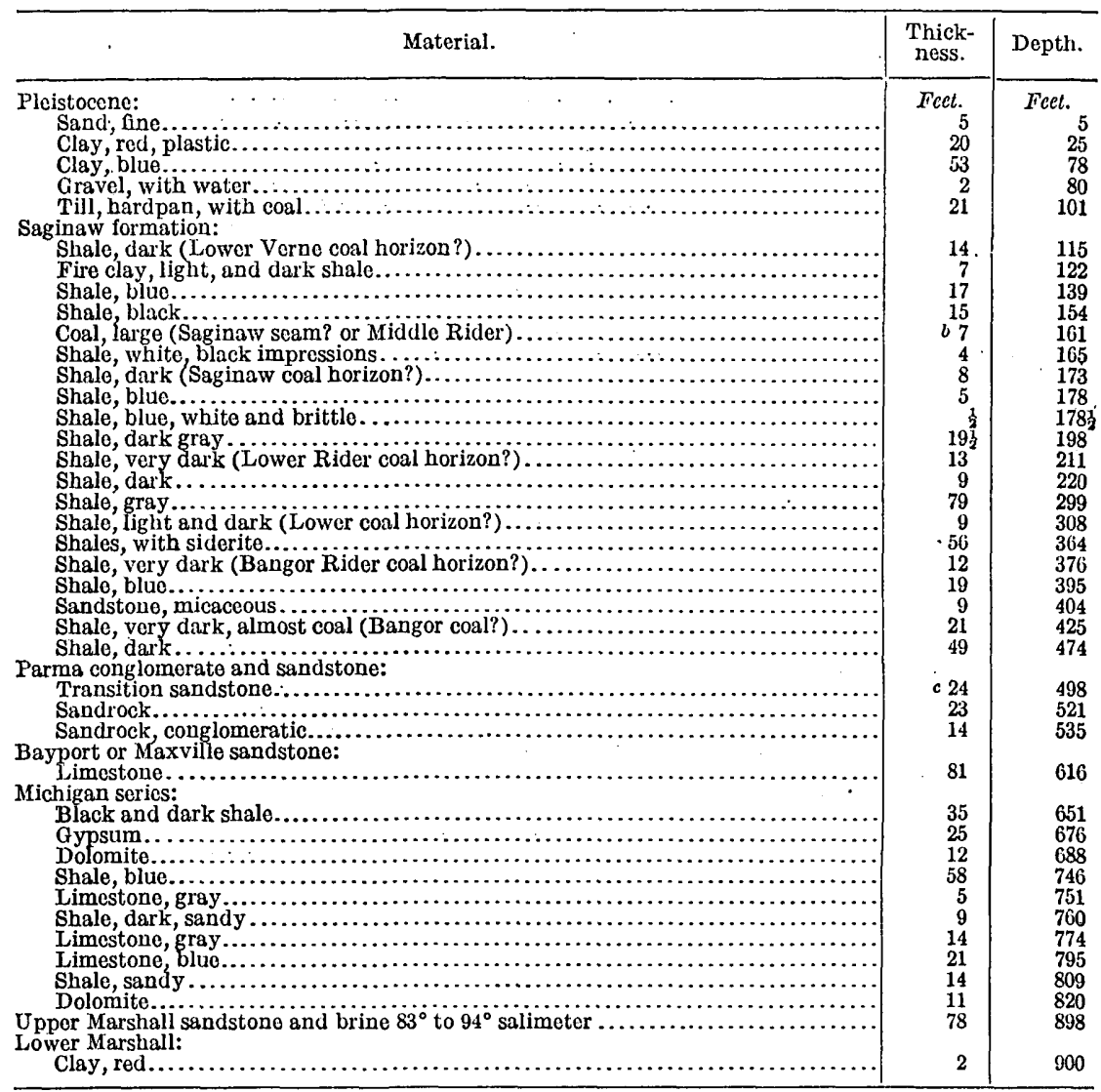

a Lane, A. C., Notes on the geological section of Michigan: Michigan Geol. Survey Ann. Rept. for 1908 , pp. 102-104, 1909.

o 6 feet in original report.

c 22 feet in original report. 
Log of well No. 15 of Dow Chemical Co., Midland, Mich.

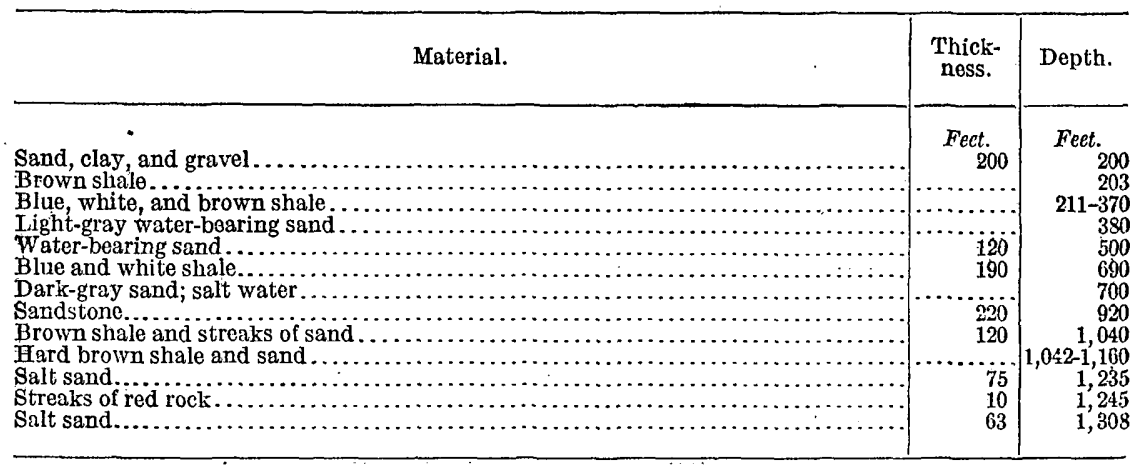

Log of well No. 14 of Dow Chemical Co., Midland, Afich.

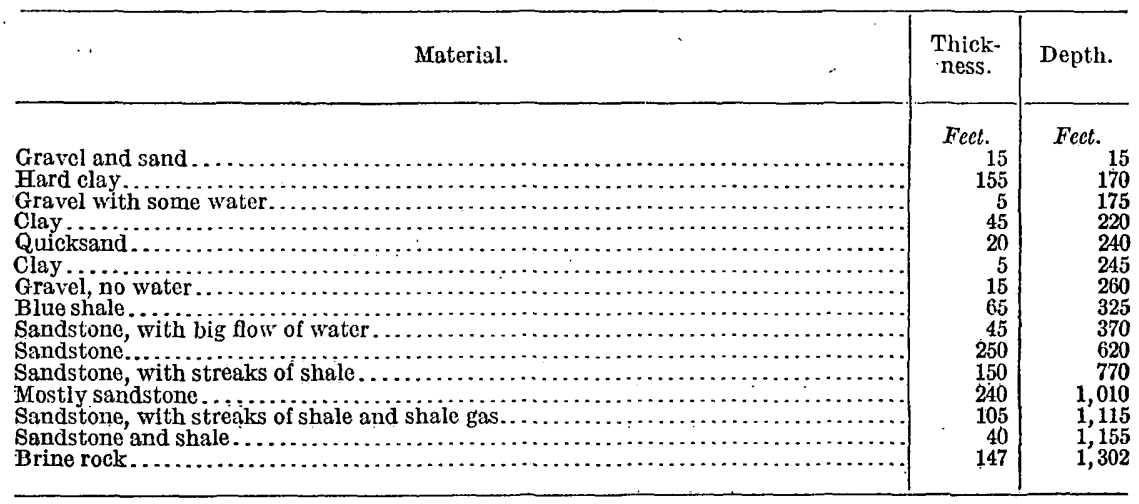

Log of Meyer well, Midland, Mich.

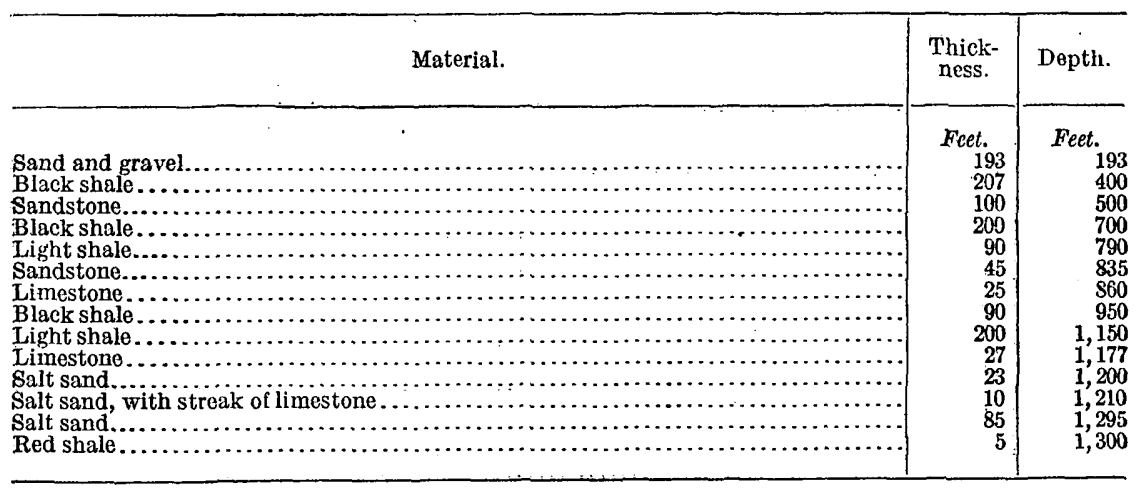

The Marshall sandstone, which is the brine-bearing bed, ranges in thickness from 100 feet to nearly 150 feet in the vicinity of Midland as revealed in the numerous wells put down in this locality. Its top ranges from about 1,150 to 1,250 feet in depth, and its base from 1,275 to 1,360 feet. 
Well of Dow Chemical Co., Mount Pleasant, Isabella County, Mich.

\begin{tabular}{|c|c|c|}
\hline Material. & $\begin{array}{l}\text { Thick- } \\
\text { ness. }\end{array}$ & Depth. \\
\hline & Feet. & Fect. \\
\hline $\begin{array}{l}\text { Gravel, glacial overwash. } \\
\text { Till, blue................. }\end{array}$ & $\begin{array}{l}80 \\
20\end{array}$ & $\begin{array}{r}80 \\
100\end{array}$ \\
\hline Quiclksand.................. & & 120 \\
\hline Till, blue... & 160 & 280 \\
\hline Porous bed, with water; coarse gravel on top, fine sand below & 74 & 354 \\
\hline 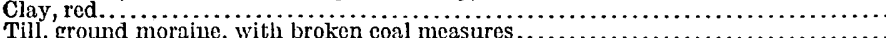 & 26 & 380 \\
\hline $\begin{array}{l}\text { Till, ground moraine, with broken coal measures } \ldots \ldots \ldots \ldots \ldots \ldots \\
\text { Shale, black, with streaks of coal at } 410,435 \text {, and } 560 \text { feet; sandstone, limestone, or }\end{array}$ & 55 & 435 \\
\hline 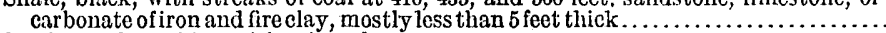 & 185 & 620 \\
\hline Sandrock, fine white, with mineral water.. & 90 & 710 \\
\hline 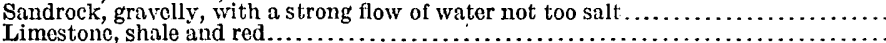 & $\begin{array}{l}80 \\
30\end{array}$ & $\begin{array}{ll}790 \\
820\end{array}$ \\
\hline 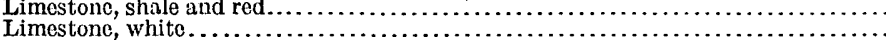 & $\begin{array}{l}30 \\
30\end{array}$ & $\begin{array}{l}820 \\
850\end{array}$ \\
\hline Iimestone, white, with very salt water... & 120 & 970 \\
\hline Limestone, white, flercely effervescing. . & 55 & 1,025 \\
\hline 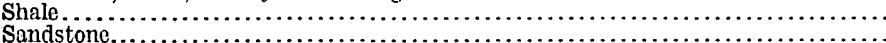 & $\begin{array}{r}5 \\
20\end{array}$ & $\begin{array}{l}1,030 \\
\text { ], } 050\end{array}$ \\
\hline Dolomite, with shale.................. & 75 & 1,125 \\
\hline Anhydrite and dolomite...$\ldots \ldots \ldots$ & 100 & 1,225 \\
\hline Anhydrite and noarly pure gypsum. & 45 & 1,270 \\
\hline $\begin{array}{l}\text { Dolomite, shalc, and anhydrite....... } \\
\text { Top of Marshall sandstone (?) }\end{array}$ & 103 & 1,373 \\
\hline Sandstone.............. & 8 & 1,381 \\
\hline Shale....... & 5 & 1,386 \\
\hline Sandstone... & & $\frac{1}{2}, 390$ \\
\hline Shale $\ldots \ldots \ldots \ldots \ldots \ldots \ldots$ & 15 & 1,405 \\
\hline Sandstone, dark, wit & 58 & 1,463 \\
\hline
\end{tabular}

\section{BIBLIOGRAPHY.}

Cook, C. W., The salt industry of Michigan: Michigan Geol. and Biol. Survey Pub. 8, Geol. ser. 6, pp. 315-336, 1912.

Garriaues, S. S., Report on the salt manufacture of Michigan: Michigan Geol. Survey, vol. 3, pt. 1, Appendix B, pp. 107-216, 1876.

Grabau, A. W., and Sherzer, W. H., The Monroe formation of southern Michigan and adjoining regions: Michigan Geol. and Biol. Survey Pub. 2, Geol. ser. 1, 239 pp., 1910.

Hubbard, L. L., The origin of salt, gypsum, and petroleum: Michigan Geol. Survey, vol. 5, pt. 2, pp. ix-xxiv, 1895.

Lane, A. C., Geological report on Huron County, Mich.: Michigan Geol. Survey, vol. 7 , pt. 2, pp. 1-329, 1900. Well sections and economic products are described on pp. 118-201, 202-226; salt on pp. 224-226.

- Salt: Michigan Geol. Survey Ann. Rept., 1901, pp. 241-242, 1902. Brief notes on well records and analyses of the brines.

- Economic geology: Michigan Geol. Survey Ann. Rept. for 1901, pp. 135-1.36, 1902; idem for 1908, pp. 61-65, 75, 92, 93, 97, 1909.

\section{oHIO.}

Ohio has ranked third among the States in recent years in both quantity and value of salt produced. The raw material is derived from both salt beds and natural brines, and the product is made by the most common processes of evaporation-the grainer and the vacuum-pan processes. No rock salt is mined. Considerable brine obtained from the beds of rock salt is utilized in the manufacture of soda. Bromine and calcium chloride also are obtained from the natural brines. 


\section{POSITION OF FIELDS.}

Ohio salt comes from two districts, one in the northeastern and the other in the southeastern part of the State. Both occurrences are distinct geologically as well as geographically. Their locations are indicated on the general map (Pl. I, p. 12), but their details are better shown in figure 3 . The southeastern field is an extension of the field in West Virginia, which lies on the opposite side of Ohio River.

\section{DEPOSITS IN NORTHEASTERN OHIO. ${ }^{1}$}

\section{EXTENT.}

Thus far the production of salt in northeastern Ohio has been restricted to Cuyahoga, Summit; Medina, Lake, and Wayne counties, though salt as such is not produced in Lake County, the brines obtained by the Diamond Alkali Co., at Fairport Harbor, being made into other sodium compounds. The salt deposits are not limited to this area, and the extension of the beds farther east is shown by the accompanying log of the Hadsell well near Cortland, the correlations in which are those of Bownocker. ${ }^{2}$

Log of Hadsell well, near Cortland, Trumbull County, Ohio.

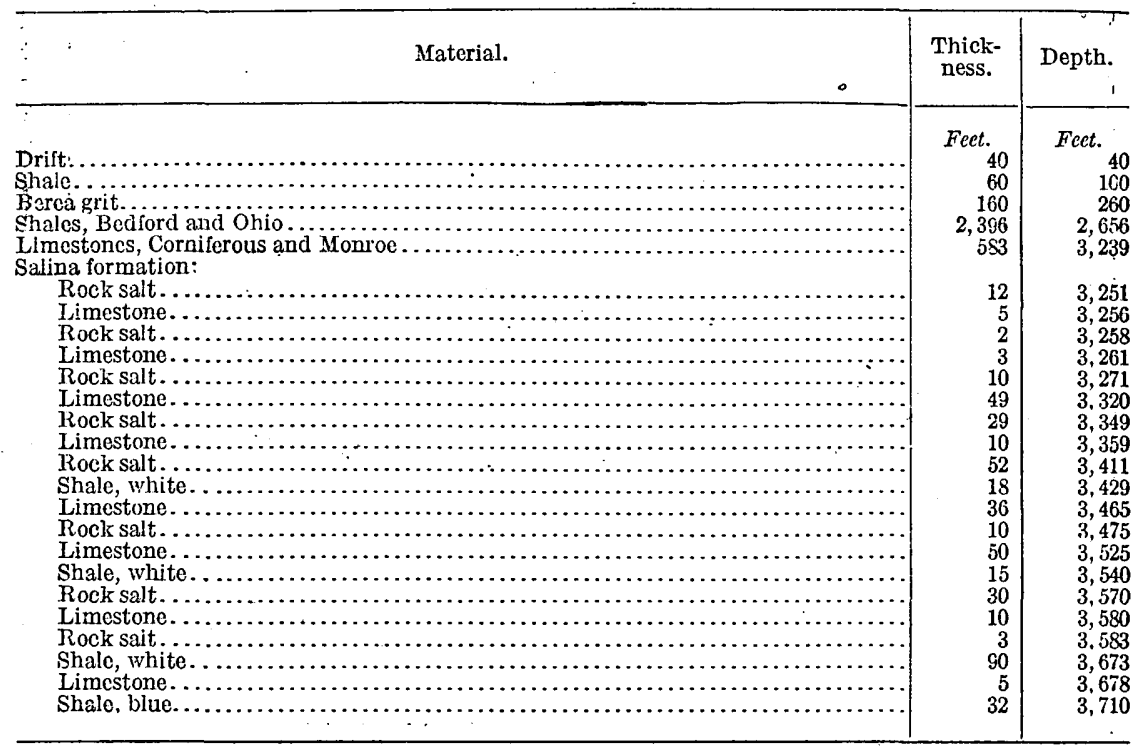

This record shows 148 feet of rock salt. If the alternating strata of limestone, like those farther west, have many large holes filled with salt, then the total quantity is much in excess of that contained

1 Bownocker, J. A., Salt deposits and the salt industry in Ohio: Ohio Geol. Survey, 4th ser., Bull. 8, 1906.

3 Idem, p. 39. 
OHIO.

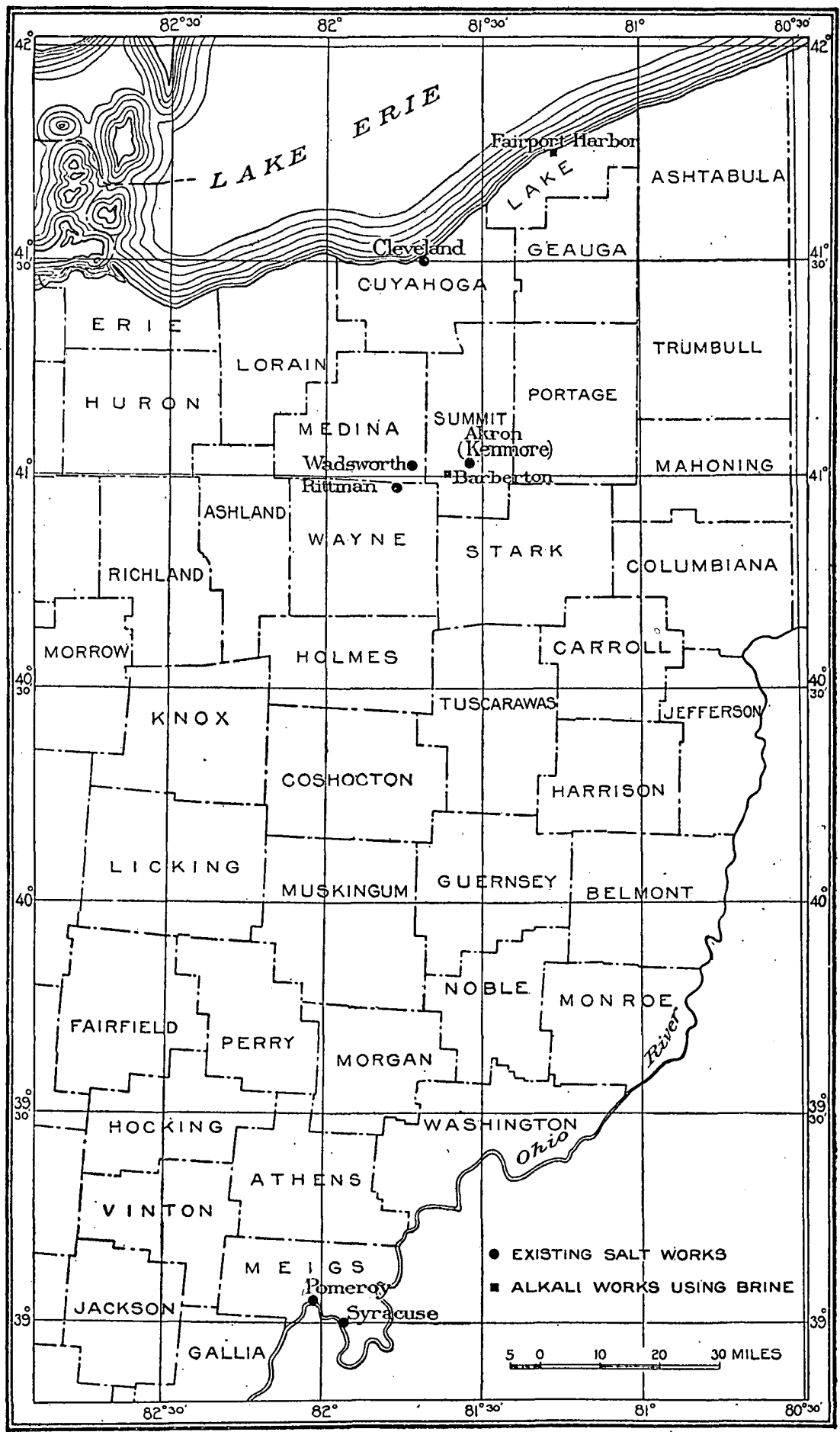

FIGURE 3.-Map of eastern Ohio showing location of salt works and alkali works using brinc. 
in the 148 feet. The record shows that the salt strata extend to the eastern limit of the State, and, although the well records in New York do not warrant the assertion, yet the presumption that the salt beds of the main New York field are continuations of those of Ohio is strong, as comparatively recent records have shown the existence of rock salt in Erie and Cattaraugus counties, N. Y., in localities where it was formerly not known. To the south the limit of the salt deposits has not been determined, because the strata dip to the south and east, and hence the salt horizon lies so deep that it has not:been reached by the drill. Westward the limit has not been determined. It can not extend as far as Sandusky, according to the following record, but of course too much weight must not be attached to the evidence afforded by a single well.

Log of well at Sandusky, Erie County, Ohio.a

\begin{tabular}{|c|c|c|}
\hline Material. & $\begin{array}{c}\text { Thick- } \\
\text { ness. }\end{array}$ & Depth. \\
\hline 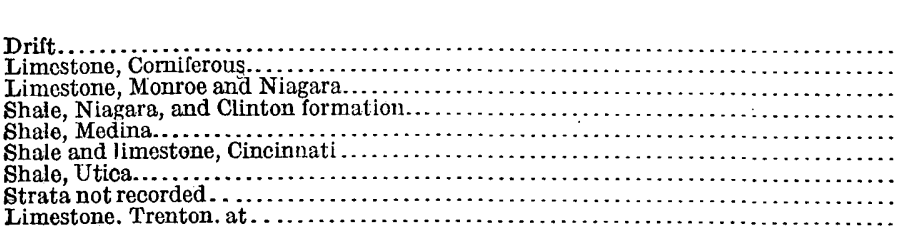 & $\begin{array}{r}\text { Feet. } \\
10 \\
100 \\
970 \\
105 \\
175 \\
500 \\
310 \\
40 \\
\ldots \ldots . . .\end{array}$ & $\begin{array}{r}\text { Fcet. } \\
10 \\
110 \\
1,080 \\
1,185 \\
1,360 \\
1 ; 860 \\
2,170 \\
2,210 \\
2,210\end{array}$ \\
\hline
\end{tabular}

a. Ohio Geol. Survey, vol. 6, p. 195, 1888.

The Monroe and Niagara were found to contain layers of gypsum but none of salt. However, when the area beneath which salt has been demonstrated to exist and the number and thickness of the salt beds are considered, the conclusion is warranted that northeastern Ohio contains enough salt to last an indefinite period at the present rate of consumption.

STRATIGRAPHY.

The salt horizon in the northeast'ern part of Ohio lies beneath the Monroe formation and in the Salina formation of the Silurian system. It would appear that the salt-bearing beds from which the artificial brine (brine formed by allowing water to come into contact with the salt beds) is obtained in this part of the State are not extensions of those of southeastern Michigan, although the salt in northeastern Ohio occurs at the same geologic horizon as that along the Detroit and St. Clair rivers in Michigan. The reason for this has been explained under Michigan, and, briefly, is due to supposed shallow water in the ancient sea.

It will be observed that in the first Ohio record given above, Bownocker has classified the beds containing rock salt in north- 
eastern Ohio as belonging to the Salina formation. This formation is not known to outcrop anywhere in the State of Ohio, but that the deposits in northeastern Ohio which contain the rock salt are a southwestward extension of the Salina formation of New York is now generally accepted. In the past some confusion has arisen from the fact that the earlier definitions of the Monroe included the salt-bearing beds, the name being used to include all rocks between the Dundee limestone above and the Niagara below. The present generally accepted definition of Monroe, however, restricts that name to the strictly marine deposits overlying the salt-bearing deposits (which according to Grabau and others are nonmarine) and underlying the Dundee limestone, and the salt-bearing deposits, which lithologically resemble as well as occupy the stratigraphic position of the Salina formation of New York, are considered as unquestionably representing the western accumulation of the Salina sea, although they are not everywhere easily separable from the overlying Monroe deposits, especially where no rock salt is present.

\section{BRINE HORIZON IN SOUTHEASTERN OHIO.}

STRATIGRAPHY AND STRUCTURE.

The surface rocks in the Ohio Valley at Pomeroy lie at the summit of the Conemaugh formation, also known as the "Lower Barren Coal Measures." 1

The depths of the wells from which the brine is obtained have undergone great variation. At first the wells were shallow, reported at about 300 feet. This reached the horizon of the first Cow Run sand, an important source of petroleum in Washington and Morgan counties. Later the wells were deepened until a larger supply of brine was obtained. When this proved inadequate, the wells were again deopened.

The following skeleton record of a well belonging to the Buckeye Salt Co. is interesting. The well head is 25 feet below the Pomeroy or No. 8 coal:

Log of well near Pomeroy, Meigs County, Ohio.

\begin{tabular}{|c|c|c|}
\hline Material. & $\begin{array}{l}\text { Thick- } \\
\text { ness. }\end{array}$ & Depth. \\
\hline Conductor. & \multirow{7}{*}{$\begin{array}{r}\text { Fcet. } \\
58 \\
492 \\
320 \\
90 \\
170 \\
365 \\
50 \\
25 \\
20\end{array}$} & \multirow{7}{*}{$\begin{array}{r}\text { Feet. } \\
588 \\
550 \\
870 \\
960 \\
1,130 \\
1,490 \\
1,54 \\
1,570 \\
1,590\end{array}$} \\
\hline Shale....................... & & \\
\hline $\begin{array}{l}\text { Sand, white and gray.. } \\
\text { Sand, whito and slate. }\end{array}$ & & \\
\hline Big Salt sand ......... & & \\
\hline Strata unrecorded....... & & \\
\hline 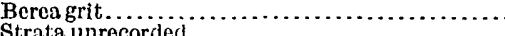 & & \\
\hline Strata unrecorded.................. & & \\
\hline
\end{tabular}

Note. - Brines were struck at 320 feet, density $6^{\circ}$ B.; at 710 feet, density $9^{\circ}$ B.; at 980 feet, density $9^{\circ}$ B.; and at 1,550 feet, density $10^{\circ} \mathrm{B}$.

1 Prosser, C. S., Revised nomenclature of the Ohio geological formations: Ohio Geol. Survey, 4th ser., Bull. 7, p. 25, 1905. 
A record furnished by the Liverpool Salt \& Coal Co. is as follows:

Log of well at Hartford, Mason County, W. Va.

\begin{tabular}{|c|c|c|}
\hline Material. & $\begin{array}{c}\text { Thick- } \\
\text { ness. }\end{array}$ & Depth. \\
\hline 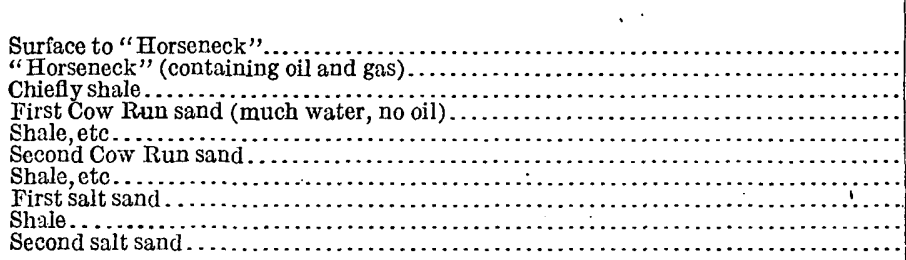 & $\begin{array}{r}\text { Feet. } \\
300 \\
50 \\
110 \\
40 \\
250 \\
40 \\
210 \\
50 \\
55 \\
60\end{array}$ & $\begin{array}{r}\text { Fcet. } \\
300 \\
350 \\
460 \\
500 \\
750 \\
790 \\
1,000 \\
1,050 \\
1,105 \\
1,165\end{array}$ \\
\hline
\end{tabular}

NoTi. - The names of the sands are those of the driller.

As soon as the second salt sand was reached the brine rose in the well to a height 600 feet below the surface. In all, the well was drilled to a depth of $1,359 \frac{1}{2}$ feet but soon partly filled up, andthe rest of the record was not procurable. It was the intention to go to the Berea, but the volume of water prevented this unless another line of casing was put in. A very small coal was reported in the record but its exact position was not given.

\section{CHARACTER OF BRINE.}

In the well at Pomeroy the brine found in the Berea is much denser than that found in the overlying rocks. The quantity, however, was small, and the well is pumped from the horizon of the Big Salt sand (Pottsville). The Buckeye Salt Co. has five wells, whose depths range from 1,089 to 1,590 feet; the deepest well penetrates the Berea. The Excelsior Co. has four wells, whose depths range from 1,100 to 1,200 feet. Wells drilled farther east to the same geologic horizon are deeper, as the rocks dip in that direction.

When drilling was begun in this territory the water is said to have risen nearly to the well heads and in some wells to have actually. overflowed. As pumping progressed the reservoirs of brine were lowered, and the tubing was consequently extended deeper into the wells, following the brine in its descent.

For many years the Excelsior works have pumped from the 750 -foot level. The brine is said to rise slightly when the wells in the neighboring plants are not in action. The density of the brine increases in the direction of the dip of the rocks-that is, to the southeast. This is shown in the following table: 
Increase of density with depth of natural brine at Pomeroy, Ohio.

Pomeroy Salt Works, west end of Pomeroy.

Excelsior Salt Co., east end of Pomeroy.

Syracuse Salt, Bromine \& Calcium Works (not now operated).

\begin{tabular}{|c|c}
$\begin{array}{c}\text { Dersity } \\
\text { of brine. }\end{array}$ & $\begin{array}{c}\text { Tempera- } \\
\text { ture of } \\
\text { brino. }\end{array}$ \\
\hline${ }^{\circ} B$. & $\circ F$. \\
8 & 61.5 \\
8.5 & 63 \\
10.5 & 62.5 \\
\hline
\end{tabular}

According to Bownocker ${ }^{1}$ the variation in density is due to the heavier brines seeking the lower level. The differences in temperature result in part from the different conditions under which the measurements were made, it not being possible in all cases to ascertain the temperature directly at the well head. The variation is due also in part to the greater depth of the wells to the southeast.

The quantity of brine that has been taken from these rocks is enormous, much more than the rocks could at any one time contain. This great excess has doubtless been derived from surrounding territory. The brine-bearing strata dip toward Pomeroy from the northwest: As the brine has been pumped from the wells, the supply has been renewed from the rocks lying at a higher level.

WELL RECORDS.

Log of well No. 4, Union Salt Co., Cleveland, Cuyahoga County, Ohio.a ,.

\begin{tabular}{|c|c|c|}
\hline Material. & $\begin{array}{l}\text { 'Thick- } \\
\text { ness. }\end{array}$ & Depth. \\
\hline 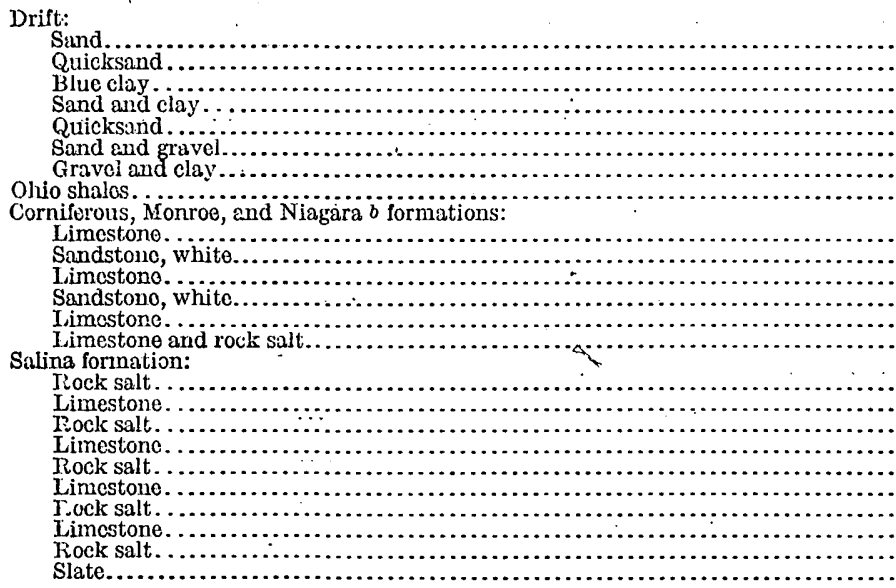 & $\begin{array}{r}\text { Fect. } \\
15 \\
6 \\
129 \\
9 \\
76 \\
6 \\
26 \\
723 \\
\\
390 \\
33 \\
11 \\
16 \\
315 \\
10 \\
\\
16 \\
16 \\
19 \\
4 \\
59 \\
21 \\
37 \\
4 \\
37 \\
13\end{array}$ & $\begin{array}{r}\text { Fect. } \\
\text {. } . .15 \\
150 \\
159 \\
235 \\
241 \\
267 \\
990 \\
1,380 \\
1,413 \\
1,424 \\
1,440 \\
1,755 \\
1,765 \\
1,781 \\
1,797 \\
1,816 \\
1,820 \\
1,879 \\
1,990 \\
1,937 \\
1,911 \\
1,978 \\
1,994\end{array}$ \\
\hline
\end{tabular}

a Bownocker, J. A., op. cit., p. 35.

$\checkmark$ Obviously an ove.sight, as the Niagara underlies the salt-bearing Salina formation.

NoTe.-Total depth by steel-line measurement, 2,0061 feet; 316 feet of 10 -inch casing; 379 fect of 84 -inch casing. 
Log of well of Union Salt Co., Newburg, Cuyahoga County, Ohio.a

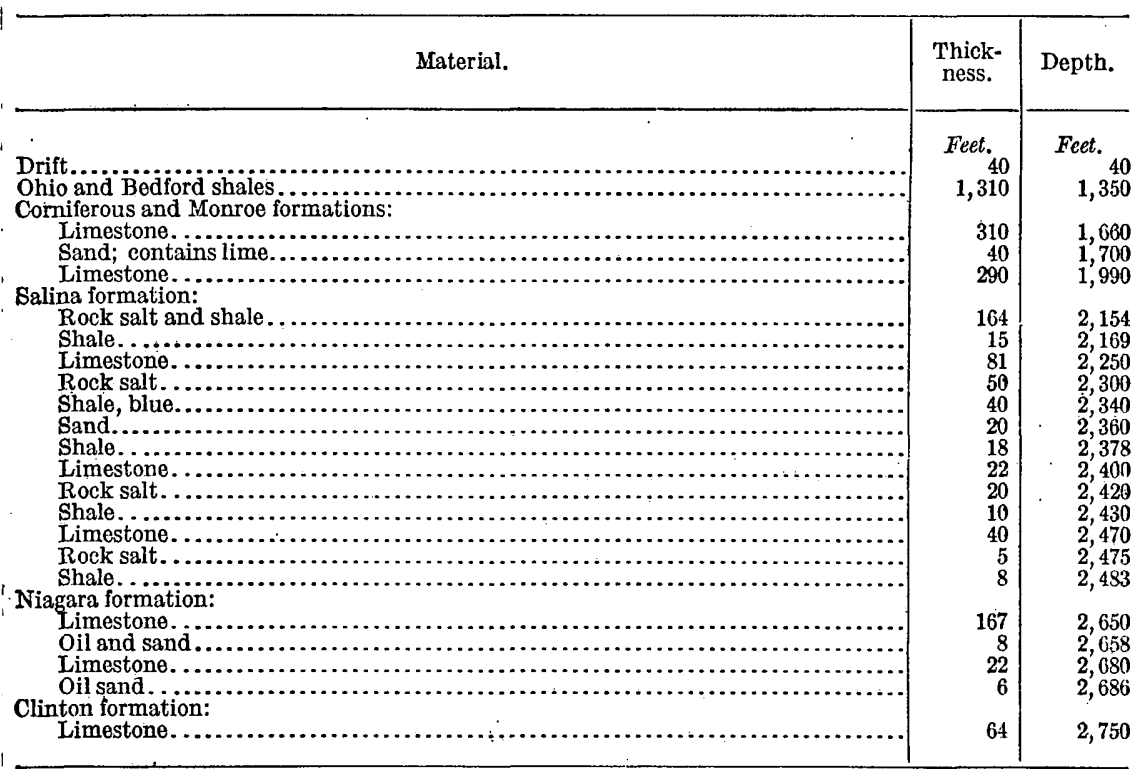

a Ohio Geol. Survey, vol. 6, p. 352, 1888.

Log of well No. 2, Cleveland Salt Co., Cleveland, Cuyahoga County, Ohio.a

\begin{tabular}{|c|c|c|}
\hline Material. & $\begin{array}{c}\text { Thick- } \\
\text { ness. }\end{array}$ & Depth. \\
\hline 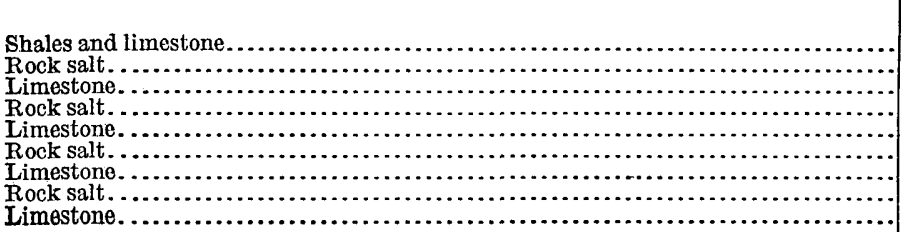 & $\begin{array}{r}\text { Feet. } \\
1,821 \\
10 \\
5 \\
5 \\
5 \\
10 \\
22 \\
72 \\
2\end{array}$ & $\begin{array}{r}\text { Fect. } \\
1,831 \\
1,836 \\
1,841 \\
1,846 \\
1,856 \\
1,878 \\
1,950 \\
1,952\end{array}$ \\
\hline
\end{tabular}

$a$ Bownocker, J. A., op. cit., p. 36.

Log of well of Cleveland Salt Co., Cleveland, Cuyahoga County, Ohio.a

\begin{tabular}{|c|c|c|}
\hline Material. & $\begin{array}{l}\text { Thick- } \\
\text { ness. }\end{array}$ & Depth. \\
\hline First gravel & Feet. & Feet. \\
\hline $\begin{array}{l}\text { First gravel } 1,1 \\
\text { Clay }\end{array}$ & $\frac{481}{7}$ & $\begin{array}{l}481 \\
488\end{array}$ \\
\hline Rock. & 30 & $\begin{array}{l}408 \\
518\end{array}$ \\
\hline 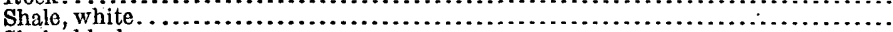 & 182 & 700 \\
\hline 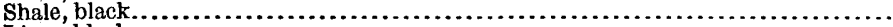 & 330 & 1,030 \\
\hline Lime, black. . . . . . . . . . . . . . . . . & 50 & 1,080 \\
\hline Lime, brown...$\ldots \ldots \ldots \ldots \ldots \ldots \ldots$ & 220 & 1,300 \\
\hline Lime, sandy $\ldots \ldots \ldots \ldots \ldots \ldots \ldots$ & 93 & 1,390 \\
\hline Lime (bitter water increasing to 1,470 feet rose to 97 feet, the level of Lake Erie). & $\begin{array}{r}50 \\
185\end{array}$ & 1,440 \\
\hline 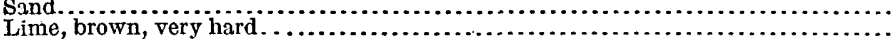 & $\begin{array}{r}185 \\
85\end{array}$ & $\begin{array}{l}1,625 \\
1,710\end{array}$ \\
\hline 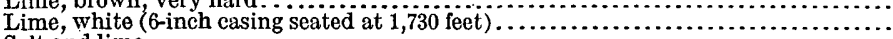 & 111 & 1,821 \\
\hline 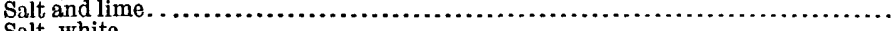 & 14 & 1,835 \\
\hline 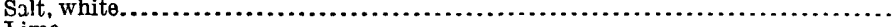 & 15 & 1,850 \\
\hline Lime. . & 5 & 1,855 \\
\hline 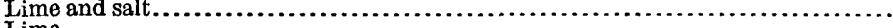 & 10 & 1,865 \\
\hline 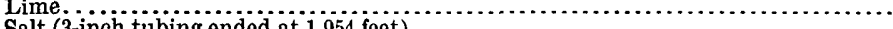 & 19 & 1,875 \\
\hline Salt ( 3 -inch tubing ended at 1,954 feet). & 80 & 1,955 \\
\hline Lime. . . . & & 959 \\
\hline
\end{tabular}

a Record furnished by the Cleveland Salt Co. 
Log of well No. 1, Colonial Salt Co., Kenmore, Summit Count!, Ohio.

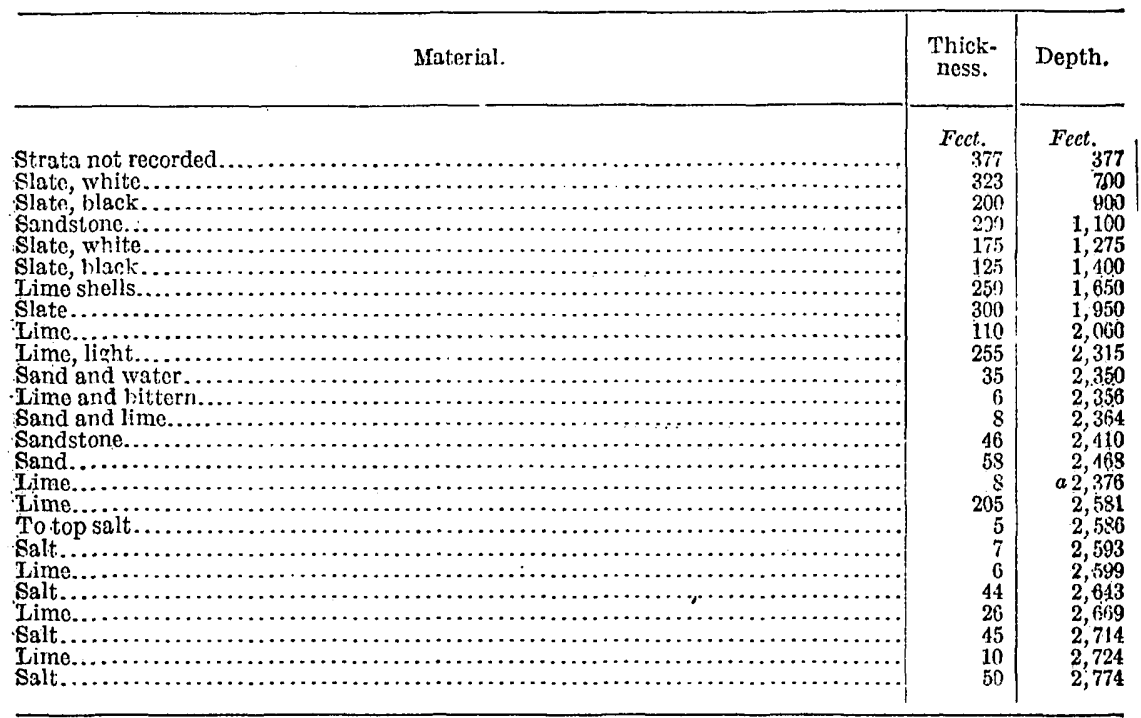

a Depth hy tape at this point, 2,383 feet.

Note.-Total depth by tape, 2,903 feet. There is an interval of 236 feet from the top of the lititern-bearing horizon at 2,350 feet to the top of the salt at 2,586 feet.

Log of well No. 2, Colonial Salt Co., Kenmore, Summit County, Ohio.

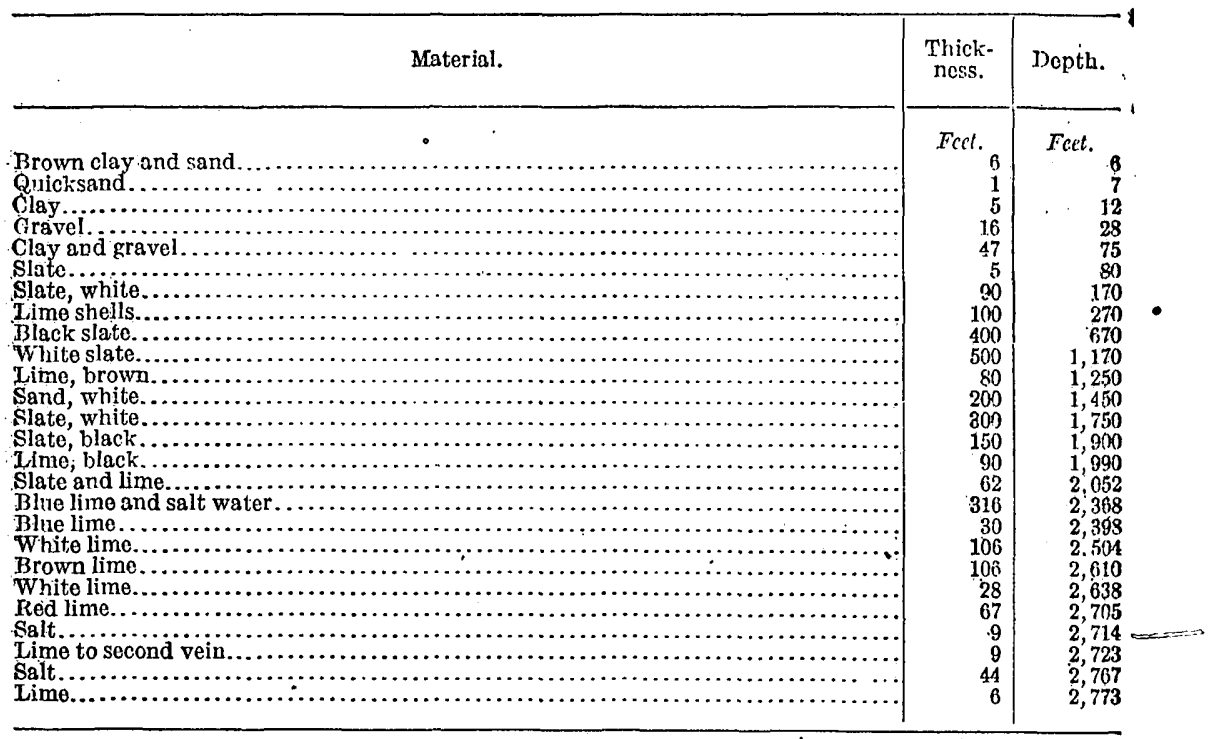

NoTe.-Depth of hole by drilling, 2,773 feet; by tape, 2,728 feet. There is an interval of 337 feet betweon the top of the bittern-bearing horizon at 2,368 feet and the top of the salt at 2,705 feet. 
Log of well No. 3, Colonial Salt Co., Kenmore, Summit County, Ohio.

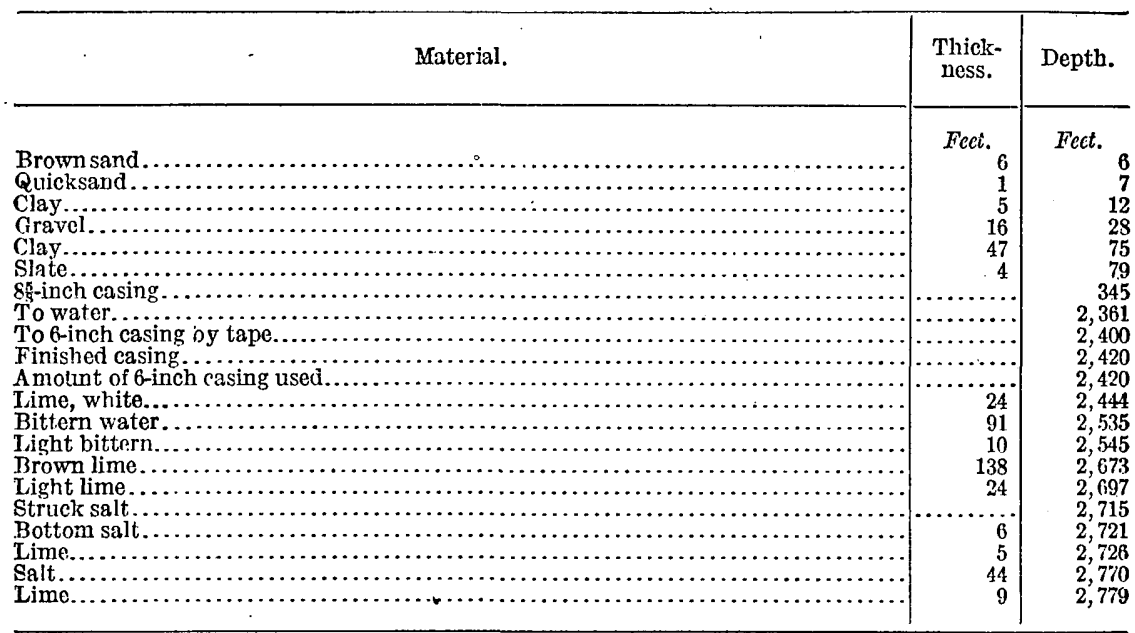

NotE.-Total depth by tape, 2,779 feet. There is apparently an interval of 271 feet from the top of the bittern-bearing horizon at 2,444 feet to the top of the salt at 2,715 fect. If the bittern were encountered at 2,381 fect, which is a possible interpretation of this record, the interval would be 344 feet. The latter figure and the corresponding elevation are more in harmony with the records of wells Nos. 1 and 2.

Log of well No. 4, Colonial Salt Co., Kenmore, Summit County, Ohio.

\begin{tabular}{|c|c|c|}
\hline Material. & $\begin{array}{l}\text { Thick- } \\
\text { ness. }\end{array}$ & Depth. \\
\hline 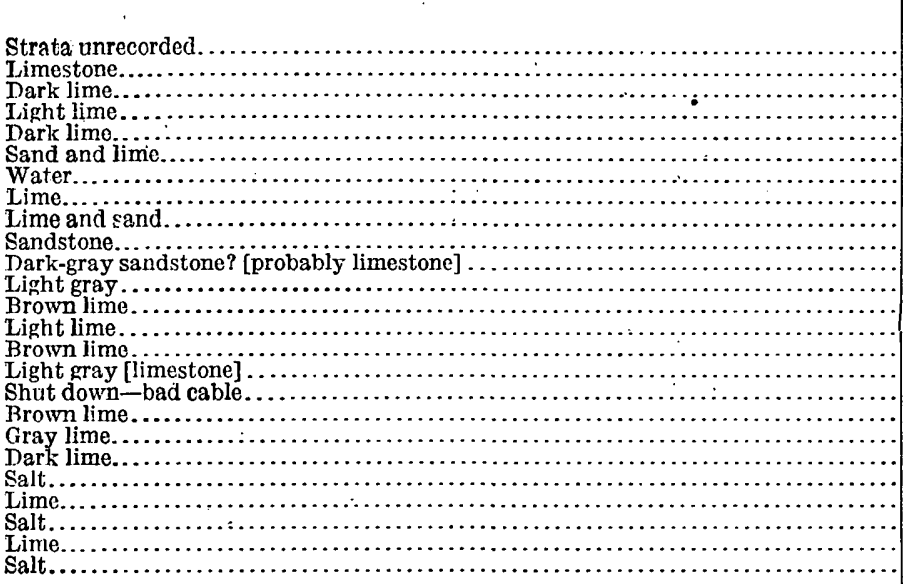 & $\begin{array}{r}F c c t . \\
2,065 \\
100 \\
50 \\
20 \\
25 \\
100 \\
11 \\
33 \\
6 \\
30 \\
30 \\
6 \\
21 \\
15 \\
30 \\
25 \\
5 \\
50 \\
40 \\
65 \\
10 \\
9 \\
40 \\
15 \\
29\end{array}$ & $\begin{array}{r}\text { Feet. } \\
2,085 \\
2,155 \\
2,215 \\
2,235 \\
2,260 \\
2,360 \\
2,371 \\
2,404 \\
2,410 \\
2,440 \\
2,470 \\
2,476 \\
2,497 \\
2,515 \\
2,545 \\
2,577 \\
2,575 \\
2,625 \\
2,665 \\
2,730 \\
2,740 \\
2,749 \\
2,789 \\
2,804 \\
2,833\end{array}$ \\
\hline
\end{tabular}

NoTE.-There is apparently an interval of 380 feet between water at 2,360 feet and the top of the salt at 2,740 feet. 
Log of well No. 6, Colonial Salt Co., Kenmore, Summit County, Ohio.

\begin{tabular}{|c|c|c|}
\hline Material. & $\begin{array}{l}\text { Thick- } \\
\text { ness. }\end{array}$ & Depth. \\
\hline 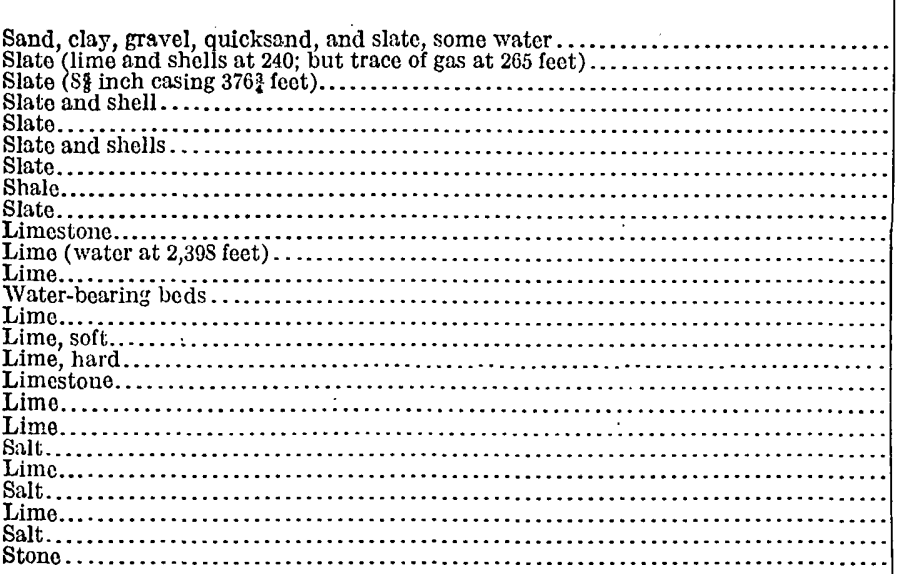 & $\begin{array}{r}\text { Fect. } \\
115 \\
155 \\
70 \\
320 \\
515 \\
155 \\
154 \\
311 \\
323 \\
14 \\
272 \\
57 \\
13 \\
23 \\
12 \\
14 \\
15 \\
115 \\
67 \\
7 \\
4 \\
37 \\
22 \\
30 \\
4\end{array}$ & $\begin{array}{r}\text { Feet. } \\
115 \\
270 \\
340 \\
660 \\
1,175 \\
1,330 \\
1,484 \\
1,795 \\
2,118 \\
2,132 \\
2,404 \\
2,461 \\
2,474 \\
2,497 \\
2,709 \\
a 2,553 \\
2,547 \\
b 2,662 \\
2,752 \\
2,759 \\
2,763 \\
2,800 \\
2,822 \\
2,852 \\
2,856\end{array}$ \\
\hline
\end{tabular}

a Depth at this point by steel tape, 2,532 fcet; subsequent record corrected by 9 feet. $b$ Depth at this point by steel tape, 2,662 feet; subsequent record corrected by 23 fect.

Note.-Drilled in 1902; 84 feet of drive pipe. Total depth by steel tape, 2,857 feet. There is an interval of $3 \overline{5} 4$ feet between the water at 2,398 fect and the top of the salt at 2,752 feet.

Log of well No. 9 of Colonial Salt Co, Kenmore, Summit County, Ohio.

\begin{tabular}{|c|c|c|}
\hline Material. & $\begin{array}{l}\text { Thick- } \\
\text { ness. }\end{array}$ & Depth. \\
\hline & Fect. & Treet. \\
\hline Loam, black.... & 30 & \\
\hline 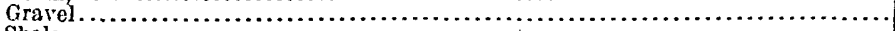 & 70 & \\
\hline 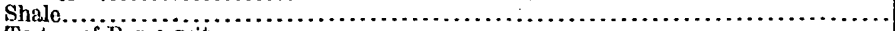 & 10 & \\
\hline To top of Berea grit $\ldots \ldots \ldots \ldots \ldots \ldots \ldots \ldots \ldots \ldots \ldots \ldots \ldots \ldots \ldots \ldots \ldots \ldots \ldots \ldots$ & 270 & 380 \\
\hline Strata unrecorded.................. & 10 & 390 \\
\hline 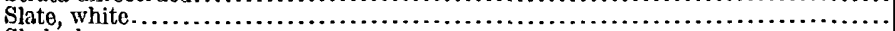 & 360 & 750 \\
\hline 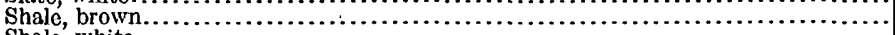 & 1,125 & 1,875 \\
\hline 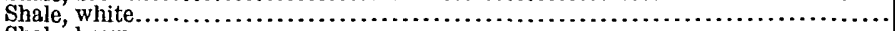 & 175 & 2,050 \\
\hline 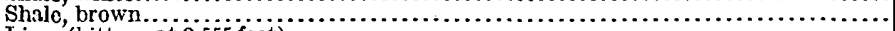 & $\mathbf{1 2 5}$ & 2,175 \\
\hline 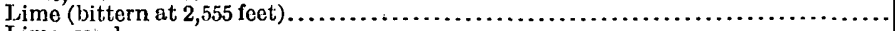 & 380 & 2,555 \\
\hline 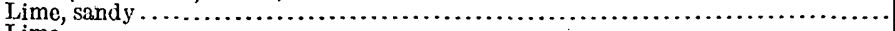 & 73 & 2,62 \\
\hline 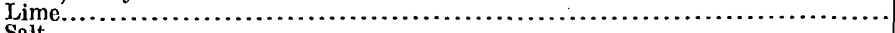 & 182 & 2,810 \\
\hline 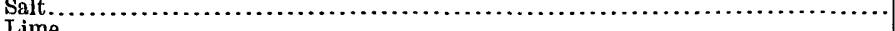 & $\stackrel{3}{8}$ & \\
\hline 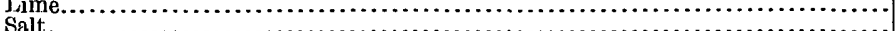 & $\begin{array}{r}8 \\
38\end{array}$ & 2,821 \\
\hline (1) & 38 & 2,809 \\
\hline (n) & 43 & 2,922 \\
\hline (n................. & 3 & 2,925 \\
\hline 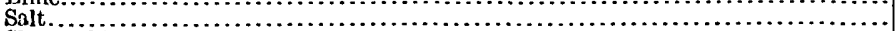 & 32 & 2,957 \\
\hline 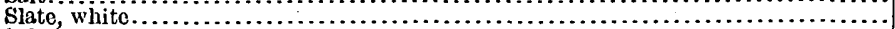 & 53 & 3,010 \\
\hline Salt.. & 25 & 3,035 \\
\hline Lime. & 55 & 3,090 \\
\hline 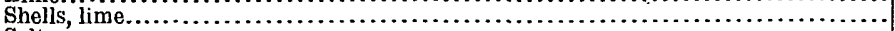 & 45 & 3,135 \\
\hline ( & 20 & 3,155 \\
\hline Lime.. & 180 & 3,335 \\
\hline I ime shells..... & 15 & 3,350 \\
\hline Iime, black.... & 50 & 3,400 \\
\hline lime, brown.............. & 40 & 3,440 \\
\hline Second water-bearing bods .......... & 10 & 3,450 \\
\hline 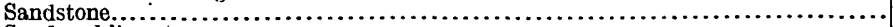 & 35 & 3,485 \\
\hline 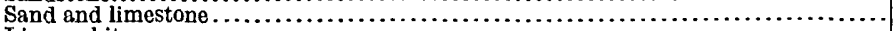 & 70 & 3,555 \\
\hline 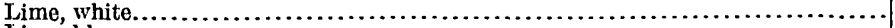 & 25 & 3,580 \\
\hline 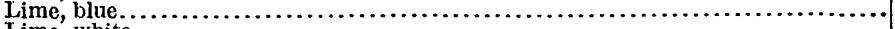 & 20 & 3,600 \\
\hline Jime, white.... & $\begin{array}{l}58 \\
85\end{array}$ & $\begin{array}{l}3,658 \\
3,743\end{array}$ \\
\hline een. & 20 & 3,7 \\
\hline Lime and sand (contains oil and gas)... & & 3,768 \\
\hline
\end{tabular}


Log of well No. 9 of Colonial Salt Co.,Kenmore, Summit County, Ohio-Continued.

\begin{tabular}{|c|c|c|}
\hline Material. & $\begin{array}{l}\text { Thick- } \\
\text { ness. }\end{array}$ & Depth. \\
\hline 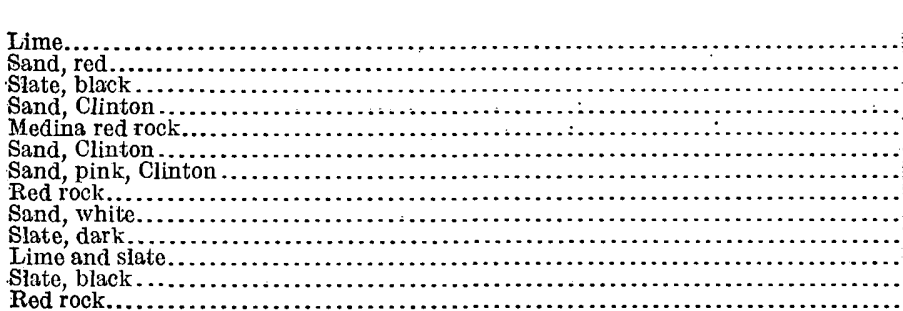 & $\begin{array}{r}\text { Feet. } \\
5 \\
5 \\
27 \\
5 \\
8 \\
4 \\
1.1 \\
13 \\
5 \\
10 \\
12 \\
97 \\
114\end{array}$ & $\begin{aligned} \text { Feet. } \\
3,773 \\
3,778 \\
3,805 \\
3,810 \\
3,818 \\
3,822 \\
3,833 \\
3,846 \\
3,851 \\
3,861 \\
3,873 \\
3,970 \\
4,084\end{aligned}$ \\
\hline
\end{tabular}

Note.-Ten-inch drive pipe, 110 feet: 6 -inch casing, 2,630 feet; finished A pril 18, 1912; first plug at 3,748 feet: second plug at 3,620 feet; third plug at 3,050 feet. There is an interval of 255 feet between the bittern at 2,555 feet and the top of the salt at 2,810 feet.

Log of well of Colonial Salt Co., Kenmore, Summit County, Ohio.a

\begin{tabular}{|c|c|c|}
\hline Material. & $\begin{array}{c}\text { Thick- } \\
\text { ness. }\end{array}$ & Depth. \\
\hline 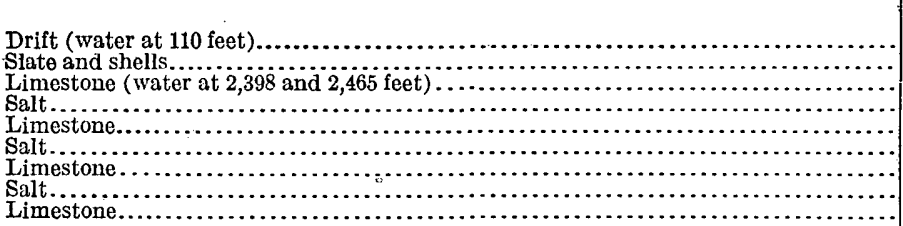 & $\begin{array}{r}\text { Feet. } \\
115 \\
1,943 \\
694 \\
7 \\
4 \\
37 \\
22 \\
30 \\
4\end{array}$ & $\begin{array}{r}\text { Feet. } \\
115 \\
2,058 \\
2,752 \\
2,759 \\
2,763 \\
2,800 \\
2,822 \\
2,852 \\
2,856\end{array}$ \\
\hline
\end{tabular}

a Bownocker, J. A., op. cit., p. 37 .

Section of well on H. R. Boyden farm, sec.66, Northfield Township, Sümmit County, Ohio.

[Record furnished by Henry S. Chapman, Cleveland, Ohio.]

Ten-inch drive pipe.......

Berea grit (with light gas)... 8 -inch casing (on shell).... Shale, with gas pockets.... Top of lime ..............

Salt water................ $6 \frac{5}{8}$-inch casing (in lime).... Dry salt................. Brown lime shells.......... Hard brown lime .......... Newburg sand (top showing oil).

Salt water................

Hard brown lime........ 3, 100-3, 170

$$
\begin{array}{r}
40 \\
140-145
\end{array}
$$

Depth (feet).

250 . Shale (black and soft)..... 3,222-3,240

270-315 White sand (hard) first..... 3, 240-3, 260

1,660 Black shale (soft) ........ 3, 260-3, 290

2,100 White sand (hard) second... 3, 290-3, 320

2,250 Green slate (soft) ......... 3,320-3, 335

2, 350-2, 420 Red sand (soft) with showing

2,421 of gas estimated at 30,000

2,860 cùbic feet at 3,387 feet.... $3,335-3,393$

Red slate (soft) "ox-blood". $3,393-3,398$

Clinton white sand (dry).... 3, 398-3,411

Medina shale (soft, red) . ... 3, 411-3, 511

Bottom of well............. $\quad 3,607$

Nore.-The "Clinton" drilled very hard, some towers making only 3 feet. Bottom of sand was coarser and softer. Well was plugged above and below red sand and "Clinton." 
Section of well on Nellie S. Chapman farm, eec. 46, Northfield Township, Summit County, Ohio.

[Record furnished by Henry S. Chapmen, Cleveland, Ohio.]

Depth (feet).

Ten-inch casing............

Berea grit................

$8 \frac{1}{4}$-inch casing.............

Shale, with gas pockets....

Top of lime...............

Salt water.................

65-inch casing.

Dry salt.

Hard brown lime.........

Newburg sand............ 3, 080-3, 104

Salt water...............

White lime............ 3, 285-3,321

Shale

40

115-165

2,114

2,342

$2,480-2,580$

2,990

3,105
180 Slate and shale.............

250 Green shale...............

1,782 White sand with showing of oil...................

Gray sand................

Clinton (gas at top with some oil and increasing in

gas downward) ,........ 3,494-3,519

Shale................ $\quad 3,520$

Stopped drilling in shale.... $\quad 3,551$

Nore.-Well completed May 27, 1912. The well was shot and tested 150,000 cubic feet of gas together with 1 barrel of oil. The gas is now used for local consumption.

Log of well No. 1, Ohio Salt Co., Rittman, Wayne County, Ohio.a

\begin{tabular}{|c|c|c|}
\hline Material. & $\begin{array}{l}\text { Thick- } \\
\text { ness. }\end{array}$ & Depth. \\
\hline Clay. & & Feet. ${ }_{40}$ \\
\hline Quicksand and grav & 133 & \\
\hline Gray sand (Berea) ........ & 20 & 193 \\
\hline $\begin{array}{l}\text { Bedford and Ohio shales: } \\
\text { Shale, black........... }\end{array}$ & & \\
\hline $\begin{array}{l}\text { Shale, black } \ldots \ldots \ldots \ldots \ldots \ldots \ldots \\
\text { Shalo, red. } \ldots \ldots \ldots \ldots \ldots \ldots\end{array}$ & 1,007 & \\
\hline 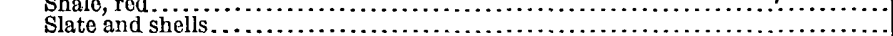 & $\begin{array}{r}50 \\
250\end{array}$ & $\begin{array}{l}1,250 \\
1,500\end{array}$ \\
\hline 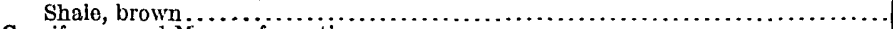 & 535 & 2,035 \\
\hline Corniferous and Monroe formations: & & \\
\hline Limestone $\ldots . \ldots \ldots \ldots \ldots \ldots \ldots$ & 268 & \\
\hline 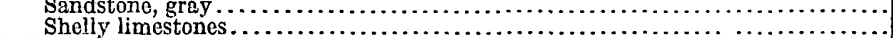 & $\begin{array}{r}30 \\
225\end{array}$ & $\begin{array}{l}2,333 \\
2,558\end{array}$ \\
\hline Salina formation: & & \\
\hline Rock salt. & 86 & 2,624 \\
\hline
\end{tabular}

a Bownocker, J. A., op. cit., p. 32.

Skeleton log of deep well, Ohio Salt Co., Rittman, Wayne County, Ohio.

\begin{tabular}{|c|c|c|}
\hline Material. & $\begin{array}{c}\text { Thick- } \\
\text { ness. }\end{array}$ & Depth. \\
\hline 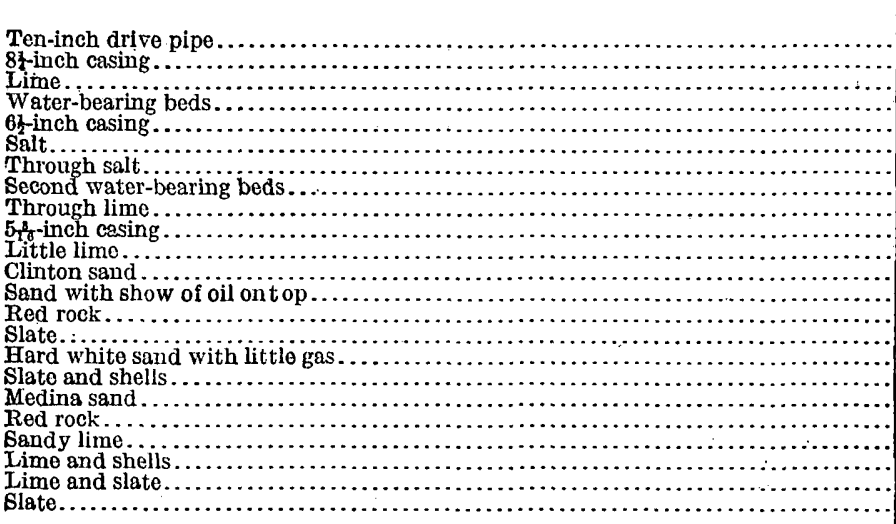 & 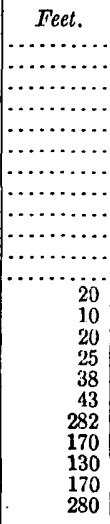 & $\begin{array}{r}\text { Feet. } \\
167 \\
230 \\
2,015 \\
2,284 \\
2,384 \\
2,540 \\
2,615 \\
3,140 \\
3,295 \\
3,314 \\
3,354 \\
3,412 \\
3,432 \\
3,442 \\
3,402 \\
3,487 \\
3,525 \\
3,538 \\
3,850 \\
4,020 \\
4,150 \\
4,320 \\
4,600\end{array}$ \\
\hline
\end{tabular}

Note.-The "pencil cave", was found at 4,600 feet. Drillod 6 weeks and made only 65 feet. 


\section{BIBLIOGRAPHY.}

Bownocker, J. A., The salt deposits of northeastern Ohio: Am. Geologist, vol. 35, pp. 370-376, 1 pl., 1905. Includes records of deep wells and discusses the occurrence of beds of rock salt as revealed by deej borings.

- Salt deposits and the salt industry in Ohio: Ohio Geol. Survey, 4th ser.; Bull. 8, 42 pp., 1906. Reviews the salt industry in Ohio and describes present operations. Includes notes on the composition of the brines, the geologic horizon of the salt beds, and well records.

Carney, Frank, The economic mineral products of Ohio: Denison Univ. Sci. Lab. Bull., vol. 16, pp. 137-181, December, 1910.

\section{WEST VIRGINIA.}

West Virginia is an important producer of salt from natural brines, which occur in part in Carboniferous sandstones. These brines also fumish bromine and calcium chloride.

\section{POSTTION OF FIELDS.}

The natural brines now utilized are found along Ohio and Kanawha rivers. The Ohio River field is an extension of the area ir Ohio. Mason and Hartford, located in Mason County, are the centers of the industry in this part of the State. Malden, 6 miles above Charleston, is the site of the salt, bromine, and calcium-chloride industry on Kanawha River.

OHIO RIVER AREA.

The Ohio River area is geologically a part of the Pomeroy district of Ohio. Mason, one of the centers of the industry in. West Virginia, is located nearly opposite Pomeroy, Ohio, and Hartford is a short distance farther up the river. The geology of the brines pumped at Pomeroy, Ohio, has already been discussed.

\section{KANAWHA RIVER AREA.}

The record of a well drilled for gas on Cool Spring Branch of Burning Springs Hollow, 2 or 3 miles from Malden, or 9 miles above Charleston, throws some light on the geologic horizon from which brines are obtained on Kanawha River near Charleston. According to $\mathrm{I}$. C. White, ${ }^{1}$ the well was begun about 100 feet below the horizon of the Campbell Creek coal bed, which is in the Kanawha formation of the Pottsville group (Pennsylvanian).

1 White, I. C., Petroleum and natural-gas precise levels: West Virginia Geol. Survey, vol. 1, p. 272, 1899. 
The log of the well is as follows:

Log of Edwards well No. 1, near Malden, Kanawha County, W. Va.

\begin{tabular}{|c|c|c|}
\hline Material. & $\begin{array}{l}\text { Thick- } \\
\text { ness. }\end{array}$ & Depth. \\
\hline 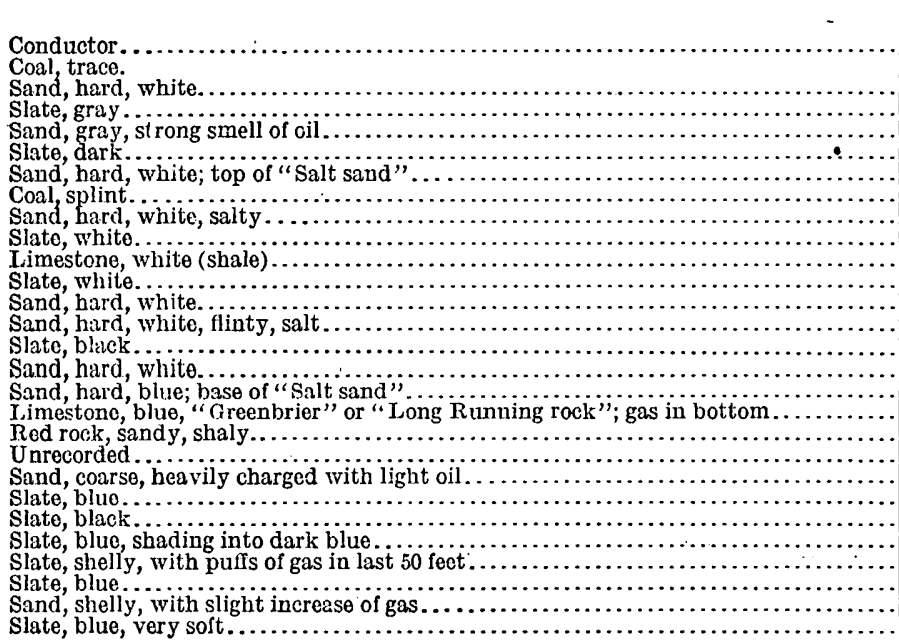 & $\begin{array}{r}\text { Fect. } \\
53 \\
\\
100 \\
8 \\
40 \\
25 \\
174 \\
6 \\
200 \\
10 \\
50 \\
40 \\
125 \\
130 \\
2 \\
50 \\
50 \\
300 \\
50 \\
187 \\
2 \\
250 \\
75 \\
323 \\
100 \\
50 \\
50 \\
92\end{array}$ & $\begin{array}{rr}\text { Feet. } & 53 \\
& 153 \\
161 \\
201 \\
226 \\
400 \\
406 \\
606 \\
616 \\
666 \\
706 \\
831 \\
961 \\
963 \\
1,013 \\
1,063 \\
1,363 \\
1,413 \\
1,600 \\
1,602 \\
1,852 \\
1,927 \\
2,250 \\
2,350 \\
2,400 \\
2,450 \\
2,542\end{array}$ \\
\hline
\end{tabular}

The horizon at which the well was begun, it is thought, is not very far from the surface at the wells near Malden. According to White, the Salt sand in this record is 837 feet thick, and from it is obtained the brine which yields the salt and bromine produced in the plant at Malden. As White has used the term Salt sand it appears to be approximately the equivalent of the Pottsville group. The brines come from the Pottsville.

\section{BIBLIOGRAPHY.}

Campbell, M. R., U. S. Geol. Survey Geol. Atlas, Charleston folio (No. 72), p. 6, 1901.

Grimsley, G. P., Iron ores, salt, and sandstones: West Virginia Geol. Survey, vol. 4, pp. 286-354, 1909.

\section{PENNSYLVANIA.}

Salt, bromine, and calcium chloride have been obtained in the North Side, Pittsburgh, Pa. Early in 1914, however, the industry in Pittsburgh was discontinued, owing to the fact that the natural brines became so dilute that it was no longer profitable to work them.

\section{GEOLOGY.}

At the plant where salt was produced four wells were in operation, the record of one of which is given below. This well, one of the deepest in Pennsylvania, reached a depth of $4,089 \frac{1}{2}$ feet and pene$40104^{\circ}-18-$ Bull. $669-6$ 
trated nearly 4,000 feet of beds that do not outcrop in the immediate territory. The brine is obtained in this well at a depth of 1,405 feet from a sand designated in the record as Salt sand. This sand is probably in the Pocono formation, which is of Mississippian age, and may possibly correspond with the Berea sandstone. ${ }^{1}$ The record of this deep well follows:

Log of the John A. Beck No. 4 gas well, at Pittsburgh, Allegheny County, Pa.

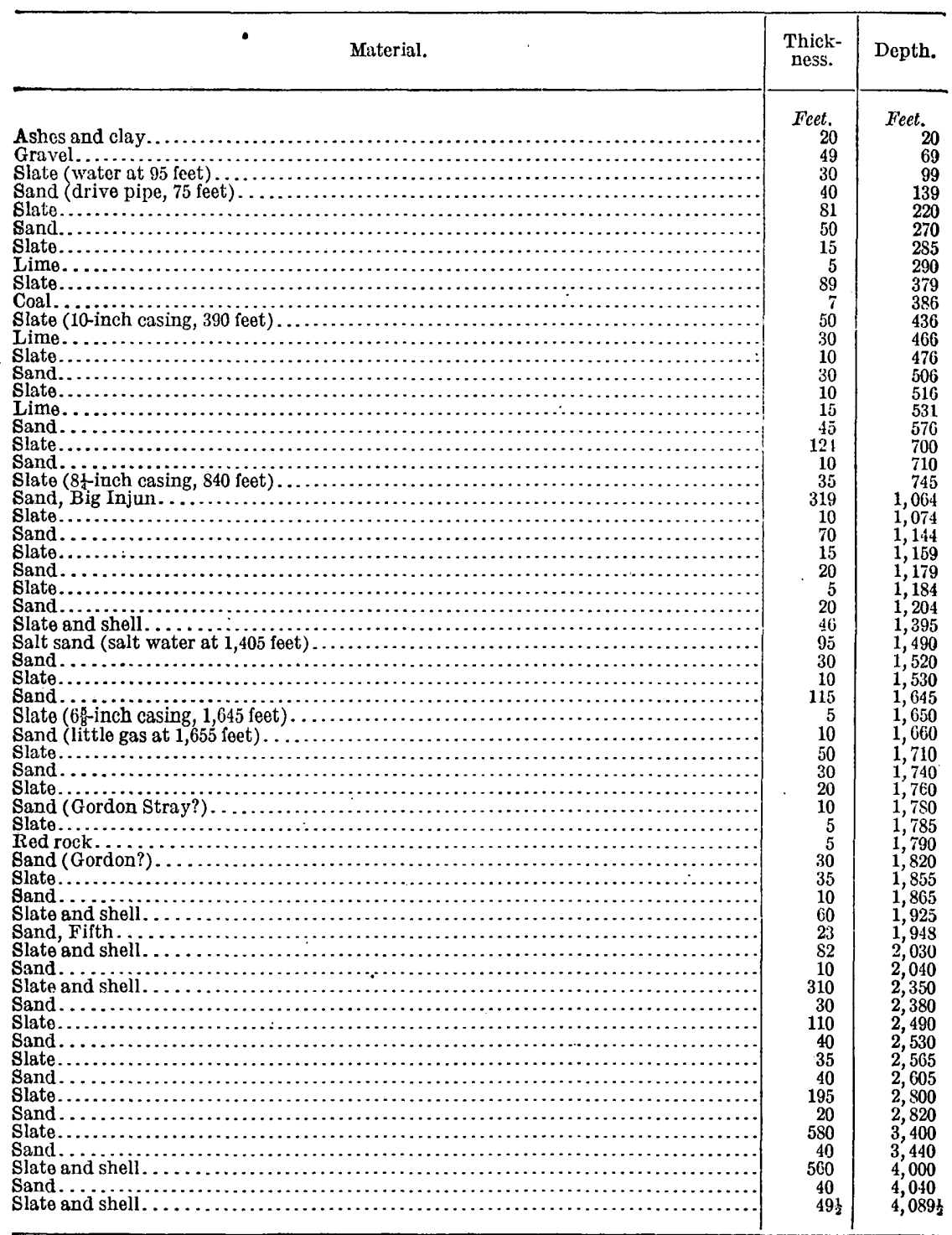

'Munn, M. J., Oil and gas fields of the Carnegie quadrangle, Pa.: U. S. Geol. Survey Bull. 456, pp. 11-12, 

PENNGYLVANIA.

Two reeords of very deep wells are in the possession of the Survey which indicate that the salt-bearing formation of New York State, the Salina, probably continues southward into Pennsylvania. One of these records is that of the Derrick City or Bradford City well, drilled by the Bradford Deep Well Co., 4 miles northeast of Bradford, McKean County, Pa., in 1912 and 1913. The second deep well, known as the McDonald well, is located about 4 miles northwest of McDonald, Washington County, Pa., or 14 miles southwest of Pittsburgh.

The Bradford well reached a depth of 5,820 feet and four beds of salt are recorded as having been encountered, which range in thickness from 10 to 47 feet. The top of the highest salt bed is at a depth of 4,490 feet; the base of the lowest is at 4,713 feet; the salt-bearing beds therefore extend through a total thickness of 223 feet.

In the McDonald well, salt water was encountered at a depth of approximately 6,825 feet, and rock salt was found in the interval between 6,825 feet and 7,175 feet, or approximately 350 feet.

The record of the Bradford City well has been kindly furnished to the Survey by the Bradford Deep Well Co. and is given below:

Log of the Bradford deep well, near Bradford, McKean County, Pa.

\begin{tabular}{|c|c|c|}
\hline Material. & $\begin{array}{l}\text { Thick- } \\
\text { ness. }\end{array}$ & Depth. \\
\hline 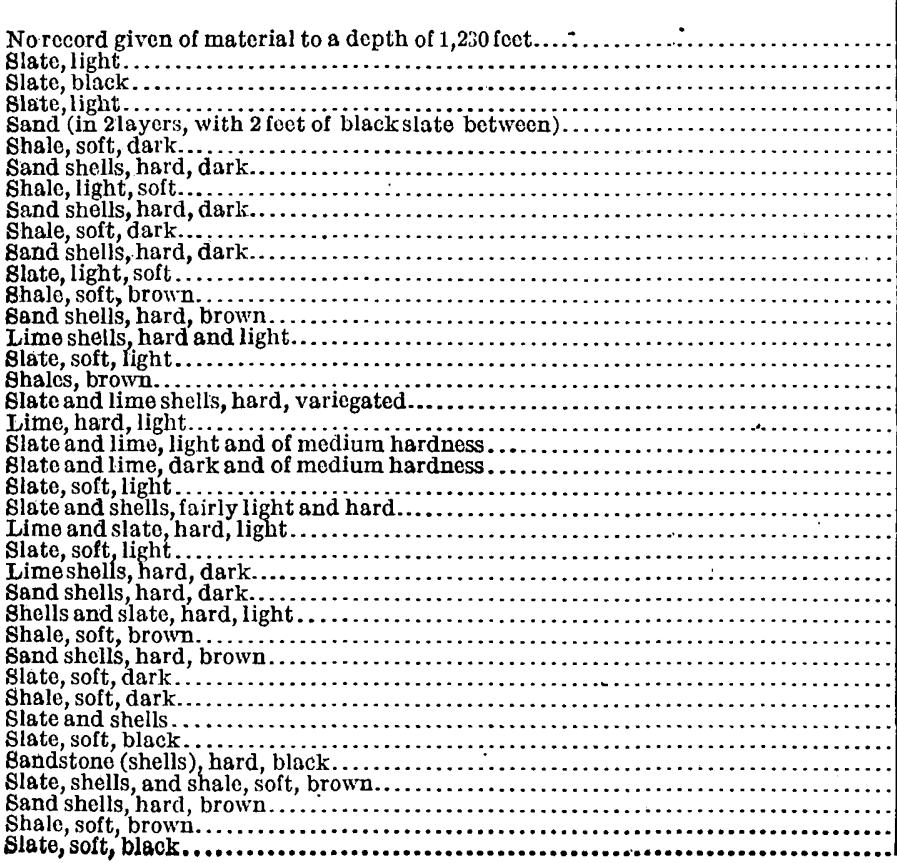 & $\begin{array}{r}\text { Feet. } \\
90 \\
110 \\
37 \\
23 \\
60 \\
20 \\
70 \\
10 \\
30 \\
40 \\
10 \\
10 \\
10 \\
50 \\
70 \\
30 \\
200 \\
50 \\
50 \\
30 \\
35 \\
35 \\
43 \\
57 \\
30 \\
10 \\
24 \\
20 \\
25 \\
25 \\
120 \\
25 \\
43 \\
22 \\
83 \\
12 \\
155 \\
100\end{array}$ & $\begin{array}{r}1,320 \\
1,430 \\
1,467 \\
1,490 \\
1,550 \\
1,570 \\
1,640 \\
1,650 \\
1,680 \\
1,720 \\
1,730 \\
1,740 \\
1,750 \\
1,800 \\
1,870 \\
1,900 \\
2,100 \\
2,150 \\
2,200 \\
2,230 \\
2,265 \\
2,300 \\
2,343 \\
2,400 \\
2,430 \\
2,446 \\
2,470 \\
2,490 \\
2,515 \\
2,540 \\
2,660 \\
2,685 \\
2,728 \\
2,750 \\
2,833 \\
2,845 \\
3,000 \\
3,100\end{array}$ \\
\hline
\end{tabular}


Log of the Bradford deep well, near Bradford, McKean County, Pa.-Continued.

\begin{tabular}{|c|c|c|}
\hline Material. & $\begin{array}{l}\text { Thick- } \\
\text { ness. }\end{array}$ & Depth. \\
\hline & Feet. & Fee \\
\hline$\ldots \ldots \ldots \ldots \ldots \ldots \ldots \ldots \ldots$ & & 3,150 \\
\hline 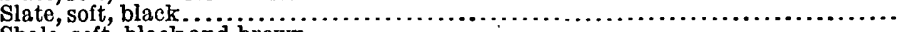 & 250 & 3,400 \\
\hline 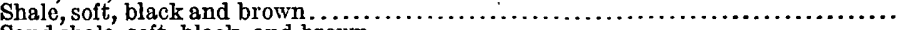 & 20 & 3,420 \\
\hline 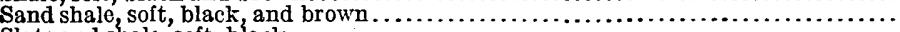 & $\mathbf{1 5 5}$ & 3,575 \\
\hline 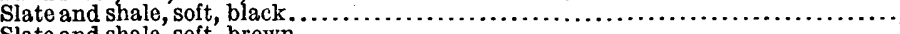 & 75 & 3,650 \\
\hline 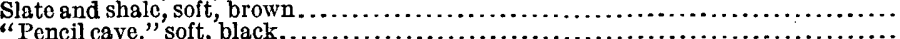 & & 3,669 \\
\hline (n. & $\begin{array}{l}31 \\
80\end{array}$ & $\begin{array}{l}3,700 \\
3,780\end{array}$ \\
\hline 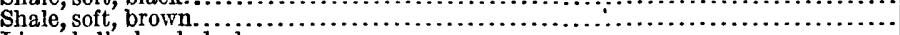 & 20 & 3,800 \\
\hline 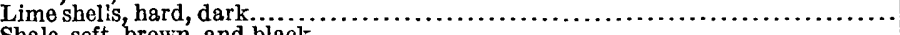 & 30 & 30 \\
\hline 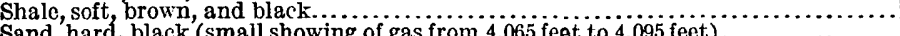 & 235 & 65 \\
\hline rd, black (small showing of gas & 30 & 4,095 \\
\hline y, black. & 20 & 4,115 \\
\hline 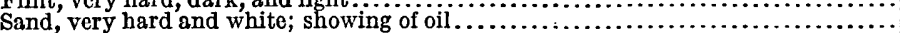 & $\begin{array}{l}20 \\
20\end{array}$ & $\begin{array}{l}4,135 \\
4,155\end{array}$ \\
\hline 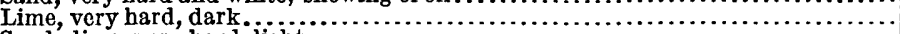 & 10 & 4,165 \\
\hline 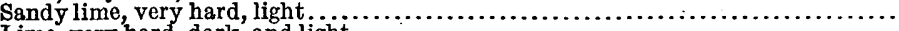 & 10 & 4 \\
\hline ark, and light. $\ldots \ldots \ldots \ldots \ldots \ldots$ & 40 & \\
\hline ne, very hard, dark (gas pocket from 4,225 feet to 4,235 feet) . . . . . . . . . . & 20 & \\
\hline 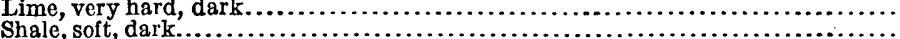 & 30 & \\
\hline $\begin{array}{l}\text { Snale, solt, dark... } \\
\text { Lime and gypsum. }\end{array}$ & $\begin{array}{r}5 \\
10\end{array}$ & \\
\hline (n) & 140 & 4,420 \\
\hline 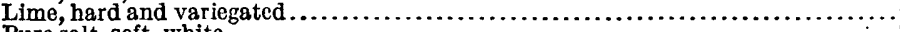 & 70 & 490 \\
\hline of olack oil from 4.520 feet to 4.535 feet) & & \\
\hline . & & $\begin{array}{l}4,535 \\
4,550\end{array}$ \\
\hline 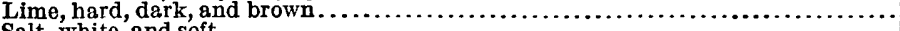 & 46 & 4,596 \\
\hline 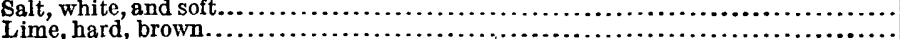 & & \\
\hline 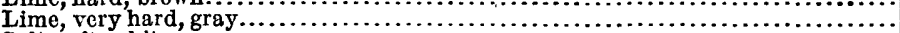 & & $\begin{array}{l}4,020 \\
4,638\end{array}$ \\
\hline$\ldots \ldots \ldots \ldots \ldots \ldots \ldots \ldots \ldots \ldots$ & & 4,685 \\
\hline 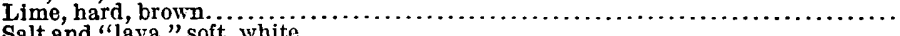 & & 4,693 \\
\hline (1, & $\begin{array}{r}20 \\
127\end{array}$ & \\
\hline , & 20 & 4,860 \\
\hline Is, hard & 40 & 4,900 \\
\hline and dark..... & 30 & 4,930 \\
\hline ............ & 15 & 4,945 \\
\hline 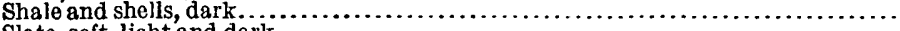 & & 4, \\
\hline 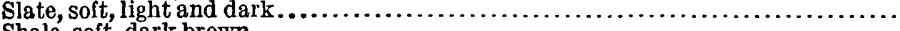 & & 4 \\
\hline 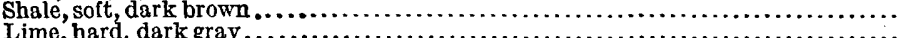 & & 5,010 \\
\hline 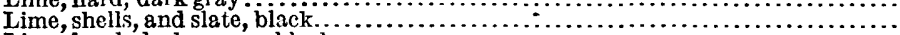 & & 5,085 \\
\hline 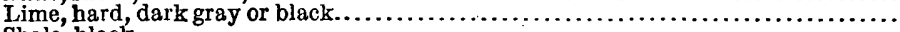 & & 5,155 \\
\hline 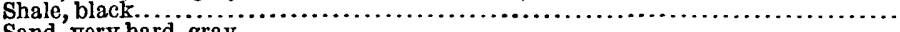 & 15 & 5,170 \\
\hline 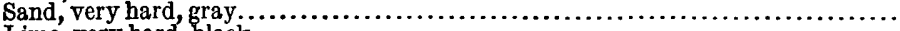 & 15 & 5, \\
\hline 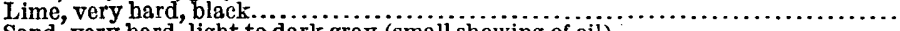 & 15 & \\
\hline hard, light to dark gray (small showing of oil) $\ldots \ldots \ldots \ldots \ldots \ldots \ldots \ldots$ & & 5,246 \\
\hline 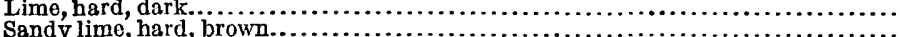 & & 5 , \\
\hline 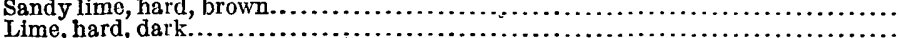 & 10 & 5, \\
\hline y, hard, brown... & 10 & 5, \\
\hline 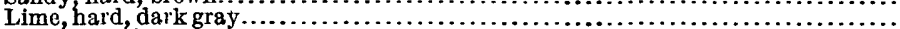 & & \\
\hline Sand, hard, light to dark gray... & 22 & 5,342 \\
\hline 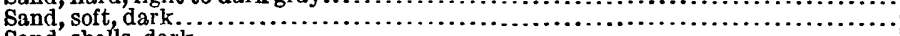 & 3 & 5,3 \\
\hline . & & 5,354 \\
\hline 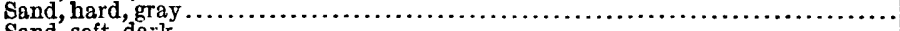 & & 5,360 \\
\hline 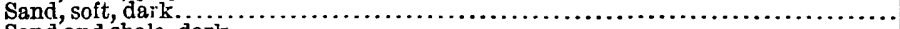 & & \\
\hline$\ldots \ldots \ldots \ldots$ & 35 & 5, \\
\hline , soft, blue and black............... & & 5, \\
\hline ite, hard, and dark gray... & & \\
\hline y solt, gray to brows & & \\
\hline na sand, very hard and red... & 10 & 5, \\
\hline ft, gray and red... & & \\
\hline ry hard, gray and white.. & & 5,6 \\
\hline red...... & & 5, \\
\hline red. & & 5 \\
\hline rally hard, reddish, white, and gray. & 19 & 5, \\
\hline e to light or dark gray .................... & & 5,675 \\
\hline soft, blue and gray... & & 5, \\
\hline very dark. & & 5, \\
\hline nd hard, light or dark gray ....... & & 5 , \\
\hline very hard, dark gray......... & & \\
\hline (nard, ng & & 5,7 \\
\hline d sand, red & & 5,2 \\
\hline d.......... & 10 & 5,770 \\
\hline sand, red. & 15 & 5 , \\
\hline (1) & & \\
\hline & & \\
\hline
\end{tabular}




\section{VIRGINIA.}

\section{POSITION AND EXTENT OF DEPOSITS.}

The only economically important deposits of salt in Virginia are in the southwestern part of the State. These, with the gypsum deposits, extend for 20 miles along the valley of the North Fork of Holston River and have been developed extensively in Smyth and Washington counties. Two gypsum plants and one salt or alkali works are now in operation in this area.

\section{STRATIGRAPHY AND STRUCTURE.}

The rocks of the region are involved in an overthrust fault which bas been called by.J. J. Stevenson the Saltville fault. ${ }^{1}$ This dislocation brings up Cambrian limestones on the southeast of the fault line and thrusts them over upon Mississippian ("Lower Carboniferous") rocks on the northwest side. The fault plane at the surface has a general direction to the northeast.

In considering the areal and geologic relations of the salt and gypsum deposits the area southeast of the fault line is not important. The deposits are confined to a belt northwest of the fault, and extend from the fault line nearly to the outcropping Mississippian sandstone along the foot of Pine and Little Brushy mountains to the northwest.

According to Eckel ${ }^{2}$ they are contained in the lower member of the Greenbrier [Newman] limestone, which ranges in thickness from 600 to 1,000 feet and consists of shaly limestones with one or more beds of gypsum underlain by blue shales or slates, which are in turn underlain by shales or shaly limestones containing thick beds of rock salt. This lower member of the Newman limestone seems to be developed only locally, as it has been recorded only in this region.

Owing to the soft nature of the rocks including the salt and gypsum beds, good natural exposures are rare, but the well records of the region throw some light on the stratigraphic succession. None of the earlier wells drilled on the Robertson property southwest of Saltville show any appreciable amount of salt, owing, according to Eckel, to the possible absence of the salt beds at the places where the drilling was performed or, more probably, to the possible stoppage of drilling before the salt horizon was reached. Though records of the beds penetrated in drilling the salt wells could not be obtained, it is known that salt was reached at a depth of about 800 feet, and it is said that the aggregate thickness of the rock-salt beds passed through is 175 feet.

\footnotetext{
1 Stevenson, J. J., Notes on the geological structure of Tazewell, Russell, Wise, Smyth, and Washington counties of Virginia: Am. Philos. Soc. Proc., vol. 22, pp. 157-160, 1885.

I Eckel, E. C., Salt and gypsum deposits of southwestern Virginia: U. S. Geol. Survey Bull. 213, pp. 406-416, 1903.
} 
By combining all the data obtainable Eckel's section of the salt and gypsum bearing or lower member of the Newman limestone is as follows:

\section{Section of lower member of Greenbrier [Newman] limestone.}

Top of gypsiferous series to top of Buena Vista wells.......... 100

Gypsum-bearing rocks and shales in deepest well.............. 600

Bottom of deepest Buena Vista well to top of salt beds, probably not over.................................... 100

Salt beds and inclosing rocks. ....................... 175

Bottom of salt beds to Lower Carboniferous [Mississippian] sand-

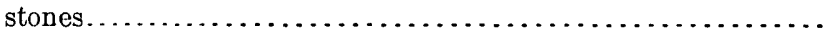

The thickness of the series therefore is considered to be approximately 1,000 feet.

According to Eckel the salt and gypsum deposits are regarded as having originated from deposition through the evaporation of sea water in a partly or entirely inclosed basin, and are of Mississippian age, being overlain by massive beds of Newman limestone and underlain by Mississippian sandstone.

In the descriptions of the area by Stose ${ }^{1}$ the local formations are treated more in detail. Stose divides the Mississippian rocks of the area into three formations, as follows: (1) An upper limestone called the Newman limestone, which has a thickness of about 3,325 feet; (2) the Maccrady formation, consisting of shales, sandstones, and limestones, which has a thickness of 1,025 feet more or less, and (3) the Price sandstone, which has a thickness ranging from 327 to 424 feet. The most striking fact in connection with the gypsum and salt deposits of this district is that they have been found in quantity only in the shales of the Maccrady formation along the Saltville fault. From these and from other data Stose's conclusions regarding the origin of the salt and gypsum deposits are quite different from those of Eckel. Stose regards them as largely secondary and not primary and as having been derived from calcareous-argillaceous sediments originally containing disseminated gypsum and salt, which were precipitated in a partially inclosed arm of the sea. This disseminated salt and gypsum was subsequently concentrated in the same formation by ground waters circulating along the fault zone between the Carboniferous and the Cambrian rocks.

\section{RECORDS OF DEEP WELLS NEAR SALTVILLE, VA.}

The wells in the open valley near Saltville, Va., are shown in Plate VII. Their records are given below as far as obtainable.

1 Stose, G. W., Geology of the salt and gypsum deposits of southwestern Virginia: U. S. Geol. Survey Bull. 530, pp. 232-255, 1913. 


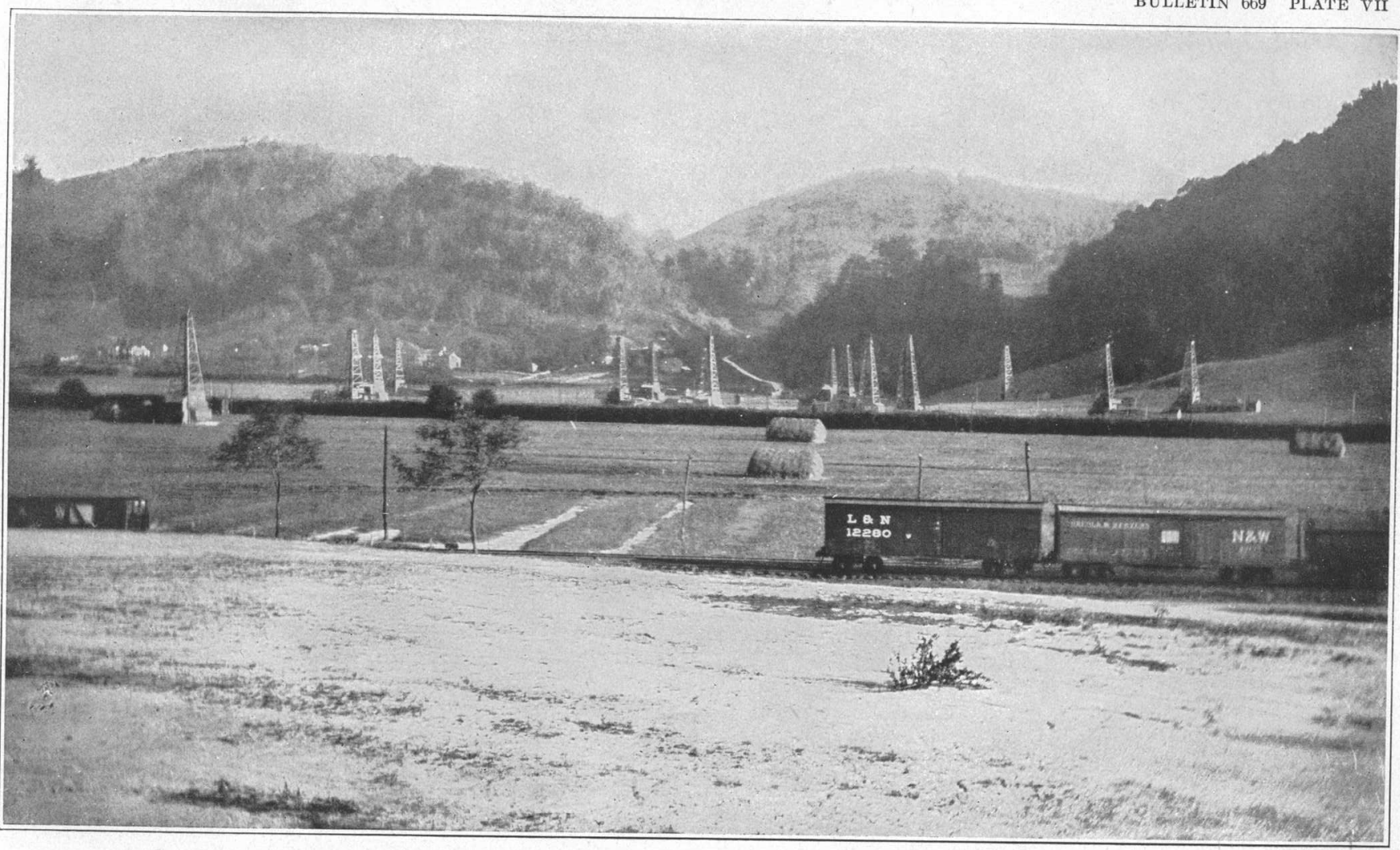

OPEN VALLEY AT SALTVILLE, VA., SHOWING BRINE WELLS.

Photograph by G. W. Stose. 
Log of well A on Robertson property, near Saltville. Smz'th County, Va.a

\begin{tabular}{|c|c|c|}
\hline Material. & $\begin{array}{l}\text { Thick- } \\
\text { ness. }\end{array}$ & Depth. \\
\hline 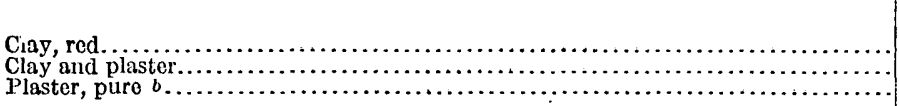 & $\begin{array}{r}\text { Feet. } \\
14 \\
106 \\
40\end{array}$ & $\begin{array}{r}\text { Fret. } \\
14 \\
120 \\
160\end{array}$ \\
\hline
\end{tabular}

a Eckel, E. C., op. cit., p. 408

$b$ The pure plaster is said to have extended 40 feet deeper-from 160 to 200 fect.

NoTe.-Bored between 1815 and 1820.

Log of well B on Robertson property, near Saltville, Smyth County, Va.a

\begin{tabular}{|c|c|c|c|}
\hline Material. & . & $\begin{array}{c}\text { Thick- } \\
\text { ness. }\end{array}$ & Depth. \\
\hline 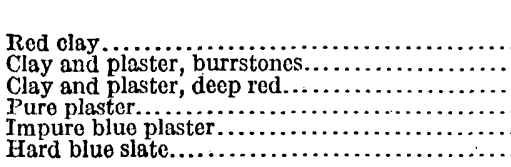 & 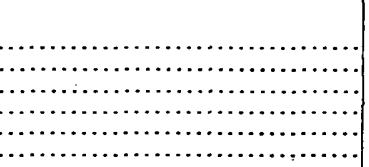 & $\begin{array}{r}\text { Feet. } \\
10 \\
20 \\
20 \\
45 \\
68 \\
257\end{array}$ & $\begin{array}{r}\text { Feet. } \\
10 \\
30 \\
50 \\
95 \\
163 \\
420\end{array}$ \\
\hline
\end{tabular}

NOTE.-Bored in 1847.

a Eckel, E. C., op. cit., p. 408.

Log of well C on Robertson property, near Saltville, Smyth County, Va.a

\begin{tabular}{|c|c|c|}
\hline Material. & $\begin{array}{c}\text { Thick- } \\
\text { ness. }\end{array}$ & Depth. \\
\hline 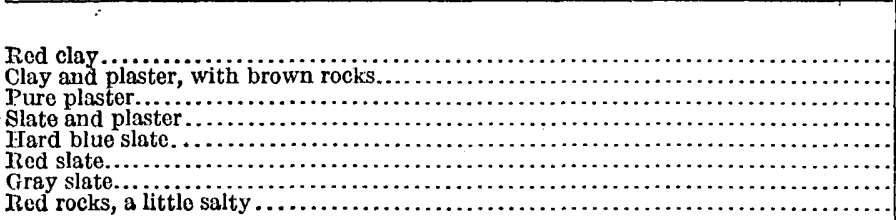 & $\begin{array}{r}\text { Feet. } \\
10 \\
60 \\
30 \\
100 \\
160 \\
120 \\
15 \\
10\end{array}$ & $\begin{array}{r}\text { Feet. } \\
10 \\
70 \\
100 \\
200 \\
360 \\
480 \\
495 \\
505\end{array}$ \\
\hline
\end{tabular}

Note.-Bored in 1847.

a Eckel, E. C., op. cit., p. 409.

Log of well D on Robertson property, near Saltville, Smyth County, Va.a

\begin{tabular}{|c|c|c|}
\hline Material. & $\begin{array}{c}\text { Thick- } \\
\text { ness. }\end{array}$ & Depth. \\
\hline 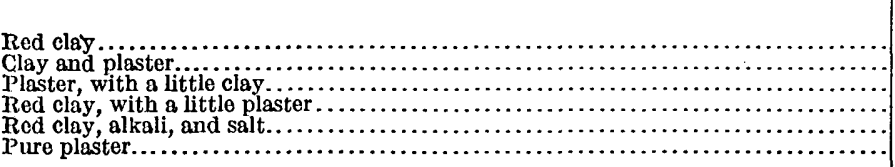 & $\begin{array}{r}\text { Feet. } \\
10 \\
52 \\
138 \\
185 \\
2 \\
203\end{array}$ & $\begin{array}{r}\text { Feet. } \\
10 \\
62 \\
200 \\
385 \\
337 \\
590\end{array}$ \\
\hline
\end{tabular}

NoTE.-Bored in 1847.

a Eckel, E. C., op. cit., p. 409. 
Log of well $E$ on Robertson property, near Saltville, Smyth County, Va.a

\begin{tabular}{|c|c|c|}
\hline Muterisl. & $\begin{array}{l}\text { Thich- } \\
\text { ness. }\end{array}$ & Depth. \\
\hline 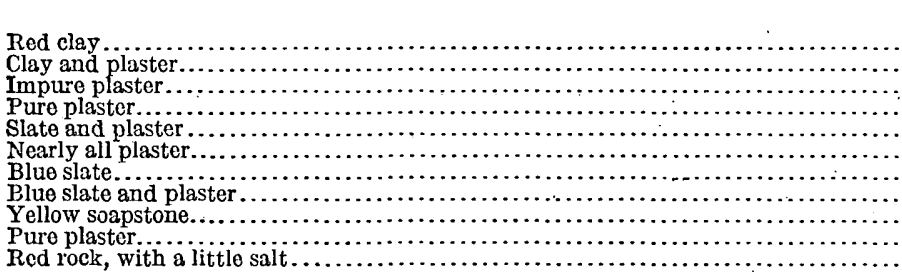 & $\begin{array}{r}\text { Feet. } \\
10 \\
6 \\
34 \\
52 \\
63 \\
45 \\
110 \\
70 \\
55 \\
45 \\
15\end{array}$ & $\begin{array}{r}\text { Feet. } \\
10 \\
16 \\
50 \\
102 \\
165 \\
210 \\
320 \\
390 \\
445 \\
490 \\
505\end{array}$ \\
\hline
\end{tabular}

NoTE.-Bored in 1847.

a Eckel, E. C., op. cit., p. 409.

Log of well F on Robertson property, near Saltville, Smyth County, Va.a

\begin{tabular}{|c|c|c|}
\hline Material. & $\begin{array}{c}\text { Thich- } \\
\text { ness. }\end{array}$ & Depth. \\
\hline 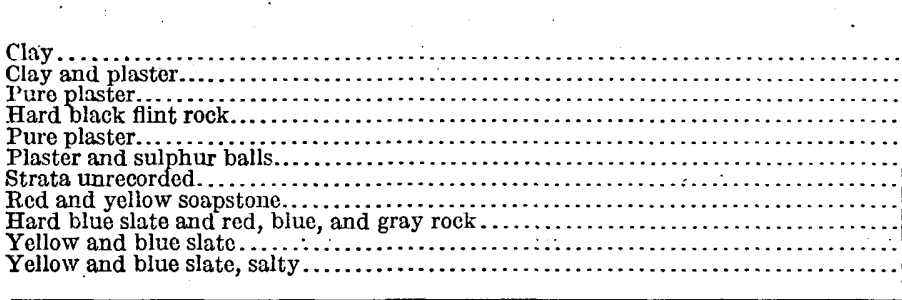 & $\begin{array}{r}\text { Fct. } \\
17 \\
33 \\
33 \\
7 \\
6 \\
9 \\
4 \\
11 \\
239 \\
31 \\
70\end{array}$ & $\begin{array}{r}\text { Fcct: } \\
17 \\
50 \\
83 \\
90 \\
96 \\
105 \\
109 \\
120 \\
359 \\
.390 \\
\ldots \quad 460 \\
\end{array}$ \\
\hline
\end{tabular}

NoTE.-Bored in $\mathbf{1 8 5 3}$.

a Eckel; E. C., op. cit., p. 409.

Log of well $G$ on Robertson property, near Saltville, Smyth County, Va.a

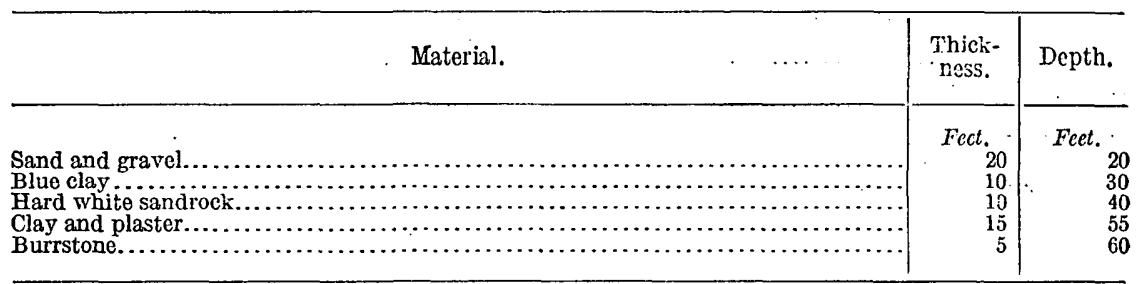

NoTE.-Bored in 1854

a Eclecl, E. C., op. cit., p. 409.

Generalized record of typical well on property of the Mathicson Co., at Saltville, Smyth County, Va.a

\begin{tabular}{|c|c|c|}
\hline Material. & $\begin{array}{l}\text { Thick- } \\
\text { ness. }\end{array}$ & Depth. \\
\hline 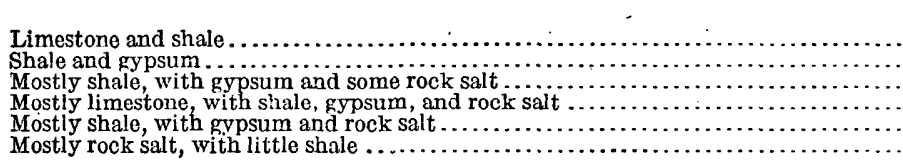 & \begin{tabular}{r|} 
Fcet. \\
26 \\
105 \\
359 \\
215 \\
100 \\
197
\end{tabular} & $\begin{array}{r}\text { Fcet. } \\
26 \\
221 \\
580 \\
795 \\
895 \\
1,092\end{array}$ \\
\hline
\end{tabular}

a Stose, G. W., Geology of tho salt and gypsum deposits of southwestern Virginia: U. S. Geol. Survey Bull. 530, p. 252, 1913 . 


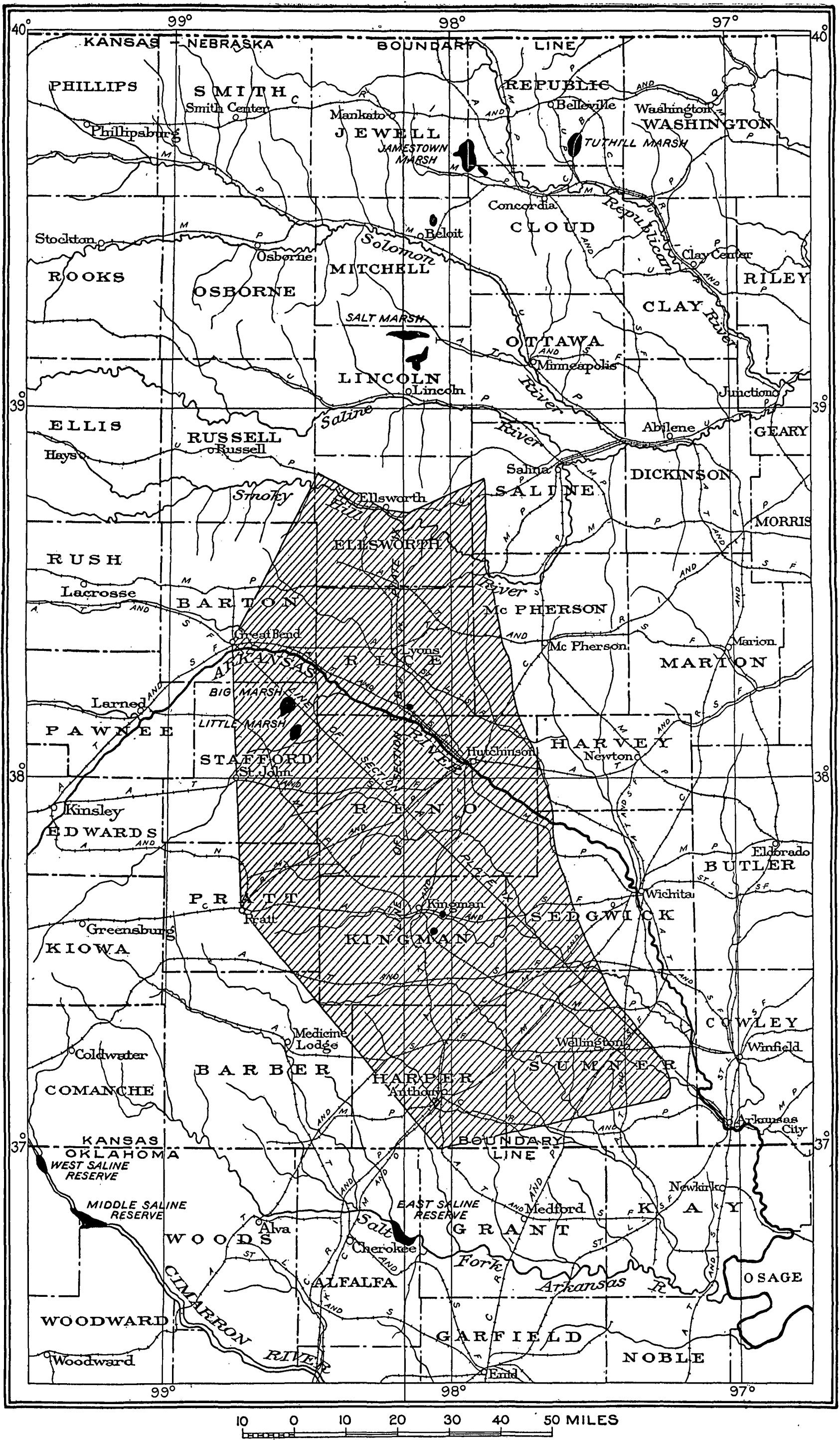

MAP OF MIDDLE KANSAS, SHOWING LOCATION OF SALT MARSHES AND AREA UNDERLAIN BY ROCK SALT.

From Kansas Univ. Geol. Survey Ann. Bull. Mineral Resources, 1898 (PI. IV). 


\section{BIBLIOGRAPHY.}

Ecket, E. C., Salt and gypsum deposits of southwestern Virginia: U. S. Geol. Survey Bull. 213, pp. 406-416, 1903.

Radcliffe, Thomas, Analysis of Saltville, Va., rock salt: The Virginias, vol. 5, p. 138, 1884; Chem. News, vol. 40, p. 187, 1879; U. S. Geol. Survey Min. Resources, 1883-84, p. 840, 1885.

Rogers, W. B., A reprint of annual reports and other papers on the geology of the Virginias, pp. 141-142, New York, 1884.

Stevenson, J. J., Notes on the geological structure of Tazewell, Russell, Wise, Smyth, and Washington counties, Va.: Am. Philos. Soc. Proc., vol. 22, pp. 157-160, 1885.

Taylor, Stephen, Discovery in Virginia of the regular mineral salt formation: Am. Jour. Sci., Ist ser., vol. 41, pp. 214-215, 1840.

Stose, G. W., Geology of the salt and gypsum deposits of southwestern Virginia: U. S. Geol. Survey Bull. 530, pp. 232-255, 1913.

Watson, T. L., Mineral resources of Virginia, pp. 211-215, 1907.

\section{KANSAS. 1}

Kansas ranked fourth among the States in both the quantity and the value of the salt produced in 1915. The State produces much rock salt and also evaporated salt obtained by the open-pan, grainer, and vacuum-pan processes.

\section{POSITION AND EXTENT OF DEPOSITS.}

In a small part of Kansas (see map, Pl. VIII) salt occurs in salt marshes as brine, which on evaporation during the dry season leaves a coating of salt and gives the name to the so-called salt plains. Salt from this source is not known to be utilized.

The rock salt which is now worked at Lyons and Kanopolis and from which brines are now obtained at Ellsworth, Hutchinson, Sterling, Lyons, and Anthony and were once obtained at ather places lies well below the surface. Salt in the form of brine also occurs in certain beds of the Permian and Pennsylvanian ("Coal Measures") in the eastern part of the State. The part of Kansas below the surface of which rock salt is known to exist is the south-central. By examining the map (Pl. VIII) the extent of the area may be readily determined. It includes Rice and Kingman counties, nearly all of Reno County, and parts of Saline, Ellsworth, Barton, McPherson, Stafford, Harvey, Pratt, Sedgwick, Barber, Harper, and Sumner counties. The heary line inclosing the shaded area is drawn from point to point where deep wells have proved the presence of rock salt. The eastern limit of the salt in Kansas probably corresponds closely to this line, as the salt approaches the surface eastward and is thinner than it is on the west and north, where it probably extends farther than represented.

1 Kirk, M. Z., and Faworth, Ezasmus, Salt: Kansas Univ. Geol. Survey Mineral Resources Ann. Bull., 1898, pp. 67-123, 1399. (That part of the bulletin relating to the geology of Kansas salt (pp. 8697) is by Haworth.) 


\section{STRATIGRAPHY AND STRUCTURE.}

THE SALT-MARSH AREA.

According to Haworth, the salt marshes in northern Kansas and possibly as far south as Stafford County obtain their salt principally from the salt-bearing shales of the Dakota sandstone. These saltbearing shales have been described as being near the base of the upper Dakota and as ranging in thickness from 15 to 30 feet. On account of their saline content they undergo erosion readily and leave low, level areas which receive the leachings from adjacent salt-bearing shales situated to the west. The origin of the salt in the marshes of Stafford County, whether from the "Red Beds" or the salt-bearing shales of the Dakota, is difficult to determine, owing to the covering of Tertiary and recent sands and gravels. Farther south, however, the salt marshes of the area on Cimarron River and the area on Salt Fork in Oklahoma are thought to come entirely from the rock salt associated with the Permian "Red Beds."

\section{THE ROCK-SALT AREA.}

The rock-salt beds of Kansas occur in rocks of Permian age known as the Marion formation. (See Pl. IX, A.) They grow thinner eastward to a point beyond Wellington and Little River and die out possibly without coming near the surface. It is thought that the salt springs at Geuda Springs, Sumner County, have their origin in these salt beds. How far the salt and associated beds extend westward is unknown. Northward and southward the beds are fairly well known from drill records, from Kanopolis, Ellsworth County, on the north, to Anthony, Harper County, on the south-that is, very nearly to the Kansas-Oklahoma State line. From the north to south cross section of the State (Pl. IX, $B$ ) it will be observed that the beds thin northward. At Anthony they are 404 feet thick (depth 946 to 1,350 feet); at Kingman, 415 feet thick (depth, 665 to 1,080 feet); a.t. Hutchinson, 380 feet thick (depth, 430 to 810 feet); at Lyons they are 275 feet thick (depth, 793 to 1,068 feet); and at Kanopolis about 250 feet thick (depth, 630 to 880 feet). If the rate of decrease in thickness from Hutchinson northward were maintained, the saltbearing beds would disappear before the north boundary of the State was reached. It must be remembered that where more than one record is obtainable at the same place, for example, at Hutchinson, the exact thickness of the salt-bearing beds, as well as the distance of the topmost of them below the surface differs somewhat and at some of these places considerably from the figures given above. The records of the wells at Kanopolis, Lyons, Hutchinson, Kingman, and Anthony contain no reference to appreciable quantities of gypsum below them. 


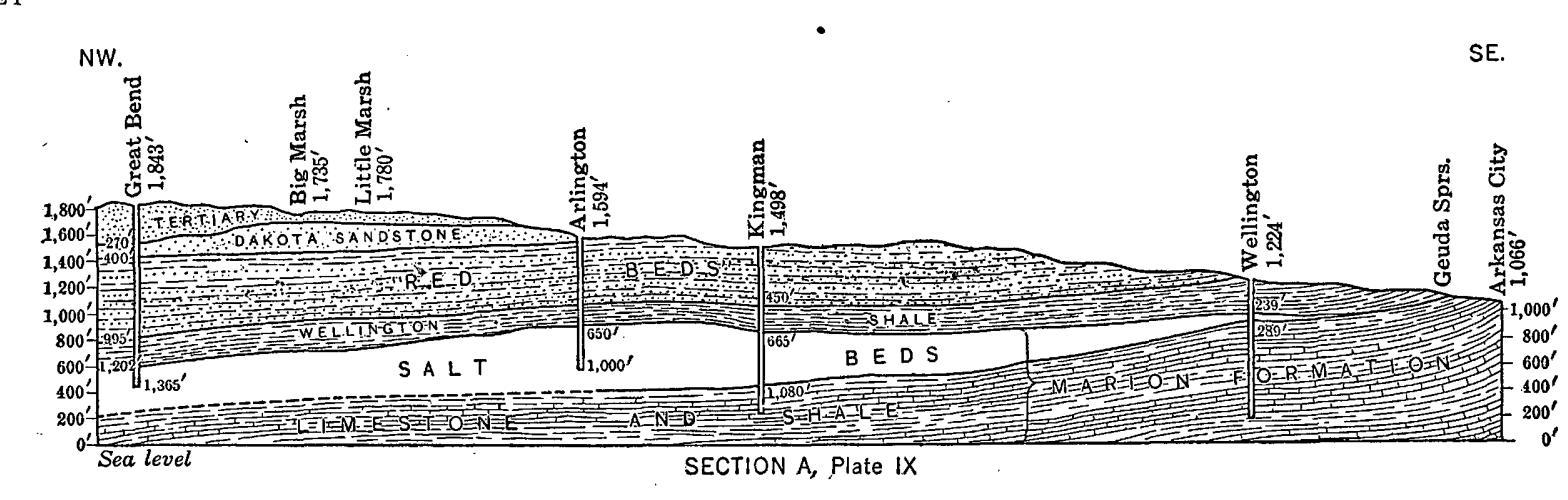

:

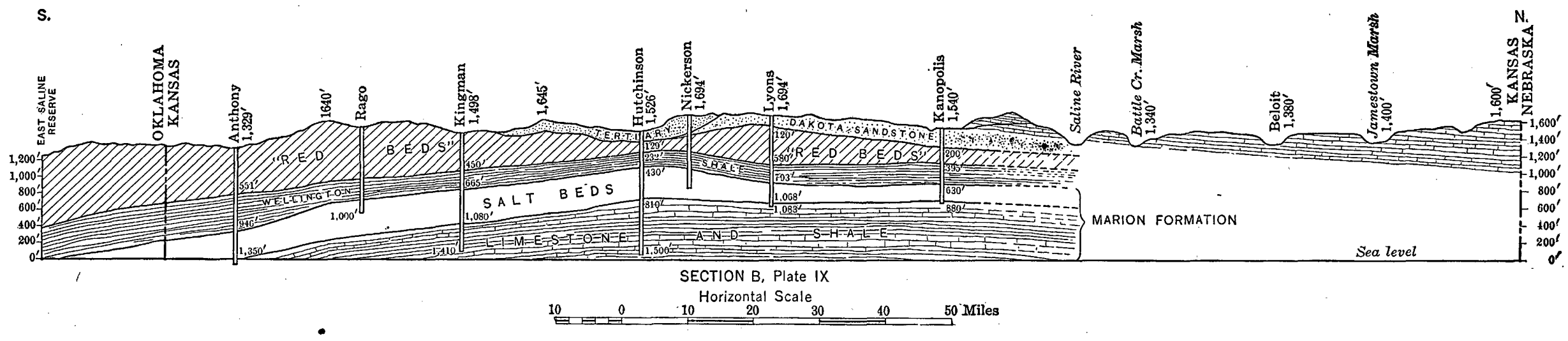

GEOLOGIC SECTIONS ACROSS THE SALT FIELD OF KANSAS.

From Kansas Univ. Geol. Survey Ann. Bull. Mineral Resources, 1898 (Pl. V). 
A most interesting question in connection with the geology of the salt beds is their retation to the extensive gypsum deposits in different parts of Kansas and of the Great Plains area. The rock gypsum in the northern part of the State, in Marshall County, lies but a few feet above the Cottonwood limestone, which would place it considerably below the Marion formation. To the south, in the gypsum central field, the rock gypsum occurs in the Wellington shale, which overlies the Marion formation. If, therefore, the correlations made by Grimsley ${ }^{1}$ are correct, the salt beds were deposited at a period of time intermediate between the formation of the Marshall County rock gypsum and that in the vicinity of Solomon.

It is difficult to understand how such extensive deposits of salt could be formed without a larger amount of gypsum being formed underneath them. The records of the wells at Kanopolis, Lyons, Hutchinson, Kingman, and Anthony contain no reference to gypsum immediately underlying the salt beds. The question is as to what became of the calcium sulphate held in solution by the ocean water from which the rock salt was obtained. It is barely possible that during the period of the formation of the Marshall County gypsum the inland sea did not reach southward to the salt-beds area, and that after the gypsum was principally precipitated out of the inclosed ocean water and before concentration was carried far enough to precipitate the salt, surface movements resulted in draining this partially purified water southward over new areas from which fresh ocean water was excluded, thus permitting the continued evaporation to deposit the salt now found in the salt beds from the sea water from which the Marshall County gypsum was produced. It is known that the Permian rocks, in general, become quite thin northward, entirely excluding the upper members of the Permian. So far as this has a bearing on the subject, it would tend to favor the view just expressed. ${ }^{2}$

WELL RECORDS.

Log of well at Wilson, Ellsworth County, Kans.a

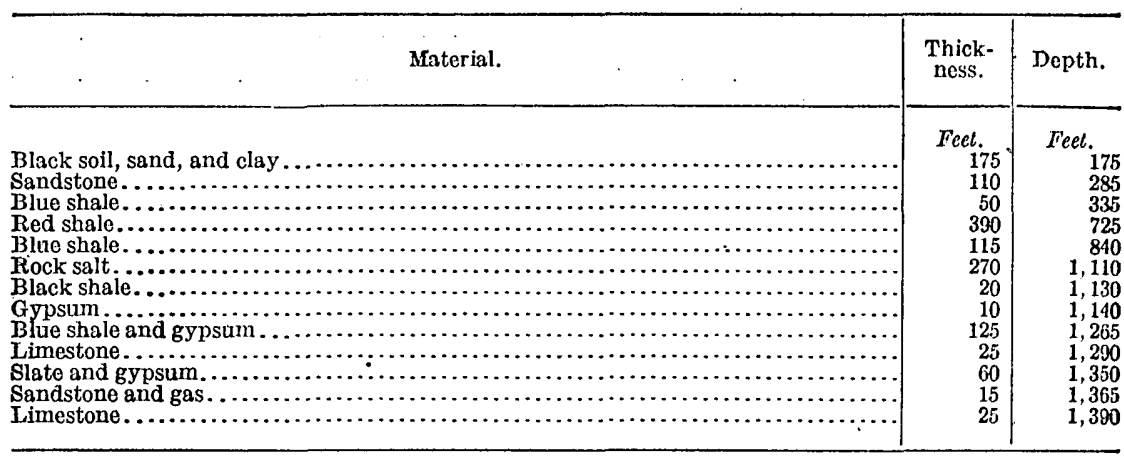

a Kirk, M. Z., and Haworth, Erasmus, op. cit., p. 97.

1 Grimsley, G. P., and Balley, E. H. S., Special report on gypsum and gypsum cement plasters: Kansas Univ. Geol. Survey, vol. 5 , pls. 2 and 3,1899 .

2 Haworth, Erasmus, Geology of Kansas salts: Kansas Univ. Geol. Survey Mineral Resources, Ann. Bull., 1898, pp. 88-89, 1899 . 
Log of woll of Crystal Salt Co., Kanopolis, Ellsworth County, Kans.

\begin{tabular}{|c|c|c|c|}
\hline Material. & $\begin{array}{c}\text { Thick- } \\
\text { ness. }\end{array}$ & \multicolumn{2}{|c|}{ Depth. } \\
\hline Co top of salt . . . . . . . . . . . . . . . & $\begin{array}{l}F t . \text { in. } \\
612\end{array}$ & ${ }_{612}^{F t}{ }^{i \gamma}$ & \\
\hline 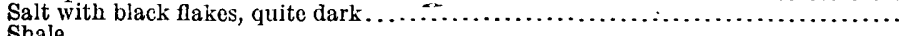 & 10 & & \\
\hline $\begin{array}{l}\text { Shale } \\
\text { Fair }\end{array}$ & 1 & 11 & \\
\hline 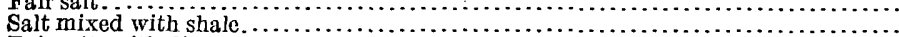 & 3 & 14 & \\
\hline 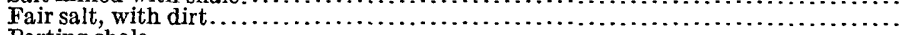 & 6 & 24 & \\
\hline 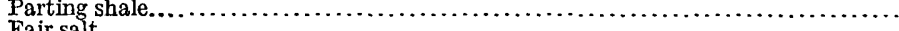 & 2 & 24 & \\
\hline $\begin{array}{l}\text { Fair salt } 1 \\
\text { Shale } \\
\text { Fhe }\end{array}$ & & 29 & \\
\hline 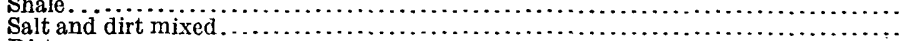 & $\begin{array}{ll}1 & 6 \\
6 & \end{array}$ & $\begin{array}{l}30 \\
36\end{array}$ & \\
\hline 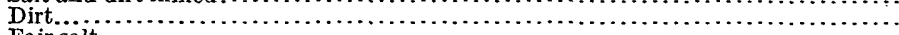 & 3 & 36 & 11 \\
\hline 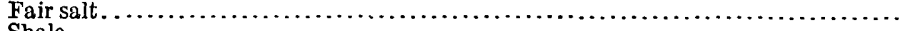 & 6 & 40 & 5 \\
\hline 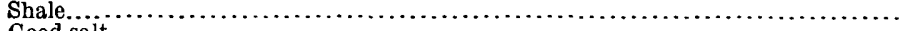 & 2 & 40 & 7 \\
\hline 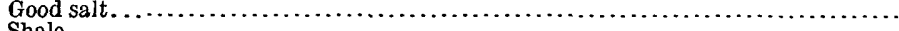 & 4 & 44 & 7 \\
\hline 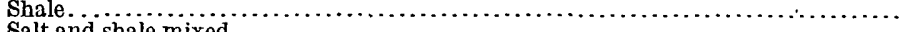 & 1 & 45 & \\
\hline 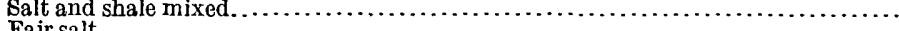 & 4 & 49 & \\
\hline 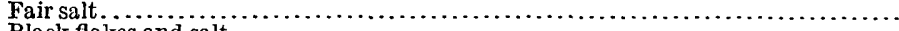 & 4 & 53 & 7 \\
\hline 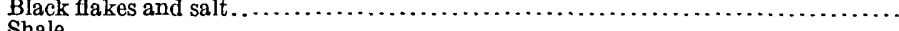 & 20 & 73 & 7 \\
\hline$\ldots \ldots \ldots \ldots \ldots \ldots \ldots \ldots \ldots \ldots \ldots \ldots \ldots \ldots$, & 8 & 74 & 3 \\
\hline 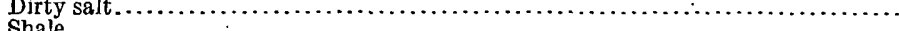 & 7 & 81 & \\
\hline 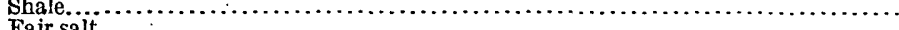 & 1 & 82 & \\
\hline 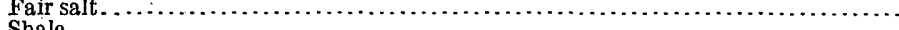 & 3 & 85 & 3 \\
\hline 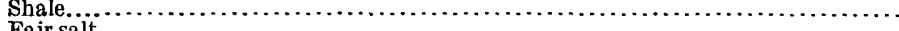 & 6 & 86 & 9 \\
\hline 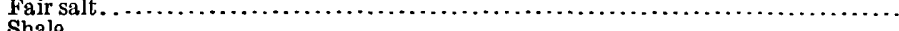 & 2 & 88 & 9 \\
\hline$\ldots \ldots \ldots \ldots \ldots \ldots \ldots$ & 2 & 90 & 9 \\
\hline 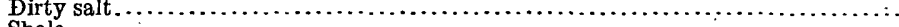 & 11 & 101 & 9 \\
\hline$\ldots \ldots \ldots \ldots \ldots \ldots \ldots \ldots$ & 1 & 102 & 9 \\
\hline$\because \ldots \ldots \ldots \ldots \ldots \ldots \ldots$ & 3 & 105 & \\
\hline 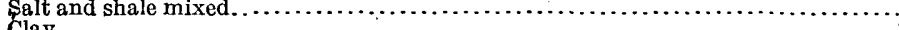 & 10 & 106 & 4 \\
\hline$\ldots \ldots \ldots \ldots \ldots \ldots$ & 7 & 113 & 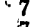 \\
\hline mixed.............. & 9 & 122 & 7 \\
\hline$k$ salt $\ldots \ldots \ldots \ldots \ldots \ldots \ldots$ & 8 & 123 & \\
\hline with blank streaks running up & 8 & 131 & 3 \\
\hline 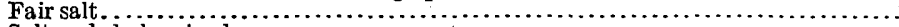 & 4 & 135 & 3 \\
\hline ale mixed........ & 6 & 136 & 9 \\
\hline Fair salt with dark streaks.............. & 6 & 142 & 9 \\
\hline 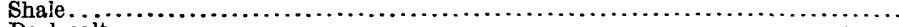 & 1 & 143 & 9 \\
\hline Dark salt & 6 & 1 & 3 \\
\hline ale............ & & 15 & \\
\hline Da & 3 & 152 & \\
\hline & & 152 & 8 \\
\hline salt. & 6 & 154 & 2 \\
\hline 1 salt. & 3 & 157 & 2 \\
\hline 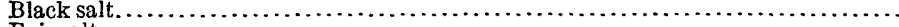 & 6 & 157 & 8 \\
\hline$\cdots \ldots \ldots \ldots \ldots$ & 5 & 163 & 2 \\
\hline$\ldots \ldots \ldots \ldots \ldots \ldots \ldots$ & 2 & 163 & 4 \\
\hline$\ldots \ldots \ldots$ & 8 & 16 & \\
\hline$t$ & 3 & 168 & \\
\hline ack salt........ & 2 & 170 & \\
\hline w being worked & 11 & 181 & 6 \\
\hline & & 793 & \\
\hline
\end{tabular}

Log of shaft No. 3, of Crystal Salt Co.a

\begin{tabular}{|c|c|c|}
\hline - Material. & $\begin{array}{c}\text { Thick- } \\
\text { ness. }\end{array}$ & Depth. \\
\hline & Ft. in. & Ft. in. \\
\hline $\begin{array}{l}\text { Shale } \\
\text { Dark } \\
\text { silt } \\
1\end{array}$ & 510 & $\cdots \cdots \cdots$ \\
\hline 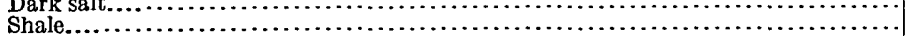 & $\begin{array}{ll}3 & 2\end{array}$ & $\begin{array}{ll}5 & 10 \\
6 & \end{array}$ \\
\hline 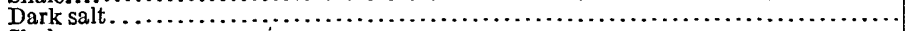 & 110 & 710 \\
\hline 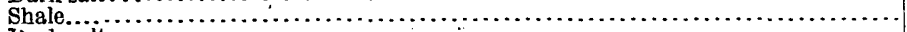 & & 711 \\
\hline 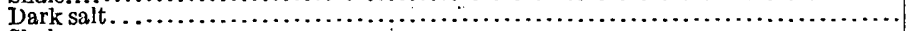 & 15 & 2211 \\
\hline 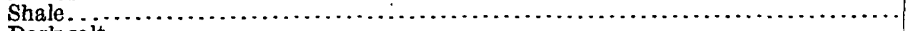 & 1 & 23 \\
\hline 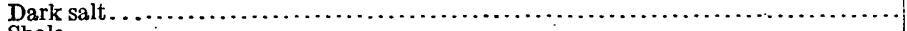 & 4 & 24 \\
\hline 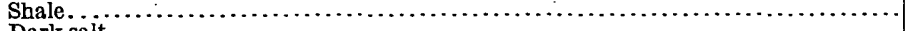 & 8 & 32 \\
\hline 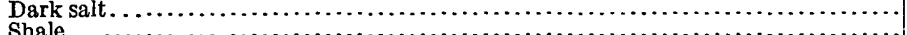 & & $\begin{array}{l}36 \\
36\end{array}$ \\
\hline 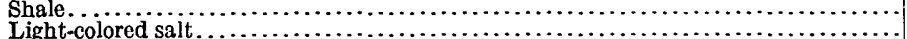 & $\begin{array}{l}1 \\
6\end{array}$ & $\begin{array}{rr}36 & 5 \\
39 & 11\end{array}$ \\
\hline Shale. . . . . . & & 40 \\
\hline Light-colored salt................. & 610 & 4610 \\
\hline
\end{tabular}

$a$ Sunk in a search for potash salt below the bottom of the sa't boing worked, Kanopolis, Kans. 
Log of well at Kanopolis, Ellsworth County, Kans.a.

\begin{tabular}{|c|c|c|}
\hline Material. & $\begin{array}{l}\text { Thick- } \\
\text { ness. }\end{array}$ & Depth. \\
\hline Soil sondy loar & Fect. ${ }_{5}$ & Fect. \\
\hline Brown sand............... & 5 & 10 \\
\hline Yellow sand ........ & & 15 \\
\hline Sand and fine gravel ..... & & 20 \\
\hline White sand and fine gravcl. & 10 & 30 \\
\hline Coarso gravel............... & & 35 \\
\hline Yellow claycy sand... & & 40 \\
\hline Gray soapstone $\ldots \ldots \ldots \ldots \ldots$ & $\begin{array}{r}10 \\
5\end{array}$ & 50 \\
\hline $\begin{array}{l}\text { Light-gray soapstone........ } \\
\text { Red shale.................... }\end{array}$ & & $\begin{array}{l}55 \\
60\end{array}$ \\
\hline Pink shalo ................. & 5 & 65 \\
\hline Gray shale .............. & 10 & 75 \\
\hline Gray sand and gravel & & 80 \\
\hline Gray shalo............ & & .110 \\
\hline Dark-blue shale ......... & & 145 \\
\hline Lead-colorod shale....... & 35 & 180 \\
\hline Red shale ............ & & 185 \\
\hline Silica or light shalo...... & & 190 \\
\hline Silica or light soit shale... & 10 & 200 \\
\hline Red Triassic b rock...... & 40 & 240 \\
\hline Brown Triassic rock...... & & 245 \\
\hline Triassic rock... & 10 & 255 \\
\hline Brown and red Triassic rock.. & 10 & 265 \\
\hline Dark-red Triassic rock ......... & 10 & 275 \\
\hline nd red Triassic roc & 20 & 295 \\
\hline Dark-brown Triassic rock. & & 300 \\
\hline Red Triassic rock ........... & 15 & 315 \\
\hline ic rock.... & & 330 \\
\hline Brown and red Triassic rock. & 5 & 335 \\
\hline Dark-red Triassic rock....... & 10 & 345 \\
\hline Brown Triassic rock..... & 15 & 360 \\
\hline Dark-red Triassic rock.... & 5 & 365 \\
\hline Dark-brown Triassic rock. & & 370 \\
\hline Dark-red Triassic rock.... & 10 & 380 \\
\hline Traces of gypsum......... & 5 & 385 \\
\hline Dark-red Triassic rock...... & & 390 \\
\hline Triassic rock. & & 395 \\
\hline Dark (gypsum) Triassic roclk & & 400 \\
\hline Brown (traces) Triassic rock. & & 405 \\
\hline Blue shale.................. & & 410 \\
\hline Blue shale and gypsum.... & 50 & 460 \\
\hline ................ & 10 & 470 \\
\hline $10 \ldots \ldots \ldots \ldots \ldots$ & 15 & 485 \\
\hline Red Triassic rock, gypsum.. & & 490 \\
\hline Brown Triassic rock, gypsum. & & \\
\hline$\theta \ldots \ldots \ldots \ldots \ldots \ldots$ & 20 & 525 \\
\hline Gray shal & 5 & 530 \\
\hline le............. & 30 & 560 \\
\hline Blue shale. & 75 & 635 \\
\hline Blue shale with few scales of & & 640 \\
\hline Blue shale and salt mixed... & & 645 \\
\hline Black shale and salt mixed.. & 5 & 650 \\
\hline & & 655 \\
\hline Salt and shale....... & 5 & 660 \\
\hline salt.............. & & \\
\hline Salt. ....................... & & 670 \\
\hline $\begin{array}{l}\text { Salt, bright crystals ....... } \\
\text { Slightly mixed with shale.. }\end{array}$ & $\begin{array}{r}185 \\
5\end{array}$ & 860 \\
\hline ly mixed with sla & 10 & 870 \\
\hline Salt and clay..... & 10 & 880 \\
\hline
\end{tabular}

a Kirk, M. Z., and Haworth, Erasmus, op. cit., p. 94.

$b$ The rocks called Triassic in this record aro now classified as Permian.

Note.-Record as furnished by the company: "Boring commenced March 1, 1889; well completed March 16. From surface to first specimen of salt intermingled with slate, 640 feet; thickness of pure salt, 230 fect; actual depth of well, 881 feet; 8 -inch drive pipc, 105 fect; 5 -inch casing, 333 fect; ;-inch tubing in the well, 851 feet and 6 inches. Piping placed in the well and the well completed ready to attach pumps, March 18 . The fresh-water well for use of drilling was sunk 35 fect, cased with 5 -inch casing properly perforated and driven to the bottom, and furnishes an abundant supply of pure water. Tho record represents the drillings found in every 5 feet." 
Log of shaft of Lyons Rock Salt Co., Lyons, Rice County, Kans.a

\begin{tabular}{|c|c|c|}
\hline Material. & $\begin{array}{c}\text { Thick- } \\
\text { ness. }\end{array}$ & Depth. \\
\hline 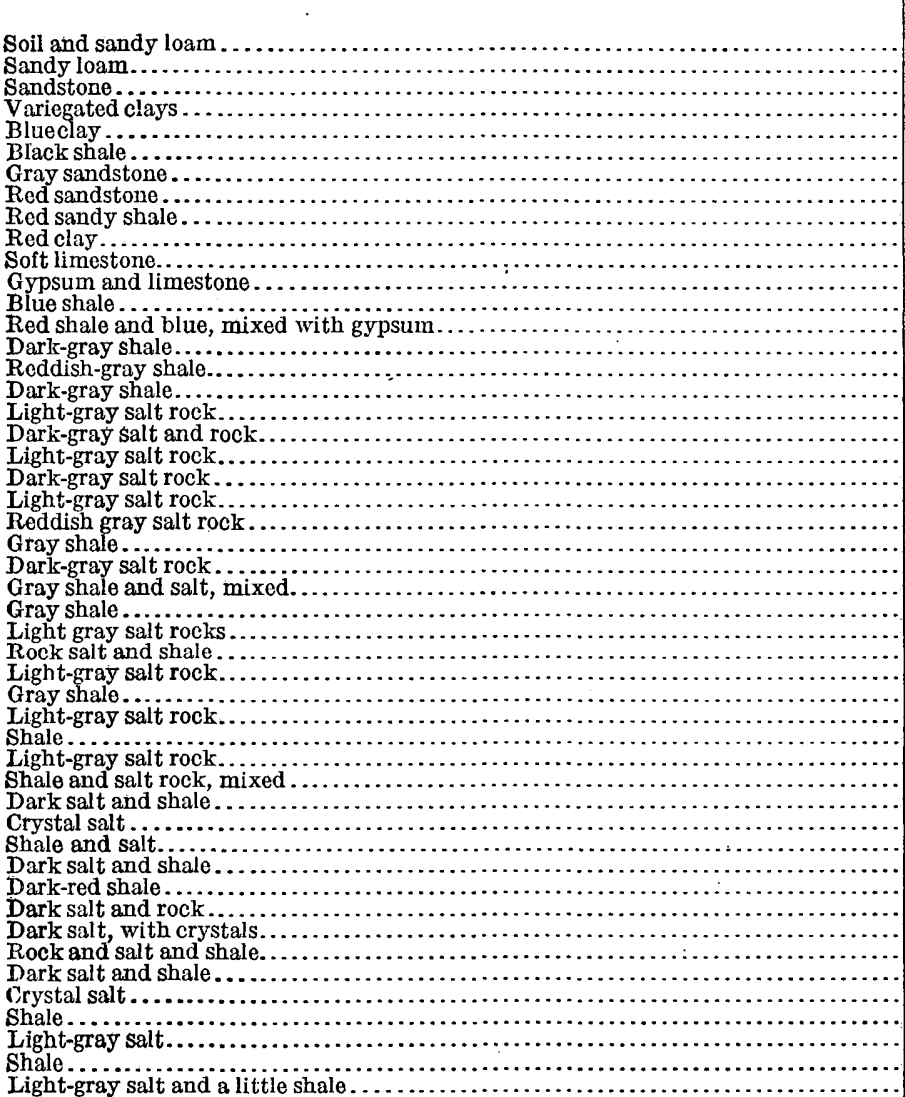 & $\begin{array}{r}\text { Feet. } \\
30 \\
15 \\
10 \\
12 \\
13 \\
30 \\
10 \\
78 \\
56 \\
18 \\
3 \\
9 \\
4 \\
292 \\
60 \\
30 \\
120 \\
2 \\
\frac{1}{2} \\
2 \frac{1}{2} \\
4 \\
3 \frac{1}{2} \\
8 \frac{1}{2} \\
8 \\
10 \frac{1}{2} \\
3 \\
4 \\
9 \\
1 \frac{1}{2} \\
8 \frac{1}{2} \\
1 \frac{1}{2} \\
8 \frac{2}{2} \\
1 \\
6 \frac{1}{2} \\
2 \frac{1}{2} \\
8 \frac{1}{2} \\
4 \\
7 \\
18 \frac{1}{2} \\
6 \\
10 \\
17 \\
19 \\
21 \\
2 \\
1 \\
9 \frac{1}{2} \\
\frac{1}{2} \\
10\end{array}$ & 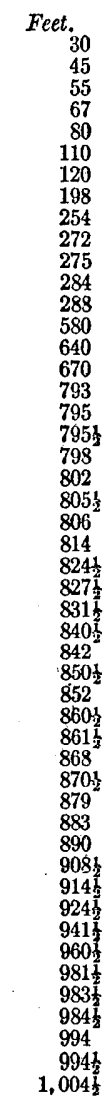 \\
\hline
\end{tabular}

a Kirk, M. Z., and Haworth, Erasmus, op. cit., p. 93. 
KANSAS.

Log of Standard Salt Co. s shaft, Little River, Rice County, Kans.

\begin{tabular}{|c|c|c|c|}
\hline Material. & $\begin{array}{l}\text { Thick- } \\
\text { ness. }\end{array}$ & Depth. & \\
\hline & Ft. in. & Ft. in & \\
\hline 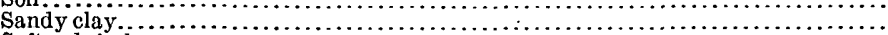 & 44 & 46 & \\
\hline 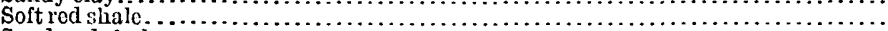 & 4 & 50 & \\
\hline 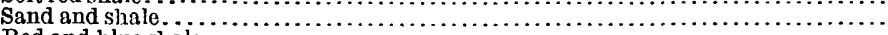 & 15 & 65 & \\
\hline 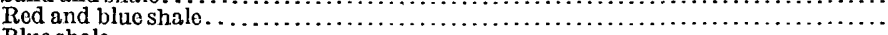 & 284 & 349 & \\
\hline 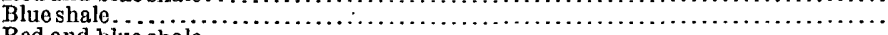 & 62 & 411 & \\
\hline Red and blue shale................. & 10 & 421 & \\
\hline Red shale............... & 13 & 434 & \\
\hline Blue shale................ & 6 & 440 & \\
\hline Red and blue shale. .............. & 22 & 462 & \\
\hline 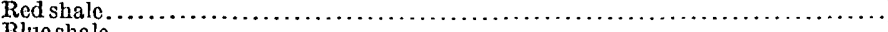 & 1 & 463 & \\
\hline 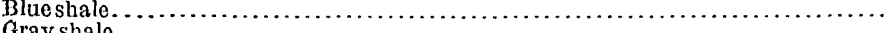 & 73 & 536 & \\
\hline 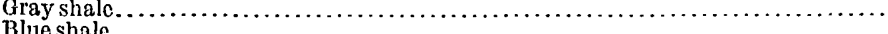 & 3 & 539 & \\
\hline 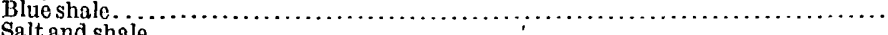 & 19 & 558 & \\
\hline 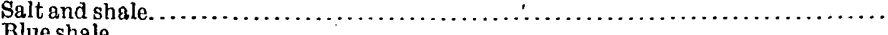 & 5 & 583 & \\
\hline 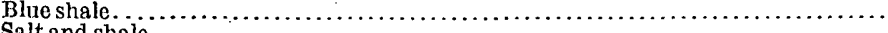 & 2 & 585 & \\
\hline 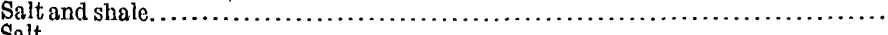 & 10 & 575 & \\
\hline 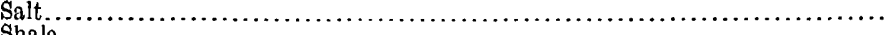 & 10 & 585 & \\
\hline 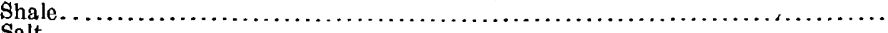 & 1 & 586 & \\
\hline 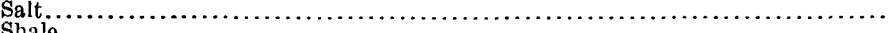 & 6 & 592 & \\
\hline$\ldots \ldots \ldots \ldots \ldots \ldots \ldots \ldots \ldots \ldots \ldots \ldots \ldots$ & 3 & 595 & \\
\hline 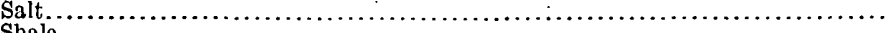 & 67 & 601 & \\
\hline 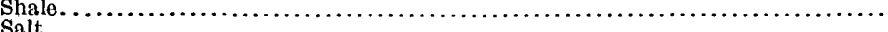 & 8 & 609 & \\
\hline & 16 & 625 & \\
\hline 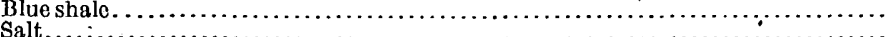 & 2 & 627 & \\
\hline 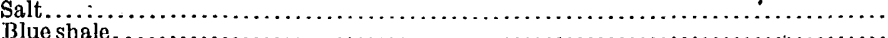 & 3 & 630 & 7 \\
\hline le $\ldots \ldots \ldots \ldots \ldots \ldots \ldots \ldots \ldots \ldots \ldots$ & 1 & $63 \mathrm{~L}$ & 7 \\
\hline$\cdots \cdots \cdots$ & 6 & 632 & \\
\hline Blue shale. ....... & 6 & 683 & \\
\hline (n. & b & 633 & \\
\hline 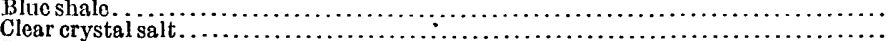 & 27 & 639 & \\
\hline 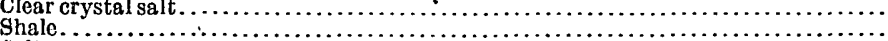 & 28 & 600 & \\
\hline & 2 & 673 & \\
\hline (n. & 1 & 6747 & \\
\hline Crystalline salt. ........... & 22 & 6867 & \\
\hline Blue shale... & 46 & 7011 & \\
\hline ne salt.................... & 31 & 7321 & 1 \\
\hline Blue and red shale................... & 12 & 733 & 3 \\
\hline 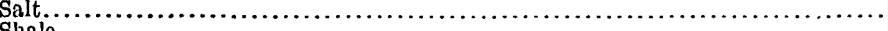 & 66 & 739 & \\
\hline$\ldots \ldots \ldots \ldots \ldots \ldots \ldots \ldots \ldots \ldots \ldots \ldots$ & 36 & 743 & 3 \\
\hline shale $\ldots \ldots \ldots \ldots \ldots \ldots \ldots \ldots$ & $\boldsymbol{B}$ & 743 & \\
\hline llized salt. $\ldots \ldots \ldots \ldots \ldots \ldots \ldots$ & 15 & 758 & \\
\hline 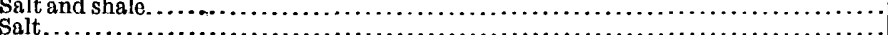 & 6 & 759 & \\
\hline Balt and shale............................ & $\begin{array}{l}5 \\
3\end{array}$ & $764: 3$ & \\
\hline Crystallized salt (planning to work this iod & & & \\
\hline shale. & 16 & $786 \mathrm{~g}$ & 9 \\
\hline 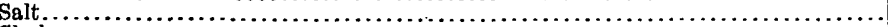 & 9 & 795 & \\
\hline Shale. & 4 & 7990 & 9 \\
\hline stallized salt... & 76 & 807 & 3 \\
\hline le.... & 96 & 816 & 9 \\
\hline Salt. & 38 & 820 & 3 \\
\hline She & 17 & 8373 & 5 \\
\hline allized salt. ... & 8 & 8453 & 5 \\
\hline and gypsum. & 108 & 953 & \\
\hline $\begin{array}{l}\text { and shale..... } \\
\text { stone. }\end{array}$ & 810 & 960 & \\
\hline gyp & $\begin{array}{rr}1 & 0 \\
16 & B\end{array}$ & 801 & \\
\hline ed sh & 10 & 988 & \\
\hline gypsum. & 8 & 9961 & 1 \\
\hline
\end{tabular}


Log of weil at Lillle River, Rice County, Kans.a

\begin{tabular}{|c|c|c|}
\hline Material. & $\begin{array}{l}\text { Thick- } \\
\text { ness. }\end{array}$ & Depth. \\
\hline Soil & Fect. & Fcet. $_{16}$ \\
\hline 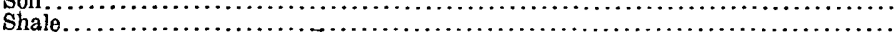 & $\begin{array}{r}16 \\
2\end{array}$ & $\begin{array}{l}16 \\
18\end{array}$ \\
\hline 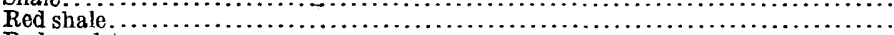 & 36 & 54 \\
\hline 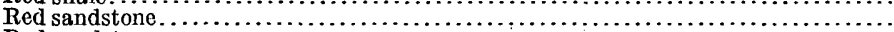 & 8 & 62 \\
\hline 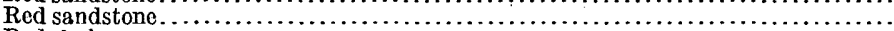 & 9 & 71 \\
\hline 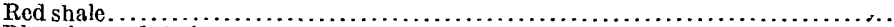 & 258 & 329 \\
\hline 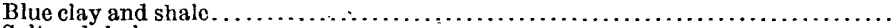 & 256 & 585 \\
\hline 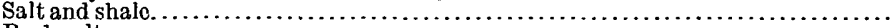 & 10 & 595 \\
\hline 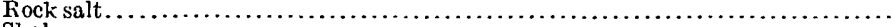 & 70 & 665 \\
\hline 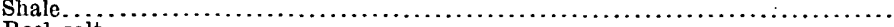 & 4 & 669 \\
\hline 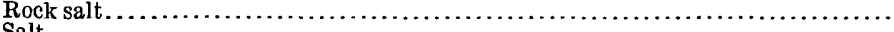 & 43 & 712 \\
\hline $\begin{array}{l}\text { Salt } \\
\text { Shale }\end{array}$ & 39 & 751 \\
\hline 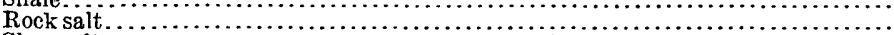 & 35 & 794 \\
\hline 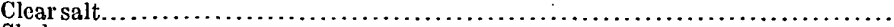 & 54 & 848 \\
\hline 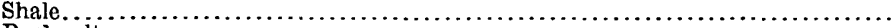 & 4 & 852 \\
\hline 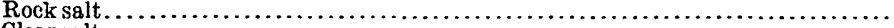 & 57 & 909 \\
\hline 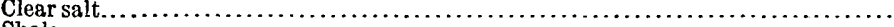 & 23 & 932 \\
\hline 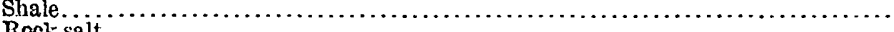 & 5 & 937 \\
\hline 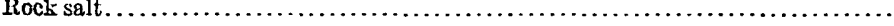 & 27 & 964 \\
\hline
\end{tabular}

$a$ Kirk, M. Z., and Haworth, Erasmus, op. cit., p. 95.

Note.-Record farnishod by the driller, J. P. Brisben, Lyons, Kans.

Log of well of Sterling Salt Co., north of plant, Sterling, Rice County, Kans.

\begin{tabular}{|c|c|c|}
\hline Material. & $\begin{array}{l}\text { Thick- } \\
\text { ness. }\end{array}$ & Depth. \\
\hline Soil & Fect. $_{8}$ & Fect. \\
\hline 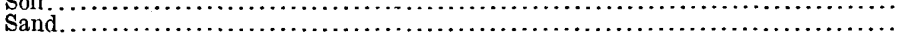 & $\begin{array}{r}8 \\
70\end{array}$ & 78 \\
\hline Clay, lime, and gypsum & 34 & 112 \\
\hline 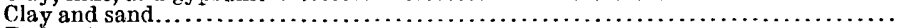 & 21 & 133 \\
\hline 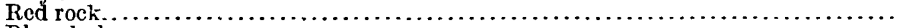 & 340 & 473 \\
\hline 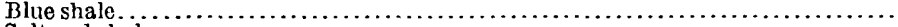 & 221 & 694 \\
\hline 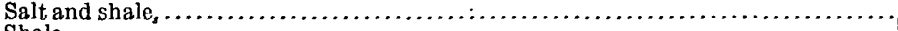 & 8 & 702 \\
\hline 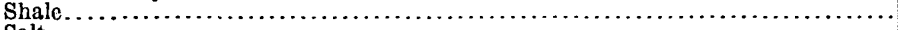 & 4 & 706 \\
\hline 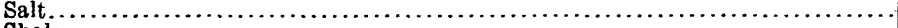 & 5 & 711 \\
\hline 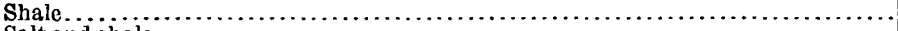 & 9 & 720 \\
\hline 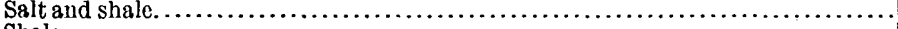 & 9 & 729 \\
\hline 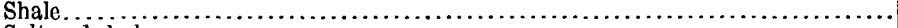 & 18 & 747 \\
\hline 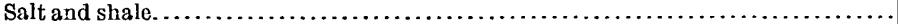 & 13 & 760 \\
\hline 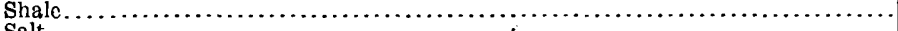 & 4 & 764 \\
\hline 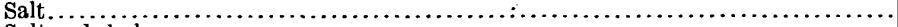 & 40 & 804 \\
\hline 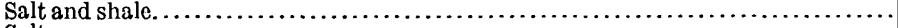 & 10 & 814 \\
\hline 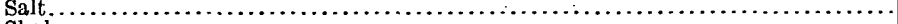 & 45 & 859 \\
\hline 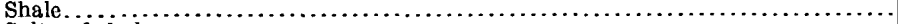 & 10 & 869 \\
\hline Salt and shalc.................. & 10 & 879 \\
\hline 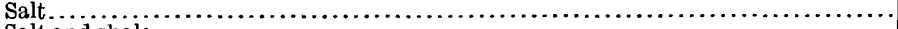 & 4 & 883 \\
\hline & 10 & 893 \\
\hline 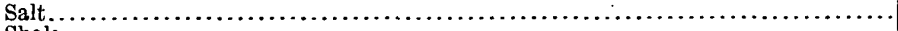 & 32 & 925 \\
\hline 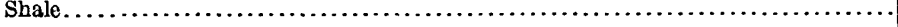 & 5 & 930 \\
\hline
\end{tabular}

NoтE.-Drive pipe, 133 feet; cassing, 204 feet; tubing, 915 feet. Put down in 1902. 
Log of well at Sterling, Rice County, Kans.a

\begin{tabular}{|c|c|c|}
\hline Material: & $\begin{array}{l}\text { Thick- } \\
\text { ness. }\end{array}$ & Depth. \\
\hline 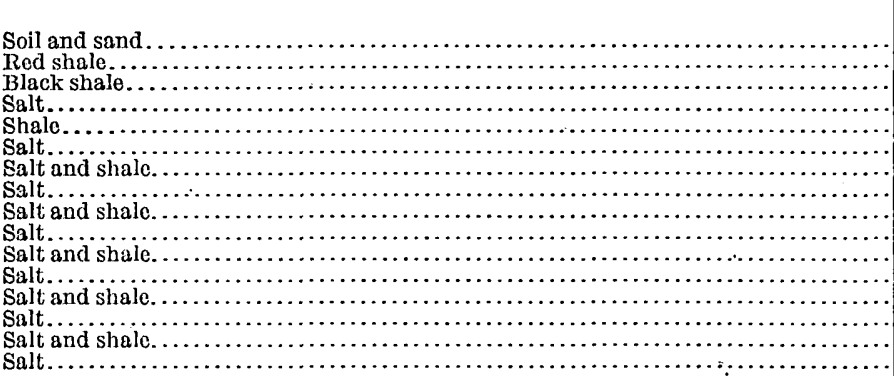 & $\begin{array}{r}\text { 2rect. } \\
136 \\
348 \\
216 \\
10 \\
25 \\
10 \\
37 \\
28 \\
5 \\
48 \\
6 \\
20 \\
8 \\
68 \\
10 \\
5\end{array}$ & $\begin{array}{r}\text { Feet. } \\
136 \\
484 \\
700 \\
710 \\
735 \\
745 \\
782 \\
810 \\
815 \\
863 \\
869 \\
889 \\
897 \\
965 \\
975 \\
980\end{array}$ \\
\hline
\end{tabular}

a Kirk, M. Z., and Haworth, Erasmus, op. cit., p. 97.

Note.-At old sugar works. Record reported by the drillers, Palmer \& Davis.

Log of well No. 2 of Hutchinson Pure Salt Co., Hutchinson, Reno County, Kans.

\begin{tabular}{|c|c|c|}
\hline Material. & $\begin{array}{l}\text { Thick- } \\
\text { ness. }\end{array}$ & Depth. \\
\hline First salt struck a & Fcct. & Fect. ${ }_{424}$ \\
\hline Salt........................ & & 456 \\
\hline Shale... & & 465 \\
\hline $\begin{array}{l}\text { Salt and } \text { shale } \\
\text { Salt }\end{array}$ & $\begin{array}{l}5 \\
4\end{array}$ & $\begin{array}{l}470 \\
474\end{array}$ \\
\hline Shalo................................. & 9 & 483 \\
\hline 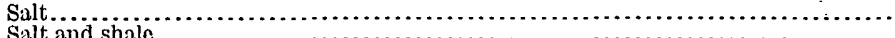 & 27 & 510 \\
\hline 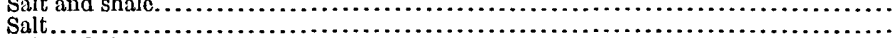 & 45 & $\begin{array}{l}515 \\
560\end{array}$ \\
\hline Salt and shale. & 10 & 570 \\
\hline …....... & $\begin{array}{r}22 \\
5\end{array}$ & 592 \\
\hline Salt... & 130 & 727 \\
\hline 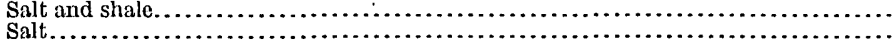 & $\begin{array}{r}5 \\
19\end{array}$ & $\begin{array}{l}732 \\
751\end{array}$ \\
\hline Shale.................................... & 4 & 755 \\
\hline
\end{tabular}

Note.-Drivo pipe, 74 fect; casing, 123 feet; tubing, 741 feet.

Log of well No. 5 of Carey Salt Co., Hutchinson, Reno County, Kans.

\begin{tabular}{|c|c|c|}
\hline Material. & $\begin{array}{l}\text { Thick- } \\
\text { ness. }\end{array}$ & Depth. \\
\hline Soil and sand......... & Fcet. & Feet. ${ }_{73}$ \\
\hline Red shale............... & & 172 \\
\hline 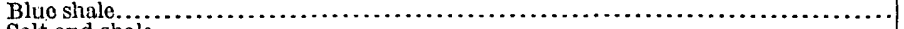 & 271 & 443 \\
\hline Salt and shale............................. & 8 & 447 \\
\hline 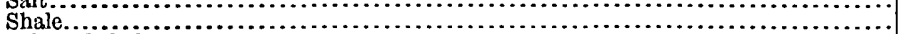 & $\begin{array}{l}8 \\
8\end{array}$ & $\begin{array}{l}405 \\
463\end{array}$ \\
\hline Salt and shale... & & 470 \\
\hline Salt......................... & 16 & 486 \\
\hline Shale................... & & $\begin{array}{l}491 \\
495\end{array}$ \\
\hline Salt and shale........ & & 500 \\
\hline $\begin{array}{l}\text { Salt } \\
\text { Salt and shale }{ }^{\prime}, \ldots\end{array}$ & $\begin{array}{l}65 \\
10\end{array}$ & $\begin{array}{l}565 \\
575\end{array}$ \\
\hline 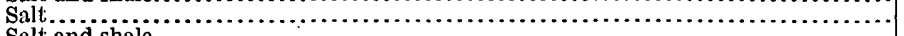 & 30 & 605 \\
\hline alt and shale............ & 9 & 614 \\
\hline Salt and shalo & $\begin{array}{l}8 \\
5\end{array}$ & 624 \\
\hline Salt...... & 20 & 644 \\
\hline $\begin{array}{l}\text { Salt and shale............. } \\
\text { Salt (very hard)....... }\end{array}$ & $\begin{array}{l}10 \\
59\end{array}$ & 654 \\
\hline Salt a & 10 & 714 \\
\hline Salt......... & $46^{\circ}$ & 760 \\
\hline Gypsum.. & 5 & 765 \\
\hline
\end{tabular}

Note.-Drivo pipe, 73 fect; casing, 143 feet; tubing, 750 fect. Total salt deposit, 240 fect; total shale and salt, 65 feet; total shale, 12 feet; gypsum, 5 feet.

$40104^{\circ}-18-$ Bull. $669-7$ 
Log of well No. 4 of Carey Salt Co., Hutchinson, Reno County, Kans.

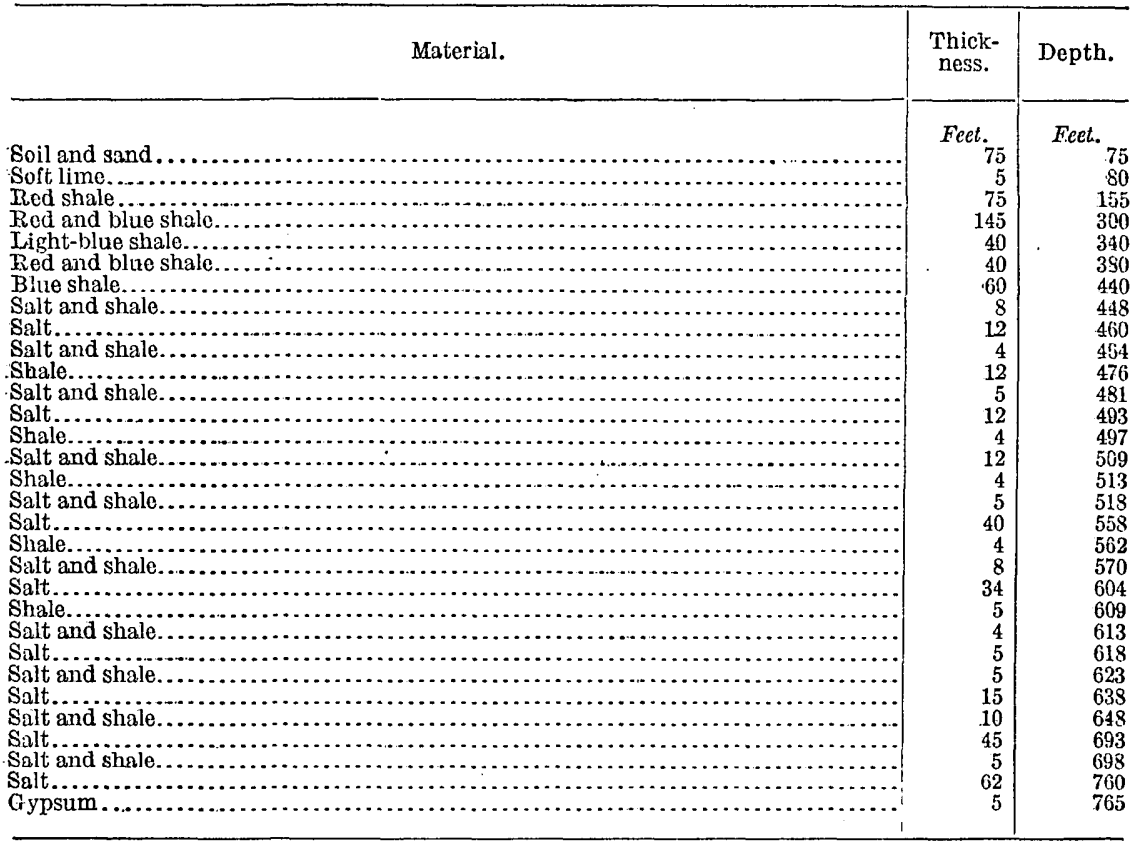

Nore.-Drive pipe, 75 feet; casing, 140 feet; tubing, 75 s feet.

Log of well of Carey Salt Co., Hutchinson, Reno County, Kans.

\begin{tabular}{|c|c|c|}
\hline Matcrial. & $\begin{array}{l}\text { Thick- } \\
\text { ness. : }\end{array}$ & Depth. \\
\hline 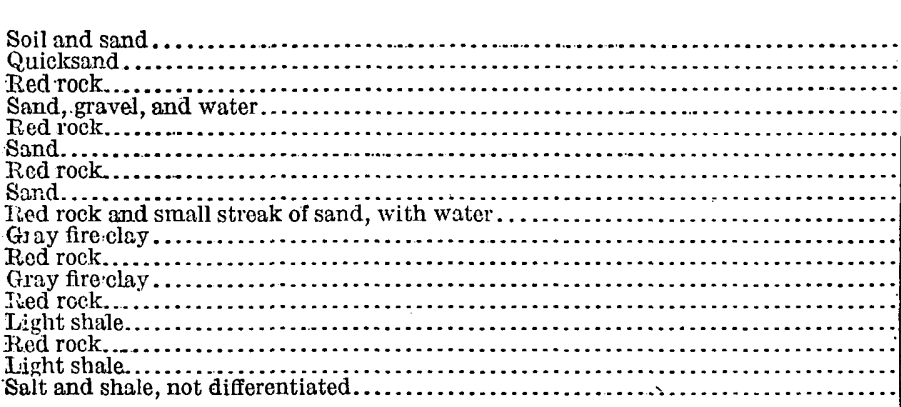 & $\begin{array}{r}\text { Fcet. } \\
8 \\
70 \\
5 \\
2 \\
8 \\
1 \\
6 \\
1 \\
63 \\
6 \\
26 \\
9 \\
25 \\
55 \\
41 \\
140 \\
307\end{array}$ & $\begin{array}{r}\text { Feet. } \\
\ldots . \\
73 \\
83 \\
85 \\
93 \\
94 \\
100 \\
101 \\
164 \\
170 \\
196 \\
205 \\
230 \\
285 \\
326 \\
466 \\
773\end{array}$ \\
\hline
\end{tabular}

NoTe. -8 -inch drive pipe, 96 feet; $.2 \frac{2}{2}$-inch tubing, 756 feet; 58 -inch pipe, 164 feet. 
Log of Ben. Blanchard prospect well, south of Arkansas River, Hutchinson, Kans.a

\begin{tabular}{|c|c|c|}
\hline Material. & $\begin{array}{c}\text { Thick- } \\
\text { ness. }\end{array}$ & Depth. \\
\hline & Feet. & Feet. \\
\hline 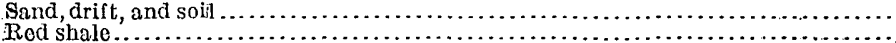 & 146 & 146 \\
\hline $\begin{array}{l}1 \mathrm{Red} \\
\text { Shal }\end{array}$ & 26 & $\begin{array}{l}172 \\
174\end{array}$ \\
\hline 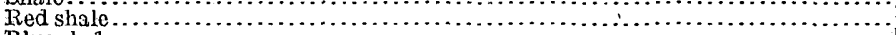 & 76 & $\begin{array}{l}174 \\
250\end{array}$ \\
\hline Blue shale. . . . . . . . . & 12 & 262 \\
\hline 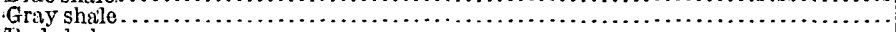 & 78 & 340 \\
\hline 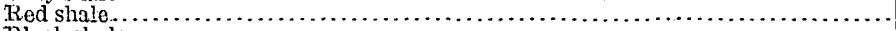 & 10 & 350 \\
\hline 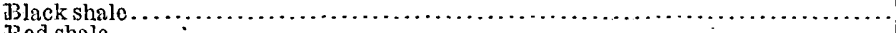 & 15 & 365 \\
\hline 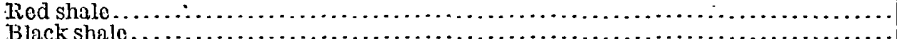 & 9 & 374 \\
\hline $\begin{array}{l}\text { Black shale } \\
\text { Black shale }\end{array}$ & 95 & 378 \\
\hline 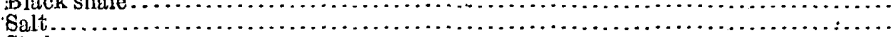 & $\begin{array}{l}95 \\
18\end{array}$ & 493 \\
\hline 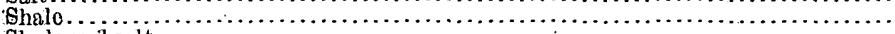 & 8 & 499 \\
\hline 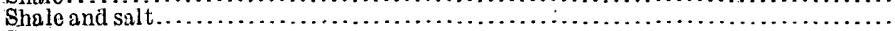 & 3. & 5024 \\
\hline 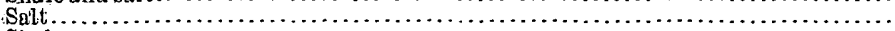 & 13 & $.515 \int_{2}^{2}$ \\
\hline 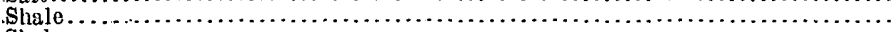 & $7 \frac{1}{3}$ & $523^{2}$ \\
\hline 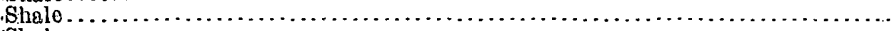 & $5 \frac{2}{2}$ & 5281 \\
\hline 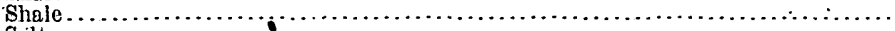 & 2 & $530 \%$ \\
\hline 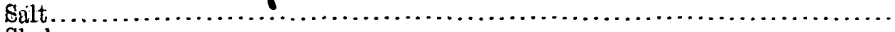 & 11 & 5.113 \\
\hline 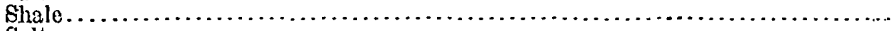 & 7 & $5481_{3}^{3}$ \\
\hline 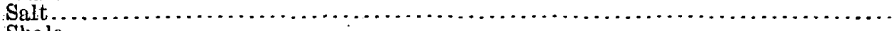 & 10 & $55,8 \frac{8}{2}$ \\
\hline 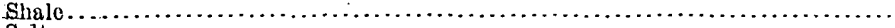 & $3 \frac{1}{3}$ & .562 \\
\hline 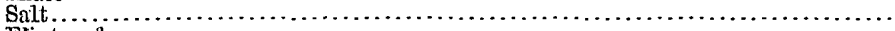 & $27^{\circ}$ & 589 \\
\hline 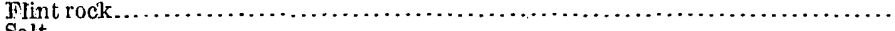 & 2 & 501 \\
\hline 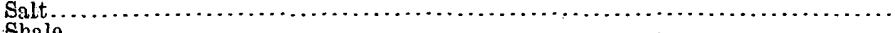 & 47 & 638 \\
\hline 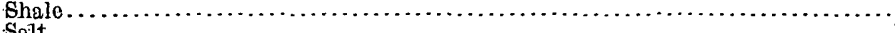 & $\begin{array}{r}3 \\
138\end{array}$ & 641 \\
\hline 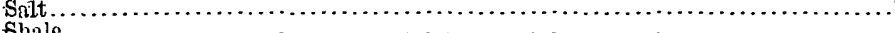 & 138 & .779 \\
\hline 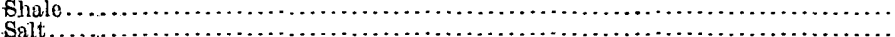 & $\begin{array}{r}13 \\
8\end{array}$ & .792 \\
\hline $\begin{array}{l}\text { Salt } \\
\text { Shale }\end{array}$ & 37 & 837 \\
\hline 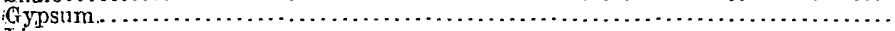 & 28 & .865 \\
\hline 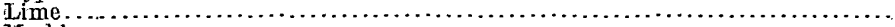 & 38 & 903 \\
\hline 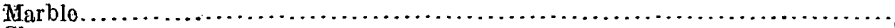 & 3 & .906 \\
\hline 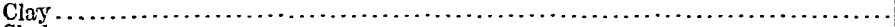 & 1 & 907 \\
\hline$\ldots \ldots \ldots \ldots \ldots \ldots \ldots \ldots \ldots \ldots \ldots$ & 4. & 911 \\
\hline$\ldots \ldots \ldots \ldots \ldots \ldots \ldots$ & 8 & 919 \\
\hline 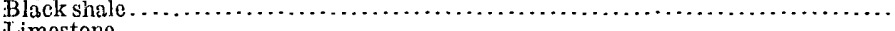 & 5 & 924 \\
\hline 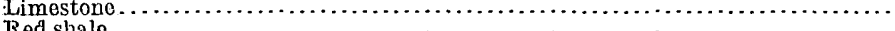 & 6 & 930 \\
\hline Red shalc $\ldots \ldots \ldots \ldots \ldots \ldots \ldots \ldots \ldots$ & 2 & 932 \\
\hline 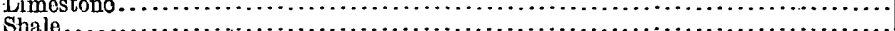 & 19 & 951 \\
\hline 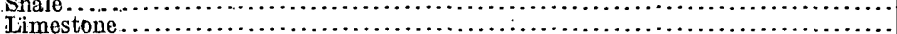 & 11 & 962 \\
\hline 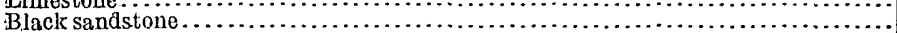 & 10 & 979 \\
\hline Limestone......... & 24 & 1,003 \\
\hline 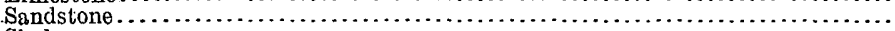 & 27 & 1,030 \\
\hline 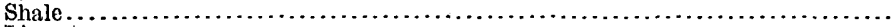 & 22 & 1,052 \\
\hline 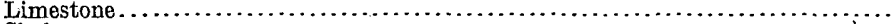 & 14 & 1,066 \\
\hline 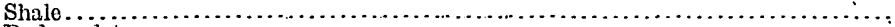 & 25 & 1,091 \\
\hline 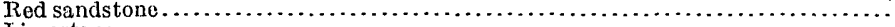 & 45 & 1,136 \\
\hline 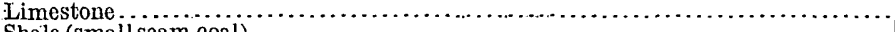 & 12 & 1,148 \\
\hline Shale (small seam coal) $\ldots \ldots \ldots \ldots \ldots$ & 36 & 1,184 \\
\hline 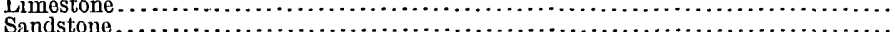 & 26 & 1,210 \\
\hline 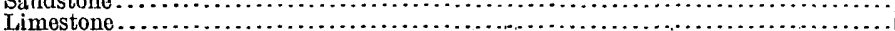 & 10 & 125 \\
\hline 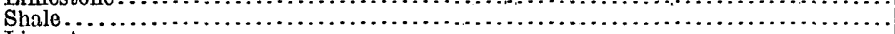 & 30 & 1,285 \\
\hline 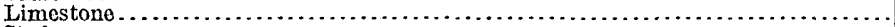 & 5 & 1,290 \\
\hline 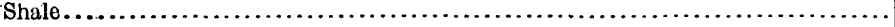 & 7 & 1,297 \\
\hline
\end{tabular}

a Kirk, M. Z., and Haworth, Erasmus, op. cit., p. 92.

NOTE,-Record furnished by the drillers, Palmer \& Davis. In the original record the total depth is given as 1,307 feet; there are certain discrepancies between thickness of individual strata and total depth. 
Log of well of Kingman Light \& Fuel Co., $1 \frac{1}{2}$ miles north of Kingman, Kans.a

\begin{tabular}{|c|c|c|}
\hline Material. & $\begin{array}{c}\text { Thick- } \\
\text { pess. }\end{array}$ & Depth. \\
\hline Redinel- & Fect. & Feet. \\
\hline 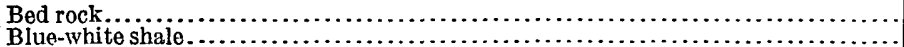 & 100 & 100 \\
\hline 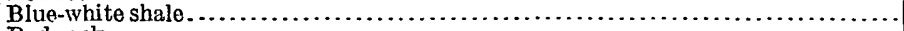 & 20 & 120 \\
\hline 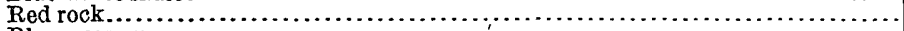 & 175 & 295 \\
\hline 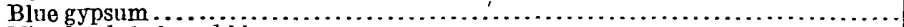 & 10 & 305 \\
\hline 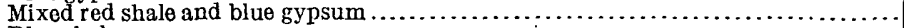 & 145 & 450 \\
\hline 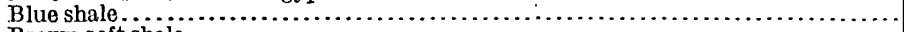 & 135 & 585 \\
\hline 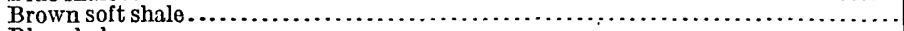 & & 590 \\
\hline 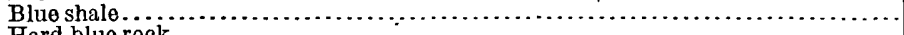 & 70 & 660 \\
\hline 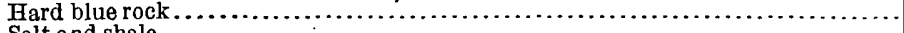 & 5 & 665 \\
\hline 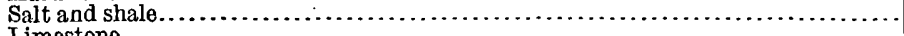 & 165 & 830 \\
\hline 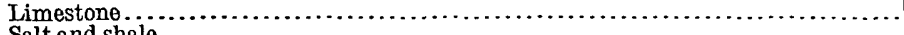 & & 835 \\
\hline 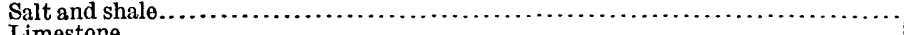 & 165 & 1,000 \\
\hline Ifimestone & $\begin{array}{r}5 \\
23\end{array}$ & $\begin{array}{l}1,005 \\
1,028\end{array}$ \\
\hline 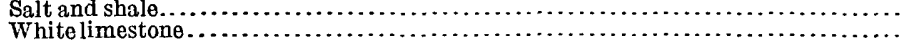 & $\begin{array}{r}23 \\
8\end{array}$ & $\begin{array}{l}1,020 \\
1,036\end{array}$ \\
\hline 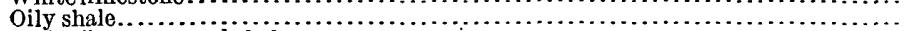 & 9 & 1,045 \\
\hline 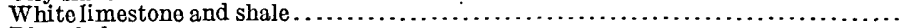 & 16 & 1,061 \\
\hline 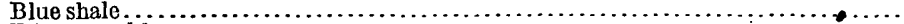 & & 1,065 \\
\hline 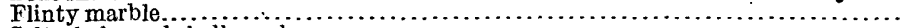 & & $1 ; 070$ \\
\hline 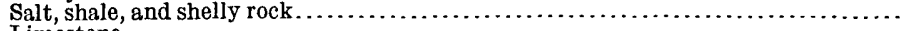 & 10 & 1,080 \\
\hline 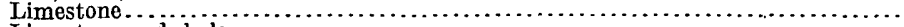 & 15 & 1,095 \\
\hline Limestone and shale................. & 39 & 1,125 \\
\hline 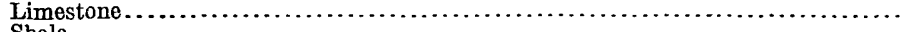 & 35 & 1,160 \\
\hline 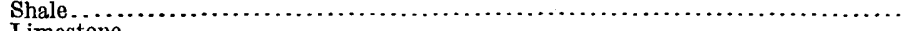 & & 1,165 \\
\hline Limestone $\ldots \ldots \ldots \ldots \ldots \ldots \ldots \ldots \ldots \ldots$ & & 70 \\
\hline 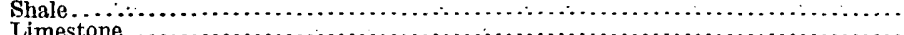 & & 1,185 \\
\hline (n) & & 1,197 \\
\hline (n. & $\begin{array}{l}13 \\
10\end{array}$ & $\begin{array}{l}1,210 \\
1,220\end{array}$ \\
\hline and shalc............ & & 1,225 \\
\hline Shale and limestone............. & 10 & 1,235 \\
\hline Shal & & 1,240 \\
\hline .... & & 1,243 \\
\hline$\ldots \ldots \ldots$ & 12 & 1,255 \\
\hline Shale and sandstone.............. & 30 & 1,285 \\
\hline$\ldots \ldots \ldots \ldots \ldots \ldots \ldots$ & 5 & 1,290 \\
\hline$\ldots \ldots \ldots$. & & 1,295 \\
\hline Red shale.. & & 1,304 \\
\hline tone.... & & 310 \\
\hline 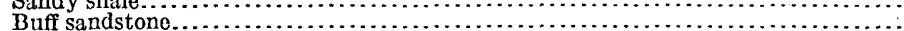 & 10 & 320 \\
\hline Shale...... & 6 & 1,320 \\
\hline 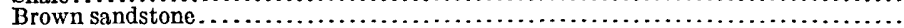 & 24 & 1,358 \\
\hline$\ldots \ldots \ldots \ldots \ldots \ldots \ldots$ & 5 & 1,363 \\
\hline$\ldots \ldots \ldots \ldots$ & 30 & 1,393 \\
\hline
\end{tabular}

a Kirk, M. Z., and Haworth, Erasmus, op. cit., p. 91.

Note.-Drilled in 1887. Record reported by county surveyor, W. H. Child. In the original the total depth is given as 1,410 feet. There are certain discrepancies, however; between thickness of individual beds and total depth.

Log of well of Orient Sall Co., Anthony, Harper County, Kans.a

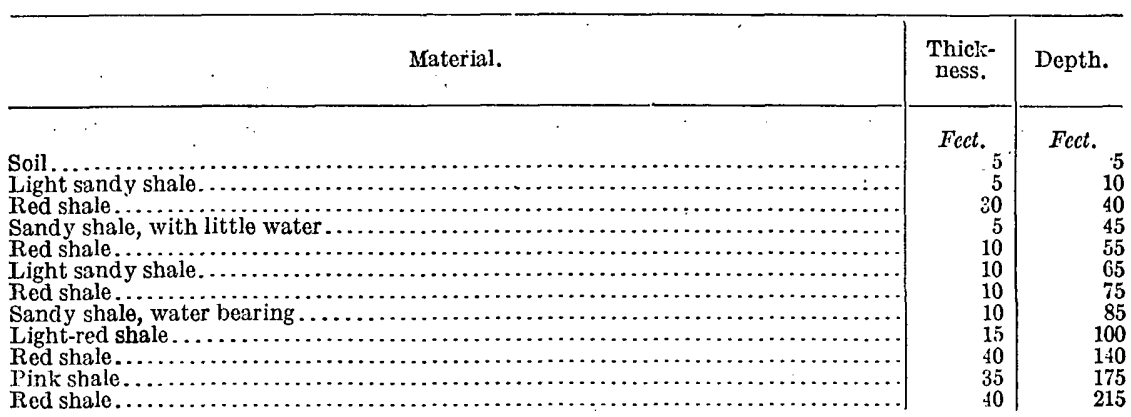

a For an additional record of strata at Anthony, Kans., see Kirk, M. Z., and Haworth, Erasmus, op. cit., p. 90 . 


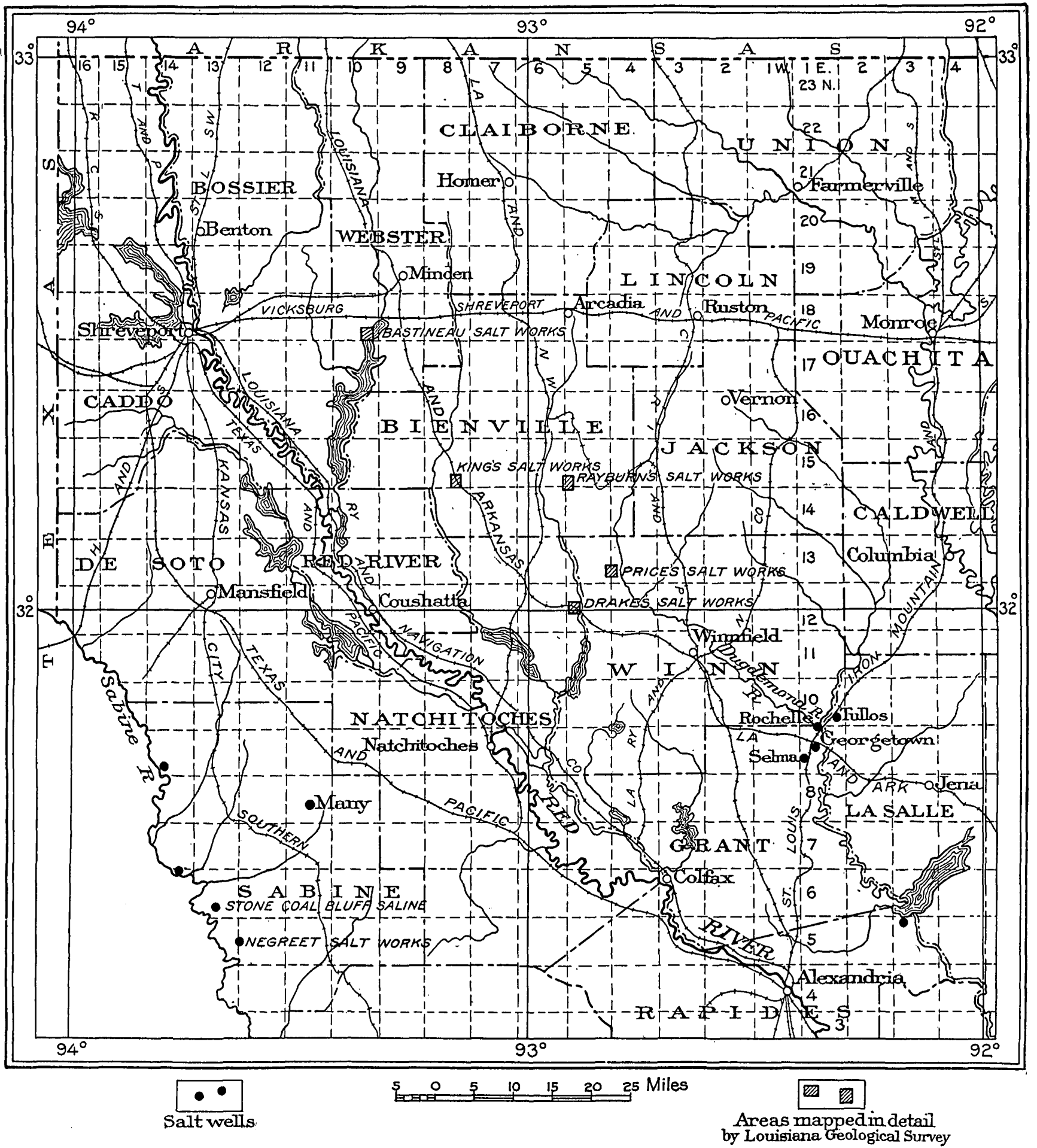

MAP OF NORTHERN LOUISIANA, SHOWING LOCATION OF SALINES.

From map by A. C. Veatch. 
Log of well of Orient Salt Co., Anthony, Harper County, Kans.-Continued.

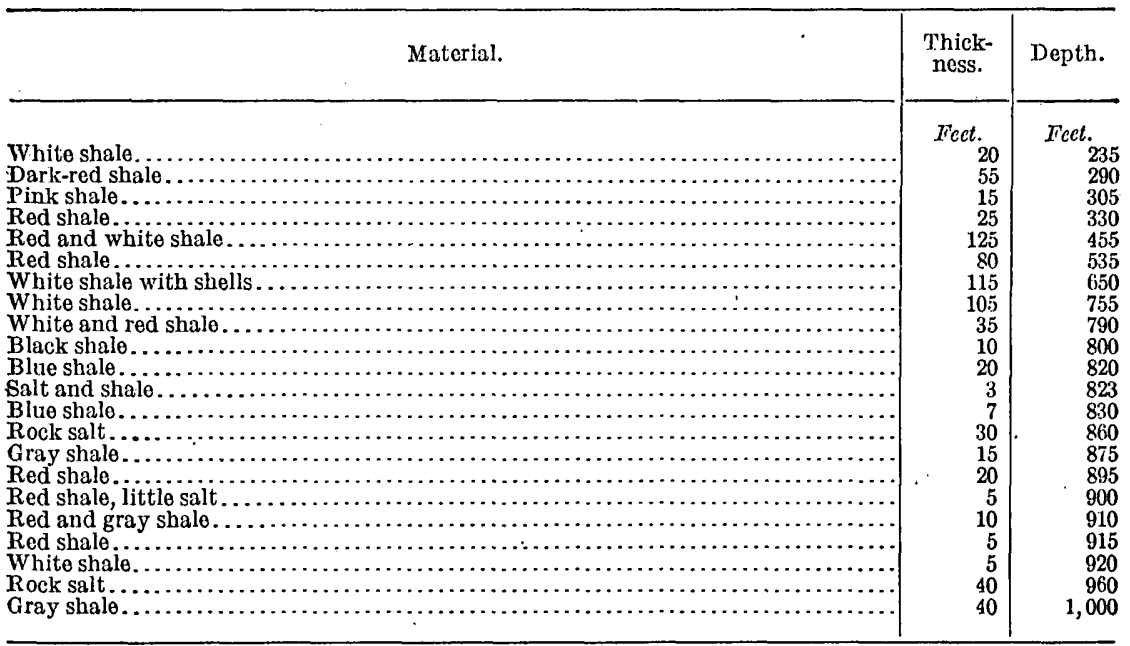

NOTE-From 1,000 feet to the total depth of the well the strata could not be named on account of excessive caving. At 790 feet a flow of brine was noticeable, and at 797 feet a flow of brine was struck which the drillers were unable to bail out, so the 8-inch casing was put in to stop the flow. The drive pipe was put down to a depth of 75 feet; 4 -inch tuhing to a depth of 1,025 feet; and 8-inch casing to 1,050 feet. It is peculiar that the caving character of the rock requircd the tubing to be protected.

\section{BIBLIOGRAPHY.}

BAlLEY, E. H. S., Salt in Kansas-its composition and methods of manufacture: Kansas State Board Agr. Eighth Bienn. Rept., pt. 2, 1891-92, pp. 167-180, 1893.

Hax, Robert, Geology and mineral resources of Kansas: Kansas State Board Agr. Eighth Bienn. Rept., pt. 2, 1891-92, pp. 99-162, 1893. Includes an account of the lead; zinc, coal, salt, and other mineral deposits. Salt, pp. 137-142.

Krrk, M. Z., Salt: Mineral resources of Kansas for 1898, pp. 67-123, 1899. That part relating to the geology of Kansas salt (pp. 86-97) is by Erasmus Haworth.

\section{LOUISIANA.}

Louisiana in 1915 ranked fifth in quantity and sixth in valuc of salt produced, the product being rock salt.

\section{POSITION OF DEPOSITS.}

Salt occurs in two distinct sections of the State, in the northcentral and northern part and in the southern part, the more important known deposits and those worked at present being in the southern part, in close proximity to the Gulf coast. The locations of the deposits or salines of the State are shown on the accompanying maps (Pl. X and fig. 4).

\section{SALINES OF NORTHERN LOUISIANA.}

\section{IOCATION.}

In the northern part of Louisiana, in the valley of Sabine River, salt springs occur at Negreet, about $1 \frac{1}{2}$ miles above the mouth of Bayou Negreet in Sabine Parish, in the SW. $\frac{1}{4}$ sec. 24, T. 5 N., 
R. 13 W.; at Stone Coal Bluff, in sec. 33 ; T. 6 N., R. 13 W..; and near Many, on the road from Marthaville to Many, near Rock Springs Church, in the NE. $\frac{1}{4}$ sec. 24 , T. 8 N., B. 11 W.

In the valley of Red River are the following: Bayou Castor Saline, 5 miles north of Rochelle or about 4 miles above the mouth of Dugdemona River; Catahoula Salt Springs, on Catahoula Lake; Brown's Saline, 6 miles west of Tullos or 18 miles southeast of Winnfield, on Dugdemona River; near Georgetown; at Rochelle, Tullos, and Selma; northwest of Winnfield, Winn Parish; at:Cedar Bayou; and at:Coochie Dome.

Important salines, from which much evaporated salt was obtained during the Civil War and earlier, were known as Drake's, Price's, Rayburn's, and King's, after the names of their respective owners or managers. A full account of the more important salines of northern Louisiana has been given by Veatch. ${ }^{1}$ Bistineau Saline, the largest saline in northern Louisiana, was in Lake Bistineau, secs. 25, 26, 35, and 36, T. 18 N., R. 10 W.

\section{HISTORY.}

The works at the old salines in nerthern Louisiana, now abandoned, were active during the Civil War and for some time before it, but since the war they have not been able to compete with those that produce salt by more improved methods at places that have better transportation facilities. Most of the old salines were areas where brine issued from the ground in the form of springs or where it was pumped in crude fashion and evaporated. These brines indicate that bodies of rock salt lie below.

\section{STRATIGRAPHY.}

The salt springs of northem Louisiana are described by Veatch as emerging generally from Upper Cretaceous outcrops and are thus mapped on the geologic map of the State accompanying the report of Harris and Veatch. ${ }^{2}$ Harris ${ }^{3}$ notes that "the Cretaceous rocks appearing about the peripheries of the northern salines are not the uppermost Cretaceous stages, but rather those at about the horizon of the Nacatoch marls or Anona limestone-that is, below the Arkadelphia clays that cap the Cretaceous in southwest Arkansas." At Rayburn's, Bistineau, and King's salines, fossils characteristic of the upper beds of the Upper Cretaceous have been found. Though proof is lacking of the Cretaceous age of the hard leaf-bearing sandy pyritic limestone that occurs at Coochie Brake and at Price's Saline and that

1 Veatch, A. C., The salines of north Louisiana; a report on the geology of.Louisiana, pp. 47-100, Louisiana Exper. Sta., 1902.

2 Harris, G. D., and Veatch, A. C., A preliminary report on the geology of Louisiana, Louisiana Exper. Sta., 1899. The map opposite.p. 44 precedes section 2 on general geology. See also The Five Islands, idem, p. 261.

'B Harris, 'G. D., The geological occurrence of rock salt in :Louisiana and east Texas: Econ. Geology, vol. 4, p. 15, 1909. 
seems to be associated with a large bed of soft chalklike limestone at Drake's, the facts thus far collected rather strongly indicate it. In a later report by. Veatch ${ }^{1}$ some salines are noted as issuing from rocks higher in the geologic column; for example, the brine from the Negreet Salt Works, which issues from the St. Maurice formation, the lower formation of the Claiborne group (Eocene).

\section{SALINES OF SOUTHERN LOUISIANA.}

\section{LOCATION.}

The most important salt deposits of Louisiana are located near the southern coast on the Five Islands, or Salt Islands as they are sometimes called, namely, Petite Anse, Grande Cote, Belle Isle, Cote Blanche, and Cote Carline. (See fig. 4.) On Avery Island (Petite Anse) and Weeks Island (Grande Cote) rock salt is being mined on an extensive scale.

Other localities in southern Louisiana where the geologic conditions are similar to those on the Five Islands and where rock salt or salt water, indicating the possible presence of rock salt, has been found in deep drillings are Anse-la-

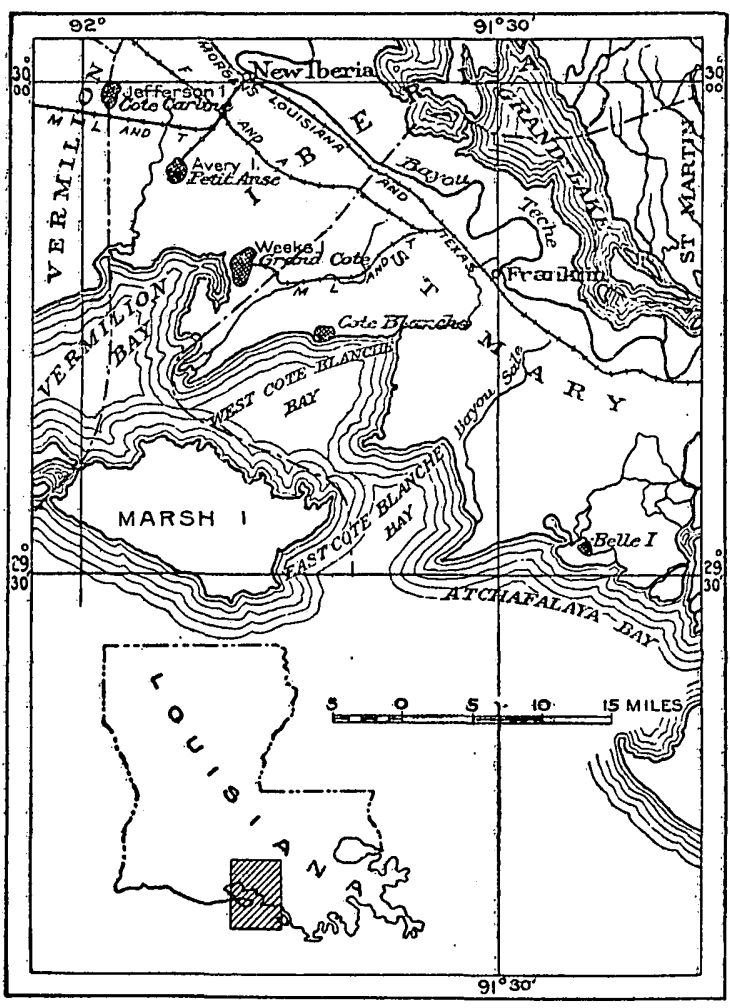

FIGURE 4.-Map of a part of the coast of southern Louisiana, showing location of salt islands.

Butte, Prairie Mamou, Welsh, Chicot, Vinton, and Hackberry.

BELLE ISLE.

Belle Isle, the southeasternmost of the Five or Salt Islands, is 8 miles from the mouth of Atchafalaya River and is reached by boat from Morgan City on the Southern Pacific Railroad. It is surrounded

\footnotetext{
1 Veatch, A. C., The salines of north Louisiana: A report on the geology of Lonisiana, p. 90, Louisiana Exper. Sta., 1902.
} 
by a network of bayous and sea marshes. The island is roughly triangular and includes about 360 acres. Along its northwest side is a range of hills, the highest of which reaches an altitude of 80 feet.

After the discovery of rock salt in a well on Cote Carline and because of the increasing difficulty of mining salt at Petite Anse, due to seepage, A. F. Lucas undertook the exploitation of Belle Isle for salt, which he discovered in December, 1896, in well No. 1, at a depth of 373 feet. ${ }^{1}$ A short time later a shaft was started on the site of hole No.11, in which salt was found at a depth of 103 feet.

Fairly complete ideas of the substructure of the island may be gained from the records of the wells drilled on it, of which eight have been plotted by Veatch. ${ }^{2}$ These records lead to the belief that the salt on Belle Isle exists in the form of an oblong, dome-shaped mass, longest in a northeast direction, and consequently having the same trend as the hills along the western side of the island, but with the difference that the salt dome is located in its northeastern part. The record of the beds passed through in sinking the shaft, which may be taken as typical of those on the island, is given below. The original figures are quoted in spite of the discrepancies which they show.

Log of shaft, Belle Isle, La.a

(Elevation above sea level, 7 feet.)

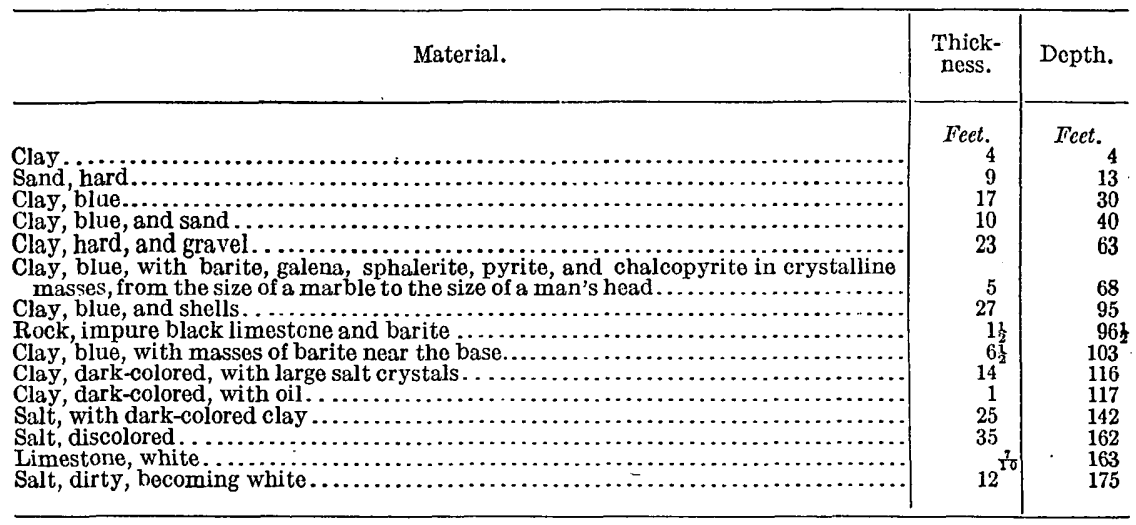

$a$ Veatch, A. C., op. cit., p. 225.

Note.-This was the depth of the shaft May 19, 1899.

Ten other wells that were sunk on the island subsequent to the investigations of Veatch have furnished most valuable data as to the substructure of the underlying salt mass and have modified in some particulars the ideas previously held regarding its shape. The record of one of these wells is as follows:

\footnotetext{
1 Veatch, A. C., The Five Islands: A preliminary report cn the geology of Louisiana, p. 222, Louisiana Exper. Sta., 1899.

2 Idem, pl. 22.
} 
Log of well No. 1, Belle Isle, La.a

[Nature of samples at depths indicated.]

\begin{tabular}{|c|c|}
\hline Material. & Depth. \\
\hline Cellow logmp clay. & Fict. \\
\hline $\begin{array}{l}\text { Yellow loamy clay......... } \\
\text { Fine sand................ }\end{array}$ & $\begin{array}{l}81 \\
85\end{array}$ \\
\hline Coarse sand...$\ldots \ldots \ldots \ldots$ & 200 \\
\hline Coarse angular gravel....... & 232 \\
\hline Coarse angular gravel with sulphur. & 256 \\
\hline Sand, with sulphur ........... & 285 \\
\hline Sand, sulphurous, with traces & 303 \\
\hline Fine gray sand................... & 450 \\
\hline Brown sand.................. & \\
\hline Sand (showing gas) ........... & 545 \\
\hline $\begin{array}{l}\text { Salt and sand } \\
\text { Salt, sand, and clay............... }\end{array}$ & $\begin{array}{l}565 \\
590\end{array}$ \\
\hline Quicksand, through second belt of so & 608 \\
\hline Sand and hard clay............................. & 655 \\
\hline $\begin{array}{l}\text { Hard clay (showing gas) } \\
\text {.Gray sand, with pyrites, hard............ }\end{array}$ & 720 \\
\hline $\begin{array}{l}\text { - Gray sand, with pyrites, hard ........ } \\
\text { Fine gray sand...................... }\end{array}$ & $\begin{array}{l}756 \\
785\end{array}$ \\
\hline Salt and hard clay.............. & 840 \\
\hline Hard gray shale.............. & \\
\hline y shale, sulphur $\ldots \ldots \ldots \ldots$ & 870 \\
\hline 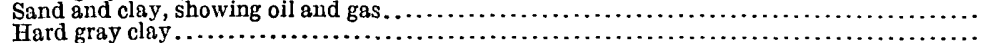 & \\
\hline 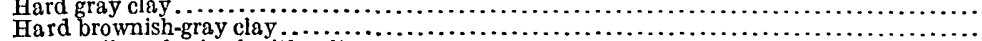 & 965 \\
\hline Brown oil sand mixed with salt. . & 985 \\
\hline Dark clay ........... & 1,010 \\
\hline Hard black clay and limestono.. & 1,022 \\
\hline Gray clay and sand & 1,039 \\
\hline Hard gray clay and gravel. & 1,040 \\
\hline Dark hard clay and sand............... & 1,058 \\
\hline $\begin{array}{l}\text { Dark hard clay and sand; casing set at } 1,066 \text { feet and baled, bringing up large hard chunks of } \\
\text { calcareous gray shale and impure crystalline gypsum. }\end{array}$ & 1,068 \\
\hline Brine, oil, sand, salt, etc. & 1,080 \\
\hline Olive and brownish clay shale, sand, and sal & 1,090 \\
\hline Gray hard sandy clay (oil showing)....... & 1,105 \\
\hline Fine brown sandy loam (good oil showing & 1,116 \\
\hline Hard dark flakin & 1,130 \\
\hline Hard gray sandy clay..$\ldots \ldots \ldots \ldots \ldots \ldots \ldots \ldots$ & 1,150 \\
\hline $\begin{array}{l}\text { Fine compact sandy shale, salty to taste, hard shell, big pressure of gas, and good showing of } \\
\text { oil. }\end{array}$ & 1,160 \\
\hline Brown sand and salt. . & 1,170 \\
\hline Dark hard clay and salt. & 1,180 \\
\hline Salt $\mathrm{a}$ & 1,202 \\
\hline Hard clay, salt, and sulphur. & 1,206 \\
\hline Fine brown sand (oil). & 1,212 \\
\hline Dark fine sand (oil). & 1,220 \\
\hline Dark fine sand (oil) .... & 1,230 \\
\hline Dark shale (drilled with cable tools) & 1,232 \\
\hline Dark hard clay and sand............. & 1,237 \\
\hline Hard clay and oil sand. & 1,240 \\
\hline Brown sand and hard clay & 1,253 \\
\hline Brown sand and hard clay. & 1,318 \\
\hline Light-drab sandy clay. & 1,355 \\
\hline Light-gray sandy clay (fine showing of oil on the return) & 1,365 \\
\hline Dark hard clay and sand (best oil showing yet).......... & 1,370 \\
\hline Hard light-drab to dark clay sandstone. & 1,430 \\
\hline Hard dark-gray shale.................... & 1,445 \\
\hline 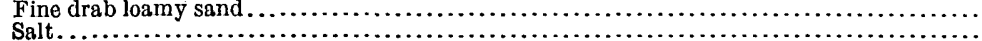 & 1,475 \\
\hline & $1,545-2,450$ \\
\hline
\end{tabular}

a Harris, G. D., Rock salt: Louisiana Geol. Survey Bull. 7, pp. 22-23, 1308.

The great depth to the salt mass in this well should be noted. The domelike shape of the salt mass explains the great differences in the depths at which the salt was encountered.

In 1907 the salt mass at Belle Isle was pierced by. I. N. Knapp, who found that the salt had a thickness of 2,740 feet at the point where the drilling was done. ${ }^{1}$

\footnotetext{
1 Lucas, A. F., Rock salt in Louisiana: Science, new ser., vol. 35, p. 962, 1912; The origin of petro-
} leum: Am. Inst. Min. Eng. Bull. 90, p. 1383, 1914. 
COTE BLANCHE.

Cote Blanche occupies the geographic center between the two extremes of the Five Islands, Cote Carline on the northwest and Belle Isle on the southeast. It lies near the center of the north shore of Cote Blanche Bay, in T. 15 S., R. 5 E. It is approximately circular and it ranks third in size among the islands, having an area of 1,400 acres.

After the discovery of salt at Petite Anse in 1862, numerous shallow pits were sunk on Cote Blanche in the search for salt. Though these threw some light on the surface geology, the main sources of information with reference to the underground geology are the eroded sea cliffs on the south side of the island and the eight well sections plotted by Harris. ${ }^{1}$ None of these borings reached a depth of 500 feet and none reached the salt mass, but possibly they were not located where the salt mass lies nearest the surface. It is possible, as Harris states, that the apex of the salt dome may now lie out at sea, for the waves are rapidly undermining the sea cliffs along the south shore of the island, which consequently has been rapidly receding for some time. Harris concludes his description of this island with the remark: "That the uplift or form of the island is due to salt and its attendant materials and phenomena, as in the other salt islands, we do not for a moment doubt." No salt has yet been discovered on Cote Blanche.

COTE CARLINE.

Cote Carline is known by various names, but perhaps best as Jefferson Island, from the fact that for several years it was the winter home of the famous actor, Joseph Jefferson. It is the northwesternmost of the Five Islands and is near the line between Vermilion and Iberia parishes, in the southwestern part of T. 12 S., R. $5 \mathrm{E}$. It is about 9 miles west of New Iberia and but a short distance from the Abbeville branch of the Southern Pacific Railroad. Its area is approximately 300 acres. Cote Carline rises out of a prairie, except on its northwestern side, where there is a body of water known as Lake Peigneur. The prairie lands surrounding the rest of the island are given up to the cultivation of rice.

Salt was discovered on the island early in the summer of 1895 at a depth of 334 feet. The same hole was drilled by A. F. Lucas to a depth of 2;090 feet and the drill was in salt when the work ceased. ${ }^{2}$ The section of the well is as follows:

\footnotetext{
1 Harris, G. D., op.' cit., pl. 28.

2 Veatch, A. C., The Five Islands; A preliminary report on the geology of Louisiana, p. 255, Louisiana Exper. Sta., 1899. Lucas, A. F., Rock salt in Louisiana: Am. Inst. Min. Eng. Trans., vol. 29, p. 465, 1900. Lucas's statement differs slightly from the one in the text. Lucas states that he took charge of the boring which resulted, in 1896, in the discovery at a depth of 290 feet of a magnificent bed of rock salt. This discovery was followed by systematic explorations determining a zone within which rock salt was encountered at 90 to 350 feet frorn the surface.
} 
Section of well No. 1, Cote Carline, La.a

\begin{tabular}{|c|c|c|}
\hline Material. & $\begin{array}{l}\text { Thick- } \\
\text { ness. }\end{array}$ & Depth. \\
\hline 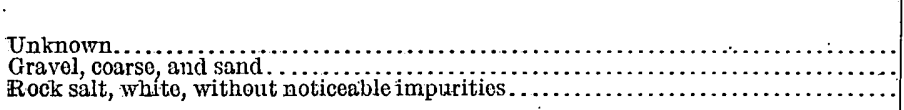 & $\begin{array}{r}\text { Fact. } \\
265 \\
69 \\
1,756\end{array}$ & $\begin{array}{r}\text { Feet. } \\
265 \\
334 \\
2,090\end{array}$ \\
\hline
\end{tabular}

$a$ Veatch, A. C., op. cit., p. 255.

Eight holes in all were drilled to determine the contours of the underlying salt mass, four of which sueceeded in reaching it. The records indicate that there is a surface layer of clay from 33 to 110 feet thick, below which are irregular layers of sand and gravel and locally layers of blue clay. In one well a layer of lignite was encountered. The salt comes nearest the surface in hole No. 8, in which the following section was measured:

Section of well No. 8, Cote Carline, La.a

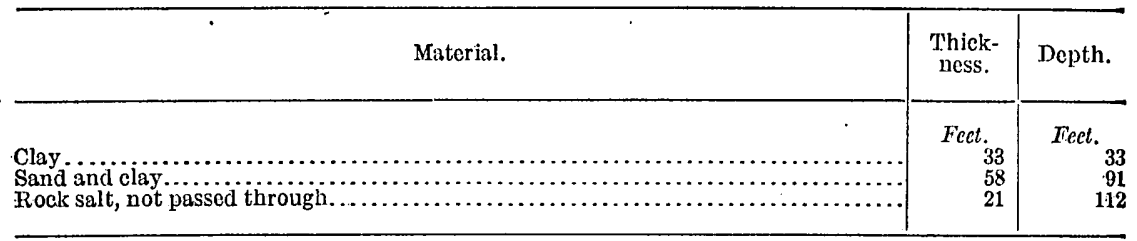

$a$ Veatch, A. C., op. cit., p. 256.

The arrangement of the beds of the island are shown in well No. 7, where drilling was carried to a depth of 442 feet without finding salt. The section of this well is as follows:

Section of well No. '\%, Cote Carline, La.a

\begin{tabular}{|c|c|c|}
\hline . Material. & $\begin{array}{l}\text { Thick- } \\
\text { ness. }\end{array}$ & Depth. \\
\hline 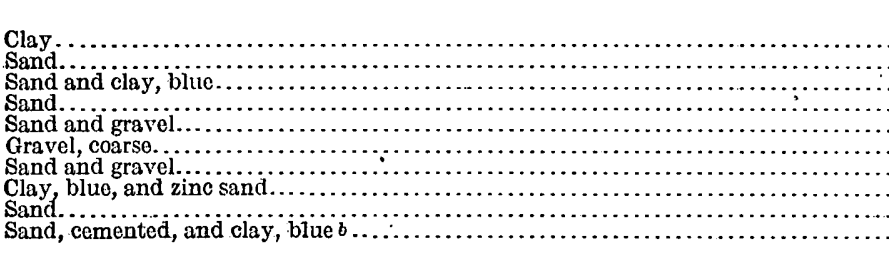 & $\begin{array}{r}\text { Fect. } \\
80 \\
107 \\
8 \\
65 \\
18 \\
25 \\
60 \\
33 \\
32 \\
16\end{array}$ & $\begin{aligned} & \text { Fcet. } 80 \\
& 187 \\
& 195 \\
& 260 \\
& 278 \\
& 303 \\
& 363 \\
& . \quad 396 \\
& 428 \\
& 444\end{aligned}$ \\
\hline
\end{tabular}

a Veatch, A. C., op. cit., p. 256.

o To this Lucas adds: "Salt is probably not very far from this point."

ANSE-LA-BUTNE.

Anse-la-Butte is about 5 or 6 miles northeast of Lafayette and 1 mile east of Bayou Vermilion in St. Martin Parish. Several wells drilled in this locality struck salt. On the southern border of 
the swamp a drill hole entered salt at a depth of 225 feet and continued in it until drilling was discontinued at a depth of 1,530 feet. In a well on the northwest side of the swamp, Fenneman ${ }^{1}$ gives the known salt mass as extending from 220 feet to the bottom of the well at a depth of 1,803 feet. In one of the first wells sunk on top of the high mound north of the swamp salt is reported as extending from depths of 391 to 570 feet and from 578 to 790 feet, an approximate total of 400 feet of salt. Salt was encountered in still another well north of the swamp.

Harris's interpretation of the facts observed at Anse-la-Butte and those obtained from the deep drillings is that the salt forms a central core and the beds of sand, gravel, and clay are bent upward around it at angles of $45^{\circ}$ or more. All the dips have been interpreted by the drillers as being away from the center of the field or swamp. In his descriptions of this occurrence Harris also gives an account of the origin of the small outlying masses of salt near many of the main salt domes of southern Louisiana and Texas.

PRAIRIE MAMOU.

Prairie Mamou (Jennings oil field) is about a mile west of the center of T. 9 S., R. 2 W., in Acadia Parish, about 6 miles northeast. of Jennings. Though a rock salt core has not been found at this place, according to Harris, ${ }^{2}$ this locality is similar to Anse-la-Butte, except that the salt mass has not been laterally concentrated and therefore occupies a broader area, in consequence of which the dome lies much deeper than it would under other conditions. The abundance of salt water obtained at this place points to the presence of a near-by mass of rock salt.

WELSH.

The occurrence at Welsh is about 4 miles west and a little north of Welsh station, on the Southern Pacific Railroad, in secs. 21 and 22, T. 9 S., R. 5 W., in Calcasieu Parish. No rock salt has thus far been found in this locality, but the abundance of salt water is evidence that it exists in the region.

chicot.

Chicot is between Oakdale and Ville Platte, 8 miles southwest of Bayou Chicot post office, in sec. 35, T. 3 S., R. 1 W., in St. Landry Parish. Thus far no salt has been discovered, but the anticlinal or dome structure and the occurrence of limestone here are points of strong resemblance to other localities where salt has been found.

\footnotetext{
1 Fenneman, N. M., Oil fields of the Texas-Louisiana Gulf Coastal Plain: U. S. Geol. Survey Bull. 282, p. $109,1906$.

2 Harris, G. D., op. cit., p. 34.
} 
VINTON.

The Vinton dome is located in secs. 33 and 34, T. 10 S., R. 12 W., and in secs. 4 and 5, T. 11 S., R. 12 W., approximately 3 miles southwest of Vinton station on the Southern Pacific Railroad, in Calcasieu Parish. No salt is known to occur here, but brine is found in small quantity.

\section{HACKBERRY.}

Published descriptions ${ }^{1}$ indicate that a feature which may possibly be a low, broad dome, with less definite domal characteristics than the one at Vinton, lies about 33 miles southwest of Lake Charles, on the south bank of Black Bayou, between Black Lake and Calcasieu Lake. The so-called island is known as Hackberry Island. Salt water has been reported here.

\section{STRATIGRAPHY.}

The appellation "island" has been applied in southern Louisiana to small domes that rise out of marshes which are sometimes dry and sometimes flooded with water. The geology of these islands has been described in detail by Lucas, Harris, Veatch, ${ }^{2}$ and others. According to Lucas, "The geological formation of this series of islands is undoubtedly Quaternary, while the salt deposits belong to the Tertiary and are supposed to rest on the Cretaceous." Harris, ${ }^{4}$ in his discussion of the geology of Petite Anse (Avery Island), states that all the exposed beds are of Quaternary age. That the true nature of the structural features of these salt domes was understood by Lucas seems apparent from his descriptions and his illustrations. The explanation of the mode of formation of these domes is another matter, about which there are many conflicting opinions. The correctness of Lucas's ideas with reference not only to the nccurrence of salt but also to the occurrence of oil was demonstrated in a signal manner after his opinion had been published.

\section{STRUCTURE AND ORIGIN OF SALT DOMES.}

The general dip of the rocks of Louisiana is southeast, or at right angles to the general strike of the Tertiary and Cretaceous formations of Texas, Arkansas, and Louisiana. Up Sabine and Red rivers the ascent is made over the beveled edges of increasingly older geologic strata. Near the surface of these formations, at the localities just

1 Fenneman, N. M., Oil ficlds of the Texas-Louisiana Gull Coastal Plain: U. S. Geol. Survey Bull. 282, px. 111-112, 1906. Hayes, C. W., and Kennedy, W., Oil fields of the Texas-Louisiana Gulf Coastal Plain: U. S. Geol. Survey Bull. 212, pp. 131-133, 1903.

2 Lucas, A. F., Rock salt in Louisiana: Am. Inst. Min. Eng. Trans., vol. 29, pp. 462-474, 1900. Harris G. D., Rock salt: Louisiana Geol. Survey Bull. 7, 1908. Veatch, A. C., The Five Islands: A preliminary report on the geology of Louisiana, pp. 209-202, Louisiana Exper. Sta., 1899.

3 Lucas, A. F., op. cit. p. 465.

4 Harris, G. D., op. cit., p. 15. 
given and at others in Texas, there are large masses of gypsum, salt, and sulphur, either alone or associated with one another and in places with salt water, oil, and gas. These chemical sediments, gypsum, salt, and sulphur, were early recognized as being foreign to the regularly bedded sedimentary clays, sands, and gravels which they accompanied. They are associated with what has been called dome structures or domes, and interest in their study has been quickened and drilling on them been pushed with vigor since the discovery of oil associated with them, by A. F. Lucas, at Spindle Top, Tex., in January, 1901. They have been studied by Fenneman, Harris, Hayes, Kennedy, Lucas, Veatch, and other geologists, and their relations to one another and to the Balcones fault zone of Texas have been pointed out. The dome structure is entirely different from that of the ordinary Appalachian anticlines. The domes are believed by some to have been formed by gas pressure from below; by others they are attributed to hydrostatic pressure; and by others to isostatic movements. Still others regard them as of volcanic origin. one such hypothesis being the volcanic-plug hypothesis of Hager. ${ }^{1}$

In discussing the dome structure of the Winnfield area of Louisiana, ${ }^{2}$ in which there are three well-defined areas that suggest the presence of dome structure, Harris has mentioned an interesting theory of their origin, which, with other theories that preceded it, is amplified in his report for 1907:3 Instead of attributing the pressure necessary for the uplifting of these remarkable circular domes with their quaquaversal dips to gas, oil, water, or any combination of them under a heavy head, or to an igneous plug, Harris regards the power of growing crystals as the agent responsible for their formation. All geologists who have studied the phenomena in Louisiana and Texas have independently concluded that the salt masses are secondary, and all perhaps will admit that water has been the dissolving and transporting agent. Accepting those fundamental facts, Harris regards precipitation of the salt from the rising brines as being due to decrease in temperature and believes that the "unlifting force is amply accounted for by the power of growing crystals." He adduces the following points in support of this hypothesis: (1) The concentric figures and streaks, very faint in places, that may be due to infiltrating waters carrying impurities; (2) the planes of cleavage explicable as having been formed by great pressure normal to their surfaces; (3) the poorly formed and crushed salt crystals at considerable depth and conversely the perfect crystals found near the surface, as at Avery Island and Belle Isle; and (4) the extreme purity of the salt in

\footnotetext{
1 Hager, Lee, The mounds of the southern oil fields: Eng. and Min. Jour., vol. 78, pp. 137-180, 1904. 2 Harris, G. D., Notes on the geology of the Winnfield sheet: Louisiana Geol. Survey Bull. 5, pp. 8-9, 1907.

${ }^{8}$ Harris, G. D., Rock salt: Louisiana Geol. Survey Bull. 7, pp. 59-82, 1908; also, The geological occurrence of rock salt in Louisiana: Econ. Geology, vol. 4, pp. 12-34, 1909.
} 
the mines where it is now being worked at considerable depths. During the slow growth of the domes by this process surface erosion would probably prevent the formation of any sharp and elevated hill that would largely increase the pressure at the base of the salt column; : indeed, some of the older domes to the north are topographically plane or even concave. For further details regarding the relations of temperature and pressure to the deposition of the salt in these domeshaped masses the reader is referred to Harris's report. ${ }^{1}$

In order to understand the arrangement of the domes and the detailed structure connected with them some of the broader geologic facts concerning the region as a whole must be comprehended. The region in which they occur is known as the Mississippi embayment, which is structurally a great pitching trough. East of Mississippi River the dips are to the southwest and west of that river the dips are to the southeast and on both sides they are much sharper than the slope of the land toward the Gulf. Thus, Tertiary and Cretaceous beds which are exposed in the northern part of Louisiana are deeply buried in the southern part of the State. It is believed that strata impregnated with salt lie beneath this pitching trough. As deposits accumulated in this oil trough slips or faulting occurred because of differential loading, and most of them probably are related to the $\mathrm{V}$-shapod area called the Mississippi embayment. There would be expected to result from this faulting a twofold system of faults or anticlinal ridges. The domes of the Guif Coast States are believed to be located along these lines of weakness. Where such faults or structural lines of weakness intersect hot saline waters from great depths could move upward to higher and cooler horizons more easily and more quickly than at other points along such structural lines. At such places the older beds and the newer ones immediately overlying them would tend to buckle upward in fourfold or quaquaversal arrangement and to form the most pronounced dome structure. Finally, it is thought that the Mesozoic and Paleozoic beds may not be buried very deeply in places in Louisiana and Texas; that the salt now found in Tertiary and Quaternary beds may have originated in these older beds, probably of early Mesozoic or later Paleozoic age; and that the local salt masses may now be increasing in size and causing the doming of superficial layers. ${ }^{2}$

In an effort to harmonize the field evidence presented by the salines of Louisiana and eastem Texas, E. G. Norton ${ }^{3}$ has formulated a hypothesis that is probably the latest attempt at an explanation of the origin of these salt deposits.

\footnotetext{
1 Rock salt: Louisiana Geol. Survey Bull. 7, pp. 75-79, 1908; also Cowles, A. H., Min. and Mctall. Soc. America Bull. 57, vol. 6, p. 44, 1913; also Econ. Geology, vol. 4, pp. 12-34, 1909.

2 Harris, G. D., op. cit., pp. 75-79.

A m. Inst. Min. Eng. Bull. 97, pp. 93-102, 1915.
} 
Briefly, he considers that the Tertiary salt deposits of the Gulf coast and the Cretaceous salines of eastem Texas and northern Louisiana were initiated by the intrusion of molten rocks into the underlying Paleozoic sediments along lines of structural weakness. These great faults were the sites of frequent upward displacements during the subsidence and deposition of the sands, clays, and littoral marine sediments of the Mississippi Embayment.

Hot ascending solutions, containing calcium and magnesium carbonates, sodium chloride, carbon dioxide, and varying amounts of hydrogen sulphide, mingled with the artesian saline waters of the Cretaceous beds. These waters were forced upward to the surface by the hydrostatic head of the region through channels that were opened by the faulting and movement which took place above the intrusions of igneous rock. Great deposits of travertine or calcareous sinter were formed near the thermal springs which issued from these openings, and the sinter continued to form as long as the hydrostatic head was sufficient to maintain the flow.

The salt was deposited by ascending solutions, which became supersaturated by the release of pressure as well as by evaporation sustained at the surface as the rapid accumulation of sinter checked the flow from springs. In this way the salt deposits were built up contemporaneously with the sedimentation of the region and formed under covers of sinter as they are found to-day. These covers protected them from erosion, so that they have been preserved in their entirety.

\section{SALT-PRODUCING LOCALITIES.}

Only rock salt is now produced in Louisiana. It is mined on Grande Cote (Weeks Island) and Petite Anse (Avery Island). (See fig. 4, p. 103.)

\section{GRANDE COTE.}

LOCATION.

Grande Cote, or Weeks Island, is located on the eastern shore of Weeks Bay, an eastern lobe of Vermilion Bay, in Iberia Parish. It can be reached over the Cypremort branch of the Southern Pacific Railroad, which runs west from Baldwin. Its position in the State is shown on the map (fig. 4, p. 103). It is called Grande Cote on account of its size, though it is barely 2 miles in diameter. It is the largest of the five islands described by Veatch. ${ }^{1}$ The topography and culture are shown in figure 5. 
GEOLOGY.

The most striking feature of the geology of Weeks Island is the great mass of rock salt which has formed or is forming beneath the thin superficial beds of unconsolidated sands, clays, and gravels. The topography is not rugged, and there are few good outcrops of the ovcrlying materials. Those that are made where the streams cut down the soft, yielding materials are soon covered by rank, rapidly

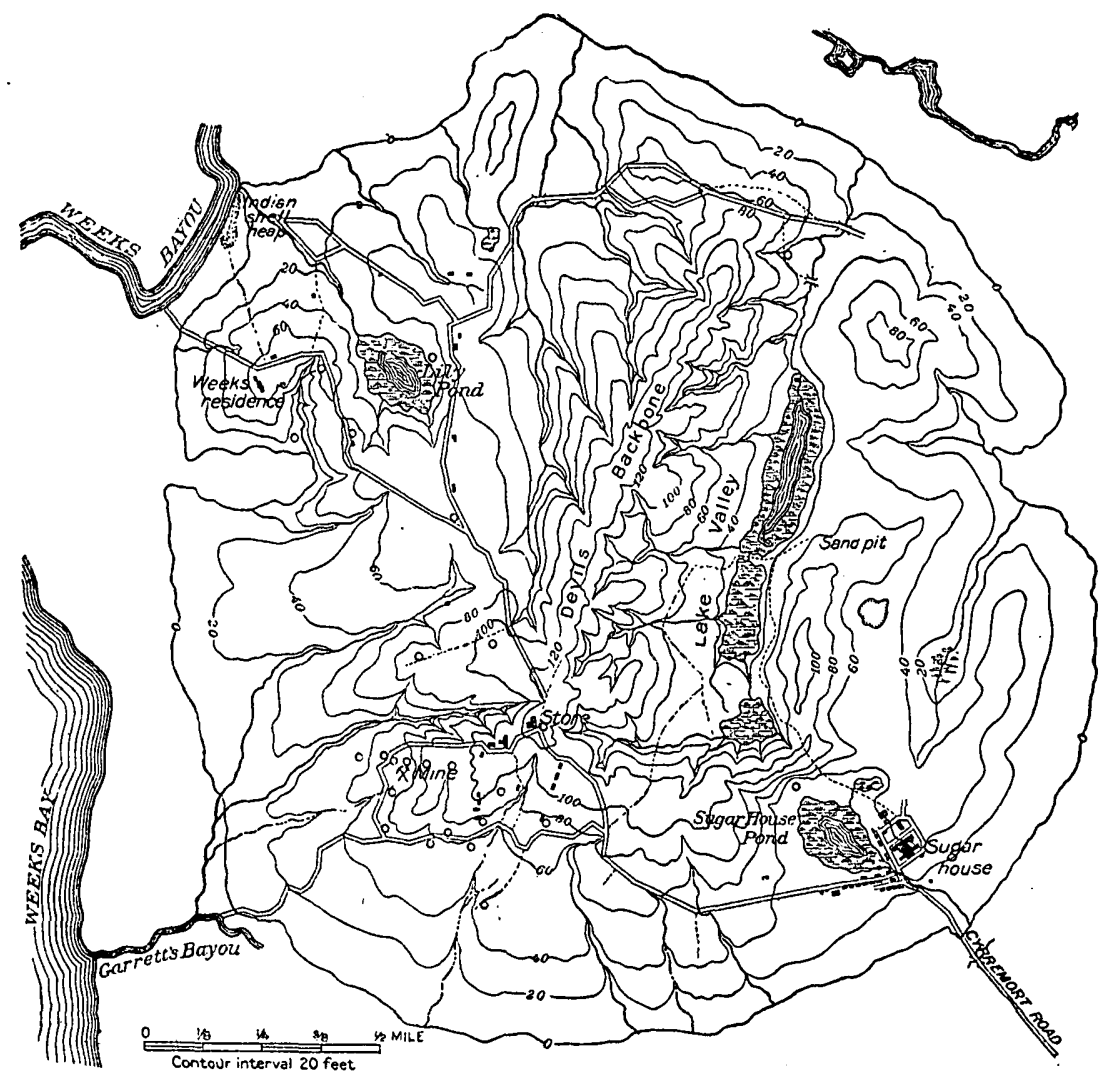

Figure 5.-Topographic sketch map of Grande Cote (Weeks Island), La. (After A. C. Veatch.)

growing regetation. The uppermost bed on the island is yellow loamy clay, which is visible in a few of the natural exposures.

The records of 44 wells driven in different parts of the island also begin in clay ranging in thickness from 40 to 60 fect. Below the clays are sands, ferruginous in places, sand containing chert pebbles, and gray sandy clays-all tilted at different angles and striking in different directions. Sections of wells driven on the island show layers of gravel and sand several hundred feet thick in places. The salt is generally, though not everywhere, overlain by a few feet of $40104^{\circ}-18-$ Bull. $669-8$ 
clay, but layers of lignite have been found just above the salt in some of the wells.

The salt mass of the island comes nearest the surface at the mine, slopes abruptly to the south and west, less abruptly to the east, and but slightly to the north. Its form is that of an elongated dome with its northem diameter longer than the other. It occupies the west side of the island and appears to be a little west of the main

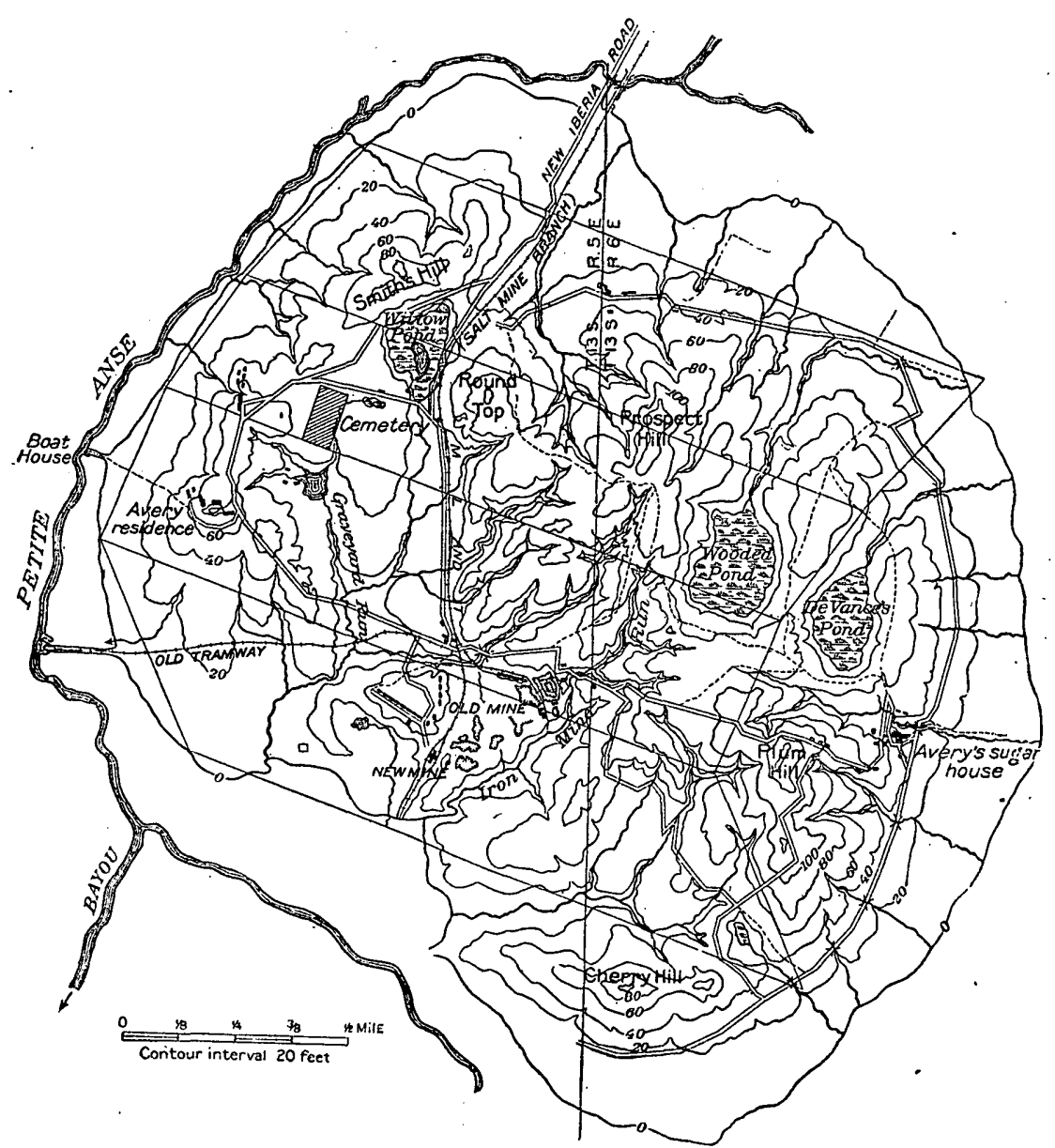

FIGURE 6.-Topographic sketch map of Avery Island (Petite Anse), La. (After A. C. Veatch.)

ridge. The upper surface of the salt mass is known to be quite irregular, and the borings already made indicate little relation between it and the surface irregularities of the island. The present general shape of the salt mass is regarded by Harris ${ }^{1}$ as nearly its original shape, and he thus thinks that its main configuration is not due to erosion or subterranean solution. The character of the strata

1 Harris, G. D., Rock salt: Louisiana Geol. Survey Bull. 7, pp. 8-9 1908. 


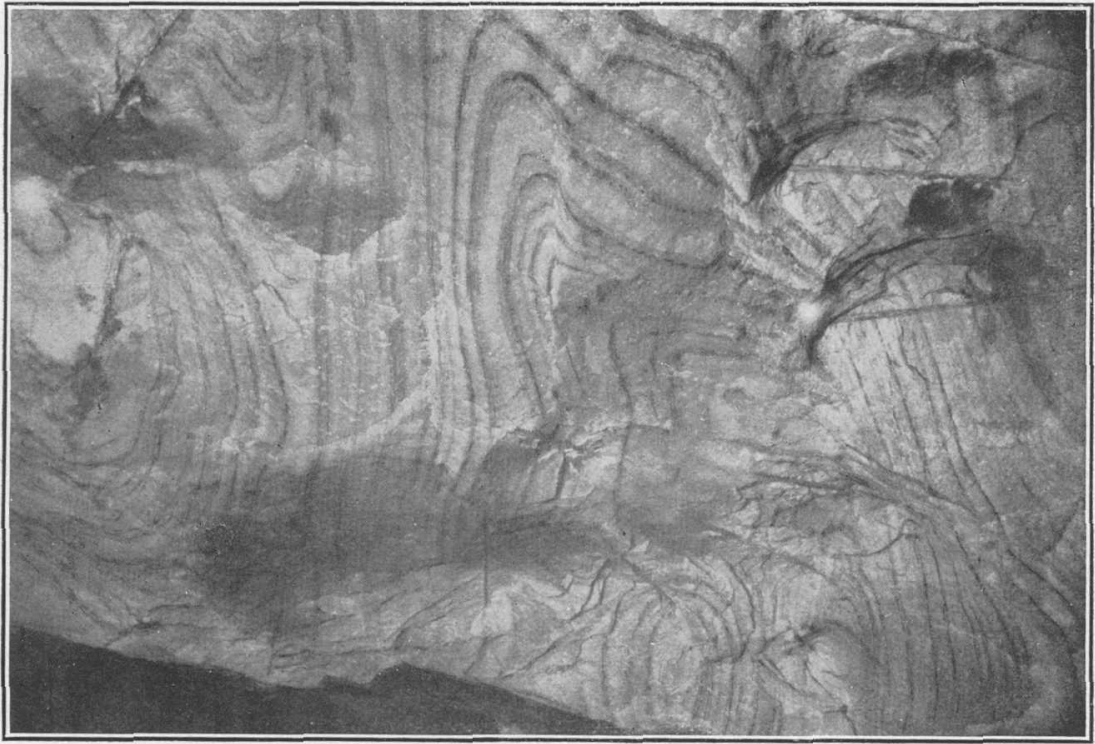

A.

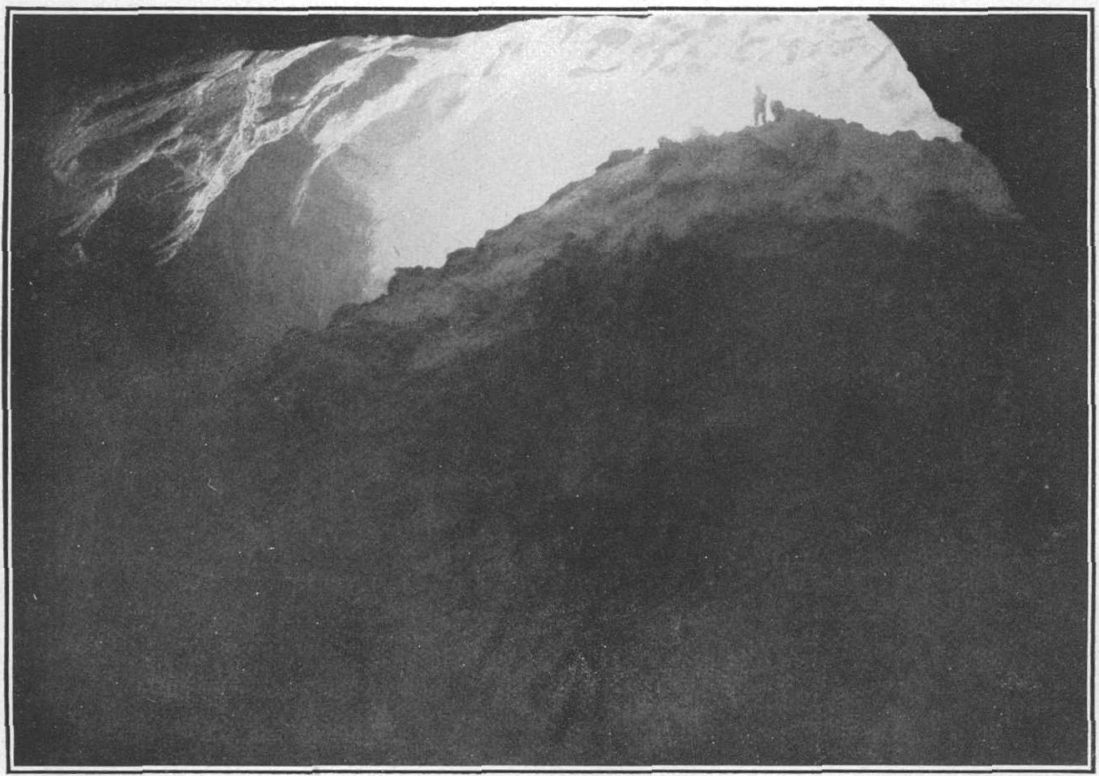

$B$.

MYLES SALT MINE, WEEKS ISLAND, LA.

$A$. Almost perpendicular strata or bands of salt lying in closely compressed folds. $B$. View in interior of mine, showing process of working. Photographs by A. C. Veatch. 
in the Myles salt mine on Weeks Island and the method of working the mine are shown in Plate XI.

\section{PETITE ANSE.}

LOCATION.

Petite Anse or Avery Island is in Iberia Parish, about 10 miles south-southwest of New Iberia, in T. 13 S., Rs. 5 and 6 E., of tho Louisiana primo meridian. (See fig. 6.)

\section{GEOLOGY.}

Veatch and others have described the geology of Petite Anse in considerable detail. ${ }^{1}$ According to Harris, ${ }^{2}$ the details given in the earlier descriptions "are of no serious moment in the interpretation of the geology of this and the other salt islands. All beds here seen are admittedly of Quaternary age, none containing anything that can not be referred to inter or post glacial times."

A brownish-yellow loamy soil forms the greater part of the surface, but exposures of gravel are commoner than on the other islands. 'ithe exposures of gravel and sand seem to be confined chiefly to the southern extremity of the island. In its northern part there aro numerous outcrops of a variegated chocolate-yellow or green jointed clay. A bed of lignite was found at the head of Iron Mine Run Hollow, and remains of Pleistocene mammals (according to Veatch) have been found.

The records of two wells which throw some light on the underground conditions of the island are given below:

Section of well near sugar house, Petite Anse, La.

\begin{tabular}{|c|c|c|}
\hline Matcrial. & $\begin{array}{l}\text { Thick- } \\
\text { ness. }\end{array}$ & Derth. \\
\hline 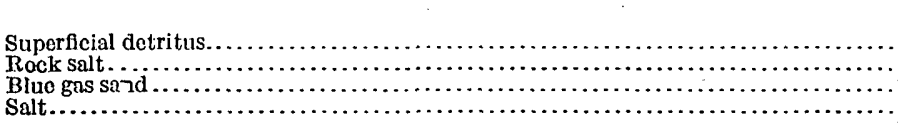 & $\begin{array}{r}\text { Feet. } \\
330 \\
2,263 \\
70 \\
66\end{array}$ & $\begin{array}{l}\text { Fcet. } \\
330 \\
2,593 \\
2,663 \\
2,729\end{array}$ \\
\hline
\end{tabular}

Section of well at pumping station, Petite Anse, La.

\begin{tabular}{|c|c|c|}
\hline Material. & $\begin{array}{l}\text { Thick- } \\
\text { ness. }\end{array}$ & Depth. \\
\hline 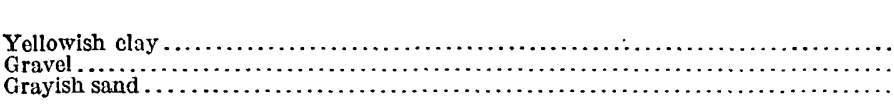 & $\begin{array}{r}\text { Feet. } \\
500 \\
200 \\
2,112\end{array}$ & $\begin{array}{r}\text { Fect. } \\
500 \\
700 \\
2,612\end{array}$ \\
\hline
\end{tabular}

Note. - A gravel bed at about 1,500 fect. No salt or water struck in the well. 
The upper surface of the salt mass is irregular, as on Weeks Island; and in a few places it rises slightly above sea level. It is therefore higher than at any place on Grande Cote or at any other point in the State. The rise of the salt mass toward the surface is confirmed by the existence here of brine springs, well known long before rock salt was actually discovered. Streaks of transparent anhydrite crystals occur here, as on Grand Cote, and the apparent darkness of the layers containing them is considered by Harris to be due to the difference in the way it and the purer salt admit, absorb, and reirract light rays.

\section{BIBLTOGRAPHY.}

CIEndeni, W. W., A preliminary report upon the Florida parishes of east Louisiana and the bluff, prairie, and hill lands of southwest Louisiana: Geology and Agriculture of Louisiana, pt. 3, pp. 159-256, Louisiana Exper. Sta., 1892. Describes topographic, drainage, and geologic features, soil, and other economic resources of this area: "Salt," pp. 216-218; "The Five Islands," pp. 234-241.

HAger, Lee, The mounds of the southern oil fields: Eng. and Min. Jour., vol. 78, pp. 137-139, 180-1.82, 1904.

Harris, G. D. (assisted by Maury, C. J., and Reinecke, L.), Rock salt, its origin, geological occurrences, and economic importance in the State of Louisiana, together with brief notes and references to all known salt deposits and industries of the world: Louisiana Geol. Survey Bull. 7, 259 pp., 1908.

- The salt domes of Louisiana and Texas: Abstract: Science, new ser., vol. 27, pp. 347-348, 1908.

The geologic occurrence of rock salt in Louisiana and east Texas: Econ. Geology, vol. 4, pp. 12-34, 1909.

Hilgand, E. W., On the geology of lower Louisiana and the rock salt deposit of Petite Anse: Am. Jour. Sci., 2d ser., vol. 47; pp. 77-88, 1869; Am. Assoc. Adv. Sci. Proc., vol. 17, pp. 327-340, 1869. $\Lambda$ bstract, Neues Jahrlb., 1873, pp. 553-554.

Lucas, A. F., The Avery Island salt mine and the Joseph Jefferson salt deposit, La.: Eng. and Min. Jour., vol. 12, pp. 463-464, 1896. Describes occurrences of salt and system of mining.

- Rock salt in Louisiana: Am. Inst. Min. Eng. Trans., vol. 29, pp. 462-474, 1900.

The dome theory of the Coastal Plain, a rejoinder: Science, new ser., vol. 35 , p. $962,1912$.

Norton, E. G., The origin of the Louisiana and east Texas salines: $\Lambda \mathrm{m}$. Inst. Min. Eng. Bull. 97, pp. 93-102, 1915.

Romern, Henry, Salt mines of Avery Island, La.: Mines and Minerals, vol. 20, pp. $438-439,1900$.

Veatch, A. C., The Five Islands: $\Lambda$ preliminary report on the geology of Louisiana, pp. 209-262, Louisiana Exper. Sta., 1899. Topographic and geologic features and occurrence of salt.

- The salines of north Louisiana: A report on the geology of Louisiana, pp. 47-100, Louisiana Exper. Sta., 1902. Describes the local geology of the various salt works and discusses the geologic structure and history of the region.

TEXAS.

LOCATION OF SALT-PRODŨOING AREAS.

Salt in Texas in recent years has come chiefly from Palestine, Anderson County, and Grand Saline, Van Zandt County, in the eastern part of the State. Colorado, Mitcholl County, in the western 
part of the State, formerly produced salt, but only solar salt now comes from this place. Some solar salt comes from Crane County also. The industry is of large commercial importance and consists chiefly in the manufacture of evaporated salt; but the salt formed naturally by solar evaporation in the playas of the western and the lagoons of the southwestern parts of the State is used locally.

\section{SALT DOMES OF EASTERN TEXAS.}

LOCATION.

Rock salt has been encountered at the following localities in southeastern Texas, all within the area mapped as Pleistocene and Recent by Deussen:1 Spindletop, Jefferson County; Sour Lake, Hardin County; High Island, Galveston County; Damon Mound, Brazoria County; and Dayton Hill, Liberty County, and there has been a single mention of salt in drilling at Batson, Hardin County, ${ }^{2}$ where, according to an observation of the drillers, 12 feet of salt was encountered in a well northeast of the center of the Batson field at a depth of 1,007 feet or 130 feet above the oil rock. In the absence of other mention of salt in this field the observation can not be finally accepted. According to Harris ${ }^{3}$ streaks of salt have been found at Kisers Hill, Brazoria County. Though no rock salt has been found, salt water in abundance has been encountered in drilling for oil and gas at Saratoga, Hardin County; Big Hill, Jefferson County; and Humble, Harris County. Saratoga, Big Hill, and Humble are all mapped by Deussen as in the Pleistocene area.

\section{GEOLOGY.}

Along or near the Gulf coast of Texas and at other places in the eastern part of the State occur domes or dome structures like those in Louisiana. (See pp. 109-112.) The general geologic conditions doscribed under Louisiana extend westward into Texas, and the correct theory of the origin of the domes or mounds in Louisiana will probably be found to hold good in Texas, not only for the mounds themselves, but also for the economic mineral products occurring in them, namely, salt; oil, gas, gypsum, and sulphur.

\section{INDUSTRIAI DEVELOPMEN'T.}

At none of the localities mentioned has salt ever been mined, and so far as known no serious attempts have been made to obtain it by evaporation of the natural brines. Efforts have been confined solely to exploitation for gas and oil, and some of them have been richly rewarded. The work done has, however, added a fund of informa-

\footnotetext{
1 Deussen, Alexander, U. S. Geol. Survey Water-Supply Paper 335, pl. 1, 1914. See also Fenneman, N. M., Oil ficlds of the Texas-Louisiana Gulf Coastal Plain: U. S. Geol. Survey Bull. 282, pl. 1, 1906.

2 Fenneman, N. M., op. cit, p. 53.

a Harris, G. D., Rock sa't: Louisiana Geol. Survey Bull. 7, p. 47, 1208.
} 
tion to our knowledge of the undergreund formations and structure of the Gulf coast domes. without which it would have been difficult if at all possible to construct any we:l-substantiated theory as to their origin.

The time may come when the salt deposits may be of value. Already the salphur deposits at Bryan Heights, Brazoria County, Tex., are being worked in the same manner as those at Sulphur City, Calcasieu Parish, La.

\section{SALINES OF EASTERN TEXAS.}

LOCATION.

The principal salines so far described in eastern Texas are Grand SaIine, Van Zandt County; Palestine, Anderson County; Steen Saline and Brooks Saline, Smith County; and a saline 2 miles east of Butler, Freestone County.

GEOLOGY.

Nearly all the salines are low, flat areas that occupy depressions where brine has been obtained by sinking shallow wells and where an industry in evaporated salt has grown up. They are surrounded by wooded hills in which white or gray limestone is found. The depressions are usually marshy and may hold water during the winter. As summer approaches, the water evaporates, leaving an incrustation of salt. The limestones are in some places siliceous and in others glauconitic. They appear from their fossils to be the equivalent of the Ripley formation (late upper Cretaceous) of Alabama and Mississippi. The underlying clays belong to the Taylor marl, also upper Cretaceous. Surrounding these salines on every side are strata of Tertiary age, and the salines themselves are therefore in the nature of Cretaceous inliers in the rocks of that system.

These salines, like those in northern Louisiana, do not form topographic features like mounds or islands, but their origin is regarded as being the same as that of the domes. in Louisiana and also farther south in Texas.

\section{GRAND SALINE.}

Grand Saline is in northeastern Texas, in Van Zandt County, on the main line of the Texas \& Pacific Railway running east from Dallas. The Texas Short Line Railway also enters the town.

The saline itself is a small prairie-like sandy plain, in which the sand is strongly impregnated with salt. It is about a mile long from east to west and about half a mile wide from north to south. From the borings made the eonclusion is reached that the beds underlying it are comparatively level, though in this general region the strata have been somewhat disturbed. 
The surficial rocks at this place belong to the Tertiary, and in the wells from which data are available the Cretaceous beds containing the rock salt are overlain by approximately 160 to 180 feet of Tertiary beds. Toward the southwestern part of the saline, beds of Quaternary age cover the surface. According to Kennedy" "the Cretaceous rocks found at Grand Saline nowhere, so far as known, approach the surface, but are covered with over 180 feet of Tertiary sands, clays, and shaly clays, and are only found in borings of the several wells put down for the purpose of obtaining salt. The rpper series of the Cretaceous formation found in these wells appears to be a blue limestone mixed with streaks of sand and gray limestone, having a thickness of 42 feet in the Lone Star well and 28 feet in the Richardson well, a few feet below which the salt deposit of 300 feet occurs."

The sections of the two wells just referred to are given below:

Log of Lone Star well, Grand Saline, Van Zandt County, Tex.

\begin{tabular}{|c|c|c|}
\hline Material. & $\begin{array}{l}\text { Thick- } \\
\text { ness. }\end{array}$ & Depth. \\
\hline & Fect. & Feet. \\
\hline 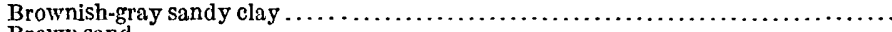 & 26 & 26 \\
\hline 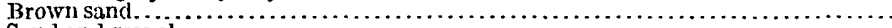 & 8 & 34 \\
\hline 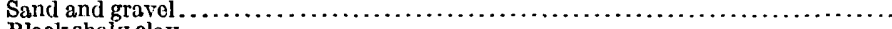 & 3 & 37 \\
\hline 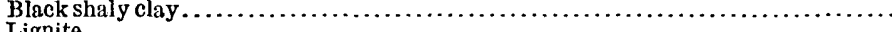 & 20 & 57 \\
\hline 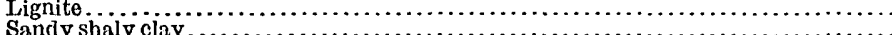 & 3 & 60 \\
\hline 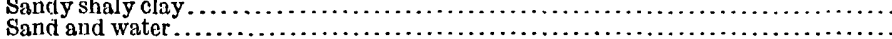 & 20 & 80 \\
\hline 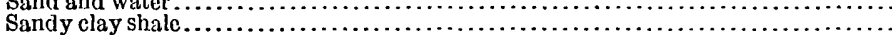 & 65 & 150 \\
\hline 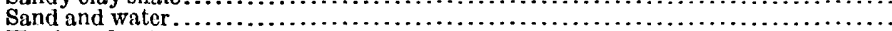 & 14 & 164 \\
\hline Hard sandrock ................ & 6 & 170 \\
\hline Shale containing pyrites........... & 4 & 174 \\
\hline Blue limestone mixed with streaks of sand and gray limestone, but blue forming & & \\
\hline 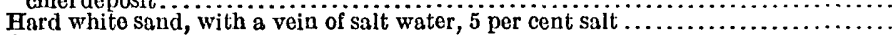 & $\begin{array}{l}42 \\
14\end{array}$ & $\begin{array}{l}216 \\
230\end{array}$ \\
\hline 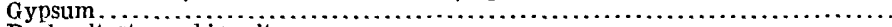 & 5 & 235 \\
\hline 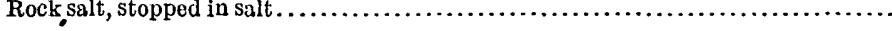 & $120+$ & $355+$ \\
\hline
\end{tabular}

Log of Richardson well, Grand Saline, Van Zandi County, Tex.

\begin{tabular}{|c|c|c|}
\hline Material. & $\begin{array}{l}\text { Thick- } \\
\text { ness. }\end{array}$ & Depth. \\
\hline Soil, brownish-black sand.......... & Fect. & Fect. $_{3}$ \\
\hline 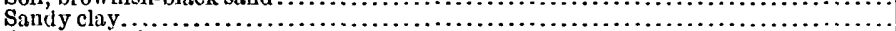 & $\ddot{12}$ & 15 \\
\hline 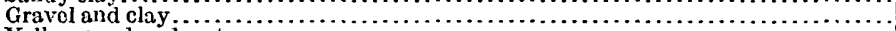 & 5 & 20 \\
\hline 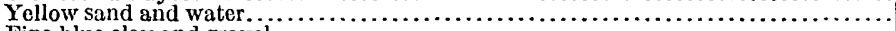 & 6 & 26 \\
\hline 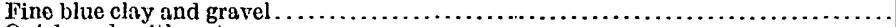 & 2 & 28 \\
\hline 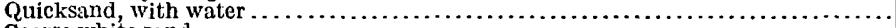 & 2 & 30 \\
\hline 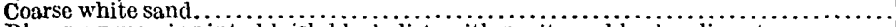 & 5 & 35 \\
\hline Blue-gray merging into bluish-black dirt, with pyrite and broken limestone. & 48 & 83 \\
\hline 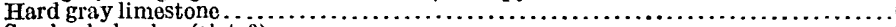 & 3 & 86 \\
\hline Sandy shaly clay (slate?)............ & 17 & 103 \\
\hline 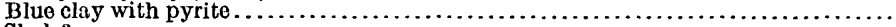 & 20 & 123 \\
\hline Shale? $\ldots \ldots \ldots \ldots \ldots \ldots \ldots \ldots \ldots$ & 9 & 132 \\
\hline Shale with irou pyrite.... & 5 & 137 \\
\hline Sandy shale with pyrite.......... & 12 & 149 \\
\hline Sandstone with pyrite............ & 14 & 163 \\
\hline Hard blue limestone............ & 25 & 188 \\
\hline 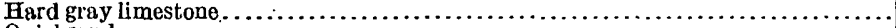 & $3 \frac{1}{2}$ & $191 \frac{1}{2}$ \\
\hline 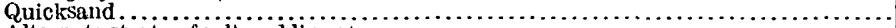 & $2 \int^{4}$ & $194^{\circ}$ \\
\hline Alternate strata of salt and limeston & $18^{*}$ & 212 \\
\hline 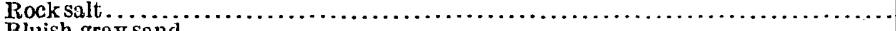 & 300 & 512 \\
\hline 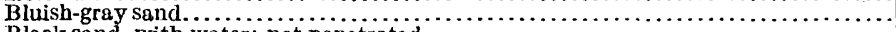 & 2 & 514 \\
\hline Black sand, with water; not penetrated .... & 6 & 520 \\
\hline
\end{tabular}

I Konnedy, William, Texas Geol. Survey Third Ann. Rept. 1891, pp. 46, 76-81, 1892. 
Six wells have been drilled at Grand Saline, 4 at the plants of B. W. Carrington \& Co. and 2 at the plant of the Grand Saline Salt Co. At the present time one well is being used at each of the two plants of the Carrington Co. and one well at the plant of the Grand Saline Salt Co. The exact thickness of the rock salt is not known in all the wells, but it is known that its development is only local. It pinches out eastwardly a few hundred feet east of the plant of the Grand Saline Salt Co. Not even brackish water is obtained here at as great a depth as 322 feet, whereas in most of the other parts of this region brackish water is obtained comparatively near the surface. West of the town of Grand Saline, where a well was sunk about 1,000 feet, salt is not encountered in depth, and from this direction the town drinking water is obtained at rather shallow depths-about 40 feet. No salt has been encountered at any considerable distance north or south of the town. The salt bed has been developed only for a mile, and it is reported that only half a mile appears favorable for exploitation.

\section{PALESTINE.}

Palestine, the county seat of Anderson County, is in the southcentral part of the county on the International \& Great Northern Railway and on the Texas State Railroad. It is in the eastern part of the State and about midway between Red River, the northern boundary of the State, and the Gulf coast.

Palestine is located on a series of glauconitic sandy and clayey beds, the sandy beds containing Tertiary (Claiborne) fossils. West of the town the land slopes toward Trinity River, and 6 miles southwest of the town the saline itself is situated. It is a flat plain, 1 mile wide from east to west, and half a mile from north to south. ${ }^{1}$ Incrustations of salt may be observed around its edge. Its surface is a dark or lead-colored clay, as at Grand Saline.

The saline is surrounded by a ring of hills rising 60 feet or more above the lowland. In places on the tops and slopes of the hills there are outcrops of white chalklike fossiliferous limestone containing specks of glauconite. The limestone is not seen continuously all around the saline, but outcrops in many places, particularly on the northwestern and eastern sides. It is also seen in outcrops on the southern side, but to the southeast the hills are 20 to 30 feet higher than elsewhere and it is quite likely that the limestone is here concealed under the overlying clay. The fossils from the limestone have been determined by R. T. Hill as belonging to the glauconitic beds of the Upper Cretaceous epoch, possibly representing the time during which the Ripley formation was laid down in Alabama. The lime-

I Dumble reverses this statement. Dumble, E. T., Texas Geol. Survey Rept. 1890, vol. 2, p. 305, 1891. 
stone contains seams of yellow crystalline calcite. It is surrounded and in many places corered by lower Tertiary clay and by river alluvium.

\section{STEEN SALINE.}

Steen saline is in the northern part of Smith County, 5 miles east of Linsdale and 14 miles north of Tyler, on Saline Creek, a short distance north of where it forks. The saline proper is a small prairie 1 oi 2 miles in length and from half a mile to three-quarters of a mile in width. The surface of the saline is covered with incrustations of salt and is composed of black or grayish-black clays. Limestone outcrops in the hills surrounding it, and this limestone is overlain and surrounded by lead-colored and laminated Tertiary clays.

Large quantities of salt were made at this saline during the Civil War by digging shallow wells and evaporating the brine thus obtained in huge iron kettles and boilers. It has been reported that as many as twenty furnaces were run at times, turning out 12,000 sacks of salt daily. It took 190 gallons of water to make 1 bushel of salt. ${ }^{1}$

\section{BROOKS SALINE.}

Brooks saline is in the southwestern part of Smith County, about 17 miles southwest of Tyler. It is about $2 \frac{1}{2}$ miles long and from a half to three-quarters of a mile wide. Its surface consists of blue and black clays, and around its edges is seen a yellow laminated clay. Like Steen Saline it is in a depression surrounded by hills in which a yellow fossiliferous limestone occurs, which, as already indicated, probably is of Ripley age (late Upper Cretaceous). During the Civil War seven furnaces, making 100 sacks of salt daily, were in operation at this saline. It has been estimated that 300 gallons of water were required to make 1 bushel of salt. ${ }^{2}$

\section{OTHER OCCURRENOES OF SALT.}

\section{NORTHWESTERN TEXAS.}

In the search for a source of drinking water at Spur, Dickens County, Tex., a well has been recently drilled by S. M. Swenson \& Sons, of New York, to a total depth of 4,489 feet.

The presence of much anhydrite and salt in the section led to the suggestion by $J$. A. Udden, of the University of Texas, that the deposits might contain potash salts. The well had in the meantime been cased below 1,300 feet. A sample was taken after the water had been bailed to a depth of 2,200 feet and was examined by S. H. Worrell, with the following result:

1 Buckley, S. B., Texas Geol. and Agrr. Survey First Ann. Rept., p. 126, 1874. 2 Idem, p. 120. 
Analysis of water from well at Spur, Tex.

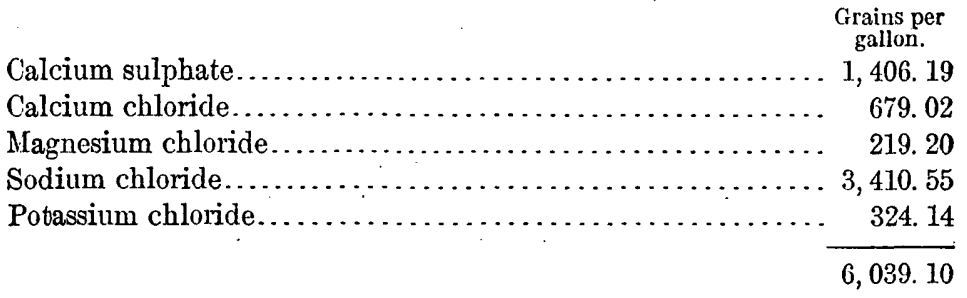

The potassium chloride, therefore, amounts to 5 grams per liter and constitutes more than 5.4 per cent of the total solids. As this quantity of potash salts is somewhat high for a natural water, arrangements were later made for obtaining samples from different depths below the foot of the casing (1,350 feet). Fourteen samples were obtained about two months later and were tested for potash salts, but only one of them contained any considerable quantity of potash salts, and this was a sample taken at the same depth as that which by. the earlier tests showed a marked content of potassium chloride, and the quantity found was only about one-third of that shown by the earlier sample. The results, therefore, seem to indicate the presence in the well of a potash-bearing layer, bed, or stratum approximately 2,200 feet below the surface.

Udden writes: ${ }^{1}$

In either direction north or south from Spur the formations lie practically horizontal for at least a hundred miles, and the potash-bearing horizon, whether it be such or not in other places, must be at about the same depth as here, in these directions. It seems to the writer that the general conditions indicated in [the Spur] boring, the existence of great salt beds and beds of anhydrite, together with the proved potashbearing stratum, warrant an examination for potash in water from the same horizon in any boring made in this territory.

The strata in the region dip to the west; hence the depth to this horizon will be greater westward and less eastward.

The elevation of the railroad depot at Spur is 2,274 feet above sea level. This is 666 feet higher than the elevation at Cisco, about 120 miles to the east-southeast. A line connecting these two points may be taken to follow the direction of the general dip of the formations to the west. The bottom of the well may be taken to represent the beds outcropping at Cisco. On this assumption the general dip between Cisco and Spur, a distance of 120 miles, will be equal to the depth of the Spur well, less the difference in elevation of the two places. This gives us a dip to the west of nearly 32 feet per mile. Our inability to fix the precise level in the Cisco formation reached in the boring may make this figure either a little too high or too low, but it can not be far from right. Talking into consideration the general east slope of the land surface which averages 6 feet per mile, any stratum should come nearer the surface at the rate of 38 feet per mile eastward from Spur.

Outcrop of potash-bearing horizon.-Assuming now that this general dip is constant [between Spur and Cisco] and that the formations are continuous, the horizon which vielded potash in the Spur well should outcrop in a belt where the land surface inter-

1 Udden, J. A., The deep boring at Spur: Texas Univ. Bull. 28, Sci. ser., pp. 82-89, 1914. 
secis the dipping plane lying 2,200 feet below the surface at Spur. This belt would extend through Haskell and Jones counties. It is not to be expected that potash should be found in any outcropping rock in this belt, owing to the surface leaching, but well waters there should show its former existence.

A number of samples of water from wells near Haskell have been analyzed and found to contain an unusually large quantity of nitrate, which is not believed to be derived from the surface.

It is suspected that this nitrate exists in the form of a potassium compound, as saltpeter. Along the line of the Kansas City, Mexico \& Orient Railroad in these counties the potash-bearing horizon may be looked for at depths of from 100 to 400 feet.

In a later publication Udden ${ }^{1}$ gives the logs of several wells drilled in the Panhandle of Texas and in the region to the south in western Texas. In nearly all the wells drilled salt in important beds was discovered, and in some of the beds significant quantities of potash salts were found. The names and locations of the wells are as follows:

Glenario well, Glenario, Deaf Snuith County.

Adrian Oil \& Gas Co. well, near Adrian, Oldham County.

Adrian Townsite Co. well, near Adrian, Oldham County.

Boden well, Potter County.

Miller ranch well, Randall County.

McLean well, Gray County.

Four wells in or near Childress, Childress

County.
Spur well, Dickens County.

Post city well, Garza County.

Justiceburg well, Garza County.

Snyder well, Scurry County.

Scoggin well, near west boundary of Kent County.

Upland well, Upton County.

Buena Vista well, Pecos County.

Deep well northwest of Toyah, Reeves County.

In the region of the Permian beds and to a certain extent in those of later beds in northwestern Texas, the constant recurrence of such geographic names as Salt Fork, Salt Creek, and Salt Basin indicates the widespread distribution of superficial or underground salines. In addition to salt lakes and springs, from which salt is obtainable by solar evaporation, extensive beds of rock salt occur. Many wells in the Permian areas of Texas yield salt water, some so salty as to render them unfit for household or drinking purposes, but they have never been utilized, so far as is known, for salt. Small areas in central Texas contain brine wells.

The conditions for the deposition of salt seem to have been peculiarly favorable during the Permian. An inclosed sea which existed in the epoch that followed the Pennsylvanian is supposed to have been very shallow for a long time. Red saline clays several feet thick and extending over broad areas in places were deposited in it. All the streams that have their origin in these clays and sandy shales are impregnated with salt, many of them to complete

\footnotetext{
1 Udden, J. A., Potash in the Texas Permian: Texas Univ. Bull. 1915, No. 17.
} 
saturation. The Salt and Double Mountain forks of Brazos, Big Wichita, and Pease rivers, and Prairie Dog and Salt forks of Red River originate in or pass through the "Red Beds" of the Triassic and Permian and are more or less impregnated with salt, the Salt forks of Brazos and Red rivers being conspicuous examples.

\section{WESTERN TEXAS.}

SALT BASIN OF TRANS-PECOS REGION.

Location.-One of the salt basins of western Texas, known as Salt Basin, which has been described by Richardson, ${ }^{1}$ is in the trans-Pecos region, and the portion studied lies north of the Texas \& Pacific Railway, near Culberson in El Paso County, west of the Guadalupe and Delaware mountains and east of the Sierra Diablo. The basin, which is one of the prominent débris-filled intermontane valleys of this region, trends to the northwest, and its total length is about 150 miles, the area described by Richardson including 70 miles of this linear extent. The area studied ranges from 8 to 20 miles in width and averages 15 miles, and is a typical closed basin. It is covered with unconsolidated Pleistocene "wash" derived from the adjacent mountains, and this loose material conceals the relations between the Pennsylvanian rocks of the Sierra Diablo on the west and the Permian rocks of the Guadalupe and Delaware mountains on the east.

Salt deposit.-The deposit of salt is on the west side of the basin, about 15 miles southwest of El Capitan Peak and a little more than 50 miles north of Van Horn. It occupies a slight depression, being one of several "salt lakes" in this part of the basin. The layer of salt that covers the surface is said to attain occasionally a thickness of 4 to 6 inches, but the measurements made by Richardson showed only 1 inch of commercially valuable deposit. The salt is grayishwhite, coarsely crystalline to granular, and deliquescent. Windblown impurities occasionally cover its surface. During the dusty dry season the salt becomes impure, but after a rain, and especially in localities where the surface salt has been recently removed, beautiful hopper-shaped crystals are formed. Analyses of these salt crystals and of a typical specimen of salt from the basin are given in the following table:

1 Richardson, G. B., Salt, gypsum, and petroleum in trans-Pecos Texas: U. S. Geol. Survey Bull. 260, pp. 573-585, 1905. 
Analyses of salt from Salt Basin, El Paso County, Tex.a

[S. H. Worrell, analyst.]

\begin{tabular}{|c|c|c|}
\hline . & $\begin{array}{l}\text { Hopper- } \\
\text { shaped } \\
\text { crystals. }\end{array}$ & $\begin{array}{c}\text { Typical } \\
\text { specimen of } \\
\text { salt deposit. }\end{array}$ \\
\hline 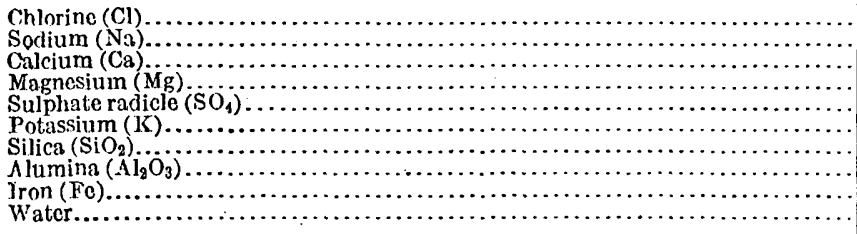 & $\begin{array}{r}59.5 \\
38.6 \\
.1 \\
.2 \\
1.2 \\
\cdots \cdots \\
\cdots \cdots \\
\cdots \cdots \\
1.0\end{array}$ & $\begin{array}{r}59.0 \\
38.3 \\
\text { Trace. } \\
\text { Trace. } \\
1.0 \\
.0 \\
.6 \\
.6 \\
\text { Trace. }\end{array}$ \\
\hline & 100.6 & 99.5 \\
\hline
\end{tabular}

a Richardson, G. B., op. cit., pp. 579-580.

The ground-water level lies very near the surface in the region, and test holes rapidly fill with water. When the surface layer of salt is removed it is replaced by brine, which, on evaporation, forms a new deposit of salt within a fow weeks. This phenomenon indicates an underground source of supply, either disseminated salt or a concentrated deposit with which the ground waters come into contact. Immense quantities of the salt have been hauled away for feeding stock and for use in metallurgic operations at Shafter, 150 miles distant. Gypsum forms the floors of these "lakes" and surrounds and unites many of them. Borax and potash salts have also been found in some of them. Strontium minerals are associated with the gypsum that surrounds Salt Lake, and traces of lithium minerals have also been noted.

COLORADO.

Salt is obtained by evaporation at Colorado, Mitchell County, in the western part of the State. Where the Pennsylvanian and Permian beds are developed in this region numerous salt springs and wells are found. At Colorado a bed of rock salt was found at a depth of 850 feet in drilling for water, and 140 fect of rock salt was passed through in the next 250 feet. The water in several wells rose within about 150 feet of the surface and could not be exhausted by pumping. There has been little or no change in the character of the water since the salt company began operations. The wolls are cased to the first bed of rock salt at 850 feet. Fresh water was found above and below the beds of salt.

OTHER LOCAIITIES.

In the northwest and west-central parts of Texas, at Graham, Young County, for example, salt has been obtained from shallow wells. The wells at Gordon and other places in Palo Pinto County, the flowing well near Waldrip, McCulloch County, and those near San Angelo, Tom Green County, yield salty water. 
Along the coast lagoons or salt lakes have yielded and can still yield a large yearly production of salt.

\section{BIBLIOGRAPHY.}

BuckLEY, S. B., Texas Geol. and Agr. Survey First Ann. Rept., p. 126, 1874.

Cummiss, W. F., Report on the geology of northwestern Texas: Texas Geol. Survey Second Ann. Rept., 1890, pp. 444-449, 1891.

Dunible, E. T., Texas Geol. Survey Second Ann. Rept., 1890, pp. 305, 315-3i7, 1891 .

Herndon, J. H., Texas Geol. Survey Second Ann. Rept., 1890, pp. 222-224, 1891. Describes salines of Smith County.

Kennedy, William, Texas Geol. Survey Second Rept. of Progress, 1891, pp. 55-69, 1892. Salt described on pages 64-66. Describes Cretaceous, Tertiary, and Quaternary strata of eastern Texas, and the contained beds of salt, lignite, etc.

Penrose, R. A. F., Preliminary report on the Gulf Tertiary of Texas: Texas Geol. Survey First Ann. Rept., 1889, p. 33, 1890. Describes Palestine saline.

Richardson, G. B., Report of a reconnaissance in trans-Pecos Texas north of the Texas \& Pacific Railway: Texas Univ. Min. Survey Bull. 9, 119 pp., 1904.

Salt, gypsum, and petroleum in trans-Pecos Texas: U. S. Geol. Survey Bull. 260 , pp. 573-585, 1905 .

Udden, J. A., The deep boring at Spur: Texas Univ. Bull. 28, Sci. ser., 109 pp., 1914. - Potash in the Texas Permian: Texas Univ. Bull. 1915, No. 17, 59 pp.

\section{OKLAHOMA.}

The salt industry in Oklahoma is unimportant and mainly local. During the last few years salt has been produced on a small scale near Ferguson, Blaine County, in the western part of the State, and near Salton and Vinson, Harmon County, in the southwestern part.

SALT PLAINS.

LOCATION.

Salt-water wells and springs are found in both eastern and western Oklahoma. In the eastern part of the State the water generally is only slightly salty; in the western part the water is so saline in places that the terms "salt springs" or "salt plains" are in common usage.

The regions where the springs are loçated are known generally as "salt plains," and according to a recent report of the Geological Survey of Oklahoma ten of these are well known, as follows: Two along Cimarron River in Woods, Woodward, and Harper counties; two in northwestern Harmon County; one each in Alfalfa, Blaine, and Beckham counties; and three on Sandy Creek, south of El Dorado, Jackson County. (See fig. 7.) A recent progress geologic map of Oklahoma issued by the State Geological Survey ${ }^{1}$ shows surficial rocks in these regions as belonging in the Permian. All the salt springs of western Oklahoma issue from the "Red Beds," and probably originate in them, but they do not all issue from the same geologic horizon. 
CLMdTARRON RIVER PLAINS.

Two salt plains, known locally as Big Salt Plain and Little Salt Plain, stretch along Cimarron River in Woods, Woodward, and Harper counties, in northwestern Oklahoma. Both plains are fed by streams that issue from the Permian "Red Beds" and lie 100 feet or less below a heavy bed of gypsum. Little Salt Plain is just south of the point on the Kansas line where Cimarron River first breaks through the gypsum hills. It is 2 or 3 miles long and a mile or more wide. Big Salt Plain is 15 or 20 miles farther down the river. Its length is 8 miles and its width ranges from half a mile to 2 miles. It lies in a broad canyon of Cimarron River, inclosed on both sides by gypsumcapped hills. During the dry season (summer) nearly all the water either evaporates or sinks into the sand. Where a small stream is left the water running in itis so impregnated with salt that a crust forms on its surface. The entire area, except just after a rain, is covered with a thin incrustation of salt crystals. According to Gould ${ }^{1}$ the combined flow of the springs which feed the plain approximates several thousand gallons an hour.

In former years there were a number of primitive salt plants in this region. The water was dipped

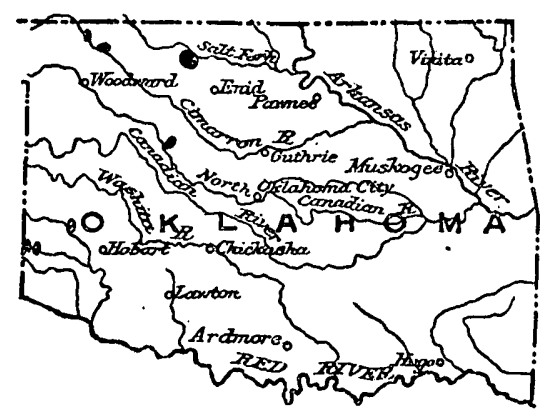

FrGURE 7.-Sketch nuap showing location of salt plains in Oklahoma. or pumped from the springs or shallow wells and evaporated either by the sun or over fires. No salt is now made in this region.

IAARMON COUNTY PLAINS.

There are salt plains in Harmon County, in small canyons in the gypsum hills south of Elm Fork of Red River, about 5 miles east of the Texas border and $1 \frac{1}{2}$ miles south of the north county line, in secs. 4 and 11, T. 6 N., R. 26 W. The plains are known locally as the Chaney or Salton Salt Plain and the Kiser Salt Plain. They are both small, neither covering an area of more than a few acres, and they are not more than a mile apart. The salt is contained in spring water that issues from shallow beds overlain by gypsum. Springs also boil up from the level floor of the plain.

A local industry has been carried on for many years in this region at the old Kiser salt works and also farther west. The springs $1 \frac{1}{2}$ miles west of these works have been worked in recent years and are now known as the Salton salt beds. The old Kiser salt beds also have recently been worked. 
ALFALFA COUNTY PLAIN.

The Alfalfa County plain is 30 miles or more from the gypsum hills, among which lie the other salt plains here described. It is about 4 miles east of Cherokee, just south of the Salt Fork of Arkansas River. It is 10 miles from north to south and 6 to 8 miles from east to west, its area being from 60 to 80 square miles.

Though it is the largest of the Oklahoma salt plains, it has no large salt springs at its surface. The plain is composed of loose reddish-brown sand and clay, apparently saturated with salt water, for a hole a few feet deep dug in any part of the plain soon fills within a few inches of the top with salt water. The surface evaporation of this water produces the white incrustation observed over the field. The supposition that the plain is underlain by rock salt is probably incorrect, a more plausible hypothesis being that the underlying shale is permeated with salt, which dissolves in the ground water and is thus brought to the surface. No salt from this area is being used.

BLAINE COUNTY PLAIN.

The Blaine County salt plain, 4 miles west of Ferguson, is fed by streams which come from the main Salt Creek canyon, among the gypsum hills. The flow from springs forms a small creek. Along the bottiom of the canyon the salt incrustations formed by evaporation cover a strip about 100 yards wide. Where the canyon widens on entering the flat country, about a mile below the springs, the salt plain expands and becomes as much as a quarter of a mile wide. Its total length is 3 miles.

This plain is nearer to both the coal fields and the market than any other in the State. A number of small salt plants have been operated at different times along its edge. The methods employed in obtaining salt were very simple. A hole or well was dug in the sand, and the brine collected in it was poured into vats and evaporated over wood fires. The trade was local, but the demand is said to have exceeded the supply for several years. It is stated that a grainer plant having a capacity of 450 barrels a day was set up at Ferguson a few years ago. The brine was piped from the plain. $\Lambda$ fter operating a short time the plant was shut down and dismantled. A small output of solar salt has lately been reported from the region.

BECKHAM COUNTY PLAIN.

The Beckham County plain is in the southeast corner of the county, in secs. $10,11,14$, and 15, T. 8 N., R. $22 \mathrm{~W}$. It is about half a mile from North Fork of Red River, near the base of the gypsum hills. Its area is about 40 acres. Springs issue from the strata beneath the gypsum beds in places and also from the level surface of 
the plain. The combined flow of the springs would form a stream of considerable volume were not much of the water lost in the sand. Salt has been manufactured in the locality from time to time.

JACKSON COUNTY PLAINS.

There are three salt plains in Jackson County, situated close to each other on the west side of Sandy Creek and on small tributaries flowing northeast into. it. They are about 3 miles from the mouth of the creek and about the same distance south of EI Dorado. The north plain is in the E. $\frac{1}{2}$ sec. 31, T. 2 S., R. 23 W.; the middle plain in the NE. $\frac{1}{4}$ sec. 5, T. 3 S., R. 23 W.; and the southern plain in the NW. $\frac{1}{6}$ sec. 5, same township and range. The north and south plains are each about a quarter of a mile long by one-sixteenth of a mile wide, and the middle plain, though approximately the same length as the others, is very much narrower. The salt water comes from numerous springs, and a thin saline incrustation covers the sandy floor of the plains. Analysis of the soluble salts in the saline incrustation showed the presence of more sulphate than chloride, and also of considerable potassium. In the incrustation from the middle plain the proportion of salt is greater than the proportion of sodium sulphate, but there is so much sodium sulphate and potassium that it is doubtful whether the common salt could be profitably extracted. The occurrence of potassium is interesting and may be important.

\section{BIBLIOGR.APHY.}

Gould, C. N., The Oklahoma salt plains: Kansas Acad. Sci. Trans., vol. 17, pp. 181-184, 1901.

Gould, C. N., Hutchison, L. L., and Nelson, Gaylord, Preliminary report on the mineral resources of Oklahoma: Oklahoma Geol. Survey Bull. 1, 84 pp., 1908. Salt, pp. $35-40$.

Gould, C. N., and others, Brief chapters on Oklahoma's minerals: Oklahoma Geol. Survey Bull. 6, pt. 2, pp. 68-71, 1910.

OreRn, D. W., The mineral production of Oklahoma from 1901 to 1911: Oklahoma Geol. Survey Bull. 15, pt. 2, p. 43, 1912.

SnIDER, L. C., The salt plains of Oklahoma: Oklahoma Geol. Survey Bull. 11, pp. 202-214, 1913.

\section{OREGON.}

No salt has been made in Oregon in recent years, but J. Ross Browne ${ }^{1}$ says in a report on the mineral resources of the State that it was made from brine from springs in the Willamette and Umpqua valloys and at other places. According to Browne, the salt works in Douglas County in the Umpqua Valley for several years prior to 1869 produced 700 to 1,000 pounds of salt daily during the summer. season. The distance from Portland, the chief market, prevented

1 Resources of the Pacific siope, pp. 255-256, San Francisco, 1 S69.

$40104^{\circ}-18-$ Bull. $669-9$ 
the development of the industry, as a cheaper supply could be obtained from works erected in the lower Willamette Valley.

The Willamette salt works were approximately 13 miles from Portland, halfway between that city and St. Helens, and half a mile from the banks of the Willamette slough. The salt was obtained from one of several salt springs, which issued from the base of a low eastward-trending range of hills. When Browne's report was written 4,000 pounds of salt were being produced daily. Samples of the salt were analyzed by W. P. Blake and were found to be free from lime and magnesia, making it of value for dairying and preserving. Springs in Jackson County are reported by Browne ${ }^{1}$ to have produced annually 10,000 pounds of a similar quality of salt.

Beds of rock salt are reported near the base of Mount Jefferson, in the Cascade Range.

\section{ALKALI LAKE.}

There is a shallow and variable lake of strong brine in Alkali Valley, southern Oregon, which occupies the bottom of one of the typical desert basins of this part of the Great Basin. A notable deposit of soda is found in and around the lake. The alkali occurs as a crust on the surface of mud in and around shallow saline ponds, and there are "pot holes" near the margin of the deposit in which almost pure soda crystallizes. These "pot holes" have been worked for soda in a small way, and the deposit as a whole has been taken up by a company which plans to work it for soda and perhaps for other products. Attention has been directed to this deposit as a possible source of potash.

Hoyt S. Gale, of the United States Geological Survey, examined this deposit in August, 1915, and took samples of the brine and salts. The results do not seem to indicate that the materials are of promise as a source of potash salts, though these may be recovered in conjunction with other salines. For example, the brine from a pool known as Little Alkali, which is probably the largest body of open water, carries 10.63 per cent dissolved matter (ignited residue), in which potash ran 3.25 per cent as potassium, or 6.19 per cent calculated as potassium chloride. This content of potash is somewhat higher than that commonly obtained in such brines, but it is not comparable, for example, with that in the brine from Searles Lake, in southern California, and the brine from Alkali Lake was less than half saturated.

ABERT AND SUMMER LAKES.

Reports have been published from time to time relating to a project for extracting salt, soda, potash, and other mineral salts from the waters of Abert and Summer lakes, southern Oregon. These lakes, 
which are of considerable size, carry alkali salts in rather dilute solution, ranging, according to analyses available, from 3 to 8 per cent in Abert Lake, and from 2 to 4 per cent in Summer Lake. Although the aggregate quantity of salts in these waters is undoubtedly large, the waters are only about as concentrated as sea water, and the potash content, as shown by authoritative determinations, is only slightly greater than that of sea water. Soda might be recovered from these waters by solar evaporation, in the same manner as salt is now recovered from sea water. It is also conceivable that potash might be recovered as a by-product.

\section{BIBLIOGRAPHY.}

Browne, J. R., Resources of the Pacific slope, pp. 255-256, San Francisco, 1869.

Phalen, W. C., Potash salts: U. S. Geol. Survey Mineral Resources, 1915, pt. 2, pp. 107-108, 1916.

\section{IDAHO AND WYOMING.}

DEVELOPMENT.

Salt has been produced in Bannock and Bear Lake counties, Idaho, in recent years. Though the production has been usually reported from Idaho, the headquarters of most of the operators have been at Auburn, Wyo.

Valuable areas of salt-bearing land lie along the Wyoming-Idaho border in Bannock County, Idaho, and the middle-western part of Uinta County, Wyo. The deposits occur west of the Salt River valley, or Star Valley, as it is locally known. In the old days, before the advent of railroads in the West, relatively large amounts of salt were boiled from the brine springs in this region and were hauled by ox team to supply Idaho and Montana mining camps. The emigrants to the Northwest along the Lander route also drew upon this region for their salt.

Interest in these salt deposits has recently been revived by the discovery of rock salt beneath the brine springs in lower Crow Creek. In deepening these springs in 1902, a formation of rock salt was encountered 6 feet below the surface which has been penetrated for a thickness of 20 feet without reaching the bottom. The exc sptional purity of the salt, its cheapness of production, and the probability of future railroad connections lend interest to the deposits of the entire district. (See fig. 8, p. 133.)

\section{LOCATION.}

The only rock salt thus far found in the region is on the southeast side of the Crow Creek valley, along the route from Montpelier, Idaho, to Star Valley. The locality is opposite the Lowe ranch, 38 miles northeast of Montpelier and 12 miles southwest of Afton, Wyo. The property is owned by John W. Booth, of Afton, who also owns 
a brine spring in upper Crow Creek, 6 miles nearer Montpelier, which has not been worked in recent years.

The principal operating brine springs are on Stump Creek and in Tygee Valley, which are west of Star Valley, on the Idaho side of the State line. Most of the springs are near the junction of Stump and Tygee creeks. The Petersen spring, now owned and operated by Soren Petersen, of Auburn, is on Tygee Creek, about half a mile southwest of the junction. The McGrew spring, owned and operated by John C. McGrew, of Stump Creek, is on Stump Creek about half a mile northwest of the junction; and a mile farther north, up Stump Creek, are the Reed springs, owned and operated by Sydney Reed, of Auburn. Still farther up Stump Creek, about 5 miles above the Reed springs, are the old Stump and White springs. These have not been operated in recent years. To the south, up Tygee Creek, the next spring operated is the Draney, 4 miles south of the Petersen spring.

Another salt-producing area is situated on the Wyoming side of the boundary line, south of Star Valley, on the route from Smoot and the upper end of Star Valley to Thomas Fork. This locality is on Salt Creek and is reported to be 7 or 8 miles northeast of Green's ranch, or the head of Thomas Fork. The plats of the General Land Office show it in the SW. $\frac{1}{4}$ sec. 26, T. 29 N., R. 119 W., east of the middle of the quarter.

\section{GEOLOGY AND ORIGIN. ${ }^{1}$}

The productive brine springs have no immediate relation to the solid rock formations occurring near by. The springs occur in the valley bottoms in barren patches of stony clay or gravel, which are rendered soggy by the contained brine. These salty places may be recognized at a distance by their gray color; in some of them a little salt incrusts the barren surface. Near by are terraces of reddish clays.

A brine spring is made by digging a hole about 3 feet deep, 2 to 4 feet wide, and 3 or 4 feet long. This soon fills with water so saturated with salt that it frequently has a sirupy consistency or appearance when dipped.

According to Breger, the salt was originally disseminated in small quantity in the red sandstones, conglomerates, and shales of the Beckwith formation (Jurassic and Cretaceous) at the time these rocks were laid down in the shallowing and disappearing Jurassic and early Cretaceous seas. The anticlines into which the porous Beckwith rocks are folded have localized the underground water circulation. On the crest of one of these anticlines are located all the productive salt areas on Stump Creek and lower Tygee Creek;

\footnotetext{
1 Breger, C. T., The salt resources of the Idaho-Wyoming border, with netes on the geology: U. S. Geol. Survey Bull. 430, pp. 566-567, 1910.
} 


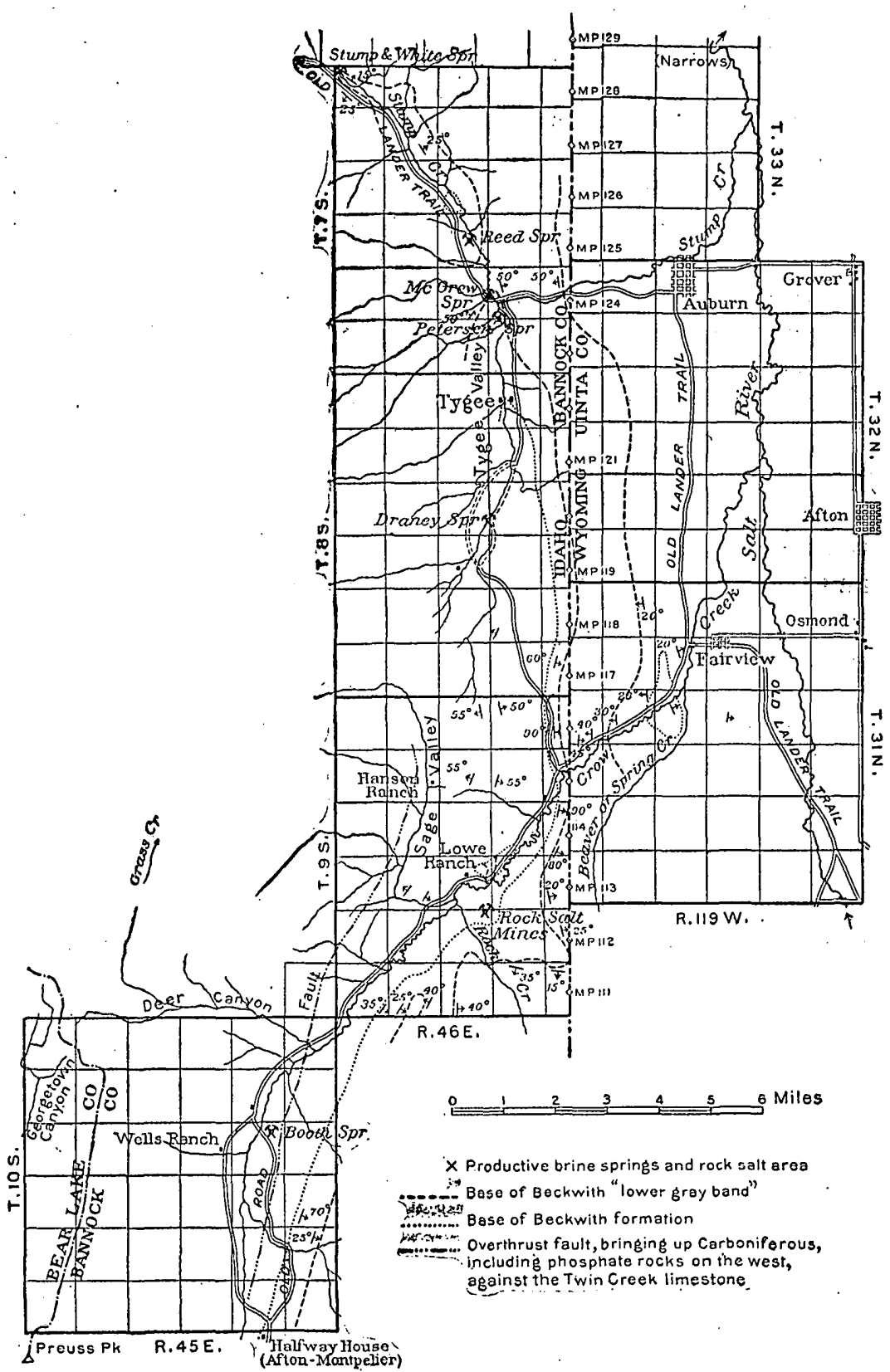

FIGURE 8.-Sketch geologic map of part of Idaho-Wyoming border country. (After C. L. Bregor, U. S. Geol. Survey Bull. 430, 1910.) 
the Draney spring is near the crest of the same anticline. The Crow Creek rock-salt area is on the crest of a prominent dome, at the mouth of a small tributary, Rock Creek.

The present productive salines were deposited during pre-Pleistocene time in the form of alkali flats at or near the mouths of incoming lateral streams or valleys. When the salt-bearing waters reached the main valleys they sank into the gravels or spread over the surface. On evaporation or partial evaporation of the waters the salt was left behind, either on the surface or in the gravels.

The hypothesis of pre-Pleistocene alkali flats and saline evaporation in the valleys to account for the present deposits is favored by the ideal conditions presented by the anticlinal folding of the saltbearing porous Beckwith rocks, coupled with the climatic aridity which has been shown to have preceded the Pleistocene. The long duration of the arid climate, which may have extended nearly as far back as the period of the Oligocene (?) conglomerates, and the antiquity of the existing drainage features also support this hypothesis.

On the recurrence of a humid climate in the Pleistocene epoch the alkali flats were buried under an outwash of the stony red clays. These clays have blanketed the salt with a nearly waterproof cover, which has protected the soluble mineral from being eroded or from being dissolved and carried away. Where recent erosion has washed the covering of Pleistocene red clays from the river bottoms the buried alkali flats yield their salt in the present productive brine-spring areas.

\section{ESTIMATED EXTENT.}

Solid salt deposits of some kind apparently underlie all the productive brine-spring areas, as is borne out by (1) the saturated character of the brines, (2) the similarity of geologic conditions in the single area positively known to contain rock salt and in all the brine-spring areas, and (3) the fact that this rock-salt area itself was originally a brine-spring area similar to those of the present brine springs. Rock salt has been reported under the Petersen spring, in Tygee Valley, and under the Booth spring, on upper Crow Creek, but on authority of uncertain value. Whether the underlying solid salt will prove to be a mass of rock salt with small amounts of disseminated red clay, as at Crow Creek, or whether the salt occurs in gravels incrusting the pebbles is conjectural. Shallow digging or drilling would undoubtedly display the character and amount of salt available under the brine-spring areas.

Definite estimates of the amount of salt underlying the brine areas are, with the present data, impossible. Although the existence of rock salt underneath them is more or less demonstrable, the thickness and continuity of the salt bodies, or old alkali flats, is problematic, 
particularly in the absence of any borings. From surface indications, however, it appears probable that the salt body to the west of Stump and Tygee creeks is more or less continuous from the Petersen spring northward to the McGrew residence, or nearly a mile. The Reed springs draw upon a probably large acreage of salt underlying the red-clay terrace near by, on the west side of Stump Creek. The acreage of the salt body supplying the Draney spring, in Tygee Valley, is wholly conjectural in the absence of borings. At the old Stump and White springs, on upper Stump Creek, the narrow valley and the presence of bedrock on both sides suggest a very small salt body. The salt body supplying the Booth spring, in upper Crow Creek, if it underlies any large part of the red-clay terrace, would be very extensive. In the absence of diggings or other data, however, its extent is problematic.

The rock salt on Crow Creek has been penetrated for a thickness of 20 feet. Not only is the bottom not in sight but the salt is purer at that depth, containing less clay than at the top. This suggests a great thickness at the particular points penetrated. The rock salt appears to underlie much of the terrace of red clays near the mouth of Rock Creek, but that the salt extends to any great extent under Crow Creek valley in front of the terrace seems improbable, though by no means impossible. The extreme north end of the terrace may not contain any salt; fresh-water springs emerge bere. The south end of the terrace has been cut through by Rock Creek and may perhaps also prove to be destitute of salt. Conservative estimates of the portion of the terrace now underlain by salt indicate an area of approximately $113^{\circ}$ acres. On the assumption that an average thickness of 15 feet can be mined out or dissolved out, this area would yield a little over $74,000,000$ cubic feet of rock salt. By weight this would produce a trifle over $5,000,000$ short tons of soluble salt (the rock salt being assumed to average 8 per cent clay and solid matter and 92 per cent soluble salt).

The existence of anticlines in the sandstones of the Beckwith formation in the hills on the west side of Star Valley and the presence of the Pleistocene stony red clays in places suggest the possibility that old buried salt flats may exist under portions of the valley. None of these have yet come to light, so far as known, but unless local conditions prevented the formation here of pre-Pleistocene salt flats it is probable that future diggings may discover buried salt bodies in some portions of Star Valley proper.

SUMMARY.

The workable areas along the Idaho-Wyoming border consist of isolated salt bodies. These were formed during a long period of pre-Pleistocene aridity by salt waters from the lateral streams (either surficial or underground drainage), which reached the valley 
bottoms and evaporated either on the surface or in the gravels. The existence of anticlines and domes near by in the porous sandstones and conglomerates of the Beckwith formation aided in the accumulation of salines, which intensified the salinity of some of the streams. The salt flats produced have been preserved by a covering of Pleistocene stony red clays.

Although the salt bodies or old alkali flats are thus meager in extent, especially in comparison with the other prominent saltproducing areas of the United States, the conservative estimate of $5,000,000$ tons for the Crow Creek rock-salt body and the possibility of a larger salt body near the Tygee and Stump Creek forks indicate that the amount of salt apparently in sight in some of the present areas would be sufficient (if proper railroad connections existed) to yield returns on large workings for a long time. It also appears quite probable that all the areas, including the smaller brine springs, contain sufficient salt to return the sums that may be advisedly invested in their development.

As to quality, salt can be easily obtained here which is above the average in chemical purity. This salt could be produced most cheaply and with the maximum of cleanliness by a process of solar evaporation.

At present the market for the salt of the area described is limited to the immediate vicinity, owing to the absence of railroad connections. With a railroad in Star Valley, however, the salt of this area would command the markets of eastern Idaho, western Wyoming, and much of Montana.

\section{COMPOSITION OF THE SALT.}

Analyses of the rock salt of the district made in the laboratory of the United States Geological Survey gave the following results:

Composition of rock salt of Idaho-Wyoming district.

[Chase Palmer, analyst.]

Soluble matter ("salt") . .........................

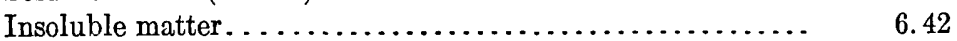

Moisture and undetermined........................ $\quad .85$

99.06

The salt has the following composition:

Analysis of salt from Idaho-Wyoming district.

Sodium chloride $(\mathrm{NaCl})$ 
The insoluble matter was determined as follows:

Analysis of insoluble matter in rock salt of Idaho-Wyoming district.

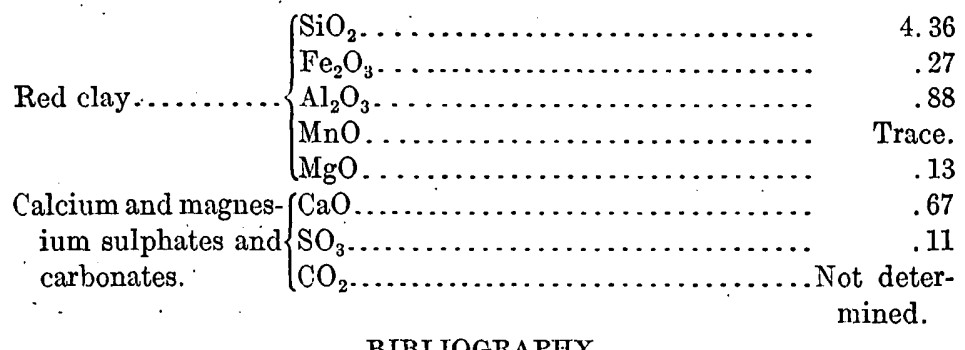

BREGER; C. L., The salt resources of the Idaho-Wyoming border, with notes on the geology: U. S. Geol. Survey Bull. 430, pp. 555-569, 1910.

\section{NEVADA.}

The salt industry in Nevada is unimportant. Scattered deposits are worked from time to time to supply local demand, but most of the enterprises started have been small and have been operated spasmodically.

\section{SALT MARSHES.}

LOCATION.

During recent years salt has come from Sand Springs, Leete, and Parran, Churchill County; from the Silver Peak playa, Esmeralda County; and from the Buffalo Salt Works, Sheepshead, Washoe County. The salt is usually obtained by solar evaporation, and the finer grades, such as table, dairy, and common fine salt, are prepared from the solar product by different refining processes. Other known deposits are at White Plains and Dixie Salt Marsh, Churchill County; Rhodes and Columbus marshes, Esmeralda County; Railroad Valley, Nye County; and west of Diamond Range, in Eureka and Elko counties. Other deposits of present or prospective importance lie along Virgin River in the southeastern part of the State. In fact numerous saline valleys are widely distributed in the part of Nevada included in the Great Basin.

\section{CHURCHILL COUNTY.}

SAND SPRINGS. 1

Sand Springs is about 25 miles southeast of Fallon, Churchill County, which is the nearest railroad point. It is in Sand Springs Valley, known also as Alkali Valley and now generally as Fourmile and Eightmile flats. Solar rock salt was produced at Sand Springs in 1915 .

The surface of the lake beds in the valley when deposited was of course horizontal. The present inclination of the beds is due to a

\footnotetext{
1 Browne, J. R., Resources of the Pacific slope, pp. 309-311, San Francisco, 1869. This book coritains an interesting account of the early workings at Sand Springs.
} 
fault which crosses the valley and strikes to the north. The tilting of the valley floor resulting from this fault caused the surface waters to drain eastward and to form a small lake at the eastern end of the valley near Sand Springs.

During the winter water collects in this lake and forms a sheet of brine 10 to 15 square miles in extent but only a few inches in depth. In the dry summer season the water evaporates and adds a layer of salt to that previously deposited. The salt deposit thus accumulated is 3 to 5 inches thick near the margins and is said to have a depth of not less than 3 feet in the center of the basin. Associated with the salt here, as well as at the Buffalo Salt Works and the Eagle Salt Works, are greater or less quantities of sodium and calcium borate. Borax has been produced at the borax works of Alkali Valley.

The occurrence of salt at Sand Springs is typical of a large class of salt deposits in Nevada and the Great Basin region in general. The amount of salt formed as indicated must be very great. In collecting the salt, the crust is broken up and scraped into heaps, formerly with broad wooden hoes, the ground being divided into long strips and gone over in regular order. The heaps thus formed are allowed to drain for a few days and are then carried in wheelbarrows or cars to platforms, where, after further drying, the salt is pulverized, if necessary, and sacked, after which it is ready for shipment. After one crust of salt is removed, another begins to form, the process repeating itself so rapidly that several crops can be gathered in a year. As the ground below is heavily charged with salt, the replacement of the layer removed would go on almost indefinitely. A large part of the alkali flat outside of the depressed area is covered with a thin coating of salt during the dry season, but generally it is too impure for gathering.

A test well sunk in the region under the direction of H. S. Gale, of the United States Geological Survey, showed a surface layer of 7 feet of hard crystalline salt underlain by soft black mud. A flow of water was encountered at a depth of 26 feet. The water was tested for potash salts, but the richest sample showed only 2.37 per cent expressed as $\mathrm{K}_{2} \mathrm{O}$. The great distance of this place from a market is one of the drawbacks to the salt industry, which is purely local. ${ }^{1}$

LEETE.

Leete, the location of the Eagle Salt Works, is in northwestern Churchill County, and is reached from Fernley, opposite the old Wadsworth station on the Southern Pacific Railroad. The region about the works is a desert mud plain covered during the summer by a white saline efflorescence. The locality is within the drainage

1 Hance, J. H., U. S. Geol. Survey Bull. 540, pp. 457-463, 1914. Young, G. J., U. S. Dept. Agr. Bull. 61, p. $59,1914$. 
boundary of the Great Basin, and the deposits associated with the salt are of Quaternary age.

The salt is procured by solar evaporation from a natural brine that stands not far below the surface. The surface material is sandy and is about 5 feet thick. It is underlain by a more or less impervious clay. At an approximate depth of 20 feet a natural flow of brine is encountered. This brine is collected in shallow excavations called vats, which are 50 or 60 feet wide and a few hundred feet long and are arranged parallel to one another. The salt water is allowed to run into them to a depth of an inch and evaporates to dryness, making a hard foundation for the salt subsequently formed. Additions of brine are made and evaporated, and the salt layer is thus thickened. The salt formed is hoed up into piles. The Eagle Salt Works has reported a substantial production in recent years.

The method described differs somewhat from the procedure formerly employed at the Eagle Salt Works, which has been described by I. C. Russell ${ }^{1}$ as follows:

Water from springs on the eastern edge of the plain is conducted over the surface of the lake beds, and is made to flood small areas inclosed by low dams or ridges of clay. The brine soaks from the flooded areas through the ridges of clay, and ente:s shallow vats dug in the lake beds on either side. Here, on evaporation, the salt deposits. The areas flooded by the fresh water are called reservoirs, the troughs between them are called "vats." They are arranged alternately and may be multiplied to any extent. A profile through a reservoir and vats is shown in the figure.

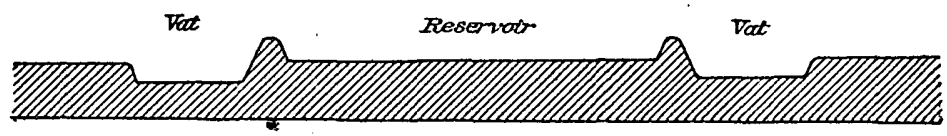

Figure 9.-Section of reservoir and vats, Eagle Salt Works, Leete, Nev. (After I. C. Russell.)

The accompanying table gives an analysis of brine from a vat in which the salt had begun to crystallize. The figures, originally stated in conventional combinations in percentage, have been calculated to ionic form in grams per kilogram. The content of potassium of this concentrated solution is very small.

Analysis of brine, Eagle Salt Works, Leete, Nev.

(Spocific gravity, 1.2115; results in grams per kilogram. F. W. Taylor, analyst.)

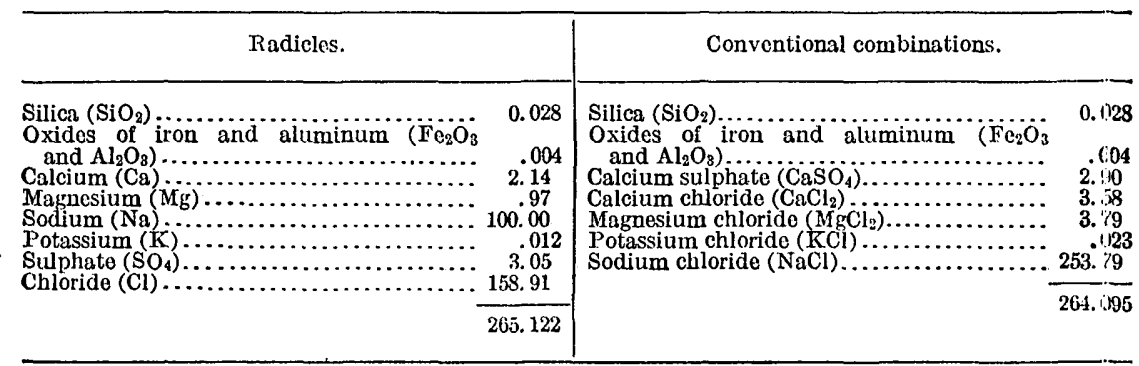

1 Russell, I. C., Geological history of Lake Lahontán, a Quaternary lake of northwestern Nevada: U. S. Geol. Survey Mon. 11, pp. 233-234, 1885. 
PARRAN.

Parran is on the main line of the Southern Pacific Railroad between Ogden and San Francisco, in the northwestern part of Churchill County, about 10 miles south of the south end of Humboldt Lake. A small quantity of salt obtained by solar evaporation and used chiefly for stock was collected there in 1911.

WHITE PLAINS.

White Plains (Huxley station) is on the main line of the Southern Pacific Railroad, about 4 miles north of Parran and 5 or 6 miles from the south end of Humboldt Lake. It is one of the notable salines in this part of Nevada. No report reached the Survey of the production of salt at this place in 1915, but formerly it was an important salt-producing locality, and the Desert Crystal Salt Co. operating there had an extensive acreage of vats for making salt by solar evaporation. These vats were simply shallow excavations inclosed by low embankments, into which the brine was run.

-

DIXIE SALT MARSH.

The saline deposit in Dixie Valley (Osobb Valley of the older reports ${ }^{1}$ ) lies east of Carson Desert and nearly 500 feet lower, being separated from it by the Stillwater Mountains. The valley was formerly occupied by a shallow lake, the final stages of the evaporation of which probably occurred on the site of the present marsh, which covers an area of about 40 square miles. An area of 9 square miles near the center of the marsh is covered with a crust of salt 1 to 5 feet thick, below which is a saline mud, underlain by layers of salt and mud. During wet seasons portions of the flat are flooded to a depth of a few inches.

During the sixties much salt was hauled from the marsh to Virginia City, where it was used to chloridize silver ores. Borax also was obtained just north of the marsh. Salt is not produced here at the present time.

The brines in the marsh have been tested by the United States Geological Survey ${ }^{2}$ and by private corporations to obtain data on the occurrence of potash salts. The tests show that the potash content of the brines and salines is commercially negligible. The following analysis by R. W. Woodward ${ }^{3}$ shows that the salts are nearly pure sodium chloride.

\footnotetext{
1 Hague, Arnold, and Emmons, S. F., Descriptive geology: U. S. Geol. Expl. 40th Par. Final Rept., vol. 2, pp. 707-708, 1877.

2 Hance, J. H., Potash in western saline deposits: U. S. Geol. Survey Bull. 540, pp. 463-464, 1914. Young, G. J., Potash salts and other salines in the Great Basin region: U. S. Dept. Agr. Bull. 61, pp. 54-56, 1914. 3 Hague, Arnold, and Emmons, S. F., op. cit., p. 708.
} 
Analysis of salt from Dixie Salt Marsh, Ncv.

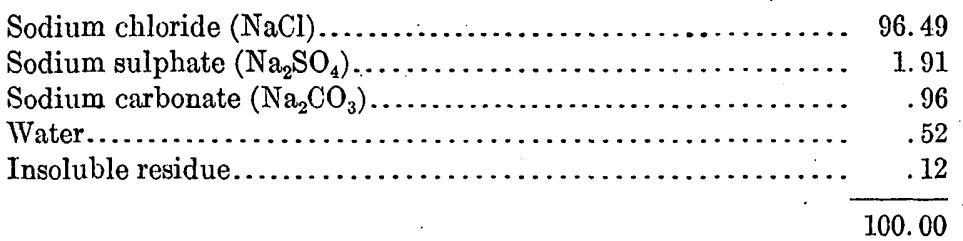

ESMERALDA AND MINERAL COUNTIES.

LOCATION OF DEPOSITS.

In a district comprising the central and northwestern parts of Esmeralda County and the southeastern part of Mineral County there is a series of extensive alkali flats containing salt deposits similar to that at Sand Springs, Churchill County. Rhodes Marsh, in Minoral County, is in the northern part of this district; Columbus Marsh is farther south, Blair Junction being a railroad station in its border; and Silver Peak Marsh, from which production of salt has been reported in recent years, lies still farther south, near the settlement of Blair.

\section{RHODES MARSH:}

Rhodes Marsh is circular in form and $2 \frac{1}{2}$ to 3 miles in diameter; its area is 5 to 6 square miles. In its center is a layer of pure salt, which occupies an area of a square mile or so. Surrounding this central crust of salt occur borax, in pure form and in the forrn of tincal, ulexite, a hydrous borate of sodium and calcium, and sodium sulphate and carbonate. Common salt is found almost everywhere, but in pure form only in the central part of the marsh.

The localization of the salts of different kinds contradicts the idea that the marsh is a simple dried-up lake. The most logical explanation is that the former lake must have been supplied by springs which brought to the surface various kinds of salts. These springs continued to act after the lake dried up, thus localizing the material deposited from them. Common salt, the most abundant ingredient of the lake water, left everywhere as a crust when the lake dried up, was subsequently leached out and accumulated in very pure form in the central or lowest part of the playa.

This marsh, as well as Columbus Marsh, was better known as a borax marsh, as it contained large deposits of the borates of lime and soda. It is of interest to know, however, that Columbus Marsh was located as a salt bed in 1864 .

The United States Geological Survey has done some drilling at Rhodes Marsh in connection with its potash investigations, and information has been obtained on the potash content of a flowing well out on the salt flat. The spring issues among blocks of basalt, 
possibly along or near a basalt dike. The salt is not worked, but there was formerly an extensive equipment on the railroad. ${ }^{1}$

COLUMBUS MARSH. ${ }^{2}$

Columbus Marsh is situated on or near the line between Esmeralda and Mineral counties. The marsh is approximately 30 square miles in area, about 8 miles in longest dimension from north to south, and about 6 miles in greatest width. It is a typical playa, and little salt shows on its surface except in the marginal areas, where several borax plants were located during the early days of the borax industry. Under the direction of the United States Geological Survey six shallow wells were sunk in the marsh during 1912 and three others during 1913. The muds encountered in these wells differed somewhat in character, consisting of sand, clay, and hard consolidated material, but no distinct saline horizons were observed. The analytical data as originally published showed that some of the muds from one of the wells contained unusual amounts of potash in the soluble salts, but a more extended investigation ${ }^{3}$ has shown that these apparent high values resulted from the method of clarifying the water extracts with ammonium chloride, that a large part of the potash present in the muds is held either mechanically or in a loosely combined form, and that only small quantities of soluble matter including potash are extracted by water alone. The average results for one of the wells, excluding surface material, gave 2.84 per cent of total dissolved salts, 5.17 per cent of which is potassium. With few exceptions the waters from the wells bored in Columbus Marsh were very dilute and contained only small amounts of potash. Consequently, it is not believed that potash salts in commercial quantity can be derived from the brines or muds of Columbus Marsh.

SILVER PEAK MARSH. ${ }^{4}$

Silver Peak Marsh is 30 miles southeast of Columbus and occupies the lowest part of the Clayton Valley. It is included in Tps. 1 and $2 \mathrm{~S} .$, Rs. 39, 40, and $41 \mathrm{E}$. It is about 10 miles long from northeast to southwest, about 4 miles wide, and has an area of approximately 32 square miles. (See Pl. XII.) It is reached on the Silver Peak Railroad, a short line running southward from Blair Junction on the Tonopah \& Goldfield Railroad to Blair.

\footnotetext{
${ }^{1}$ LeConte, Joseph, California State Mineralogist Third Ann. Rept., 1883. Young, a. J., op. cit., pp. 42-43.

2 Gale, H. S., Potash tests at Columbus Marsh, Nev.: U. S. Geol. Survey Bull. 540, pp. 422-427, 1914. Young, G. J., op. cit., pp. 53-54.

${ }^{3}$ Hicks, W. B., Composition of muds from Columbus Narsh, Nev.: U. S. Geol. Survey Prof. Paper 95, pp. 1-11, 1915.

4 Dole, R. B., Exploration of salines in Silver Peak Marsh, Nev.: U. S. Geol. Survey Bull. 530, pp. 330345, 1911. Young, G. J., op. cit., pp. 39-43.
} 


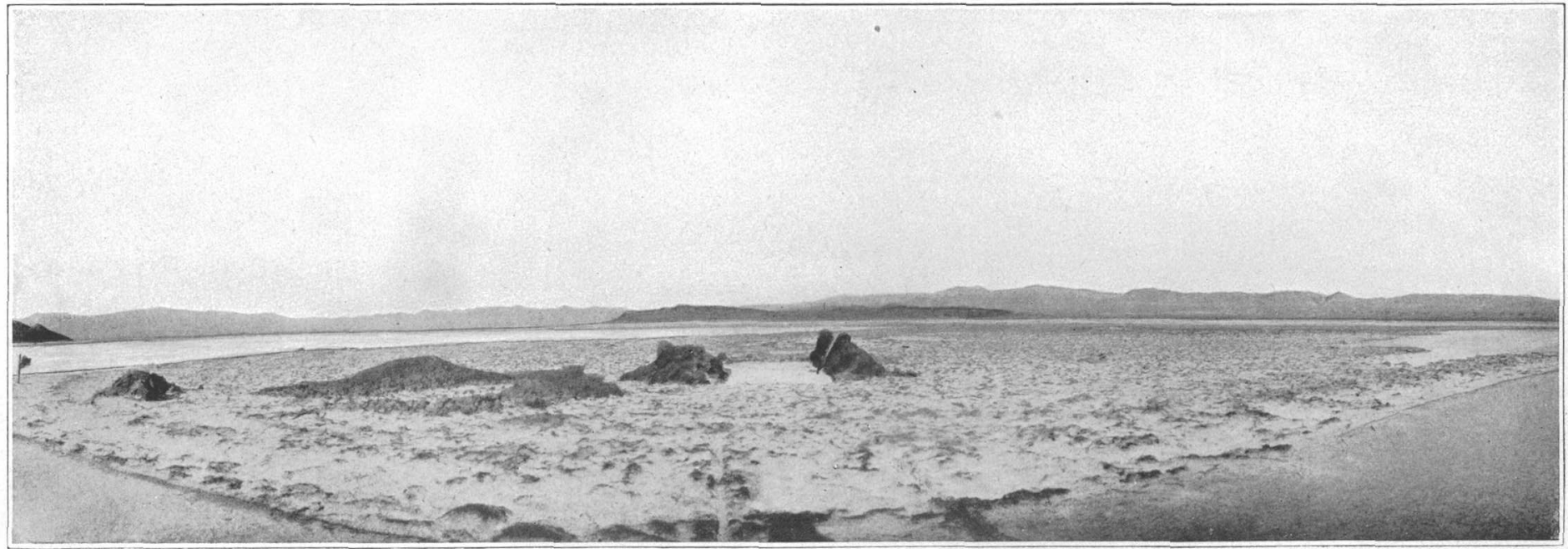

VIEW OF SILVER PEAK MARSH, NEV., A TYPICAL PLAYA.

Photograph by F. R. Porter. 
The surface of the marsh is generally dry but, after a heavy rainfall may be covered a foot deep with water. Ground-water level is near the surface, and shallow holes find mud and concentrated brines. The water has been derived in part at least from the drainage of the surrounding mountains. According to Dole, leachings from the stratified Tertiary rocks, extensive areas of which occur in the basin, account in part for the saline residue, and it is possible that a far greater area than the present basin was formerly tributary to Silver Peak Marsh and furnished part of the saline material now found in it.

The drainage area of each of the playas in this region includes large districts of upturned early Tertiary sediments, so that the playa deposits would naturally be expected to show the same charscteristics. However, they do not, and the difference in chemical composition between the salts in Silver Peak Marsh and those farther north, which contain borax predominantly, has led Spurr ${ }^{1}$ to suggest that special agencies have been at work in Silver Peak Marsh. The special agency which has given rise to the salt (sodium chloridc) at Silver Peak he regards as the deep-seated hot springs, which furnish water whose solid contents differ in composition from the surface leachings from the Tertiary borate deposits in the surrounding hills. This explanation was also offered for the localization of salts in the Rhodes Marsh, by Le Conte. ${ }^{2}$ Dole further suggests, however, that the brine springs may get their salt from the muds of the flat instead of adding salt to them.

The following quotation on the commercial possibilities of salt production at Silver Peak Marsh is taken from Dole: ${ }^{3}$

Practically the entire surface of the playa, 32 square miles, is covered with salt that averages in depth about one-quarter of an inch. The upper muds, averaging probably 10 feet thick, contain not less than 2 per cent of salt. It is estimated that not less than 15 square miles of the northeastern part contains a 10-foot saline bed, of which at least 60 per cent is salt. It is calculated from these moderate estimates that $15,000,000$ tons of salt lies within 40 feet of the surface. The high rate of evaporation, which would permit solar concentration of brines, the absence of long-ccintinued rainfall to interfere with operations, the nearness of a railroad, and more especially the high degree of purity of the product as indicated by analyses of the brines, are extremely favorable in considering the possibility of utilizing these deposits.

Salt is now being produced on a small scale by Frank Porter, of Silver Peak, whose works are situated in sec. 24, T. 2 S., R. 39 E. Brines from pits in the upper muds or from furrows filled with rainwater that has become saturated are concentrated and crystallized by solar evaporation in shallow vats dug in the playa, and the salt thus obtained is bagged for sale. Mr. Porter states that about 1.50 tons has been produced in three years.

A composite sample of the salt that crystallizes in surface pits in Silver Peak Marsh was collected by Dole, May 25, 1912. It was com-

1 Spurr, J. E., Ore deposits of the Silver Peak quadrangle, Nev.: U. S. Geol. Survoy Prol.: Paper 55, pp. 158-165, 1906.

2 Le Conte, Joseph, California State Mineralogist Third Ann. Ropt., p. 51, 1883.

B Op. cit., pp. 340-341. 
posed of 35 portions taken from sumps at the foot of every second pole along the power line crossing the marsh. The composite, having a total weight of 5 pounds, was dried, mixed," quartered, and analyzed. The results are shown in the following table:

Analysis of salt from Silver Peak Marsh, Nev.

[W. B. Hicks, analyst.]

\begin{tabular}{|c|c|c|c|c|}
\hline Constituents. & $\begin{array}{l}\text { Percent- } \\
\text { age of } \\
\text { sample } \\
\text { as } \\
\text { collected. }\end{array}$ & $\begin{array}{l}\text { Percent- } \\
\text { age of } \\
\text { soluble } \\
\text { matter. }\end{array}$ & Conventional combinations. & $\begin{array}{l}\text { Percont- } \\
\text { age of } \\
\text { total } \\
\text { weight. }\end{array}$ \\
\hline 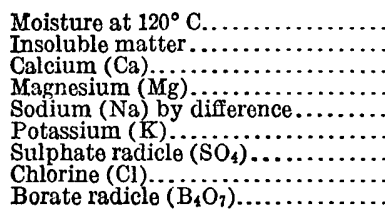 & $\begin{array}{r}1.22 \\
1.12 \\
\text { Trace. } \\
37.15 \\
.66 \\
.82 \\
58.46 \\
.06\end{array}$ & $\begin{array}{r}0.52 \\
\text { Trace. } \\
38.00 \\
.67 \\
.84 \\
59.92 \\
.06\end{array}$ & 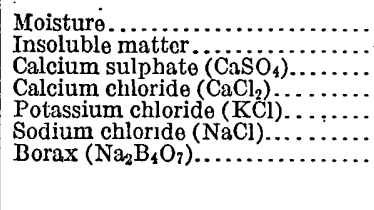 & $\begin{array}{r}1.22 \\
1.12 \\
1.16 \\
.46 \\
1.26 \\
94.71 \\
.07 \\
100.00\end{array}$ \\
\hline
\end{tabular}

NYE COUNTY.

RAILROAD VALLEY'.

Railroad Valley is about 100 miles northeast of Tonopah and a somewhat shorter distance southwest of Ely, the two nearest railroad stations. The valley proper is a typical desert basin, extending 85 miles in a northerly direction and having a maximum width of 15 miles. A saline mud playa occupies the lowest part of the valley. It is lowest in the north-central part and has an area of approximately 40 square miles. The surface of the mud bears a thin crust of salt, especially after flooding and evaporation. The margins of the mud flats also show salt deposits. At the north end of the marsh is a series of so-called "salt pans." These are irregularly shaped areas more heavily incrusted with salt than the rest of the marsh. They range in size from a fraction of an acre to several acres. Saline efflorescences several inches thick occur on them. After periods of high water, following floods, they drain to the lower parts of the marsh. Salt from the pans at the north end of the marsh has for many years been collected for local use. In the early days it was scraped into piles and hauled to Tybo, a mining camp 45 miles southwest, for chlorinating lead-silver ores.

These saline efflorescences were long reported to contain considerable potash salts, and samples of them tested by the United States Geological Survey were found to contain as high as 12 per cent

1 Hance, J. H., Potash in western saline deposits: U. S. Geol. Survoy Bull. 540, pp. 457-462, 1914. Young, G. J., Potash salts and other salines in the Great Basin region, U. S. Dept. Agr. Bull. 61, pp. 56-59, 83-85, 1914. Railroad Valley Saline Co., Potash, Sept. 7, 1911. Free, E. E., Potash, Aug. 22, 1912; rev. ed., Nov. 25, 1912. Chandler, A. E., Railroad Valley water supply, Aug. 12, 1912. Marcan, H. W., Railroad Valley soils, Aug. 10, 1912. Several minor circulars also were issued by the Railroad Valley Co. 
potash $\left(\mathrm{K}_{2} \mathrm{O}\right)$ in the soluble portion. The valley has also been drilled by the Railroad Valley Co. for potash salts, but only negative results have thus far been obtained. Analyses of saline residues and natural spring and well waters from the drainage basin of Railroad Valley, together with analyses of brines from shallow pits in salt pans north and northwest of Butterfield Marsh, have been published by the Geological Survey.' These analyses, numbering 164 in all, were undertaken primarily to determine the potash content. The results of the analyses of 85 samples of saline residues, including efflorescences and crusts from the drainage basin of Railroad Valley, show an average content of 5.23 per cent potash in the soluble portion, which was 45.57 per cent of the sample. Eleven samples of brine from shallow pits dug in the salt pans north and northwest of Butterfield Marsh were also analyzed. The average content of dissolved salts, dried at $105^{\circ} \mathrm{C}$., expressed in grams per 100 cubic centimeters of original sample, is 12.33. The content of potash expressed as percentage of dissolved salts is 7.23.

\section{ELKO AND EUREKA COUNTIES.}

WEST OF DIAMOND RANGE.

Arnold Hague ${ }^{2}$ mentions the occurrence of salt in the lower Quaternary plains which occupy the valley west of the Diamond Range, Nev. These plains are strongly impregnated with salt, and on evaporation of the water in the upper end of the valley exhibit broad fields of salt crust, which was used years ago for extracting: silvor from its ores.

\section{WASHOE COUNTY.}

BUFTALO SPRINGS SALT WORKS. ${ }^{3}$

Salt was formerly obtained at the Buffalo Springs Salt Works, on: the west side of Smoky Creek Desert, Washoe County. The desert; is a vast expanse of barren yellowish mud, impassable except during the dry season. Water that flows over the surface of the lake beds in the vicinity of the salt works soon becomes strongly impregnated and on evaporating in low places leaves a crust of salt several inches thick. The less pure grades formerly used in chloridizing silver ores were obtained from this source. Sodium sulphate and other saline minerals are also found at places in the lake beds. The sodium sulphate is known to be several feet thick in places, but it has never been completely explored. At the salt works the brine

1 Hance, J. H., op. cit., pp. 457-462.

2 Hague, Arnold, and Emmons, S. F., Descriptive geology: U. S. Geol. Expl. 40th Par. Final Rept., vol. 2, pp. 549-550, 1877.

3 Russell, I. C., Geological history of Lake Lahontan, a Quaternary lake of northwestern Nevada: U.S. Geol. Survey Mon. 11, pp. 232-233, 1885.

$40104^{\circ}-18-B u l l .669-10$ 
which impregnates the lake beds was collected in wells and was then pumped into surface vats, where it evaporated, and the resulting crust was gathered. The brine from the wells has been analyzed, with the following results:

Analysis of brine, Buffalo Springs Salt Works, Washoe County, Nev.

[Specific gravity, 1.133. F. W. Taylor, analyst.]

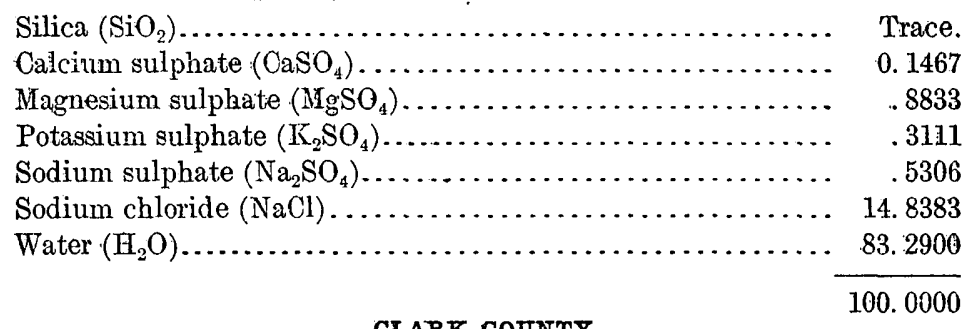

CLARK COUNTY.

VIRGIN RIVER SAIT DEPOSITS.

Virgin River valley is mostly in Nevada. Rock salt occurs in this valley a few miles north of the Colorado in beds that lie below beds of gypsum. 'The presence of the gypsum and salt indicates that the formation containing them is not a part of the overlying Temple Bar conglomerate (Quaternary), which does not contain gypsum or salt in the typical exposures so far observed. The stratigraphic position of the saline beds indicates that the formation containing them may be the time equivalent of the Greggs breccia (Tertiary).

The cliffs of salt, which are remarkable, are exposed in natural outcrop along the valley of Virgin River. (See Pl. XIII.) Although these have attracted attention from the days of earliest exploration in the West, they lie in a region that is not readily accessible, and the salt has not been utilized except locally in a very small way. Hoyt S. Gale contributes the following notes regarding the deposits:

The salt ledges are exposed at several places along both sides of the Virgin River valley between St. Thomas and the mouth of the Virgin at Colorado River, the outcrops extending over a distance of at least 12 miles. Similar outcrops are also reported 30 miles east of St. Thomas, so it appears evident that the salt was originally a continuous and widely distributed stratum laid down during the formation of a certain part of the sedimentary rocks of this part of the country. The salt is associated with a great thickness of gypsum and gypsiferous shales and is included in a series of characteristically red shales and sandstones, usually referred to as "Red Beds," of Triassic or Permian age. The beds including the salt have been very much faulted and folded, and the present outcrops represent disconnected parts of them. Only in exceptional positions has the salt itself been preserved in open exposures or under shallow cover above ground-water level. 


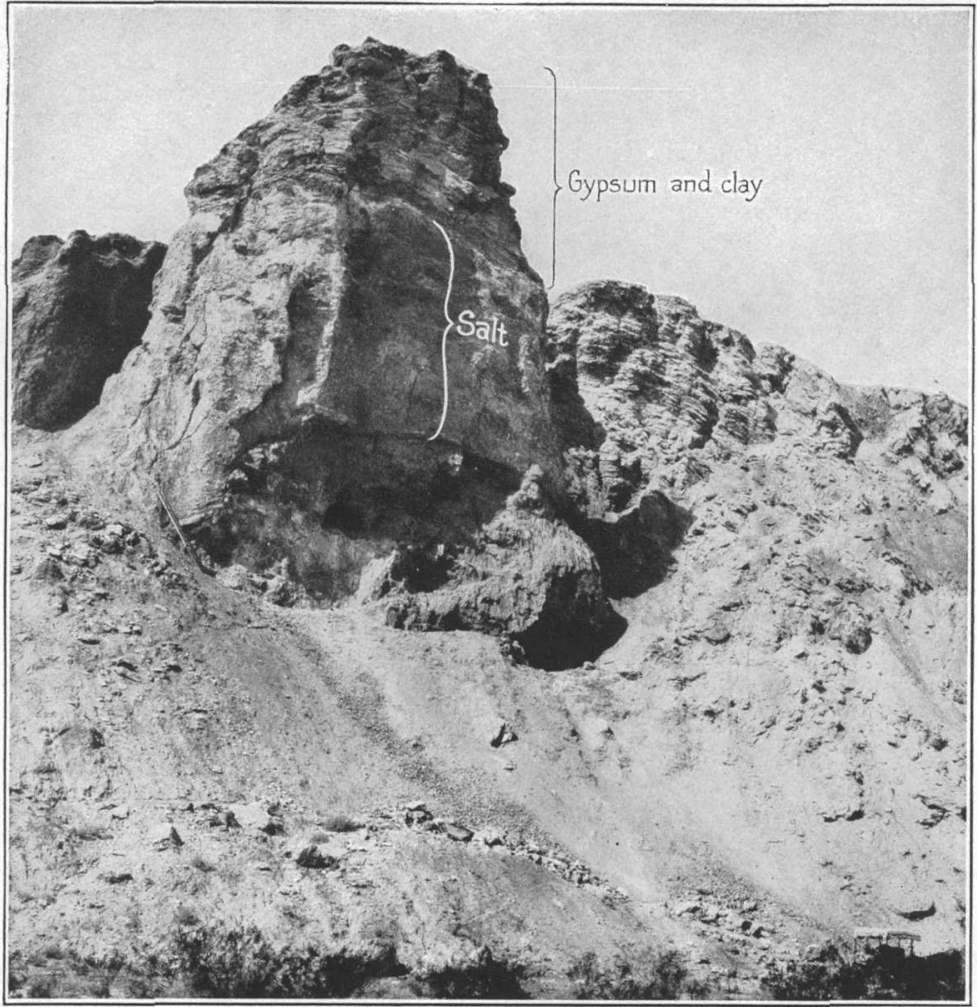

A. SALT EXPOSED ON WEST SIDE OF VIRGIN RIVER 5 MILES SOUTH OF ST. THOMAS, NEV.

Photograph by N. H. Darton.

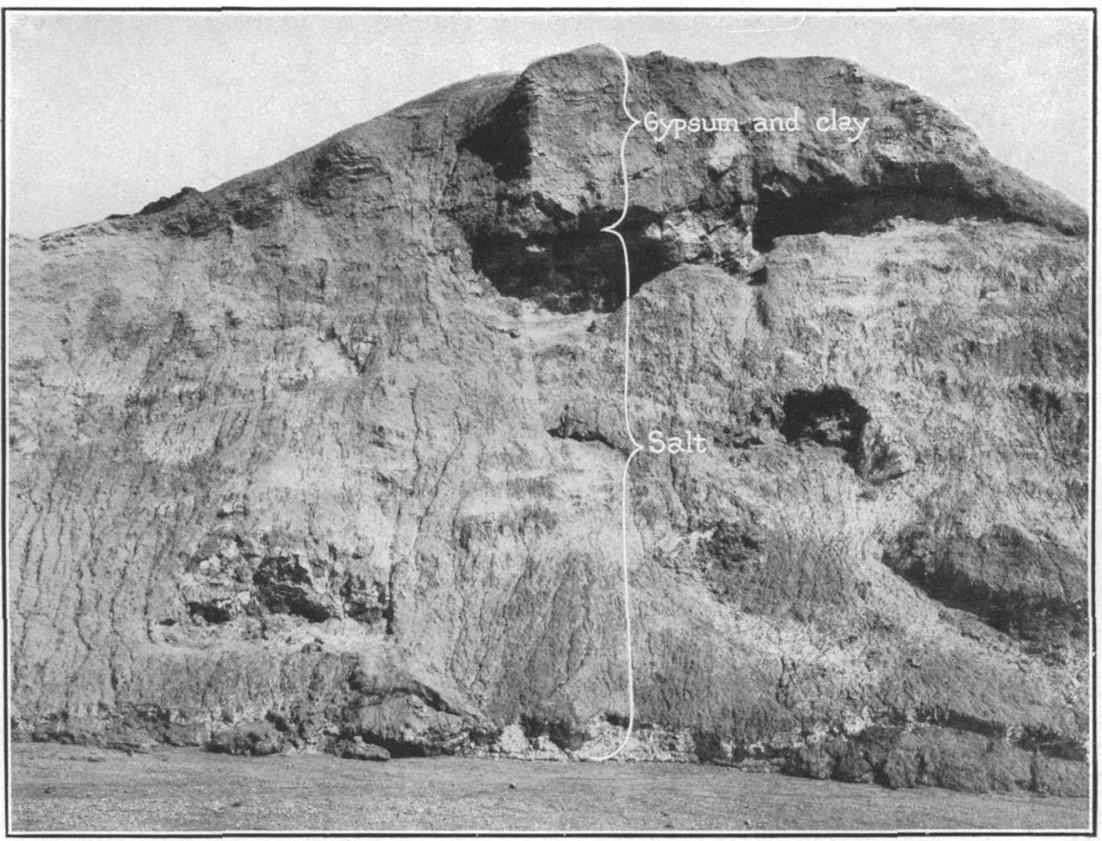

B. SALT IN ARROYO NEAR VIRGIN RIVER BOTTOM 5 MILES SOUTH OF ST. THOMAS, NEV.

Photograph by N. H. Darton. 
It is natural to look to such a region as this for the possible occurrence of potash-rich portions of these saline deposits. The largest salt ledge exposes an almost vertical face of solid crystalline salt, representing a bed at least 100 feet in height, in nearly horizontally bedded position. The base is concealed, so the bed may be actually much thicker. The top of the salt is very sharply defined, and the bed is overlain by reddish clay and higher in the section by gypsum, shale, and red sandstone, the beds including also an interbedded flow of dark lava. Samples of the salt clug from the face of this cliff have been analyzed with the following results:

Tests of samples from Salt Cliff, $\grave{3}_{\frac{1}{2}}$ miles south of St. Thomas, on Virgin River, Nev.

\begin{tabular}{|r|r|r|r|}
\hline No. & $\begin{array}{r}\text { Distance } \\
\text { below top } \\
\text { of cliff. }\end{array}$ & $\begin{array}{c}\text { Soluble } \\
\text { portion. }\end{array}$ & $\begin{array}{r}\text { KCl in } \\
\text { soluble } \\
\text { portion. }\end{array}$ \\
\hline & Feet. & Per cent. & Per cent. \\
1 & 60 & 94.98 & 0.29 \\
2 & 50 & 93.52 & 0.08 \\
5 & 40 & 97.12 & 0.09 \\
6 & 35 & 98.88 & $\mathbf{0 . 0 8}$ \\
\hline
\end{tabular}

The great mass of crystalline translucent salts appears to be rather uniform in composition, though it contains an interbedded layer of gypsiferous clay a few inches thick. So far as present evidence goes, it appears to carry no potash-rich layers.

The other salt cliffs or exposures down the Virgin River valley, including the last one just below the "Narrows," about 6 miles above the mouth of the Virgin, were examined and some samples taken, with results similar to those already given. A salt well near Colorado River below the mouth of the Virgin was also visited and sampled, and the results of the tests are as follows:

Potassium chloride in soluble portion of samples from salt well on Colorado River.

Brine containing 30.77 per cent of dissolved salts

Per cent.

Efflorescence about rim of well containing 33.31 per cent of matter

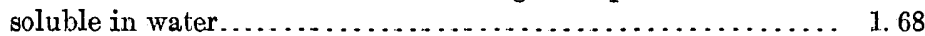

Samples of river water above and below this salt field were taken to obtain information concerning salt beds that were being leached.

Tests of samples of water from lower Virgin River valley, Nev.

\begin{tabular}{|c|c|c|}
\hline & $\begin{array}{c}\text { Total solu- } \\
\text { ble salts. }\end{array}$ & $\begin{array}{c}\mathrm{KCl} \text { in } \\
\text { total salts. }\end{array}$ \\
\hline 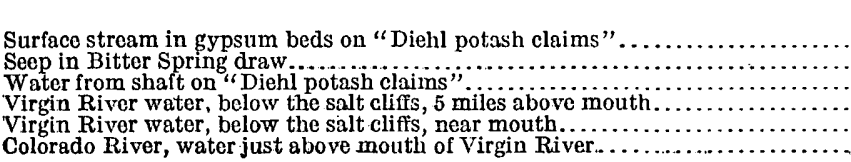 & $\begin{array}{c}\text { Per cent. } \\
0.97 \\
.38 \\
4.19 \\
.365 \\
.38 \\
\text { a. } 102\end{array}$ & $\begin{array}{r}\text { Per cent. } \\
3.07 \\
7.82 \\
\text { Not dist. } \\
4.93 \\
\text { Not dist. }\end{array}$ \\
\hline
\end{tabular}

a This result may be too high, as sample was difficult to filter. 
Probably the object of these last tests was not accomplished because the test was not complete enough. One result, that from the seep in Bitter Spring Draw, which gave 7.82 per cent of potassium chloride in the salts dissolved in a rather dilute water, may be of some significance. Of itself, of course, so dilute a water could be of no value, and the quantity of the flow is insignificant.

Potash may be present in this area, in association with salt and gypsum, but no very definite indication of its existence, certainly not in commercial quantity, has been brought to light.

\section{BIBLIOGRAPHY.}

Browne, J. R., Resources of the Pacific slope, pp. 256, 309-312, 338, 414, 418, 419, San Francisco, 1869.

Dole, R. B., Exploration of salines in Silver Peak Marsh, Nev.: U. S. Geol. Survey Bull. 530, pp. 331-345, 1912 .

Gale, H. S., Potash tests at Columbus Marsh, Nev.: U. S. Geol. Survey Bull. 540, pp. 422-427, 1913.

HANCE, J. H., Potash in western saline deposits: U. S. Geol. Survey Bull. 540, pp. 457-464, 1913.

HIcks, W. B., Composition of muds from Columbus Marsh, Nev.: U. S. Geol. Survey Prof. Paper 95, pp. 1-11, 1915.

HrlaArd, E. W., Salt: U. S. Geol. Survey Mineral Resources, 1882, pp. 543-547, 1883.

LeConte, Joseph, California State Mineralogist Third Ann. Rept., 1883.

Phalen, W. C., Potash salts: U. S. Geol. Survey Mineral Résources, 1915, pt. 2, pp. 108-110 1916.

Russell, I. C., Geological history of Lake Lahontan: U. S. Geol. Survey Mon. 11, pp. 232-235, 1885.

Srurr, J. E., Ore deposits of the Silver Peak quadrangle, Nev.: U. S. Geol. Survey Prof. Paper 55, pp. 158-165, 1906.

Younc, G. J., Potash salts and other salines in the Great Basin region: U. S. Dept. Agr. Bull. 61, 96 pp., 6 pls., 1914.

\section{NEW MEXICO.}

\section{PRODUCTION OF SALT.}

That the actual commercial output of salt in New Mexiso is and has been small is not due to a scarcity of salt. The salt-bearing lakes or salines of this State are to be considered among its important future resources. Little of the product is exported, but a considerable quantity of crude salt is used for salting stock. The salt thus used is gathered by scraping up the deposit formed about salt springs or as a thin layer on the surface of the salines or playas during the dry season. The principal lake-basin deposits are those in Estancia Valley, from which a small production of salt has been reported during recent years.

\section{SALT DEPOSITS.}

\section{GENERAL GEOLOGIC OCCURRENCE.}

Salt in New Mexico occurs chiefly in the upper Carboniferous "Red Beds." It is noteworthy that salt accumulated in this region mainly in upper Carboniferous time and that conditions favoring its deposi- 
tion prevailed over a wide extent of territory. "Red Beds" underlie the greater part of New.Mexico, they outcrop in nearly half the State, and there is more or less salt and gypsum associated wit.' them throughout their extent. It does not follow from these facts, however, that salt in commercial quantities may be found everywhere in the "Red Beds," but the association is so general as to be a helpful guide in the search for both salt and gypsum. The salt worked so far has all been in more recent deposits, probably derived in part directly from the "Red Beds" and in part from springs flowing from them.

\section{ESTANCIA SALT BASIN.}

LOCATION

The salt basin of Estancia Valley is in the central part of Torrance County, near the geographic center of New Mexico. It lies in a depression having no outlet. This depression has a maximum extent of about 65 miles from north to south and 40 miles from east to west and has an area of about 2,000 square miles. The valley is traversed by two railroads, the Panhandle division of the Santa $\mathrm{Fe}$ system and the New Mexico Central Railroad, both of which pass near the salt basin.

GEOLOGY.

West of the valley are the Manzano Mountains, a high range composed largely of metamorphic rocks, including schists and quartzites, with associated masses of granite and other igneous rocks. This range forms a sharp divide between the Estancia and the Rio Grande basins. On the east are the Hills of Pedernal, made up principally of quartzite. Mesas and isolated mountains form the north rim of the valley, and the Mesa Jumanes bounds it on the south.

EXTENT OF THE ANCIENT LAKE.

At the period of its greatest extension the lake that occupied the central portion of the valley was about 35 miles long and 23 miles wide; its area was approximately 450 square miles. Its maximum depth at this period was about 150 feet, and its shore line, which nearly coincides with the 6,200-foot contour, was about 150 miles long. If the ancient lake were now in existence several of the villages in this region would be under water. The evidence of the existence of the ancient lake in this valley consists of shore features and lake sediments.

ChaRACTER AND EXTENT OF THE DEPOSITS.

The salt basins in the Estancia Valley are not remnants of the ancient lake but are rather distinct basins sunk below the level of the plain by which they are surrounded, and most of them are bordered 
by definite and nearly vertical walls. Their flat bottoms coincide practically with the ground-water level and consist of mud covered with crusts of salt, but after rains they may be covered with water. The floor of one basin-Salt Lake (Laguna Salina) - is covered with salt sufficiently thick and pure to be commercially valuable. Thin layers of bloedite crystals $\left(\mathrm{MgSO}_{4} \cdot \mathrm{Na}_{2} \mathrm{SO}_{4} \cdot 4 \mathrm{H}_{2} \mathrm{O}\right)$ occur here, this being one of the two recorded occurrences of this mineral in the United States.

The largest basin, Dog Lake (Laguna del Perro), is about 12 miles long and covers an area nearly equal to the combined areas of all the other basins. Altogether there are scores of salt basins, and their total area is estimated at 13,500 acres.

According to Meinzer, ${ }^{1}$ the most reasonable hypothesis to account for the salinity of the water is that at several horizons in the valley of the central area there are beds which were impregnated at the time of their formation with salt :deposited by evaporating waters and that afterward these beds were buried under later accumulations. It is likely that the shallow sheet of brine coincides approximately with a buried deposit of salt, laid down at the bottom of the ancient lake at a certain stage of its existence. This hypothesis would also explain the sharp boundary of the saline area. 'The geologic horizon of the zone from which the salt is supposed to have been derived originally is that of the Carboniferous "Red Beds."

SAIT IAKES OF THE WHITE SAND PLAINS.

The White Sand Plains of New Mexico are in the Tularosa Basin, which includes parts of Dona Ana, Socorro, and Otero counties. The extent of these plains from north to south is about 35 miles; their greatest breadth, at their southern margin, is 18 miles. The lines connecting the extreme points are irregular, inclosing a roughly triangular area of about 350 square miles. To this area may be added a tract nearly as large, comprising saline land on the west and that in isolated localities on the south. The whole plain is Quaternary, but inasmuch as it is either higher than the rest of the basin or is more completely drained to the south, the saline materials are not brought to the surface. ${ }^{2}$

The salt flats occur among the gypsum ridges. This occurrence of the salines accounts for the most curious and notable of the many peculiarities of these plains, namely, the dunes of white sand from which the plains take their name. These drifting sands are almost pure gypsum and are derived from the gypsum sand formed in the lakes. The common salt and the alkaline salts are also driven with

1 Meinzer, O. E., Geology and water resources of Estancia Valley, N. Mex.: U. S. Gieol. Survey WaterSupply Paper 275, p. 51, 1911.

2 Herrick, C. L., The.geology of the white sands of New Mexico: New Mexico Univ. Bull., vol. 2, fascicle 3, p. 12,1900 . 
the gypsum, but on account of their solubility they do not rernain in the dunes. These dunes lie to the south and east of the flats whither they are driven by the prevailing winds, and they not only cover a large part of the salines themselves but form a growing fringe to the east and soutb. The soil underneath them is impregnated with salt and soda, and salt lakes are scattered over the area. INear the southeastern limit of the sands is a salt lake which for many years has been a source of salt for the surrounding ranches. Near the south end of the basalt flow, about a mile from the Malpais Spring, there is still another small salt lake, which likewise has furnished salt to ranches within a large radius for many years, and which is usually covered with a thin crust of pure salt. Farther west, along the course of a drainage arroyo, are numerous salines and alkali flats, which gradually broaden and form what may be described as one vast alkali and salt plain, in which brine stands for part of the year. Where these arroyos end in the salt lake and along the shores of the lake are erosion bluffs, some over 20 feet high, in which are exposed the various deposits of the valley filling, some of recldish tint, with their contained saline and gypsum deposits.

Herrick ${ }^{1}$ has given a detailed description of the general geclogy of this region and of Lake Otero, as he has called the basin. The saline beds comprised in the lake basin are called the Otero marls by Herrick, who says in his later descriptions of the salines:

The salts upon the playas differ in different cases. In some cases, when dry, there is a layer of nearly pure salt (chloride of sodium) several inches thick. More frequently other salts occur in considerable abundance. When carbonate of soda preponderates it will often form a dense crust in which little common salt is a prominent ingredient. Borax and carbonate of potassium also occur under somewhat different conditions. There seems to be considerable uniformity in the amount of salt in the several divisions. Thus in the series of playas north of the barrier above described as separating the great western salt lakes into two portions an average of two samples gave over 6 per ccnt of salt, while to the south the Soda Lake, which is the southern part of this chain, gave an average of 14.6 per cent, besides large quantities of other salts. This might seem to indicate a tendency to concentrate toward the southern part of the area. Nevertheless the area near "Malpais Spring," which issues from the southern end of the lava sheet, and the flats of the northern end of the old Lake Otero are heavily charged with salt. An average of over 15 per cent was found here without including several lakes whence commercial supplies of salt have been taken and which afford a continuing supply of the pure mineral.

All the arroyos in the east side of the basin are saline. The water flowing in Lost River, for example, carries 7 per cent salt, while soil in Tularosa Arroyo runs 7.8 per cent. The salt lake into which Lost River flows is saturated brine and furnishes commercial supplies. Analyses of the "white sands" show that this gypsum sand contains very little salt.

.1 Herrick, C. L., Lake Otero, an ancient salt lake basin in southeastern New diexico: Am. Geologist, vol. 34, pp. 186-187, 1904. 
Meinzer and Hare ${ }^{1}$ state that the deposits of sodium chloride, or common salt, and sodium sulphate, locally and incorrectly called "soda," are found in certain low places. Thin crusts of salt occur on the small northern alkali flats, in places along Salt Creek, and in some of the arroyos and small flats east of the white sands. The salines were formed in part when the ancient lake dried up. They were also formed in part and are still being formed by the evaporation of mineralized ground waters that reach the surface through springs and by capillary action. Of the sodium salts common salt is the most abundant, but in certain localities the sulphate predominates.

Free ${ }^{2}$ who examined the basin of Lake Otero, concluded that potash salts do not occur in commercial quantity as surface deposits, as the mountains bordering the basin are made up of rocks almost entirely of sedimentary origin, and hence can not be expected to carry or to yield any significant quantity of potash salts. He estimates that less than 5 per cent of the exposed rocks in the drainage area are potash bearing and therefore concludes that potash salts are not entering the present drainage basin and that the supply in the past was probably no greater than at present. Though saline beds probably underlie the present surface of the basin, the chance that potash salts may be found associated with them is considered negligible. Free expresses the opinion that the chances for finding buried beds of potash salts in this basin are less than in many other undrained basins of the region.

\section{ZUNI SAIT DEPOSITS.}

The Zuni salt deposits of New Mexico are in the northwestern part of Socorro County, about 80 miles south of Gallup, which is on the main line of the Atchison, Topeka \& Santa Fe Railway, and about the same distance west of Magdalena, which is on a branch line of the same system.

The salt deposits occur in a lake and in part of a deep depression in a plain of Cretaceous sandstone. The depression is about a mile in diameter and is inclosed by walls of sandstone, capped in part by lava, and averaging 150 feet in height. The lake is about 4,000 feet long east and west and about 3,000 feet wide and is apparently shallow. The water is practically saturated with salt, which crystallizes out, especially where the water is most shallow. In the southern part of the lake extensive bodies of salt rise a few inches above the surface of the water.

The lake is fed by a spring or springs below the water level near the southern margin. The springs are believed to emerge from "Red Beds," which occur at no great distance below the bottom of the

\footnotetext{
1 Meinzer, O. E., and Hare, R. F., Geology and water resourcẹs of Tularosa Basin, N. Mex.: U. S. Geol. Survey Water-Supply Paper 343, pp. '72, 130, 1915.

2 Free, E. E., U. S. Dept. Agr. Bur. Soils Circ. 61, 1912.
} 
depression and are usually slightly saline. In the southern part of the lake are two cinder cones, one of which contains a crater that has a salt pool in its bottom, in which the water stands at lake level. The water in this pool is salty though somewhat less so than that in the lake.

It is probable that at one time the lake filled the entire depression, but owing to evaporation and the deposition of wash from the adjacent slopes it has shrunk to its present size. Extensive bodies of salt will probably be found below the bottom of the lake and along its shores. .

The deposit has been a source of supply for Indians and Mexicans for centuries, and the salt is still collected by a small colony of Mexicans in a very crude manner and is hauled to the surrounding ranches. A large output could be obtained by solar evaporation of the lake water, if the demand justified the effort.

The soluble matter in samples of the brine and of the mud from the bottom of the lake analyzed in the laboratory of the United States Geological Survey is nearly pure sodium chloride.

\section{OTHER LOCALITIES.}

The water of a small lake 15 miles southeast of Carlsbad, sampled by Hance ${ }^{1}$ and analyzed in the Survey laboratory, contained 11.15 per cent of dissolved salts, 0.85 per cent of which was potash. The dissolved material probably came from the adjacent rocks, which belong to the "Red Beds." A lake at Playas reported as alkaline was also visited by Hance, ${ }^{2}$ but the water in it was found to be comparatively fresh. At certain seasons of the year the lake bed is entirely dry, but even then very little alkali is present.

There are many salt springs in New Mexico, but salt is not obtained from them except for local use. One large spring is on the Rio Salada, 30 miles northwest of Albuquerque; another is 20 miles west of Belen, and a third is at the south end of the Malpais in Tular:osa Valley, 48 miles northwest of Alamogordo. There are scores of sinall salt springs in this State.

The "Red Beds" which underlie the Pecos Valley and Staked Plains in Eddy, Chaves, and Roosevelt counties contain many thick beds of salt of wide extent, but they lie far beneath the surface. Information regarding them is derived from records of scattered borings for water or oil. These salt deposits are 300 to 500 feet thick and occur in heavy beds separated by layers of clay or sand; in part of the area they lie only a few hundred feet below the surface. The 2,600-foot boring at Carlsbad penetrated many thick salt beds in this area; they have been reached also by borings easit of Artesia and Roswell, as well as by numerous deep holes in the Staked

1 Hance, J. H., Potash in wostern saline deposits: U. S. Geol. Survey Bull. 540, pp. 467-468, 1913. 2 Idem. 
Plains region in western Texas, some of them not far east of the New Mexico line.

BIBLIOGRAPHY.

Darton, N. H., Zuni salt deposits, N. Mex.: U. S. Geol. Survey Bull. 260, pp. 565$566,1905$.

The Zuni Salt Lake: Jour. Geology, vol. 13, pp. 185-193, 1905.

Free, E. E., An investigation of the Otero Basin, N. Mex., for potash salts: U. S. Dept. Agr. Bur. Soils Circ. 61, p. 7, 1912.

Hance, J. H., Potash in western saline deposits: U. S. Geol. Survey Bull. 540, pp. $467-468,1913$.

Herrick, C. L., Salt in New Mexico: New Mexico Univ. Hadley Lab. Bull., vol. 2, pt. 1, p. 6, 1900 .

Geology of the white sands of New Mexico: New Mexico Univ. Hadley Lab. Bull., vol. 2, pt. 1, fascicle 3, 17 pp., 1900.

- Report of a geological reconnaissance in western Socorro and Valencia counties, N. Mex.: Am. Geologist, vol. 25, pp. 331-346, 1900.

- Lake Otero, an ancient salt lake basin in southeastern New Mexico: Am. Geologist, vol. 34, pp. 174-189, 1904.

Jones, F. A., New Mexico mines and mïnerals, Santa Fe.

Keyes, C. R., Ephemeral lakes in arid regions: Am. Jour. Sci., 4th ser., vol. 16, pp. 377-378, 1903.

Lindgren, Waldemar, Graton, L. C., and Gordon, C. H., The ore deposits of New Mexico: U. S. Geol. Survey Prof. Paper 68, 1910.

Meinzer, O. E., Geology and water resources of Estancia Valley, N. Mex.: U. S. Geol. Survey Water-Supply Paper 275, 1911.

Meinzer, O. E., and Hare, R. F., Geolegy and water resources of Tularosa Basin, N. Mex.: U. S. Geol. Survey Water-Supply Paper 343, pp. 72, 130, 1915.

\section{ARIZONA.}

Though no salt is produced at present on a commercial scale in Arizona, the mineral exists in appreciable quantities in places.

\section{OCCURRENCES.}

SALT RIVER VALLEY.

Common salt and other chemically precipitated salts have been deposited along with clastic sediments from the river water in the valley of Salt River. These salts do not form important deposits in the geologic sense, being irregularly diffused through the sediments comprising the valley fill, but they are of great economic importance because of their effect on the river water. The salt (sodium chloride) in Salt River is thought to be derived from large salt springs in the upper reaches of the river. The water issuing from these springs has been described as a weak brine.

\section{VIRGIN RIVER VALLEY.!}

Virgin River valley is mostly in Nevada, but its geology has been studied chiefly from the Arizona side of Colorado River. Between Temple Bar and Boulder Canyon along the northwestern boundary 
of Arizona Colorado River crosses an old débris-filled valley. The old valley fill is composed of two distinct formations, the older consisting of sand and clay beds with important gypsum deposits. Rock salt occurs in the Virgin River valley a few miles north of the Colorado in beds similar to those containing the gypsum.

The salt deposits are described under Nevada. (See pp. 146-148.)

OTHER IOCALITIES.

Blake ${ }^{1}$ refers to the occurrence of rock salt disseminated in the beds in the valley of Verde River, Yavapai County, in the southcentral part of the State.

Though a prehistoric lake covered Cochise Flat, which is about 50 square miles in area and borders the Southern Pacific Railroad in southeastern Arizona, no notable concentration of salts seems to have taken place there. A sample of the efflorescence contained 11.74 per cent of soluble material, 1.29 per cent of which was potash. ${ }^{2}$

\section{BIBLIOGRAPHY.}

Browne, J. R., Resources of the Pacific slope, pp. 256, 311, San Francisco, 1869.

BLAKE, W. P., Mineralogical notes: Am. Jour. Sci., 3d ser., vol. 39, p. 44, 1890.

Hance, J. H., Potash in western saline deposits: U. S. Geol. Survey Bull. 540, p. 469; 1913.

Lee, W: T., Underground waters of Salt River valley, Ariz.: U. S. Geol. Survey Water-Supply Paper 136, 1905.

- Geologic reconnaissance of a part of western Arizona: U. S. Geol. Survey Bull. 352, p. 36, 1908.

Phalen, W. C., Potash salts: U. S. Geol. Survey Mineral Resources, 1915, pt. \&, pp. 108-110, 1916.

UTAF.

The nonmetallic mineral resources of Utah, like those of other Western States, are still so little known that descriptions of almost any class of them are incomplete, particularly of deposits of rock salt and underground brine.

The salt industry of Utah, which is important and flourishing, is located mainly on the east shore. of Great Salt Lake, at Saltair, 15 miles west of Salt Lake City. Some salt is produced also at Garfield. All the salt now and heretofore obtained along the lake shore is produced by solar evaporation of the water of the lake.

\section{PRODUCING LOCALITIES.}

The most important occurrences of salt in the State are as brine in the water of Great Salt Lake; as rock salt in Sevier Valley, near Salina, Redmond, and Gunnison, in Sevier and Sanpete counties; as

1 Blake, W. P., Am. Jour. Sci., 3d ser., vol. 39, p. 44, 1890.

2 Hance, J. H., Potash in western salino deposits: U. S. Geol. Survey Bull. 540, p. 469, 1913. 
rock salt east of Nephi, Juab County, where brine also is found; as salt lake crusts near Clear Lake, in the eastern part of Millard County; and as brine at Salduro Salt Marsh, Tooele County. (See Pl. XIV, A.) Salt is or has been produced at all these localities.

\section{GREAT SALT LAKE.}

Production has been reported from time to time along the shores of Great Salt Lake in Box Elder, Weber, Davis, and Salt Lake counties, but with the exception of the works of the Inland Crystal Salt Co., at Saltair, the operations are small and are carried on somewhat sporadically. Small quantities of salt are reported to have been gathered recently at Promontory Point, Box Elder County, at Withee, Weber County, 15 miles west of Ogden, at Syracuse, Davis County, and at Garfield, Salt Lake County. The processes of evaporation employed along the lake shore are generally similar, and the methods of the Inland Crystal Salt Co. are typical. ${ }^{1}$ The chemical composition of the lake water is discussed on pages $220-221$.

\section{SEVIER VAILEY.}

Salina, Redmond, and Gunnison are in the valley of Sevier River, the first two places in Sevier County and the last in Sanpete County. The rock salt mined near these places is obtained entirely in open cuts, and the views given show the method of procuring it (see Pl. XIV). Several small mines are in operation on each side of the valley, most of them being on the west-side. Some are as much as 50 feet deep. Though the deposits on the west side are close to the wall of the valley, they nevertheless lie definitely within the valley proper. The deposits of the Gunnison Valley Salt Co., however, lie well up on the eastern valley wall.

The salt occurs in places in thin beds apparently separated by layers of clay. At the mine of the Inland Crystal Salt Co. the beds appear to have been disturbed and to stand on edge. On the east side of the valley the structure is more complex and the beds are involved in folds or faults, possibly in both. The salt occurs also massive in places. It is found impregnated with red clay, and the deposits are covered by a thin mantle of residual clay left by the leaching of the accompanying salt.

As to the age of the deposits, on maps of the Wheeler Survey, ${ }^{2}$ the general area occupied by the salt beds is mapped as Quaternary, with small areas of Jurassic. In another place Howell ${ }^{3}$ says:

Salt is found in apparently inexhatustible quantities in a red clay of Jurassic age. near Mount Nebo, on Salt Creek; on the west side of the Sevier Valley between Gun-

1 Phalen, W. C., Technology of salt making in the United States: Bur. Mines Bull. 146, pp. 49-52, 1917.

2 U. S. Geog. Surveys W. 100th Mer., atlas sheets 50 and 59, 1875.

3 Howell, E. E., U. S. Geog. Surveys W. 100th Mer. Final Rept., vol. 3, pp. 263-264, 1875. 


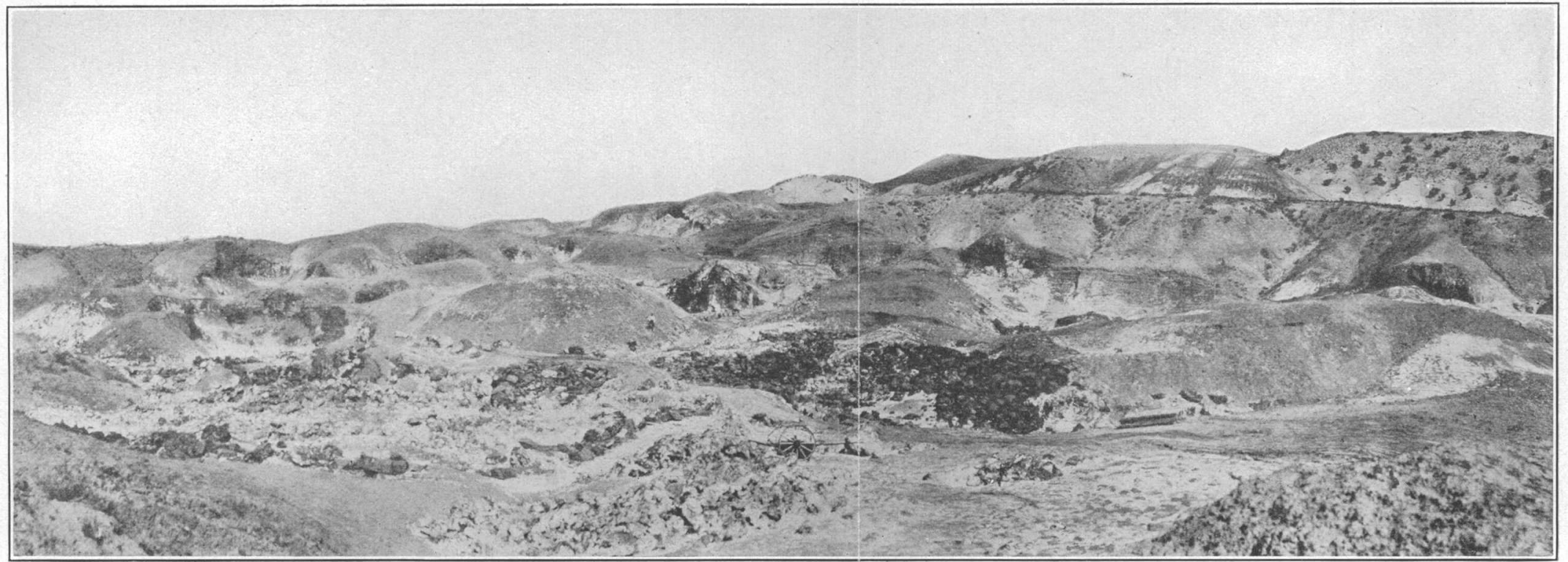

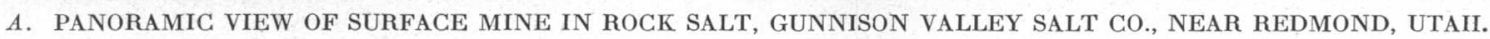

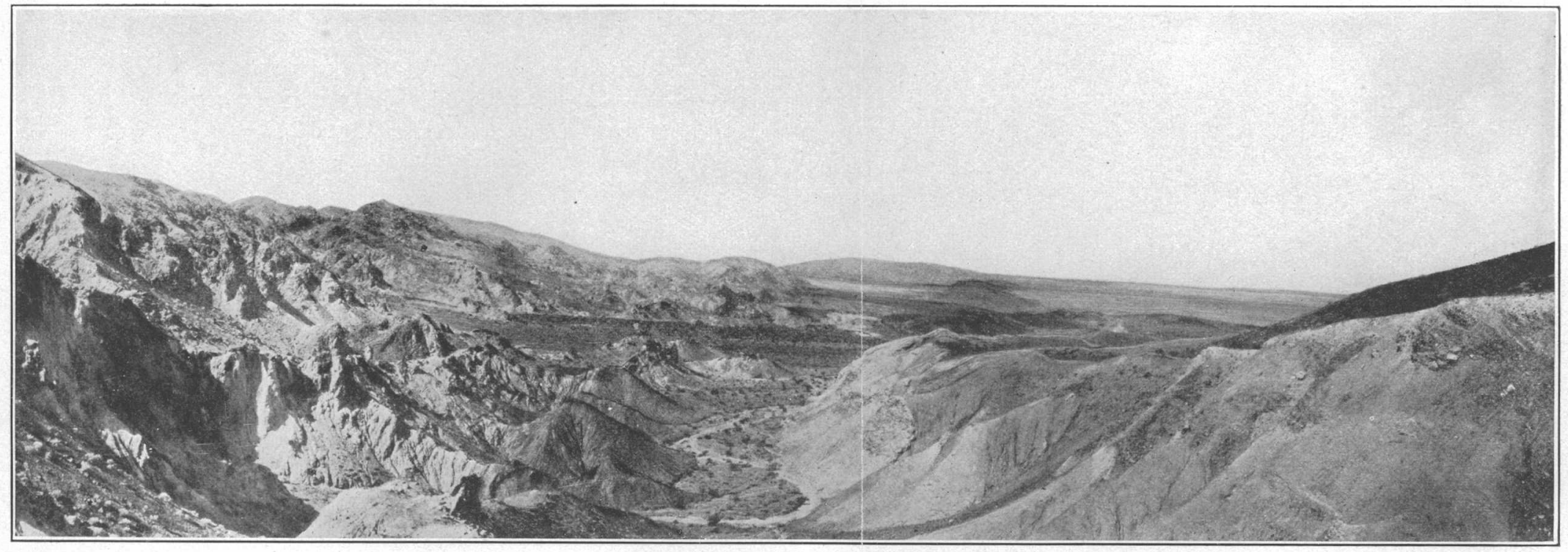

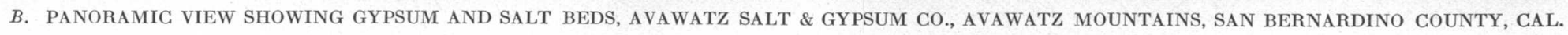


nison and Salina, a few miles south of Salina; and in Salina Canyon. Thesc salt deposits are all of excellent quality, being remarkably free from sulphates and from the other chlorides.

Thus the age of the deposits under discussion is gircn as Jurassic by the geologists of the Wheeler Survey.

In the geologic reconnaissance map accompanying Richardson's report on underground water in Sanpete and central Sevier valleys, Utah, ${ }^{1}$ the areas containing the salt are mapped provisionally as Jurassic. They are regarded by Richardson as certainly older than Cretaceous. The salt deposits west of Sevier River are associated with two Jurassic inliers in Quaternary beds and extend for a total length of about 6 miles; the deposits east of the river are in Jurassic beds and extend intermittently in a northeast direction for approximately 35 miles.

Regarding the rocks of the Jurassic and the associated beds of salt, Richardson states: ${ }^{2}$

So far as known, the oldest rocks of Sanpete and Sevier valleys are of Jurassic age. They consist of a considerable but undetermined thickness of fissile clay shales, generally drab in color but locally red, with some intercalated layers of drab sandstone ranging in thickness from a few inches to a few feet. Lenses of gypsum and rock salt are irregularly interbedded throughout the formation. These rocks outcrop in a range of low hills, about 30 miles long and 2 miles wide, that extend along the eastern margin of Sevier Valley from Glenwood to the vicinity of Mayfield. A less extensive outcrop occurs in the center of the valley, mostly west of Sevier River, between Redmond and Gunnison. On the east a fault causes these Jurassic strata to abut against Tertiary beds, as mentioned later, but relations are generally concealed by Quaternary deposits. The hills are practically bare of vegetation, and the soft beds have been eroded into badland topography. These rocks are of no value in the recovery of underground water. They exert, however, an important deleterious influence upon the character of streams with which they come in contact because of the ready solubility of their interbedded salt and gypsum.

Dutton ${ }^{3}$ does not indicate the presence of Jurassic beds in the Sevier Valley west of Sevier River in the vicinity of Salina, Redmond, and Gunnison. The Jurassic is indicated, however, east of the river. Dutton explains in the preface to his report that the greater portion of his time was devoted to acquiring a general and connected view of the broader features of the geology of this region, and that details could not receive the attention which their importance really demanded. For this reason it is possible that a small area in the valley proper may have been overlooked. In describing the Jurassic system, however, no mention is made of salt occurring in it, but the presence of gypsum is noted.

\footnotetext{
1 Richardson, G. B., Underground water in Sanpete and central Sevier valleys, Utah: U. S. Geol. Survey Water-Supply Paper 199, pl. 2, 1907.

2 Op. cit., pp. 8-9.

${ }^{3}$ Dutton, C. E., Report on the geology of the high plateaus of Utah, atlas sheet 2: U. S. Creog. and Geol. Survey Rocky Mtn. region, 18s0.
} 
NEPHI, JUAB COUNTY.

The salt deposits east of Nephi, Juab County, are in Salt Creek canyon. They have been worked on a small scale, but no rock salt is now being taken out. Salt springs occur in the district, and from the brine of one of these springs salt is made at a small evaporating plant belonging to Jackson Bros., of Nephi.

The deposits of salt in this locality are among those mentioned in the quotation above by E. E. Howell, of the Wheeler Survey, as occurring on Salt Creek near Mount Nebo. On the atlas sheets of that Survey the rocks of the locality are mapped as Jurassic sediments and the mass of Mount Nebo to the north as composed of Carboniferous rocks. The salt occurs in the area mapped as Jurassic, and the springs probably originate along the fault plane and encounter salt beds before they emerge at the surface.

CLEAR LAKE, MILLARD COUNTY.

The salt deposits of Clear Lake, Millard County, are derived most probably from beds of Quaternary age. The salt occurs in the waters of a salt lake found in the Quaternary basin of ancient Lake Bonneville. During the dry season the water of the lake dries up and leaves a crust of salt, which has been 'gathered and used. No salt is now produced.

\section{SALDURO SALT MARSH, TOOELE COUNTY.}

In the northwestern part of Utah, west and southwest of Great Salt Lake, is a desert of enormous extent, over a great portion of which a crust of salt was deposited from the waters of Lake Bonneville. The waters of this ancient lake have receded greatly and have left only remnants, the most important of which are Great Salt and Sevier lakes. The waters, on evaporating, left bodies of salt, of which that covering the floor of Great Salt Lake Desert, in Tooele County, is an example. Other deposits of salt are probably buried and will be revealed only by drilling or by seepages from springs. Only a little of the salt from this desert has been utilized, and this in recent years, but plans are now under way to obtain salt commercially from the Salduro salt marsh.

Salduro salt marsh, in Great Salt Lake basin, is west of Great Salt Lake and on the main line of the Western Pacific Railroad. It was examined with special reference to the possibility of obtaining potash, in October, 1914, by H. S. Gale, of the United States Geological Survey, who contributes the following notes:

Several shallow holes were bored through the hard surface salt crust that forms the floor of this basin and into the underlying mud. Analyses of samples taken from these borings show that the surface salt is comparatively pure sodium chloride, containing an exceedingly 
small quantity of potassium. The water-soluble potassium contained in the underlying mud ranges from about 1.8 to 3.5 per cent (expressed as $\mathbf{K}$ ) of the dissolved salts included in the mud, which salts formed about 12 to 15 per cent of the entire samples taken, about 5 to 7 per cent of the samples being water. Brines were found both in the salt crust and in the underlying mud and on analysis proved to be saturated solutions carrying 25.68 to 26.85 per cent dissolved salts, of which 2.8 to 4 per cent was potassium (expressed as $\mathrm{K}$ ). This is equivalent to 0.75 to 1.03 per cent of potassium in the entire solution, or only about half the potassium content of the brine in Searles Lake, Cal. It is, however, about double the potash content of the water of Great Salt Lake (0.34 per cent potassium in the sample taken in October, 1913), which, however, is not usually a saturated solution. The brine at Salduro appears to flow freely into holes cut into the salt or mud. It is possible that potash might be produced there in some form, perhaps as a by-product of some other industry, or perhaps only under the stimulus of present abnormal conditions.

\section{OTHER OCCURREMCES.}

Other occurrences of salt in Utah are in Little Salt Lake, Iron County; south of Beaver, in Beaver County; and in the salt marshes in Snake Valley, in the western part of Millard County.

\section{BIBLIOGRAPHY.}

Browne, J. R., Resources of the Pacific slope, p. 256, San Francisco, 1869.

Howell, E. E., Report on the geology of portions of Utah, Nevada, Arizona, and New Mexico: U. S. Geog. and Geol. Surveys W. 100th Mer., vol. 3, pp. 227-301, 1875; also U. S. Geog. Surveys W. 100th Mer. atlas sheets 50 and 59.

Dutron, C. E., Report on the geology of the high plateaus of Utah, U. S. Geog. and Geol. Survey Rocky Mtn. Region, 1880.

Gribert, G. K., Lake Bonneville: U. S. Geol. Survey Mon. 1., pp. 223-228, 230-259.

Rabora, W. A., Salt: U. S. Geol. Survey Mineral Resources, 1888, pp. 605-607, 1890.

Parker, E. W., Salt: U. S. Geol. Survey Nineteenth Ann. Rept., pt. 6 (continued), pp. 608-610, 1898.

Eckes, E. C., Salt industry of Utah and California: U. S. Geol. Survey Bull. 225, pp. 488-495, 1904.

Richardson, G. B., Underground water in Sanpete and central Sevier valleys, Utah: U. S. Geol. Survey Water-Supply Paper 199, pp. 8-9, 1907.

Younc, G. J., Potash salts and other salines in the Great Basin region: U. S. Dept. Agr. Bull. 61, 96 pp., 6 pls., 1914.

Phalen, W. C., Potash salts: U. S. Geol. Survey Mineral Resources, 1915, pt. 2, p. 108, 1916.

\section{CALIFORNIA.}

California ranked sixth among the States in the quantity of salt produced in 1915; in value of output the State ranked fifth. 


\section{OCCURRENCE OF SALT.}

Salt occurs in California in practically every known form. In solution it is found in the Pacific Ocean, which borders the entire length of the State; in salt springs; in salt lakes or marshes; and in saline streams, of which certain tributaries of Salinas River, in San Luis Obispo County, are examples. In Inyo, San Bernardino, and other counties in the Great Basin, many springs and streams are slightly

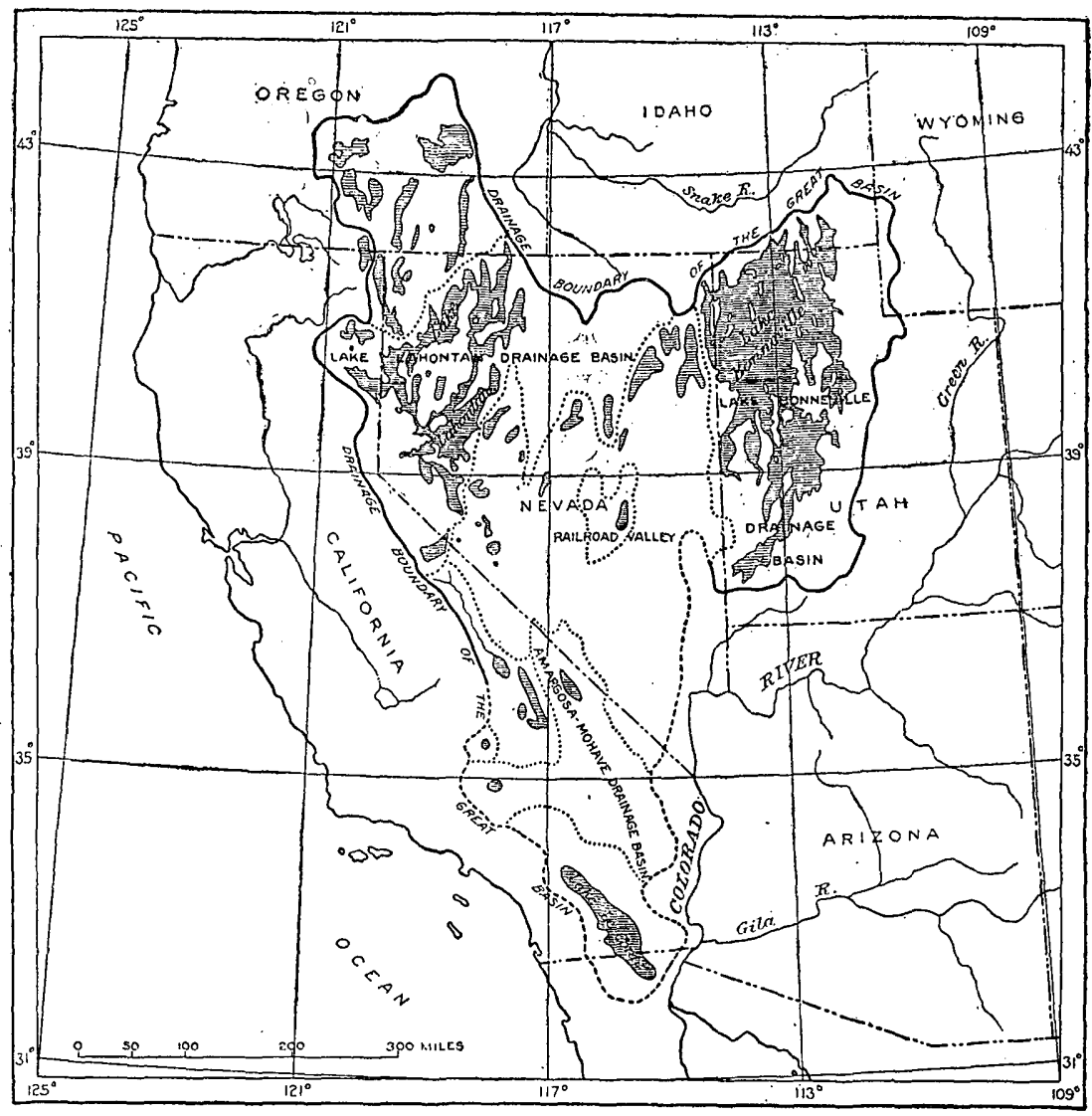

FIGURE 10.-Map showing drainage boundary and Ploistocenelakes of the Great Basin. (After H. S. Galo.)

brackish or salty. Many of the so-called alkaline or salt lakes contain water only during certain seasons of the year; during the dry seasons they are covered with a crust of salt, locally several inches thick. The Great Basin region (see fig. 10) contains many of these marshes, playas, or lakes, from which the salt may be collected by scraping the crust. In addition to the deposits of salt resulting from the evaporation of these saline solutions, rock salt undoubtedly will be found, either disseminated or segregated in beds or masses, in the sediments of Quaternary lakes. These salt deposits have originated 
in the periods of desiccation that were followed by periods of deposition of clastic materials at certain stages of the lakes. Rock salt occurs in a few deposits in the earlier lake beds, of which the deposit on the north side of the Avawatz Mountains is a fine example. (See Pl. XIV, $B$, p. 156.)

\section{PRODUCING LOCALITIES.}

More than 97 per cent of the salt produced in California is obtained by the solar evaporation of sea water along the coast, where the main centers of population afford an immediate market for the product, and the cost of transportation is reduced to a minimum. Most of the solar salt, including the finer grades, comes from the shores of San Francisco Bay, in Alameda and San Mateo counties. The headquarters of the salt industry are atAlvarado, Newark, Mount Eden, Russell, and Baumberg, formerly Arffs, in Alameda County, on the east shore of San Francisco Bay, and at Redwood City and San Mateo, in San Mateo County, on the west shore. In the southern part of the State solar salt is made at Ostend station, near Long Beach, Los Angeles County, and on San Diego Bay, San Diego County. General methods of procuring this salt and preparing it for market are described in the bulletin on the technology of the manufacture of sait. ${ }^{1}$

In addition to the output along the coast, salt has also been produced in small quantity in recent years at inland points as follows: Tramway (Keeler post office), Inyo County; Ward, San Bernardino County; Saltus (Amboy post office), San Bernardino County; Cedarville, Modoc County; Ceneda, a few miles southwest of Randsburg; and Saltdale, Kern County.

COLUSA COUNTY.

About 25 years ago the manufacture of salt was begun at certain brine springs near Sites, Colusa County, and has continued more or less intermittently at that locality ever since, though the latest reports are that no more salt is being gathered. A number of other salt springs are known in different parts of Colusa County.

INYO COUNTY.

Inyo County is in eastern California and is wholly within the boundaries of the Great Basin. In this county are included Owens Lake, Death Valley, the Saline Valley salt marsh, and the dried valleys of numerous other salt lakes.

1 Phalen, W. C., Technology of salt making in the United States: Bur. Mines Bull. 146, pp. 40-48, 1917. 40104 $-18-B u l 1.669-11$ 
OWENS LAKE.

By H. S. Gaue.

GENERAL FEATURES.

The salts found in solution in the water of Owens Lake have been brought in by the rivers that enter it. The salts dissolved in the water of Owens River have been carefully studied in connection with the diversion of the river for the Los Angeles municipal water supply. An estimate has been published giving the content and total weight of dissolved salts in the water of Owens River at Charlies Butte from November, 1906, to November, 1907, a period of 13 months. ${ }^{1}$ This estimate is based on determinations made on 40 or more samples collected at different times throughout the year, and according to it the average dissolved salt content of the river water for that year was 278 parts per million. The mean of thirty-six 10-day composite samples collected from December 31, 1907, to December 31, 1908, showed the mean salinity of the river water for that period to be 339 parts per million. ${ }^{2}$ The latter figures indicate a greater concentration, but the discharge in 1908. was only little more than half that of the preceding year. Thus the saline material may prove to be very constant from year to year when all the compensating factors are considered.

The salts that accumulate in the water of the lake do not at all represent the constituents brought in by the drainage, for it is well known that these constituents undergo many changes, which result in their precipitation after they reach the lake as well as earlier, during their stay in the tributary waters. Two radicles, however, that are stable under most conditions are the sodium and chlorine radicles, and from the data accumulated for the year 1908, it is estimated that 17,000 tons of sodium and 9,500 tons of chlorine were contributed by Owens River to Owens Lake during that year. The figures of course represent the sodium and chlorine content of water passing Charlies Butte and not the content of the river as it enters the lake.

COMPOSITION OF THE WATER.

Owens Lake is a large, shallow body of water in the extreme southern part of Owens Valley. (See Pl. XV.) Its water is a dense brine, containing common salt, soda, borax, and other salts in solution. The lake lies in a depression which has no outlet, so that its volume depends on its water supply, or on the relation of inflow to evaporation.

The composition of the water of Owens Lake is recorded in a series of analyses that have been made from time to time, beginning with one by J. Arthur Phillips from a sample collected in January, 1866. These analyses agree fairly well, as appears from the following table:

1 Los Angeles Aqueduct Third Ann. Rept., pp. 113-114, 1907.

2 Van Winkle, Walton, and Eaton, F. M., The.quality of the surface waters of California: U. S. Geol. Survey Water-Supply Paper 237, p. 121, 1910. 


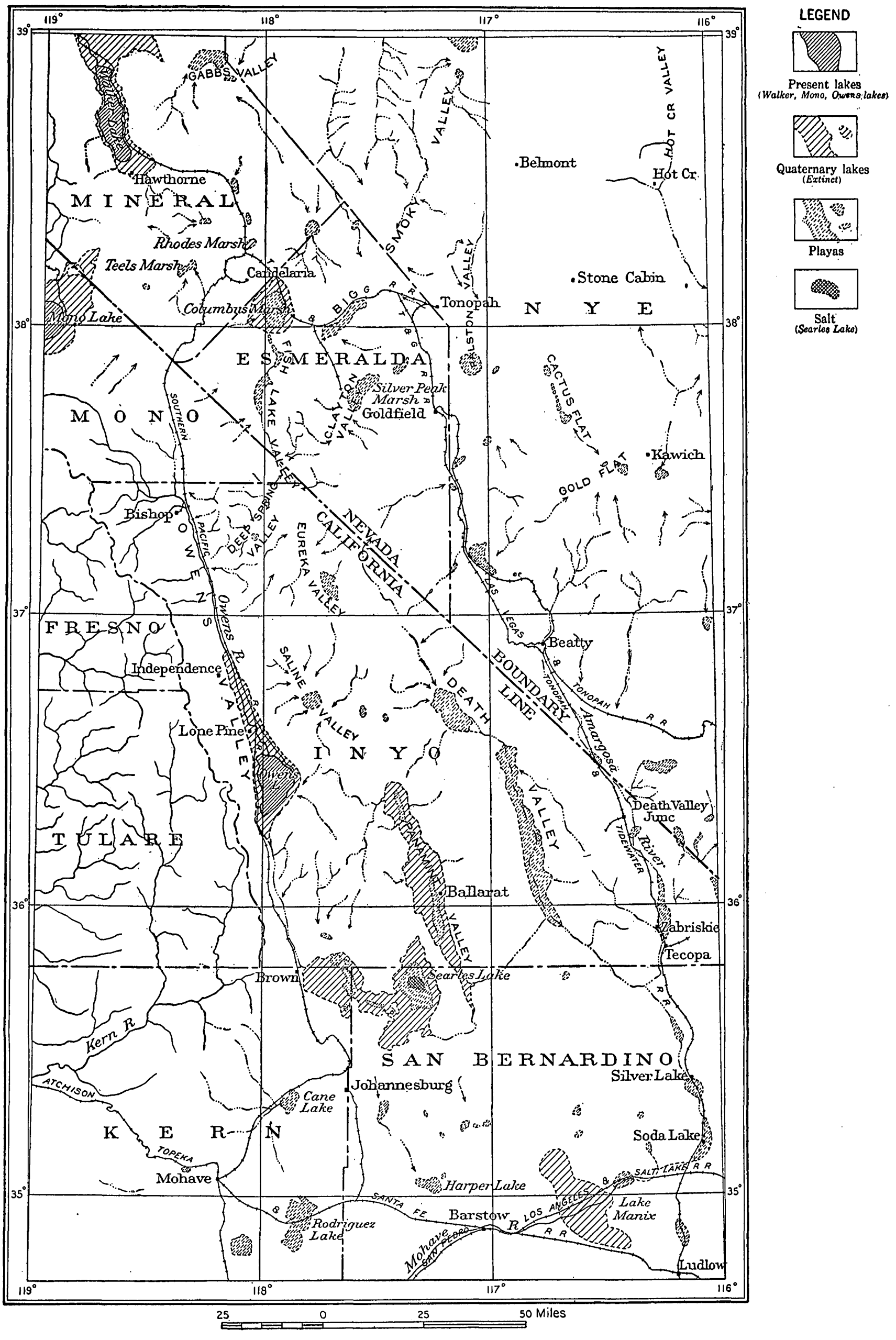

MAP SHOWING THE GENERAL LOCATION OF THE OWENS-SEARLES-PANAMINT LAKE SYSTEM, CAL. 


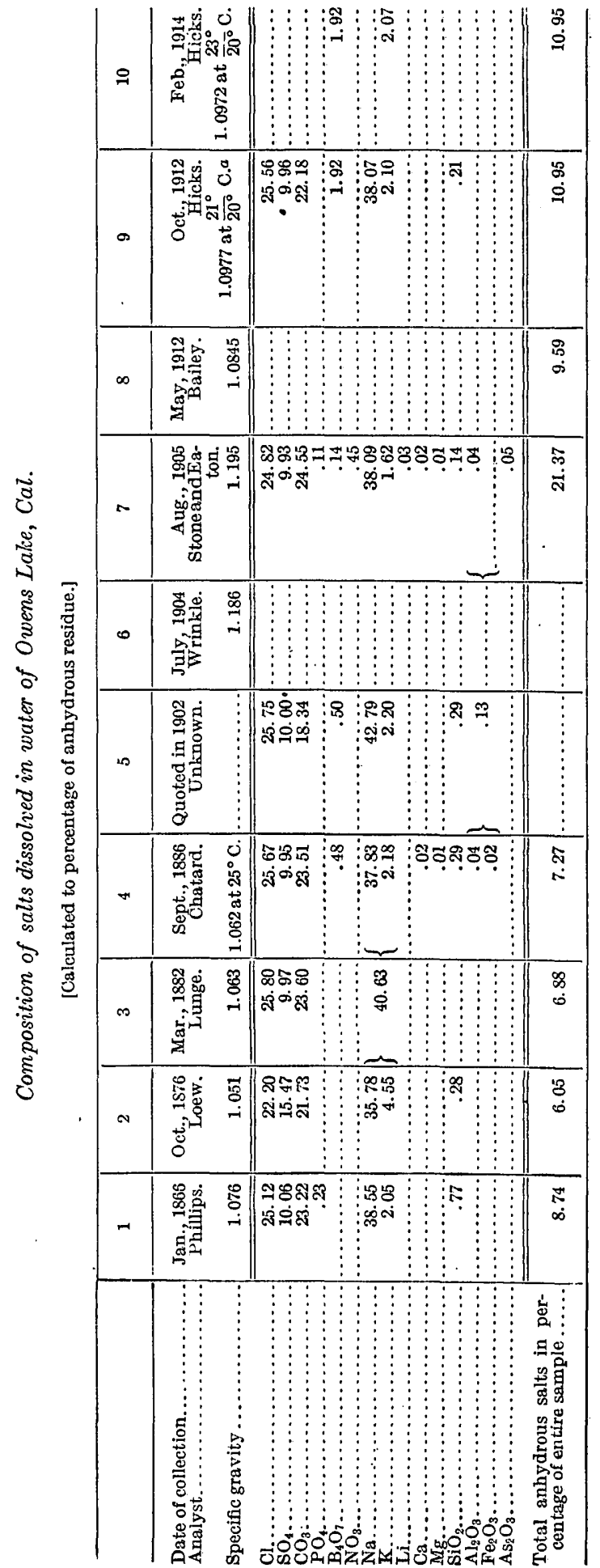

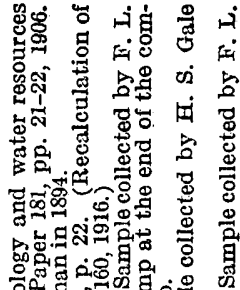

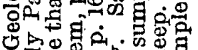

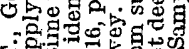
Fi

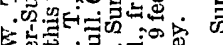

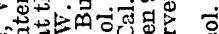
०

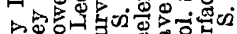

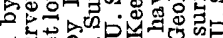
ठํㅕㅇ 计-

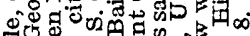

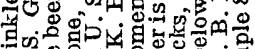
ED

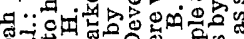
ठึี

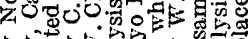

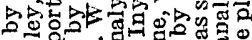
क तै

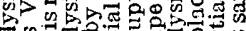

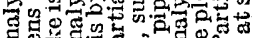

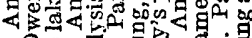

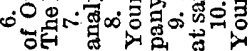

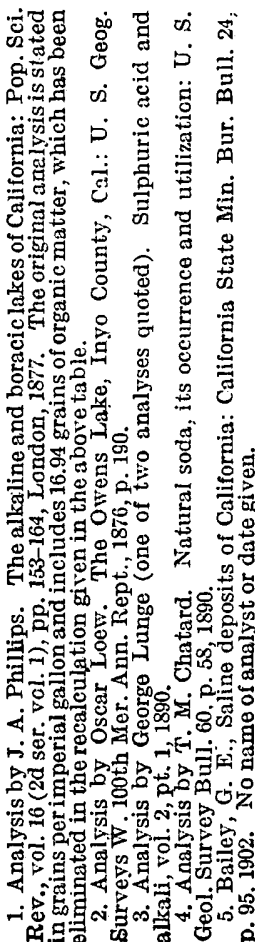


In all these analyses bicarbonate in the original solution is reduced to carbonate in the anhydrous residue and is so expressed. In the sample of October 23, 1912, analyzed by W. B. Hicks, the bicarbonate radicle $\left(\mathrm{HCO}_{3}\right)$ amounted to 4,790 parts per million by weight.

On the assumption that the lake level in October, 1912, when the last recorded sample for fairly complete analysis was taken, was about 3,577 feet, a volume of approximately 1,000,000 acre-feet of water is indicated. A calculation from the analysis quoted shows that the lake waters contain in round numbers as follows:

Approximate total content of chlorine, sodium, and other substances, in the waters of Owens Lake.

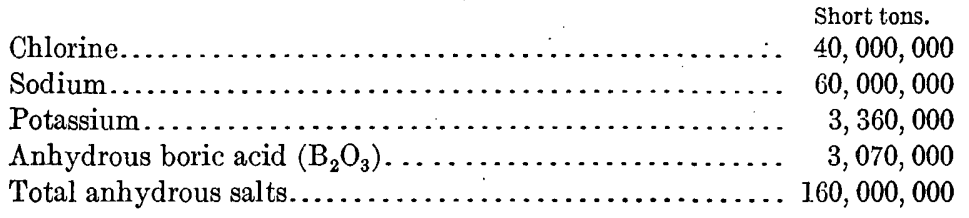

TOTAL SALINES.

These figures are considerably in excess of the estimates made by Loew, ${ }^{1}$ who calculated 5,000,000 tons of sulphate of potash; but Loew's figures for volume were very moderate, even for the data which he then had, and the present estimates have the advantage of much more exact computations of volume.

The estimate that over 3,000,000 tons of potassium is dissolved in the Owens Lake water is doubtless not far from correct, but this figure is not intended for direct comparison with the estimates of available potash given for the deposits of Searles Lake. The percentage of potash in the water of Owens Lake is so much lower than that in the brine of Searles Lake that there is much doubt if the water of Owens Lake may ever be used for the extraction of that substance, unless it is obtained as a by-product of some other process, or unless the water shall reach a greater natural concentration. There is, of course, a vastly greater quantity of potassium in the water-soluble salts in the Searles Basin than that included in the 4,000,000-ton estimate made by the United States Geological Survey and the Bureau of Soils in 1912.

\section{SEARLES LAKE. ${ }^{2}$}

By H. S. Gale.

GENERAL FEATURES.

Searles Lake or Searles Marsh, also known as Slate Range Marsh and Borax Flat, is a dry lake basin, superficially much like many other desert basins of the western arid region of the United States.

1 U. S. Geog. Surveys W. 100th Mer. Ann. Rept., p. 190, 1876.

${ }^{2}$ Described here for convenience, though it lies chiefly in San Bernardino County. 
These names, as generally applied, refer to the broad, flat saltincrusted surface in the center of the desert basin, although, except when it is flooded by shallow waters, the region does not contain a lake at all. The basin in which Searles Lake is situated seems to have no generally accepted name, but will here be designated the Searles Basin. It is a broad, oval valley or depression, extending 8 to 10 miles from east to west and 20 to 25 miles from north to south, and bordered by the abruptly rising slopes of the surrounding mountain ranges. This basin lies between the Argus Range on the west or northwest and the Slate Range on the east, which is a narrow rocky wall that divides it from the larger and deeper depression of the Panamint Valley. (See Pl. XV, p. 162.) The camp at the old soda works in the Searles Basin is in the northwest corner of the main desert flat, about 25 miles by road from Searles post office, formerly Garden station, an old stage station of the Overland Route through this part of the desert country. Garden station is now only about a mile east of the branch line of the Southern Pacific Railroad. Searles Lake was reached by the regular stage that runs from Johannesburg past Garden station or Searles to Searles Lake and thence on to Ballarat and Skidoo, and passenger traffic doubtless still goes this way, although the branch railroad is now completed that connects the Searles Basin with the Southern Pacific main line.

During a part of the glacial epoch the Searles Basin was occupied by at least one deep lake, whose traces are still so distinct as to be indisputable. While the waters stood at their highest level the Searles Basin was flooded to a depth of 635 to 640 feet above the present valley bottom, and the lake extended back through the Salt Wells Valley and joined a broad, shallow lake that flooded the greater part of the Indian Wells Valley. When the water level was lowered less than 75 feet, the divide in the volcanic peaks between Indian Wells Valley and Salt Wells Valley became an actual division between two distinct bodies of water, and for a time here also there was an overflow from Indian Wells Valley to the lower waters in the Searles Basin in the same way that Owens Valley overflowed and spilled its waters into Indian Wells Lake.

These changes in drainage are attested by the remnants of ancient shore lines and water channels. Horizontal beaches and shore markings on the more rocky parts of the marginal slopes appear around the present valley, though they are preserved in certain places much more clearly than in others and have been practically removed in still other places by recent erosion. The old shore lines are more or less marked with deposits of calcareous tufa, in some places amounting to very considerable masses and resembling the tufa deposits of the Lahontan, 
Mono, and Bonneville basins, described bÿ Russell ${ }^{1}$ and Gilbert. ${ }^{2}$ Calcareous tufa forms conspicuous deposits along several of the more distinct shore lines and coats most of the minor shore benches. It is evident that these deposits are built up from lime precipitated from the entering ground or surface waters, presumably deposited as these solutions became exposed to the air and mingled with the stronger standing waters of the lake.

Owens Lake during a period of former greater water supply overflowed the divide at the south end of its basin, and its surplus waters flooded in turn a succession of lower basins, of which the Searles Basin was one of the largest. The waters of Owens Lake after passing the Haiwee divide dropped about 1,500 feet in about 30 miles to Indian Wells Valley and there spread out in a broad, shallow sheet of water. This lake in turn also overflowed, its water passing by way of Salt Wells Valley and a rock-cut gorge at the lower end of that valley into the Searles Basin. Eventually the waters rose in the Searles Basin to such a height that all three of these valleys were submerged in one continuous body of water. The maximum water level in this basin was clearly determined by the elevation of an outlet pass on the south side of the basin, whence its surplus waters flowed into the extreme south end of Panamint Valley. In the Panamint Basin a history similar in some respects to that of the Searles Basin was repeated. The waters rose until the height of the lowest outlet was reached, and as they evidently remained stationary at about that level for a long period, it is presumed that this level was determined by the overflow of the surplus water.

The record of these ancient lakes is found in various traces left in the present dry valleys. This record, including especially the saline deposits left by the evaporating water, is discussed below. The general features of Indian Wells Valley and Salt Wells Valley are first described, as these valleys were included in the greatest expansion of the ancient Searles Lake.

INDIAN WELLS VALLEY.

Indian Wells Valley, also known as Browns Valley, lies south and southeast of Owens Valley. It is a broad, open stretch of country, mostly filled with a surficial deposit of heavy deep sandy soil. This valley was formerly a part of an extensive lake, whose principal history is very closely linked with that of the deep lake of the Searles Basin. The inlet by which the waters from the Owens Basin entered is in the northwest corner of the valley, and there is a channel of

1 Russell, I. C., Geological history of Lake Lahontan, a Quaternary lake of northwestern Nevada: U. S. Geol. Survey Mon. 11, 1885.

2 Gilbert, G. K., Lake Bonneville: U.S. Geol. Survey Mon. 1, 1890. For more details concerning these ancient water lines see Gale, H. S., U. S. Geol. Survey Bull. 580, pp. 251-323, 1915. 
overflow to the southeast through the barrier of volcanic peaks that separates Indian Wẹlls Valley from Salt Wells Valley.

The broad Indian Wells Valley is now filled deep with loose sandy materials-a veritable delta deposit. At the edge of the valley farthest from the inlet and nearest the outlet, in the lowest part of the basin, there is a typical mud playa known as China Lake or China Borax Lake. This name was given presumably because the borax works here were formerly operated by Chinese labor. The playa surface is scarcely 30 feet below the low divide traversed by the outlet between it and the Searles Basin. Thus, a rise of waters of more than 30 feet in the China Lake flat would cause an overflow through the pass into the Searles Basin, but there is no record of such an occurrence within historic time. It is difficult to estimate the amount of the filling that may have taken place in Indian Wells Valley, or how deep the original lake in this basin may have been below the fill. However, it seems fair to assume that during the greater part of its history as a lake it served principally as a settling basin for the sand and silt from Owens Valley, which were laid down as a broad delta deposit, so that the clarified water drained through the outlet on the opposite side. That the valley was thus filled nearly to its present level with sediments while the waters continued to overflow seems more likely than that this basin ever served as a concentrating reservoir. The configuration of the basin at the last of the lake periods, when it finally separated from the waters in Searles Lake, was practically what it is to-day, as is shown by the water lines still preserved in the sandy and alluvial slopes about its margin. These lines indicate that the final lake in this basin was not much over 100 feet deep, although it was of broad expanse. The lake in Indian Wells Valley seems therefore to have served one notable function in the system - that of a settling basin, where the bulk of suspended sand and silt was separated out, and only the clarified waters flowed on to the lower lakes. Possibly to this feature chiefly is due the freedom of the deposits of Searles Lake from the admixture with muds that is characteristic of most desert salt deposits.

SALT WELLS VALLEY.

A smaller basin, known as Salt Wells Valley, constituted an arm of the ancient Searles Lake and in lower-water stages formed the channel by which the Indian Wells Valley overflowed into the Searles Basin. It contains a small mud playa but is in effect a part of the drainage area tributary to the present Searles Basin. Salt Wells Canyon, which enters the main Searles Basin, is a gorge cut in granite and basalt. The channel was clearly graded to a steeper slope than that of the present stream channel. The rock-cut gorge is filled with sediments at its lower end, indicating that at some period its. 
grade was directed to a lower level than the present surface of the deposits in the Searles Basin. This channel broadens as it approaches the Searles Lake playa, and the former gorge is filled with the palegreenish dipping or horizontally bedded, lake-deposited clays or with sand and alluvial wash. This indicates that the former Searles Basin must have been far deeper than the present basin, a conclusion which is also bome out by the record of the deeper borings put down within it.

A large acreage was located for borax early in the seventies in this valley and was worked for a time, but nothing except assessment work is reported to have been done here for several years. It is stated that some salt has been made as a by-product at the borax works. Sodium sulphate occurs as a crust 3 to 10 inches thick over a part of the lake. ${ }^{1}$

AREA OF THE ANCIENT LAKE.

The area of the former Searles Lake at its greatest expansion was about 385 square miles, including both that portion which occupied the Searles Basin and its extension into. Salt Wells and Indian Wells valleys. At this time the level of the waters was evidently determined by the height of the outlet pass on the south side of the Searles Basin, by which the surplus waters found their way into the lower Panamint Valley.

THE SALINE DEPOSITS.

The most distinctive feature of this desert basin is the immense sheet of solid white salts that lies exposed in its bottom. It is to this salt deposit that the name Searles Lake (Searles Dry Lake) has generally been applied. So far as known at present the deposit is unique in this country in the variety of its saline minerals. The immense salt fields in Death Valley are less well known and doubtless contain a larger quantity of sodium chloride and possibly other minerals, but they seem to be of the ordinary playa type, and so of a somewhat different class from the Searles Lake saline deposits.

As in other desert basins the valley deposits in the Searles Basin may be distinguished as occupying several more or less distinct areas or zones. These are:

(a) The central area of firm crusted salt, constituting what is described hereafter as the main salt deposit. This is estimated at 11 to 12 square miles in area.

(b) The playa zone, including the central, salt area and a broad surrounding margin of salt-incrusted mud and sand, bare of vegetation and composed of salts and mixed alluvial material washed in toward the center of the basin from the surrounding valley slopes. The area of the playa zone is roughly about 60 square miles.

1 Gale, H. S., Salines in the Owens, Searles, and Panamint basins, southeastern California: U. S. Geol. Survey Bull. 580, p. 270, 1915. 
(c) The alluvial slopes surrounding the playa zone, composed of detrital material washed from the surrounding mountains and spread out in broad, low, flat alluvial fans, the surfaces generally covered with scattered brush.

(d) The bare rocky slopes of the bordering mountain ranges which lie beyond and above the alluvial fans and the steeper rocktalus slopes.

The area of salt crust in the Searles Basin is roughly circular, elongated slightly from northwest to southeast and almost central in the basin. It is estimated at 11 to 12 square miles in extent, as determined by the private surveys and the drilling that has been done. Its surface is the lowest part of the basin and the altitude, determined by spirit leveling in connection with the preparation of the Geological Survey map, is 1,618 feet above sea level. In unusually wet seasons surface drainage from the surrounding country sometimes floods the salt surface to a depth of a few inches. Not uncommonly a thin sheet of water, flooded out upon the flat from some local storm, is swept across the surface by the force of the wind, so that perhaps nearly the whole mass of the water is moved from one side of the basin to the other. The surface salt is dissolved to a slight extent by these floods and when it again dries the salt crystallizes with a snowy whiteness that is exceedingly dazzling in the bright sun. Dust storms, which are common in this desert region, scatter more or less dirt over the salt crust, and a certain amount of such material is thus almost constantly mixed with the salt.

The surface of the main or central salt deposit is a firm crust of salt crystals, mostly cubic halite, so hard and compact that it will support the weight of a wagon and team or even of the heavy drill rig. The surface shows a tendency to crack along irregular lines, so that it is divided into cakes or blocks. Flooding and re-solution tend to level inequalities that arise, and the cakes and fractures are not so pronounced a feature here as they are on some salt surfaces of similar type elsewhere.

The depth of the salt is shown by the drillings to be fairly uniform and is reported to range from 60 to more than 100 feet; it probably averages 70 to 75 feet in the main part of the deposit. In the central zone the proportion of mud layers found with the salt is comparatively small, so that the mass is in effect a solid body of salts. At and beyond the margin mud is found not only at the surface but intermingled with the salt deposits in depth, so that a sharp delimitation of the main salt deposit would probably be difficult. It is known, however, that the thick mass of solid salts is much more extensive than is indicated by the surface outline of the central salt area, and that a very considerable thickness of crystal- 
line salts underlies a large area which is represented on the surface by playa mud and salt. Just how far this main salt body extends can of course be shown only by drilling.

The more solid part of the main deposit consists essentially of crystalline salts, in which more or less distinction by layers, from the bottom up, may be recognized, undoubtedly indicating the order of deposition in which the mass was originally laid down. One of the wells drilled through the salt crust on September 20, 1913, was carefully sampled, under the writer's direction, by W. B. Hicks, of the United States Geological Survey, and the samples are now on file awaiting mineralogic and chemical examination. All these samples consist mainly of crystalline salts, more or less completely drained of the brine in which they were naturally immersed.

The deposit of salts is in effect a consolidated mass crystallized from an evaporating mother-liquor brine, in which the salts are still immersed, so that it represents a product of desiccating solutions of which the desiccation has not yet been carried to completion.

The soft mud zone surrounding the main salt deposit contains a very large amount of saline material, which doubtless also includes much crystalline salt. Its surface when dry is crusted with white salt and is not readily distinguishable from the more solid mass of the central salt area, but the proportion of mud mixed with the salts is very evidently greater toward the outer margins of the deposit. The marginal salt and mud zone rises slightly, in general only a few feet, above the level of the central part of the basin, and its surface is more irregular. It is saturated with a dense brine, which makes much of the surface so soft as to be difficult or impossible to cross. The water is evidently seepage from the higher slopes surrounding the flat. The soft ground extends baok until the increasing pro-, portion of coarse material renders its surface sufficiently compact to remain firm.

CHEMICAL COMPOSITION OF THE SALINES.

The chemical composition of the salts and brines in the main deposit has been determined by numerous analyses, special attention having been given in the more recent investigations to the brine that permeates the whole deposit rather than to the-salts themselves. For the brine these determinations may be summarized in a fairly simple form by the quotation of a few representative analyses, as the composition shown throughout the deposit, whether in samples from different localities or from top to bottom at one locality, seems to be remarkably uniform. In the following table are given six analyses made by Walton Van Winkle, of the United States Geological Survey, from as many samples which were collected from different parts of the deposit: 
Composition of brine from Searles Lake, Cal.

(Percentage of ignited residue. Walton Van Winkle, analyst.)

\begin{tabular}{|c|c|c|c|c|c|c|}
\hline & 1 & 2 & 3 & 4 & 5 & 6 \\
\hline 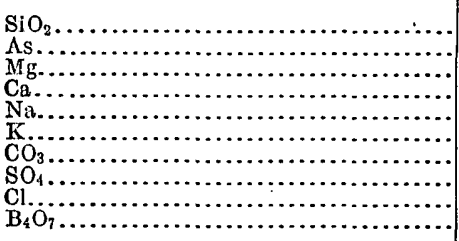 & $\begin{array}{r}.0 .05 \\
.06 \\
.00 \\
.00 \\
33.37 \\
6.53 \\
7.37 \\
12.00 \\
35.97 \\
3.07\end{array}$ & $\begin{array}{r}0.03 \\
.06 \\
.00 \\
.00 \\
32.57 \\
7.27 \\
7.95 \\
12.49 \\
35.53 \\
1.58\end{array}$ & $\begin{array}{r}0.00 \\
.05 \\
.00 \\
.00 \\
33.16 \\
5.98 \\
6.65 \\
13.41 \\
36.50 \\
1.77\end{array}$ & $\begin{array}{r}0.00 \\
.06 \\
.00 \\
.00 \\
33.92 \\
5.54 \\
6.89 \\
11.89 \\
37.13 \\
2.03\end{array}$ & $\begin{array}{r}0.00 \\
.06 \\
.00 \\
.00 \\
33.23 \\
6.29 \\
6.85 \\
13.79 \\
36.40 \\
2.08\end{array}$ & $\begin{array}{r}0.03 \\
.08 \\
.00 \\
.00 \\
32.00 \\
5.69 \\
6.94 \\
13.00 \\
36.79 \\
4.14\end{array}$ \\
\hline Total salts (ignited residue, percentage of & 98.42 & 97.48 & 97.52 & 97.46 & 98.70 & 99.57 \\
\hline 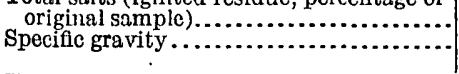 & $\begin{array}{r}33.48 \\
1.3002\end{array}$ & $\begin{array}{r}33.94 \\
1.3045\end{array}$ & $\begin{array}{r}33.30 \\
1.2989\end{array}$ & $\begin{array}{r}32.96 \\
1.2935\end{array}$ & $\begin{array}{r}33.21 \\
1.2959\end{array}$ & $\begin{array}{r}32.88 \\
1.2932\end{array}$ \\
\hline
\end{tabular}

Each sample was collected by lowering a stoppered and weighted bottle to a depth of 35 to 40 feet in the brine, and then, by means of a separate cord provided for the purpose, pulling out the stopper and allowing the bottle to fill.

The original brine contains a variable percentage of bicarbonate which is converted to the carbonate form in the anhydrous residue and is so expressed.

Another analysis, made by W. H. Ross in the laboratory of the Bureau of Soils, Department of Agriculture, is probably the most complete statement on record as regards the composition of this brine. It represents the natural solution pumped from well "SE 7." It is given below, and for comparison is added the average of the six analyses already quoted, which corresponds very closely to it.

Chemical composition of salts dissolved in mother-liquor brine of Searles Lake, Cal.

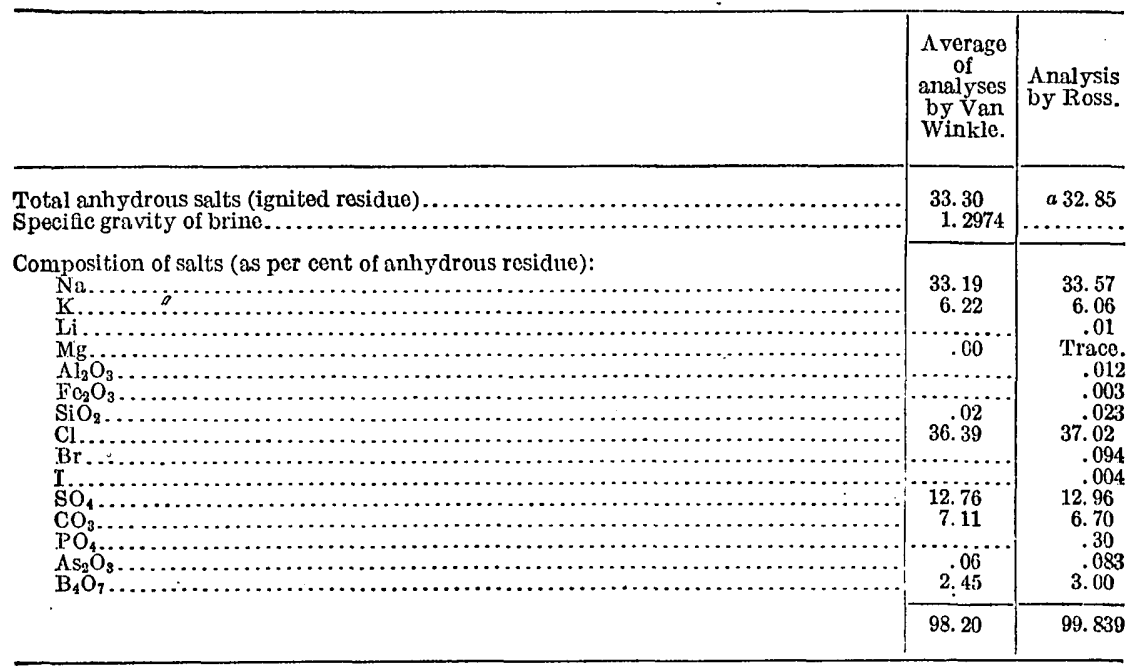

a Approximate; the specific gravity of this sample was not determined. 
The following notes are added to Mr. Ross's analysis:

$\mathrm{Rb}, \mathrm{Ba} ; \mathrm{NH}_{4}, \mathrm{NO}_{3}, \mathrm{Ca}, \mathrm{Mn}, \mathrm{Cu}$, none.

Loss on ignition, 0.69 per cent water and organic matter.

Sodium carbonate, 3.04 per cent in original solution.

Sodium bicarbonate, 0.75 per cent in original solution.

Potash, 2.17 per cent in original solution.

The average analysis has been recalculated to the form of hypothetical anhydrous salts which might be derived from such a brine, as follows:

Hypothetical average composition of anhydrous residue of brine from Searles Lake.

Sodium chloride $(\mathrm{NaCl})$

61.61

Sodium sulphate $\left(\mathrm{Na}_{2} \mathrm{SO}_{4}\right)$

Sodium carbonate $\left(\mathrm{Na}_{2} \mathrm{CO}_{3}\right)$

12.79

Sodium tetraborate $\left(\mathrm{Na}_{2} \mathrm{~B}_{4} \mathrm{O}_{7}\right)$

3.23

Potassium chloride ( $\mathrm{KCl}$ ).

12.07

Sodium arsenate $\left(\mathrm{Na}_{3} \mathrm{AsO}_{4}\right)$.

99.09

The composition of the salts has been given by private analyses, made during the testing of the deposit for soda and borax, as follows:

Analyses of samples from well "SE 8," Searles Lake, Cal.

\begin{tabular}{|c|c|c|c|c|c|c|c|}
\hline Depth. & $\begin{array}{l}\text { Insoluble, } \\
\text { mud, etc. }\end{array}$ & $\mathrm{NaCl}$ & $\mathrm{Na}_{2} \mathrm{SO}_{4}$ & $\mathrm{Na}_{2} \mathrm{CO}_{3}$ & $\mathrm{NaHCO}_{3}$. & $\mathrm{Na}_{2} \mathrm{~B}_{4} \mathrm{O}_{7}$. & $\mathrm{H}_{2} \mathrm{O}$. \\
\hline 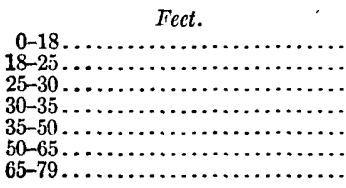 & $\begin{array}{r}0.2 \\
1.4 \\
1.4 \\
3.0 \\
1.4 \\
\text { Trace. } \\
\text { Trace. }\end{array}$ & $\begin{array}{r}79.7 \\
44.0 \\
47.3 \\
42.7 \\
43.5 \\
82.8 \\
19.0\end{array}$ & $\begin{array}{r}7.6 \\
30.5 \\
28.1 \\
17.1 \\
22.3 \\
10.6 \\
7.3\end{array}$ & $\begin{array}{r}3.2 \\
14.8 \\
10.6 \\
19.1 \\
9.5 \\
3.2 \\
40.3\end{array}$ & $\begin{array}{r}0.0 \\
2.5 \\
.0 \\
5.9 \\
2.5 \\
18.8 \\
18.5\end{array}$ & $\begin{array}{r}\text { Trace. } \\
1.0 \\
2.0 \\
2.0 \\
5.5 \\
\text { Trace. } \\
.5\end{array}$ & $\begin{array}{r}3.3 \\
5.8 \\
10.6 \\
10.2 \\
15.3 \\
2.6 \\
14.4\end{array}$ \\
\hline
\end{tabular}

Well "SE 8" is 1 milo due east of well "SE 7," of which the complete brine analysis is given above, and both are situated near the center of the main salt deposit.

In these analyses potash was not determined, and presumably it is expressed as soda in the various combinations given. A single analysis showing the potash content of the salts is given below:

Analysis of a composite of a number of samples from "trona reef," Searles Lake, Cal. [Made by private chemists.]

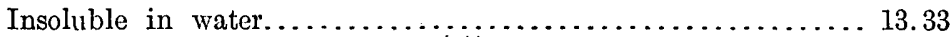

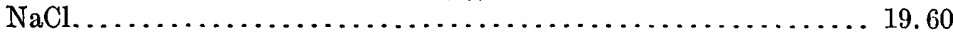

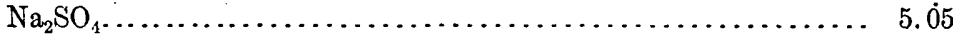

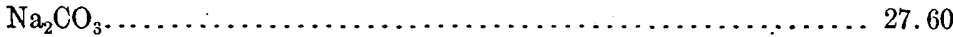

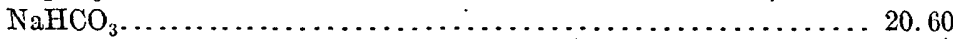

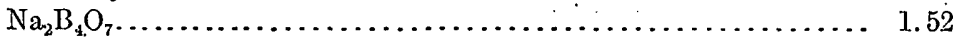

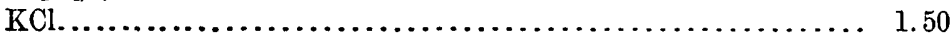


A most significant feature of the chemistry of the deposits is found in the predominant deposition of sodium carbonate and bicarbonate in approximate "trona" proportions at the very bottom of the deposit. There seems also to have been a subordinate recurrence of the same condition at depths of 30 to 40 feet in the central part of the deposit, together with an increase in the amount of sediment (insoluble) contained and apparently a concentration of the borax at or about this general position. It is not shown by this record, but may be noted here, that the mineral hanksite and individual borax crystals, also probably sulphohalite, likewise characterize this zone. This evidence may indicate a temporary interruption of the general process of evaporation while the salt deposition was going on.

The records from wells in different parts of the margin show greater variation. There is commonly a difference in the amount of included sediment at different depths. Possibly some parts of the deposit are richer in borax than others. The principal point that appears to be emphasized, however, is the deposition of the carbonate and bicarbonate at the base of the deposit, and the relation this bears to the evaporation experiment to be referred to presently. There is a relative increase in the sodium sulphate in the upper parts of the deposit and apparently a concentration of sodium chloride at the very top. The experiments of Chatard ${ }^{1}$ are particularly significant in considering the origin of the salt deposits at Searles Lake. They are believed to show that these deposits are the normal product of the desiccation of a body of water of the same chemical character as the Owens Lake of the present time.

RED COLOR IN THE SALTS AND BRINE.

The surface salt and the strong brine standing in trenches or in pools about the margin of the salt deposit is characterized by a deepred color, which is also imparted to some of the salt crystals at the surface of the deposit. The nature of this color has been discussed by Chatard and others, but the following quotation from Lunge ${ }^{2}$ is perhaps the latest statement published with reference to its appearance in these particular deposits:

The red color exhibited by many alkaline salt lakes, which is often also apparent in the salts deposited, is ascribed by Payen $^{3}$ to the presence of small crustaceans, Artemia salina Leach (Cancer salinus Linné), which appear in large masses when the water has attained a density of $\mathbf{1 . 1 6}$ and which are of a gray or greenish color; on further concentration to specific gravity 1.21 they die and form a red froth at the surface. * * * I, for my part, must decline to accept the assumption that the red color is regularly caused by the presence of Artemia or other animal organisms, if it is ever due to that cause; for the samples of red water which I had myself taken from the lakes of the Wade Atrun have preserved that color during the many years $I$ have

1 Chatard, T. M.; Natural soda, its occurrence and utilization: U. S. Geol. Survey Bull. 60, pp. 59-67, 1890.

2 Lunge, Gcorge, Sulphuric acid and alkali, vol. 2, pt. 1, p. 58, 1909.

3 Payen, Anselme, Annales chim. et phys., 2d ser., vol. 65, p. 156, 1837. 
kept those samples. It remains after frequent filtrations. The red filtrate shows nothing under the microscope; the color is at once discharged by adding nitric acid or hypochloride and hydrochloric acid and is evidently caused by organic substances present in solution. There is no iron present.

Perhaps the latest explanation is that it is due to the red chromogenic bacteria which grow in the brines and even in and on heaps of crude salt. ${ }^{1}$

\section{PANAMINT VALLEY.}

By H. S. Gale.

THE FORMER LAKE.

While the waters in the Searles Basin stood at their highest level they undoubtedly overflowed by way of the pass at the south end of that basin and entered the larger and deeper basin of Panamint Valley. (See Pl. XV, p. 162.) Here they formed the principal water supply of a lake which received also contributions of the desert drainage tributary to its valley. This immense body of water, which had an origin similar to that of Searles Lake, may have produced in the Panamint Valley saline deposits resembling those in the Searles Basin, but there are many qualifying factors to be considered in offering judgment as to whether such deposits exist there.

Panamint Lake was 60 miles in length from north to south and 5 or 6 miles wide for the greater part of its length, though nearly 10 miles wide in the broader portion of the valley north of Ballarat. It was confined in a long, narrow, deep basin, whereas Searles Lake occupied a broad, oval basin. Panamint Lake narrowed to a point at its south end, and this was not only the point of inlet for the overflow from the Searles Basin but also near the probable outlet during the period of its maximum flooding. The greatest depth of Panamint Lake was probably determined by Wingate Pass, through which an overflow is believed to have passed for some time into Death Valley. Panamint Lake is apparently analogous to Searles Lake, as each lake receives its waters by overflow from a higher basin and each at some stage undoubtedly overflowed to a lower basin. The crusted salt about this basin has been scraped for local domestic and stock use.

SALINES IN PANAMINT VALLEY.

Prospecting in the Panamint Valley for buried saline deposits was begun by private interests in November or December, 1913. One or more shallow holes had been sunk earlier in the year. The more complete exploration of this basin offers a practical and interesting test of the hypothesis of buried salts from the desiccation of a

1 Peirce, G. J., in McDougal, D. T., and others, The Salton Sea: Carnegie Inst. Washington Pub. 193, p. $52,1914$. 
Quaternary lake that is known to have evaporated and left only an insignificant deposit on the surface.

A saline deposit, if one exists in the Panamint Valley, will doubtless be of much the same type as that of Searles Lake, for it must have been laid down mainly by waters that overflowed from the Searles Basin. As the waters of Searles Lake were supposedly dilute during their highest stages, it seems unlikely that much differentiation could have taken place within them, so that the overflow to the Panamint Lake was not in the nature of a mother liquor.

Some quantitative idea of the interpretations to be placed on the history of the lake may be obtained from the following computations: The water content of the ancient Panamint Lake at its highest level was approximately $85,000,000$ acre-feet. If the concentration of the water at this highest level, necessarily a matter of pure assumption, was 300 parts per million of dissolved salts, or about that of the present flow of Owens River, the total quantity of salts dissolved in this ancient body of water would be about $35,000,000$ short tons of anhydrous salts. This would be equivalent to a layer of the anhydrous salts 20 acres in extent and 1 foot deep, or with some water of crystallization and mother liquor perhaps the same area to a depth of several feet.

The single filling and evaporation of a lake like that which formerly existed in the Panamint Valley would not necessarily result in the deposition of a large mass of salts when the lake dried up, but such a lake must continue to concentrate waters of the character described for a long period in order to produce a very thick deposit of salines. That such a long-continued concentration actually took place in the Searles Basin is very certain, and there seems to be ample possibility that a similar concentration may have occurred in the Panamint Basin, though definite assumption of its occurrence is scarcely warranted.

\section{PROSPECTS FOR POTASH.}

THE DESERT BASINS.

When general interest was first aroused in the subject of potash in the West, the dominant idea in the exploration of the desert basins for saline and potash deposits was based on the assumed former existence of saline lakes, whose waters by evaporation must have left their salts as massive residues. This idea has been referred to as the desert-basin hypothesis.

As a summary it is probably safe to say that commercially valuable concentrations of potash are not generally to be looked for in the desert-basin deposits. Salts deposited by shallow intermittent lakes are not only so mixed with muds as to render their profitable 
recovery very doubtful, but such deposits are unlikely to retain on a large scale any considerable percentages of potassium in the soluble form. Only in basins where large and deep saline lakes have existed and dried up under favorable conditions are massive deposits of salines free from mixture with mud to be expected. Such conditions are exceptional. Probably few desert saline lakes have in fact dried up so free from the mixture of clay or other sediments that their water-soluble salts have retained the greater part of the potash originally present in the lake water. These exceptional conditions may exist in some places, and it seems that in Searles Lake one such place has been found.

\section{DEATH VALLEY.}

Death Valley is known also as the "sink" of Amargosa River, and the salts deposited on its floor' are generally considered to have been derived from the drainage waters which have flowed into it. The salt deposits uplifted and exposed to erosion in the neighboring Avawatz Mountains have undoubtedly contributed some of the saline material which has found its way into the Amargosa drainage, and thence into Death Valley, but it is certainly not necessary to assume that the saline material in Death Valley has been derived entirely or even largely from this source. Gale ${ }^{1}$ says:

A vast amount of saline material is accumulated on and beneath the floor of Death Valley. A central area of crusted salt lies in the lowest part of the valley, extending for many miles from north to south. At the very lowest part of the valley or so-called sink there is an irregular area several miles across which is usually a smooth field of snowy-white salt. Occasionally this is flooded by storm waters, which subsequently evaporate and again leave the surface crusted with white salts. Beyond the smooth salt to the north and south are the fields of rough salt. These differ from the area of smooth salt principally in the fact that the salt crust, not having been recently flooded and wholly redissolved, has been gradually broken into cakes and tilted at various angles, probably by expansion'due to the growth of crystallization, thus producing a surface so rough that it is extremely difficult to traverse. A rim of soft mud lies between the main salt fields and the valley margin, this part also being occasionally flooded by storm waters and kept wet by the seepage of ground water from the marginal slopes. Beyond the mud rim are sand dunes and alluvial slopes of rock débris, such as characterize these desert regions generally.

The outlines of these types of surface deposits are represented in the accompanying map of a portion of the valley [fig. 11], which is based on data collected by Charles $\mathrm{E}$. Watson for the Geological Survey at the time the wells were being drilled. The location of the wells is also indicated.

\footnotetext{
1 Gale, H. S., Prospecting for potash in Death Valley, Cal.: U. S. Geol. Survey Bull. 540, pp. 407-415,
} 1914. 




Frgure 11.-Map showing salt deposits in Death Valley, Cal., and location of wells drilled by the United States Geological Survey. (After H. S. Gale.) 
Published analyses ${ }^{1}$ of salt in Death Valley are as follows:

Analyses of salt from Death Valley, Cal.

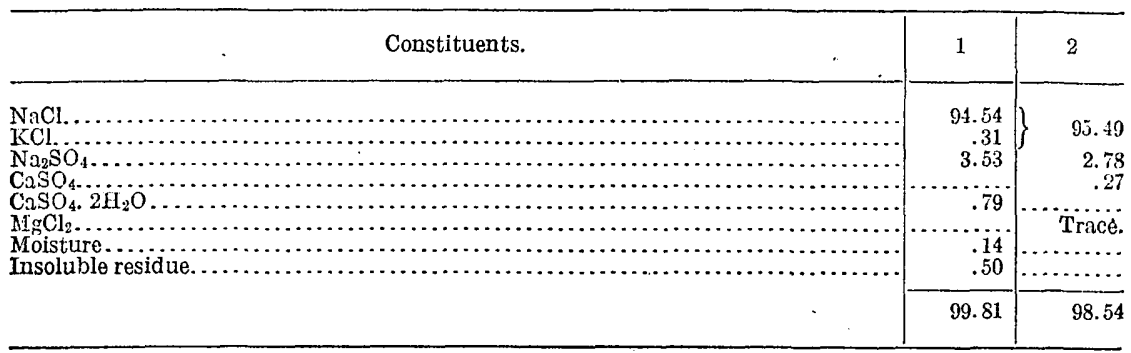

1. Surface salt from the middle of the area of rough salt, on the road between Furnace Creek ranch and Bennetts Well, where the crust is nearly 3 miles wide. M. R. Campbell, collector. Analysis by George Steiger, expressed in percentage of total weight. U. S. Geol. Survey Bull. 200, p. 18, 1902.

2. Deposit 1 to 3 inches thick covering many square miles. Lieut. R. Birnie, collector. Analysis by Oscar Loew, expressed in percentage of anhydrous residue. U. S. Geog. Surveys W. 100th Mer. Ann. Rept. 1876, p. 176.

Explorations of the saline deposits in the floor of Death Valley were recently undertaken by the United States Geological Survey for the purpose of ascertaining whether the strata of the valley contain an appreciable amount of potash salts. In all 83 samples of brines and saline deposits were collected, some of which have been analyzed and the results published. ${ }^{2}$ The borings, which were sunk to depths of 100 feet or less, show that the valley is underlain by alternating. layers of clay or mud and rock salt. Salt brines were found at several horizons; usually in layers just below beds of erystalline salt and rarely in the mud layers themselves.

The principal constituent of the brines analyzed is sodium chloride, and the potash content is small. Analyses of 28 portions of solid material from different depths in one of the borings (No. 200) in the lowest part of the valley and thought to be fairly representative were also examined. After the moisture was dried out under conditions approximating those normal in the region, the dried material averaged 65 per cent of soluble salts, of which 0.72 per cent was potash, corresponding to 1.13 per cent of potassium chloride.

The log of the well from which the sample was obtained is given on page $179 .^{3}$

\footnotetext{
1 For additional analyses see G.J. Young, Potash salts and other salines in the Great Basin region: U. S. Dept. Agr. Bull. 61, 1914.

2 Gale, H. S., op. cit., pp. 410-411.

3 Idem, pp. 412-413.
} 
Log of United States Geological Survey boring No. 200, Death Valiey, Cal.

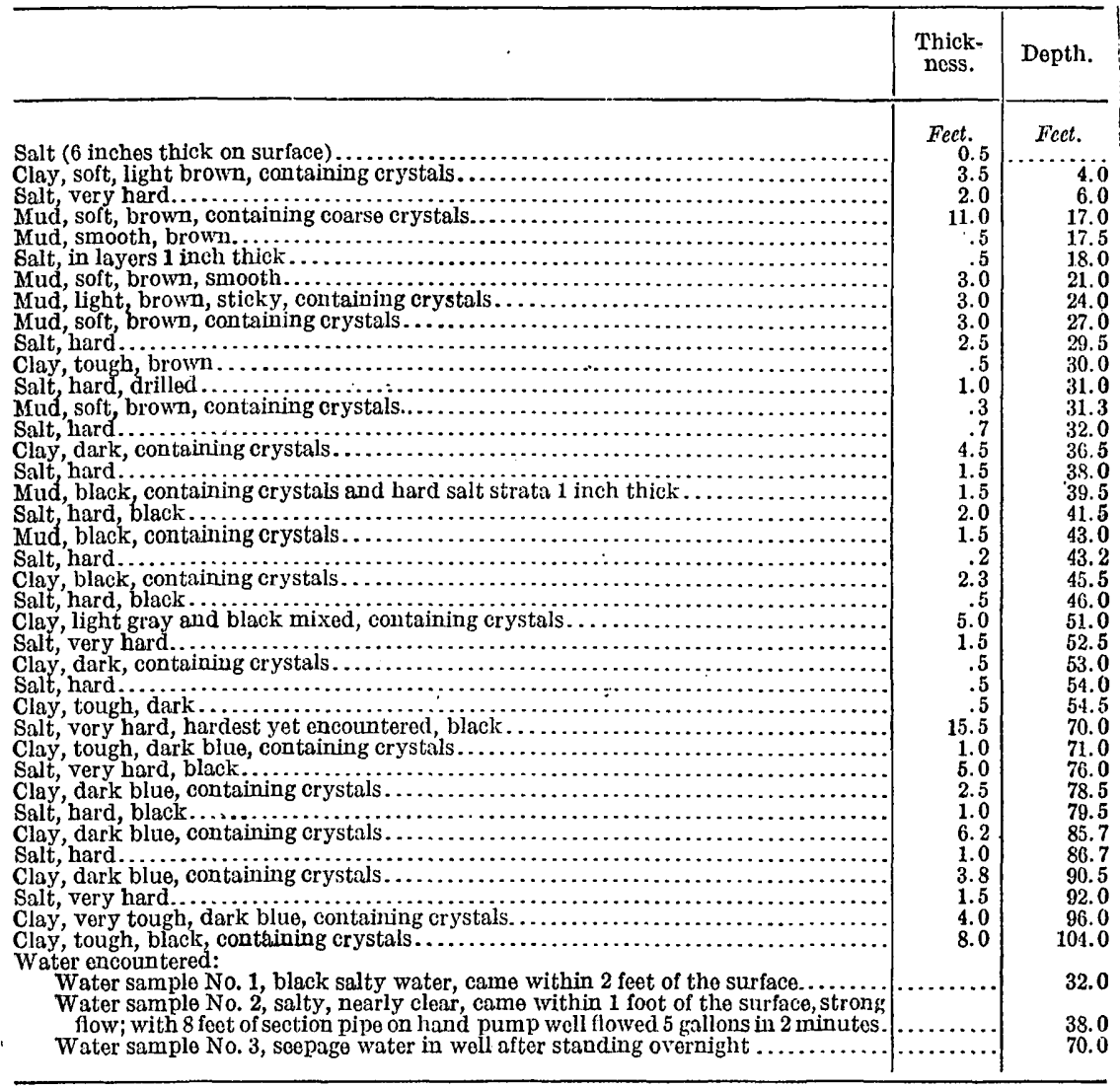

With reference to the possibility. of finding deposits of potash salts deeply buried in the valley, Gale concludes that evidence of former deep submergence of the valley has not been found; that the appearance of the deposits is such as to indicate that they are the result of alternate periods of shallow submergence and desiccation; and hence that there is little justification for any present assumption that important deposits of potash salts lie in the valley.

\section{SALINE VALLEY.}

Saline Valley, which was also visited by Gale, ${ }^{1}$ is in the westcentral part of Inyo County, between the Inyo Mountains on the west and the Panamint Mountains on the east. (See fig. 12.) The salt deposits of the valley occupy the lowest part of the depression, which is without outlet and is completely inclosed by high mountains. The central depression of the valley has without doubt been

1 Gale, H. S., Salt, borax, and potash in Saline Valley, Inyo County, Cal.: U. S. Geol. Survey Bull. 540, pp. 416-421, 1914. 
occasionally submerged; but perhaps to shallow depths only, as no evidence of former shore lines of considerable height has been observed in the valley. Of the central deposit of mud and salts,

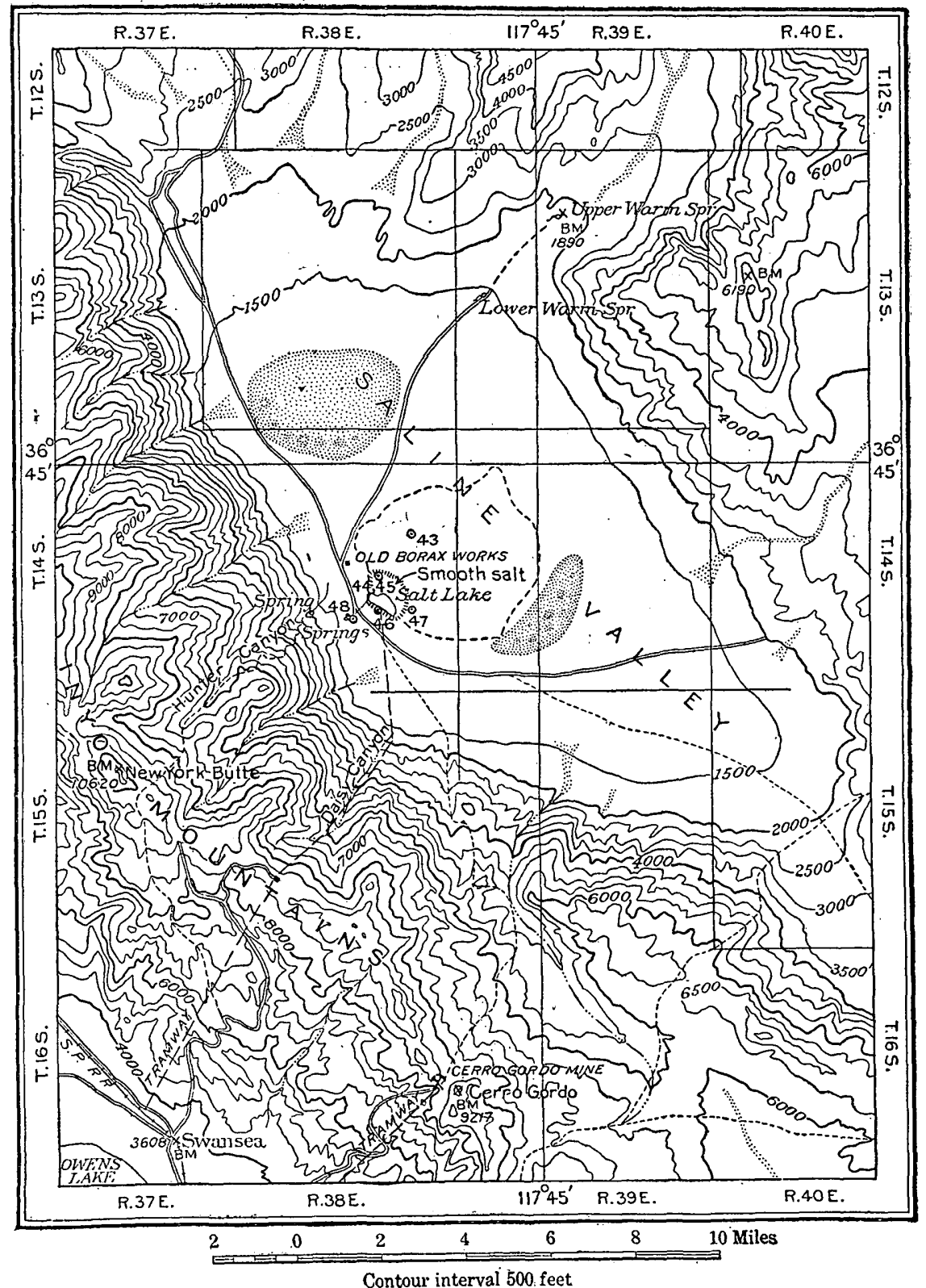

FraUre 12.-Map of Saline Valley and vicinity, Cal., showing location of salt deposits. (After H. S. Gale.)

approximately 1 square mile is a smooth white crust of salt, including a small open pond of salt water. Adjacent to this smooth crust is a rough expanse of broken and tilted salt-crust blocks, with a sharp 
craggy surface. A stock company has been organized to develop this deposit for the salt it contains, and a production was reported in 1913. The salt from the smooth crust in the lowest part of the valley was sampled as it stood piled in stacks ready for shipment, and the analysis of the samples showed it to contain 98.52 per cent of sodium chloride, and thus to be of high grade for a natural product. The complete analysis of the salt sample is as fcllows:

Analysis of salt sample from stacks in Saline Valley, Cal.

[R. K. Bailey, analyst.]

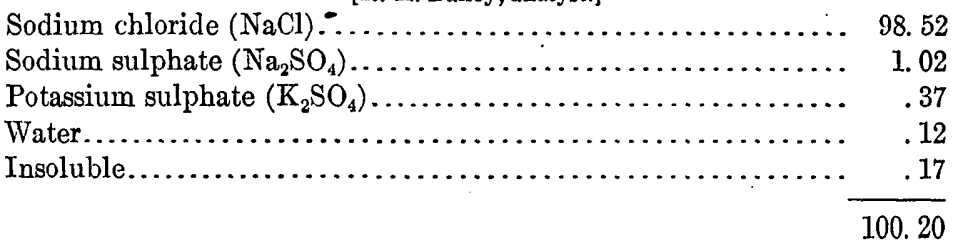

The thickness of the deposit is not known, as no drilling to any considerable depth has been done. Shallow holes dug in the surface of the white crust showed a surface thickness of 4 inches of loosetextured, porous white crystalline salt, below which there is a layer of dark-greenish or almost black saline mud several inches thick. Salt layers occur still farther down, but excavation is hindered by freely flowing brine, which fills the holes. Samples of the brine were collected and tested for potash salts, but the results indicated that potash is not present in quantities of commercial importance. It is quite likely that no extensive or deep lake ever existed in this valley and that the salines represent the accumulation from the surrounding and somewhat restricted drainage area. The results of the analyses of the brine collected from this region are given in the table below:

Potash analyses of brine from Saline Valley, Cal.

[Nos. 43-46, R. K. Bailey, analyst; Nos. 47 and 48, W. B. Hicks, analyst.]

\begin{tabular}{|c|r|r|r|r|}
\hline $\begin{array}{c}\text { Sample } \\
\text { No. }\end{array}$ & $\begin{array}{c}\text { Total salts } \\
\text { (ignited } \\
\text { residuc). }\end{array}$ & \multicolumn{3}{|c|}{$\begin{array}{c}\text { Potassium in the total salts } \\
\text { expressed as- }\end{array}$} \\
\cline { 3 - 5 } & & $\mathrm{K}$ & $\mathrm{K}_{2} \mathrm{O}$. & $\mathrm{KCl}$ \\
\hline 43 & 29.77 & 1.29 & 1.56 & 2.47 \\
44 & 28.10 & .78 & .94 & 1.48 \\
45 & 28.05 & .81 & .99 & 1.55 \\
46 & 28.77 & 1.29 & 1.56 & 2.47 \\
47 & 28.26 & .95 & 1.15 & 1.82 \\
48 & .10 & .05 & .06 & .10 \\
\hline
\end{tabular}

OTHER OCCURRENCES.

Salt strata have been encountered in dug wells at Tecopa, just rorth of the boundary between Inyo and San Bernardino counties; and the water of Confidence Spring, near "The Narrows," in south 
Death Valley, is salty. The niter beds in the canyon of Amargosa River contain some rock salt and numerous layers rich in salt. The name Amargosa River is somewhat misleading, as the river does not often carry enough water to flow on the surface as far as the lowest depression of Death Valley. The waters in the lower courses of the river are decidedly briny; where the stream widens out into the large playa at Resting Springs Dry Lake it leaves fields of salt as well as of borax and niter, and the desert on either side of the river is dotted with patches of salt. Salt Spring, in San Bernardino County, is in the valley of South Fork of Amargosa River, where it turns northwest to join the main Amargosa near the south end of Death Valley.

For lists of the springs which may be fresh, brackish, or salty, the reader is referred to the reports of Bailey and Mendenhall in the bibliography (p. 192).

KERN COUNTY.

CAMERON LAKE.

Cameron Lake is in the southern part of Kern County, in T. 32 S., R. 34 E., between Tehachapi and Cameron stations on the Southern Pacific Railroad. Bailey reports that it is a salt lake about 1 mile square, with a "saline stratum 5 to 6 feet deep." The lake dries up, and during dry seasons a salt crust is left 3 to 4 inches thick.

KANE LAKE.

Kane Lake is about 10 miles southwest of Randsburg, in the eastern part of Kern County, on the road between Mohave and Randsburg. The salt occurs in the bed of a dry lake or sink 6 miles long and 3 miles wide. The lake has no outlet, and the spring and fall rains cover it generally to a depth of 10 inches. About 3,000 acres are reported to be under water when this depth is attained. After the lake has evaporated to dryness, the salt is shoveled up and piled into heaps. Generally two crops a year may be secured, but in some years there is uncertainty about the fall crop on account of the September and October rains.

Two companies have been operating here, but recently the Diamond Salt Co. has bought them out. An artesian well has been sunk to procure water in addition to that supplied by the rainfall, if needed. Only crude solar salt is now produced; but it is planned to ship the crude salt to Los Angeles and there refine it for table and other uses.

OTHER OCCURRENCES.

Castac Lake, in the southwestern part of Kern County, is a shallow lake which in dry seasons is covered with a thick crust of salt. Northward as far as Kern River the entire county is an alkali desert, whose soil is heavily impregnated with salt. At one place, about 
14 miles from the Canyon de las Uvas, salt was prepared some years ago. At other dry lakes in different parts of the county salt occurs in appreciable quantities. In the northeast corner of the county a number of wells give the name "Salt Wells Valley" to a considerable area of land.

\section{MONO COUNTY.}

Mono Lake is in Mono County, near the Nevada line, at an altitude of 6,730 feet, and is the highest above the ocean of the saline lakes of the Great Basin. Its water is dense and alkaline. Owing to tho presence of volcanic rocks in the lake basin alkaline carbonates are abundant in the water, as shown by the following complete analysis made by T. M. Chatard:1

Analysis of water of Mono Lake, Cal.

[Grams per liter.]

Silica

0.0700

Calcium carbonate................................ .0500

Magnesium carbonate............................... . 1928

Potassium chloride............................... 1.8365

Sodium chloride................................. 18. 5033

Sodium sulphate................................ 9.8690

Sodium carbonate................................... 18. 3556

Sodium bicarbonate................................ 4.3856

Sodium tetraborate.................................. . 2071

Alumina ........................................ .0030

53.4729

The results of this analysis show that sodium chloride constitutes nearly 35 per cent of the total solids. Experiments by Chatard on the fractional crystallization of the mineral content of the water gave the results presented below, which show the same general rule of deposition as at Owens Lake. The water used in the experiments had already been evaporated to about one-sixth of its original volume and had a specific gravity of 1.210 .

Analyses of salts deposited by fractional crystallization of water of Mono Lake, Cal.a

\begin{tabular}{|c|c|c|c|c|c|}
\hline & 1 & 2 & 3 & 4 & 5 \\
\hline 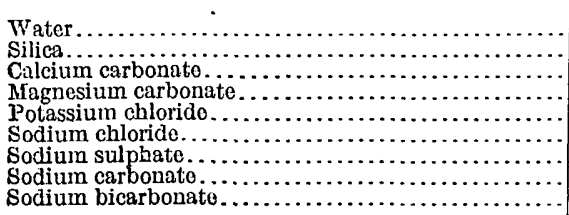 & \begin{tabular}{r|}
12.28 \\
.07 \\
.05 \\
.48 \\
.69 \\
19.18 \\
2.73 \\
36.87 \\
27.37
\end{tabular} & $\begin{array}{r}10.98 \\
.17 \\
.14 \\
.46 \\
.69 \\
21.34 \\
14.18 \\
41.07 \\
10.99\end{array}$ & $\begin{array}{r}0.69 \\
.16 \\
.05 \\
.02 \\
.47 \\
29.96 \\
49.13 \\
18.27 \\
10.03\end{array}$ & $\begin{array}{r}4.18 \\
.07 \\
.7 .71 \\
60.75 \\
16.22 \\
14.22 \\
3.83\end{array}$ & $\begin{array}{r}11.31 \\
.13 \\
.02 \\
15.20 \\
32.36 \\
6.65 \\
33.69 \\
.49\end{array}$ \\
\hline & 99.72 & 100.02 & 99.78 & 100.03 & 99.85 \\
\hline
\end{tabular}

$a$ U. S. Geol. Survey Bull. 60, p. 66, 1890.

1 Chatard, 'T. M., Analyses of the waters of some American alkali lakes: Am. Jour. Sci., 3d ser., vol. 36 , p. 149, 1888; also Natural soda-its occurrence and utilization: U. S. Geol. Survey Bull. 60, p. 53, 1890. 
The lake has an area of 85.5 square miles and an average depth of 61.5 feet. From its volume and the mineral content of its water the amount of the various salines which it contains has been estimated. The results indicate the presence in the lake of $86,099,600$ tons of common salt and 10,538,100 tons of potassium chloride. ${ }^{1}$ Such figures show that the saline reserves in this and other incompletely evaporated or playa lakes of the desert region of California and other public-land States are very large and may prove valuable when transportation facilities have been developed and methods for the extraction of the salts perfected. ${ }^{2}$

\section{RIVERSIDE COUNTY.}

The main source of salt in Riverside and Imperial counties, Cal., was Salton Sink, an immense basin in which thousands of tons of water were evaporated annually. This water was supplied by the drainage from the east side of the San Jacinto Range, Carrizo Creek, and a part of the San Bernardino Mountains, and in times of extremely high water the basin served as a reservoir for the excess in Colorado River. ${ }^{3}$ According to Mendenhall ${ }^{4}$ it receives normally only the occasional overflows from the tributaries of the Colorado. With the flooding of the sink by Colorado River in 1905 and 1906 the salt-producing industry in this region ceased. The sink is now filled by a lake having an area of about 450 square miles and a maximum depth of 67.5 feet. $^{5}$. If further inflow is prevented it will only be a decade or so before the original conditions are restored.

The bed of salt, until the last overflow, was extensively exploited by the New Liverpool Salt Co., and shipments were made from Salton by rail.

In 1892 the lake was described as a salt marsh connected by a branch railway with the main line of the Southern Pacific Railroad. The company's works were located about 3,000 feet west of the railroad, on a spur track that extended into the marsh a distance of 10,000 feet. Beyond the end of the track a well was bored by the company to a depth of 300 feet. The topmost material of the well consisted of a layer of black mud 6 inches thick, resting on a crust of sodium and magnesium chlorides, 7 inches thick. On passing through the crust the drill dropped through 22 feet of black ooze containing over 50 per cent of water. This ooze consisted largely of sodium and magnesium chlorides and carbonates, the sodium salts predominating; also fine sand, iron oxide, clay, and organic matter.

1 Bailey, G. E., The saline deposits of California: California State Min. Bur. Bull. 24, p. 101, 1902.

2 See also notes in Young, G. J., op. cit.

3 Preston, E. B., Salton Lake: California State Mineralogist Eleventh Rept., p. 389, 1893.

4 Mendenhall, W. C., Some desert watering places in southeastern California and southwestern Nevada: U. S. Geol. Survey Water-Supply Paper 224, p. 10, 1903.

${ }^{6}$ Freeman, W. B., and Bolster, R. H., Surface water supply of the Colorado River basin, 1907-8:

U. S. Geol. Survey Water-Supply Paper 249, p. 46, 1910. 
The ooze rested on hard clay, through which the drill passed for the remaining distance, 277 feet. In this clay were two or three streaks of cement. ${ }^{1}$

\section{SAN BERNARDINO COUNTY.}

Searles Lake is mainly in San Bernardino County, near the corner of Inyo, San Bernardino, and Kern counties, but it has been described under Inyo County for convenience. (See pp. 164-174.)

SALTUS.

In recent years salt has been produced near Saltus (post office, Amboy), a station on the Atchison, Topeka \& Santa Fe Railway, in the southeastern part of San Bernardino County. The writer has not visited the locality, and the following notes were orally communicated. The salt occurs in the bottom of an old lake bed in the form of layers of rock salt. To work these layers the overburden, which is approximately 5 feet thick, has to be removed. The upper layer of rock salt is 5 to 7 feet thick, and the interval between the base of this upper and the next underlying bed of salt is about 20 feet. The exact thickness of the lower salt bed is unknown, as it has been penetrated to a depth of only a few feet, and difficulties have been encountered in attempts to work it on account of the water in the intermediate stratum.

\section{AMARGOSA RIVER. ${ }^{2}$}

A short stretch of Amargosa River is in San Bernardino County, but most of the river is in Inyo County and in Amargosa Desert, Nye County, Ner. Its source is a group of springs about 17 miles northeast of Bullfrog, Nev. It flows southeast, passing Franklin dry lake, Resting Springs dry lake, and thence through a rugged canyon to a point near Sperry, on the Tonopah \& Tidewater Railroad. There it turns southwestward and flows around the south end of the Black Mountains, and then to the northwest into the sink of Death Valley. The term "river" is somewhat misleading. Its total length is about 140 miles, and throughout its course it disappears and reappears, its water being absorbed by the porous beds over and through which it flows. In recent years it has flowed on the surface only a few miles beyond Saratoga Springs, in San Bernardino County, even during the heaviest floods. Though the water in the river is potable near its source, it takes up during its flow large amounts of the various salts, becoming finally heavily charged, a fact which has givon the river its name--"Amargosa," meaning bitter in Spanish.

i Preston, E. B., op. cit., p. 388. Seo also McDougal, D. T., and others, Tho Salton Sea, Carnegio Inst. Washington Pub. 193, p. 10, 1914.

2 For analyses of water from Amargosa Valley sce Young, G. J., Potash salts and other salines in the Great Basin region: U. S. Dept. Agr. Bull. 61, p. 78, 1914, Analyses are by J. A. Cullen. 
In the lower courses, including San Bernardino County, where the water comes to the surface these salts are deposited as white crusts, which contain salt and the borate minerals. These crusts have been removed and marketed, and some of them by natural re-solution and recrystallization have been rendered quite pure.

AVAWATZ MOUNTAINS.

Salt occurs as rock salt in upturned beds on the northern slopes of the Avawatz Mountains in San Bernardino County. It outcrops over a large acreage in a zone between 4 and 5 miles long. To judge from the attitude of the beds it must underlie an extensive territory. The salt occurs as a member of a series of saline deposits, consisting essentially of celestite at the base, gypsum, and salt, the entire series being underlain and overlain by lake beds. (See Pls. XIV, $B, \mathrm{p}, 156$, and XVI.)

The underlying lake beds are made up chiefly of compacted sands and shales, including conglomerates in places. Celestite is found near the top of the series at the base of the overlying gypsum. A little gypsum is disseminated in part of the lake beds but not enough to make it of any economic consequence. In places sodium sulphate and niter are reported as found respectively in the shales toward the center of the deposits and along what is locally known as "pipe-line wash." The overlying lake beds consist chiefly of gravels and sands and contain a small amount of clay, gypsum, and possibly other salts. In places both the lower and the upper lake beds are characterized by the rather brilliant hues of the shales composing them, white, maroon, yellow, rose, and green being not uncommon colors.

The saline deposits and their underlying and overlying lake beds lie between (1) a basement complex of sedimentary rocks, which have been in part metamorphosed and intruded by igneous rocks, and (2) gravel beds of unknown thickness, which cover the economic deposits in part, form alluvial cones and fans, and extend into the valley on the north side of the mountains. In general the surface of the gravels, especially away from the edge of the foothills, is very smooth, this smoothness characterizing also the surface of the alluvial fans.

The salt layers proper, as would naturally be expected, are not sharply demarked in all places from the underlying gypsum layers. The line of division comes most naturally in clayey sediments containing both gypsum and salt between the main deposits of salt and of gypsum. There is also a transitional zone between the salt deposits and the overlying shales and sands of the upper lake beds, but the main salt body is distinctive. The salt has been leached in places and is covered with a mantle of reddish saline clays. Very little is exposed at the surface, but some of it approaches close to the surface and is distinguished by a peculiar "steplike" structure, by 


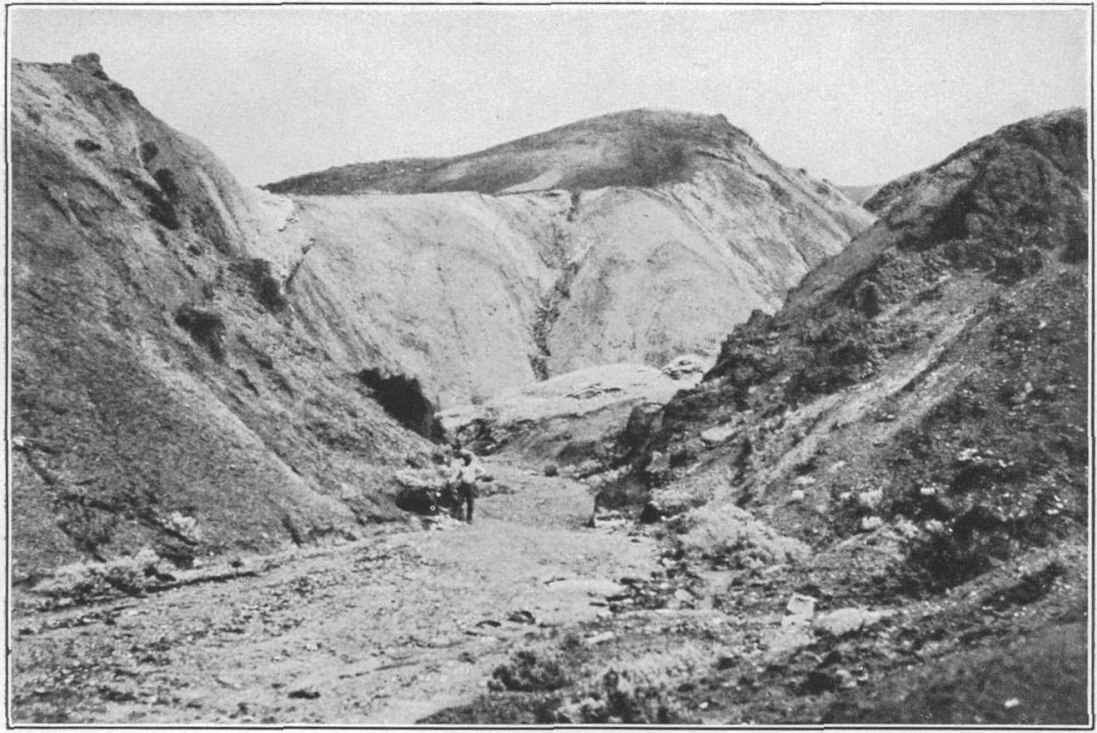

A. HOGBACK OF CELESTITE WITH GYPSUM IN BACKGROUND, AVAWATZ SALT \& GYPSUM CO., SAN BERNARDINO COUNTY, CAL.

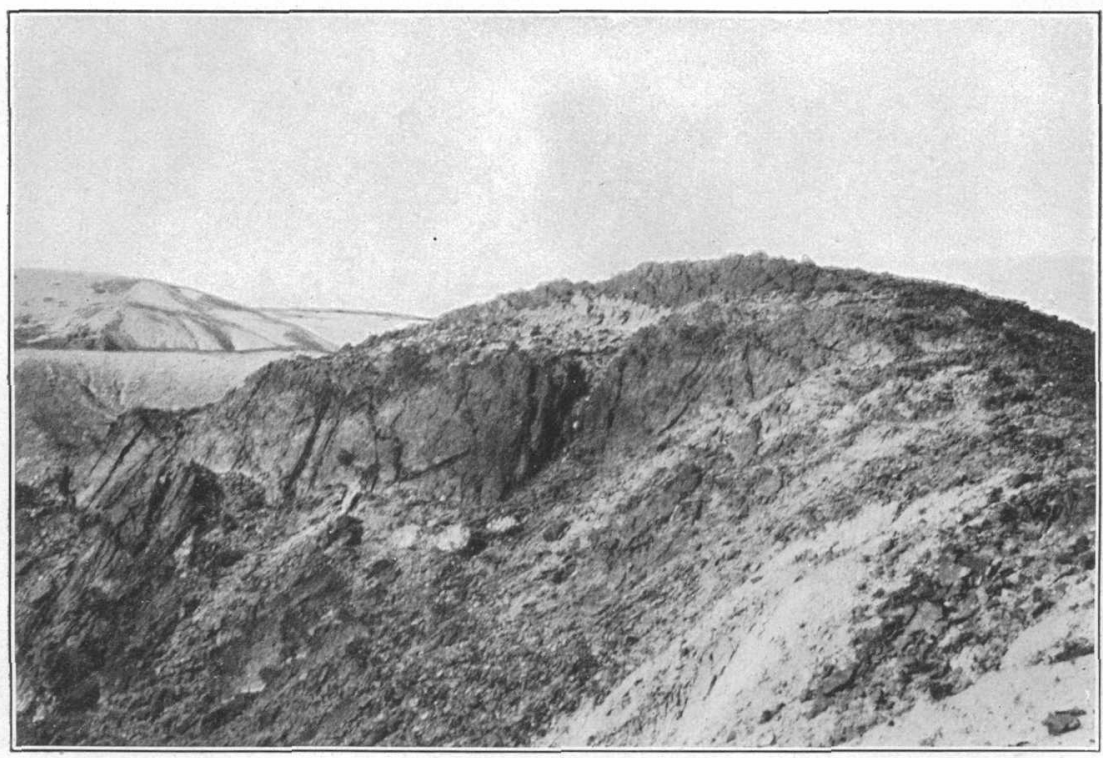

B. BEDDED STRUCTURE IN CELESTITE, AVAWATZ SALT \& GYPSUM CO., SAN BERNARDINO COUNTY, CAL. 
the formation of hard crusts, or by saline efflorescences. Dectailed measurements of thickness are difficult to make until developments have progressed farther than at present.

The quantity of rock salt present must be very great. Where it has been worked its purity has increased with depth. Some chemical analyses show that it is 98 per cent pure. It is massively crystalline. Its color is generally brownish near the surface, the discoloration being usually due to reddish-brown clay, the color of which is in turn due to iron oxide.

DANBY.

Salt has been mined 30 miles southeast of Danby, a station on the Atchison, Topeka \& Santa Fe Railway, in the southeastern part of San Bernardino County, in T. 7 N., R. 16 E., on a dry lake known as Danby Lake. The old mines are 6 miles from the south ond of Old Womans Mountain. The salt lies in two beds, each ranging from a few inches to several feet in thickness, separated by a thick layer of clay and protected by a layer of sand and dust. The salt bed has been developed over a tract covering many acres, which includes, however, only a small part of the deposits. When the mines were worked, the salt was hauled in traction wagons to Danby, where it was sold to chloridize silver ore. The shafts are said to have passed through salt 22 feet thick in one place and 35 feet in another. The salt was said to be 98 per cent pure. A small house built of rock salt has been erected at the lake.

\section{MOHAVE RIVER AND SINK.}

The Mohave River rises in the San Bernardino Mountains, flows north and northeast through Barstow and Daggett along tho line of the Atchison, Topeka \& Santa Fe Railway, thence more nearly to the east, following the Los Angeles \& Salt Lake Railroad to Soda Lake, which is the sink of Mohave River, otherwise known as Mohave Sink. Silver Lake, north of Soda Lake, is in the basin of this river and the divide between Silver Lake and Silurian Dry Lake, ${ }^{1}$ which is the source of the south fork of Amargosa River, is only 30 feet high and consists of sand, the two river systems being separated by this low, frail barrier. Mohave River is about 100 miles long and, except during flood season, has little surface flow, and then only in places where ledges lie athwart its course and force the water to the surface. The water of the river is saline but probably not so saline as that of Amargosa River. Saline efflorescences occur all along its course.

Soda Lake or Mohave Sink during the wet season contains water which on evaporation during the dry season leaves a crust of saline minerals, principally salt, sodium carbonate, and sodium sulphate, and small amounts of potash salts, borates, bicarbonates, and siica.

\footnotetext{
1 Mendenhall, W. C., Some desert watering places in southeastern California and southwestern Nevada: U. S. Geol. Survey Water-Supply Paper 224, p. 18, 1909.
} 
During the wet season the degree of concentration of the solution has been found to range from 282 parts per 100,000 to complete saturation. The area of the sink is about 80 square miles.

Some salt has been made here by diverting water from the surrounding hills to certain parts of the lake. The salt is dissolved, and the brine is conveyed to vats and there evaporated. Only coarse salt has been marketed from the region.

Samples of brine have been collected by H. S. Gale from Soda Lake or the sink of the Mohave River, about 30 miles north of Ludlow, Cal. The analyses of these samples are given below. They show the saline material to consist principally of chlorides, sulphates, carbonates, and borates of sodium, and a small amount of potash. The analyses by $R$. K. Bailey do not indicate the presence of lime magnesium salts, but the analysis by Oscar Loew ${ }^{1}$ shows considerable quantities of these bases. Loew's solutions were very dilute compared with those collected by Gale, but, as stated above, the degree of concentration of the solutions occurring in Soda Lake varies greatly, according to the season. The concentration of Loew's sample was approximately only one one-hundredth of that of the samples collected by Gale. The results of the analyses made in the Survey laboratory and Loew's results are as follows:

Analyses of brines from Soda Lake, San Bernardino County, Cal.

Radicles in grams per liter.

\begin{tabular}{|c|c|c|}
\hline & 104 & 105 \\
\hline $\begin{array}{l}\ldots \ldots \ldots \\
\cdots \cdots . . .\end{array}$ & $\begin{array}{c}0.009 \\
142.75\end{array}$ & $\begin{array}{r}0.01 \\
145.28\end{array}$ \\
\hline Mg... & & $\cdots$ \\
\hline \multirow[t]{2}{*}{ 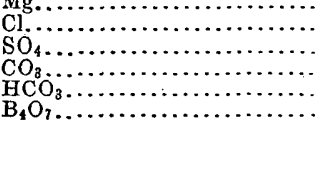 } & $\begin{array}{r}155.75 \\
65.00 \\
12.29 \\
3.00 \\
2.62\end{array}$ & $\begin{array}{r}148.68 \\
74.59 \\
8.69 \\
2.83 \\
2.39\end{array}$ \\
\hline & 381.419 & 382.47 \\
\hline
\end{tabular}

Combinations in grams per liter.

\begin{tabular}{|c|c|c|}
\hline & 104 & 105 \\
\hline \multirow[t]{2}{*}{ 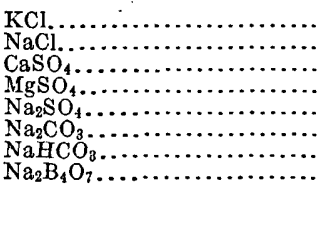 } & $\begin{array}{r}0.01 \\
256.69 \\
\text { None. } \\
\text { None. } \\
96.14 \\
21.62 \\
4.14 \\
3.40\end{array}$ & $\begin{array}{r}0.01 \\
250.99 \\
\text { None. } \\
\text { None. } \\
110.32 \\
15.36 \\
3.93 \\
3.10\end{array}$ \\
\hline & 382.00 & 383.71 \\
\hline
\end{tabular}

Radicles in percentage of anhydrous residue.

\begin{tabular}{|c|c|c|}
\hline & 104 & 105 \\
\hline \multirow[t]{2}{*}{ 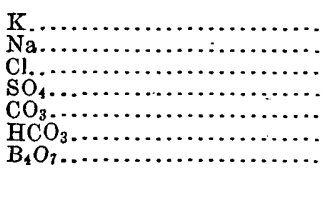 } & $\begin{array}{l}0.002 \\
37.43 \\
40.84 \\
17.05 \\
3.22 \\
.78 \\
.68\end{array}$ & $\begin{array}{r}0.002 \\
37.98 \\
38.90 \\
19.50 \\
2.25 \\
.74 \\
.63\end{array}$ \\
\hline & 100.002 & 100.002 \\
\hline
\end{tabular}

Combinations in percentage of anhydrous residue.

\begin{tabular}{|c|c|c|}
\hline & 104 & 105 \\
\hline 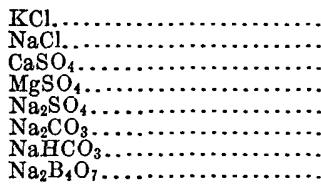 & $\begin{array}{r}0.01 \\
67.19 \\
\text { None. } \\
\text { None. } \\
25.16 \\
5.67 \\
1.08 \\
.89\end{array}$ & $\begin{array}{r}0.01 \\
65.41 \\
\text { None. } \\
\text { None. } \\
28.75 \\
4.00 \\
1.02 \\
.81\end{array}$ \\
\hline & 100.00 & 100.00 \\
\hline
\end{tabular}

104. Brine from Soda Lake, San Bernardino County, Cal. Collected by H. S. Gale; R. K. Bailey, analyst. Specific gravity, 1.25 .

105. Brine from Soda Lake, San Bernardino County, Cal. Collected by H. S. Gale; R. K. Bailey, analyst. Specific gravity, 1.26 . 
Analysis of water from the saline flats of Mohave River or Soda Lake, San Bernardino County, Cal.

[Parts per 100,000 parts of solution. Oscar Loew, analyst.]

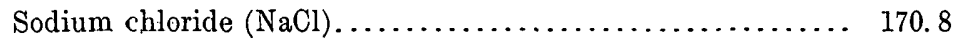

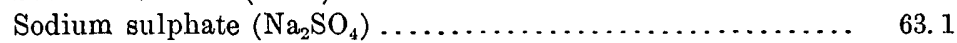

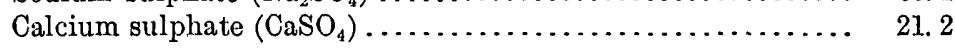

Magnesium sulphate $\left(\mathrm{MgSO}_{4}\right) \ldots \ldots \ldots \ldots \ldots \ldots \ldots \ldots \ldots .6 .5$

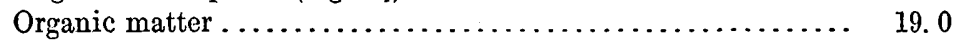

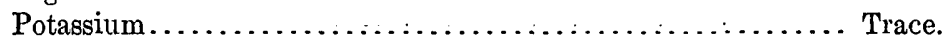

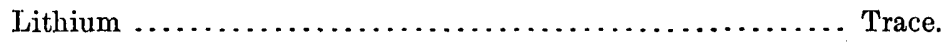

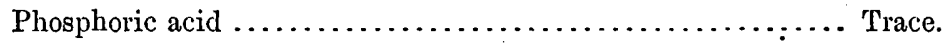

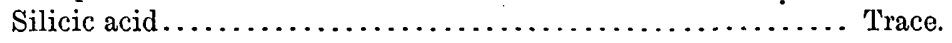

BITTER SPRINGS.

282.6

Bittcr Springs, San Bernardino County, at the southeast end of Bitter Lake, in T. 13 N., R. 5 E. San Bernardino meridian, contain salt and sodium sulphate.

\section{DAGGETT.}

Beds of salt mixed with sand underlying the desert in the vicinity of Daggett, San Bernardino County, are reported to have been utilized years ago by silver miners. Salt is said to be associated with the borate minerals of the Calico district, ${ }^{1}$ north and northeast of Daggett.

\section{OWL SPRING DISTRICT.}

The Owl Spring district is in the northwestern part of San Bernardino County, between the west end of Avawatz Mountains and the east flank of Owl Mountains, and was named from the well-known "Owl Hole" or "Owl Spring." The southwestern or higher part of the district, which abuts the mountains, contains colemanite and other borates, and the northeastern part contains deposits of rock salt and heary salt crusts. Some niter also has been found.

OTHER LOCAJITIES.

Other localities in San Bernardino County where salt is known to occur are the Salt Springs on the south fork of Amargosa River, at the southeast end of Death Valley; near Saratoga Springs, 14 miles northwest of Salt Springs (here the borax beds contain 20 per cent of salt); and Valley Springs, about 8 miles northwest of Saratoga Springs, whose water is so salty as to be undrinkable.

Valley Springs are probably formed by a part of the water of Amargosa River coming to the surface, as a rock reef extends across the valley and is exposed half a mile below the springs. An analysis of the water from the springs is as follows:

1 Bailey, G. E., The saline deposits of California: California State Min. Bur. Bull. 24, p. 128, 1902. 
Analysis of water from Valley Springs, Cal.

[Grams per liter; Thomas Price, analyst.]

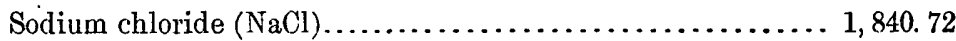

Sodium carbonate $\left(\mathrm{Na}_{2} \mathrm{CO}_{3}\right) \ldots \ldots \ldots \ldots \ldots \ldots \ldots \ldots \ldots \ldots \ldots \ldots \ldots \ldots \ldots \ldots \ldots, 724.11$

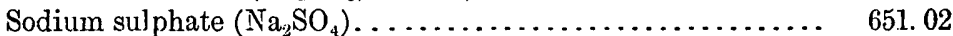

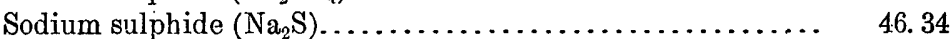

Potassium chloride $(\mathrm{KCl}) \ldots \ldots \ldots \ldots \ldots \ldots \ldots \ldots \ldots \ldots \ldots . \quad 132.30$

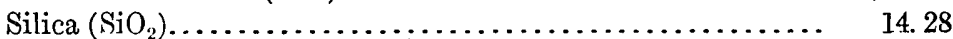

Organic matter...................................... 13.48

Willards Lake is in the northwestern part of San Bernardino County, in Tps. 30 and 31 S., R. 42 E. Mount Diablo meridian. The bed of the lake, like most lake beds in this region, is impregnated with salt, and the shore is marked with white crusts. Willard's well is at the northeast end of the dry lake and contains a good supply of slightly brackish water.

\section{SAN LUUIS OBISPO COUNTY.}

Soda Lake or Salt Lake, in Carrizo Plain, contains important deposits of sodium sulphate, with which small amounts of ordinary salt are associated. Carrizo Plain is near the eastern boundary of San Luis Obispo County, and the lake is in T. 31 S., Rs. 19 and 20 E. (See fig. 13.) The lake receives the drainage of the plain and the surrounding mountain slopes. The saline deposits are estimated to cover an area of 2,800 to 3,000 acres, and they have the following composition:

Analysis of salt crust from Soda Lake, Cal.

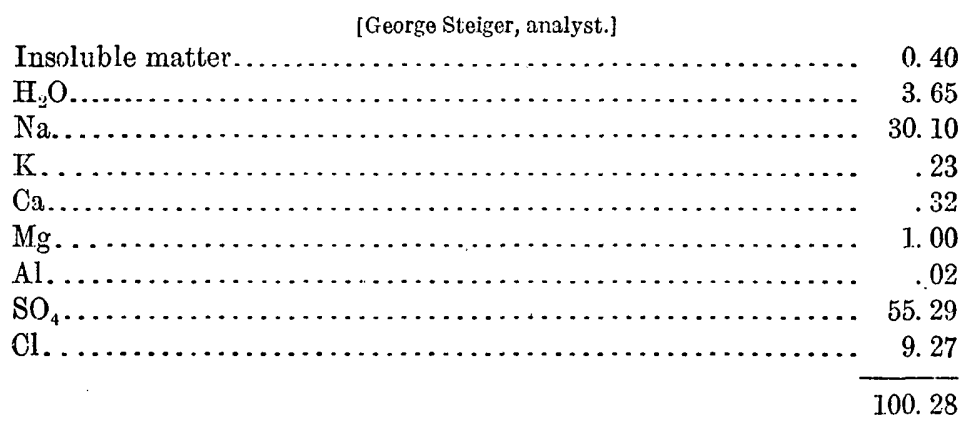

Exploitation of the deposits for sodium sulphate was undertaken, but operations were discontinued a few years ago and have not been resumed. Gale ${ }^{1}$ reports that soluble potash salts are not associated with the sodium sulphate in sufficient quantity to be commercially significant.

Water from the following springs in the county has been analyzed and found to contain salt: Near El Paso del Robles-Mud Spring,

1 Gale, H. S., Sodium sulphate in the Carrizo Plain, San Luis Obispo County, Cal.: U. S. Geol. Survey Bull. 540, pp. 428-433, 1914. Arnold, Ralph, and Johnson, H. R., Sodium sulphate in Soda Lake, Carrizo Plain, San Luis Obispo County, Cal.: U. S. Geol. Survey Bull. 380, pp. 369-372, 1909. 
Sulphur Spring, Soda Spring, Garden Spring, Sand Spring, White Sulphur Spring, Iron Spring, and Congress Spring; at San Luis ObispoSycamore Spring.

\section{OTHER COUNTIES.}

Other places in the State wheresalt has been found in small quantities are as follows:

Calaveras County.-Salt springs occur on Mokelumne River, 6 miles south of Silver Lake.

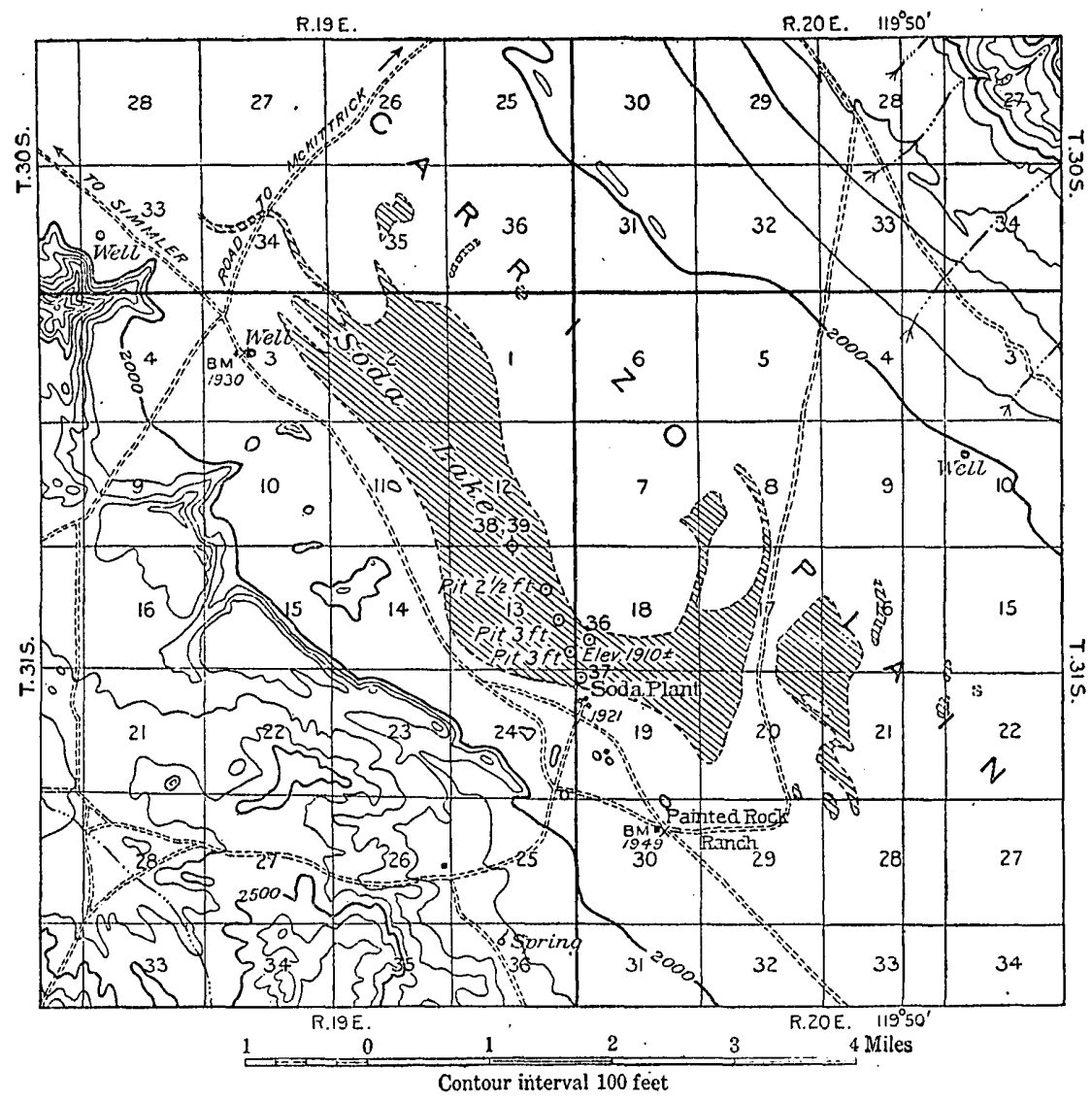

Figure 13.-Map of Soda Lake, San Luis Obispo County, Cal.

Contra Costa County.-Alhambra Minoral Springs.

Humboldt County.-Eureka Springs.

Lake County.-Allen Spring, Borax Lake, Lake Hachinhama, Hot Borate Spring, Clear Lake, Howard Spring, and Siegler Spring.

Los Angeles County.-According to G. E. Bailey ${ }^{1}$ large salt springs are found 14 miles from the city of Los Angeles, but a more exact location is not given. 
Modoc County.-Near Cedarville.

Napa County.-Aetna Springs, Calistoga Springs, White Sulphur Springs.

Placer County.-Salt springs are reported to exist near the Clipper Gap iron mine.

San Benito County.-Andersons Springs.

Santa Clara County.-Pacific Congress Springs, Alum Spring, Azule Spring, Blodgett Spring, near Gilroy, New Almaden Spring.

Shasta County.-Salt was made at one time on Salt or Stinking Creek, 12 miles east of Redding.

Siskiyou County.-Strong brine is reported to flow from a well near Yreka 675 feet deep.

Solano County.-Tolenas Springs.

Sonoma County.--Santa Rosa Spring, Skaggs Springs, White Sulphur Springs.

Tehama County.-Tuscan Springs, Little Salt Creek.

\section{BIBLIOGRAPHY.}

Arnold, RAl.FH, and Johnson, H. R., Sodium sulphate in Soda Lake, Carrizo Plain;

San Luis Obispo County, Cal.: U. S. Geol. Survey Bull. 380, pp. 369-371, 1909.

BaIley, G. E., California State Min. Bur. Bull. 24, pp. 105-138, 1002.

BLAKE, W. P., see McDougal, D. T., and others.

Browne, J. R., Resources of the Pacific slope, pp. 254-255, San Francisco, 1869.

Davis, A. P., The new inland sea: Nat. Geog. Mag., vol. 18, pp. 37-48, 1907.

Dolbear, C. E., The Searles Lake potash deposit: Eng. and Min. Jour., vol. 95, pp. 259-261, 1913.

Ecres, E. C., Salt industry of Utah and California: U. S. Geol. Survey Bull. 255, pp. 488-495, 1904.

GaLe, H. S., Prospecting for potash in Death Valley, Cal.: U. S. Geol. Survey Bull. 540, pp. 407-415, 1913.

Notes on the Quaternary Lakes of the Great Basin, with special reference to the deposition of potash and other salines: U. S. Geol. Survey Bull. 540, pp. 399-406, 1914.

- Sodium sulphate in the Carrizo Plain, San Luis Obispo County, Cal.: U. S. Geol. Survey Bull. 540, pp. 428-433, 1914.

Salt, borax, and potash in Saline Valley, Inyo County, Cal.: U. S. Geol. Survey Bull. 540, pp. 416-421, 1914.

McDoulat, D. T., and others, The Salton Sea; a brief study of the geography, the geology, and the floristics and ecology of a desert basin: Carnegie Inst. Washington Pub. 193, 1914.

Mendenhali, W. C., Some desert watering places in southeastern California and southwestern Nevada: U. S. Geol. Survey Water-Supply Paper 224, 1909.

Parker, E. W., Salt, U. S. Geol. Survey Eighteenth Ann. Rept., pt. 5, pp. 9-10, 1897.

Young, G. J., Potash salts and other salines in the Great Basin region: U. S. Dept. Agr. Bull. 61, 96 pp., 6 pls., 1914.

The chapters on salt in the volumes of Mineral Resources of the United States published by the Geological Survey contain data on the occurrence and technology of salt in California and the United States in general. 


\section{ORIGIN AND FORMATION OF SALINE DEPOSITS.}

\section{AGE OF SALINE DEPOSITS.}

The deposition of salt has been taking place probably during all geologic ages since the early Cambrian, and the process is observable at the present time. Many of the most extensive deposits of rock salt in the United States, like those of western New York and of certain parts of Michigan, were formed during late Silurian time. On the other hand, most of the deposits in the desert basins of the West represent accumulations during Quaternary time.

The following table represents the geologic distribution of salt in the United States:

Geologic distribution of saline deposits and brines.

\begin{tabular}{|c|c|c|}
\hline \multicolumn{2}{|c|}{ Time. } & Locality. \\
\hline \multicolumn{2}{|c|}{ Recent. } & $\begin{array}{l}\text { Salt formed or forming in inland seas: Great Salt } \\
\text { Lake, Utah; Lake at Zuni, N. Mex.; Owens, } \\
\text { Searles, and Mono lakes, Cal.; alkali lakes of } \\
\text { Oregon; salt plains or marshes in Oklahoma; } \\
\text { trans-Pecos region of Texas, Nevada, New } \\
\text { Mexico, Utah, California; widely scattered salt } \\
\text { springs in Western States. }\end{array}$ \\
\hline \multicolumn{2}{|c|}{ Tertiary. } & $\begin{array}{l}\text { Salt domes of Louisiana and Texas (part of Louisi- } \\
\text { ana deposits are Quaternary and possibly lato } \\
\text { Cretaceous); deposits near Idaho-W yoming bor- } \\
\text { der; Virgin River valley, Nov. }\end{array}$ \\
\hline \multicolumn{2}{|c|}{ Jurassic. } & Sevier Valley, Utah. \\
\hline \multirow{3}{*}{ Carboniferous. } & Permian. & $\begin{array}{l}\text { Kansas, Oklahoma. northwestern and western } \\
\text { Texas, eastern New Mexico. }\end{array}$ \\
\hline & Pennsylvanian. & $\begin{array}{l}\text { Along Ohio River near Pomeroy, Ohio, and Mason } \\
\text { and Hartiord, W. Va.; Malden, W. Va. }\end{array}$ \\
\hline & Mississippian. & $\begin{array}{l}\text { Saginaw Valley, Mich.; Saltville, Va.; Pittsburgh, } \\
\text { Pa. }\end{array}$ \\
\hline \multicolumn{2}{|c|}{ Silurian. } & $\begin{array}{l}\text { New York, Michigan (excluding Saginaw Valley), } \\
\text { northern Ohio. }\end{array}$ \\
\hline
\end{tabular}

\section{GENERAL PRINCIPLES OF DEPOSITION.}

If a saturated solution of a salt is concentrated by evaporation, part of the salt is deposited in crystalline form until the solution has again reached equilibrium of saturation. Different salts possess different degrees of solubility, or in other words, different amounts of them saturate a given amount of water at a given temperature. Therefore, if a solution containing equal amounts of several salts is gradually concentrated by evaporation one salt reaches its point of saturation and begins to crystallize before the others, forming a $40104^{\circ}-18-$ Bull. $669-13$ 
deposit of that salt; subsequently another salt reaches its point of saturation and forms a deposit mixed with more or less of the first salt, which is still depositing. Finally, after all the water except that retained in the crystals has been evaporated, a series of deposits, remains, grading from the deposit of the salt which first reached saturation at the bottom through various proportions of the others to a deposit of the most soluble salt at the top. If the supernatant liquid is removed before the second salt reaches its point of saturation, the deposit of the first salt is only slightly contaminated by adhering solution and can be rendered very pure by being dissolved in fresh water and recrystallized. This is the principle of the ordinary process of purification by fractional crystallization. If, on the other hand, more of the original mixed solution is added before the second salt begins to crystallize, the concentration of the first salt is decreased less than that of the others, and the deposition of it is thereby retarded less; consequently a thick deposit of the first salt may gradually be formed by continuous evaporation and successive additions of mixed solution, until finally the concentration of the other salts in the solution becomes so great that they also begin to deposit. This is the principle of separation followed in the grainer process. These fundamental processes, which can be demonstrated in any laboratory, are generally believed to have been followed in the formation of natural saline deposits.

Sea water is the most abundant natural saline solution, and it is generally believed that most of the great natural saline deposits of the world have been formed in accordance with the principles just outlined by evaporation of oceans or of sea water in semidetached arms of oceans. Whether the sea water from which such depositions have occurred had the same composition as the present ocean is conjectural, though many natural conditions support that common belief. According to Dittmar and others (see p. 219) the mineral matter in sea water has in round numbers the following composition:

Approximate average composition of the mineral matter in sea water.

\begin{tabular}{|c|c|c|c|}
\hline \multicolumn{2}{|l|}{ Radicles. } & \multicolumn{2}{|l|}{ Conventional combinations. } \\
\hline \multirow[t]{2}{*}{ 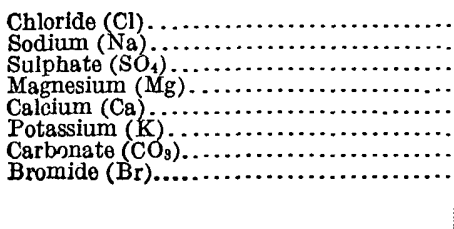 } & $\begin{array}{r}55.3 \\
30.6 \\
7.7 \\
3.7 \\
1.2 \\
1.1 \\
.2 \\
.2\end{array}$ & \multirow[t]{2}{*}{ 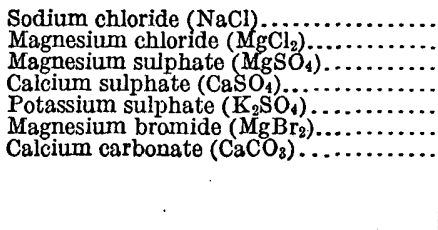 } & $\begin{array}{r}77.8 \\
10.9 \\
4.7 \\
3.6 \\
2.5 \\
.2 \\
.3\end{array}$ \\
\hline & 100.0 & & 100.0 \\
\hline
\end{tabular}


The order and the magnitude of natural saline deposits conform in general to the relative abundance and solubility of salts indicated in this table. Sodium chloride, the most abundant salt in sea water, is most abundant in saline deposits, and calcium sulphate, relatively small in quantity in sea water but also very low in solubility, ranksnext in abundance in deposits. The salts of magnesium and potassium, more especially the chlorides, are very soluble and are present in small proportion and consequently are less abundant in deposits. The order of deposition in general is in reverse order of solubility, but the presence of several compounds in the solution and the continually changing concentration of them affects materially their solubility and consequently their rate of deposition: The values in the following table show that calcium sulphate, for example, is relatively insoluble in pure water but is much more soluble in solutions containing chlorides. Mass action and the crystallization of double salts also increase the complexity, so that the order and other phenomena of the deposition become extremely complicated.

The study of the solubility of definite salts in solutions containing various other salts constitutes a branch of physical chemistry. The results are usually expressed by curves. Examples of such curves may be found in any work on the phase rule, ${ }^{1}$ which deals especially with the character and composition of the solid phases or salts that may be formed at certain temperatures. Curves showing the solubility of all common salts in pure water at different temperatures may be found in the physicochemical tables of Landolt-BörnsteinRoth. The solubilities of oceanic salts were determined by Van't Hoff, whose results have been published in special papers. Illustrations of all these solubility measurements may be found in books on the phase rule.

In the following table are given the solubilities of certain salts, most of which are present in ocean water and enter in varying quantity into the saline deposits resulting from either the complete or partial desiccation of such water.

1 For example, Findlay, Aloxandor, The phase rulo and its applications, Longmans \& Co., 1904. 
Solubility of certain salts. ${ }^{a}$

\begin{tabular}{|c|c|c|c|}
\hline \multirow[b]{2}{*}{ Salt. } & \multirow[b]{2}{*}{$\begin{array}{c}\text { Tempera- } \\
\text { ture. }\end{array}$} & \multicolumn{2}{|c|}{$\begin{array}{l}\text { Amount of pure } \\
\text { compound with- } \\
\text { out water of crys- } \\
\text { tallization- }\end{array}$} \\
\hline & & $\begin{array}{c}\text { Dissolved } \\
\text { in } 100 \\
\text { grams of } \\
\text { water. }\end{array}$ & $\begin{array}{l}\text { Dissolved } \\
\text { in } 100 \\
\text { cubic } \\
\text { centi- } \\
\text { meters of } \\
\text { the solu- } \\
\text { tion. }\end{array}$ \\
\hline & ${ }^{\circ} C$. & Grams. & Grams. \\
\hline $\begin{array}{l}\text { Sodium chloride }(\mathrm{NaCl}) \ldots \\
\text { Do } \ldots \ldots \ldots \ldots \ldots \ldots \ldots \ldots \\
\end{array}$ & $\begin{array}{r}0 \\
10\end{array}$ & $\begin{array}{l}35.7 \\
35.8\end{array}$ & ........... \\
\hline Do.......... & $\begin{array}{l}10 \\
25\end{array}$ & $\begin{array}{l}35.8 \\
36.12\end{array}$ & an. \\
\hline 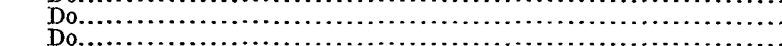 & 50 & 37.0 & (n) \\
\hline 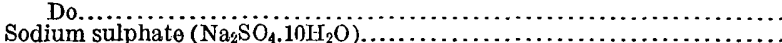 & 100 & 39.8 & (n........ \\
\hline 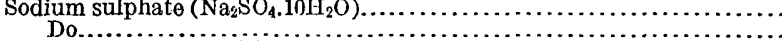 & $\begin{array}{r}0 \\
25\end{array}$ & 5.0 & (n........ \\
\hline Sodium sulphate $\left(\mathrm{Na}_{2} \mathrm{SO}_{4} .7 \mathrm{H}_{2} \mathrm{O}\right)$. & $\begin{array}{r}20 \\
0\end{array}$ & $\begin{array}{l}28.0 \\
19.5\end{array}$ & $\cdots$ \\
\hline 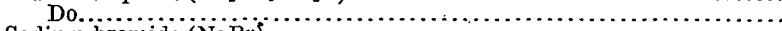 & 25 & 53 & a............ \\
\hline Sodium bromide (NaBr)........... & 0 & 66 & $\ldots \ldots \ldots \ldots$ \\
\hline Sodium iodide $\left(\mathrm{NaI} 2 \mathrm{H}_{2} \mathrm{O}\right)_{\ldots} \ldots .$. & $\begin{array}{r}20 \\
0\end{array}$ & $\begin{array}{c}77 \\
158.7\end{array}$ & 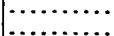 \\
\hline 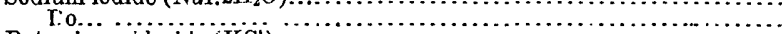 & 25 & 184.2 & an. \\
\hline Potassium chloride $(\mathrm{KCl}) \ldots \ldots \ldots \ldots$ & 0 & 27.6 & ........... \\
\hline 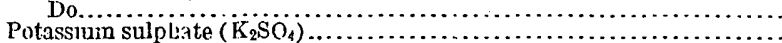 & $\begin{array}{r}25 \\
0\end{array}$ & $\begin{array}{c}35.5 \\
7.35\end{array}$ & an..... \\
\hline 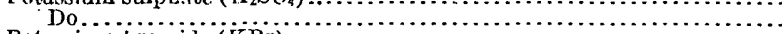 & 25 & 10.75 & an...... \\
\hline Potassium Lromide $(\mathrm{KBr}) \ldots \ldots$. & 0 & 53.5 & (n) \\
\hline 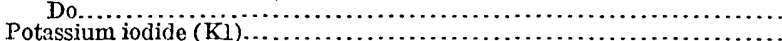 & $\begin{array}{r}25 \\
0\end{array}$ & $\begin{array}{r}67.7 \\
127.5\end{array}$ & $\cdots \ldots \ldots$ \\
\hline 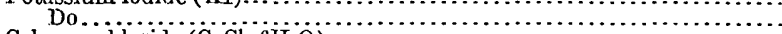 & 25 & 148 & ann. \\
\hline Calcrum chlorido $\left(\mathrm{CaCl}_{2} 6 \mathrm{H}_{2} \mathrm{O}\right) \ldots \ldots$ & 0 & 59.5 & (n)...... \\
\hline 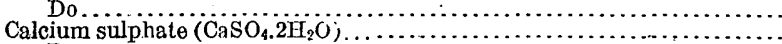 & $\begin{array}{r}20 \\
0\end{array}$ & 91.0 & $\cdots \cdots$ \\
\hline 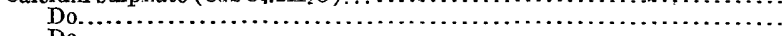 & 25 & (n...... & $\begin{array}{r}0.1708 \\
.2080\end{array}$ \\
\hline 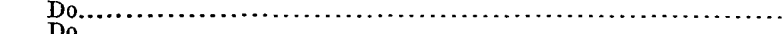 & 25 & 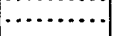 & b. 426 \\
\hline $\begin{array}{l}\text { Do....... } \\
\text { Do..... }\end{array}$ & $\begin{array}{l}25 \\
25\end{array}$ & $\cdots \cdots \cdots \cdots$ & $\begin{array}{l}c .569 \\
d .1620\end{array}$ \\
\hline Do.......... & 25 & $\mid \cdots \cdots \cdots \cdots$ & e. .1471 \\
\hline Do.... & 26 & ........... & $f .666$ \\
\hline Do......... & 26 & $\cdots \cdots$ & $g .650$ \\
\hline Do..... & 25 & $\begin{array}{l}20.9 \\
38.5\end{array}$ & …….... \\
\hline Magnesium chloride $\left(\mathrm{MgCl}_{2} 6 \mathrm{H}_{2} \mathrm{O}\right)$. & 0 & 52.8 & (a............ \\
\hline Do & 25 & 56.7 & ............ \\
\hline Do... & 25 & 97.6 & \\
\hline Magnesium iodide & 25 & & $\dddot{3} 54.4$ \\
\hline
\end{tabular}

$a$ Seidell, Atherton, Handbook of solubilities, New York, 1907.

$b$ Solution containing 8.5 grams per liter of $\mathrm{MgCl}_{2}$.

$c$ Solution containing $19.8 \mathrm{grams}$ per liter of $\mathrm{MgCl}_{2}$.

d Solution containing 3.20 grams per liter of $\mathrm{MgSO}_{4}$.

$e$ Solution containing 10.64 grams per liter of $\mathrm{MgSO}_{4}$.

$f$ Solution containing 91.15 grams per liter of $\mathrm{NaCl}$.

$g$ Solution containing 264.17 grams per liter of $\mathrm{NaCl}$

$h$ Dissolved in 100 grams of the aqueous solution.

Calcium carbonate may be ignored in this discussion, as it is not strictly to be considered among the salines, and its manner of deposition is radically different from that of other substances. ${ }^{1}$

The physicochemical principles just outlined have been applied in discussing the formation of saline deposits. The first theory here summarized and the one that has obtained the widest acceptance is the bar theory of Ochsenius, by which he explains the formation of the

1 Vaughan, T. W., Preliminary remarks on the geology of the Bahamas, with special reference to the origin of the Bahaman and Floridian oolites; Carnegie Inst. Washington Pub. 182, pp. 47-54, 1914; also The building of the Marquesas and Tortugas atolls and a sketch of the geologic history of the Florida reef tract: Idem, pp. 55-67. Drew, G. H., On tho precipitation of calcium carbonate in the sea by marine bacteria: Idem, pp. 7-45 
well-known deposits at Stassfurt, Germany. Russell's discussion of an important corollary of the bar theory, the desiccation theory, explaining the process of burial of salines, particularly in the Great Basin of the United States, is next quoted. This discussion is followed by general consideration of the origin of brines, the origin of rock salt in the Salina of New York, Ontario, and Michigan, and references to various types of saline deposits with their essential peculiarities. Finally, the stratigraphy and mineralogy of the great potash beds of Germany are reviewed, as these deposits offer the largest and most nearly complete record of saline deposition thus far discovered.

\section{THE BAR THEORY OF OCHSENIUS.}

The theory developed by Ochsenius ${ }^{1}$ in regard to the origin of the Stassfurt deposits is known as the "bar" theory. Ochsenius maintained that deposits of such magnitude, purity, and uniformity of development as those in the Permian section at Stassfurt, Germany, could be produced only by overflowing of the sea into shallow coastal lagoons and subsequent evaporation of the sea water and the deposition of its saline content.

The salts dissolved in sea water are of the same chemical nature as those in the Stassfurt deposits. Sea water contained, however, less than 4 per cent of salts, and consequently the evaporation of a single body of sea water, even of great depth, could leave a saline deposit of relatively slight thickness; therefore the origin of a series of deposits like those at Stassfurt, with a thickness of 3,000 to 4,000 feet, can be postulated only on the theory of periodic additions of sea water. Ochsenius asserts that at least 40 periods of deposition must have occurred in order to produce only the average thickness of the Stassfurt deposits.

The inland sea or lagoon in which the deposits of salts are supposed to have formed is assumed by Ochsenius to have been cut off from the ocean by a bar of such width and height that only so much sea water could flow into the inclosed sea as could be evaporated from its surface. To accomplish the evaporation a climate with small rainfall and conditions of drainage that preclude the inflow of much fresh water are postulated. If the bar were too low, as in the Strait of Gibraltar, an outward undercurrent would result from the inflowing superficial current, and the more strongly concentrated solutions, which would sink by virtue of greater specific gravity, would flow back in to the open ocean. If the bar were too high, continuous union of the inland sea and the ocean would be lacking. But under the conditions postulated by Ochsenius all the ocean water entering the inclosed basin would leave its saline content during each period of

\footnotetext{
1 Ochsenius, C., Die Bildung der Steinsalzlager und ihrer Mutterlaugensàlze, Halle, 1877.
} 
evaporation, and deposits would form whose thickness would be dependent only on the duration of the process and the depth of the inclosing basin. In the lowest part of the deposit calcium and magnesium carbonates would form. The point of saturation of the solution for calcium sulphate would next be reached, and its separation would follow. Then sodium chloride, or common salt, would separate. Thus it is explained why rock salt usually rests on a layer of gypsum or anhydrite, as well as why rock salt is found interbedded with those minerals. The thickness of the mass of precipitated salts and the quantity of the more soluble potassium and magnesium salts in the supernatant bittern would increase as evaporation proceeded. If no special conditions existed after the upper surface of the bittern reached the top of the dam or bar, a further rise in the former (corresponding to a fall in the bar) would cause a reflux of the heavy mother liquors into the open ocean, as at the Strait of Gibraltar. In this manner is explained the absence of potash and magnesium salts from the deposits of anhydrite and rock salt of various geologic ages.

In its fundamental principles the bar theory of Ochsenius furnishes at least a logical explanation of the primitive origin of the Permian salt deposits. The progress of geologic disclosures and the more recent chemical investigations of Van't Hoff and his associates have, however, added greatly to conceptions of the mode of formation of the Permian series. It should be added that Ochsenius's conception of the primitive mode of origin of the Stassfurt series did not meet with universal acceptance. It was sharply criticized by J.Walther ${ }^{1}$ and E. Erdmann. ${ }^{2}$

Another theory, advanced by Walther, explains them by lixiviation of the saline contents of sedimentary rocks and accumulation of the resulting solutions in desert basins. The massiveness and homogeneity of the Stassfurt deposits, their chemical structure as a whole, and the entire lack of clastic sediments from which the salts might have been derived are weighty points in opposition to Walther's theory. It was held to be untenable and was ably disputed by Ochsenius himself.

\section{DE SICCATION THEORY.}

Deposits of salt resulting from the evaporation of inclosed seas or lakes are not uncommon. The salt fields in Osobb Valley, Nev., the saline deposits left by the evaporation of Middle Lake in Surprise Valley, Cal., in 1872, and the broad salt field covering the desiccated basin of Sevier Lake, Utah, are examples. Russell ${ }^{3}$ states, however, that deposits of this character which have resulted directly from the

1 Das Gesetz der Wüstenbildung, Berlin, 1900; Ochsenius's answer to Walther's criticism, Centralbl. Mineralogie, pp. 551-557, 1902; Walther's rejoinder Centralbl. Mineralogie, p. 211, 1903.

2 Zeitschr. angew. Chemie, vol. 21, p. 1265, 1908; vol. 22, p. 238. 1909.

8 Russell, I. C., Geological history of Lake Lahontan, a Quaternary lake of northwestern Nevada: U. B. Geol. Survey Mon. 11, p. 223, 1885. 
evaporation of the former Lake Lahontan are nowhere to be found in the deposits of the Lahontan basin. He says:

The accumulations of common salt, sulphate of soda, etc., occurring in considerable quantities at certain localities have in all cases been deposited since the evaporation of the former lake. In some instances these accumulations are due to the leaching of saline clays and the evaporation of the resultant brine in restricted areas, as in the case of the salt fields in Alkali Valley; at other times saline deposits of considerable thickness have resulted from the evaporation of spring waters. Over very large areas the Lahontan beds are frequently whitened with a saline efflorescence, which also owes its accumulation to secondary causes.

Wherever the Lahontan sediments have been examined they have been found more or less highly charged with salts of the same character as those that were most common in the waters of the former lake. The total quantity of saline matter thus imprisoned is certainly very great and is assumed to represent the more soluble substances contributed to Lake Lahontan.

The apparent anomalous phenomena of the dessiccation of a great lake without leaving a surface deposit of salt seems explicable in only one way. Adopting the suggestion advanced by Gilbert ${ }^{1}$ in explanation of some portion of the history of Lake Bonneville, the absence of saline deposits is accounted for by the hypothesis that they were buried and absorbed by lacustral clays and playa deposits during periods of desiccation.

The freshening of a lake by desiccation may be illustrated in all its stages in the various basins that have been examined in the far West. A lake after a long period of concentration becomes strongly saline, and finally evaporates to dryness, leaving a deposit of various salts over its bed. During the rainy season the bottom of the basin is converted into a shallow lake of brine which deposits a layer of sediment; on evaporating to dryness during the succeeding arid season, a stratum of salt is deposited, which is, in turn, covered by sediment during the succeeding rainy season. This process taking place year after year results in the formation of a stratified deposit consistof salts and saline clays in alternating layers. The saline deposits may thus become more and more earthy until the entire annual accumulation consists of clays. The site of the former lake then becomes a playa. A return of humid conditions would refill a basin of this character and might form a fresh-water lake, the bottom of which would be the level surface of the submerged playa.

The larger lakes of the Lahontan basin, as well as a number of less importance in eastern Nevada and southern Oregon, are without outlet. They occur in basins that in almost all càses were occupied by much larger water bodies during the Quaternary, which, like their modern representatives, never overflowed. From the long period of evaporation that has taken place one would expect the existing lakes to be dense mother liquors. The fact is, however, that they are but slightly charged with saline matter, and in some instances are sweet to the taste and sufficiently fresh for all culinary purposes. In many localities the lacustral beds surrounding and underlying the present lakes are highly charged with soda salts, which rise to the surface during the dry season as efflorescences. As these lake basins were never filled to overflowing, we are forced to conclude that influx was counterbalanced solely by evaporation, and that during periods of extreme desiccation the saline deposits became buried and absorbed by the marls and clays which accumulated in the valleys.

\section{Russell further develops this theory in a later contribution:2}

As shown by the average composition of river water, about one-half of the total solids carried in solution by surface streams is calcium carbonate. This is the most

1 Gilbert, G. K., Lake Bonneville: U. S. Geol. Survey Mon. 1, p. 208, 1890.

2 Russell, I. C., Present and extinct lakes of Nevada: Nat. Geog. Soc. Mon., vol. 1, No. 4, pp. 101-132, 1895. 
difficult of solution of any of the salts ordinarily found in such waters, and the first to be precipitated when concentration by evaporation takes place. The more soluble salts consist mainly of sodium sulphate, sodium carbonate or bicarbonate, sodium chloride, magnesium, potash, iron, etc.

The amount of these more soluble substances carried into Lake Lahontan must therefore have been about equal to the amount of calcareous tufa precipitated. As the lake never overflowed, these salts must still exist in its now nearly desiccated basin; yet, in riding through the valleys that were formerly flooded, no deposits of the salts referred to can be found at all commensurate with the vast quantity of calcium carbonate that attracts one's attention. The disappearance of the salts referred to seems to be satisfactorily explained in the following hypothesis:

After the last great rise of Lake Lahontan there was a long-continued episode during which its basin was more arid than at present. Evaporation during that time is thought to have been equal to precipitation, and the residual lakes were reduced to the playa condition-that is, the remants of the great lake gathered in the lowest depressions of its basin were annually or occasionally evaporated to dryness, and their contained salts were precipitated and either absorbed by the clays, etc., deposited at the same time, or buried beneath such mechanical deposits. The process may be observed in action in many of the valleys of Nevada in which ephemeral lakes occur. The broad, naked playas of Black Rock, Smoke Creek, and Carson deserts, as well as the level floors of the basins occupied by Pyramid, Winnemucca, and Walker lakes, are in support of this hypothesis. Should the lakes just mentioned be evaporated to dryness, playas would be left similar to those in neighboring valleys of less depth. It is beneath the level floors of these valleys and lake basins that the more soluble salts once dissolved in the waters of Lake Lahontan are buried. Borings at certain localities might reveal the presence of strata of various salts, but in most cases they are probably disseminated through great thicknesses of clay, sand, and other mechanical sediments.

Deposits of salt and gypsum must have formed in past geologic epochs by direct deposition from original solution or by leaching from other salt beds or diffused salts in adjoining areas, followed by deposition. Deposits formed by the first method may be termed primary and those formed by the last method secondary. The existence of such deposits therefore indicates the former presence of continental seas or of arms of the ocean which were separated from it by the uplifted parts of the earth's crust or by bars or reefs. The saline content of such waters has been increased by influxes from the sea or from streams. A necessary further condition is evaporation in a comparatively rainless climate like that in many deserts of the world to-day. All these conditions have doubtless existed in some part of the earth's surface ever since continents have existed and have been subject to oscillation.

The salt domes of Louisiana and Texas are most probably examples of secondary deposits formed by subterranean leaching of other deposits. The salt in these domes was derived by leaching of older salt deposits and was later redeposited or crystallized from ascending solutions among Tertiary, Quaternary, and possibly late Cretaceous beds. The age of the rocks from which this salt was derived is not 
known, but it may have been late Paleozoic or early Mesozoic. The beds of rock salt in southwestern Virginia also are secondary. ${ }^{1}$

The most instructive example of what is usually considered, at least in its main features, as a primary saline deposit is that known as the Stassfurt deposit, in which the complete or nearly complete series of salts was formed and has been preserved so perfectly and on so grand a scale that the deposit constitutes the only important source of potassium salts now known in the world. The only other noteworthy occurrences of potassium or mother liquor salts are those at Kalusz and Stebnik in Galicia, and those in Alsace. ${ }^{2}$ The deposits in Spain and Chile are not well known, and only a few commercial reports have been issued with regard to them. ${ }^{3}$

\section{FORMATION OF ROCK SALT IN MICHIGAN, NEW YORK, AND ONTARIO.}

The formation of rock salt has been explained by two hypotheses, one assuming it to be of marine origin and the other to be of continental origin. The marine origin of salt beds has already been outlined as the bar theory (pp. 197-198).

The continental theory has been stated by Grabau and Sherzer ${ }^{4}$ in accounting for the deposits of rock salt in the Salina formation of Michigan, New York, and Ontario. After the disappearance of the Niagaran sea from continental North America and during the ensuing arid period, the deposition of Salina muds began in the MichiganOntario-New York area, which consisted of one or more basin-shaped depressions. As these muds were derived from the Niagaran rocks, which are largely calcareous, the deposits were likewise calcareous, though the argillaceous sediments are abundant, especially in Michigan. During exposure of these limestones, which were impregnated with a small percentage of saline matter, salt and gypsum appeared on them as an efflorescence, which during rainy periods was dissolved and washed toward the center of the basin, where it was deposited by evaporation just as salt is being deposited in the desert basins of to-day. Before that time the Salina sea had occupied only the deeper basin where rock salt is now found. The general conclusion is drawn by Grabau and Sherzer from their calculations that the Niagara rocks alone were able to furnish all the salt that exists in the Salina of New

I Stose, G. W., Geology of the salt and gypsum deposits of southwestern Virginia: U. S. Gool. Survey Bull. 530, p. 255, 1013.

2 Bocke, H. E., Uebersicht der Mineralogie, Petrographic, und Geologic der Kalisalz-Lagerstïtten, Berlin, 1909. Die Kalibergwerke im. Oberelsass; abstracted from Jahresb. der Industriellen Gesell. von Mülhausen, im Elsass, Strassburg, 1913.

3 Hurst, C. B., U. S. Consul General, Barcelona, Spain: Supplement to Commerce Reports No. 15 C, July 10, 1915. Salcedo, S., Eng. and Min. Jour., vol. 100, p. 218, Aug. 7, 1915.

4 G rabau, A. W., and Sherzer, W. H., The Monroe formation of Michigan and adjoining regions: Michigan Gool. and Biol. Survey, Pub. 2, Geol. ser. 1, pp. 235-236, 1910. 
York, Ontario, and Michigan. Turrentine, ${ }^{1}$ however, believes that certain assumptions made by Grabau and Sherzer unnecessarily introduce doubtful elements.

If the theory propounded by Grabau and Sherzer is correct there appears to be no hope of finding potash salts in the Salina of either New York or Michigan, unless such salts were occluded and later deposited with the common salt in the Niagaran. In view, however, of the explanation given by Grabau and Sherzer that the salt and gypsum in the Salina deposits represent the old sea salt imprisoned in the Niagaran and earlier marine strata at the time of their formation under the sea and their statement that the beginning of the period during which the Salina deposits were formed was characterized by the withdrawal of the widespread Niagaran sea it appears to be a warrantable assumption that desiccation of the Niagaran sea may not have proceeded to the point where potassium salts would have been deposited. It is interesting to note in connection with this discussion that the upper strata of the salt beds in New York contain a larger proportion of magnesium chloride than the lower strata, ${ }^{2}$ a condition that indicates final deposition from the mother liquor.

\section{THE DEAD SEA.}

The Dead Sea in Palestine furnishes a present-day example of an inclosed sea that is becoming more strongly saline by the influx of salts dissolved in its affluents. Its water is a bittern, the result of evaporation during a long period. Its large content of magnesium chloride $\left(\mathrm{MgCl}_{2}\right)$ proves that much of its sodium content has already separated. Since this body of water has inflowing streams and no outflowing streams, the water added to it is expelled only by evaporation, which leaves behind the salts carried in solution. The River Jordan, the principal affluent, is rich in dissolved salts obtained by the leaching of sediments in the area from which it flows. It is particularly rich in sodium and magnesium chlorides, containing in 100,000 parts, 52 parts of sodium chloride and 32 parts of magnesium chloride. From this river water the sodium chloride will separate first, leaving calcium chloride and magnesium chloride behind. As soon as the river water reaches its destination, it loses sodium chloride at the same rate at which it takes up magnesium chloride. In the Dead Sea, therefore, there has resulted a mother liquor, which at a depth of 650 feet contains in every 100 parts 25.3 parts of dissolved salts, which reduced to percentages are as follows:

\footnotetext{
1 Turrentine, J. W., The occurrence of potassium salts in the salines of the United States: U. S. Agr. Dept. Bur. Soils Bull. 94, p. 22, 1913.

${ }^{2}$ Merrill, F. J. H., Salt and gypsum industrieș in New York: New York State Museum Bull. 11, p. 62, 1893.
} 
Salts dissolved in water of Dead Sea.

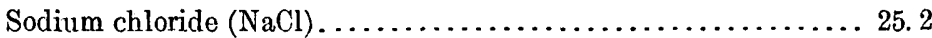

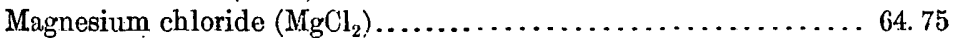

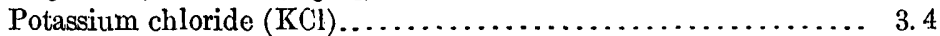

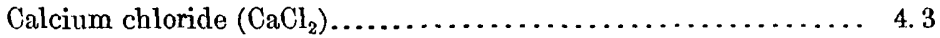

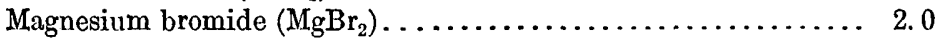

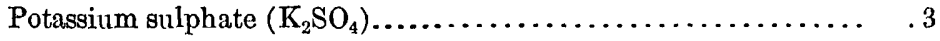

Complete evaporation of this body would yield a saline deposit consisting principally of magnesium chloride, with which would be associated sodium, calcium, and potassium chlorides and smaller amounts of bromides and sulphates.

\section{KARABOGHAZ GULF.}

Continuous deposition of salt in a partly inclosed arm of a sea is now taking place in the Karaboghaz, a gulf on the eastern side of the Caspian Sea. Though the water of the Caspian Sea contains only 1.3 per cent of saline matter, the water of the gulf contains 28 per cent. ${ }^{1}$ Water continuously flows from the sea into the gulf and is there evaporated. A continually thickening layer of rock salt and Glauber salt is forming on its bed, and a gypsum crust is forming along its shore.

\section{THE STASSFURT DEPOSITS.}

\section{EXTENT AND DEVELOPMENT.}

The term Stassfurt deposits is misleading, as the German potash deposits are of much broader areal distribution than the territory near Stassfurt. They occur in a large area in middle and northern Germany and also on the lower Rhine. ${ }^{2}$

Geologically the city of Stassfurt is in the southeastern part of the Magdeburg-Halberstadt-Zechstein Basin. The natural boundary of this basin on the south is the Harz Mountains and on the north or northeast is the Flechtinger Höhenzug. The basin is open to the west. Geographically the city is in the central part of Germany, at the northern border of the. Duchy of Anhalt, not more than 20 miles from Elbe River.

Mining operations were commenced about 1857, and the first two mines on the so-called Stassfurt saddle are those of Heydt and Leopoldshall. The potash industry developed rapidly during the last quarter of the nineteenth century; shafts were sunk north and

\footnotetext{
1 Analyses by C. Schmidt, Acad. Sci. St.-Pétersbourg Bull., vol. 24, p. 177, 1878; quoted by Clarke, F. W., The data of geochemistry: U. S. Gool. Survey Bull. 616, p. 166, 1916.

2 The plates contained in Deutschlands Kalibergbau, Berlin, 1907, give a good idea of the areal extent and the degree of exploitation of the German deposits of potash salts up to that year.
} 
south of the Harz Mountains; operations were pushed into the province of Hanover, and during the last few years they have extended into the northern and northwestern parts of that province. East of the Flechtinger Höhenzug deposits of potash have been encountered in a number of borings, among which are those at Sperenberg and Rüdersdorf, near Berlin. In northern Germany deposits of potash salts are known and are worked at Ilssenitz and Friedrich Franz (Lübtheen), in the northwest corner of Mecklenburg-Schwerin.

\section{ZECHSTEIN SECTION.}

Only the saline series of the Stassfurt-Egeln saddle corresponds completely with the theoretical arrangement of salts deposited from evaporated sea water. It is, therefore, a singular coincidence that these salts should have been discovered in true theoretical arrangement in the small area in which the industry had its beginning and in which, therefore, the deposits were first studied and are best known. Hence. the Stassfurt type of the immense Zechstein (Upper Permian) deposits may be considered the primary type, of which all other deposits are modifications. The section of the Zechstein deposits. at Stassfurt from the lower boundary of the Buntersandstein (lower Trias) downward is as follows:

\section{Section of saline deposits at Stassfurt, Germany. ${ }^{a}$}

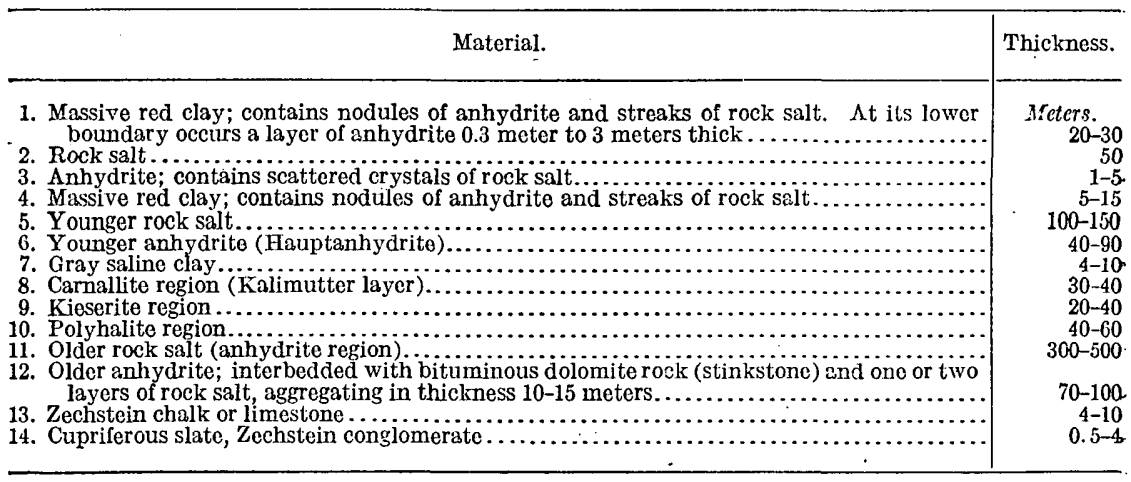

a Everding, H., Deutschlands Kalibergbau, Berlin, p. 36, 1907. This section agrees in its main features with that of C. Reimann, Die Geologie der deutschen Salzlagerstätten, Stassfurt, p. 20, 1908. See also. the section of $\mathrm{L}$. Loewe, Zeitschr. prakt. Geologie, 1903, pp. 332-333.

This section may be compared with the diagram (fig. 14) representing a section in the shaft of the Ludwig II mine at Stassfurt.

The Zechstein limestone (13), the principal member of the lower part of the section, is a purely marine formation. The deposits. aboveit, with the exception of the intermediate beds of clay (4 and 7), represent materials precipitated from evaporated sea water. The beds of clay indicate interruptions in the process of desiccation, during which there were influxes of muddy water containing suspended 


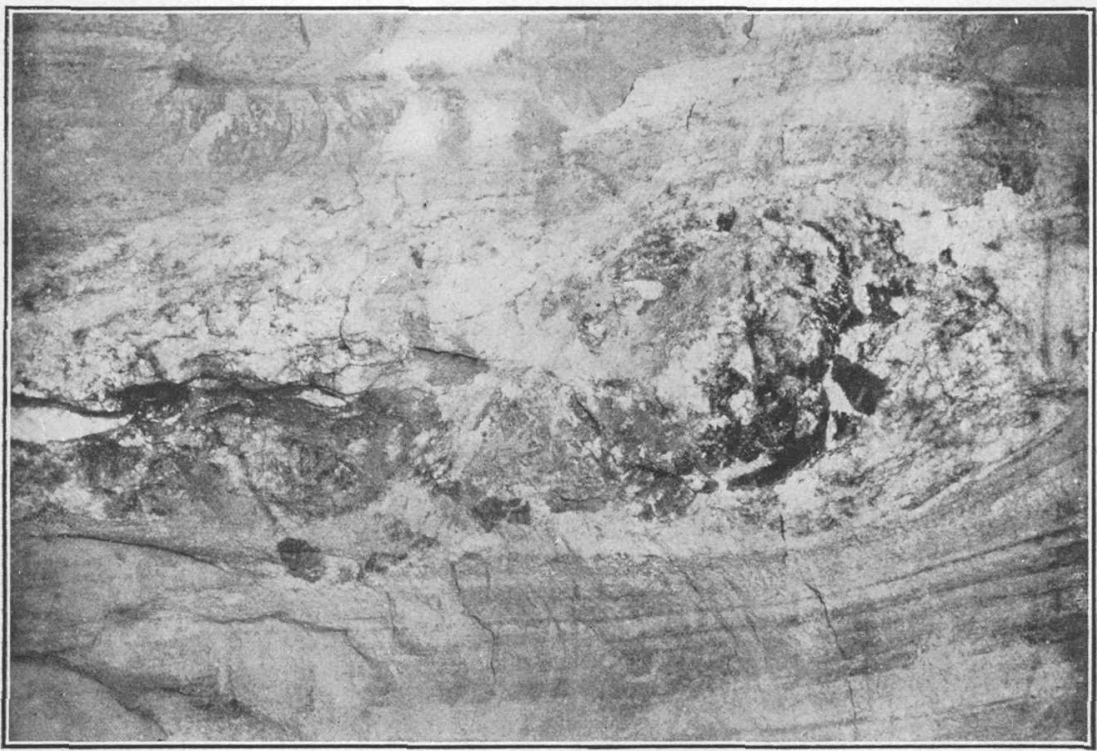

A. BED OF "MIXED SALT," LIVONIA SALT MINE, LIVONIA, N. Y.

From Report of New York State Geologist, 1896 (PI. I).

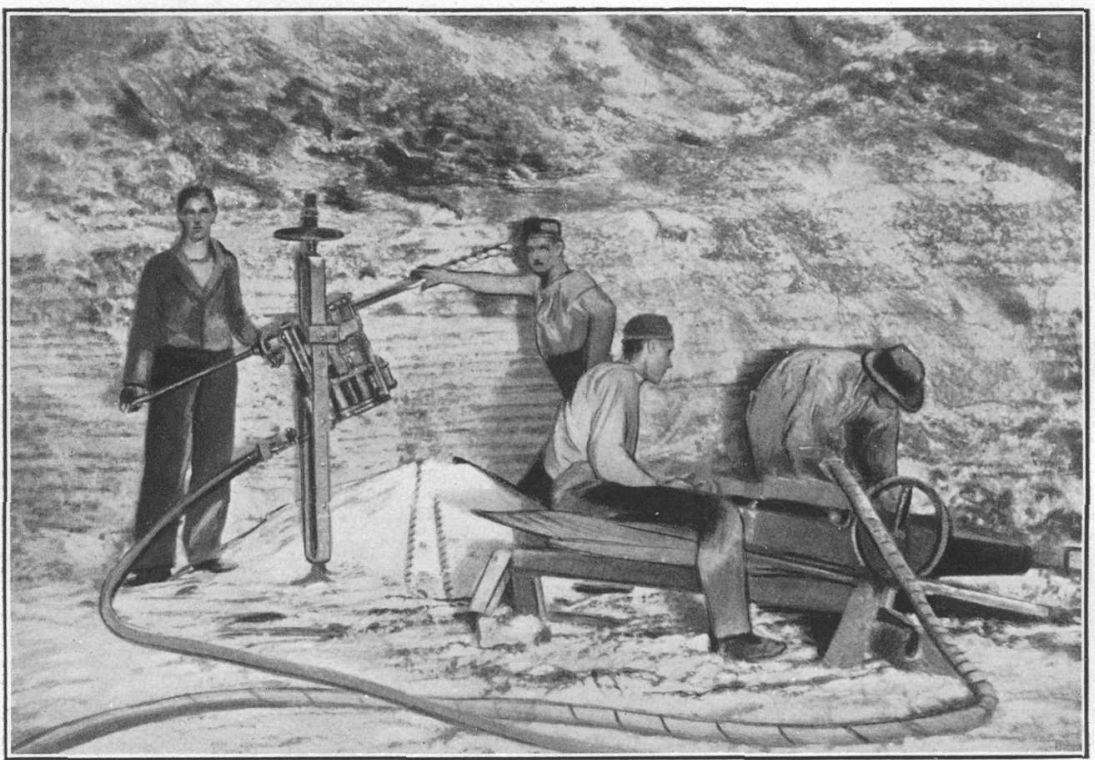

B. STRATIFIED SHALE AND SALT, BEVIS ROCK SALT CO.'S MINE, LYONS, KANS. Photograph by Sam Ainsworth. 
material that formed layers of clay or shale. Such intermediate layers are characteristic of salt deposits and have been observed in the salt mines of New York, Kansas, and other States. ${ }^{1}$ (See Pl. XVII.)

The older saline series begins with the masses of anhydrite (12) of the middle Zechstein, most of the middle portion of which is the so-called older rock salt (11). The end member of the middle Zechstein is the carnallite region (8). In the section (fig. 14) gray saline clay (7) is represented overlying the carnallite region.

At Douglashalle a layer of salt intervenes between the carnallite and the clay. In parts of the field kainite overlies the carnallite and is in turn overlain by sylvinite, as is illustrated in the section at the Ludwig II mine (fig. 14). The total thickness of the older rock salt (11), the polyhalite region (10), and the kieserite region (9) is estimated by Loewe ${ }^{2}$ to range from 150 to 1,000 meters. As the older róck salt is impregnated with anhydrite, it is designated the anhydrite region in the

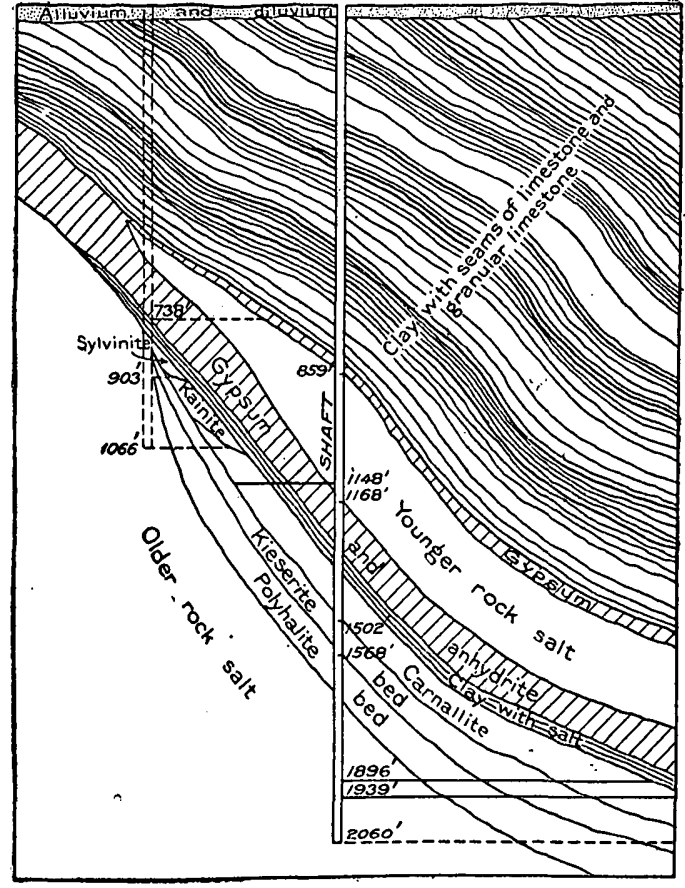

FIGURE 14.-Section of shaft in German potash mine, Ludwig II, Stassfurt, Germany. (After a figure in "The Stassfurt industry," published by the German Kali Works.)

section. The gypsum bands are interpreted as annual deposits (Jahres Ringe) due possibly to seasonal variations in temperature or to alternating drought and rain.

Above the intermediate layer of saline clay (7) there follows a younger series of salts, beginning with another massive deposit of anhydrite (6), and continuing upward with rock salt (5). Unlike the lower series it is not capped by a zone of potash salts but is overlain by a bed of red clay permeated with nodules of anhydrite (4). Above this intermediate clay anhydrite (3) and rock salt (2) are again repeated. This youngest and comparatively thin bed of salt is not succeeded at Stassfurt by mother-liquor salts but is capped by

1 Luther, D. D., The brine springs and salt wells of the State of New York and the geology of the salt district: New York State Geologist Sixteenth Ann. Rept., pp. 175-226, 1859.

2 Loewe, L., Zeitschr. prakt. Gcologie, 1903, p. 333. 
a deposit of red clay containing anhydrite nodules and having a thin layer of anhydrite at its base. The red clay is overlain by clay sediments of the lower Buntersandstein.

\section{MINERALOGY.}

The number of minerals mined on a commercial scale at Stassfurt is small compared with the total number found there. Thus far approximately 30 minerals have been found. They comprise chiefly the chlorides and sulphates, the main mineral constituents of sea water, as shown in the list below: ${ }^{1}$

\section{Minerals in the saline deposits, Stassfurt, Germany.}

Abundant and widely distributed minerals.

Anhydrite........... $\mathrm{CaSO}_{4}$.

Gypsum............SOSO ${ }_{4} \cdot 2 \mathrm{H}_{2} \mathrm{O}$.

Kieserite.........MgSO $\mathrm{Mg}_{2} \mathrm{O}$.

Kainite............ $\mathrm{MgSO}_{4} \cdot \mathrm{KCl} .3 \mathrm{H}_{2} \mathrm{O}$.
Rock salt. ........NaCl.

Sylvite. ........ KCl.

Carnallite.......... $\mathrm{MgCl}_{2} \cdot \mathrm{KCl} \cdot 6 \mathrm{H}_{2} \mathrm{O}$.

\section{Less abundant minerals.}

Langbeinite...... $\mathrm{K}_{2} \mathrm{SO}_{4} .2 \mathrm{MgSO}_{4}$.

Schoenite........... $\mathrm{MSOO}_{4} \cdot \mathrm{K}_{2} \mathrm{SO}_{4} \cdot 6 \mathrm{H}_{2} \mathrm{O}$.

Polyhalite......... $\mathrm{MgSO}_{4} \cdot 2 \mathrm{CaSO}_{4} \cdot \mathrm{K}_{2} \mathrm{SO}_{4}$.

$2 \mathrm{H}_{2} \mathrm{O}$.

\author{
Bischofite........ $\mathrm{MgCl}_{2} \cdot 6 \mathrm{H}_{2} \mathrm{O}$. \\ Tachydrite......... $\mathrm{CaCl}_{2} \cdot \mathrm{MgCl}_{2} \cdot 12 \mathrm{H}_{2} \mathrm{O}$. \\ Boracite......2. $\mathrm{Mg}_{3} \mathrm{~B}_{8} \mathrm{O}_{15} \cdot \mathrm{MgCl}_{2}$.
}

Rare minerals or minerass only locally abundant.

\begin{tabular}{|c|c|}
\hline Glaserite........KNa) ${ }_{2} \mathrm{SO}_{4}$ & $\mathrm{MgSO}_{4} \cdot 4 \mathrm{CaSO}_{4} \cdot \mathrm{K}_{2} \mathrm{SO}_{4}$ \\
\hline Reichardite. .....MgSO $4.7 \mathrm{H}_{2} \mathrm{O}$. & $2 \mathrm{H}_{2}$ \\
\hline Leonite .......... $\mathrm{MgSO}_{4}(\mathrm{KNa})_{2} \mathrm{SO}_{4} \cdot 4 \mathrm{H}_{2} \mathrm{O}$ & Rinneite....... FeCl $2.3 \mathrm{KCl} . \mathrm{NaCl}$ \\
\hline $\begin{array}{l}\text { Astrakanite. . . . MgSO } \mathrm{MgSO}_{4} \cdot \mathrm{Na}_{2} \mathrm{SO}_{4} \cdot 4 \mathrm{H}_{2} \mathrm{O} \text {. } \\
\text { Glauberite........CaSO} 4 . \mathrm{Na}_{2} \mathrm{SO}_{4} .\end{array}$ & Ascharite . . ...... $\mathrm{MgBO}_{3} \mathrm{H}$. \\
\hline
\end{tabular}

Very rare minerals.

Loewite..........MgSO $\mathrm{Na}_{2} \mathrm{SO}_{4} \cdot 2 \frac{1}{2} \mathrm{H}_{2} \mathrm{O}$.

Vanthoffite.........MgSO ${ }_{4} \cdot 3 \mathrm{Na}_{2} \mathrm{SO}_{4}$.

Syngenite...........

Keonenite......... $\mathrm{Al}_{2} \mathrm{O}_{3} .3 \mathrm{MgO} .2 \mathrm{MgCl}_{2} .6$ (or

8) $\mathrm{H}_{2} \mathrm{O}$.
Pinnoite.......... $\mathrm{MgB}_{2} \mathrm{O}_{4} \cdot 3 \mathrm{H}_{2} \mathrm{O}$.

Kaliborite. . .... KMgg $\mathrm{KM}_{11} \mathrm{O}_{19} .9 \mathrm{H}_{2} \mathrm{O}$.

Sulfoborite........ $\mathrm{Mg}_{6} \mathrm{~B}_{4} \mathrm{O}_{10}\left(\mathrm{SO}_{4}\right)_{2} \cdot 3 \mathrm{H}_{2} \mathrm{O}$.

The researches ${ }^{2}$ of Van't Hoff and those of Precht and Boeke on the iron salts indicate that several more minerals (as listed below) may be found in the Stassfurt deposits. Some of them have already been found at other places.

1 Boeke, H. E., Uebersicht der Minerologie, Petrographie, und Geologio der Kalisalz-Lagerstätten pp. 10-11, 1909.

2 Collected in Zur Bildung der ozeanischen Salzablagerungen, vols. 1 and 2, 1005 and 1909; also in Deutsch. chem. Gesell. Ber., vol. 12, p. 557, 1879; vol. 13, p. 2326, 1880. In part in K. Akad. Wiss. Berlin Sitzungsber., 1909, pp. 632-638; Kali, vol. 3, p. 147, 1909. 
Minerals possibly present in the deposits at Stassfurt, Germany.

\begin{tabular}{|c|c|c|}
\hline Sulphates. & Borates. & Chlorides. \\
\hline $\begin{array}{l}\text { Thenardite }\left(\mathrm{Na}_{2} \mathrm{SO}_{4}\right) \cdot a \\
\text { Hexahydrated } \text { magnesium sul- } \\
\text { phate }\left(\mathrm{MgSO}_{4} \cdot 6 \mathrm{H}_{2} \mathrm{O}\right) \text {. } \\
\text { Potassium pentacalcium sulphate } \\
\left(\mathrm{K}_{2} \mathrm{SO}_{4} \cdot 5 \mathrm{CaSO}_{4} \cdot \mathrm{H}_{2} \mathrm{O}\right) \text {. }\end{array}$ & 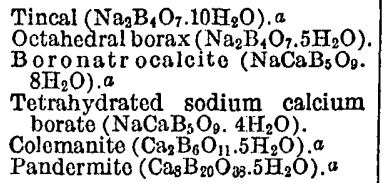 & \begin{tabular}{l} 
Tetrahydrated forrous chlorido \\
$\left(\mathrm{FeCl}_{2} .4 \mathrm{H}_{2} \mathrm{O}\right)$. \\
Dihydrated ferrous chloride \\
$\left(\mathrm{FeCl}_{2} .2 \mathrm{H}_{2} \mathrm{O}\right)$. \\
Ferrous magnesium chlorido \\
$\left(\mathrm{MgCl}_{2} . \mathrm{FeCl}_{2} .8 \mathrm{H}_{2} \mathrm{O}\right)$. \\
Douglasito $\left(\mathrm{FeCl}_{2} .2 \mathrm{KCl} .2 \mathrm{H}_{2} \mathrm{O}\right) . b$ \\
\multicolumn{2}{c}{,}
\end{tabular} \\
\hline
\end{tabular}

a Found in natural deposits at other places.

$b$ Believed by-Precht to be a mixture of rock salt, sylvite, and 3.5 per cent ferrous chloride.

Of the 28 saline minerals named above only 5 constitute the mass of the Stassfurt deposits ${ }^{1}$-rock salt, kieserite, sylvite, carnallite, and kainite. Kainite is limited almost entirely to the zone of alteration at the apices or saddles (hutzonen) of the Zechstein beds that are buried under and folded with the overlying Mesozoic rocks. The other salts also are found in these cap zones, but they occur as well in the deeper Zechstein deposits. The structure and appearance of the salts in the cap zones are, however, very different from those of the more deeply buried salines. The salts in the cap zones are usually believed to be secondary and those in the regular Zechstein series to be primary; some investigators believe, however, that changes took place in the Zechstein in the originally deposited salines, and if that is true they likewise may be considered truly secondary.

Dolomite (calcium-magnesium carbonate) occurs in the footwall of the salt deposits, but not a trace of it has been found in the salts themselves. Bromine accompanies the chlorine, particularly in the minerals bischofite, carnallite, and sylvite. Iron and aluminum are present and impart to the salts with which they are associated the hues peculiar to their compounds. Minerals that are usually colorless are reddened by ferric oxide $\left(\mathrm{Fe}_{2} \mathrm{O}_{3}\right)$ or blackened by magnetite $\mathrm{Fe}_{3} \mathrm{O}_{4}$ ). Aluminum silicate or clay gives its characteristic gray shade to the minerals that it accompanies. Considerable quantities of iron occur locally in the form of the mineral rinneite, and aluminum occurs in the salt clay and in the efflorescences of the mineral koenenite $\left(\mathrm{Al}_{2} \mathrm{O}_{3} .3 \mathrm{MgO} .2 \mathrm{MgCl}_{2} .8 \mathrm{H}_{2} \mathrm{O}\right)$.

Iodine, boron, and silicon are minor constituents of sea water. The first element is found in small quantity at Stassfurt, and boron in the form of borates occurs in somewhat larger but insignificant amounts. Silica occurs as microscopic crystals of quartz in the residue from the solution of some of the salts; it is present of course in large quantities in the salt clay. Not a trace has been found of many of the elements that are present in sea water.

1 Everding, H., Zur Geologie der Zechstainsalze: Deutschlands Kalibergbau, Berlin, pp. 29-34, 1907. 
If the final bittern was deposited by evaporation it would seem that the presence of such easily detected elements as manganese, copper, and phosphorus could be established; the condition of the deposit indicates, however, that the final bittern flowed back into the open ocean. The conditions for finding some of the less abundant elements are more propitious, either because they are present in such form as to separate readily from the material associsited with themrubidium, caesium, lithium, thallium, and ammonium-or because the most refined methods were employed in searching for them, as for silver and gold. Celestite, rutile, sulphur, and pyrite are present. The two latter minerals were apparently produced from the sulphates as a result of reduction by organic matter.

The two types of secondary alteration indicated below are separated by a long time interval, which is represented by the entire Triassic, Jurassic, and part of the Cretaceous. The saline compounds that were formed during the two periods of alteration are alike in chemical composition but different in structure and appearance as well as in position. To call them both secondary, therefore, is confusing, for the decision whether a deposit is secondary in one sense or the other or whether it is primary is of great practical importance in judging a deposit, in placing it in the geologic section, and in locating shafts for mining operations. It is highly desirable to replace the ambiguous designations by terms that will closely indicate the genetic relations between the original form and the alteration forms. To meet this difficulty certain German scientists have proposed the terms, mother formation, descendant formation, and posthumous formation. Mother formation (Mutterbildungen) is used to indicate those saline deposits whose composition and structure indicate that they must have been produced directly by evaporation of an inclosed body of sea water; subordinate to this are "mother rock salt" (Muttersteinsalz) "mother potash salt" (Mutterkalisalz), and "mother-saline series" (Muttersalzfolge), whose meanings are obvious. Descendant formation (deszendente Bildungen) is applied to those deposits which resulted from the transformation or alteration of the mother formation immediately after its precipitation and during Zechstein time; the materials comprising the formation are called the descendant salts (Deszendenzsalze), and the period of their origin the descendant period (Deszendenzperiode). Posthumous formations are those salts that are regarded as having originated in post-Permian time, after the mother formations and the descendant formations had been covered by Mesozoic rocks; they have been involved in the folding and faulting of the Mesozoic cover. The salts occurring in the cap zones belong to the posthumous formation.

The rock salt, kieserite, sylvite, and carnallite at Stassfurt occur in the three groups of formations just defined. To assign a salt to 
the proper period of origin its structure, petrographic character, and other characteristics must be ascertained, as well as the paragenesis of its associated minerals. Rock salt, for example, separated originally as mother rock salt. It may have recrystallized as rock salt during the descendant period, and later it may have recrystallized again as posthumous salt. Chemically the salt remained the same throughout the different periods but petrographically the mother, the descendant, and the posthumous rock salts are distinct. These relations are true not only regarding the simple minerals like rock salt but also regarding the more complex minerals, whose molecules are made up of molecules of several earlier minerals. Only a study of the petrography and the geologic relations of the formation in which the minerals are situated furnishes a basis for a conclusion as to the type of saline.

The most important potassium minerals both practically and scientifically in the Stassfurt deposits are sylvite and carnallite. Distinctive names have been applied to mixtures of sylvite with other minerals. The mixture of sylvite and rock salt is called sylvinite, and the mixture of sylvite, rock salt, and kieserite is called hartsalz. No such easy classification of carnallite and its associated minerals has won widespread usage. Despite the fact that one of the principal mixtures found in the Stassfurt deposits consists of rock salt and kieserite and 55 per cent of carnallite, the term carnallite is usually applied to it, a mixture of carnallite and rock salt is also known as carnallite, and lastly the pure mineral itself is known as carnallite. These confusing uses of the term have led Everding ${ }^{1}$ to suggest a nomenclature like that of sylvite and its associated minerals. He proposes the name carnallitite for the mixture of carnallite and rock salt, and the name hauptsalz for the mixture of carnallite, rock salt, and kieserite, which is the principal product of the potash mines. The term carnallite is thus restricted to the mineral itself. The posthumous mineral kainite occurs in the cap zone intergrown with rock salt. Everding has proposed the term kainitite for this mixture to distinguish it from the simple mineral itself.

The most abundant accessory minerals in the potash deposits are anhydrite, boracite, langbeinite, schoenite, and bischofite. Particles of clay are distributed throughout the formations. Rock salt and anhydrite are disseminated in all the saline layers below the main potash-bearing beds. Polyhalite is limited chiefly to the compact layers below the potash minerals.

1 Deutschlands Kalibergbau, p. 33, Berlin, 1907.

$40104^{\circ}-18-B u l l, 669-14$ 
IN VESTIGATIONS.

The researches of Van't Hoff and Usiglio have thrown much light on the chemical conditions under which the Stassfurt salts were formed. The investigations of Van't Hoff and his associates, among whom are many Amerieans, have been conducted by a society formed for that purpose. The publications of its members have been specially listed. ${ }^{1}$ Many elaborate researches have been cenducted and many are still in progress. ${ }^{2}$

Study of the scientific results obtained at Stassfurt will undoubtedly yield information that will be extremely valuable in the search for potash salts in this country. The work of Van't Hoff ${ }^{3}$ on the conditions under which the minerals were deposited is of special interest, and the studies and descriptions of Erdmann ${ }^{4}$ are also helpful, as are those of Precht, Pfeiffer, Muspratt, Fürer, Ost, Kubierschky, and Ehrhardt. The lectures of Van't Hoff ${ }^{5}$ delivered at the University of Chicago in 1901 and printed in English should also be consulted. Those especially interested will be obliged to consult the German technical literature, in which practically all the researches have first appeared. An article on the subject has been published by Turrentine. ${ }^{6}$

\section{CHEMICAT COMPOSITION OF SATINE MATERIALS.}

\section{SCOPE OF ANALYSE.S.}

Nearly all of the analyses in the following pages were made in the course of a cooperative search for commercially valuable deposits of potash salts in the salt fields of the eastern United States. The field studies and collections were made chiefly by the United States Geological Survey and the analyses by the Bureau of Soils, Department of. Agriculture. Besides these data analyses of certain samples of eastern brines and western saline material collected by the writer and examined by W. B. Hicks and R. K. Bailey, of the United States Geological Survey, are reported, together with special tests by the Bureau of Soils of bitterns from solar-salt refineries on the Pacific coast. The analyses of sea water and of the water of Great Salt Lake are quoted from Clarke. ${ }^{7}$

The analyses as a whole represent the most complete and most reliable tests yet made to show the proportions of the chief constituents of American salines. There are many brines in the eastern United

\footnotetext{
1 See the bibliography in Deutschlands Kalibergbau, pp. 137-183, Berlin, 1907.

$2 \mathrm{~K}$. Akad. Wiss. Berlin.Sitzungsber., No. 39, p. $7.72,1910$.

'Van't Hoff, J. H., Zur Bildung der ozeanischen Salzablagerungen, Braunschweig, 1905.

1 Die Chemie und industrie der Kalisalze: Deutschlands Kalibergbau, Berlin, 123 pp., 1907.

6 Van't Hoff, J. H., Physical chemistry in the service of the sciences, Chicago, 1903.

${ }^{6}$ Turrentine, J. W., The occurrence of potassium salts in the brines of the United States: U. S. Dept. Agr. Bur. Soils Bull. 94, pp. 81-88, 1913.

${ }^{7}$ Clarke, F. W., The data of geochemistry, 3d ed.: U. S. Gool. Survey Bull. 616, 1916.
} 
States whose composition is not given, chiefly because they are too weak to be worth consideration as sources of either sodium chloride or potassium compounds. Though many saline deposits in the western deserts have been analyzed they have not yet attained commercial importance as sources of salt. Briefly the analyses in the following tables represent all the present centers of production of salt in the eastern United States.

\section{COLLECTION OF SAMPLES.}

Most of the samples were collected personally by the writer or by J. W. Turrentine, of the Bureau of Soils, and unless it is otherwise specified in the notes following the analytical tables the writer was the collector. In the summer of 1911, after correspondence with all the salt producers and many well drillers of the country, many samples of brine and bittern, collected according to explicit directions in special containers furnished by the Geological Survey, were forwarded for analysis.

\section{ANALYTICAL METHODS.}

GENERAL FEATURES.

The chemical work, except that done in the laboratory of the United States Geological Survey by W. B. Hicks and R. K. Bailey, was performed under the immediate supervision of J. W. Turrentine by J. A. Cullen, R. F. Gardiner, and A. R. Merz in the laboratories of the Bureau of Soils, Department of Agriculture. The following notes regarding the analytical methods have been taken from an article by Turrentine. ${ }^{1}$ The methods recommended by the Association of Official Agricultural Chemists for the analysis of mineral waters were generally employed in the determination of iron, aluminum, calcium, magnesium, sodium, potassium, and sulphate, but certain modifications tending to abbreviate the analytical processes were introduced where they were expedient.

PREPARATION OF THE SOLUTION.

After the sample of brine had stood until all sediment had settled, 10 cubic centimeters of the clear supernatant liquid was transferred by means of a dry calibrated pipette to a 200 cubic centimeter graduated flask, which was then filled to the mark with distilled water. Aliquot portions of this solution were taken for the various determinations.

1 Turrentine, J. W., The occurrence of potassium salts in the salines of the United States; U. S. Dept. Agr. Bur. Soils Bull. 94, pp. 47-52, 1913; also Composition of the salines of the United States: Jour. Ind. and Eng. Chemistry, vol. 4, pp. 828, 885, 1912; vol. 5, p. 19, 1913. 
TOTAL DISSOLVED SALTS.

A convenient volume of the dilute solution was evaporated to dryness in a weighed platinum dish, and the residue was heated to constant weight at $105^{\circ} \mathrm{C}$., cooled, and weighed. This estimate is not reported but was used as a check on the analysis.

\section{IRON AND ALUMINUM.}

If the brine was colored, iron and aluminum were estimated; if it was colorless, they were not estimated.

An aliquot portion of the dilute solution was treated with ammonium chloride and heated to boiling. Ammonium hydroxide was then added, a drop at a time, until an excess of the reagent was barely perceptible to the smell, after which the solution was boiled until the odor of ammonia had practically diasappeared. The precipitate was then separated by filtration, washed with hot water, ignited, and weighed as ferric oxide and alumina $\left(\mathrm{Fe}_{2} \mathrm{O}_{3}+\mathrm{Al}_{2} \mathrm{O}_{3}\right)$. The filtrate was used for the determination of calcium and magnesium.

Another aliquot portion of the diluted brine was treated with 2 or 3 cubic centimeters of concentrated sulphuric acid and evaporated to a sirupy. consistency. The solution was then diluted with water, reduced by means of metallic zinc, and filtered. The quantity of iron $(\mathrm{Fe})$ in the filtrate was estimated by titration with a standard solution of potassium permanganate, and the content of aluminum was calculated by difference.

\section{CALCIUM AND MAGNESIUM.}

The filtrate from the precipitation of iron and aluminum was treated with ammonium hydroxide and ammonium oxalate and allowed to stand overnight. The precipitate was then separated by filtration, washed twice with hot water by decantation, dissolved in hydrochloric acid, and reprecipitated by ammonium hydroxide and a little more ammonium oxalate. After the solution had stood overnight the precipitate was separated by filtration and washed on the paper previously used. The precipitate was ignited, blasted, and weighed as calcium oxide, from which calcium $(\mathrm{Ca})$ was calculated. After the combined filtrates had been evaporated to dryness in platinum the greater part of the salts of ammonium was volatilized by heating and the residue was dissolved in dilute hydrochloric acid. After filtration the filtrate was made slightly ammoniacal, and enough solution of sodium phosphate was added, drop by drop, to precipitate all the magnesium, and finally, drop by drop, 10 cubic centimeters of concentrated ammonium hydroxide was added. The solution was allowed to stand overnight. The precipitate was then separated by 
filtration, washed with 2.5 per cent ammonium hydroxide until it was free from chlorides, then dried, blasted, and weighed as magnesium pyrophosphate, from which magnesium $(\mathrm{Mg})$ was calculated. This procedure for separation of calcium and magnesium is not applicable in the presence of weighable amounts of the phosphate radicle, but no difficulty was experienced from that source in these analyses.

\section{SULPHATE.}

Another portion of the diluted brine was acidified with hydrochloric acid and treated while boiling with hot dilute solution of barium chloride. After the precipitate had completely formed it was separated by filtration, washed, ignited, and weighed as barium sulphate, from which sulphate $\left(\mathrm{SO}_{4}\right)$ was calculated. The filtrate was used for estimation of the alkalies.

\section{SODIUM AND POTASSIUM.}

The filtrate from the determination of sulphate was evaporated to dryness and the residue was dissolved in a little water. If the presence of lithium was suspected, a spectroscopic test for the characteristic lithium lines was made on this solution. Though traces of lithium were found in some samples, none contained enough to justify quantitative estimation.

$\Lambda$ solution of barium hydroxide was then added to the solution and the insoluble precipitate was filtered off and washed thoroughly with hot water. The combined filtrate and washings were treated with ammonium hydroxide, ammonium carbonate, and a little ammonium oxalate, and were allowed to stand overnight to precipitate calcium and barium. This precipitate was filtered off and thoroughly washed. The filtrate and washings were evaporated to dryness and the residue was dried in an oven. The salts of ammonium were then driven off by gentle heating. The residue was extracted with water, and the solution was filtered through a small filter and washed with as little water as possible. The filtrate and washings were evaporated to a small volume and again treated with a drop of ammonium hydroxide and 2 or 3 drops of ammonium carbonate and ammonium oxalate. If any precipitate appeared, the filtration and precipitation were repeated. In every analysis the solution was filtered from the magnesium hydroxide that was precipitated on concentrating the solution. The filtrate was evaporated to dryness in platinum and all ammonium was expelled by heating to a little below redness. The residue was then dissolved in a little water, the solution was filtered through a small filter, washed with as Iithle water as possible, evaporated to dryness, and again heated in platinum to a temperature slightly below red heat. By this procedure all the magnesium 
was removed. The residue was dissolved in a little water, the solution was filtered into a weighed platinum dish, a few drops of hydrochloric acid was added, and the solution was evaporated to dryness. This final residue was dried in an oven, heated to a little below redness, cooled, and weighed as the combined chlorides of potassium and sodium.

The contents of the dish were dissolved in hot water and transferred to a porcelain dish. A small amount of chlorplatinic acid was added, and the solution was evaporated nearly to dryness. The residue was extracted with 80 per cent alcohol. A yellow color of the alcoholic solution indicated that sufficient excess of chlorplatinic acid had been added; otherwise more was added until the yellow color persisted. The precipitate was filtered out in a weighed Gooch crucible and washed thoroughly with 80 per cent alcohol and with a 20 per cent solution of ammonium chloride that had been saturated with potassium chlorplatinate. After a final washing with alcohol the residue was dried to constant weight at $100^{\circ}$ to $102^{\circ} \mathrm{C}$. and weighed as potassium platinic chloride. The contents of sodium $(\mathrm{Na})$ and potassium $(\mathrm{K})$ were then calculated from the weight of the combined sodium and potassium chlorides and the weight of the potassium platinic chloride.

\section{BROMINE.}

A proper amount of the diluted brine was rendered alkaline by sodium carbonate and evaporated to dryness. An aliquot portion of the alkaline filtrate obtained by extracting this residue was then evaporated to dryness on the steam bath. The residue was treated with 2 or 3 cubic centimeters of water and enough absolute alcohol to make the percentage of alcohol about 90 , and the solution was then boiled and filtered. Treatment of the residue with 90 per cent alcohol was repeated once or twice. The filtrates with 2 or 3 drops of a solution of sodium hydroxide were then evaporated to dryness. The process of extracting with 90 per cent alcohol was repeated on the new residue, and the extract filtered from the undissolved portion was treated with a drop of sodium hydroxide and evaporated to dryness. The residue was dissolved in a little distilled water, acidified with a little sulphuric acid (1 to 5), 3 or 4 drops excess being added, and transferred to a small flask. Freshly prepared chlorine water was added to it; usually 2 to 8 cubic centimeters of a saturated solution of chlorine was sufficient to set free the bromine. Care must be taken not to add too great an excess of chlorine, which might cause the formation of a bromochloride that would spoil the color reaction. The best results are obtained by adding approximately the same excess of chlorine to the standards as to the sample. This may be accomolished by adding 1 cubic centimeter of chlorine at a time and 
shaking between additions. After a little practice one can determine approximately when the chlorine ceases to set bromine free. After all the bromine had been thus set free 5 cubic centimeters of freshly purified carbon bisulphide was added to the contents of the flask, which was thoroughly shaken. The water solution was separated from the carbon bisulphide by filtration through a moistened filter, and the contents of the filter were washed two or three times with water and then transferred to a 12 cubic centimeter Nessler tube by means of about 1 cubic centimeter of carbon bisulphide. This extraction of the filtrate was repeated twice, with 3 cubic centimeters of carbon bisulphide each time. The combined carbon bisulphide extracts usually measured 11.5 to 12 cubic centimeters. If they did not quite reach the 12 cubic centimeter mark on the Nessler tube, enough carbon bisulphide was added to complete the required volume. The color of the solution thus extracted from the brine was compared with that of solutions of known strength of potassium bromide that had received exactly the same treatment and at the same time the acidification by sulphuric acid was begun. All the bromine is not extracted by the amounts of carbon bisulphide recommended. Consequently if the content of bromine is large it is well to make one or two extra extractions with carbon bisulphide, transfer the extracts to a Nessler tube, and compare the color with that of the weaker standards.

\section{CALCULATION OF RESULTS.}

The results of each analysis of brine or bittern are expressed in two forms-(1) the amounts of the radicles determined in grams per liter and (2) the radicles in percentage of the anhydrous residue. The statements of the analyses in percentage composition of the anhydrous residues have been calculated from Turrentine's results by R. K. Bailey, to whom the writer is greatly indebted for this valuable assistance. As the computations were made with a slide rule the second place of decimals may be inaccurate by one or two units, but such an error is insignificant.

An page 277 will be found a table of factors for converting radicles to compounds, or conventional combinations. This can be done in several ways, and mainly for this reason it has been thought best to omit statements of conventional combinations. With the aid of the table, however, the conversion can be made if desired.

The figures of the analyses have been recalculated and extensively rerised under the direction of Mr. Turrentine since the publication of Bulletin 94 of the Bureau of Soils, consequently the differences between the figures in the following tables and those in Bulletin 94 should be attributed to corrections and not to errors in transcription. 


\section{COMPOSITION OF ROCK SALT.}

The samples of rock salt whose analyses are given in the following table were collected either by J. W. Turrentine or by the writer, except No. 10, which was forwarded by the company. In order that the sample might be as nearly representative as possible it was usually taken from a working face in the mine. A groove a few inches wide was cut from the top to the base of the working face, care being taken to remove small fragments so as not to give undue representation to any particular part of the bed. Most of the samples represent the entire thickness of the salt bed, as the entire thickness is usually worked. The fragments were then broken into uniform smaller fragments an inch or less in diameter and were thoroughly mixed and quartered, the latter operations being repeated until a sample of convenient size was obtained for shipment to the laboratory.

Analyses of rock salt from New York, Michigan, Kansas, and Louisiana.

Radicles in percentage of material soluble in water.

\begin{tabular}{|c|c|c|c|c|c|c|c|c|c|c|}
\hline & $1 a$ & 2 & 3 & 4 & $5 J$ & 6 & 7 & 8 & 9 & 10 \\
\hline \multirow[t]{2}{*}{ 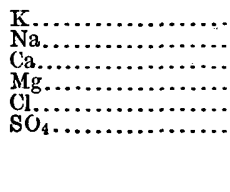 } & $\begin{array}{r}0.2 \\
36.0 \\
1.96 \\
.50 \\
59.94 \\
1.13\end{array}$ & $\begin{array}{r}\text { Trace. } \\
38.9 \\
.2 \\
.1 \\
59.6 \\
1.2\end{array}$ & $\begin{array}{r}\text { Trace. } \\
38.0 \\
1.0 \\
.1 \\
59.7 \\
1.2\end{array}$ & $\begin{array}{r}\text { Trace. } \\
39.0 \\
\text { Trace. } \\
.2 \\
59.3 \\
.5\end{array}$ & $\begin{array}{r}\text { Trace. } \\
38.8 \\
\text { Trace. } \\
.3 \\
59.8 \\
1.0\end{array}$ & $\begin{array}{r}\text { Trace. } \\
38.4 \\
.8 \\
\text { Trace. } \\
60.0 \\
.8\end{array}$ & $\begin{array}{r}0.1 \\
38.6 \\
.4 \\
.1 \\
60.0 \\
.8\end{array}$ & $\begin{array}{r}\text { Trace. } \\
38.3 \\
.8 \\
\text { Trace. } \\
60.0 \\
.8\end{array}$ & $\begin{array}{r}\text { Trace. } \\
38.3 \\
.4 \\
.3 \\
60.2 \\
.6\end{array}$ & $\begin{array}{r}\text { Trace. } \\
39.1 \\
\text { Trace. } \\
.1 \\
59.9 \\
. \quad .9\end{array}$ \\
\hline & 99.73 & 100.0 & 100.0 & 99.0 & 99.9 & 100.0 & 100.0 & 99.9 & 99.8 & 00.0 \\
\hline
\end{tabular}

a Expressed in percentage of dry sample.

1. Retsof Mining Co., Retsof, N. Y: Middle of rock-salt bed, 1911. J. A. Cullen, analyst.

2. Retsof Mining Co., Retsof, N. Y. Near floor in 8-foot worling face of Room 24, 1911. R. F. Gardiner, analyst.

3. Sterling Salt Co., Halite, N. Y. Rock-salt dust beneath main crushers, 1911. R. F. Gardiner, analyst. 4. Sterling Salt Co., Halite, N. Y. From roof to floor in working face, west side of Room 1, northwest, 1911. R. F. Gardiner, analyst. J. W: Turrentine, collector.

5. Detroit Salt Co., Detroit, Mich. From roof to floor in working face, 1911. R. F. Gardiner, analyst.

6. Crystal Rock Salt Co., Kanopolis, Kans. From roof to floor in working face, 1911. R. F. Gardiner, analyst.

7. Royal Rock Salt Co., Kanopolis, Kans. From roof to floor in working face, 1911. R. F. Gardiner, analyst.

8. Bevis Rock Salt Co., Lyons, Kans. From top to bottom of 16-foot bed, 1911. R. F. Gardiner, analyst. 9. Bevis Rock Salt Co., Lyons, Kans. Fine salt screened from coarse, 1911. R. F. Gardiner, analyst. 10. Avery Rock Salt Co., Avery Island, La. From working face, 1911. R. F. Gardiner, analyst. Collected by company.

Though these analyses represent the water-soluble material they practically represent also the composition of the rock salt, as there was very little insoluble matter. A comparison of these analyses with those of salts in sea water (p. 217) will show how the salt purifies itself as it crystallizes from the complex sea water. The uniform and nearly complete exclusion of impurities is particularly noticeable. These results prove that the rock-salt beds now worked are negligible as sources of potassium salts. 


\section{COMPOSITION OF NATURAL SURFACE BRINES.}

\section{SEA WATER.}

Sea water, whose composition has been the subject of elaborate investigation in many parts of the world, is mainly a solution of the chlorides and sulphates of sodium, magnesium, calcium, and potassium, but it contains also many other substances. It carries appreciable amounts of bromine, iodine, iron, silicon, carbonate, and phosphate, and the presence in it of fluorine, nitrogen, arsenic, boron, lithium, rubidium, caesium, barium, strontium, aluminum, manganese, nickel, cobalt, lead, silver, copper, zinc, gold, and radium has been demonstrated. ${ }^{1}$

Many of the more recent analyses of sea water from different parts of the world have been collated by Clarke, ${ }^{2}$ whose tabulation of them is presented in the following table, the percentage composition of the anhydrous residues of the waters being given. The salinity or total content of mineral matter of each sample is given in the key following the table and is expressed in percentage or in grams per 100 grams.

Analyses of ocean salts.

\begin{tabular}{|c|c|c|c|c|c|c|c|c|}
\hline & 1 & 2 & 3 & 4 & 5 & 6 & 7 & 8 \\
\hline \multirow{5}{*}{ 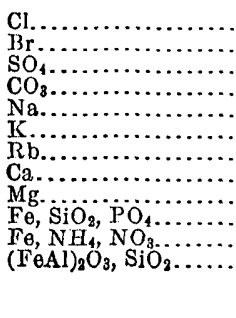 } & $\begin{array}{r}55.292 \\
.188 \\
7.692 \\
.207 \\
30.593 \\
1.106\end{array}$ & $\begin{array}{r}55.185 \\
.179 \\
7.914 \\
.213 \\
30.260 \\
1.109\end{array}$ & $\begin{array}{r}55.04 \\
.19 \\
7.86 \\
.18 \\
30.71 \\
1.06\end{array}$ & $\begin{array}{r}55.21 \\
.19 \\
7.69 \\
.09 \\
30.82 \\
1.16\end{array}$ & $\begin{array}{r}55.01 \\
.13 \\
8.00 \\
.14 \\
30.47 \\
.96 \\
.04\end{array}$ & $\begin{array}{r}54.62 \\
\cdots 8.01 \\
.27 \\
30.20 \\
2.10\end{array}$ & $\begin{array}{r}55.24 \\
.17 \\
7.54 \\
.34 \\
30.80 \\
1.10\end{array}$ & $\begin{array}{r}55.25 \\
7.56 \\
.37 \\
30.76 \\
1.14\end{array}$ \\
\hline & $\begin{array}{l}1.197 \\
3.725\end{array}$ & $\begin{array}{l}3.244 \\
3.896\end{array}$ & $\begin{array}{l}\because 1.27 \\
3.69\end{array}$ & $\begin{array}{l}1.21 \\
3.61\end{array}$ & $\begin{array}{l}.04 \\
1.67 \\
3.53\end{array}$ & $\begin{array}{l}1.36 \\
3.36\end{array}$ & $\begin{array}{l}1.22 \\
3.59\end{array}$ & $\begin{array}{l}1.22 \\
3.70\end{array}$ \\
\hline & & & $\mid \cdots \ldots \ldots \ldots$ & & .05 & & & $\cdots$ \\
\hline & & & & & & .08 & & $\cdots$ \\
\hline & 100.000 & 100.000 & 100.00 & 100.00 & 100.00 & 100.00 & 100.00 & 100.00 \\
\hline
\end{tabular}

1. Mean of 77 analyses of ocean water from many localities, collected by the Challenger expedition. W. Dittmar, analyst. Challenger Rept., Physics and chemistry, vol. 1, p. 203, 1884. Salinity, 3.301 to 3.737 per cent.

2. Atlantic water, mean of 22 samples collected on a voyage from the Cape of Good Hope to England. C. J. S. Makin, Chem. News, vol. 77, pp. 155, 171, 1898. Salinity, average, 3.631 per cent.

3. The A tlantic near Dieppe. Analysis by T. Schloesing, Compt. Rend., vol. 142, p. 320, 1906. Salinity, 32.420 grams per liter.

32.420 Trams per liter. The small amounts of $\mathrm{Fe}_{2} \mathrm{O}_{3}, \mathrm{NH}_{3}$, and $\mathrm{N}_{2} \mathrm{O}_{5}$ are here added together. $\Lambda$ trace of lithium was also roported.

5. The Baltic Sea between Oeland and Gothland. Analysis by $\mathrm{C}$. Schmidt, $\Lambda$ cad. Sci. St.-Pétersbourg Bull., vol. 24, p. 231,1878 . In all Schmidt's analyses the bicarbonates given by him have been here reduced to normal salts. The quantities of $\mathrm{Fe}, \mathrm{PO}_{4}$, and $\mathrm{SiO}_{2}$ found by Schmidt are so small that they have here been added together. Salinity of this sample, 0.7215 per cent.

6. The A tlantic at Bahia Blanca, coast of Argentina. Mean of two samples, taken at low and high tide. Analyses by F. Lahille, reported by E. H. Ducloux, Soc. cient. Argentina An., vol. 54, p. 62, 1902. Salinity, 3.365 per cent. Another pair of analyses is given of water taken at the mouth of Rio Negro.

7. The Gulf of Mexico off Loggerhead Key, Tortugas, near Florida. Analysis by George Steiger, laboratory of the U. S. Geological Survey, 1910 . Salinity, 3.549 per cent.

8. Atlantic Ocean near Beaulort, North Carolina. Mean of five analyses, by A. S. Wheeler, of samples taken under varying conditions. Am. Chem. Soc. Jour., vol. 32, p. 646, 1910. Salinity, 3.179 to 3.607 per cent.

1 Forchhammer, G., Philos. Trans., vol. 155, pp. 203-262, 1865. Dittmar, W., Challenger Rept., Physics and chemistry, vol. 1, p. 1, 1884. Clarke, F. W., The data of geochemistry, 3d ed.: U. S. Geol. Survey Bull. 616, pp. 119-128, 1916.

${ }^{2}$ Op. cit., pp. 123-125. 
Analyses of ocean salts-Continued.

\begin{tabular}{|c|c|c|c|c|c|c|c|c|}
\hline & 9 & 10 & 11 & 12 & 13 & 14 & 15 & 16 \\
\hline \multirow[t]{3}{*}{ 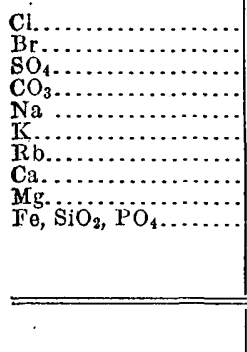 } & $\begin{array}{r}55.46 \\
7.59 \\
.30^{\circ} \\
30.53 \\
1.12 \\
1.21 \\
3.79 \\
\ldots \ldots . . .\end{array}$ & $\begin{array}{r}55.22 \\
.14 \\
7.88 \\
.10 \\
30.65 \\
.93 \\
.04 \\
1.21 \\
3.75 \\
.08\end{array}$ & $\begin{array}{r}55.30 \\
.14 \\
7.78 \\
.07 \\
30.85 \\
.89 \\
.04 \\
1.16 \\
3.69 \\
.08\end{array}$ & $\begin{array}{r}55.45 \\
7.79 \\
30.41 \\
1.17 \\
\ldots .18 \\
3.82 \\
\ldots \ldots\end{array}$ & $\left\{\begin{array}{r}55.53 \\
.18 \\
7.74 \\
.19 \\
30.37 \\
1.09 \\
\ldots \ldots .67 \\
1.26 \\
3.64 \\
\ldots \ldots . .\end{array}\right.$ & \begin{tabular}{r}
55.11 \\
.19 \\
7.89 \\
.20 \\
30.64 \\
1.09 \\
\hdashline 1.23 \\
3.65 \\
$\cdots$
\end{tabular} & $\begin{array}{r}55.30 \\
.16 \\
7.72 \\
.19 \\
30.51 \\
1.12 \\
1.19 \\
3.81 \\
\ldots \ldots\end{array}$ & 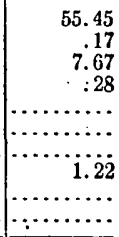 \\
\hline & 100.00 & 100.00 & 100.00 & 100.00 & 100.00 & 100.00 & 100.00 & $\because$ \\
\hline & 17 & 18 & 19 & 20 & 21 & 22 & 23 & 24 \\
\hline 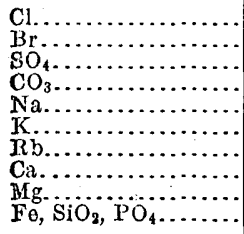 & $\begin{array}{r}55.12 \\
.18 \\
7.47 \\
.46 \\
30.46 \\
1.16 \\
\ldots .41 \\
3.74 \\
\ldots \ldots . . .\end{array}$ & $\begin{array}{r}55.59 \\
.14 \\
7.67 \\
.01 \\
31.21 \\
.64 \\
.03 \\
1.05 \\
3.64 \\
.02\end{array}$ & $\begin{array}{r}55.60 \\
.13 \\
7.65 \\
.02 \\
30.81 \\
.97 \\
.04 \\
.89 \\
3.87 \\
.02\end{array}$ & $\begin{array}{r}55.96 \\
.18 \\
7.49 \\
.13 \\
30.31 \\
1.06 \\
\ldots \ldots .22 \\
3.65 \\
\ldots \ldots . .\end{array}$ & $\begin{array}{r}55.46 \\
.13 \\
7.91 \\
.04 \\
30.23 \\
.94 \\
.03 \\
1.19 \\
4.03 \\
.04\end{array}$ & $\begin{array}{r}55.43 \\
.13 \\
7.76 \\
.03 \\
30.67 \\
.97 \\
.04 \\
1.19 \\
3.75 \\
.03\end{array}$ & $\begin{array}{r}55.41 \\
.13 \\
7.79 \\
.05 \\
30.89 \\
.85 \\
.03 \\
1.16 \\
3.67 \\
.02\end{array}$ & $\begin{array}{r}54.78 \\
.26 \\
7.60 \\
.72 \\
30.57 \\
1.11 \\
\ldots \ldots .25 \\
1.25 \\
3.71 \\
\ldots \ldots\end{array}$ \\
\hline . & 100.00 & 100.00 & 100.00 & 100.00 & 100.00 & 100.00 & 100.00 & 100.00 \\
\hline
\end{tabular}

9. The north Atlantic between Norway, the Faroe Islands, and Iceland, and north ward to Spitzbergen. Mean of 51 incomplete analyses by L. Schmelck, Den Norske Nordhavs-Expedition, pt. 9, p. 1, 1882. Soda and carbonic acid estimated by calculation, not directly determined. Salinity, 3.37 to 3.56 per cent. 10. The White Sea. Average of three analyses by C. Schmidt. Acad. Sci. St.-Pétersbourg Bull., vol. 24, p. 231, 1878 . Salinity, 2.598 to 2.968 per cent.

11. The Arctic Ocean between the White Sea and Nova Zembla. Mean of two analyses by Schmidt, idem.

12. The Siberian Ocean. Water collected by the Vega expedition. Mean of four analyses by Forsberg, Vega Exped. Rept., vol. 2, p. 376,1883 . Salinity, 1.378 to 3.457 per cent.

13. Mediterranean Sea near Carthage. Analysis by T. Schloesing, Compt. Rend., vol. 142, p. $320,1906$. Salinity, 38.9744 grams per liter.

14. The Mediterranean, midsea, between Bizerta and Marseille. Salinity, 38.789 grams per liter. Analysis by Schloesing, idem.

15. The eastern Mediterranean, waters collected during the voyages of the Austrian steamer $P$ ola.

Analyst, K. Natterer, Monatsh. Chemie, vol. 13, pp. 873, 897, 1892; vol. 14, p. 624, 1893; vol. 15, p. 530, 1804. Three hundred samples of water were examined, some only for gases. The figures given here are the everage from 42 analyses which were fairly complete. Salinity, 3.836 to 4.115 per cent.

16. The Sea of Marmora. Natterer, Monatsh. Chemie, vol. 16, p. 405, 1895; 44 partial analyses. Natterer gives the figures here utilized as averages of varying numbers of determinations. $\mathbf{M g}, \mathrm{Na}$, and $\mathbf{K}$ not determined. Salinity, 2.310 to 4.061 per cent.

17. The Black Sea. Average of six analyses by S. Kolotoff, Russ. Phys. Chem. Soc. Jour., vol. 24, p. 82, 1893. Salinity, 1.826 to 2.223 per cent.

18. The Suez Canal at Ismailia. Analysis by C. Schmidt, Acad. Sci. St.-Petersbourg Bull., vol. 24, p. 231, 1878. Salinity, 5.103 per cent. For other data on the Suez Canal, see L. Durand-Claye, Annales chimie et phys., 5 th ser., vol. 3 , p. 188, 1874. Very high salinities were noted. For a recent, incomplete analysis of Red Sea water, seo J. B. Coppock, Chem. News, vol. 96, p. 212, 1907.

19. The Red Sea near the middle. Analysis by Schmidt, op. cit. Salinity, 3.976 per cent.

20. The Red Sea. Average of four analyses by Natterer, Monatsh. Chemie, vol. 20, p. 1, 1899; vol. 21, p. 1037, 1900. Water collected in the Suez Canal, the Timsah Lake, and the two Bitter Lakes. Many other partial analyses are given. The salinity of these particular samples ranged from 5.085 to 5.854 per cent.

21. The Straits of Malacca. Salinity, 2.7965 per cent.

22. The China Sea. Salinity, 3.208 per cent.

23. The Indian Ocean, mean of two analyses; salinity, 3.5534 and 3.6681 per cent. Analyses 21, 22, 23, by C. Schmidt, Mél. phys. chim., vol. 10, p. 594. Also Jahresber. Chemie, p. 1370, 1877. Schmidt's rubidium determinations need verification.

24. The "Mare Morto," an inclosed body of water on the island Lacromo in the Adriatic, having underground connection with the sea. Salinity, 3.1744 per cent. Analysis by W. Loebisch and L. Sipöcz, Min. Mitt., p. 171, 1876.

Other analyses of Atlantic water, taken off the coast of Brazil, with analyses of water from the mouths of the Amazon, are given by F. Katzer, in K. böhm. Gesell. Wiss. Sitzungsb., 1897, No. 17. These represent mixtures of sea and river water. For special determinations of bromine in sea water and its ratio to the chlorine see E. Berglund, Deutsch. chem. Gesell. Ber., vol. 18, p. 2888, 1885. An analysis of water from the Ionian Sea, by F. Wibel, is printed in Deutsch. chem. Gesell. Ber., vol. 6, p. 184, 1873 . One by A. Vierthaler (Akad. Wiss. Wien Sitzungsb., vol. 56, p. 479, 1867), of Adriatic water taken near Spalato shows abnormally low sodium and high calcium presumably due to admixtures of water from the land. See also W. Skey, New Zealand Colonial Mus. and Lab., 3d Ann. Rept., 1868, for seven analyses of sea water taken near that island; C. J. White, Roy. Soc. New South Wales Proc., vol. 41, p. 55, 1907, one analysis of water taken off Coogee; A. Burada, Ann. sci. Univ. Jassy, vol. 5, p. 251 , 1909, one analy'sis of water from the Black Sea. On salinity of the Persian Gulf, Annalen der Hydrographie, vol. 7, p. 293, 1908 . Two recent analyses of Adriatic water are reported by V. Gegenbauer, Min. pet. Mitt., val. 29, p. 357, 1910. 
The most striking feature brought out by these analyses is the remarkably uniform composition of the saline matter in spite of relatively large differences in concentration. Dittmar's results, given in column 1, may be taken as a standard of comparison, for they represent the largest number of refined complete analyses of samples covering the widest ranges of depth and geographic position. According to him the salinity of ocean water ranges from 3.301 to 3.737 per cent; the lower figure is the salinity of water from Indian Ocean south of $66^{\circ}$ latitude, and the higher figure is that of the water from the middle of the north Atlantic near the Tropic of Cancer; the depth below the surface at which the samples were taken is not stated. According to Forchhammer ${ }^{1}$ sea water contains an average of 3.4404 per cent (34.404 grams per kilogram) of salts, including 0.007 to 0.01 per cent of insoluble material left on treating with puro water the total solids obtained by evaporation. This concentration represents a possible content of about 2.7 per cent of sodium chloride. A saturated solution of sodium chloride, according to Gerlach, ${ }^{2}$ contains 26.395 per cent of sodium chloride at $15^{\circ} \mathrm{C}$. $\left(59^{\circ} \mathrm{F}\right.$.). Thus it will be seen that concentrated salt solutions contain more than nine times as much sodium chloride as sea water.

The figures in the following table represent the average content of various salts in sea water calculated by Dittmar from his 77 complete analyses. This composition may be considered general for sea water. It should be remembered, however, that this combination of acidic and basic radicles to form salts is more or less arbitrary and is merely a convenient convention adopted for the purpose of indicating the possibilities of recovery of the salts by evaporation.

Conventional combinations representing the salts dissolved in sea water.

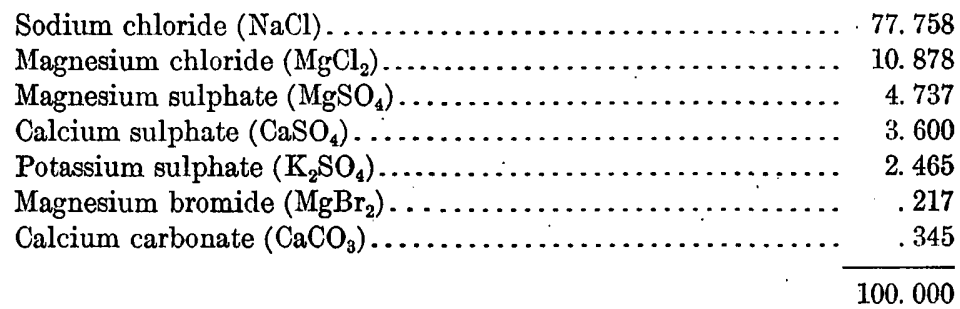

In connection with the present interest in potash salts, it may be noted that the figure for potassium sulphate, 2.465 per cent, is equivalent to 2.110 per cent of potassium chloride and 1.106 per cent of potassium. 


\section{WATER OF GREAT SALT LAKE.}

The chief differences in the results of various chemists who have analyzed the water of Great Salt Lake are in the degree but not in. the character of the salinity. It is to be expected that the concentration would change with greater or less dilution from local sources. Though the degree of salinity ranges from four to seven times that of ocean water the composition of the saline matter is much like that in ocean water. A sample from the lake, north of Lucin Cutoff, near Withee Junction, Utah, collected by the writer in 1912 had a salinity of 13.35 per cent according to a test by R. K. Bailey.

The following analyses tabulated by Clarke ${ }^{1}$ show the composition of the water. Other analyses have been given by Gilbert. ${ }^{2}$

Analyses of water from Great Salt Lake.

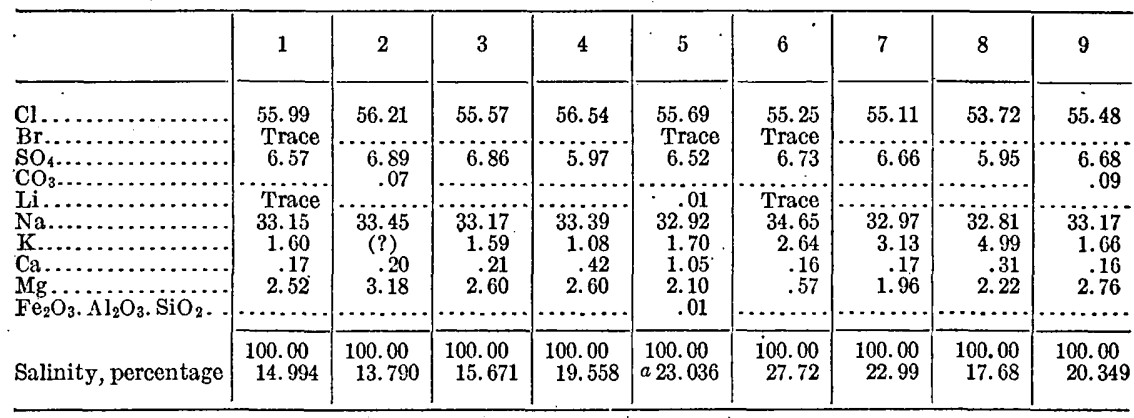

a More correctly, 230.355 grams per liter.

1. By O. D. Allen, analyst. U. S. Geol. Expl. 40th Par. Rept., vol. 2, p. 433, 1877. Water collected in 1869. A trace of boric acid is aiso reported in addition to the substances named in the table. Allen also gives analyses of a saline soil from a mud flat near Great Salt Lake. It contained 16.40 per cent of soluble matter much like that of the lake water.

2. By Charles Smart, analyst. Cited in Resources and attractions of the Territory of Utah, Omaha, 1879. Analyses made in 1877.

3. By E. von Cochenhausen, analyst for C. Ochsenius. Deutsch. geol. Gesell. Zeitschr., vol, 34, p. 350 , 1882. Sample collected by Ochsenius, April 16,1879 . Ochsenius also gives an analysis of the salt manufactured from the water of Great Salt Lake.

4. By J. E. Talmage, analyst. Science, vol. 14, p. 455, 1889. Collected in 1889. An analysis of a sample taken in 1885 is also given.

5. By E. Waller, analyst. School of Mines Quart., vol. 14, p. 57, 1892. A trace of boric acid is also reported.

6. By W.. Blum, analyst. Collected in 1904. Recalculated to 100 per cent. Reported by Talmage in Scottish Geog. Mag., vol. 20, p. 424, 1904. An earlier paper by Talmage on the lake is in the same journal, vol. $17, \mathrm{p}_{.} 617,1901$.

7. By W. C. Ebaugh and K. Williams, analysts. Chem. Zeitung, vol. 32, p. 409, 1908. Collected in October, 1907.

8. By W. Macfarlane, analyst. Science, vol. 32, p. 568; 1910: Collected in February, 1910. A number of other analyses, complete or incomplete, are cited in this paper by Ebaugh and Macfarlane.

9. By R. K. Bailey, analyst. U. S. Geological Survey laboratory. Sample collected by H. S. Gale, October 24, 1913 .

Sodium is higher, but calcium and magnesium, especially calcium, are distinctly lower in the lake water than in sea water. (See pp. 217-218.) Carbonates are almost entirely absent from the lake water but are present to an appreciable extent in ocean water. Calcium carbonate is precipitated on the shore of the lake in the form of

1 Clarke, F. W., The data of geochemistry: U. S. Geol. Survey Bull. 491, p. 144, 1911, and Bull. 616, p. $155,1916$.

2 Gilbert, G. K., Lake Bonneville: U. S. Geol. Survey Mon. 1, pp. 253-254, 1890 
oolitic sand. Gilbert ${ }^{1}$ states that the quantity of sodium chloride in the water of the lake is about $400,000,000$ tons and that the amount of sodium sulphate is about $30,000,000$ tons.

As the lake is shallow, its volume is greatly affected by small changes in its level. The total salinity (salt content) may be considered fairly constant, only the strength of the brines being affected by these changes in level. Observations were made in 1850, when the lake was at its lowest observed stage; in 1873, when the lake was at its highest stage; in 1869, when it was at an intermediate stage; and in 1885 and 1889. From a comparison of the extreme results it appears that the salinity was decreased 39 per cent by a rise of 10.5 feet, which represents on the assumed basis of no change in total saline content an increase of 73 per cent in the volume of water in the lake. The saline matter presumably has been derived chiefly from the fresh-water rivers flowing into it and from the brackish springs along its edges. Whether these springs derive their saline matter from extraneous sources or from beds originally deposited in the Bonneville basin is unknown. If the latter is true the springs could hardly be regarded as contributing an original quota of saline material. Gilbert ${ }^{2}$ says that it must be regarded as an open question whether the existing lake and its characteristic brine date from the end of the Bonneville overflow (Pleistocene) or from a subsequent epoch of extreme aridity.

\section{COMPOSITION OF NATURAL AND ARTIFICIAL UNDERGROUND BRINES.}

BRINES AND SAMPLES.

Natural brines are those that are pumped from the ground in their natural state-that is, they are natural solutions of salt. Artificial brines, as the term is used in this paper, signifies brines that are formed by forcing fresh water into salt beds and thereby producing an artificial solution. The impurities of the water presumably enter into the brine. Important differences in chemical composition make it desirable to distinguish between the two types of commercial underground brine.

The brines whose analyses are given in the following tables arranged and discussed by States were sampled usually at the places where they flowed into the preliminary settling tanks. Composite samples were collected wherever possible, as it is believed that an analysis of united contributions from several wells is more nearly representative of the brine in a field than an analysis of brine from a single well. 


\section{NEW YORK.}

Analyses of artificial brines of New York.

Radicles in grams per liter.

\begin{tabular}{|c|c|c|c|c|c|c|c|c|c|}
\hline \multirow{3}{*}{ 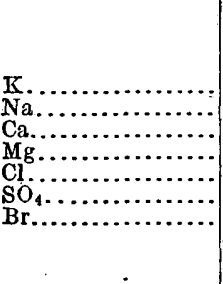 } & 1 & 2 & 3 & 4 & 5 & 6 & 7 & 8 & $a 9$ \\
\hline & $\begin{array}{r}0.3 \\
114.0 \\
3.2 \\
.3 \\
180.4 \\
2.3 \\
\ldots . . . .\end{array}$ & $\begin{array}{r}110.6 \\
2.7 \\
.3 \\
181.1 \\
2.4 \\
\ldots . . . .\end{array}$ & $\begin{array}{r}0.8 \\
93.8 \\
9.3 \\
1.0 \\
163.5 \\
.9 \\
\hdashline .9 .\end{array}$ & $\begin{array}{r}0.5 \\
100.8 \\
2.7 \\
160.7 \\
3.1 \\
2\end{array}$ & $\begin{array}{r}11.8 \\
104.4 \\
4.8 \\
1.6 \\
179.1 \\
1.6 \\
1.1\end{array}$ & $\begin{array}{r}12.0 \\
108.4 \\
3.4 \\
1.4 \\
181.9 \\
2.4 \\
1.1\end{array}$ & $\begin{array}{r}2.0 \\
104.0 \\
4.2 \\
1.6 \\
171.6 \\
3.4 \\
.8\end{array}$ & $\begin{array}{r}0.4 \\
113.0 \\
3.8 \\
.2 \\
179.5 \\
2.6 \\
.7\end{array}$ & $\begin{array}{r}0.2 \\
85.3 \\
.4 \\
.2 \\
129.4 \\
3.8 \\
.6\end{array}$ \\
\hline & 300.5 & 297.1 & 269.3 & 268.3 & 304.4 & 310.6 & 287.6 & 300.2 & 219.9 \\
\hline
\end{tabular}

Radicles in percentage of anhydrous residue.

\begin{tabular}{|c|c|c|c|c|c|c|c|c|c|}
\hline \multirow[t]{2}{*}{ 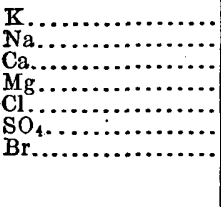 } & $\begin{array}{r}0.10 \\
37.92 \\
1.06 \\
.10 \\
60.06 \\
. \quad .76 \\
\therefore \ldots . .\end{array}$ & $\begin{array}{r}37.25 \\
.91 \\
.10 \\
60.94 \\
.80 \\
\ldots . . .\end{array}$ & $\begin{array}{r}0.29 \\
34.82 \\
3.45 \\
.37 \\
60.74 \\
.33 \\
\ldots . . .\end{array}$ & $\begin{array}{r}0.18 \\
37.60 \\
1.00 \\
.18 \\
59.90 \\
1.14 \\
\end{array}$ & $\begin{array}{r}3.87 \\
34.29 \\
1.58 \\
.52 \\
58.86 \\
.52 \\
.36\end{array}$ & $\begin{array}{r}3.87 \\
34.90 \\
1.09 \\
.45 \\
58.57 \\
.77 \\
.35\end{array}$ & $\begin{array}{r}0.69 \\
36.17 \\
1.46 \\
.56 \\
59.66 \\
1.18 \\
.28\end{array}$ & $\begin{array}{r}0.13 \\
37.69 \\
1.26 \\
.06 \\
59.76 \\
.87 \\
.23\end{array}$ & $\begin{array}{r}0.09 \\
38.81 \\
.18 \\
.09 \\
58.83 \\
1.73 \\
.27\end{array}$ \\
\hline & 100.00 & 100.00 & 100.00 & 100.00 & 100.00 & 100.00 & 100.00 & 100.00 & 100.00 \\
\hline
\end{tabular}

$a$ Natural brine (?).

1. Worcester Salt Co., Silver Springs, N. Y. From well No. 3, 1911. A. R. Merz, analyst.

2. Rock Glen Salt Co., Rock Glen, N. Y. 1911. A. R. Merz, analyst.

3. Star \& Crescent Salt Co., Saltvale, N. Y., 1911. A. R. Merz, analyst.

4. Genesee Salt Co., Piffard, N. Y. 1911. A.. R. Merz, analyst.

5. Watkins Salt Co., Watkins, N. Y. 1910. R. F. Gardiner, analyst. Collected by company.

6. International Salt Co., Watkins, N. Y., 1910. R. F. Gardiner, analyst. Collected by company.

7. Genesee Salt Co., Piffard, N. Y., 1910. R. F. Gardiner, analyst. Collected by company.

8. Remington Salt Co., Ithaca, N. Y., 1910. R. F. Gardiner, analyst. Collected by company.

9. Onondaga Pipe Line Co., Liverpool, N. Y., i910. R. F. Gardiner; analyst. Collected by company.

The salinities and compositions of the brines represented by the analyses in the preceding table agree very well except that of sample 9 , which probably represents the dilute natural brine from the glacial gravels and not an artificial brine. The abnormal content of potassium shown by samples 5 (Watkins Salt Co.) and 6 (International Salt Co.) is open to some doubt as to being truly representative of general conditions. On account of this doubt W. B. Hicks, of the United States Geological Survey, collected in 1914 several additional samples of these brines, the analyses of which are given further on.

The analytical results obtained by W. B. Hicks and R. K. Bailey have been converted from grams per thousand into grams per liter, making use of the specific-gravity determinations. This was done to make the results comparable with the majority of the analyses in this report. The analyses showing the high potash co atent are given in the first column of the tables.

So far as saturation of the brine obtained at the Watkins Salt Co.'s plant goes, the results appear to be about the same as those obtained by the Bureau of Soils. The brine is nearly saturated. The analyses of the brine by Hicks indicate a much smaller content in potash than the analysis by Gardiner, and the smaller content is 
more in harmony with analyses of brines from other New York plants. Analyses Nos. 4 and 5 in the next table, which are of bitterns from vacuum pans, would naturally show higher concentration than analyses of the brines, but in the bitterns also the quantity of potash salts is low.

The analyses in the second following table, which are of samples collected at the plant of the International Salt Co., near Watkins, show, in general, similar low results for potash and in most respects are comparable with those obtained from the brines and bitterns of the Watkins Salt Co.

Merrill ${ }^{1}$ has observed from study of many analyses of New York brines and salts that the samples from the top of a salt bed contain considerably more magnesium chloride than those from the bottom and that though the brine from a new well generally contains little magnesium chloride it contains more as the underground cavity increases in size or becomes connected with other cavities. He suggests that the overlying shales may be more highly charged with this soluble chloride than the salt beds-a condition that fits well into the theory of the deposition of this salt from an arm of the sea. If Merrill's hypothesis is true the existence of workable deposits of potassium salts over such beds is extremely doubtful.

Analyses of artificial brines of New York.

Radicles in grams per liter.a

\begin{tabular}{|c|c|c|c|c|c|c|c|c|c|c|c|c|}
\hline & \multicolumn{2}{|c|}{1} & \multicolumn{2}{|c|}{2} & \multicolumn{2}{|c|}{3} & \multicolumn{2}{|c|}{4} & \multicolumn{2}{|c|}{5} & \multicolumn{2}{|l|}{6} \\
\hline & Grams. & $\begin{array}{c}\text { Per- } \\
\text { cent- } \\
\text { age. }\end{array}$ & Grams. & $\begin{array}{l}\text { Per- } \\
\text { cent- } \\
\text { age. }\end{array}$ & Grams. & $\begin{array}{l}\text { Per- } \\
\text { cent- } \\
\text { age. }\end{array}$ & Grams. & $\begin{array}{l}\text { Per- } \\
\text { cent- } \\
\text { age. }\end{array}$ & Grams. & $\begin{array}{l}\text { Por- } \\
\text { cent- } \\
\text { age. }\end{array}$ & $\begin{array}{c}\text { Grains } \\
\text { por } \\
\text { thou- } \\
\text { sand } \\
\text { grams. }\end{array}$ & $\begin{array}{l}\text { Per- } \\
\text { cent- } \\
\text { age. }\end{array}$ \\
\hline \multirow[t]{2}{*}{ 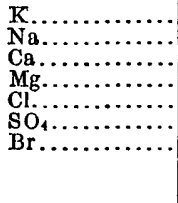 } & $\begin{array}{r}11.8 \\
104.4 \\
4.8 \\
1.6 \\
179.1 \\
1.6 \\
1.1\end{array}$ & $\begin{array}{r}3.87 \\
34.29 \\
1.58 \\
.52 \\
58.86 \\
.52 \\
.36\end{array}$ & $\begin{array}{r}0.48 \\
117.01 \\
3.10 \\
1.48 \\
184.59 \\
2.15 \\
\cdots \cdots\end{array}$ & $\begin{array}{r}0.16 \\
38.00 \\
1.01 \\
.16 \\
59.97 \\
.70\end{array}$ & $\begin{array}{r}0.31 \\
119.62 \\
3.59 \\
.56 \\
190.71 \\
2.22\end{array}$ & $\begin{array}{r}0.10 \\
37.74 \\
1.17 \\
.18 \\
60.11 \\
.70 \\
\ldots . \cdots\end{array}$ & $\begin{array}{r}1.81 \\
103.61 \\
17.17 \\
2.54 \\
197.07 \\
.48\end{array}$ & $\begin{array}{r}0.56 \\
32.12 \\
5.33 \\
.79 \\
61.05 \\
.15 \\
\ldots . \cdots\end{array}$ & $\begin{array}{r}1.69 \\
102.20 \\
17.27 \\
2.42 \\
197.15 \\
.48\end{array}$ & $\begin{array}{r}0.53 \\
31.86 \\
5.38 \\
.75 \\
61.33 \\
.15\end{array}$ & $\begin{array}{r}0.45 \\
349.64 \\
8.54 \\
1.45 \\
539.40 \\
8.52\end{array}$ & $\begin{array}{r}0.05 \\
38.49 \\
.94 \\
.16 \\
59.40 \\
.96 \\
\ldots . . .\end{array}$ \\
\hline & 304.4 & 100.00 & 307.81 & 100.00 & 317.01 & 100.00 & 322.68 & 100.00 & 321.21 & 100.00 & 908.00 & 100.00 \\
\hline
\end{tabular}

Samples from Watkins Salt Co., Watkins, N. Y.:

1. $\Lambda$ rtificial brine collected by company, $1910 . \ddot{\mathrm{R}}$. F. Gardiner, analyst.

2. Artiflcial brine from wells Nos. 1 and 2, collected by W. B. Hicks, 1914. W. B. Hicks, analyst.

3. Artificial brine from well No. 3, collected by W. B. Hicks, 1914. R. K. Bailey, analyst.

4. Bittern resulting from 24 -hour run collected from top portion direct from vacuum pan by W. B. Hicks, 1914. W. B. Hicks, analyst.

5. Bittern resulting from 24 -hour run collected from bottom portion from the discharge pipe by W. B. Hicks, 1914. W. B. Hicks, analyst.

6. Salt from drainago bin, ready for driers, collected by W. B. Hicks, 1914. R. K. Bailey, analyst.

1 Merrill, F. J. H., Salt and gypsum industries of New York: New York State Mus. Bull. 11, p. 62, 1893. 
Analyses of artificial brines of New York.

Radicles in grams per liter.a

\begin{tabular}{|c|c|c|c|c|c|c|c|c|c|c|}
\hline & 1 & 2 & 3 & 4 & 5 & 6 & 7 & 8 & 9 & $10^{\circ}$ \\
\hline $\begin{array}{l}\mathrm{K} \ldots \\
\mathrm{Na} \\
\mathrm{Ca} \\
\mathrm{Mg} \\
\mathrm{Mg} \\
\mathrm{Cl} \\
\mathrm{SO} \\
\mathrm{BO} \\
\mathrm{Br}\end{array}$ & $\begin{array}{r}12 \\
108.4 \\
3.4 \\
1.4 \\
181.9 \\
2.4 \\
1.1 \\
\end{array}$ & $\begin{array}{r}0.16 \\
128.27 \\
3.35 \\
.73 \\
183.92 \\
2.39\end{array}$ & $\begin{array}{r}0.37 \\
122.05 \\
4.00 \\
.70 \\
178.41 \\
2.94\end{array}$ & $\begin{array}{r}0.39 \\
111.43 \\
3.02 \\
.43 . \\
187.11 \\
2.34\end{array}$ & $\begin{array}{r}0.19 \\
121.42 \\
3.42 \\
.75 \\
184.23 \\
2.22\end{array}$ & $\begin{array}{r}0.27 \\
110.66 \\
.99 \\
.12 \\
190.82 \\
6.30\end{array}$ & $\begin{array}{r}0.48 \\
114.31 \\
3.22 \\
.48 \\
182.73 \\
2.03 \\
\cdots \cdots \\
\end{array}$ & $\begin{array}{r}0.48 \\
113.64 \\
3.21 \\
.48 \\
181.48 \\
2.14 \\
\cdots \ldots \ldots . . \\
\end{array}$ & $\begin{array}{r}3.78 \\
80.03 \\
34.53 \\
6.22 \\
204.47 \\
1.22 \\
\ldots \ldots \ldots . \\
\end{array}$ & \begin{tabular}{r}
0.4 \\
378.6 \\
2.4 \\
.2 \\
581.5 \\
$3: 3$ \\
\hdashline$\ldots .$. \\
\end{tabular} \\
\hline & 310.6 & 318.82 & 308.47 & 304.72 & 312.23 & 309.1 & 303.25 & $301: 43$ & 330.25 & $a 966.4$ \\
\hline
\end{tabular}

Radicles in percentage of anhydrous residuc.

\begin{tabular}{|c|c|c|c|c|c|c|c|c|c|c|}
\hline 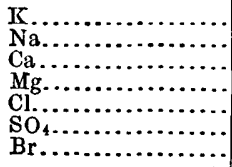 & $\begin{array}{r}3.87 \\
34.90 \\
1.09 \\
.45 \\
58.57 \\
.77 \\
.35\end{array}$ & $\begin{array}{r}0.05 \\
40.24 \\
1.08 \\
.23 \\
57.67 \\
.75 \\
. . .\end{array}$ & $\begin{array}{r}0.12 \\
39.66 \\
1.30 \\
.23 \\
57.97 \\
.72 \\
. . .\end{array}$ & $\begin{array}{r}0.13 \\
36.57 \\
.99 \\
.14 \\
61.40 \\
.77 \\
.7 .\end{array}$ & $\begin{array}{r}0.06 \\
38.89 \\
1.10 \\
.24 \\
59.00 \\
.71 \\
\hdashline . . .\end{array}$ & $\begin{array}{r}0.09 \\
35.80 \\
.30 \\
.04 \\
61.69 \\
b \quad 2.08 \\
\hdashline .6 .\end{array}$ & $\begin{array}{r}0.16 \\
37.71 \\
1.06 \\
.16 \\
60.24 \\
.67 \\
\ldots . . .\end{array}$ & $\begin{array}{r}0.16 \\
37.69 \\
1.07 \\
.16 \\
60.21 \\
.71 \\
\hdashline . . .\end{array}$ & $\begin{array}{r}1.15 \\
24.23 \\
10.46 \\
1.88 \\
61.91 \\
.37 \\
\hdashline . . .\end{array}$ & $\begin{array}{r}0.04 \\
39.17 \\
.25 \\
.02 \\
60.18 \\
.34 \\
\hdashline . . .\end{array}$ \\
\hline & 100.00 & 100.00 & 100.00 & 100.00 & 100.00 & 100.00 & .100 .00 & 100.00 & 100.00 & 100.00 \\
\hline
\end{tabular}

$a$ Liter $=1,000$ grams.

b Probably too high.

Samples from International Salt Co., Watkins, N. Y. These samples except No. 1 were collected by W. B. Hicks, 1914.

1. Sample collected by company, 1910. R. F. Gardiner, analyst.

2. Artificial brine from well No. 1. R. K. Bailey, analyst.

3. Artificial brine from well No. 2. R. K. Bailey, analyst.

4. Artificial brine from well No. 3. R. K. Bailey, analyst.

5. Artificial brine from well No. 4. R. K. Bailey, analyst.

6. Artificial brine from well No. 5. R. K. Bailey, analyst.

7. Artificial brine from well No. 6. W. B. Hicks, analyst.

8. Artificial brine from well No 7. W. B. Hicks, analyst.

9. Bittern taken from settling tank immediately after it had been drawn off from vacuum pan. W. B. Hicks, analyst.

10. Sample of salt taken from drainage bin. W. B. Hicks, analyst. 


\section{MICHIGAN.}

Analyses of artificial brines of western Michigan.

Radicles in grams per liter.

\begin{tabular}{|c|c|c|c|c|c|c|c|c|c|}
\hline & 1 & 2 & 3 & 4 & 5 & 6 & 7 & 8 & 9 \\
\hline 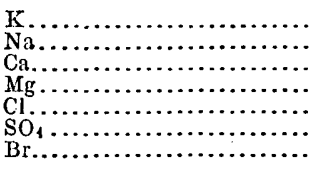 & $\begin{array}{r}0.1 \\
113.7 \\
1.8 \\
.4 \\
176.9 \\
3.3 \\
\hdashline\end{array}$ & $\begin{array}{r}\text { Trace. } \\
109.9 \\
1.2 \\
1.4 \\
173.6 \\
2.2 \\
\text { Trace. }\end{array}$ & $\begin{array}{r}0.8 \\
120.2 \\
2.0 \\
.3 \\
188.0 \\
3.9 \\
\text { None. }\end{array}$ & $\begin{array}{r}0.1 \\
113.4 \\
2.1 \\
.4 \\
176.9 \\
3.7 \\
\hdashline . . .\end{array}$ & $\begin{array}{r}0.2 \\
112.3 \\
1.9 \\
.7 \\
175.9 \\
3.2 \\
3 .\end{array}$ & $\begin{array}{r}0.5 \\
119.2 \\
2.3 \\
1.3 \\
191.4 \\
3.0 \\
\text { Trace. }\end{array}$ & $\begin{array}{r}0.1 \\
114.4 \\
1.8 \\
.8 \\
178.6 \\
4.0 \\
\cdots\end{array}$ & $\begin{array}{r}0.2 \\
113.4 \\
1.2 \\
178.0 \\
0.8 \\
\text { Trace. }\end{array}$ & $\begin{array}{r}0.1 \\
120.8 \\
2.0 \\
.4 \\
188.2 \\
3.7 \\
\text { Trace. }\end{array}$ \\
\hline & 296.2 & 288.3 & 315.2 & 296.6 & 294.2 & 317.7 & 299.7 & 294.2 & 315.2 \\
\hline
\end{tabular}

Rodicles in percentage of anhydrous residue.

\begin{tabular}{|c|c|c|c|c|c|c|c|c|c|}
\hline 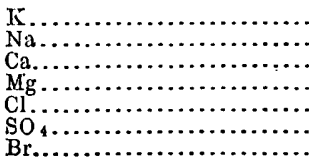 & $\begin{array}{r}0.03 \\
38.37 \\
.60 \\
.13 \\
59.63 \\
1.24 \\
\ldots\end{array}$ & $\begin{array}{r}0.00 \\
38.13 \\
.41 \\
.48 \\
60.22 \\
.76 \\
.00\end{array}$ & $\begin{array}{r}0.25 \\
38.12 \\
.63 \\
.09 \\
59.68 \\
1.23 \\
.00\end{array}$ & $\begin{array}{r}0.03 \\
38.29 \\
.71 \\
.13 \\
59.60 \\
1.24 \\
\ldots\end{array}$ & $\begin{array}{r}0.06 \\
38.20 \\
.64 \\
.22 \\
59.79 \\
1.09 \\
\end{array}$ & $\begin{array}{r}0.16 \\
37.52 \\
.72 \\
.41 \\
60.25 \\
.94 \\
.00\end{array}$ & $\begin{array}{r}0.03 \\
38.17 \\
.60 \\
.27 \\
59.68 \\
1.25 \\
\end{array}$ & $\begin{array}{r}0.06 \\
38.58 \\
.41 \\
.18 \\
60.50 \\
.27 \\
.00\end{array}$ & $\begin{array}{r}0.03 \\
38.34 \\
.63 \\
.13 \\
59.70 \\
1.17 \\
.00\end{array}$ \\
\hline$\cdot$ & 100.00 & 100.00 & 100.00 & 100.00 & 100.00 & 100.00 & 100.00 & 100.00 & 100.00 \\
\hline
\end{tabular}

1. Louis Sands Salt \& Lumber Co., Manistec, Mich. Jrom wells. A. R. Merz, analyst.

2. Louis Sands Salt \& Lumber Co., Manistec, Mich. From well 2,013 fcet deep. Collected by the company, 1910. R. F. Gardiner, analyst.

3. Louis Sands Salt \& Lumber Co., Manistee, Mich. From well No. 2, 1910. J. A. Cullen, analyst.

4. R. G. Peters Salt \& Lumber Co., East Lake, near Manistee, Mich. Composito from 6 wells, 1911 ; contains hydrogen sulphide. A. R. Merz, analyst.

5. Filer \& Son, Filer City, near Manistee, Mich. From wells, 1911. A. R. Merz, analyst.

6. Filer \& Son, Filer City, near Manistee, Mich. From hot settlers. Collected by J. W. Turrentine, 1910. J. A. Cullen, analyst.

7. State Lumber Co., Manistee, Mich. Composite from 2 wells at plant No. 2, 1911. A. R. Merz and R. F. Gardiner, analysts.

8. Stearns Salt \& Lumber Co., Ludington, Mich. Composite from 4 wells, 1911. R. F. Gardiner, analyst.

9. Anchor Salt Co., Ludington, Mich. From settlers. Collected by company, 1910. J. A. Cullen; analyst.

The brines of the west shore of Michigan, like those of the east shore, are almost completely saturated. Their uniformity of composition suggests that they may be derived from a single bed. For a long time it was thought that there was but one bed of salt in this region, ${ }^{1}$ but well No. 4 of the Anchor Salt Co. showed the presence of four beds, 20,12, 7, and 5 feet, respectively, in thickness. The brines are exceptionally low in calcium and magnesium, and the percentage of sulphate is uniformly low.

1 Lane, A. C., Michigan Geol. Survey Ann. Rept., 1908, p. 59, 1509. Cook, C. W., Mineral resources of Michigan: Michigan Geol. and Biol. Survey Pub. 8, Geol. ser. 6, p. 319, 1911.

$40104^{\circ}-1 \mathrm{~S}-$ Bull. $660-15$ 
Analyses of natural brines of eastern Michigan.

Radicles in grams per liter.

\begin{tabular}{|c|c|c|c|c|c|c|c|c|c|c|c|}
\hline & 1 & 2 & 3 & 4 & 5 & 6 & 7 & 8 & 9 & 10 & 11 \\
\hline 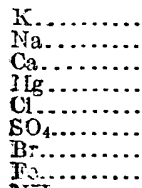 & $\begin{array}{r}\text { Trace. } \\
77.8 \\
10.8 \\
3.8 \\
145.4 \\
4.2 \\
.4\end{array}$ & $\begin{array}{r}0.4 \\
100.0 \\
7.6 \\
1.0 \\
155.1 \\
2.4 \\
1.7\end{array}$ & $\begin{array}{r}1.4 \\
92.2 \\
12.8 \\
3.6 \\
155.4 \\
26.0 \\
2.0\end{array}$ & $\begin{array}{r}0.8 \\
78.2 \\
10.8 \\
3.2 \\
145.9 \\
2.2 \\
.5\end{array}$ & $\begin{array}{r}1.0 \\
86.6 \\
16.0 \\
4.4 \\
172.8 \\
1.2 \\
.4\end{array}$ & \begin{tabular}{|r} 
Trace. \\
69.7 \\
36.6 \\
8.6 \\
197.6 \\
1.2 \\
2.2 \\
.8
\end{tabular} & \begin{tabular}{|r}
1.2 \\
52.5 \\
50.2 \\
11.6 \\
205.4 \\
.6 \\
Trace. \\
.8
\end{tabular} & $\begin{array}{r}\text { Trace. } \\
85.5 \\
15.8 \\
4.0 \\
163.0 \\
.6 \\
2.0\end{array}$ & $\begin{array}{r}\text { Trace. } \\
111.5 \\
4.2 \\
13.2 \\
205.4 \\
1.8 \\
2.8\end{array}$ & $\begin{array}{r}\text { Trace. } \\
64.8 \\
36.4 \\
165.8 \\
165.6 \\
\text { Trace. }\end{array}$ & $\begin{array}{r}5.29 \\
70.70 \\
18.56 \\
4.93 \\
156.68 \\
\text { Trace. } \\
4.23 \\
.12\end{array}$ \\
\hline \multirow{4}{*}{ 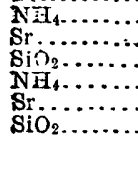 } & & & & & & & & & & & \multirow{3}{*}{$\begin{array}{l}.59 \\
\text { Trace. } \\
.59 \\
\text { Trace. }\end{array}$} \\
\hline & & & & & $\cdots$ & .3 & & & & & \\
\hline & & & & & & & & & & & \\
\hline & 242.4 & 268.2 & 293.4 & 241.6 & 282.4 & 317.0 & 322.3 & 270.9 & 338.9 & 268.2 & 261. 10 \\
\hline
\end{tabular}

Radicles in percentage of anhydrous residue.

\begin{tabular}{|c|c|c|c|c|c|c|c|c|c|c|c|}
\hline \multirow[t]{2}{*}{ 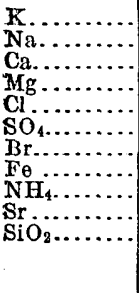 } & $\begin{array}{r}0.00 \\
32.13 \\
4.45 \\
1.57 \\
59.96 \\
1.73 \\
.16 \\
\ldots \ldots . .\end{array}$ & $\begin{array}{r}0.15 \\
37.27 \\
2.83 \\
.37 \\
57.86 \\
.89 \\
.63 \\
\ldots \ldots \ldots \\
\ldots \ldots\end{array}$ & $\begin{array}{r}0.48 \\
31.42 \\
4.36 \\
1.23 \\
52.97 \\
8.86 \\
.68 \\
\ldots \ldots . . . \\
\ldots . . .\end{array}$ & $\begin{array}{r}0.33 \\
32.36 \\
4.47 \\
1.32 \\
60.40 \\
.91 \\
.21 \\
\ldots \ldots . . . \\
\ldots . . .\end{array}$ & $\begin{array}{r}0.35 \\
30.63 \\
5.67 \\
1.56 \\
61.23 \\
.42 \\
.14 \\
\ldots \ldots . . . \\
\end{array}$ & $\begin{array}{r}0.00 \\
21.99 \\
11.54 \\
2.71 \\
62.35 \\
.38 \\
.69 \\
.25 \\
.09\end{array}$ & $\begin{array}{r}0.37 \\
16.27 \\
15.57 \\
3.60 \\
63.75 \\
.19 \\
.00 \\
.25 \\
\ldots . . . . \\
\ldots . . . .\end{array}$ & $\begin{array}{r}0.00 \\
31.55 \\
5.83 \\
1.47 \\
60.19 \\
.22 \\
.74 \\
\ldots \ldots . . \\
\hdashline\end{array}$ & $\begin{array}{r}0.00 \\
32.90 \\
1.24 \\
3.90 \\
60.60 \\
.53 \\
.83 \\
\ldots \ldots . . \\
\ldots \ldots\end{array}$ & $\begin{array}{r}0.00 \\
24.18 \\
13.57 \\
.30 \\
61.73 \\
.22 \\
.00 \\
\ldots \ldots . . . \\
\ldots . . . \\
\ldots \ldots . .\end{array}$ & $\begin{array}{r}2.02 \\
27.08 \\
7.11 \\
1.89 \\
60.01 \\
\text { Trace. } \\
1.62 \\
.04 \\
\ldots \ldots . .23 \\
.23 \\
\text { Trace. }\end{array}$ \\
\hline & 100.00 & 100.00 & 100.00 & 100.00 & 100.00 & 100.00 & 100.00 & 100.00 & 100.00 & 100.00 & 100.00 \\
\hline
\end{tabular}

1. Bliss, Van Auken Co., Saginaw, Mich. Composite from 3 wells, 1911. R. F. Gardiner, analyst.

2. Edward Germain, Saginaw, Mich. From well No. 1 (750 feet deep), 1910. R. F. Gardiner, analyst. 3. Mershon, Eddy, Parker \& Co., Saginaw, Mich. Composite from 2 welis, 1911. R. F. Gardiner, analyst.

4. S. L. Eastman Flooring Co., Saginaw, Mich. Composite from 2 wells, 1911. R. F. Gardiner, analyst. 5. Saginaw Plate Glass Co., Saginaw, Mich. Composite from 10 wells, 1911 . R. F. Gardiner, analyst.

6. Dow Chemical Co., Midland, Mich. Composite from 12 wells, 1911. R. F. Gardiner, analyst.

7 . Dow Chemical Co., Mount Pleasant, Mich. Composite from 5 wells, 1911. R. F. Gardiner, analyst. (After removal of brominc.)

8. Saginaw Salt Co., St. Charles, Mich. From a well at Plant No. 1, 1911. R. F. Gardiner, analyst.

9. Saginaw Salt Co., St. Charles, Mich. Composite from 2 wells at Plant No. 2, 1911. R. F. Gardiner, analyst.
10. A. W. Wright, Alma, Mich. From depth of 2,863 feet, 1910. Collected by company. R. F. Gardiner, analyst.

11. Huron Milling Co., Harbor Beach, Mich. From äwell approximately 2,000 fect deep. R. K. Bailey, analyst.

As the natural brines whose analyses are given in this table are from the Marshall sandstone of Michigan, with the possible exception of Nos. 10 and 11, it might be expected that there should be a certain consistency among the results. In a general way this is shown in the analyses of the first five samples, except No. 3, which is different in concentration and in content of sulphate. For natural brines the small amounts of sulphate are rather notable.

As the center of the geologic basin of the Lower Peninsula is approached there is a tendency toward increase in salinity. The heavier liquids tend to travel toward the lower levels. The bromides increase in the same direction, as do also the heavy iron salts, which precipitate as the basic ferric salts after the solutions have stood in the air for some time. 
The Harbor Beach brine is of interest on account of its large content of potassium. Analyses of this brine have been published in the report of the Michigan Geological Survey, ${ }^{1}$ and it was these published analyses indicating a very high potassium content and approximately complete saturation that first attracted attention. The results of the examination by the United States Geological Survey do not agree with those published. The degree of saturation obtained is lower, as is also the percentage of potassium chloride in the total salts. The brine can not be regarded as saturated if its specific gravity, which is 1.1745 at $17^{\circ} \mathrm{C}$., its parts per thousand, and its content in calcium and magnesium are considered. The high content of bromine is of interest, especially if compared with that of brines which are now utilized for their bromine content in Michigan. As a source of bromine this brine should not be ignored.

Analyses of artificial brines of eastern Michigan and Canada.

Radicles in grams per liter.

\begin{tabular}{|c|c|c|c|c|c|c|c|c|c|}
\hline$!$ & 1 & 2 & 3 & 4 & 5 & 6 & 7 & 8 & 9 \\
\hline \multirow[t]{2}{*}{ 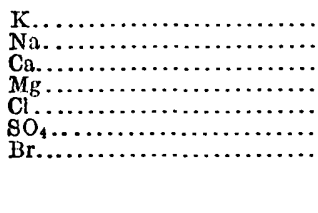 } & $\begin{array}{r}0.8 \\
132.6 \\
2.8 \\
.4 \\
205.4 \\
3.6 \\
1.1\end{array}$ & $\begin{array}{r}\text { Trace. } \\
120.6 \\
.8 \\
\text { Trace. } \\
183.8 \\
4.4 \\
\text { Trace. } \\
\end{array}$ & $\begin{array}{r}1.4 \\
78.2 \\
17.8 \\
12.8 \\
182.1 \\
4.2 \\
1.7\end{array}$ & $\begin{array}{r}2.4 \\
123.3 \\
.8 \\
\text { Trace. } \\
189.3 \\
4.0 \\
.9 \\
\end{array}$ & $\begin{array}{r}\text { Trace. } \\
121.3 \\
.6 \\
\text { Trace. } \\
185.2 \\
3.4 \\
\text { None. } \\
\end{array}$ & $\begin{array}{r}\text { Trace. } \\
114.5 \\
.6 \\
1.0 \\
179.0 \\
2.2 \\
\cdots \\
\end{array}$ & $\begin{array}{r}\text { Trace. } \\
119.2 \\
1.4 \\
.4 \\
185.0 \\
2.8 \\
\text { Trace. }\end{array}$ & $\begin{array}{r}3.8 \\
119.6 \\
1.4 \\
.9 \\
191.4 \\
2.8 \\
1.0 \\
\end{array}$ & $\begin{array}{r}1.4 \\
110.1 \\
6.4 \\
3.0 \\
190.2 \\
.6 \\
\text { None. }\end{array}$ \\
\hline & 346.7 & 309.6 & 298.2 & 320.7 & 310.5 & 297.3 & 308.8 & 320.9 & 311.7 \\
\hline
\end{tabular}

Radicles in percentage of anhydrous residue.

\begin{tabular}{|c|c|c|c|c|c|c|c|c|c|}
\hline 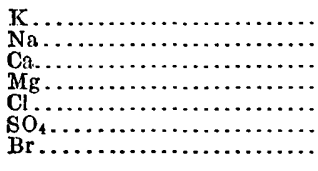 & $\begin{array}{r}0.23 \\
38.25 \\
.81 \\
.11 \\
59.25 \\
1.03 \\
.32 \\
\end{array}$ & $\begin{array}{r}0.00 \\
38.93 \\
.25 \\
.00 \\
59.40 \\
1.42 \\
.00 \\
\end{array}$ & $\begin{array}{r}0.47 \\
26.20 \\
5.97 \\
4.29 \\
61.09 \\
1.41 \\
.57 \\
\end{array}$ & $\begin{array}{r}0.74 \\
38.40 \\
.24 \\
.00 \\
59.10 \\
1.24 \\
.28\end{array}$ & $\begin{array}{r}0.00 \\
39.08 \\
.19 \\
.00 \\
59.64 \\
1.09 \\
.00\end{array}$ & $\begin{array}{r}0.00 \\
38.55 \\
.20 \\
.33 \\
60.18 \\
.74\end{array}$ & $\begin{array}{r}0.00 \\
38.62 \\
.42 \\
.12 \\
59.94 \\
.90 \\
.00\end{array}$ & $\begin{array}{r}1.18 \\
37.30 \\
.43 \\
.28 \\
59.63 \\
.87 \\
.31\end{array}$ & $\begin{array}{r}0.45 \\
35.31 \\
2.06 \\
.96 \\
61.03 \\
.19 \\
.00\end{array}$ \\
\hline & 100.00 & 100.00 & 100.00 & 100.00 & 100.00 & 100.00 & 100.00 & 100.00 & 0 \\
\hline
\end{tabular}

1. Port Huron Salt Co., Port Huron, Mich. From a well about 1,900 feet deep, 1911. R. F. Gardincr, analyst.

2. Diamond Crystal Salt Co., St. Clair, Mich. From a single well, 1911. R. F. Gardiner, analyst.

3. Davidson, Wonsey Co., Marine City, Mich. From 2 wells, 1911. R. F. Gardiner, analyst.

4. Michigan Salt Works, Marine City, Mich. From company's single well, 1911. R. F. Gardiner, analyst.

5. Worcester Salt Co. Ecorse, near Detroit, Mich. From 2 wells. R. F. Gardiner, analyst.

6. Delray Salt Co., Délray, near Detroit, Mich. From well, 1911. R. F. Gardiner, analyst.

7. Michigan Alkali Co., Detroit, Mich. From well, 1911. R. F. Gardiner, analyst.

8. Mulkey Salt Co., Detroit, Mich. From 3 wells, 1911. R. F. Gardiner, analyst.

9. Western Canada Flour Mills Co., Goderich, Canada. From well No. 1, 1911. R. F. Gardiner, analyst.

The artificial brines pumped in the southeastern part of Michigan are generally similar in concentration, all being nearly saturated. Except in analyses Nos. 3 and 9, there is substantial agreement in sodium and chlorine. The content of sulphate also is fairly uniform except in No. 9. In view of the probability that the brines are 
pumped from different salt beds of the Monroe group and in view of the wide geographic range of the samples the uniformity in composition of the brines, which indicates uniformity in the composition of the original salt layers, is striking and indicates uniformity in the original physical geologic conditions of deposition. The high content of calcium and magnesium in analyses Nos. 3 and 9 is noteworthy. These samples resemble bitterns in composition, and they may be salt deposited in the last stages of evaporation in an interior basin or salt dissolved chiefly from the upper part of a salt bed or possibly from roof shales. The observations made in connection with the presence of magnesium salts in New York brines may apply here. (See p. 223.)

\section{NORTHEASTERN OHIO.}

Analyses of natural and artificial brines of northeastern Ohio.

Radicles in grams per liter.

\begin{tabular}{|c|c|c|c|c|c|c|c|c|c|c|c|}
\hline & 1 & 2 & 3 & 4 & 5 & 6 & 7 & 8 & 9 & 10 & 11 \\
\hline 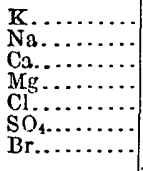 & $\begin{array}{r}0.4 \\
123.0 \\
1.0 \\
\text { Trace. } \\
189.4 \\
2.8 \\
\text { Trace. } \\
\end{array}$ & $\begin{array}{r}3.2 \\
68.0 \\
29.0 \\
6.4 \\
170.2 \\
8.6 \\
.2 \\
\end{array}$ & $\begin{array}{r}0.2 \\
117.2 \\
.8 \\
\text { Trace. } \\
176.8 \\
6.8 \\
\text { None. }\end{array}$ & $\begin{array}{r}0.8 \\
126.8 \\
.4 \\
.9 \\
195.8 \\
4.6 \\
\text { Trace. } \\
\end{array}$ & $\begin{array}{r}3.2 \\
62.7 \\
30.8 \\
6.4 \\
164.8 \\
\text { Trace. } \\
2.0 \\
\end{array}$ & $\begin{array}{r}0.4 \\
122.1 \\
.6 \\
\text { Trace. } \\
184.6 \\
6.4 \\
\text { None. } \\
\end{array}$ & $\begin{array}{r}1.0 \\
128.2 \\
\text { Trace. } \\
\text { Trace. } \\
189.5 \\
9.8 \\
.7\end{array}$ & $\begin{array}{r}3.0 \\
122.0 \\
.2 \\
\text { Trace. } \\
189.4 \\
1.8 \\
\text { Trace. }\end{array}$ & $\begin{array}{r}5.8 \\
48.0 \\
45.6 \\
9.8 \\
187.0 \\
\text { None. } \\
.4 \\
\end{array}$ & $\begin{array}{r}3.9 \\
43.4 \\
48.6 \\
11.2 \\
188.4 \\
.2\end{array}$ & $\begin{array}{r}4.2 \\
62.0 \\
35.4 \\
7.8 \\
182.2 \\
3.2 \\
\text { Trace. }\end{array}$ \\
\hline & 316.6 & 285.6 & 301.8 & 329.3 & 269.9 & 314.1 & 329.2 & 316.4 & 296.6 & 295.7 & 294.8 \\
\hline
\end{tabular}

Radicles in percentage of anhydrous residue.

\begin{tabular}{|c|c|c|c|c|c|c|c|c|c|c|c|}
\hline $\begin{array}{l}\mathrm{K} . \ldots \ldots \\
\mathrm{Na} . \ldots \ldots \\
\mathrm{Ca} \ldots \ldots \\
\mathrm{Mg} \ldots \ldots \\
\mathrm{Cl} \ldots \ldots \\
\mathrm{SO}_{4} \ldots \ldots \\
\mathrm{Br} . \ldots \ldots\end{array}$ & $\begin{array}{r}0.12 \\
38.88 \\
.31 \\
.00 \\
59.81 \\
.88 \\
.00\end{array}$ & $\begin{array}{r}1.15 \\
24.50 \\
10.45 \\
2.30 \\
61.32 \\
.21 \\
.07\end{array}$ & $\begin{array}{r}0.06 \\
38.90 \\
.24 \\
.00 \\
58.60 \\
2.20 \\
.00\end{array}$ & $\begin{array}{r}0.24 \\
38.51 \\
.12 \\
.27 \\
59.47 \\
1.39 \\
.00\end{array}$ & $\begin{array}{r}1.14 \\
23.22 \\
1142 \\
2.37 \\
61.14 \\
.00 \\
.71\end{array}$ & $\begin{array}{r}0.12 \\
38.93 \\
19 \\
.00 \\
58.73 \\
2.03 \\
.00\end{array}$ & $\begin{array}{r}0.30 \\
38.98 \\
.00 \\
.00 \\
57.54 \\
2.97 \\
.21\end{array}$ & $\begin{array}{r}0.95 \\
38.57 \\
.06 \\
.00 \\
59.85 \\
.57 \\
.00\end{array}$ & $\begin{array}{r}1.95 \\
16.20 \\
15.37 \\
3.30 \\
63.05 \\
.00 \\
.13\end{array}$ & $\begin{array}{r}1.32 \\
14.69 \\
16.44 \\
3.79 \\
63.70 \\
.00\end{array}$ & $\begin{array}{r}1.42 \\
21.05 \\
12.00 \\
2.64 \\
61.81 \\
1.08 \\
.00\end{array}$ \\
\hline & 100.00 & 100.00 & 100.00 & 100.00 & 100.00 & 100.00 & 100.00 & 100.00 & 100.00 & 100.00 & 100.00 \\
\hline
\end{tabular}

1. Colonial Salt Co., Kenmore, near Akron, Ohio. Artificial brine from well No. 6, 1911. R. F. Gardiner, analyst.

2. Colonial Salt Co., Akron, Ohio. Natural brine in strata above rock-salt horizon, 1911. R. F. Gardiner, analyst.

3. Columbia Chemical Co., Barberton, Ohio. Artificial brine forced to surface by hydraulic pressure,

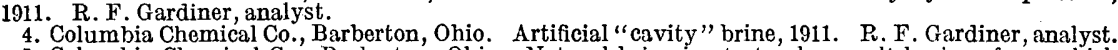
5. Columbia Chemical Co., Barberton, Ohio. Natural brine in strata above salt horizon from which artificial brine is obtained, 1911. R. F. Gardiner, analyst.

6. Cleveland Salt Co., Cleveland, Ohio. Composite artificial brine from 2 wells, 1911. R. F. Gardiner, analyst.

7. Union Salt Co., Cleveland, Ohio. Artificial brine from 1 well, 1911. R. F. Gardiner, analyst.

8. Ohio Salt Co., Rittman, Ohio. Composite artificial brine from 2 wells, 1911 . R. F. Gardiner, analyst. 9. Diamond Alkali Co., Fairport Harbor, Ohio. Natural brine in strata 300 feet above rock-salt horizon, 1911. R. F. Gardiner, analyst.

10. Same horizon as No. 9 , but from another well half a mile distant, 1911. R. F. Gardiner, analyst.

11. Northeastern Oil \& Gas Co., Austinburg, Ashtabula County, Ohio. Natural brine from well 2,000 feet deep, yielding about 5 barrels a day, collected by company, 1910. R. F. Gardiner, analyst.

The analysis of the artificial brines show close agreement in concentration, all the brines being nearly saturated, and also close agreement in content of sodium.. The content of sulphate is vari- 
able, but it is usually somewhat higher than that of the artificial brines of New York. The almost complete absence of calcium and magnesium and the commonly low content of potassium are notable.

Comparison of the composition of natural with that of artificial brines is particularly facilitated by this table. The greater content of potassium, calcium, and magnesium of the natural brines is noteworthy. None of these brines contains much bromine or sulphate, and as a class they are neither so strong nor so pure solutions of salt as the artificial brines.

The geologic position of this natural-brine horizon in northern Ohio ranges from 350 to more than 400 feet above the highest salt beds from which artificial brines are pumped, a few records showing this distance as about 250 feet. This stratum of brine is sharply defined and is of wide extent. The brine is carefully cased off to prevent its getting into the artificial brines used in the manufacture of salt and alkali near Akron and Fairport Harbor, as it would injure the product.

The relatively high content of potassium of these natural brines is noteworthy. In fractional crystallization of the solution sodium chloride would separate first, carrying with it calcium sulphate. The calcium sulphate probably would not separate as an entity first because of its small amount and the relative abundance of the other salts. ${ }^{1}$ This would leave the chlorides of potassium, calcium, and magnesium, and small amounts of iron. The removal of part of the lime and magnesia in order to bring the percentage of potassium up to that of a low-grade fertilizer presents a problem for the industrial chemist. These natural brines of Ohio deserve careful study for the purpose of ascertaining the potential value of the sodium-free residue as a fertilizer, and their position in a densely populated agricultural section makes the problem the more interesting.

The brine from the well at Austinburg (No.11, p. 228) is not used for the production of salt, but it probably comes from the same horizon as other natural brines of northeastern Ohio. If this assumption is correct, this brine horizon extends 25 miles father east than it has been developed.

1 Van't Hoff, J. H., Physical chemistry in the service of the sciences: Chicago Univ. Deconnial Pub., 2d ser., vol. 18, pp. 100-101, 1903. 


\section{SOUTHERN OHIO AND WEST VIRGINIA.}

Analyses of natural brines of southern Ohio and West Virginia.

Radicles in grams per liter.

\begin{tabular}{|c|c|c|c|c|c|c|}
\hline . & 1. & 2 & 3 & 4 & 5 & 6 \\
\hline \multirow[t]{2}{*}{ 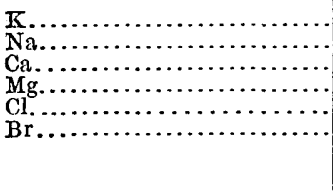 } & $\begin{array}{r}0.2 \\
29.1 \\
4.8 \\
1.7 \\
58.2 \\
.3 \\
\end{array}$ & $\begin{array}{r}0.2 \\
33.2 \\
5.4 \\
1.9 \\
66.1 \\
.3\end{array}$ & $\begin{array}{r}0.4 \\
28.3 \\
4.3 \\
1.4 \\
55.3 \\
.3\end{array}$ & $\begin{array}{r}0.2 \\
29.7 \\
5.7 \\
1.8 \\
61.3 \\
.3\end{array}$ & $\begin{array}{r}0.3 \\
32.1 \\
5.3 \\
1.8 \\
64.1 \\
.3\end{array}$ & $\begin{array}{r}0.3 \\
26.2 \\
6.9 \\
1.5 \\
56.9 \\
.4\end{array}$ \\
\hline & 94.3 & 107.1 & 90.0 & 99.0 & 103.9 & 92.2 \\
\hline
\end{tabular}

Radicles in percentage of anhydrous residue.

\begin{tabular}{|c|c|c|c|c|c|c|}
\hline \multirow[t]{2}{*}{ 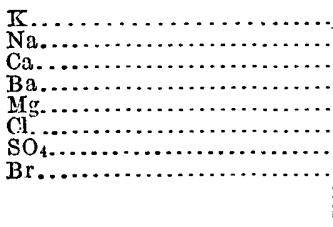 } & $\begin{array}{r}0.23 \\
30.86 \\
5.13 \\
\text { Trace. } \\
1.79 \\
61.69 \\
\text { Trace. } \\
.30\end{array}$ & $\begin{array}{r}0.21 \\
30.96 \\
5.25 \\
\text { Trace. } \\
1.73 \\
61.56 \\
\text { None. } \\
.29\end{array}$ & $\begin{array}{r}0.42 \\
31.49 \\
4.81 \\
\text { Trace. } \\
1.53 \\
61.46 \\
\text { None. } \\
.29\end{array}$ & $\begin{array}{r}0.22 \\
30.00 \\
5.80 \\
\text { Trace. } \\
1.83 \\
61.81 \\
\text { None. } \\
.34\end{array}$ & $\begin{array}{r}0.27 \\
30.84 \\
5.10 \\
\text { Trace. } \\
1.76 \\
61.71 \\
\text { Nons. } \\
.32\end{array}$ & $\begin{array}{r}0.30 \\
28.48 \\
7.52 \\
\text { Trace. } \\
1.65 \\
61.66 \\
\text { None. } \\
.39\end{array}$ \\
\hline & 100.00 & 100.00 & 100.00 & 100.00 & 100.00 & $100.00^{\circ}$ \\
\hline
\end{tabular}

1. Pomeroy Chemical Co., Pomeroy, Ohio, 1918. R. K. Bailey, analyst; W. B. Hicks, collector. Total solids by determination, 8.86 per cent. Density at $18.6^{\circ} \mathrm{C}$., 1.065 . Little iron precipitate formed at bottom of vessel before analysis.

2. Pomeroy Salt Association, Pomeroy, Ohio, 1918. R. K. Bailey, analyst; W. B. Hicks, collector. Total solids by determination, 9.92 per cent. Density at $18.6^{\circ}$ C., 1.079. Little iron precipitate formed at bottom of vessel before analysis.

3. Ohio River Salt Co., Mason, W. Va., 1918. R. K. Bailey, analyst; G. B. Richardson, collector. Total solids by determination, 8.49 per cent. Density at $21.5^{\circ} \mathrm{C}$., 1.061. Little iron precipitate formed at bottom of vessel before analysis.

4. Liverpool Salt \& Coal Co., Hartford, W. Va., 1918. R. K. Bailey, analyst; W. B. Hicks, collector. Total solids by determination, 9.27 per cent. Density at $18.6^{\circ} \mathrm{C} ., 1.068$. Little iron precipitate formed at bottom of vessel before analysis.

5. Mason Coal \& Chemical Co., Hartford, W. Va., 1918. R. K. Bailey, analyst; W. B. Hicks, collector. Total solids by determination, 9.70 per cent. Density at $18.6^{\circ} \mathrm{C} ., 1.071$. Little iron formed in bottom of vessel before analysis.

6. J. Q. Dickinson \& Co., Malden, W. Va., 1918. R. K. Bailey, analyst; G. B. Richardson, collector. Total solids by determination, 8.68 per cent. 'Density at $20.5^{\circ} \mathrm{C}$., 1.062. Little iron precipitate formed at bottom of vessel before analysis.

The samples of natural brines of which analyses are given in the accompanying table were collected from the same geologic horizon along Ohio River in Ohio and West Virginia, except sample No. 6, which is from the interior of West Virginia, on Kanawha River.

A tendency toward greater concentration of calcium and magnesium to the southeast as the great trough formed by the coalbearing rocks of the northern Appalachian field is approached might be expected, for it seems reasonable to suppose that the heavier liquid would move southeastward, and some such relation is indicated by these analyses.

The general presence of measurable amounts of bromine may be noted. These natural brines are sources of bromine.

The general similarity in composition of the brine from Malden, W. Va., to those collected along Ohio River is very apparent. The 
Malden brine is utilized in the manufacture of salt, bromine, and calcium chloride. It contains a greater proportion of calcium than the brines along Ohio River and a greater proportion of magnesium than many of them. Though its proportionate content of bromine also is large, its total salinity is less than that of the brines along Ohio River.

Analyses of brine from oil wells in southern Ohio and West Virginia.a

Radicles in grams per liter.

\begin{tabular}{|c|c|c|c|c|c|c|c|c|c|c|c|}
\hline & 1 & 2 & 3 & 4 & 5 & 6 & 7 & 8 & 9 & 10 & 11 \\
\hline 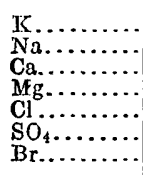 & $\begin{array}{r}0.3 \\
34.7 \\
9.5 \\
1.5 \\
74.9 \\
\text { Trace. } \\
.6\end{array}$ & $\begin{array}{r}0.2 \\
55.9 \\
19.0 \\
2.6 \\
125.3 \\
.2 \\
1.2\end{array}$ & $\begin{array}{r}4.4 \\
59.0 \\
4.2 \\
3.0 \\
109.0 \\
2.0 \\
.2\end{array}$ & $\begin{array}{r}0.9 \\
13.9 \\
3.9 \\
1.0 \\
31.6 \\
.2 \\
.5\end{array}$ & $\begin{array}{r}0.4 \\
43.2 \\
2.0 \\
1.0 \\
72.0 \\
1.6 \\
\text { Trace. }\end{array}$ & \begin{tabular}{r|}
0.4 \\
38.2 \\
7.2 \\
2.2 \\
76.4 \\
2.4 \\
Trace.
\end{tabular} & $\begin{array}{r}0.4 \\
53.8 \\
18.4 \\
2.9 \\
123.8 \\
.2 \\
1.2\end{array}$ & $\begin{array}{r}\text { Trace. } \\
53.3 \\
18.0 \\
2.6 \\
120.1 \\
2.2 \\
.3\end{array}$ & $\begin{array}{r}0.2 \\
44.5 \\
8.2 \\
\text { Trace. } \\
83.2 \\
\text { Trace. } \\
\text { None. }\end{array}$ & $\begin{array}{r}2.7 \\
28.0 \\
6.8 \\
.9 \\
54.5 \\
.5 \\
.8\end{array}$ & $\begin{array}{r}1.2 \\
45.5 \\
19.6 \\
1.7 \\
110.4 \\
.3 \\
1.0\end{array}$ \\
\hline & 121.5 & 204.4 & 181.8 & 52.0 & 120.2 & 126.8 & 200.7 & 196.5 & 136.1 & 94.2 & 179.7 \\
\hline
\end{tabular}

Radicles in percentage of anhydrous residue.

\begin{tabular}{|c|c|c|c|c|c|c|c|c|c|c|c|}
\hline 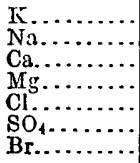 & $\begin{array}{r}0.25 \\
28.57 \\
7.81 \\
1.23 \\
61.65 \\
.00 \\
.49\end{array}$ & $\begin{array}{r}0.09 \\
27.35 \\
9.29 \\
1.28 \\
61.36 \\
.09 \\
.54\end{array}$ & $\begin{array}{r}2.42 \\
32.45 \\
2.31 \\
1.65 \\
59.96 \\
1.10 \\
.11\end{array}$ & $\begin{array}{r}1.73 \\
26.73 \\
7.51 \\
1.92 \\
60.78 \\
.38 \\
.95\end{array}$ & $\begin{array}{r}0.33 \\
35.00 \\
1.66 \\
.83 \\
59.95 \\
1.33 \\
.00\end{array}$ & $\begin{array}{r}0.31 \\
30.13 \\
5.68 \\
1.73 \\
60.25 \\
1.90 \\
.00\end{array}$ & $\begin{array}{r}0.19 \\
26.82 \\
9.17 \\
1.45 \\
61.74 \\
.09 \\
.54\end{array}$ & $\begin{array}{r}0.00 \\
27.12 \\
9.16 \\
1.33 \\
61.12 \\
1.12 \\
.15\end{array}$ & $\begin{array}{r}0.15 \\
32.66 \\
6.05 \\
.00 \\
61.14 \\
.00 \\
.00\end{array}$ & $\begin{array}{r}2.86 \\
29.72 \\
7.22 \\
.95 \\
57.87 \\
.53 \\
.85\end{array}$ & $\begin{array}{r}0.62 \\
25.31 \\
10.91 \\
.91 \\
61.52 \\
.15 \\
.55\end{array}$ \\
\hline & 100.00 & 100.00 & 100.00 & 100.00 & 100.00 & 100.00 & 100.00 & 100.00 & 1.00 .00 & 100.00 & 100.00 \\
\hline
\end{tabular}

a Samples collected by local representatives at the request of the United States Geological Survey.

1. South Penn Oil Co., Jefferson district, Pleasant County, W. Va. Brine from salt sand, 1910. J. $\Lambda$. Cullicn, analyst.

2. South Penn Oil Co., Mannington district, Marion County, W. Va. Brine from Big Injun sand in well 2,092 feet deep, 1910. J. A. Cullen, analyst.

3. South Peun Oil Co., Mannington district, Marion County, W. Va. Brine from Big Injun sand at depth of 1,853 feet. R. F. Gardiner, analyst.

4. South Penn Oil Co., Union district, Wood County, W. Va. Brine from Cow Run sand, 1910. J. $\Lambda$. Cullen, analyst.

5. South Penn Oil Co., Union district, Wood County, W. Va. Brine from Big Injun sand, 1910. R. F. Gardiner, analyst.

6. South Penn Oil Co., Union district, Wood County, W. Va. Brine from Berea sand, 1910. R. F. Gardiner, analyst.

7. South Penn Oil Co., McElroy district, Tyler County, W. Va. Brino from Big Injun sand in oil wcll No. 1, 1,843 feet deep, on farm of the Con way heirs; yield, 20 barrels of brine and 10 barrels of oil a day, 1910 . J. A. Cullen, analyst.

8. South Penn Oil Co., Ellsworth district, Tyler County, W. Va. Brine from well 1,859 feet deep, yiolding 110 barrels of brine a day from Big Injun sand at a depth of 1,782 feet, 1910. R. F. Gardiner, analyst.

9. Pine Oil Co., Sistersville, Tyler County, W. Va. Natural brine from a well 1,250 feet deep, 1910. R. F. Gardiner, analyst.

10. South Penn Oil Co., Grant district, Ritchio County, W. Va. Brine from salt sand, 1910. J. $\Lambda$. Cullen, analyst.

11. South Penn Oil Co., Clay district, Harrison County, W. Va. Brine from 50-foot stratum of sand in well 2,094 foet deep, 1910. J. A. Cullen, analyst. 
Analyses of brine from oil wells in southern Ohio and West Virginia-Continued

Radicles in grams per liter.

\begin{tabular}{|c|c|c|c|c|c|c|c|c|c|c|}
\hline & 12 & 13 & 14 & 15 & 16 & 17 & 18 & 19 & 20 & 21 \\
\hline 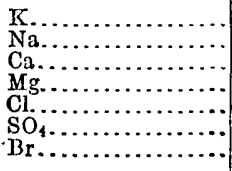 & $\begin{array}{r}0.7 \\
55.1 \\
19.8 \\
1.5 \\
124.5 \\
.4 \\
1.2\end{array}$ & $\begin{array}{r}0.4 \\
28.5 \\
9.0 \\
2.1 \\
64.4 \\
\text { Trace. } \\
.8\end{array}$ & $\begin{array}{r}\text { Trace. } \\
51.3 \\
14.4 \\
3.4 \\
108.3 \\
6.6 \\
1.3\end{array}$ & $\begin{array}{r}0.2 \\
58.6 \\
7.0 \\
1.2 \\
103.5 \\
3.4 \\
.1\end{array}$ & $\begin{array}{r}\text { Trace. } \\
52.4 \\
\text { Trace. } \\
\text { Trace. } \\
80.2 \\
.8 \\
\text { Trace. }\end{array}$ & $\begin{array}{r}0.2 \\
32.8 \\
7.0 \\
1.2 \\
65.6 \\
1.2 \\
\text { Trace. }\end{array}$ & $\begin{array}{r}0.6 \\
34.6 \\
5.8 \\
.2 \\
64.2 \\
.4 \\
.4 \\
\text { Trace. }\end{array}$ & $\begin{array}{r}0.6 \\
39.5 \\
9.4 \\
1.2 \\
80.2 \\
.2 \\
.2\end{array}$ & $\begin{array}{r}5.0 \\
139.5 \\
16.6 \\
4.2 \\
258.8 \\
1.8 \\
.2\end{array}$ & $\begin{array}{r}3.9 \\
58.1 \\
40.6 \\
1.8 \\
168.6 \\
1.1 \\
2.5\end{array}$ \\
\hline & 203.2 & 105.2 & 185.3 & 174.0 & 133.4 & 108.0 & 105.8 & 131.3 & 426.1 & 276.6 \\
\hline
\end{tabular}

Radicles in percentage of anhydrous residue.

\begin{tabular}{|c|c|c|c|c|c|c|c|c|c|c|}
\hline 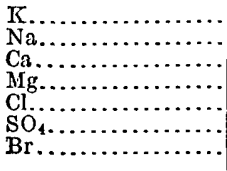 & $\begin{array}{r}0.34 \\
27.17 \\
9.74 \\
.74 \\
61.25 \\
.19 \\
.57 \\
\end{array}$ & $\begin{array}{r}0.38 \\
27.08 \\
8.55 \\
1.99 \\
61.24 \\
.00 \\
.76\end{array}$ & $\begin{array}{r}0.00 \\
27.64 \\
7.78 \\
1.83 \\
58.49 \\
3.56 \\
.70\end{array}$ & $\begin{array}{r}0.11 \\
33.65 \\
4.02 \\
.66 \\
59.56 \\
1.95 \\
.05 \\
\end{array}$ & $\begin{array}{r}0.00 \\
39.28 \\
.00 \\
.00 \\
60.12 \\
.60 \\
.00 \\
\end{array}$ & $\begin{array}{r}0.18 \\
30.36 \\
6.48 \\
1.11 \\
60.76 \\
1.11 \\
.00\end{array}$ & $\begin{array}{r}0.56 \\
32.73 \\
5.49 \\
.18 \\
60.68 \\
.36 \\
.00\end{array}$ & $\begin{array}{r}0.45 \\
30.08 \\
7.15 \\
.01 \\
61.11 \\
.15 \\
.15\end{array}$ & $\begin{array}{r}1.17 \\
32.72 \\
3.89 \\
.98 \\
60.77 \\
.42 \\
.05\end{array}$ & $\begin{array}{r}1.41 \\
21.01 \\
14.67 \\
.65 \\
60.97 \\
.39 \\
.90\end{array}$ \\
\hline & 100.00 & 100.00 & 100.00 & 100.00 & 100.00 & 100.00 & 100.00 & 100.00 & 100.00 & 00.0 \\
\hline
\end{tabular}

12. South Penn Oil Co., Union district, Harrison County, W. Va. Brine from fourth salifcrous sand in woll 2,122 feet deep, 1910 .' J. A. Cullen, analyst.

13. South Penn Oil Co., Grant district, Wetzel County, W. Va. Brine at 2,770 fcet, 1910. J. A. Cullen, analyst.

14. South Penn Oil Co., Grant district, Doddridge County, W. Va. Brinc from Gordon sand at depth of 3,047 feet, 1910 . R. F. Gardiner, analyst.

15. South Penn Oil Co., Freemans Creek district, Lewis County, W. Va. Brine from well No. 2, 2,247 feet deep on farm of T. M. Bode, 1910. R. F. Gardiner, analyst.

16. Geo. T. Berlin. Brine from well 1,167 feet deep at Bethel, Monroe County, Ohio; yicld, 3 barrels a day, 1910. R. F. Gardiner, analyst.

17. Geo. T. Berlin. Brine from well, 1,228 feet deep at Bethel, Monroe County, Ohio; yield, 5 barrels a day, 1910. R. F. Gardiner, analyst.

18. G. A. Gifford. Brine from well 1,600 feet deep at Center, Monroe County, Ohio; yield, 15 barrels a day, 1910. R. F. Gardiner, analyst.

19. G. A. Gifford. Brine from well 1,560 feet deep at Green, Monroe County, Ohio; yield, 18 barrels a day. This sample is from the Newcastle pool, the greatest salt-water pool in eastern Obio, 1910. R. F. Gardiner, analyst.

20. Southern Oil Co., Junction City, Perry County, Ohio. Brine from well 2,700 feet deep; yield, 48 barrels a day, 1910. R. F. Gardiner, analyst.

21. Southern Oil Co., Vinton County, Ohio. Brine from a well 2,100 fect deep; yield, 150 barrels a day, 1910. J. A. Cullen, analyst.

Most of the brines tested from oil wells in southern Ohio and West Virginia are rather dilute compared with brines used for making salt, though some of them contain unusually high proportions of potassium, calcium, and magnesium. Analyses Nos. 3, 10, 20, and 21 represent natural brines carrying more than 2.5 grams per liter of potassium. The relative proportions of calcium and magnesium in the brines represented by analyses Nos. 2, 7, 8, 11, 12, 14, 20, and 21 are great enough to give the solutions the characters of bitterns. As a group the brines of this section contain little sulphate.

The marked differences in the concentration and composition of all the brines suggests that they come from different horizons or at least from different vertical positions in the saline deposits. The brines from Monroe County, Ohio (see Nos. 16-19), just across Ohio River from Wetzel, Tyler, Doddridge, and Marion counties, W. Va., are much alike in composition and resemble the natural brines around 
Mason and Pomeroy (see Nos. 1-6, p. 230). The brines from Junction City and Vinton County (Nos. 20 and 21) are distinctly different, being more like bitterns.

PENNSYLVANIA.

Analyses of natural brines of Pennsylvania.

Radicles in grams per liter.

\begin{tabular}{|c|c|c|c|c|c|c|}
\hline & 1 & 2 & 3 & 4 & 5 & 6 \\
\hline \multirow[t]{2}{*}{ 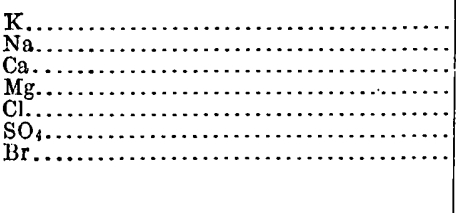 } & $\begin{array}{r}0.7 \\
26.0 \\
7.0 \\
1.1 \\
56.2 \\
\text { Trace. } \\
.8\end{array}$ & $\begin{array}{r}\text { Trace. } \\
27.3 \\
6.9 \\
1.3 \\
57.9 \\
\text { Trace. } \\
.5\end{array}$ & $\begin{array}{r}0.2 \\
2.1 \\
\text { Trace. } \\
\text { Trace. } \\
3.4 \\
\text { Trace. } \\
\text { None. }\end{array}$ & $\begin{array}{r}0.9 \\
28.6 \\
10.7 \\
2.0 \\
68.3 \\
1.4 \\
1.0\end{array}$ & $\begin{array}{r}0.6 \\
38.3 \\
6.0 \\
.6 \\
70.0 \\
2.4 \\
\text { Tracc. }\end{array}$ & $\begin{array}{r}\text { Trace. } \\
27.0 \\
4.0 \\
.6 \\
50.4 \\
\text { Trace. } \\
\text { Trace. }\end{array}$ \\
\hline & 91.8 & 93.9 & 5.7 & 112.9 & 117.9 & 82.0 \\
\hline
\end{tabular}

Radicles in percentage of anhydrous residue.

\begin{tabular}{|c|c|c|c|c|c|c|}
\hline \multirow[t]{2}{*}{ 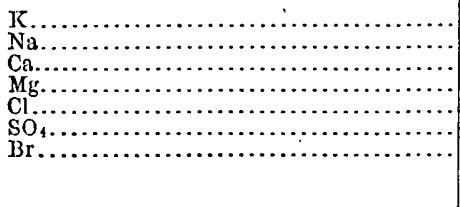 } & $\begin{array}{r}0.76 \\
28.32 \\
7.62 \\
1.19 \\
61.24 \\
.00 \\
.87\end{array}$ & $\begin{array}{r}0.00 \\
29.10 \\
7.34 \\
1.38 \\
61.65 \\
.00 \\
.53\end{array}$ & $\begin{array}{r}3.51 \\
36.85 \\
.00 \\
.00 \\
59.64 \\
.00 \\
.00\end{array}$ & $\begin{array}{r}0.80 \\
25.33 \\
9.48 \\
1.76 \\
60.51 \\
1.24 \\
.88\end{array}$ & $\begin{array}{r}0.51 \\
32.49 \\
5.09 \\
.51 \\
59.37 \\
2.03 \\
.00\end{array}$ & $\begin{array}{r}0.00 \\
32.9^{\prime} \\
4.87 \\
.73 \\
61.48 \\
.00 \\
.00\end{array}$ \\
\hline & 100.00 & 100.00 & 100.00 & 100.00 & 100.00 & 100.00 \\
\hline
\end{tabular}

1. John A. Beck Salt Co., Pittsburgh, Pa. Composite from 4 wells, 1911. J. A. Cullen, analyst.

2. John A. Beck Salt Co., Pittsburgh, Pa. From well 1,600 feet deep. Collected by the company, 1910. J. A. Cullen, analyst.

3. N. V. V. Franchot, Eldred, McKean County, Pa. From oil well 1,100 feet decp, 1910. R. F. Gardiner, analyst.

4. Southern Oil Co., Pittsburgh, Pa. From oil well 1,187 feet deep, Highland, Clarion County, Pa. Collected by Clarence Fennen, Clarion, $\mathrm{Pa}$. 1910. J. A. Cullen, analyst.

5. Southern Oil Co., Pittsburgh, Pa. From oil well 1,727 fect deep, Butler, Butler County, Pa.; yicld, 2 barrels a day. Collected by the company, 1910. R. F. Gardiner, analyst.

6 . From weli 1, 591 feet deep, producing 8 barrels a day. Collected by H. H. Hemphill, Penn Tornship, Butler County, Pa., 1010. R. F. Gardiner, analyst.

The two analyses of brine from wells of the John A. Beck Salt Co. (Nos. 1 and 2) check closely. The brine was used for the manufacture of salt, bromine, and calcium chloride, and the large proportion of the last salt and of magnesium chloride indicated by the conventional combinations should be noted. The Beck plant is no longer in existence, and salt is not now manufactured in Pittsburgh. The other analyses in this table represent brines from oil wells not now used as sources of salt. 
KANSAS.

Analyses of artificial brines of Kansas.

Radicles in grams per liter.

\begin{tabular}{|c|c|c|c|c|c|c|c|c|c|}
\hline & 1 & 2 & 3 & 4 & 5 & 6 & 7 & 8 & 9 \\
\hline \multirow[t]{2}{*}{ 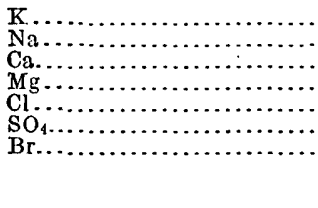 } & $\begin{array}{r}0.4 \\
132.0 \\
\text { Trace. } \\
199.0 \\
7.4 \\
\text { Trace. }\end{array}$ & $\begin{array}{r}0.8 \\
133.4 \\
2.2 \\
.8 \\
184.8 \\
37.8 \\
\text { Trace. }\end{array}$ & $\begin{array}{r}0.1 \\
120.9 \\
2.0 \\
188.0 \\
3.9 \\
\text { None. }\end{array}$ & $\begin{array}{r}\text { Trace. } \\
100.3 \\
\text { Trace. } \\
1.2 \\
154.4 \\
4.6 \\
\text { None. }\end{array}$ & $\begin{array}{r}0.5 \\
116.7 \\
2.0 \\
183.2 \\
4.1 \\
\text { Trace. }\end{array}$ & $\begin{array}{r}0.5 \\
116.2 \\
1.6 \\
3.0 \\
186.6 \\
6.8 \\
\text { Trace. }\end{array}$ & $\begin{array}{r}0.1 \\
.5 \\
.5 \\
.3 \\
2.3 \\
.3 \\
\text { None. }\end{array}$ & $\begin{array}{r}\text { Trace. } \\
100.3 \\
3.2 \\
.8 \\
162.2 \\
\text { Trace. } \\
\text { Trace. }\end{array}$ & $\begin{array}{r}0.2 \\
116.6 \\
1.2 \\
181.8 \\
4.2 \\
\text { None. }\end{array}$ \\
\hline & 339.2 & 359.8 & 315.1 & 260.5 & 307.2 & 314.7 & 4.0 & 266.5 & 301.7 \\
\hline
\end{tabular}

Radicles in percentage of anhydrous residue.

\begin{tabular}{|c|c|c|c|c|c|c|c|c|c|}
\hline \multirow[t]{2}{*}{ 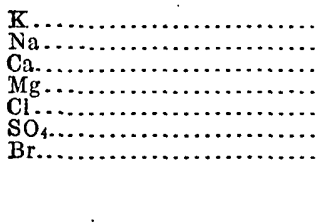 } & $\begin{array}{r}0.11 \\
38.90 \\
.00 \\
.11 \\
58.70 \\
2.18 \\
.00\end{array}$ & $\begin{array}{r}0.22 \\
37.07 \\
.61 \\
.22 \\
51.37 \\
10.51 \\
.00\end{array}$ & $\begin{array}{r}0.03 \\
38.37 \\
.63 \\
.06 \\
59.68 \\
1.23 \\
.00\end{array}$ & $\begin{array}{r}0.00 \\
35.50 \\
.00 \\
.46 \\
59.28 \\
1.76 \\
.00\end{array}$ & $\begin{array}{r}0.16 \\
38.02 \\
.65 \\
.23 \\
59.61 \\
1.33 \\
.00\end{array}$ & $\begin{array}{r}0.15 \\
36.96 \\
.51 \\
.95 \\
59.27 \\
2.16 \\
.00\end{array}$ & $\begin{array}{r}2.50 \\
12.50 \\
12.50 \\
7.50 \\
57.50 \\
7.50 \\
.00\end{array}$ & $\begin{array}{r}0.00 \\
37.06 \\
1.31 \\
.30 \\
60.83 \\
.00 \\
.00\end{array}$ & $\begin{array}{r}0.07 \\
38.27 \\
.39 \\
.26 \\
59.63 \\
1.38 \\
.00\end{array}$ \\
\hline & 100.00 & 100.00 & 100.00 & 100.00 & 100.00 & 100.00 & 100.00 & 100.00 & 100.00 \\
\hline
\end{tabular}

1. Barton Salt Co., Hutchinson, Kans. Composite from 3 wells, 1910. R. F. Gardiner, analyst.

2. Carey Salt Co. Hutchinson, Kans. Composite from 4 wells, 1911. R. F. Gardiner, analyst.

3. Western Salt Works, Hutchinson, Kans. Composite from 3 wells, 1910. J. A. Cullen, analyst.

4. Union Ice \& Salt Co., Hutchinson, Kans. From a depth of 700 feet, running very light. Collectod by the company, 1910. R. F. Cardiner, analyst.

5. Hutchinson Salt Co., Hutchinson, Kans. Composite from 8 or 9 wells at Joy Morton works, 1911. J. A. Cullen, analyst.

6. Orient Salt Co., Anthony, Kans. From company's well.

7. Natural water from a flowing well 130 feet deep, drilled for gas near Ellsworth, Kans.

8. Ellsworth Salt Co., Ellsworth, Kans. Composite from 5 wells, 1910. R. F. Gardiner, analyst.

9. Sterling Salt Co., Sterling, Kans. From 1 well, 19i1. J. A. Cullen, analyst.

These analyses show the composition of artificial brines used in the manufacture of salt. Nearly all are almost completely saturated, and most of them contain a large proportion of salt. They are low in potassium, calcium, and magnesium, and contain only traces of bromine.

No. 7 represents a comparatively fresh water. The sulphate in No. 2 is surprisingly high, and the figure is probably erroneous. 


\section{LOUISIANA.}

Analyses of natural brines of Louisiana.

Radicles in grams per liter.

\begin{tabular}{|c|c|c|c|}
\hline & 1 & 2 & 3 \\
\hline \multirow[t]{2}{*}{ 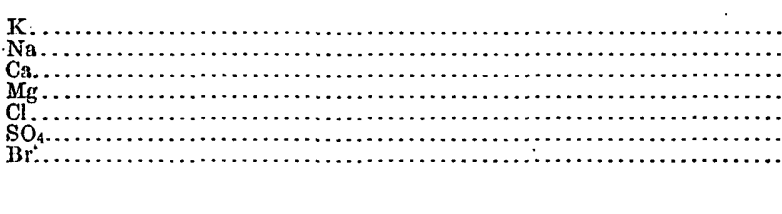 } & $\begin{array}{r}0.4 \\
2.3 \\
.2 \\
\text { Trace. } \\
2.0 \\
3.2 \\
\text { Traco. }\end{array}$ & $\begin{array}{r}0.8 \\
4.4 \\
\text { Trace. } \\
6.4 \\
2.2 \\
\text { None. }\end{array}$ & $\begin{array}{r}0.6 \\
47.6 \\
\text { Trace. } \\
\text { Trace. } \\
72.4 \\
1.6 \\
\text { Traco. }\end{array}$ \\
\hline & 8.1 & 14.2 & 122.2 \\
\hline
\end{tabular}

Radicles in percentage of anhydrous residue.

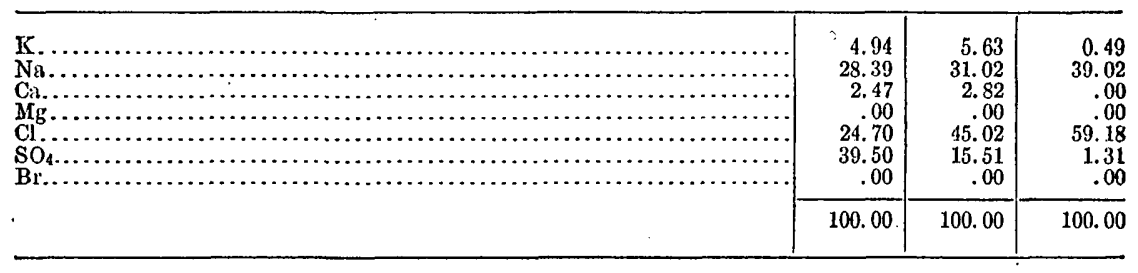

1. New Mansfield, De Soto Parish, La. From well 830 fect decp, yiclding 4,000,000 cubic fect a day of brine at a pressure of 380 pounds. Collected by S. S. Hunter, Shreveport, La., 1910. R. F. Gardiner, analyst.

2. Caddo oil field, La. From oil well. Collected by S. S. Hunter, Shroveport, La., 1910. R. F. Gardiner, analyst.

3. Evangeline oil field, Evangeline, La. From oil well, 1910. R. F. Gardiner, analyst.

These natural brines, which come from oil or gas wells in Louisiana, are too dilute for practical use as sources of saline material. 
TEXAS.

Analyses of natural and artificial brines of Tcxas.

Radicles in grams per liter.

\begin{tabular}{|c|c|c|c|c|c|c|c|c|}
\hline . & 1 & 2 & a 3 & 4 & 5 & 6 & 7 & 8 \\
\hline $\begin{array}{l}\mathrm{K} \\
\mathrm{Na} \\
\mathrm{Ca} \\
\mathrm{Ca} \\
\mathrm{M} \mathrm{M}_{\mathrm{g}} \ldots \ldots \ldots \ldots \ldots \ldots\end{array}$ & $\begin{array}{r}0.3 \\
118.2 \\
2.1 \\
-.7 \\
188.7 \\
\text { Trace. } \\
\text { Trace. }\end{array}$ & $\begin{array}{r}0.2 \\
114.4 \\
1.8 \\
1.0 \\
179.4 \\
3.6 \\
\text { Trace. }\end{array}$ & $\begin{array}{r}0.1 \\
102.1 \\
1.5 \\
\text { Trace. } \\
157.1 \\
3.4 \\
\ldots . .\end{array}$ & $\begin{array}{r}2.4 \\
98.9 \\
10.4 \\
.8 \\
172.2 \\
3.8 \\
\text { Trace. }\end{array}$ & $\begin{array}{r}\text { Traco. } \\
4.0 \\
.2 \\
.4 \\
6.0 \\
2.2 \\
\text { Trace. }\end{array}$ & $\begin{array}{r}0.6 \\
47.6 \\
13.4 \\
2.0 \\
102.6 \\
1.1 \\
.8\end{array}$ & $\begin{array}{r}3.4 \\
62.7 \\
5.2 \\
\text { Trace. } \\
104.4 \\
6.0 \\
\text { Traco. }\end{array}$ & $\begin{array}{r}3.2 \\
20.0 \\
3.4 \\
1.4 \\
42.8 \\
1.2 \\
\text { None. }\end{array}$ \\
\hline & 310.0 & 300.4 & 264.2 & 288.5 & 12.8 & 168.1 & $1 S 1.7$ & 72.0 \\
\hline
\end{tabular}

Radicles in percentage of anhydrous residue.

\begin{tabular}{|c|c|c|c|c|c|c|c|c|}
\hline \multirow[t]{2}{*}{$\begin{array}{l}\mathrm{K} \\
\mathrm{Na} \\
\mathrm{Ca} \\
\mathrm{Mg} \\
\mathrm{M} \\
\mathrm{Cl} \\
\mathrm{S}, \ldots \ldots \ldots \ldots \ldots\end{array}$} & $\begin{array}{r}0.09 \\
38.15 \\
.67 \\
.22 \\
60.87 \\
.00 \\
.00\end{array}$ & $\begin{array}{r}0.07 \\
38.06 \\
.60 \\
.33 \\
59.74 \\
1.20 \\
.00\end{array}$ & $\begin{array}{r}0.04 \\
38.71 \\
.53 \\
.00 \\
59.44 \\
-1.28 \\
\cdots . . .\end{array}$ & $\begin{array}{r}0.83 \\
34.25 \\
3.61 \\
.28 \\
59.71 \\
1.32 \\
.00\end{array}$ & $\begin{array}{r}0.00 \\
31.26 \\
1.56 \\
3.12 \\
46.88 \\
17.18 \\
.00\end{array}$ & $\begin{array}{r}0.35 \\
28.32 \\
7.97 \\
1.19 \\
61.08 \\
.65 \\
.44\end{array}$ & $\begin{array}{r}1.87 \\
34.51 \\
2.86 \\
.00 \\
57.46 \\
3.30 \\
.00\end{array}$ & $\begin{array}{r}4.45 \\
27.79 \\
4.72 \\
1.94 \\
59.42 \\
1.68 \\
.00\end{array}$ \\
\hline & 100.00 & 100.00 & 100.00 & 100.00 & 100.00 & 100.00 & 100.00 & 100.00 \\
\hline
\end{tabular}

a Grams per kilogram.

1. Grand Saline Salt Co., Grand Saline, Tex. Artificial brine from well 418 feet deep, ready for evapo-

rators. Collocted by the company, 1910. J. A. Cullen, analyst. Collected by the company, 1910. R. F. Gardiner, analyst.

3. B. W. Carrington, Grand Saline, Tex. Artificial brine from well at plant No. 2. R. K. Bailey, analyst 4. Edward Bros., Midland, Crane County, Tex.; Salt Lake, Juan Cordova Survey. Collected by Edward Bros., 1910. R. F. Gardiner, analyst.

5. Brine from well in sec. 15, block 2, Crane County, Tex. Collected by Edward Bros., Midland, Tex., 1910. R. F. Gardiner, analyst.

6. Producers Oil Co., Houston, Tex. Natural brine from oil well 1,800 feet deep, Wichita County, Tex.; yield, half a barrel a day. Collected by Frank Cullison, Electra, Tex., 1910. J. A. Cullen, analyst.

7. Producers Oil Co. Houston, Tex. Natural brine from well 1,198 feet deep, Herman lease Hardin County, Tex.; yiold, 75 barrels a day. Collected by E. F. Woodward, Humble, Tex., 1910. R. F. Gardiner, analyst.

8. Producers Oil Co., Houston, Tex. Brine from well 1,350 feet deep, Sour Lake, Tex.; yield, 50 barrels: of brine a day. Collected 1910. R. F. Gardiner, analyst.

Nos. 1-4 represent brines used in the manufacture of salt. These are normal brines except No. 4, which is somewhat low in sodium. chloride. No. 6 represents a dilute brine approaching a bittern in composition, as indicated by its rather large content of chlorides of calcium and magnesium. The high relative proportion of potassium shown by No. 8 indicates a weak natural brine resembling a bittern. so far as character and relative proportions of dissolved constituents. are concerned. 
OKLAHOMA.

Analyses of natural brines.

Radicles in grams per liter.

\begin{tabular}{|c|c|c|c|c|c|c|c|c|c|}
\hline & 1 & 2 & 3 & 4 & 5 & 6 & 7 & 8 & 9 \\
\hline 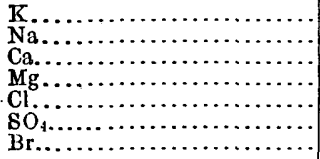 & $\begin{array}{r}0.2 \\
94.9 \\
2.6 \\
1.5 \\
153.5 \\
4.0 \\
\text { Trace. }\end{array}$ & $\begin{array}{r}1.2 \\
112.8 \\
3.0 \\
2.2 \\
185.0 \\
3.8 \\
\text { Trace. }\end{array}$ & $\begin{array}{r}0.2 \\
5.9 .9 \\
2.1 \\
1.1 \\
95.2 \\
3.9 \\
\text { Trace. }\end{array}$ & $\begin{array}{r}0.4 \\
112.1 \\
7.6 \\
1.2 \\
185.8 \\
3.8 \\
.4\end{array}$ & $\begin{array}{r}0.6 \\
115.1 \\
2.7 \\
1.9 \\
185.2 \\
3.3 \\
\text { Trace. }\end{array}$ & $\begin{array}{r}0.2 \\
38.2 \\
3.6 \\
.8 \\
67.1 \\
.7 \\
.6\end{array}$ & $\begin{array}{r}1.0 \\
14.0 \\
1.3 \\
.6 \\
25.4 \\
.9 \\
\text { Trace. }\end{array}$ & $\begin{array}{r}0.6 \\
19.9 \\
5.0 \\
1.6 \\
43.4 \\
1.6 \\
\text { Trace. }\end{array}$ & $\begin{array}{r}0.6 \\
40.9 \\
3.6 \\
1.4 \\
71.4 \\
3.4 \\
\text { Trace. }\end{array}$ \\
\hline & 256.7 & 308.0 & 161.4 & 311.3 & 308.8 & 111.2 & 43.2 & 72.1 & 121.3 \\
\hline
\end{tabular}

Radicles in percentage of anhydrous residue.

\begin{tabular}{|c|c|c|c|c|c|c|c|c|c|}
\hline 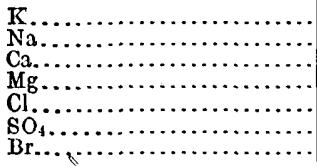 & $\begin{array}{r}0.08 \\
36.94 \\
1.02 \\
.59 \\
59.81 \\
1.56 \\
.00\end{array}$ & $\begin{array}{r}0.39 \\
36.61 \\
.97 \\
.71 \\
60.09 \\
1.23 \\
.00\end{array}$ & $\begin{array}{r}0.12 \\
36.40 \\
1.30 \\
.68 \\
59.03 \\
2.41 \\
.00\end{array}$ & $\begin{array}{r}0.13 \\
36.03 \\
2.44 \\
.39 \\
59.66 \\
1.22 \\
.13\end{array}$ & $\begin{array}{r}0.19 \\
37.28 \\
.86 \\
.61 \\
60.00 \\
1.06 \\
.00\end{array}$ & $\begin{array}{r}0.18 \\
34.36 \\
3.23 \\
.72 \\
60.34 \\
.63 \\
.54\end{array}$ & $\begin{array}{r}2.31 \\
32.42 \\
3.01 \\
1.39 \\
58.79 \\
2.08 \\
.00\end{array}$ & $\begin{array}{r}0.83 \\
27.60 \\
6.93 \\
2.22 \\
60.20 \\
2.22 \\
.00\end{array}$ & $\begin{array}{r}0.49 \\
33.72 \\
2.98 \\
1.15 \\
58.86 \\
2.80 \\
.00\end{array}$ \\
\hline & 100.00 & 100.00 & 100.00 & 100.00 & 100.00 & 100.00 & 100.00 & 100.00 & 100.00 \\
\hline
\end{tabular}

Radicles in grams per liter.

\begin{tabular}{|c|c|c|c|c|c|c|c|c|}
\hline & 10 & 11 & 12 & 13 & 14 & 15 & 16 & 17 \\
\hline \multirow[t]{2}{*}{ 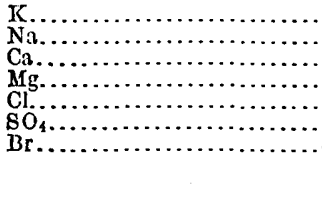 } & $\begin{array}{r}0.9 \\
45.0 \\
8.0 \\
1.7 \\
89.3 \\
.8 \\
.6\end{array}$ & $\begin{array}{r}0.2 \\
2.5 \\
1.1 \\
.2 \\
6.4 \\
.1 \\
\text { None. }\end{array}$ & $\begin{array}{r}0.7 \\
46.7 \\
7.9 \\
1.7 \\
92.8 \\
1.0 \\
.4\end{array}$ & $\begin{array}{r}1.1 \\
47.2 \\
9.0 \\
1.3 \\
93.2 \\
.4 \\
.5\end{array}$ & $\begin{array}{r}0.9 \\
51.4 \\
13.8 \\
.6 \\
105.9 \\
\text { Trace. } \\
.5\end{array}$ & $\begin{array}{r}0.5 \\
66.0 \\
9.7 \\
.7 \\
120.7 \\
.7 \\
.4\end{array}$ & $\begin{array}{r}0.8 \\
46.2 \\
6.1 \\
2.2 \\
89.4 \\
\text { Trace. } \\
\text { Trace. }\end{array}$ & $\begin{array}{r}0.3 \\
41.6 \\
7.1 \\
2.4 \\
82.5 \\
.7 \\
.3\end{array}$ \\
\hline & 146.3 & 10.5 & 151.2 & 152.7 & 173.1 & 198.7 & 144.7 & 134.9 \\
\hline
\end{tabular}

Radicles in percentage of anbydrous residue.

\begin{tabular}{|c|c|c|c|c|c|c|c|c|}
\hline \multirow[t]{2}{*}{ 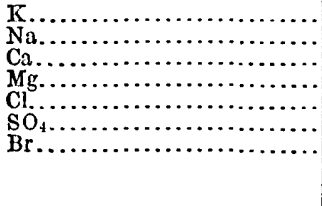 } & $\begin{array}{r}0.61 \\
30.77 \\
5.46 \\
1.16 \\
61.05 \\
.54 \\
.41\end{array}$ & $\begin{array}{r}1.90 \\
23.82 \\
10.47 \\
1.90 \\
60.96 \\
.95 \\
.00\end{array}$ & $\begin{array}{r}0.46 \\
30.89 \\
5.22 \\
1.12 \\
61.39 \\
.66 \\
.26\end{array}$ & $\begin{array}{r}0.72 \\
30.89 \\
5.89 \\
.85 \\
61.07 \\
.26 \\
.32\end{array}$ & $\begin{array}{r}0.52 \\
29.70 \\
7.97 \\
.34 \\
61.18 \\
.00 \\
.29\end{array}$ & $\begin{array}{r}0.25 \\
33.27 \\
4.88 \\
.35 \\
60.70 \\
.35 \\
.20\end{array}$ & $\begin{array}{r}0.55 \\
31.96 \\
4.21 \\
1.52 \\
61.76 \\
.00 \\
.00\end{array}$ & $\begin{array}{r}0.22 \\
30.84 \\
5.26 \\
1.78 \\
61.16 \\
.52 \\
.22\end{array}$ \\
\hline & 100.00 & 100.00 & 100.00 & 100.00 & 100.00 & 100.00 & 100.00 & 100.00 \\
\hline
\end{tabular}

1. A. Henquenet, Ferguson, Blaine County, Okla. From well 5 feet deep, 1910 . J. A. Cullen, analyst. 2. D. A. Thomas, Salton, Harmon County, Okla. From spring No. 1, 1910. J. A. Cullen, analyst.

3. D. A. Thomas, Salton, Harmon County, Okla. From spring No. 2, 1910. J. A. Cullen, analyst.

4. W. H. Chaney, Salton, Harmon County, Okla. From spring, 1910. R. F. Gardiner, analyst.

5. W. H. Chaney, Salton, Harmon County, Okla. From spring, 1910. J. A. Cullen, analyst.

6. Prairie Oil \& Gas Co., Muskogee County, Okla. From well 1,569 feet deep, producing 50 barrels of brine a day, 1910. J. A. Cullen, analyst.

7. Prairio Oil \& Gas Co., Nowata County, Okla. From well 430 fect decp, producing 4 barrels a day, 1910. J. A. Cullen, analyst

8. Prairie Oil \& Gas Co., Nowata County, Okla. From well 1,674 fect deep, producing 800 barrels a day, 1910. R. F. Gardiner, analyst.

9. Prairie Oil \& GasCo., Nowata County, Okla. From well 1,240 feet deep, in NE. $\frac{1}{4}$ NE. $\frac{1}{2}$ sec. 14, T. 27 N., R. 14 E.; 7iold, 100 barrels a day, 1910. R. F. Gardiner, analyst.

10. Prairio Oil \& Gas Co., Bryan, Okmulgee County, Okla. From well 1,674 feet deep, producing 80 barrels a day, 1910 . J. A. Cullen, analyst.

11. Prairie Oil \& Gas Co., Hamilton, Okmulgee County, Okla. From well 2,222 feet deep, producing 3 barrels a day, 1910 . J. A. Cullen, analyst.

12. Prairie Oil \& Gas Co., Morris, Okmulgee County, Okla. From well 1,587 fect deep, producing 25 barrels a day, 1910. J. A. Cullen, analyst.

13. Prairie Oil \& Gas Co., Schulten, Okmulgee County, Okla. From well 2,007 feet deep, producing 40 barrels a day, 1910 . J. A. Cullen, analyst.

14. Prairie Oil \& Gas Co., Hominy, Osage County, Okla. From well 2,375 feet deep, producing 500 barrels a day, 1910. J. A. Cullen, analyst.

15. Prairie Oil \& Gas Co., Osage County, Okla. From well 1,565 feet deep, producing 15 barrels a day; sample sent from Bartlesville, Okla., 1910. J. A. Cullen, analyst.

16. Prairie Oil \& Gas Co. Cleveland, Pawnee County, Okla. From oil well 1,750 feet decp, producing 50 barrels a day, 1910. J. A. Cullen, analyst.

17. Prairie Oil \& Gas Co., Tulsa County, Okla. From well 1,557 feet deep, in NE. 1 SE. $\$$ sec. 18, T. 17 N., R. 12 E.; yield, 6 barrels a day, 2910 . J. A. Cullen, analyst. 
Analyses of natural brines-Continued.

Radicles in grams per liter.

\begin{tabular}{|c|c|c|c|c|c|c|c|c|c|}
\hline & 18 & 19 & 20 & 21 & 22 & 23 & 24 & 25 & 28 \\
\hline $\begin{array}{l}\mathrm{K} . . \\
\mathrm{Na} . \\
\mathrm{Ca} . \\
\mathrm{Mg} . \\
\mathrm{Cl}^{-} . \\
\mathrm{SO}_{4 .} \\
\mathrm{Br} . .^{-}\end{array}$ & $\begin{array}{r}\text { Trace. } \\
37.3 \\
13.2 \\
1.0 \\
82.8 \\
1.0 \\
\text { Trace. }\end{array}$ & $\begin{array}{r}1.0 \\
38.4 \\
8.2 \\
2.0 \\
80.7 \\
\text { Trace. } \\
.4\end{array}$ & $\begin{array}{r}1.0 \\
43.3 \\
6.9 \\
1.7 \\
84.7 \\
\text { Trace. } \\
.4\end{array}$ & \begin{tabular}{|r|} 
Trace. \\
40.0 \\
7.8 \\
1.4 \\
79.4 \\
Trace. \\
Trace.
\end{tabular} & $\begin{array}{r}0.5 \\
32.1 \\
4.5 \\
2.2 \\
63.9 \\
.1 \\
.6\end{array}$ & $\begin{array}{r}0.6 \\
34.4 \\
4.8 \\
2.4 \\
68.8 \\
.5 \\
.5\end{array}$ & $\begin{array}{r}\text { Trace. } \\
23.9 \\
2.2 \\
.2 \\
40.0 \\
1.6 \\
\text { Trace. }\end{array}$ & $\begin{array}{r}1.0 \\
122.9 \\
2.3 \\
1.3 \\
195.9 \\
4.4 \\
\text { Trace. }\end{array}$ & $\begin{array}{r}1.0 \\
117.7 \\
1.0 \\
1.6 \\
183.0 \\
8.0\end{array}$ \\
\hline & 135.3 & 130.7 & 138.0 & 128.6 & 103.9 & 112.0 & 67.9 & 327.8 & 312.3 \\
\hline
\end{tabular}

Radicles in percentage of anhydrous residue.

\begin{tabular}{|c|c|c|c|c|c|c|c|c|c|}
\hline 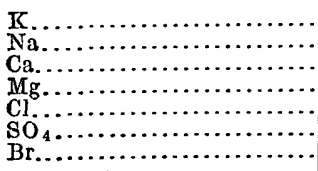 & $\begin{array}{r}0.00 \\
27.59 \\
9.75 \\
.74 \\
61.18 \\
.74 \\
.00\end{array}$ & $\begin{array}{r}0.76 \\
29.41 \\
6.27 \\
1.52 \\
61.75 \\
.00 \\
.30\end{array}$ & $\begin{array}{r}0.72 \\
31.41 \\
5.00 \\
1.23 \\
61.36 \\
.00 \\
.2 S\end{array}$ & $\begin{array}{r}0.00 \\
31.08 \\
6.06 \\
1.09 \\
61.77 \\
.00 \\
.00\end{array}$ & $\begin{array}{r}0.48 \\
30.92 \\
4.33 \\
2.12 \\
61.53 \\
.09 \\
.53\end{array}$ & $\begin{array}{r}0.53 \\
30.67 \\
4.27 \\
2.14 \\
61.41 \\
.49 \\
.49\end{array}$ & $\begin{array}{r}0.00 \\
35.20 \\
3.24 \\
.29 \\
58.92 \\
2.35 \\
.00\end{array}$ & $\begin{array}{r}0.31 \\
37.47 \\
.70 \\
.39 \\
59.79 \\
1.34 \\
.00\end{array}$ & $\begin{array}{r}0.32 \\
37.68 \\
.32 \\
.51 \\
58.61 \\
2.56 \\
\ldots \ldots\end{array}$ \\
\hline & 100.00 & 100.01 & 100.00 & 100.00 & 100.00 & 100.00 & 100.00 & 100.00 & 100.00 \\
\hline
\end{tabular}

18. Prairie Oil \& Gas Co., Tulsa County, Okla. From well 1,148 feet deep, in T. 21 N.; yield, 7 barrels a day, 1910. R. F. Gardiner, analyst.

19. Prairie Oil \& Gas Co., Tulsa County, Okla. From oil well No. 2, 1,178 feet deep, producing 500 barrels a day, 1910 . J. A. Cullen, analyst.

20. Prairie Oil \& Gas Co., Dawson, Tulsa County, Okla. From well 1,150 feet deep, producing 10 barrels a day, 1910. J. A. Cullen, analyst.

21. Producers' Oil Co., Tulsa County, Okla. From well 1,200 feet deep, producing 200 barrels a day, 1910. R. F. Gardiner, analyst.

22. Prairie Oll \& Gas Co., Washington County, Okla. From well 925 feet deep, producing 240 barrels a day, 1910 . J. A. Cullen, analyst.

23. Prairie Oil \& Gas Co., Washington County, Okla. From well 1,305 feet deep, producing 25 barrels a day, 1910 . J. A. Cullen, analyst.

24. Prairie Oil \& Gas Co., Jefferson, Washington County, Okla. From well 1,224 feet deep, producing 30 barrels a day, 1910 . R. F. Gardiner, analyst.

25. From spring, Woodward County, Okla. Collected by P. L. Clifton, Pomeroy, Ohio, 1910. J. A. Cullen, analyst.

26. Irom spring in sec. 33 , T. 27 N., R. 19 W., north of Woodward, Woodward County, Okla. Collected by P. L. Clifton, 1910 . R. F. Gardiner, analyst.

Most of the samples from Oklahoma were collected by drillers and represent natural brines from wells drilled for oil or gas. Nearly all are rather dilute, but Nos. 25 and 26, which are from the same locality, and Nos. 2, 4, and 5, which are likewise from the same locality, are strong natural brines from springs and are purer solutions of sodium chloride than the brines from the oil and gas wells.

The rather large amount of calcium chloride and magnesium chloride and the small amounts of sulphate in the natural brines are noteworthy. A few of the analyses indicate a tendency toward concentration of potassium salts, though they do not warrant further investigation of these brines as sources of potash. Small amounts of bromine are generally present in the brines. 


\section{MISCELLANEOUS.}

Analyses of natural brines of Illinois, Kentucky, Tennessee, Virginia, and Utah.

Radicles in grams per liter.

\begin{tabular}{|c|c|c|c|c|c|}
\hline & $1 \circ$ & 2 & 3 & 4 & $a 5$ \\
\hline \multirow[t]{2}{*}{ 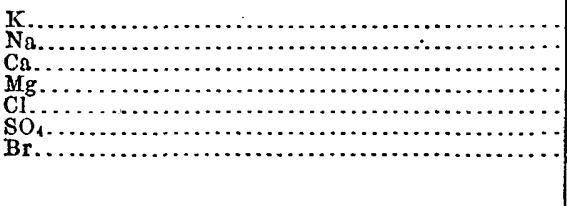 } & $\begin{array}{r}\text { Trace. } \\
16.5 \\
.8 \\
1.6 \\
31.2 \\
.2 \\
\text { Trace. }\end{array}$ & $\begin{array}{r}0.1 \\
15.5 \\
1.2 \\
1.8 \\
28.2 \\
4.2 \\
\text { None. }\end{array}$ & $\begin{array}{r}0.6 \\
2.4 \\
\text { Trace. } \\
\text { Trace. } \\
2.0 \\
2.2 \\
\text { None. }\end{array}$ & $\begin{array}{r}1.5 \\
114.6 \\
2.3 \\
.3 \\
180.6 \\
3.7 \\
\text { None. }\end{array}$ & $\begin{array}{r}0.4 \\
102.1 \\
.1 \\
\text { Trace. } \\
156.8 \\
3.2 \\
\end{array}$ \\
\hline & 50.3 & 51.0 & 7.2 & 303.0 & 262.6 \\
\hline
\end{tabular}

Radicles in percentage of anhydrous residue.

\begin{tabular}{|c|c|c|c|c|c|}
\hline 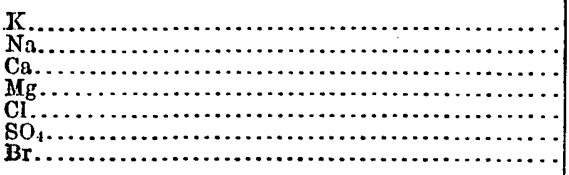 & $\begin{array}{r}0.00 \\
32.82 \\
1.58 \\
3.16 \\
62.05 \\
.39 \\
.00\end{array}$ & $\begin{array}{r}0.19 \\
30.40 \\
2.35 \\
3.52 \\
55.31 \\
8.23 \\
.00\end{array}$ & $\begin{array}{r}8.33 \\
33.32 \\
.00 \\
.00 \\
27.79 \\
30.56 \\
.00\end{array}$ & $\begin{array}{r}0.49 \\
37.80 \\
.76 \\
.10 \\
59.63 \\
1.22 \\
.00\end{array}$ & $\begin{array}{r}0.13 \\
38.89 \\
.05 \\
.00 \\
59.71 \\
1.22 \\
\end{array}$ \\
\hline . & 100.00 & 100.00 & 100.00 & 100.00 & 100.00 \\
\hline
\end{tabular}

a Grams per kilogram.

1. From Shlaffly oil well, 1,052 foot deep, yielding 75 barrels a day, in southwest corner of SE. 1 SE. $\frac{1}{2}$ soc. 3 T. 2 N., R. 3 W. Clinton County, Iil. Collected by E. W. Shaw, 1911 . R. F. Gardiner, analyst. 2. Irom well 300 feet deep in Griffin, Wayne County, Ky. Collected by New Domain Oil \& Gas Co., Lexington, Ky., 1910. R. F. Gardiner, analyst.

3. From Douglas well No. 1 in Spring Vallep oil field, Overton County, Tenn., about 1 mile south of Netherland. The well flowed several thousand barrels of oil from a depth of less than 55 feet, and the oil was followed by this water, which has been flowing since 1866 . Collected by M. J. Munn, 1910 . R. $\mathrm{R}$. Gardiner, analyst.

4. Mathieson Alkali Works, Saltville, Smyth County, Va. Brine from a depth of approximately 1,000 feet, 1910. J. A. Cullen, analyst.

5. Brine from salt springs in Salt Creek Canyon, east of Nephi, Juab County, Utah. Collected by Jacksoin Bros., 1912. R. K. Bailey, analyst.

Tests of miscellaneous natural substances from Nevada, Utah, Wyoming, and California.

\begin{tabular}{|c|c|c|c|c|}
\hline & \multirow{2}{*}{$\begin{array}{c}\text { Total } \\
\text { water- } \\
\text { soluble } \\
\text { salts, dried } \\
\text { and ighited } \\
\text { (percentage } \\
\text { of original } \\
\text { sample). }\end{array}$} & \multicolumn{3}{|c|}{$\begin{array}{l}\text { Potassium in percentage of ignited } \\
\text { residuo. }\end{array}$} \\
\hline & & $\begin{array}{c}\text { Equivalent } \\
\text { as potas- } \\
\text { sium }(\mathbf{K}) .\end{array}$ & $\begin{array}{c}\text { Equivalent } \\
\text { as potas- } \\
\text { sium oxido } \\
\left(\mathrm{K}_{2} \mathrm{O}\right) .\end{array}$ & $\begin{array}{l}\text { Equivalent } \\
\text { as potas- } \\
\text { sium ehlo- } \\
\text { ride (KCl). }\end{array}$ \\
\hline 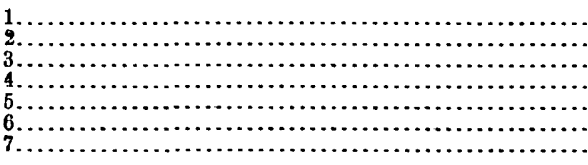 & $\begin{array}{r}79.89 \\
9.34 \\
92.93 \\
6.74 \\
21.55 \\
54.19 \\
65.84\end{array}$ & $\begin{array}{r}0.49 \\
4.92 \\
.72 \\
3.18 \\
.85 \\
.34 \\
2.59\end{array}$ & $\begin{array}{r}0.59 \\
5.92 \\
.87 \\
3.83 \\
1.02 \\
.41 \\
3.12\end{array}$ & $\begin{array}{l}0.93 \\
9.38 \\
1.38 \\
6.07 \\
1.61 \\
.65 \\
4.94\end{array}$ \\
\hline
\end{tabular}

1. Saline incrustation on surface of desert near Withee Junction, west of Ogden, Utah. Collected in 1912. R. K. Bailey, analyst.

2. Yellow deposit at outlet of bathing tank, Hot Springs, north of Brigham, Utah. G. F. Loughlin, collector, 1912. R. K. Briley, analyst.

3. Salt from seepage on flat below spring inclosure near a hot spring on Oregon Short Line, $10 \mathrm{miles}$ north of Ogden, Utah. G. F. Loughlin, collector, 1912, R. K. Bailey, arialyst.

4. Green clay half a mile east of Salt Springs, near entrance to Death Valley, Cal. Unsurveyed Iand. This clay, exposed 7 or 8 feet thick where the road crosses an arroyo, is supposed to contain nitrates. Collected in 1912. R. K. Bailey, analyst.

5. Natural soda on bank of Green River, near toll gate, 1 mile north of Green River, Wyo. Collected in 1912. R. K. Bailey, analyst.

6. Natural soda near base of river cliff, about 1 mile southeast of Green River, Wyo. Collected in 1912. IR. K. Bailey, analyst.

7. Saline material collected at Steamboat Springs, Nev. Collected in 1912. R. K. Bailey, analyst. 
COMPOSITION OF BITTERNS.

NEW YORK.

Analyses of bitterns from artificial brines of New York.

Radicles in grams per liter.

\begin{tabular}{|c|c|c|c|c|c|c|c|}
\hline & 1. & 2 & 3 & 4 & 5 & 6 & 7 \\
\hline \multirow[t]{2}{*}{ 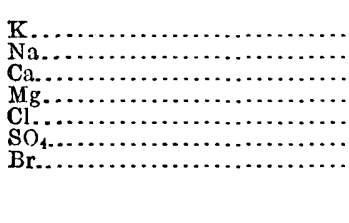 } & $\begin{array}{r}\text { Trace. } \\
117.0 \\
4.8 \\
2.2 \\
187.9 \\
3.6 \\
1.1\end{array}$ & $\begin{array}{r}\text { Trace. } \\
120.0 \\
4.0 \\
.8 \\
190.6 \\
4.6 \\
.9\end{array}$ & $\begin{array}{r}1.0 \\
109.1 \\
10.3 \\
1.6 \\
191.1 \\
.6 \\
\end{array}$ & $\begin{array}{r}0.2 \\
114.9 \\
5.4 \\
.8 \\
185.4 \\
2.4 \\
.8\end{array}$ & $\begin{array}{r}0.6 \\
111.4 \\
8.2 \\
.6 \\
185.6 \\
2.0 \\
2.0\end{array}$ & $\begin{array}{r}0.2 \\
73.2 \\
5.3 \\
.7 \\
122.8 \\
1.1 \\
\ldots . .\end{array}$ & $\begin{array}{r}0.6 \\
112.0 \\
.8 \\
.8 \\
173.4 \\
1.2 \\
.6\end{array}$ \\
\hline & 316.6 & 320.9 & 313.7 & 309.9 & 310.4 & 203.3 & 289.4 \\
\hline
\end{tabular}

Radicles in percentage of anhydrous residue.

\begin{tabular}{|c|c|c|c|c|c|c|c|}
\hline \multirow[t]{2}{*}{ 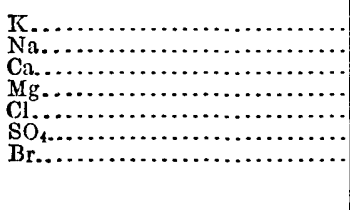 } & $\begin{array}{r}0.00 \\
36.08 \\
1.52 \\
.69 \\
59.37 \\
1.10 \\
.34\end{array}$ & $\begin{array}{r}0.00 \\
37.39 \\
1.25 \\
.25 \\
59.40 \\
1.43 \\
.28\end{array}$ & $\begin{array}{r}0.32 \\
34.80 \\
3.28 \\
.51 \\
60.90 \\
.19 \\
. . . .\end{array}$ & $\begin{array}{r}0.06 \\
37.21 \\
1.74 \\
.25 \\
59.72 \\
.77 \\
.25\end{array}$ & $\begin{array}{r}0.19 \\
35.90 \\
2.64 \\
.19 \\
59.80 \\
.64 \\
.64\end{array}$ & $\begin{array}{r}0.09 \\
36.01 \\
2.64 \\
.34 \\
60.38 \\
.54 \\
. .2 .\end{array}$ & $\begin{array}{r}0.21 \\
38.72 \\
.27 \\
.27 \\
59.91 \\
.41 \\
.21\end{array}$ \\
\hline & 100.00 & 100.00 & 100.00 & 100.00 & 100.00 & 100.00 & 100.00 \\
\hline
\end{tabular}

Radicles in grams per liter.

\begin{tabular}{|c|c|c|c|c|c|c|c|}
\hline & 8 & 9 & 10 & 11 & 12 & 13 & 14 \\
\hline \multirow[t]{2}{*}{ 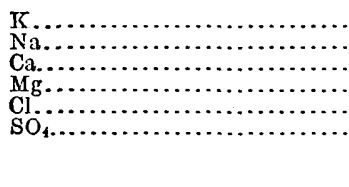 } & $\begin{array}{r}1.7 \\
110.1 \\
11.4 \\
1.0 \\
193.1 \\
.7\end{array}$ & $\begin{array}{r}2.8 \\
100.3 \\
19.9 \\
1.8 \\
197.2 \\
-\quad .5\end{array}$ & $\begin{array}{r}1.9 \\
106.7 \\
13.5 \\
1.5 \\
193.5 \\
.8\end{array}$ & $\begin{array}{r}9.4 \\
56.8 \\
20.2 \\
1.6 \\
135.0 \\
2.2\end{array}$ & $\begin{array}{r}1.8 \\
93.7 \\
25.2 \\
2.6 \\
197.5 \\
.4\end{array}$ & $\begin{array}{r}1.3 \\
114.2 \\
6.4 \\
1.9 \\
192.8 \\
1.2\end{array}$ & $\begin{array}{r}2.2 \\
108.9 \\
7.6 \\
1.9 \\
187.5 \\
1.3\end{array}$ \\
\hline & 318.0 & 322.5 & 317.9 & 225.2 & 321.2 & 317.8 & 309.4 \\
\hline
\end{tabular}

Radicles in percentage of anhydrous residue.

\begin{tabular}{|c|c|c|c|c|c|c|c|}
\hline 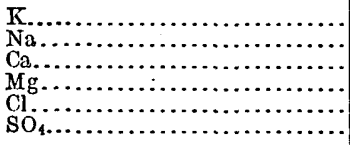 & $\begin{array}{r}0.53 \\
34.61 \\
3.59 \\
.34 \\
60.71 \\
.22\end{array}$ & $\begin{array}{r}0.87 \\
31.01 \\
6.17 \\
.56 \\
61.24 \\
.15\end{array}$ & $\begin{array}{r}0.60 \\
33.52 \\
4.25 \\
.47 \\
60.91 \\
.25\end{array}$ & $\begin{array}{r}4.17 \\
25.23 \\
8.97 \\
.71 \\
59.94 \\
.98\end{array}$ & $\begin{array}{r}0.56 \\
29.18 \\
7.85 \\
.81 \\
61.48 \\
.12\end{array}$ & $\begin{array}{r}0.41 \\
35.95 \\
2.01 \\
.60 \\
60.66 \\
.37\end{array}$ & $\begin{array}{r}0.71 \\
35.21 \\
2.45 \\
.61 \\
60.60 \\
.42\end{array}$ \\
\hline & 100.00 & 100.00 & 100.00 & 100.00 & 100.00 & 100.00 & 100.00 \\
\hline
\end{tabular}

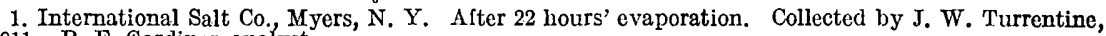
1011. R. F. Gardiner, analyst.

2. International Salt Co., Myers, N. Y. Collected by J. W. Turrentine, 1911. R. F. Gardiner, analyst. 3. Remington Salt Co., Ithaca, N. Y. From evaporators, representing a concentration of 350 tons of original brine to 25 tons.' Collected by J. W. Turrentine, 1911. A. R. Merz, analyst.

4. Remington Salt Co., Ithaca, N. Y. From centrifuges at $9 \mathrm{a}$. m., first hour of centrifuging. Collected by J. W. Turrentine, 1911. R. F. Gardiner, analyst.

5. Remington Salt Co., Ithaca, N. Y. From centrifuges at end of 7 hours' centrifuging. Collected by J. W. 'Turrentine, 1911. 'R. F. Gardiner, analyst.

6. Le Roy Salt Co., Le Roy, N. Y. Waste bittern from the plant, 1911. A. R. Merz, analyst.

7. Solvay Process Co., Syracuse, N.Y. From brine from 50-foot salt bed 1910. R. F. Gardiner, analyst.

8. Worcester Salt Co., Silver Springs, N. Y. From vacuum pan, 1911. A. R. Merz, analyst.

9. Worcester Salt Co., Silver Springs, N. Y. From grainer No. 6, 1911. A. R. Merz, analyst.

10. Rock Glen Salt Co., Rock Glen, N. Y. After 10 days' evaporation in open pans, 1911. A. R. Merz, analyst.

11. Rock Glen Salt Co., Rock Glen, N. Y. After 6 weeks' evaporation in grainer, taken at time of runoff, 1910. R. F. Gardiner, analyst.

12. Star \& Crescent Salt Co., Saltvale, N. Y. From open pans, representing concentration of $85,000 \mathrm{gal}-$ lons of original brine to approximately 2,250 gallons, taken at time of run-off, 1911 . A. R. Merz, analyst.

13. Genesee Salt Co., Piffard, N. Y. From open pans after 36 hours' cvaporation, representing concentration of 30,000 gallons to 15,000 gallons, 1911. A. R. Merz, analyst.

14. Gênesee Salt Co., Piffard, N. Y. From grainer after 2 weeks' evaporation, 1911. A. R. Merz, analyst. 


\section{MICHIGAN.}

Analyscs of bitterns from artificial brines of western Michigan.

Radicles in grams per liter.

\begin{tabular}{|c|c|c|c|c|c|c|}
\hline & 1 & 2 & 3 & 4 & 5 & 6 \\
\hline 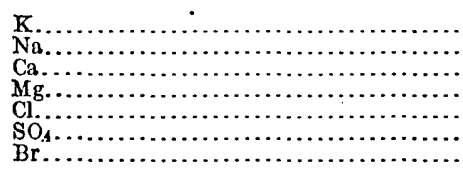 & $\begin{array}{r}2.0 \\
89.7 \\
5.2 \\
15.4 \\
191.8 \\
3.2 \\
\text { Tracc. }\end{array}$ & $\begin{array}{r}0.5 \\
115.1 \\
3.9 \\
3.0 \\
191.4 \\
2.3\end{array}$ & $\begin{array}{r}0.2 \\
119.1 \\
2.4 \\
11.6 \\
189.8 \\
3.4\end{array}$ & $\begin{array}{r}6.0 \\
107.6 \\
8.4 \\
3.4 \\
191.8 \\
5.0 \\
\text { None. }\end{array}$ & $\begin{array}{r}0.7 \\
111.1 \\
3.5 \\
4.6 \\
189.8 \\
2.3\end{array}$ & $\begin{array}{r}121.4 \\
2.8 \\
190.4 \\
2.4 \\
\ldots \ldots . .\end{array}$ \\
\hline & 307.3 & 316.2 & 316.5 & 322.2 & 312.0 & 317.3 \\
\hline
\end{tabular}

Radicles in percentage of anhydrous residue.

\begin{tabular}{|c|c|c|c|c|c|c|}
\hline \multirow[t]{2}{*}{ 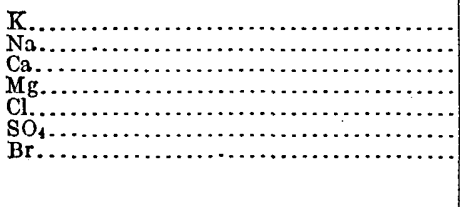 } & $\begin{array}{r}0.65 \\
29.19 \\
1.69 \\
5.02 \\
62.41 \\
1.04 \\
.00\end{array}$ & $\begin{array}{r}0.16 \\
36.40 \\
1.23 \\
.95 \\
60.54 \\
.72 \\
\end{array}$ & $\begin{array}{r}0.06 \\
37.61 \\
.76 \\
.51 \\
59.99 \\
1.07 \\
\end{array}$ & $\begin{array}{r}1.86 \\
33.40 \\
2.61 \\
1.05 \\
59.53 \\
1.55 \\
.00\end{array}$ & $\begin{array}{r}0.22 \\
35 . \mathrm{C6} \\
1.12 \\
1.47 \\
60.80 \\
.73 \\
\end{array}$ & $\begin{array}{r}38.26 \\
.88 \\
.09 \\
60.01 \\
.76 \\
\ldots . . .\end{array}$ \\
\hline & 100.00 & 100.00 & 100.00 & 100.00 & 100.00 & 100.00 \\
\hline
\end{tabular}

-1. Filer \& Son, Filer City, ncar Manistce, Mich. Drippings from salt, 1911. R. F. Gardincr, analyst.

2. R. G. Peters Salt \& Lumber Co., East Lake, Manistec, Mich. From grainer after 10 days' evaporation, 1911. A. R. Merz analyst.

3. Buckley-Douglas Lumber Co. (formerly State Lumber Co.), Manistee, Mich. From grainer after 4 weeks' evaporation, 1911. A. R. Merz, analyst.

4. Buckley-Douglas Lumber Co., Manistee, Mich. From grainer after 17 days' evaporation, 1911. R. F. Gardiner, analyst.

5. Louis Sands Salt \& Lumber Co., Manistec, Mich. From grainer after 3 weeks' evaporation, 1911. A. R. Merz, analyst.

6. Stearns Salt \& Lumber Co., Ludington, Mich. From grainer, 1911. A. R. Merz, analyst.

Certain of the bitterns of western Michigan are slightly less concentrated than the brines from which they are derived. (See analyses above.) This difference is not greater, however, than would be accounted for by the usual variations in strength of both brines and bitterus. Generally the relative proportions of sodium and sulphate are less in the bitterns than in the brines and the relative proportions of calcium and magnesium are greater, because of the precipitation of crystals of sodium chloride and calcium sulphate and the gradual concentration of the alkaline-earth chlorides with which the solution is not completely saturated. Several of the bitterns have resulted from the concentration of very large amounts of brine; the constitution of the bitterns, therefore, indicates the marked paucity of deliquescent chlorides and salts of potassium in the brines of western Michigan.

$40104^{\circ}-18-B u l l .669-16$ 
Analyses of bitterns from artificial brines of eastern Michigan and Canada.

Radicles in grams per liter.

\begin{tabular}{|c|c|c|c|c|c|c|c|c|c|}
\hline & 1 & 2 & 3 & 4 & 5 & 6 & 7 & 8 & 9 \\
\hline $\begin{array}{l}\mathrm{K} \ldots \ldots \\
\mathrm{Na} . . \\
\mathrm{Ca} \ldots \\
\mathrm{Mg} \ldots \\
\mathrm{Cl} \ldots . \\
\mathrm{SO}_{4} . . \\
\mathrm{Br}_{\ldots} \ldots\end{array}$ & $\begin{array}{r}\text { Trace. } \\
119.9 \\
1.8 \\
\text { Trace. } \\
184.2 \\
4.8 \\
\text { Trace. }\end{array}$ & $\begin{array}{r}0.1 \\
120.3 \\
2.0 \\
.2 \\
186.8 \\
3.8\end{array}$ & $\begin{array}{r}\text { Trace. } \\
121.1 \\
1.9 \\
187.2 \\
3.4\end{array}$ & $\begin{array}{r}0.4 \\
115.9 \\
2.2 \\
1.4 \\
184.8 \\
3.6 \\
\text { None. }\end{array}$ & $\begin{array}{r}\text { Trace. } \\
117.1 \\
3.4 \\
6.6 \\
188.0 \\
2.0 \\
.8\end{array}$ & $\begin{array}{r}\text { Trace. } \\
121.4 \\
.6 \\
\text { Trace. } \\
18.5 \\
1.8 \\
2.5\end{array}$ & $\begin{array}{r}2.0 \\
104.6 \\
13.8 \\
2.7 \\
194.6 \\
.6\end{array}$ & $\begin{array}{r}1.6 \\
118.4 \\
1.2 \\
\text { Trace } \\
179.6 \\
4.6 \\
7.8\end{array}$ & $\begin{array}{r}1.4 \\
115.7 \\
4.6 \\
2.4 \\
191.6 \\
3.2 \\
\text { Nonc. }\end{array}$ \\
\hline & 310.7 & 313.2 & 314.1 & 308.3 & 311.9 & 311.8 & 318.3 & 313.2 & 318.9 \\
\hline
\end{tabular}

Radicles in percentage of anhydrous residue.

\begin{tabular}{|c|c|c|c|c|c|c|c|c|c|}
\hline 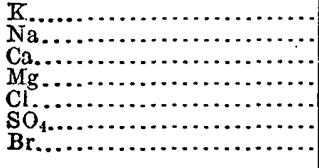 & $\begin{array}{r}0.00 \\
38.57 \\
.58 \\
.00 \\
59.31 \\
1.54 \\
.00\end{array}$ & $\begin{array}{r}0.03 \\
38.43 \\
.65 \\
.06 \\
59.65 \\
1.18 \\
\end{array}$ & $\begin{array}{r}0.00 \\
38.57 \\
.61 \\
.06 \\
59.68 \\
1.08 \\
\end{array}$ & $\begin{array}{r}0.13 \\
37.63 \\
.71 \\
.45 \\
59.91 \\
1.17 \\
.00\end{array}$ & $\begin{array}{r}0.00 \\
37.54 \\
1.09 \\
.19 \\
60.29 \\
.64 \\
.25\end{array}$ & $\begin{array}{r}0.00 \\
38.93 \\
.19 \\
.00 \\
59.50 \\
.58 \\
.80\end{array}$ & $\begin{array}{r}0.63 \\
32.86 \\
4.34 \\
.85 \\
61.14 \\
.18 \\
\ldots\end{array}$ & $\begin{array}{r}0.51 \\
37.79 \\
.38 \\
.00 \\
57.36 \\
1.47 \\
2.49\end{array}$ & $\begin{array}{r}0.43 \\
36.32 \\
1.44 \\
.75 \\
60.06 \\
1.00 \\
.00\end{array}$ \\
\hline & 100.00 & 100.00 & 100.00 & 100.00 & 100.00 & 100.00 & 100.00 & 100.00 & 100.00 \\
\hline
\end{tabular}

1. Port Huron Salt Co., Port Huron, Mich. From grainer after 2 weeks' evaporation, 1911. R. F. Gardiner, analyst.

2. Delray Salt Co., Delray, near Detroit, Mich. Drippings from salt being conveyed from vacuum pans, 1911. A. R. Merz, analyst.

3. Delray Salt Co., Delray, near Detroit, Mich. From grainer after 12 days' evaporation, 1911. A. R. Merz analyst.

4. Pennsylvania Salt Co., Wyandotte, Mich. From dripping vats, 1910. R. F. Gardiner, analyst.

5. Diamond Crystal Salt Co., St. Clair, Mich. From grainer after 23 days' evaporation, 1911. R. F. Gardiner, analyst.

6. Davidson, Wonsey Co., Marine City, Mich. Drippings from vacuum-pan salt, 1911. R. F. Gardiner, analyst.

7. Michigan Salt Works, Marine City, Mich. From grainer after 6 weeks' evaporation, 1911. A. R. Merz, analyst.

8. Mulkey Salt Co., Detroit, Mich. After 30 to 35 days' evaporation, 1911. R. F. Gardiner, analyst.

9. Western Canada Flour Mills Co., Goderich, Canada. From grainer after 5 weelss' evaporation, 1911.

R. F. Gardiner, analyst.

The analyses in the accompanying table indicate that the bitterns from artificial brines of eastern Michigan are similar in character to the brines from which they are derived. (See analyses, pp. 226-227.) Indeed some of the brines are more strongly concentrated than the resultant bitterns. The content of alkaline-earth metals in the bitterns is not large, and the contents of sodium and chlorine are not markedly different from those of the original brines. The relative content of sulphate is ordinarily less in the bitterns because of its tendency to precipitate in combination with calcium as the solution is heated. The content of bromine in bittern No. 8 is abnormally large compared with that of the other samples. The fact that the Mulkey Salt Co. pumps from the 950-foot level in the upper bed of salt, the top of which lies about 900 feet below the surface, may explain the bittern-like nature of the brine but does not explain its low content of magnesium. 
Analyses of bitterns from natural brines of eastern Michigan.

Radicles in grams per liter.

\begin{tabular}{|c|c|c|c|c|c|c|c|c|c|c|}
\hline & 1 & 2 & 3 & 4 & 5 & 0 & 7 & 8 & 9 & 10 \\
\hline 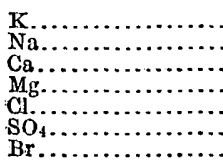 & $\begin{array}{r}1.3 \\
66.1 \\
40.6 \\
11.5 \\
207.7 \\
. .4 \\
\ldots . . .\end{array}$ & $\begin{array}{r}1.6 \\
75.2 \\
32.4 \\
9.6 \\
200.8 \\
\text { Trace. } \\
4.4\end{array}$ & $\begin{array}{r}4.2 \\
64.7 \\
36.4 \\
11.0 \\
204.1 \\
.8 \\
3.3\end{array}$ & $\begin{array}{r}2.6 \\
76.1 \\
32.8 \\
9.6 \\
195.8 \\
1.4 \\
2.2\end{array}$ & $\begin{array}{r}10.2 \\
.0 \\
192.6 \\
35.2 \\
452.2 \\
\text { None. } \\
\text { Trace. }\end{array}$ & $\begin{array}{r}8.2 \\
1.8 \\
174.0 \\
40.4 \\
433.3 \\
3.0 \\
.5\end{array}$ & $\begin{array}{r}\text { Trace. } \\
6.2 \\
82.0 \\
25.4 \\
223.6 \\
3.4 \\
.4\end{array}$ & $\begin{array}{r}5.4 \\
8.2 \\
87.2 \\
16.3 \\
219.2 \\
1.8 \\
\text { Trace. }\end{array}$ & $\begin{array}{r}1.2 \\
52.5 \\
50.2 \\
11.6 \\
205.4 \\
\text { Trace. }\end{array}$ & $\begin{array}{r}\text { Trace. } \\
60.9 \\
.6 \\
.4 \\
91.5 \\
3.6 \\
4.3\end{array}$ \\
\hline & 327.6 & 324.0 & 324.5 & 320.5 & 690.2 & 661.2 & 341.0 & 338.1 & 321.5 & 161.3 \\
\hline
\end{tabular}

Radicles in percentage of anhydrous residue.

\begin{tabular}{|c|c|c|c|c|c|c|c|c|c|c|}
\hline 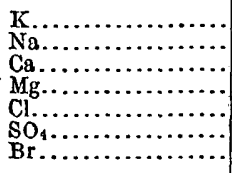 & $\begin{array}{r}0.40 \\
20.20 \\
12.39 \\
3.51 \\
63.38 \\
.12 \\
\ldots\end{array}$ & $\begin{array}{r}0.50 \\
23.21 \\
10.00 \\
2.97 \\
61.97 \\
.00 \\
1.35\end{array}$ & $\begin{array}{r}1.29 \\
19.93 \\
11.22 \\
3.39 \\
62.90 \\
.25 \\
1.02\end{array}$ & $\begin{array}{r}0.81 \\
23.74 \\
10.21 \\
3.00 \\
61.12 \\
.44 \\
.68\end{array}$ & $\begin{array}{r}1.48 \\
.00 \\
27.91 \\
5.10 \\
65.51 \\
.00 \\
.00\end{array}$ & $\begin{array}{r}1.24 \\
.27 \\
26.33 \\
6.11 \\
65.53 \\
.45 \\
.07\end{array}$ & $\begin{array}{r}0.00 \\
1.82 \\
24.04 \\
7.45 \\
65.58 \\
1.00 \\
.11\end{array}$ & $\begin{array}{r}1.60 \\
2.40 \\
25.72 \\
4.97 \\
64.78 \\
.53 \\
.00\end{array}$ & $\begin{array}{r}0.37 \\
16.33 \\
15.60 \\
3.63 \\
63.89 \\
.18 \\
.00\end{array}$ & $\begin{array}{r}0.00 \\
37.79 \\
.37 \\
.24 \\
56.69 \\
2.24 \\
2.67\end{array}$ \\
\hline & 100.00 & 100.00 & 100.00 & 100.00 & 100.00 & 100.00 & 100.00 & 100.00 & 100.00 & 100.00 \\
\hline
\end{tabular}

1. Hine \& Co., Bay City, Mich. From grainer after 5 days' evaporation, 1911. A. R.-Merz, analyst.

2. Bliss-Van Auken Co., Saginaw, Mich. From grainer after 5 days' evaporation, 1011. R. F. Gardiner, analyst.

3. Edward Germain, Saginaw, Mich. From grainer after 14 days' cvaporation, 1911. R. F. Gardiner, analyst.

4. Mershon-Eddy-Parker Co., Saginaw, Mich. From grainer after 4 days' evaporation, 1911. R. F. Gardiner, analyst.

5. Saginaw Chemical Works, Saginaw, Mich. Bittern concentrated to 8.5 per cent of the volume of the original brine before the final evaporation for the preparation of calcium chloride. When the hot sample had cooled a crystalline solid separated, which contained 1.1 per cent potassium, equivalent to 2.3 per cent potassium chloride. Collected by J. W. 'Turrentine, 1911. IR. F. Gardiner, analyst.

6. Saginaw Plate Glass Co., Saginaw, Mich. From grainer, concentrated to $45^{\circ}$ Baumé, 1910. R. F. Gardiner, analyst.

7. Saginaw Plate Glass Co., Saginaw, Mich. From a grainer just before going to the chemical plant; concentrated to $30-31^{\circ}$ Baumé, 1910 . R. F. Gardiner, analyst.

8. W. J. Mason, Saginaw, Mich. "Mother water." Collocted by Mr. Mason, 1910. R. F. Cardiner, analyst.

9. Dow Chemical Co., Mount Pleasant, Mich. After removal of bromide; it contains iron. Collected in 191i. R. F. Cardiner, analyst.

10. Saginaw Salt Co., St. 'Charles, Mich. From grainer after 4 days' evaporation, 1911: R. F. Cardinor, analyst.

For comparing the composition of bitterns the statements of composition in percentage are the most useful, because the degree of salinity of the bitterns is so divergent, partly because of the varying periods of time during which they have accumulated but chiefly because of the varying amounts of original brine which they represent. Analysis No. 10 obviously represents a diluted sample, for the bittern is less strongly concentrated than the brines from which it is supposed to have been formed. All the sulphate and sodium have been removed from No. 5 by its high degree of concentration; the high proportion of potassium in this bittern is noteworthy, but in the others the quantity of potassium is small and variable. 


\section{NORTHEASTERN OHIO.}

Analyses of bitterns from artificial brines of northeastern Ohio.

Radicles in grams per liter.

\begin{tabular}{|c|c|c|c|c|c|c|}
\hline & 1 & 2 & 3 & 4 & 5 & 6 \\
\hline \multirow[t]{2}{*}{ 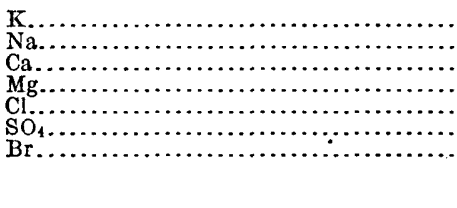 } & $\begin{array}{r}2.8 \\
108.4 \\
12.8 \\
1.6 \\
193.0 \\
5.0 \\
\text { Trace. }\end{array}$ & $\begin{array}{r}1.2 \\
100.1 \\
16.3 \\
3.7 \\
194.5 \\
.7 \\
\text { Trace. }\end{array}$ & $\begin{array}{r}\text { Trace. } \\
103.9 \\
4.2 \\
3.0 \\
174.2 \\
2.4 \\
\text { Trace. }\end{array}$ & $\begin{array}{r}0.7 \\
103.7 \\
16.5 \\
1.3 \\
192.3 \\
1.1 \\
\text { Trace. }\end{array}$ & $\begin{array}{r}1.8 \\
97.6 \\
12.0 \\
2.4 \\
187.8 \\
1.8 \\
\text { Trace. }\end{array}$ & $\begin{array}{r}2.8 \\
104.8 \\
13.5 \\
2.2 \\
192.3 \\
3.3 \\
.5\end{array}$ \\
\hline & 323.6 & 316.5 & 287.7 & 315.6 & $3 \mathrm{C3.} 4$ & 319.4 \\
\hline
\end{tabular}

Radicles in percentage of anhydrous residue.

\begin{tabular}{|c|c|c|c|c|c|c|}
\hline \multirow[t]{2}{*}{ 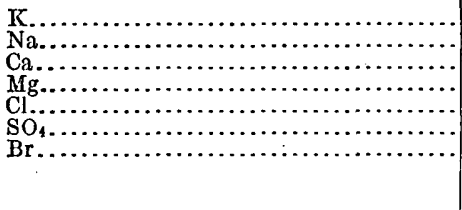 } & $\begin{array}{r}0.86 \\
33.53 \\
3.95 \\
.49 \\
59.62 \\
1.55 \\
.00\end{array}$ & $\begin{array}{r}0.38 \\
31.64 \\
5.15 \\
1.17 \\
61.44 \\
.22 \\
.00\end{array}$ & $\begin{array}{r}0.00 \\
36.08 \\
1.46 \\
1.04 \\
60.59 \\
.83 \\
.00\end{array}$ & $\begin{array}{r}0.22 \\
32.88 \\
5.23 \\
.41 \\
60.91 \\
.35 \\
.00\end{array}$ & $\begin{array}{r}0.59 \\
32.20 \\
3.96 \\
.79 \\
61.87 \\
.59 \\
.00\end{array}$ & $\begin{array}{r}0.87 \\
32.83 \\
4.23 \\
60.69 \\
60.20 \\
1.03 \\
.15\end{array}$ \\
\hline & 100.00 & 100.00 & 100.00 & 100.00 & 100.00 & 100.00 \\
\hline
\end{tabular}

1. Colonial Salt Co., Kenmore, near Akron, Ohio. Bittern from grainer after $5 \frac{1}{2}$ months' cvaporation, 1911. R. F. Gardiner, analyst.

2. Union Salt Co., Cleveland, Ohio. Bittern from grainer after 5 days' evaporation, 1911. A. R. Merz, analyst.

3. Cleveland Salt Co., Cleveland, Ohio. Bittern after 30 days' evaporation.

4. Ohio Salt Co., Rittman, Ohio. Bittern after 35 days' evaporation, 1911. $\Lambda . R$. Merz, analyst.

5. Ohio Salt Co., Rittman, Ohio. Bittern from boot of vacuum pan, 1911. A. R. Morz and R. F. Gardiner, analysts.

6. Ohio Salt Co., Rittman, Ohio. Saline solution from boot of vacuum pan, 1911. J. $\Lambda$. Cullen, analyst.

These bitterns from brines of northeastern Ohio are comparable in concentration with the brines from which they were made. The chief differences between the composition of the brines and that of the bitterns are the larger amounts of calcium, magnesium, and potassium and the smaller amounts of sodium in the bitterns. The content of sulphate is generally less in the bitterns, probably because of its precipitation during evaporation. 
SOUTHERN OHIO AND WEST VIRGINIA.

Analyses of bitterns from natural brines of southern Ohio and West Virginia.

Radicles in grams per liter.

\begin{tabular}{|c|c|c|c|c|c|c|}
\hline & 1 & 2 & 3 & 4 & 5 & 6 \\
\hline \multirow[t]{2}{*}{$\begin{array}{l}\mathrm{K} \\
\mathrm{N}{ }_{\mathrm{N}} \\
\mathrm{Ca} \\
\mathrm{Mg} \\
\mathrm{Cl} \\
\mathrm{Cl} \\
\mathrm{Br}\end{array}$} & $\begin{array}{r}2.7 \\
1.1 \\
142.9 \\
40.1 \\
371.7 \\
8.8\end{array}$ & $\begin{array}{r}1.6 \\
.7 \\
148.1 \\
53.5 \\
422.1 \\
12.5\end{array}$ & $\begin{array}{r}3.1 \\
6.9 \\
112.0 \\
31.3 \\
299.1 \\
6.9\end{array}$ & $\begin{array}{r}1.6 \\
1.6 \\
151.5 \\
43.2 \\
395.4 \\
9.6\end{array}$ & $\begin{array}{r}3.7 \\
4.1 \\
123.0 \\
35.5 \\
327.3 \\
7.7\end{array}$ & $\begin{array}{r}3.5 \\
4.6 \\
131.7 \\
28.8 \\
321.9 \\
7.1\end{array}$ \\
\hline & 567.3 & 638.5 & 459.3 & 602.9 & 501.3 & 497.6 \\
\hline
\end{tabular}

Radicles in percentage of anhydrous residue.

\begin{tabular}{|c|c|c|c|c|c|c|}
\hline 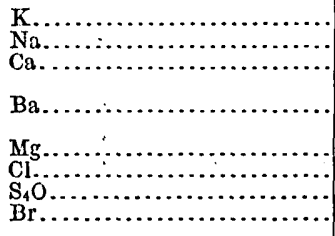 & $\begin{array}{c}0.49 \\
25.20 \\
25.19 \\
\text { Trace } \\
\text { or } \\
\text { none. } \\
7.07 \\
65.50 \\
\text { None. } \\
1.55\end{array}$ & $\begin{array}{c}0.25 \\
\vdots 12 \\
23.19 \\
\text { Trace } \\
\text { or } \\
\text { none. } \\
8.37 \\
66.11 \\
\text { None. } \\
1.96\end{array}$ & $\begin{array}{r}0.67 \\
1.52 \\
24.38 \\
\text { Present, } \\
\text { not deter- } \\
\text { mined. } \\
6.83 \\
65.10 \\
\text { None. } \\
1.50\end{array}$ & $\begin{array}{c}0.27 \\
.27 \\
25.12 \\
\text { Trace } \\
\text { or } \\
\text { none } \\
7.17 \\
65.58 \\
\text { None. } \\
1.59\end{array}$ & $\begin{array}{r}0.75 \\
.82 \\
24.53 \\
\text { Trace. } \\
7.08 \\
65.28 \\
\text { None. } \\
1.54\end{array}$ & $\begin{array}{r}0.70 \\
91 \\
26.47 \\
\text { Trace } \\
\text { or } \\
\text { nono. } \\
5.80 \\
64.70 \\
\text { None. } \\
1.42\end{array}$ \\
\hline & 100.00 & 100.00 & 100.00 & 100.00 & 100.00 & 100.00 \\
\hline
\end{tabular}

1. Pomeroy Salt Association, Pomeroy, Ohio, 1918. R. K. Bailey, analyst; G. B. Richardson, collector.

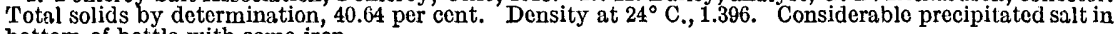
bottom of bottle with some iron.

2. Pomeroy Chemical Co., Pomeroy, Ohio, 1918. R. K. Bailey, analyst; G. B. Richardson, collector. Total solids by determination, 44.37 per cent. Density at $24^{\circ} \mathrm{C} ., 1.439$. Considerable salt and iron pre-

cipitatcd on bottom of vesscl. Total solids by determination, 34.59 per cent. Density at $24^{\circ} \mathrm{C}, 1.328$. Considerable salt and iron precipitated at bottom of vessel.

4. Mason Coal \& Chemical Co., Hartford, W. Va., 1918. R. K. Bailey, analyst; G. B. Richardson, collector. Total solids by determination, 42.46 per cent. Density at $24.0^{\circ} \mathrm{C} ., 1.420$. Considerable salt and

some iron precipitated at bottom of vessel. 5 . R. K. Bailey, analyst; G. B. Richardson, collector. 'Total solids by determination, 36.94 per cent. Density at $21.5^{\circ} \mathrm{C} ., 1.357$. Considerable salt and some iron precipitated at bottom of vessel.

6. J. Q. Dickinson \& Co., Malden, W. Va., 1918. R. K. Bailey, analyst; W. B. Hicks, collector. 'Total solids by determination, 36.75 per cent. Density at $18.6^{\circ} \mathrm{C}, 1.354$. Trace of iron precipitate found in bottom of vessel.

The high concentration and the low percentage of sodium chloride in the bitterns from the natural brines along Ohio and Kanawha rivers should be noted. The analyses of these bitterns should be compared with a subsequent one of calcium chloride, obtained by further concentration. (See analysis, p. 248.) These bitterns are sources of bromine, and attention is directed to this element. 
KANSAS.

Analyses of bitterns from artificial brines of Kansas.

Radicles in grams per liter.

\begin{tabular}{|c|c|c|c|c|c|}
\hline . & 1 & 2 & 3 & 4 & 5 \\
\hline 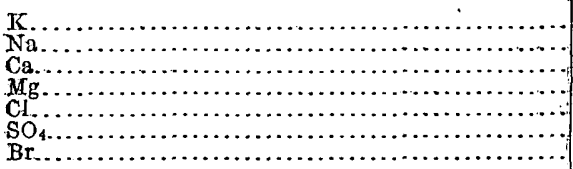 & $\begin{array}{r}1.0 \\
90.4 \\
1.4 \\
15.8 \\
182.5 \\
3.4 \\
.9\end{array}$ & $\begin{array}{r}0.4 \\
117.8 \\
2.3 \\
1.6 \\
188.5 \\
3.4 \\
\text { Trace. }\end{array}$ & $\begin{array}{r}\text { Trace. } \\
118.2 \\
.8 \\
2.4 \\
186.2 \\
5.4 \\
\text { Trace. }\end{array}$ & $\begin{array}{r}0.2 \\
101.1 \\
11.4 \\
182.0 \\
11.2 \\
\text { Trace. }\end{array}$ & $\begin{array}{r}1.4 \\
116.6 \\
2.5 \\
1.6 \\
189.4 \\
3.4 \\
\text { Trace. }\end{array}$ \\
\hline . & 295.4 & 314.0 & 313.0 & 306.5 & 314.9 \\
\hline
\end{tabular}

Radicles in percentage of anhydrous residue.

\begin{tabular}{|c|c|c|c|c|c|}
\hline 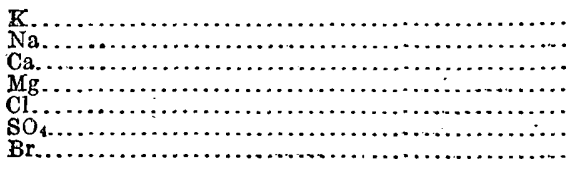 & $\begin{array}{r}0.34 \\
30.61 \\
.47 \\
5.36 \\
61.77 \\
1.15 \\
.30\end{array}$ & $\begin{array}{r}0.12 \\
37.48 \\
.73 \\
.51 \\
60.08 \\
1.08 \\
.00\end{array}$ & $\begin{array}{r}0.00 \\
37.74 \\
.26 \\
.77 \\
59.50 \\
1.73 \\
.00\end{array}$ & $\begin{array}{r}0.06 \\
33.02 \\
.13 \\
3.78 \\
59.35 \\
3.66 \\
.00\end{array}$ & $\begin{array}{r}0.44 \\
37.03 \\
.79 \\
.51 \\
60.15 \\
1.08 \\
.00\end{array}$ \\
\hline & 100.00 & 100.00 & 100.00 & 100.00 & 100.00 \\
\hline
\end{tabular}

1. Western Salt Works, Hutchinson Salt Co., Hutchinson, Kans. From open pan after 25 days' evaporation, 1911. R. F. Gardiner, analyst.

2. Barton Salt Co., Hutchinson Kans. After 24 days' evaporation, 1911. J. A. Cullen, analyst.

3. Sterling Salt Co., Sterling, Kans. From grainer after 30 days' evaporation, 1911. R. F. Cardiner, analyst.

4. Orient Salt Co., Anthony, Kans. From grainer after 8 days' evaporation, 1911. R. F. Gardiner, analyst.

5. Ellsworth Salt Co., Ellsworth, Kans. From grainer, 1911. J. A. Cullen, analyst.

The bitterns of Kansas thus far examined are similar in concentration to the artificial brines from which they are derived. They differ from the brines in their content of calcium and magnesium, but part of the content of alkaline earths possibly comes from the water used in dissolving the salt. The content of sulphate is notably lower than that of the brines. The content of potassium salts is too small to be of importance. Analyses 1 and 4 indicate the presence of surprisingly large amounts of magnesium in two of the bitterns. 
TEXAS AND UTAH.

Analyses of bitterns from brines of Texas and Utah.

Fadicles in grams per liter.

\begin{tabular}{|c|c|c|}
\hline & 1 & 2 \\
\hline 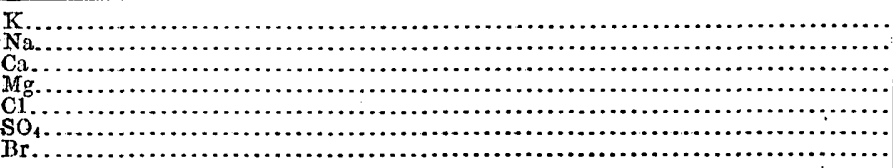 & $\begin{array}{r}0.4 \\
101.3 \\
1.5 \\
\text { Tracs. } \\
158.3 \\
2.5 \\
-\end{array}$ & $\begin{array}{r}8.4 \\
79.5 \\
\text { Tracs. } \\
13.8 \\
146.8 \\
34.0 \\
\end{array}$ \\
\hline & 264.0 & 282.5 \\
\hline
\end{tabular}

Radicles in percentage of anhydrous residue.

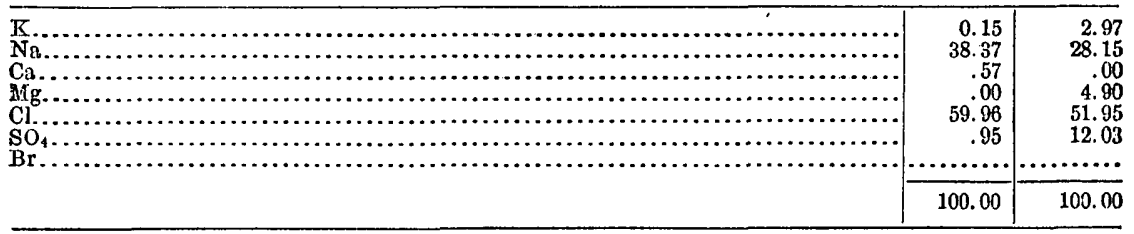

1. B. W. Carrington, Grand Saline, Tex. From grainer after 6(?) weeks' evaporation, 1012. R. K. Bailey, analyst.

2. Inland Crystal Salt Co., Saltair, Utah. Residual bittern after salt had been making 4 weeks in harvesting pond; ordinarily evaporation would be allowed to progress 2 weeks longer. Collected in 1912 . $R$. K. Bailey, analyst.

SEA WATER.

Analyses of bitterns from sea water.

[Samples collected by E. E. Freo, 1912. R. F. Gardiner, analyst.]

Radicles in grams per liter.

\begin{tabular}{|c|c|c|c|c|c|c|c|c|}
\hline$\cdot$ & 1 & 2 & 3 & 4 & 5 & 6 & 7 & a 8 \\
\hline \multirow[t]{2}{*}{ 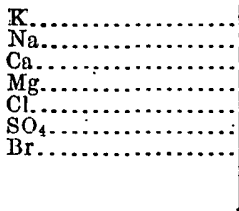 } & $\begin{array}{r}8.2 \\
80.0 \\
1.2 \\
24.0 \\
179.2 \\
30.0 \\
3.0\end{array}$ & $\begin{array}{r}13.4 \\
75.8 \\
2.2 \\
23.4 \\
176.6 \\
31.4 \\
3.0\end{array}$ & $\begin{array}{r}13.2 \\
38.8 \\
.6 \\
50.6 \\
179.4 \\
53.6 \\
3.0\end{array}$ & $\begin{array}{r}14.6 \\
27.7 \\
.5 \\
62.7 \\
183.3 \\
74.2 \\
3.0\end{array}$ & $\begin{array}{r}21.5 \\
9.1 \\
1.0 \\
79.4 \\
220.1 \\
62.0 \\
2.0\end{array}$ & $\begin{array}{r}35.0 \\
93.6 \\
.2 \\
8.6 \\
180.4 . \\
29.0 \\
2.0\end{array}$ & $\begin{array}{r}11.8 \\
60.1 \\
1.1 \\
43.9 \\
190.8 \\
55.8 \\
2.8\end{array}$ & $\begin{array}{r}0.7 \\
61.0 \\
\text { Traco. } \\
24.8 \\
148.5 \\
34.1 \\
\ldots \ldots . .\end{array}$ \\
\hline & 325.6 & 325.8 & 339.2 & 366.0 & 395.1 & 348.8 & 366.3 & 269.1 \\
\hline
\end{tabular}

$a$ Grams per kilogram.

Radicles in percentage of anhydrous residue.

\begin{tabular}{|c|c|c|c|c|c|c|c|c|}
\hline \multirow[t]{2}{*}{ 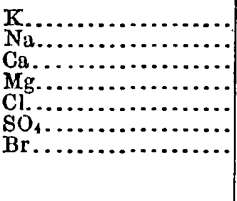 } & $\begin{array}{r}2.51 \\
24.57 \\
.37 \\
7.38 \\
55.03 \\
9.22 \\
.92\end{array}$ & $\begin{array}{r}4.11 \\
23.27 \\
.68 \\
7.18 \\
54.20 \\
9.64 \\
.92\end{array}$ & $\begin{array}{r}3.89 \\
11.45 \\
.18 \\
14.92 \\
52.88 \\
15.80 \\
.88\end{array}$ & $\begin{array}{r}3.99 \\
7.57 \\
.14 \\
17.13 \\
50.07 \\
20.28 \\
.82\end{array}$ & $\begin{array}{r}5.44 \\
2.30 \\
.26 \\
20.09 \\
55.71 \\
15.69 \\
.51\end{array}$ & $\begin{array}{r}10.03 \\
26.83 \\
.08 \\
2.47 \\
51.72 \\
8.32 \\
.57\end{array}$ & $\begin{array}{r}3.22 \\
16.41 \\
.30 \\
11.98 \\
52.10 \\
15.23 \\
.76\end{array}$ & $\begin{array}{r}0.25 \\
22.68 \\
.00 \\
9.21 \\
55.19 \\
12.07 \\
\ldots \ldots \ldots .\end{array}$ \\
\hline & 100.00 & 100.00 & 100.00 & 100.00 & 100.00 & 100.00 & 100.00 & 100.00 \\
\hline
\end{tabular}

1. Leslie Salt Refining Works, San Mateo, Cal. Representative sample taken near northwest corner of mother-liquor pond.

2. Leslie Salt Refining Works, San Mateo, Cal. From southeast corner of mother-liquor pond.

3. Leslie Salt Refining Works, San Mateo, Cal. From salt-making pond, in which salt had been forming during the summer.

4. Oliver Salt Works, Mount Eden, Cal. From slop pond, representing 5 years' accumulation.

5. Oliver Salt Works, Mount Eden, Cal. Mother liquor that had been subjected to special treatment.

6. California Salt Co., Alvarado, Cal. From slop pond, representing 3 years' accumulation, though considerable quantities had been abstracted for use in forcing, and small quantities of other waste liquors had been added.

7. Pioneer Salt Co., San Francisco, Cal. One year's accumulation.

8. Long Beach Salt Co., Long Boach, Cal. Abnormally concentrated bittern from an outlying tank, 1912. R. K. Bailey, analyst. 
The analyses of the bitterns resulting from extraction of salt from sea water on the California coast are remarkable for the indicated amounts of magnesium salts, both the chloride and the sulphate, and also for the rather large amount of potassium. Calcium is present in very small amount, probably in the form of sulphate. Bromine is relatively small in amount. The relatively large contents of potassium make it probable that these bitterns might be evaporated and utilized in the manufacture of low-grade fertilizer material, such as manure salts, hartsalz, and kainite.

\section{COMPOSITION OF CALCIUM CHLORIDE.}

The following analyses show the composition of the calcium chloride obtained from the brines of Michigan, Ohio; West Virginia, and Pennsylvania.

Analyses of calcium chloride obtained from brines of Michigan, Ohio, West Virginia, and Pennsylvania.

Radicles in percentage of total weight.

\begin{tabular}{|c|c|c|c|c|c|c|c|}
\hline$\cdot$ & 1 & 2 & 3 & 4 & 5 & 6 & 7 \\
\hline 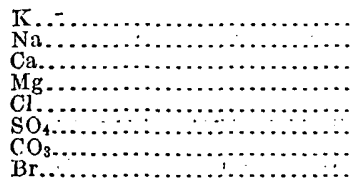 & $\begin{array}{r}0.7 \\
.6 \\
19.5 \\
4.9 \\
50.4 \\
\text { None. } \\
\cdots . . . \% \\
\ldots . . . \%\end{array}$ & $\begin{array}{r}0.8 \\
2.4 \\
19.6 \\
5.1 \\
53.9 \\
\text { None. } \\
\text { None. }\end{array}$ & $\begin{array}{r}\text { Trace. } \\
3.7 \\
18.5 \\
5.3 \\
53.9 \\
\text { None. } \\
\text { Trace. }\end{array}$ & $\begin{array}{r}\text { Trace. } \\
\text { Trace. } \\
24.6 \\
6.3 \\
62.0 \\
1.6 \\
\text { None. }\end{array}$ & $\begin{array}{r}0.3 \\
.0 \\
18.9 \\
4.6 \\
43.9 \\
\text { None. } \\
.6 \\
1.1\end{array}$ & $\begin{array}{r}0.2 \\
.1 \\
18.4 \\
3.4 \\
42.6 \\
\text { None. } \\
.3 \\
\text { None. }\end{array}$ & $\begin{array}{r}\text { Trace. } \\
\text { None. } \\
30.4 \\
1.8 \\
59.0 \\
\text { Trace. } \\
\text { None. }\end{array}$ \\
\hline & 76.1 & 81.8 & $81 . \dot{4}$ & 94.5 & 69.4 & 65.0 & 91.2 \\
\hline
\end{tabular}

1. Eureka Calcium Works, Pomeroy, Ohio, 1911. R. F. Gardiner, analyst.

2. Liverpool Salt \& Coal Co., Hartford, W. V.a., 1911. R. F. Gardiner, analyst.

3. Hartford City Salt Co., Hartford, W. Va., 1911. R. F. Gardiner, analyst.

4. J. Q. Dickinson \& Co., Malden, W. Va., 1911. J. A. Cullen, analyst.

5. Saginaw Chemical Works, Saginaw, Mich. Traces of barium and strontium. Collected in 1911. R. F. Gardiner, analyst.

6. Van Schaack Calcium Works, Mount Pleasant, Mich., 1911. R. F. Gardiner, analyst.

7. Pittsburgh Calcium Chloride Works, Pittsburgh, Pa., 1911. R. F. Gardiner, analyst.

\section{COMPOSITION OF MISCELLANEOUS SUBSTANCES.}

The composition of miscellaneous substances obtained in the manufacture of salt from brines of New York, Michigan, and Ohio is shown by the following analyses: 
Analyses of miscellaneous substances obtained in the manufacture of salt from brines of New York, Michigan, and Ohio.

Radicles in percentage of total weight.

\begin{tabular}{|c|c|c|c|c|c|}
\hline & 1 & 2 & 3 & 4 & $a 5$ \\
\hline \multirow[t]{2}{*}{ 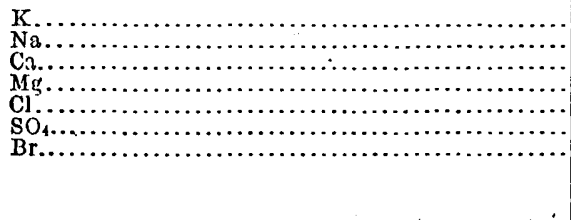 } & $\begin{array}{r}\text { Trace. } \\
26.0 \\
8.6 \\
\text { Trace. } \\
40.4 \\
20.0 \\
\text { None. }\end{array}$ & $\begin{array}{r}\text { Trace. } \\
31.9 \\
.1 \\
3.4 \\
45.0 \\
19.6 \\
\end{array}$ & $\begin{array}{r}0.1 \\
19.1 \\
14.2 \\
51.2 \\
5.0 \\
\text { None. }\end{array}$ & $\begin{array}{r}\text { Trace. } \\
18.4 \\
2.0 \\
3.2 \\
31.8 \\
2.4 \\
\text { Nonc. }\end{array}$ & $\begin{array}{r}1.4 \\
51.1 \\
10.8 \\
3.4 \\
107.8 \\
1.4 \\
\text { Trace. }\end{array}$ \\
\hline & 95.0 & 100.0 & 89.7 & 52.8 & 175.9 \\
\hline
\end{tabular}

$a$ Results expressed in grams per liter.

1. Worcester Salt Co., Silver Spring, N. Y. Dust from salt driers, said to contain an accumulation of gypsum, 1911. R. F. Gardiner, analyst.

2. Different sample of No. 1 .

3. Bliss-Van Auken Co., Saginaw, Mich. Sludge from grainer floor, removed during clean up, 1911. R. F. Gardiner, analyst.

4. Port Huron Salt Co., Port Huron, Mich. Sludge from settling tanks, 1911. R. F. Gardiner, analyst.

5. Slagel Salt Co., Mason, W. Va. Sediment from settler, 1911. R. F. Gardiner, analyst.

\section{POTASH FROM COMMERCIAL BRINES AND BITTERNS.}

The artificial brines and the bitterns derived from the main salt fields of the eastern United States appear to be valueless as sources of even low-grade salts of potassium.

The natural brines of Ohio, New York, and Michigan seem, however, to offer attractive fields for future investigation by industrial chemists. The brines found 250 to 400 feet above the top of the salt beds at some points in Ohio might be evaporated to make a low grade of manure salts, hartsalz, or kainite. Similar use might be made of the bitterns produced from sea water on the California coast. Detailed investigation of the chemical engineering features of such recovery may develop economic possibilities.

\section{POTASH SALTS.}

\section{SCOPE OF INVESTIGATIONS.}

The United States Geological Survey has concentrated its investigations of the possibilities of finding commercial deposits of soluble potash salts in the United States along the following lines: (1) Exploration by deep drilling for deposits in Nevada, Texas, and other western States; (2) examination of occurrences of certain rocks and minerals that are rich in potash; (3) investigation of the salt deposits, brines, and bitterns in the United States; (4) general geologic study of the "Red Beds" in the Southwest to determine the most favorable locations for future drilling operations. In addition to these general studies special investigations have been undertaken in areas where potash salts have been reported.

The papers listed below comprise those of most importance published to date on the series of studies just outlined. 


\section{BIBLIOGRAPHY.}

Butler, B. S., and Gale, H. S., Alunite, a newly discovered deposit near Marysvale, Utah: U. S. Geol. Survey Bull. 511, 64 pp., 1912.

Buther, B. S., Potash in certain copper and gold ores: U. S. Geol. Survey Bull. 620, pp. $227-236,1.915$.

Dole, R. B., Exploration of salines in Silver Peak Marsh, Nev.: U. S. Geol. Survey Bull. 530, pp. 330-345, 1913.

Gate, H. S., The search for potash in the desert basin region: U. S. Geol. Survey Bull. 530, pp. $295312,1913$.

- Nitrate deposits: U. S. Geol. Survey Bull. 523, 36 pp., 1912.

- Notes on the Quaternary lakes of the Great Basin, with special reference to the deposition of potash and other salines: U. S. Geol. Survey Bull. 540, pp. 339-406, 1914.

- Prospecting for potash in Death Valley, Cal.: U. S. Geol. Survey Bull. 540, pp. 407-415, 1914.

- Salt, borax, and potash in Saline Valley, Inyo County, Cal.: U. S. Geol. Survey Bull. 540, pp. 416-421, 1914.

— Potash tests at Columbus Marsh, Nev.: U. S. Geol. Survey Bull. 540, pp. 422427,1914

- Sodium sulphate in the Carrizo Plain, San Luis Obispo County, Cal.: U. S. Geol. Survey Bull. 540, pp. 428-433, 1914.

Salines in the Owens, Searles, and Panamint basins, southeastern California: U. S. Geol. Survey Bull. 580, pp. 251-323, 1914.

Hance, J. H., Potash in western saline deposits: U. S. Geol. Survey Bull. 540, pp. $457-469,1914$.

Hrcks, W. B., Composition of muds from Columbus Marsh, Nev.: U. S. Geol. Survey Prof. Paper 95, pp. 1-11, 1915.

- Evaporation of potash brines: U. S. Geol. Survey Prof. Paper 95, pp. 65-72, 1916.

Evaporation of brine from Searles Lake, Cal.: Prof. Paper 98, pp. 1-8, 1916.

Larsen, E. S., Alunite in the San Cristobal quarlrangle, Colo.: U. S. Geol. Survey Bull, 530, pp. 179-183, 1913.

Loughlin, G. F., Recent alunite developments near Marysvale and Beaver, Utah: U. S. Geol. Survey Bull. 620, pp. 237-270, 1915.

Mansfield, G. R., Nitrate deposits in southern Idaho and eastern Oregon: U. S. Geol. Survey Bull. 620 , pp. 19-94, 1915.

Phalen, W. C., Occurrence of potash salts in the bitterns of the eastern United States: U. S. Geol. Survey Bull. 530, pp. 313-329, 1913.

- Potash salts, their uses and occurrence in the Uniter States: U. S. Geol. Survey Mineral Resources, 1910, pt. 2, pp. 747-767, 1911.

—_ Potash salts: U. S. Geol. Survey Mineral Resources, 1911, pt. 2, pp. 889-917, 1912.

— Potash salts: U. S. Geol. Survey Mineral Resources, 1912, pt. 2, pp. 877-908, 1913.

- Potash salts: U. S. Geol. Survey Mineral Resources, 1913, pt. 2, pp. 85-107, 1914.

1. Potash salts, 1914: U. S. Geol. Survey Mineral Resources, 1914, pp. 9-34, 1916. Potash salts, 1915, with Simple tests for potash, by W. B. Hicks: U. S. Geol. Survey Mineral Resources, 1915, p.t. 2, pp. 95-133, 1916.

Rrchards, R. W., Niter near Melrose, Mont.: U. S. Geol. Survey Bull. 540, pp. 470$473,1914$. 
Schrader, F. C., Alunite in granite porphyry near Patagonia, Ariz.: U. S. Geol. Survey Bull. 540, pp. 347-350, 1914.

Alunite at Bovard, Nev.: U. S. Geol. Survey Bull. 540, pp. 351-356, 1914.

Schultz, A. R., and Cross, Whitman, Potash-bearing rocks of the Leucite Hills; Wyo.: U. S. Geol. Survey Bull. 512, 39 pp., 1912.

WELLS, R. C., Experiments on the extraction of potash from wyomingite: U. S. Geol. Survey Prof. Paper 98, pp. 37-40, 1916 (Prof. Paper 98-D).

\section{PRODUCTION OF SALT IN THE UNITED STATES.}

By A. T. Coons.

\section{RELIABILTTY OF STATISTICS.}

The figures given below as representing the production of salt in the United States for the years 1880 to 1917 are compiled from the records of the division of mineral resources of the United States Geological Survey and have been published in the annual volumes of Mineral Resources. The figures for 1880 are those collected by the Tenth Census and are for the census year June 1, 1879, to May 31, 1880. The statement for 1881 was largely estimated, and the returns for 1882 were derived from official reports made by the State salt inspectors and from estimates made by persons closely connected with the salt business. For the years 1883 and 1884 the figures were obtained more and more from the producers by correspondence, and from 1885 to the present time the figures have been compiled directly from reports of producers and contain practically no estimates. The unit of measurement of salt varies for different localities, the salt reported being measured in bushels of 56 pounds, in barrels of 280 pounds, and in tons of 2,000 pounds. As the earliest figures were all reduced to the barrel and published in that way, this measurement has been adhered to, although at present the measurement by tons is probably more common, all of the rock salt and a large part of the manufactured material being now sold by that standard. Many of the values given for the barreled salt prior to 1893 included the value of the barrels. This was obviously not the true value of the salt, and from 1893 to the present time the value has been that of the bulk salt itself as sold by the producer f. o. b. at point of shipment. 


\section{TOTAL PRODUCTION.}

The following table gives the statistics of the salt produced and sold in the United States from 1880 to 1917:

Salt produced and sold in the Uniied States, 1880-191'.

\begin{tabular}{|c|c|c|c|c|c|c|c|c|c|}
\hline \multirow{2}{*}{ Year. } & \multicolumn{2}{|c|}{$\begin{array}{l}\text { Salt manufactured } \\
\text { (evaporated). }\end{array}$} & \multicolumn{2}{|c|}{$\begin{array}{l}\text { Salt in brine (sold } \\
\text { or used by chemical } \\
\text { works). }\end{array}$} & \multicolumn{2}{|c|}{ Rock salt. } & \multicolumn{2}{|c|}{ Total. } & \multirow{2}{*}{$\begin{array}{c}\text { Aver } \\
\text { age } \\
\text { price } \\
\text { per } \\
\text { barrel. }\end{array}$} \\
\hline & $\begin{array}{c}\text { Quantity } \\
\text { (barrels, } \\
280 \\
\text { pounds). }\end{array}$ & Value. & $\begin{array}{l}\text { Quantity } \\
\text { (barrels, } \\
280 \\
\text { pounds). }\end{array}$ & Value. & $\begin{array}{c}\text { Quantity } \\
\text { (barrels, } \\
280 \\
\text { pounds). }\end{array}$ & Value. & $\begin{array}{c}\text { Quantity } \\
\text { (barrels, } \\
230 \\
\text { pounds). }\end{array}$ & Value. & \\
\hline $\begin{array}{l}1905 . \\
1906 . \\
1907 . \\
1908 . \\
1909 . \\
1910 . \\
1911 . \\
1912 . \\
1913 . \\
1914 . \\
1915 . \\
1916 .\end{array}$ & 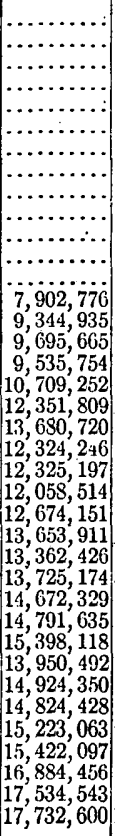 & 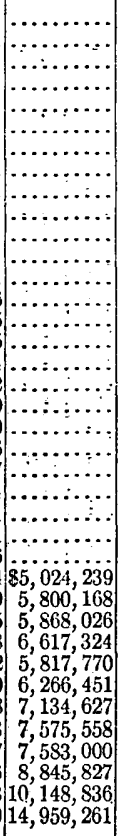 & 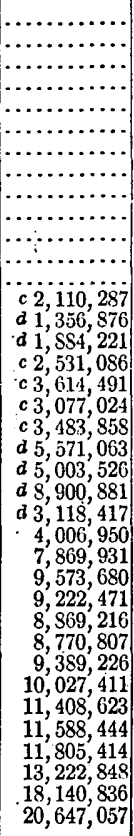 & 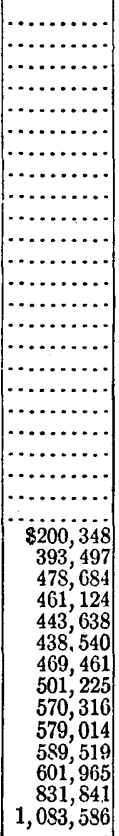 & 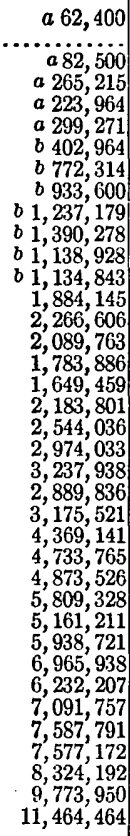 & \begin{tabular}{r}
$\ldots \ldots .$. \\
\hdashline $1,155,427$ \\
$1,347,031$ \\
$1,241,968$ \\
$1,287,967$ \\
$1,613,113$ \\
$1,578,016$ \\
$1,697,829$ \\
$1,968,567$ \\
$2,024,898$ \\
$2,229,894$ \\
$2,665,270$ \\
$3,897,595$
\end{tabular} & $\begin{array}{r}\mathbf{5}, 961,060 \\
6,200,000 \\
6,412,373 \\
6,192,231 \\
6,514,937 \\
7,038,653 \\
7,707,081 \\
8,003,962 \\
8,055,881 \\
8,005,565 \\
8,876,991 \\
9,987,945 \\
11,698,890 \\
11,897,208 \\
12,968,417 \\
13,669,649 \\
13,850,726 \\
15,973,202 \\
17,612,634 \\
19,708,614 \\
20,869,342 \\
20,566,661 \\
23,849,231 \\
18,968,089 \\
22,030,002 \\
25,966,122 \\
28,172,380 \\
29,704,128 \\
28,822,062 \\
30,107,646 \\
30,305,656 \\
31,183,968 \\
33,324,808 \\
34,399,298 \\
34,804,683 \\
38,431,496 \\
45,449,329 \\
49,844,121 \\
\end{array}$ & \begin{tabular}{|}
$\$ 4,829,566$ \\
$4,200,000$ \\
$4,320,140$ \\
$4,251,042$ \\
$4,197,734$ \\
$4,825,345$ \\
$4,736,585$ \\
$4,093,846$ \\
$4,374,203$ \\
$4,195,412$ \\
$4,752,286$ \\
$4,716,121$ \\
$5,654,915$ \\
$4,154,668$ \\
$4,739,285$ \\
$4,423,084$ \\
$4,040,839$ \\
$4,920,020$ \\
$6,212,554$ \\
$6,867,467$ \\
$6,944,603$ \\
$6,617,449$ \\
$5,668,636$ \\
$5,286,988$ \\
$6,021,222$ \\
$6,095,922$ \\
$6,658,350$ \\
$7,608,323$ \\
$7,553,632$ \\
$8,343,831$ \\
$7,900,344$ \\
$8,345,692$ \\
$9,402,772$ \\
$10,123,139$ \\
$10,197,417$ \\
$11,747,686$ \\
$13,645,947$ \\
$19,940,449$ \\
\end{tabular} & $\begin{array}{r}80.81 \\
.68 \\
.67 \\
.69 \\
.64 \\
.69 \\
.61 \\
.51 \\
.54 \\
.52 \\
.54 \\
.47 \\
.48 \\
.35 \\
.37 \\
.32 \\
.29 \\
.31 \\
.35 \\
.35 \\
.33 \\
.32 \\
.24 \\
.28 \\
.27 \\
.23 \\
.24 \\
.26 \\
.26 \\
.28 \\
.26 \\
.27 \\
.28 \\
.29 \\
.29 \\
.31 \\
.30 \\
.40\end{array}$ \\
\hline
\end{tabular}

a Louisiana.

$b$ J.ouisiana and New York.

c Includes a small quantity of solar salt. $d$ Includes a small quantity of manufactured sait.

With the exception of fluctuations in the years $1883,1889,1901,1903$, and 1908, caused by trade conditions, there has been a steady increase in both quantity and value of the salt produced in the United States since figures of production have been available. During the last 10 years the total quantity has increased 65 per cent, while the value has increased 162 per cent, with an increase in average price of 14 cents. The large increase in value has been due in part to the gradual adoption of various processes of making high grades of salt for table, dairy, and manufacturing use, the increased use of rock salt, and since 1914 to the increase in prices necessary to offset the increased cost of fuel, labor, and supplies caused by the war. The values and average 


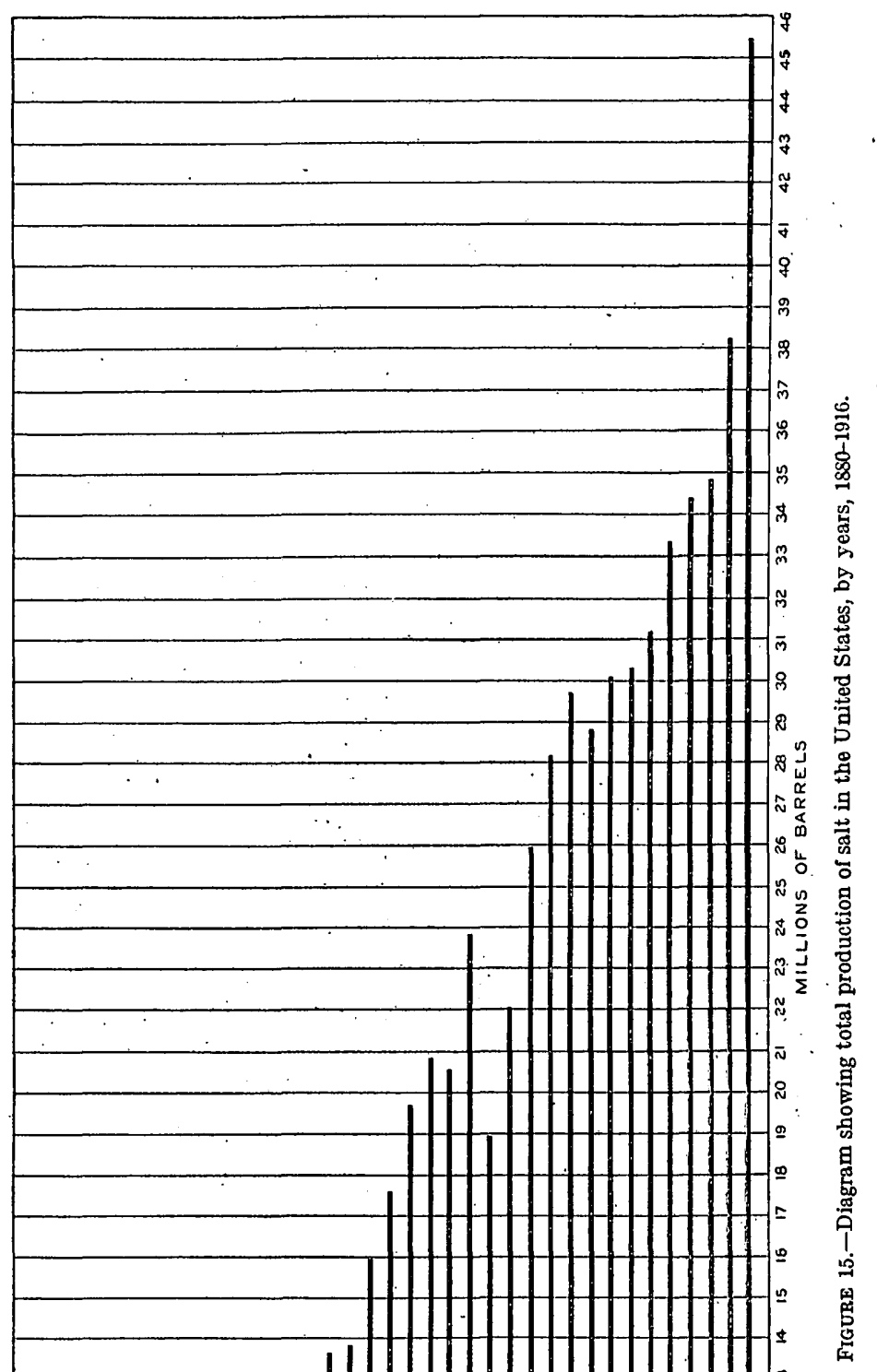


prices given in the above table are influenced by the increase in quantity of salt produced and used by alkali and chemical manufacturers. The salt content of the brines used by these firms has necessarily a low value, as the producers do not calculate the value of this salt until after its conversion into other chemicals. During the last 10 years the salt in these brines has increased 123 per cent.

Rock-salt production has increased 97 per cent during this period; a gain which is accounted for by the increased demand for chemicals

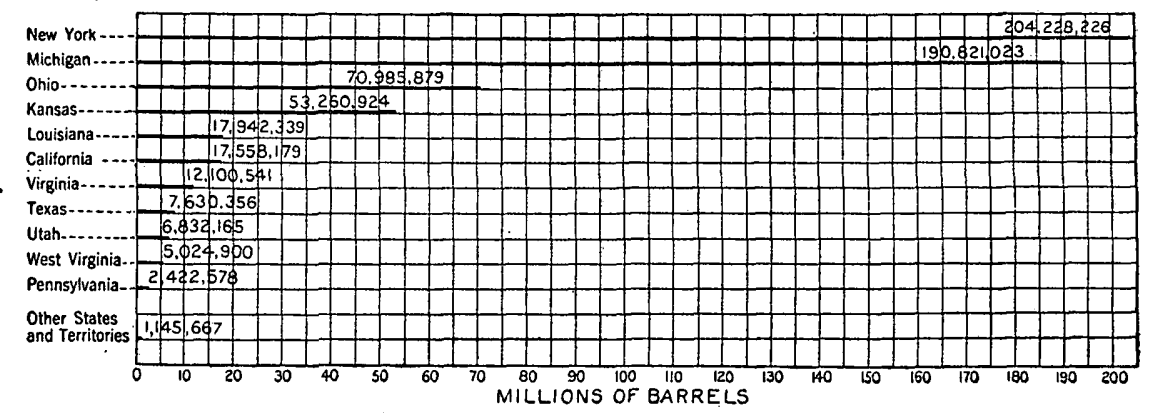

FIGURE 16.-Diagram showing total production of salt in the United States, by States, 1894-1916. .

and the readiness with which the production by mining can be expanded in comparison with the evaporation of brine.

The production of evaporated salt increased 20 per cent during the 10 years, and in 1917 showed an increase of but 1.1 per cent over 1916, compared with increases of 13.8 per cent and 17.3 per cent, respectively, for salt contained in brines and in rock salt.

The increase in the production of salt in the United States from 1880 to 1916 is shown diagrammatically in figures 15 and 16 .

\section{PRODUCTION BY GRADES.}

The collection of statistics by grades of manufactured salt was not attempted until 1893. Though the various grades are not known by the same trade names in all the States, the following table is presented as representing the method of grading the salt sold in the United States: 


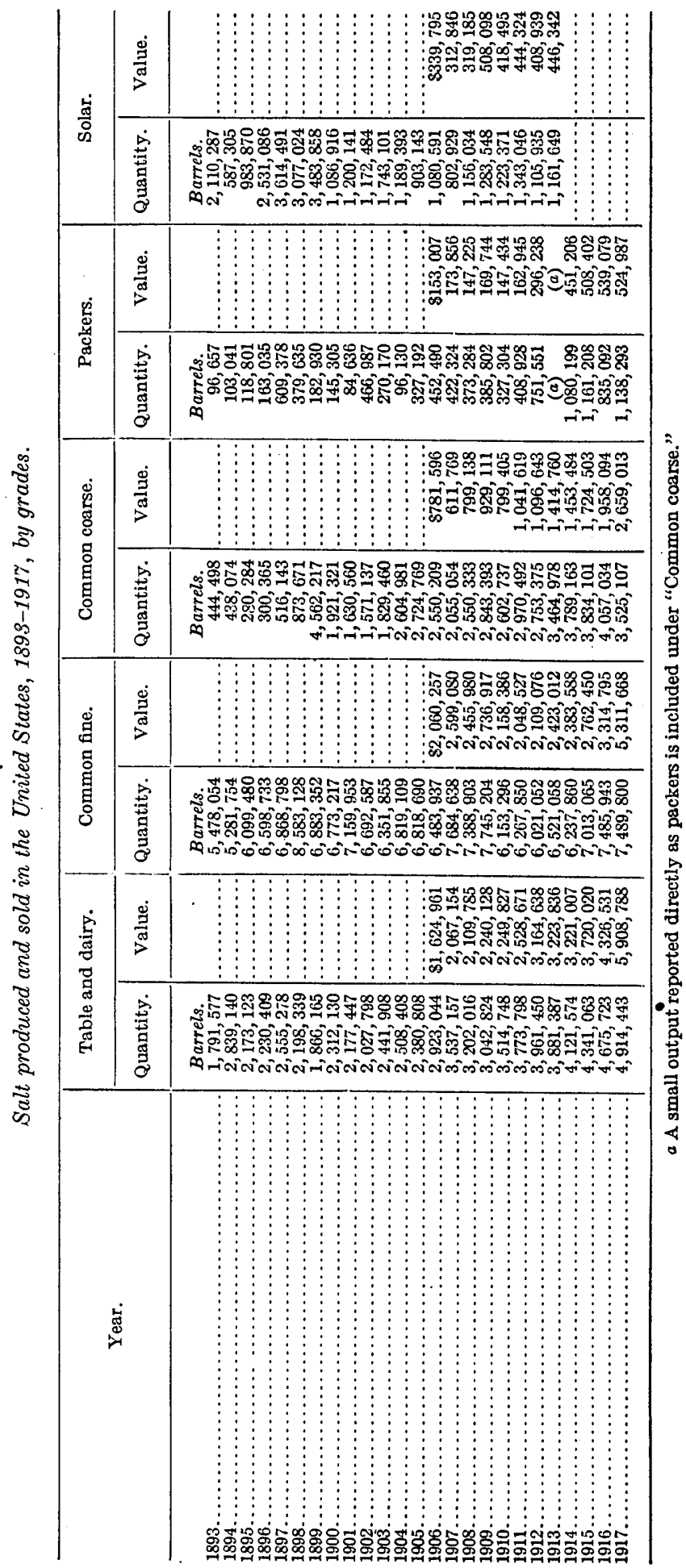




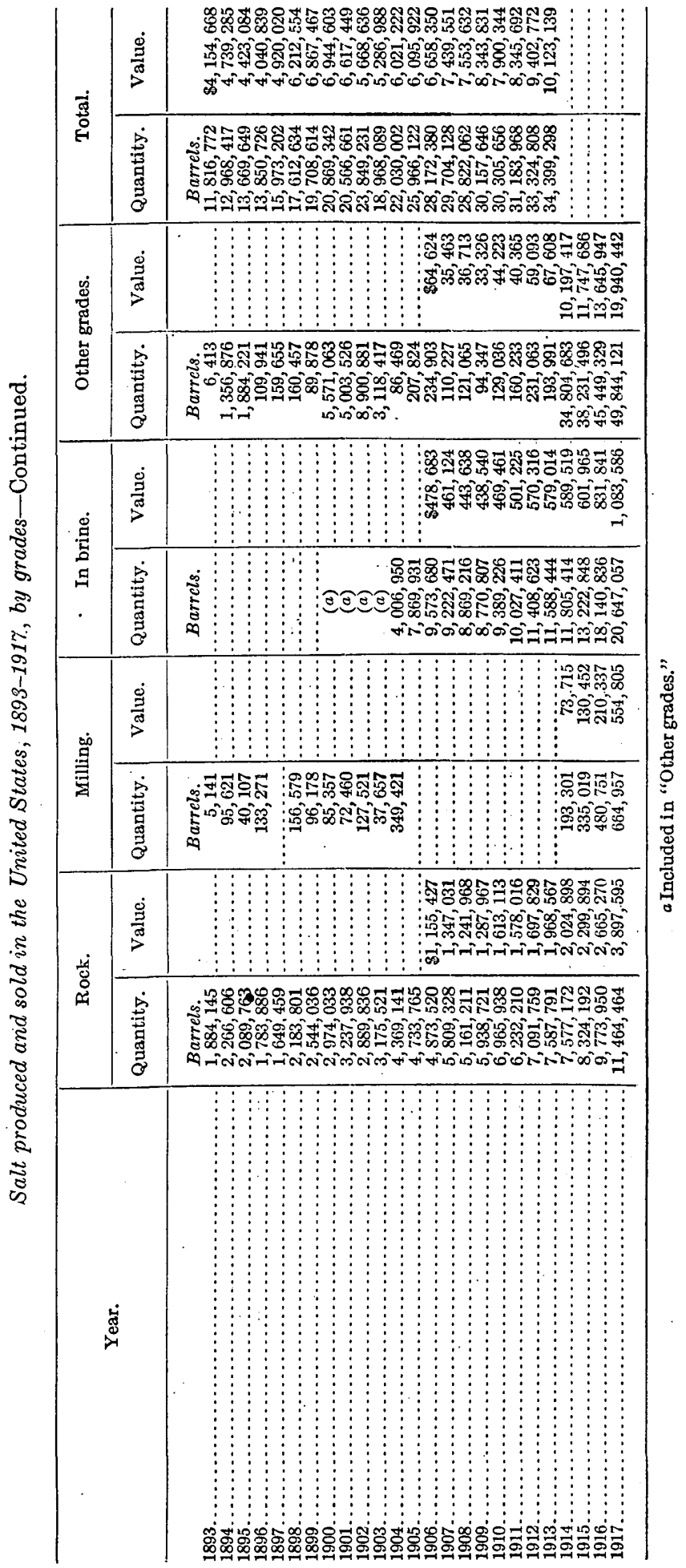


In this classification table and dairy salt includes tablo, butter, cheese, pretzel, casing, "paste," and similar special brands, generally artificially dried. Packers', common fine, and common coarse include salt used in curing fish, packing moat, preparing pickles, curing hides, and for packing purposes in general, and also salt known as "medium No. 1" and "ground alum." Coarse solar, as the name suggests, includes coarse salt manufactured by solar evaporation. Rock salt includes all salt mined and shipped, whether ground, lumped, or screened. Other grades include all second-grade or No. 2 salt, such as agricultural and refuse salt, including swcepings. Salt in brine includes the salt content of all salt liquor used in the manufacture of soda ash and other chemicals or sold without being eraporated to dryness.

\section{PRODUCTION BY STATES.}

The statistics of the production of salt by States are rather unsatisfactory for the first few years because of the difficulty experienced in getting into touch with the producers themselves and the necessity of depending on dealers, railroads, and State inspectors for information. Nevertheless the following comparative tables are presented, the records for the earlier years being the most complete obtainable.

Salt produccd and sold in the United States, 1880-191\%, by States.

\begin{tabular}{|c|c|c|c|c|c|c|}
\hline \multirow{2}{*}{ State. } & \multicolumn{2}{|c|}{$1880 a$} & \multicolumn{2}{|c|}{1881} & \multicolumn{2}{|c|}{1882} \\
\hline & $\begin{array}{l}\text { Quantity } \\
\text { (barrels). }\end{array}$ & V'alue. & $\begin{array}{l}\text { Quantity } \\
\text { (barrels). }\end{array}$ & Value. & $\begin{array}{l}\text { Quantity } \\
\text { (barrels). }\end{array}$ & Value. \\
\hline 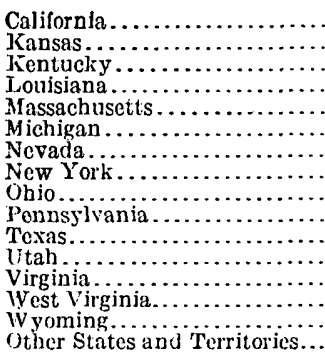 & $\begin{array}{r}176,949 \\
2,600 \\
16,600 \\
62,400 \\
1,915 \\
2,485,177 \\
36,482 \\
1,749,641 \\
530,060 \\
170,290 \\
10,120 \\
96,760 \\
85,179 \\
535,887 \\
1,000 \\
\ldots \ldots\end{array}$ & $\begin{array}{r}\$ 121,650 \\
5,700 \\
21,950 \\
56,160 \\
3,800 \\
2,271,913 \\
92,640 \\
1,107,760 \\
363,791 \\
177,415 \\
29,700 \\
60,280 \\
127,678 \\
380,369 \\
8,760 \\
\ldots \ldots \ldots\end{array}$ & 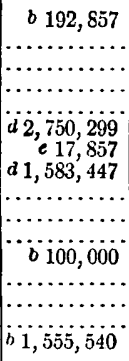 & 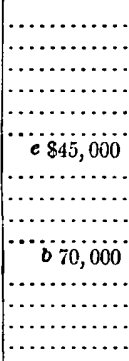 & 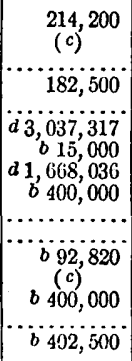 & $\begin{array}{c}\$ 150,000 \\
(c) \\
\cdots \ldots \ldots \\
(c) \\
\ldots \ldots \\
2,126,122 \\
37,800 \\
834,018 \\
300,000 \\
\ldots \ldots \ldots . . \\
\ldots \ldots 5,000 \\
(c) \\
300,000 \\
\ldots \ldots \\
507,200\end{array}$ \\
\hline & $5,061,060$ & $4, \$ 29,506$ & $6,200,000$ & $4,200,000$ & $6,412,373$ & $4,320,140$ \\
\hline
\end{tabular}

a Figures for census year ending May 31, 1880.

$b$ Estimated.

c Included in "Other States and Territories."

$d$ Report of State salt inspector.

e Churchill County only.

$40104^{\circ}-18-$ Bull. $669-17$ 
Salt produced and sold in the United States, 1880-191\%, by States-Continued.

\begin{tabular}{|c|c|c|c|c|c|c|}
\hline \multirow{2}{*}{ State. } & \multicolumn{2}{|c|}{1883} & \multicolumn{2}{|c|}{1884} & \multicolumn{2}{|c|}{1885} \\
\hline & $\begin{array}{l}\text { Quantity } \\
\text { (barrels). }\end{array}$ & Value. & $\begin{array}{l}\text { Quantity } \\
\text { (barrels). }\end{array}$ & Value. & $\begin{array}{l}\text { Quantity } \\
\text { (barrels). }\end{array}$ & Value. \\
\hline \multirow[t]{2}{*}{ 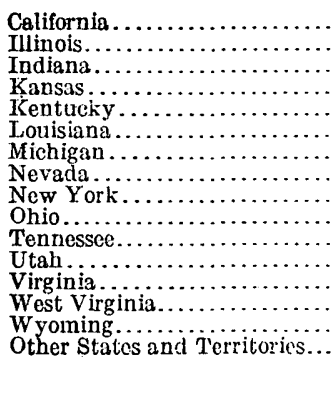 } & $\begin{array}{c}214,286 \\
(a) \\
(a) \\
(a) \\
(a) \\
265,215 \\
2,394,672 \\
21,429 \\
1,619,486 \\
350,000 \\
(a) \\
107,143 \\
(a) \\
320,000 \\
\ldots \ldots \ldots\end{array}$ & $\begin{array}{c}\$ 150,000 \\
(a) \\
(a) \\
(a) \\
(a) \\
141,125 \\
2,344,684 \\
15,000 \\
680,638 \\
231,000 \\
(a) \\
100,000 \\
(a) \\
211,000\end{array}$ & $\begin{array}{c}178,571 \\
(a), \\
(a) \\
(a) \\
(a) \\
223,964 \\
3,161,806 \\
17,857 \\
1,788,454 \\
320,000 \\
(a) \\
114,255 \\
(a) \\
310,000 \\
(a) \\
400,000\end{array}$ & $\begin{array}{l}\$ 120,000 \\
(a) \\
(a) \\
(a) \\
(a) \\
125,677 \\
2,392,5310 \\
12,500 \\
705,978 \\
201,600 \\
(a) \\
80,000 \\
(a) \\
195,000 \\
(a) \\
301,443\end{array}$ & $\begin{array}{c}221,428 \\
(a) \\
(a) \\
(a) \\
(a) \\
299,271 \\
3,297,403 \\
28,593 \\
2,304,787 \\
305,847 \\
(a) \\
107,140 \\
(a) \\
223,184 \\
(a) \\
250,000\end{array}$ & $\begin{array}{l}\$ 160,000 \\
(a) \\
(a) \\
(a) \\
(a) \\
139,911 \\
2,967,663 \\
20,000 \\
874,258 \\
109,150 \\
(a) \\
75,000 \\
(a) \\
145,070 \\
(a) \\
243,993\end{array}$ \\
\hline & $(i, 192,231$ & $4,251,042$ & $6,514,937$ & $4,197,734$ & $7,038,653$ & $4,825,345$ \\
\hline \multirow{2}{*}{ State. } & \multicolumn{2}{|c|}{1889} & \multicolumn{2}{|c|}{1887} & \multicolumn{2}{|c|}{1888} \\
\hline & $\begin{array}{l}\text { Quantity } \\
\text { (barrels). }\end{array}$ & Value. & $\begin{array}{l}\text { Quantity } \\
\text { (barrels). }\end{array}$ & Value. & $\begin{array}{l}\text { Quantity } \\
\text { (barrels). }\end{array}$ & Value. \\
\hline \multirow[t]{2}{*}{ 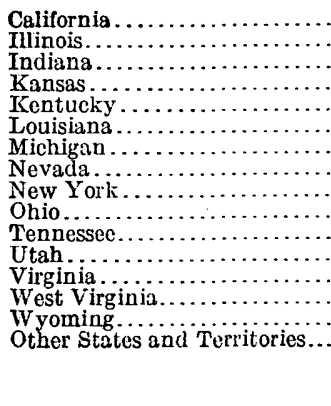 } & $\begin{array}{c}214,285 \\
(a) \\
(a) \\
(a) \\
(a) \\
299,691 \\
3,677,257 \\
30,000 \\
2,431,563 \\
400,000 \\
(a) \\
164,285 \\
(a) \\
250,000 \\
(a) \\
240,000\end{array}$ & $\begin{array}{l}\$ 150,000 \\
(a) \\
(a) \\
(a) \\
(a) \\
108,372 \\
2,426,989 \\
21,000 \\
1,243,721 \\
260,000 \\
(a) \\
100,000 \\
(a) \\
162,500 \\
(a) \\
264,003\end{array}$ & $\begin{array}{c}200,000 \\
(a) \\
(a) \\
(a) \\
(a) \\
341,093 \\
3,944,304 \\
\cdots 2, \ldots 3,560 \\
2,353,50 \\
355,000 \\
(a) \\
325,000 \\
(a) \\
225,000 \\
250,000\end{array}$ & $\begin{array}{c}\$ 140,000 \\
(a) \\
(a) \\
(a) \\
(a) \\
118,735 \\
2,291,842 \\
\cdots \ldots 30,894 \\
219,000 \\
(a) \\
102,375 \\
(a) \\
135,000 \\
150,009\end{array}$ & $\begin{array}{c}220,000 \\
(a) \\
(a) \\
155,000 \\
(a) \\
394,385 \\
3,866,228 \\
(a) \\
2,318,483 \\
380,000 \\
(a) \\
151,785 \\
(a) \\
220,000 \\
350,000\end{array}$ & $\begin{array}{l}892,400 \\
(a) \\
(a) \\
189,000 \\
(a) \\
134,652 \\
2,2 i j 1,743 \\
(a) \\
1,130,409 \\
247,000 \\
(a) \\
32,000 \\
(a) \\
143,000\end{array}$ \\
\hline & $7,707,081$ & $4,736,585$ & $8,003,962$ & $4,093,340$ & $8,055,881$ & $4,374,203$ \\
\hline \multirow{2}{*}{ State. } & \multicolumn{2}{|c|}{1889} & \multicolumn{2}{|c|}{1890} & \multicolumn{2}{|c|}{1891} \\
\hline & $\begin{array}{l}\text { Quantity } \\
\text { (barrols). }\end{array}$ & Value: & $\begin{array}{l}\text { Ruantity } \\
\text { (barrels). }\end{array}$ & Value. & $\begin{array}{l}\text { Quantit.y } \\
\text { (barrels). }\end{array}$ & Value. \\
\hline 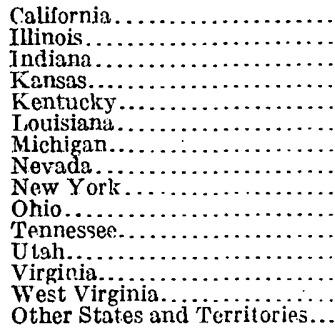 & \begin{tabular}{c}
150,000 \\
$(a)$ \\
$(a)$ \\
450,000 \\
$(a)$ \\
325,629 \\
$3,856,929$ \\
\hdashline $2,27,007$ \\
250,000 \\
$(a)$ \\
200,000 \\
$(a)$ \\
200,000 \\
300,000
\end{tabular} & $\begin{array}{l}863,000 \\
(a) \\
(a) \\
202,500 \\
(a) \\
152,000 \\
2,089,909 \\
1,133 j, 503 \\
162,500 \\
(a) \\
60,000 \\
(a) \\
130,000 \\
200,000\end{array}$ & $\begin{array}{c}62,363 \\
(a) \\
(a) \\
882,666 \\
(a) \\
273,553 \\
3,837,632 \\
(a) \\
2,532,030 \\
231,303 \\
(a) \\
427,500 \\
(a) \\
229,038 \\
300,000\end{array}$ & $\begin{array}{c}\$ 5 \overrightarrow{7}, 085 \\
(a) \\
(a) \\
397,199 \\
(a) \\
132,000 \\
2,302,579 \\
(a) \\
1,266,018 \\
166,617 \\
(a) \\
126,100 \\
(a) \\
134,688 \\
200,000\end{array}$ & $\begin{array}{r}200,949 \\
39,670 \\
\ldots 855,536 \\
7173,714 \\
3,961,784 \\
60,799 \\
2,839,544 \\
(a) \\
(a) \\
969,000 \\
70,442 \\
(a) \\
811,507\end{array}$ & $\begin{array}{r}\$ 90,303 \\
34,309 \\
\times 304,775 \\
109,375 \\
2,037,289 \\
39,898 \\
1,340,036 \\
(a) \\
(a) \\
265,350 \\
70,425 \\
(a), \\
430,761\end{array}$ \\
\hline & $8,005,565$ & $4,195,412$ & $8,776,091$ & $4,752,286$ & $9,997,945$ & $4,716,121$ \\
\hline
\end{tabular}

a Included in "Other States and Territories." 
Salt produced and sold in the United States, 1980-191\%, by States-Continued.

\begin{tabular}{|c|c|c|c|c|c|c|}
\hline \multirow{2}{*}{ Staid } & \multicolumn{2}{|c|}{1892} & \multicolumn{2}{|c|}{ 189? } & \multicolumn{2}{|c|}{1894} \\
\hline & $\begin{array}{l}\text { Quantity } \\
\text { (ba: rels). }\end{array}$ & Valtue. & $\begin{array}{l}\text { Quantity } \\
\text { (barrels). }\end{array}$ & Value. & $\begin{array}{l}\text { Quantily } \\
\text { (barrels). }\end{array}$ & Value. \\
\hline \multirow[t]{2}{*}{ 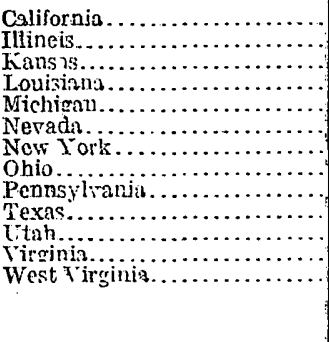 } & $\begin{array}{r}235,774 \\
60,000 \\
1,480,100 \\
209,000 \\
3,829,478 \\
29,929 \\
3,472,073 \\
a 899,244 \\
25,571 \\
121,250 \\
1,292,471 \\
60,000 \\
(b)\end{array}$ & $\begin{array}{r}\$ 104,938 \\
48,000 \\
773,989 \\
100,000 \\
2,046,963 \\
22,806 \\
1,662,816 \\
a 394,720 \\
10,741 \\
99,500 \\
340,442 \\
50,000 \\
(b)\end{array}$ & $\begin{array}{r}292.858 \\
59,161 \\
1,277,180 \\
191,430 \\
3,057,898 \\
6,559 \\
5,662,074 \\
543,963 \\
280,343 \\
126,900 \\
189,006 \\
210,736\end{array}$ & $\begin{array}{r}\$ 137,962 \\
30,168 \\
471,543 \\
97,200 \\
888, \$ 37 \\
4,481 \\
1,870,084 \\
209,393 \\
136,436 \\
110,267 \\
130,075 \\
68,292\end{array}$ & $\begin{array}{r}322,246 \\
50,000 \\
1,382,409 \\
186,050 \\
3,341,425 \\
3,670 \\
6,270,588 \\
528,990 \\
203,230 \\
142,857 \\
268,180 \\
64,222 \\
194,532\end{array}$ & $\begin{array}{r}8172,073 \\
27,500 \\
529,392 \\
86,134 \\
1,243,619 \\
4,030 \\
1,999,146 \\
197,432 \\
83,750 \\
101,000 \\
209,077 \\
43,580 \\
51,947\end{array}$ \\
\hline & $11,698,890$ & $5,65 \pm, 915$ & $11,897,208$ & $4,154,668$ & $12,908,417$ & $4,739,285$ \\
\hline \multirow{2}{*}{ State. } & \multicolumn{2}{|c|}{1895} & \multicolumn{2}{|c|}{1890} & \multicolumn{2}{|c|}{1897} \\
\hline & $\begin{array}{l}\text { Quantity } \\
\text { (barrels). }\end{array}$ & Value. & $\begin{array}{l}\text { Quantity } \\
\text { (barrels). }\end{array}$ & Value. & $\begin{array}{l}\text { Quantity } \\
\text { (barrels). }\end{array}$ & Value. \\
\hline \multirow[t]{2}{*}{ 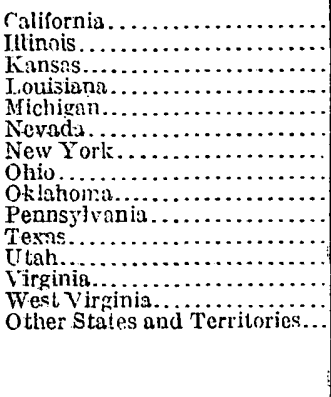 } & $\begin{array}{r}318,935 \\
67,119 \\
1,341,617 \\
159,771 \\
3,343,395 \\
7,000 \\
6,832,331 \\
731,033 \\
\ldots .37,233 \\
155,000 \\
294,485 \\
65,000 \\
176,720 \\
\ldots \ldots . \ldots .\end{array}$ & $\begin{array}{r}8158,683 \\
31,548 \\
483,701 \\
78,169 \\
1,048,251 \\
5,600 \\
1,943,398 \\
326,520 \\
\ldots \ldots 7,411 \\
53,000 \\
121,762 \\
40,000 \\
63,041\end{array}$ & $\begin{array}{c}430,121 \\
(c) \\
1,408,607 \\
(c) \\
3,1(i 4,238 \\
(c) \\
6,069,040 \\
1,6 f i 2,359 \\
\cdots 198,596 \\
(c) \\
270,800 \\
(c) \\
176,921 \\
461,045\end{array}$ & $\begin{array}{c}8198,963 \\
(c) \\
397,296 \\
(c) \\
718,408 \\
(c) \\
1, \$ 96,681 \\
432,877 \\
956,717 \\
(c) \\
96,550 \\
(c) \\
50,717 \\
192,630\end{array}$ & $\begin{array}{c}470,893 \\
(c) \\
1,538,327 \\
(c) \\
3,993,225 \\
(c) \\
6,805,851 \\
1,575,414 \\
(c) \\
164,287 \\
(c) \\
405,179 \\
(c) \\
441,893 \\
579,130\end{array}$ & $\begin{array}{c}\$ 162,654 \\
(c) \\
489,022 \\
(c) \\
1,253,403 \\
(c) \\
1,948,759 \\
421,757 \\
(c) \\
45,107 \\
(c) \\
196,056 \\
(c), \\
160,129 \\
214,133\end{array}$ \\
\hline & $13,669,649$ & $4,423,084$ & $13,850,720$ & $4,040,839$ & $15,973,202$ & $4,920,020$ \\
\hline \multirow[b]{2}{*}{ State. } & \multicolumn{2}{|c|}{1898} & \multicolumn{2}{|c|}{1899} & \multicolumn{2}{|c|}{1900} \\
\hline & $\begin{array}{l}\text { Quantity } \\
\text { (barrels). }\end{array}$ & Value. & $\begin{array}{l}\text { Quantity } \\
\text { (barrels). }\end{array}$ & Value. & $\begin{array}{l}\text { Quantity } \\
\text { (barrels). }\end{array}$ & Value. \\
\hline 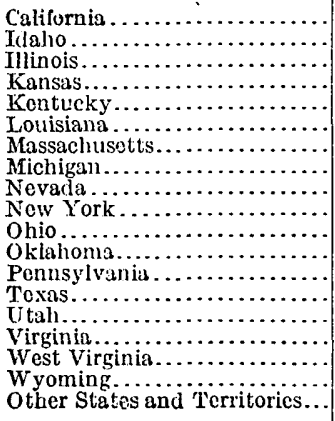 & 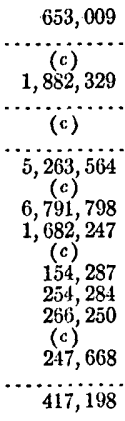 & $\begin{array}{r}\$ 185,848 \\
(c) \\
616,591 \\
(c) \\
\ldots \ldots \ldots \\
1,628,081 \\
(c) \\
2,369,323 \\
826,868 \\
(c) \\
46,000 \\
119,700 \\
103,778 \\
(c) \\
88,462 \\
\ldots \ldots 27,903\end{array}$ & $\begin{array}{c}642,563 \\
(c) \\
(c) \\
1,645,350 \\
(c) \\
(c) \\
(c) \\
7,117,382 \\
7,671 \\
7,489,105 \\
1,460,516 \\
5,248 \\
(c) \\
312,436 \\
236,135 \\
(c) \\
221,534 \\
(c) \\
570,674\end{array}$ & $\begin{array}{c}\$ 281,741 \\
(c) \\
(c) \\
546,291 \\
(c) \\
(c) \\
(c) \\
2,205,924 \\
10,084 \\
2,540,426 \\
575,864 \\
4,704 \\
(c) \\
204,330 \\
115,100 \\
(c) \\
107,987 \\
(c) \\
275,016\end{array}$ & $\begin{array}{c}621,857 \\
(c) \\
(c) \\
2,233,878 \\
(c) \\
(c) \\
(c) \\
7,210,621 \\
(c) \\
7,897,071 \\
1,425,283 \\
5,861 \\
(c) \\
(c) \\
249,128 \\
(c) \\
243,873 \\
\ldots \ldots 31,770 \\
980\end{array}$ & $\begin{array}{c}\$ 216,291 \\
(c) \\
(c) \\
1,076,945 \\
(c) \\
(c) \\
(c) \\
2,033,731 \\
(c) \\
2,171,418 \\
696,326 \\
6,136 \\
(c) \\
(c) \\
151,662 \\
(c) \\
118,407 \\
\ldots \ldots 73,687 \\
473,687\end{array}$ \\
\hline & $17,612,634$ & $6,212,554$ & $19,708,614$ & $6,867,467$ & $20,869,342$ & $6,944,603$ \\
\hline
\end{tabular}


Salt produced and sold in the United States, 1880-191\%, by States-Continued.

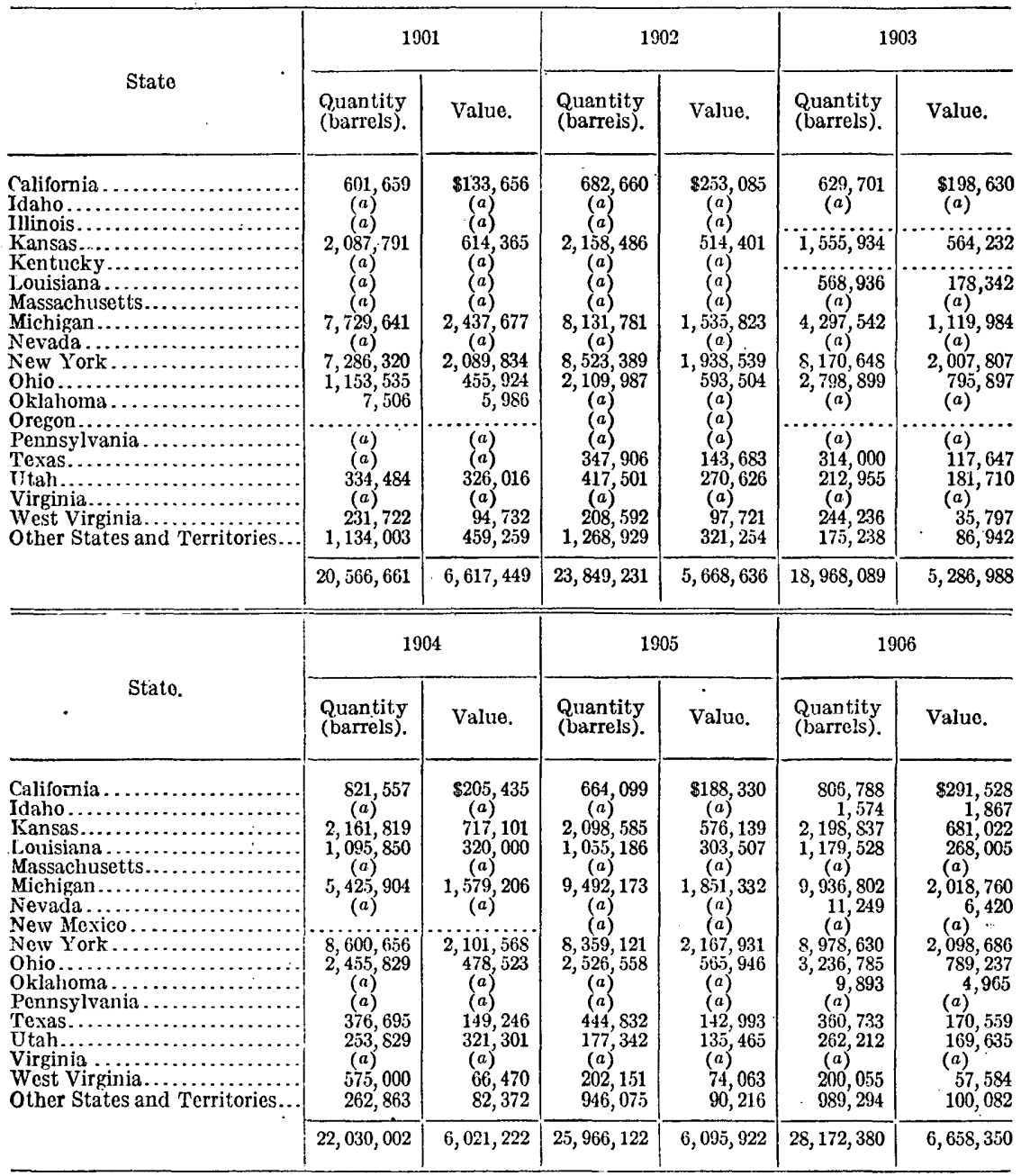


Salt produced and sold in the United States, 18\$0-191\%, by States-Continued.

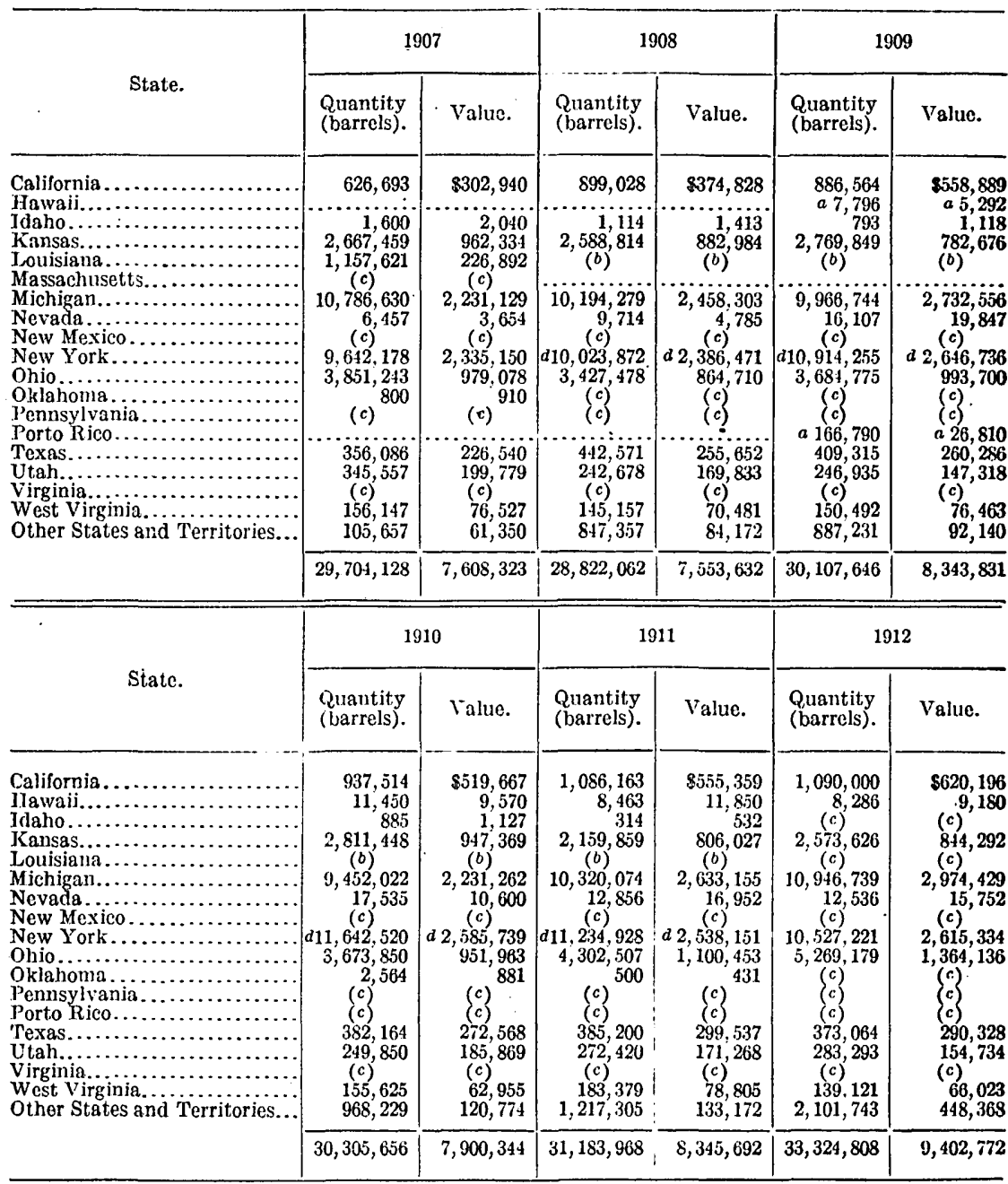

a Statisties not obtained before 1909

$b$ Included in New York.

c Included in "Other States and Territories."

d Includes Louisiana. 
Salt produced and sold in the Linited States, 1880-191\%, by States-Continued.

\begin{tabular}{|c|c|c|c|c|c|c|}
\hline \multirow{2}{*}{ State. } & \multicolumn{2}{|c|}{1913} & \multicolumn{2}{|c|}{1914} & \multicolumn{2}{|c|}{ 191; } \\
\hline & $\begin{array}{l}\text { Quantity } \\
\text { (barrels). }\end{array}$ & Value. & $\begin{array}{l}\text { Quantity } \\
\text { (barrels). }\end{array}$ & Value. & $\begin{array}{l}\text { Quantity } \\
\text { (barrels). }\end{array}$ & Value. \\
\hline \multirow[t]{2}{*}{ 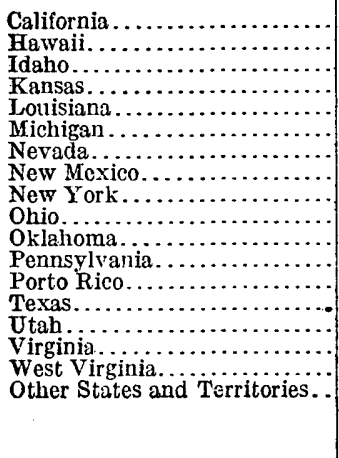 } & $\begin{array}{c}1,082,993 \\
6,071 \\
(a) \\
2,638,079 \\
(a) \\
11,528,800 \\
8,971 \\
(a), \\
10,780,514 \\
5,310,135 \\
(a) \\
(a) \\
(a) \\
355,529 \\
330,443 \\
(a) \\
113,921 \\
2,183,842\end{array}$ & $\begin{array}{r}\$ 759,485 \\
5,950 \\
(a) \\
860,404 \\
(a) \\
3,293,032 \\
7,947 \\
(a) \\
2,865,187 \\
1,318,156 \\
(a) \\
(a) \\
(a) \\
278,008 \\
191,680 \\
(a), \\
63,803 \\
479,481\end{array}$ & $\begin{array}{r}1,100,443 \\
2,967,864 \\
(a) \\
11,670,976 \\
4,336 \\
(a) \\
10,389,314 \\
5,482,836 \\
(a) \\
(a) \\
(a) \\
334,979 \\
375,457 \\
(a) \\
145,429 \\
2,332,649\end{array}$ & $\begin{array}{r}\$ 782,921 \\
520 \\
924,550 \\
(a) \\
3,299,005 \\
2,448 \\
(a) \\
3,824,733 \\
1,320,554 \\
(a) \\
(a) \\
(a) \\
251,493 \\
231,512 \\
(a) \\
78,036 \\
481,646\end{array}$ & $\begin{array}{r}1,048,457 \\
(a) \\
3,765,164 \\
(a) \\
12,588,788 \\
6,929 \\
(a) \\
11,217,471 \\
5,880,243 \\
(a) \\
(a) \ldots \\
444,978 \\
394,850 \\
(a) \\
232,239 \\
2,652,37 i\end{array}$ & $\begin{array}{l}\$ 694,070 \\
(a) \\
(a) \\
1,035,879 \\
(a) \\
4,301,731 \\
3,930 \\
(a) \\
2,970,405 \\
1,462,192 \\
(a) \\
(a) \\
(a) \\
345,944 \\
266,331 \\
(a) \\
115,143 \\
543,033\end{array}$ \\
\hline & $34,399,298$ & $10,123,139$ & $34,804,683$ & $10,197,417$ & $38,231,496$ & $11,747,686$ \\
\hline \multirow{2}{*}{\multicolumn{3}{|c|}{ State. }} & \multicolumn{2}{|c|}{1916} & \multicolumn{2}{|c|}{1917} \\
\hline & & & $\begin{array}{l}\text { Quantity } \\
\text { (barrels). }\end{array}$ & Value. & $\begin{array}{l}\text { Quantity } \\
\text { (barrels). }\end{array}$ & Value. \\
\hline 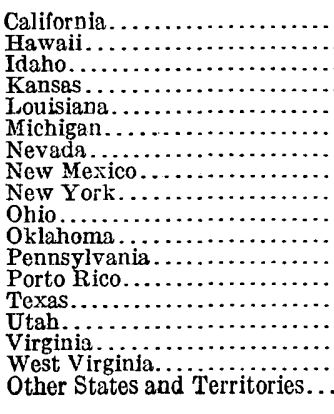 & ……...... & 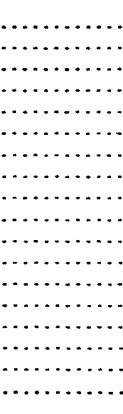 & $\begin{array}{r}1,124,236 \\
(a) \\
314 \\
4,564,793 \\
(a) \\
14,918,275 \\
(a) \\
(a) \\
14,087,750 \\
6,706,193 \\
(a) \\
(a) \\
541,157 \\
433,233 \\
(a), 493 \\
238,493 \\
2,834,879 \\
\end{array}$ & $\begin{array}{r}\$ 656,975 \\
(a) \\
1,311 \\
1,302,359 \\
(a) \\
4,612,567 \\
(a) \\
(a) \\
3,698,798 \\
2,038,749 \\
(a) \\
(a) \\
467,119 \\
289,457 \\
(a) \\
122,669 \\
496,743 \\
\end{array}$ & $\begin{array}{r}1,536,514 \\
(a) \\
114 \\
5,335,543 \\
(a) \\
16,078,136 \\
\quad(a) \\
\quad(a) \\
15,457,636 \\
7,345,307 \\
(a) \\
(a) \\
(a) \\
608,436 \\
565,678 \\
(a) \\
177,457 \\
2,750,000 \\
\end{array}$ & $\begin{array}{l}\$ 933,429 \\
(a) \\
2,027,465 \\
(a) \\
6,377,202 \\
(a) \\
(a) \\
5,371,713 \\
2,839,575 \\
(a) \\
(a) \\
(a) \\
564,029 \\
352,145 \\
(a) \\
191,043 \\
1,783,623 \\
\end{array}$ \\
\hline Other States and Territories. & & & $45,449,329$ & $13,645,947$ & $49,844,121$ & $19,940,442$ \\
\hline
\end{tabular}

a Included in "Other States and Territories."

\section{RANK OF STATES.}

The following table presents general information of interest to the salt trade. It gives for the three years 1915-1917 the number of operating plants, the average price per short ton, and the relative rank of the individual States as to both quantity and value of the salt produced. 
Number of plants producing salt, rank of Slates, and average price per short ton, 1915-191\%.

\begin{tabular}{|c|c|c|c|c|c|c|c|c|c|c|c|c|}
\hline \multirow{3}{*}{ State. } & \multicolumn{4}{|c|}{1915} & \multicolumn{4}{|c|}{1916} & \multicolumn{4}{|c|}{1917} \\
\hline & \multirow{2}{*}{$\begin{array}{l}\text { Num- } \\
\text { ber of } \\
\text { oper- } \\
\text { ating } \\
\text { plants. }\end{array}$} & \multicolumn{2}{|c|}{$\begin{array}{c}\text { Rank of State } \\
\text { by }-\end{array}$} & \multirow{2}{*}{$\begin{array}{c}\text { A ver- } \\
\text { age } \\
\text { price } \\
\text { per } \\
\text { ton. }\end{array}$} & \multirow{2}{*}{$\begin{array}{l}\text { Num- } \\
\text { ber of } \\
\text { oper- } \\
\text { ating } \\
\text { plants. }\end{array}$} & \multicolumn{2}{|c|}{$\begin{array}{c}\text { Rank of State } \\
\text { by- }\end{array}$} & \multirow{2}{*}{$\begin{array}{l}\text { Aver- } \\
\text { age } \\
\text { price } \\
\text { per } \\
\text { ton. }\end{array}$} & \multirow{2}{*}{$\begin{array}{l}\text { Num- } \\
\text { ber of } \\
\text { oper- } \\
\text { ating } \\
\text { plants. }\end{array}$} & \multicolumn{2}{|c|}{$\begin{array}{c}R \text { ank of State } \\
\text { by- }\end{array}$} & \multirow{2}{*}{$\begin{array}{l}\text { Aver- } \\
\text { age } \\
\text { price } \\
\text { per } \\
\text { ton. }\end{array}$} \\
\hline & & $\begin{array}{c}\text { Total } \\
\text { quan- } \\
\text { tity. }\end{array}$ & $\begin{array}{l}\text { Total } \\
\text { value. }\end{array}$ & & & $\begin{array}{l}\text { Total } \\
\text { quan- } \\
\text { tity. }\end{array}$ & $\begin{array}{l}\text { Total } \\
\text { value. }\end{array}$ & & & $\begin{array}{c}\text { Total } \\
\text { quan- } \\
\text { tity. }\end{array}$ & \begin{tabular}{|l} 
Total \\
value.
\end{tabular} & \\
\hline California. & a 25 & 7 & 5 & $\left\{\begin{array}{r}b \$ 3.98 \\
c 4.73\end{array}\right\}$ & a 26 & 7 & 5 & $\left\{\begin{array}{l}b \$ 2.99 \\
c 4.20\end{array}\right.$ & $a 20$ & 5 & & $\left\{\begin{array}{r}b \$ 4.21 \\
c 4.34\end{array}\right.$ \\
\hline Hawaii. & c 1 & 12 & 11 & $\mid \begin{array}{l}c \\
c 3.00\end{array}$ & c 1 & 12 & 12 & c 7.00 & $c 1$ & 13 & 12 & $\begin{array}{l}c c 4.34 \\
c 15.00\end{array}$ \\
\hline Idaho... & $c 1$ & 16 & 10 & $c 10.00$ & a 3 & 15 & 16 & $\left\{\begin{array}{l}b 10.00 \\
c 15.00\end{array}\right.$ & $a 4$ & 17 & 17 & $\left\{\begin{array}{l}b 10.00 \\
c 15.60\end{array}\right.$ \\
\hline Kansas... & $\begin{array}{lll}a & 10\end{array}$ & 4 & 4 & 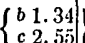 & $\begin{array}{lll}a & 10\end{array}$ & 4 & & 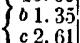 & $\begin{array}{lll}a & 10\end{array}$ & 4 & 4 & $\left\{\begin{array}{l}b 1.66 \\
c 3.63\end{array}\right.$ \\
\hline Louisiana.. & $\begin{array}{ll}b & 2\end{array}$ & 5 & & b 2.52 & $b_{2}$ & 5 & & $b 2.28$ & $b 2$ & 6 & 6 & b 3.37 \\
\hline Michigan... & a 27 & 1 & 1 & $\left\{\begin{array}{lll}b & 2 . & 02 \\
c & 2 & .43\end{array}\right\}$ & a 27 & 1 & 1 & $\left\{\begin{array}{l}b 2.60 \\
c 2.18\end{array}\right.$ & $a 24$ & 1. & 1 & $\left\{\begin{array}{l}b 2.92 \\
c 3.06\end{array}\right.$ \\
\hline Nevada. & $c 3$ & 14 & 14 & 4.07 & $c 2$ & 13 & 14 & $c 4.35$ & $a_{2}$ & 14 & 14 & $\left\{\begin{array}{l}03.00 \\
c 3.18\end{array}\right.$ \\
\hline New Mexico... & $c 1$ & 13 & 13 & $c 2.76$ & $c 1$ & 12 & 13 & c 2.00 & $c 2$ & 12 & 13 & $\begin{array}{l}1 \\
c 2.41\end{array}$ \\
\hline New York. & a 26 & 2 & 2 & $\left\{\begin{array}{lll}b & 1.95 \\
c & 1 & 8\end{array}\right\}$ & a 25 & 2 & 2 & 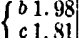 & a 23 & 2 & 2 & $\left\{\begin{array}{l}b 2.41 \\
c 2.52\end{array}\right.$ \\
\hline $\begin{array}{l}\text { Ohio } \\
\text { Oklahoma.......... } \\
\text { Pennsylvania.. }\end{array}$ & $\begin{array}{r}c 10 \\
c 2\end{array}$ & $\begin{array}{r}3 \\
15\end{array}$ & $\begin{array}{r}3 \\
15\end{array}$ & $\mid \begin{array}{ccc}c & . & 00 \\
c & 0 & 78 \\
c & 6.9\end{array}$ & $\begin{array}{r}c 10 \\
c 2\end{array}$ & $\begin{array}{r}3 \\
14\end{array}$ & $\begin{array}{r}3 \\
15\end{array}$ & $\mid \begin{array}{l}c 2.017 \\
c 2.22 \\
c 6.22\end{array}$ & $\begin{array}{ll}c & 9 \\
c & 2 \\
c & 1\end{array}$ & $\begin{array}{r}3 \\
16 \\
15\end{array}$ & $\begin{array}{r}3 \\
15 \\
16\end{array}$ & $\begin{array}{l}c 2.77 \\
c 6.61 \\
c 3.00\end{array}$ \\
\hline $\begin{array}{l}\text { Porto Rico.... } \\
\text { Texas......... }\end{array}$ & $\begin{array}{l}c 2 \\
c 5\end{array}$ & rii & 10 & $\mid \begin{array}{l}c 2.57 \\
c 5.55\end{array}$ & $\begin{array}{l}c 2 \\
c 5\end{array}$ & $\begin{array}{r}1 i \\
8\end{array}$ & $\begin{array}{r}10 \\
6\end{array}$ & $\left|\begin{array}{r}c 2.62 \\
c 5.46\end{array}\right|$ & $\begin{array}{ll}c 2 \\
c 5\end{array}$ & $\begin{array}{r}11 \\
8\end{array}$ & 10 & $\begin{array}{l}c 4.24 \\
c 6.62\end{array}$ \\
\hline Utah...... & $a 7$ & 9 & 8 & $\left\{\begin{array}{ccc}0 & 2 & 29 \\
c & 5 & 0\end{array}\right\}$ & a 7 & 9 & 8 & 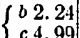 & $a 7$ & 9 & 8 & $\left\{\begin{array}{l}b 2.54 \\
c 4.60\end{array}\right.$ \\
\hline $\begin{array}{l}\text { Virginia........ } \\
\text { West Virginia.. }\end{array}$ & $\begin{array}{ll}c & 1 \\
c & 4\end{array} \mid$ & $\begin{array}{r}6 \\
10\end{array}$ & $\begin{array}{r}12 \\
9\end{array}$ & 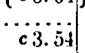 & $\begin{array}{ll}c & 1 \\
c & 4\end{array} \mid$ & $\begin{array}{r}6 \\
10\end{array}$ & $\begin{array}{r}11 \\
9\end{array}$ & $\mid \begin{array}{c}\cdots \\
c 3.67\end{array}$ & $\begin{array}{ll}c & 1 \\
c & 4\end{array}$ & 10 & $\begin{array}{r}11 \\
0\end{array}$ & $\because 7.69$ \\
\hline $\begin{array}{c}\text { Total brine } \\
\text { and rock } \\
\text { salt......... }\end{array}$ & 127 & & & $\left\{\begin{array}{lll}b & 1.97 \\
c & 2 . & 26\end{array}\right\}$ & 128 & & & 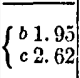 & 125 & & & $\left\{\begin{array}{l}b 2.43 \\
c 2.99\end{array}\right.$ \\
\hline $\begin{array}{l}\text { Total United } \\
\text { States....... }\end{array}$ & & & & & & & & & & & & 2.86 \\
\hline
\end{tabular}

For the Census of 1880,268 salt plants reported operations. There were 161 plants in 1897, 136 in 1911, and only 129 in 1913.

\section{PRODUCTION ON THE ONONDAGA SALT SPRINGS RESERVATION, N. Y.}

The longest record of production of salt in any district in the United States is that of the Onondaga Salt Springs Reservation, $\mathrm{N}$. Y., and the quantity of salt produced in this reservation from 1797 to 1917 is shown in the following table. The figures from 1905 to 1917 are not those of salt inspected but of salt sold and have been compiled from reports made by the Onondaga Coarse Salt Association, as the State sold the springs in 1908. A quantity of brine used from 1888 to 1896 in chemical works at Syracuse is included in the production of this district, although outside of the reservation. These figures do not, of course, represent the total production of salt in the State of New York during recent years. 
Salt produced on the Onondaga Salt Springs Reservation, $N . Y$., 1797-1917, as reported by the State superintendent of salt inspection, in bushels of 56 pounds.

\begin{tabular}{|c|c|c|c|c|c|c|c|}
\hline Year. & Solar salt. & Fine salt. & Total. & Year. & Solar salt. & Fine salt. & Total. \\
\hline 180 & & $2 j, 474$ & $25,47.1$ & 1850 & $1,345,022$ & $5,549,250$ & $6,894,277$ \\
\hline 1798. & & 59,928 & 59,923 & 1860 . & $1,462,565$ & $4,130,682$ & $5,593,242$ \\
\hline 1799. & & 42,704 & 42,704 & $18 \ddot{101}$ & $1,854,697$ & $5,315,694$ & $7,200,391$ \\
\hline 1800. & & 50,000 & 50,000 & 1862. & 83,022 & $7,070,852$ & $9,053,874$ \\
\hline 1801. & & 62,000 & 62,003 & 1863. & $1,437,650$ & $6,504,727$ & $7,942,383$ \\
\hline 1802. & & 75,000 & 75,003 & 1864 & $1,971,122$ & $5,407,712$ & $7,378,834$ \\
\hline 1803. & & 90,000 & 90,000 & 1865. & $1,886,760$ & $4,499,170$ & $6,385,930$ \\
\hline 1804. & & 100,000 & 100,000 & 1866. & $1,978,183$ & $5,180,320$ & $7,108,503$ \\
\hline 1805 & & 154,071 & 154,071 & 1867 & $2,271,892$ & $5,323,673$ & $7,595,565$ \\
\hline 1506 . & & 122,577 & 122,577 & 1868 & $2,02 \pi, 490$ & $6,639,126$ & $8,666,616$ \\
\hline 1807 & & 175,448 & 175,448 & 1869. & $1,857,942$ & $6,804,295$ & $8,662,237$ \\
\hline 1808. & & 319,618 & 319,618 & 1870. & $2,487,691$ & $6,250,422$ & $8,748,113$ \\
\hline 1809. & & 128,282 & 128,282 & 1871. & $2,404,464$ & $5,910,492$ & $8,374,956$ \\
\hline 1810. & & 450,000 & 450,000 & 1872. & $1,882,604$ & $6,048,321$ & $7,930,925$ \\
\hline 1811. & & 200,000 & 200,000 & 1873. & $1,691,359$ & $5,768,998$ & $7,460,357$ \\
\hline 1812. & & 221,011 & 221,011 & 1874. & 67,368 & 1,932 & $6,029,300$ \\
\hline 1813. & & 226,000 & 226,000 & 1875. & $2,655,955$ & $4,523,491$ & $7,179,446$ \\
\hline 1814. & & 295,000 & 295,000 & 1876. & $2,308,679$ & $3,083,998$ & $5,392,677$ \\
\hline 1815 & & 322,058 & 322,058 & 1877. & $2,525,335$ & $3,902,648$ & $6,427,983$ \\
\hline 1816 & & $348,66.5$ & 348,665 & 1878. & $2,788,754$ & $4,387,443$ & $7,176,197$ \\
\hline 1817. & & 408,665 & 408,665 & 1879. & 7,744 & $5,364,418$ & $8,322,162$ \\
\hline 1818. & & 406,540 & 406,540 & 1880. & $2,516,485$ & $5,482,265$ & $7,998,750$ \\
\hline 1819 & & 548,374 & 548,374 & 1881. & $3,011,461$ & $4,905,775$ & $7,917,236$ \\
\hline 1820 . & & 458,329 & 458,329 & 1882. & 32,447 & $5,307,733$ & $8,340,180$ \\
\hline $1 \times 21$. & & $52 i, 049$ & 526,049 & $18 \$ 3$. & 4,374 & 3,057 & $7,497,431$ \\
\hline 1822 . & & 481,562 & 481,562 & 1884. & $2,353,860$ & $4,588,410$ & $6,942,270$ \\
\hline 1823. & & $72 i, 988$ & 726,983 & 1895. & $2,439,332$ & $4,494,967$ & $6,934,299$ \\
\hline $1 \times 24$. & & 816,634 & 816,634 & 1886. & $2,772,343$ & $3,329,409$ & $6,101,757$ \\
\hline 1825. & & 757,203 & - 757,203 & 1887. & $3,118,974$ & $2,576,823$ & $5,695,797$ \\
\hline 1826. & & 811,023 & 811,023 & 1888 & $3,115,314$ & $2,542,053$ & $5,657,367$ \\
\hline 1827. & & 983,410 & 983,410 & 188 & 6,922 & $2,448,117$ & $5,365,039$ \\
\hline 1828. & & $1,160,888$ & $1,160,889$ & 1890. & $2,72 ., 471$ & $2,201,051$ & $4,928,122$ \\
\hline 1829. & & $1,129,280$ & $1,129,280$ & 1891. & $2,113,727$ & $1,735,186$ & $3,848,913$ \\
\hline 1830. & & $1,435,446$ & $1,435,446$ & 1892. & $3,122,789$ & $1,2 S 2,885$ & $4,405,674$ \\
\hline 1831. & & $1,514,037$ & $1,514,037$ & 1893. & $2,332,052$ & 733,854 & $3,065,906$ \\
\hline 1832. & & $1,652,985$ & $1,652,985$ & 1894. & 5,394 & 871,860 & $3,227,254$ \\
\hline 1833. & & $1,838,646$ & $1,838,640$ & $189 \overline{5}$ & 8,289 & 605,835 & $3,214,125$ \\
\hline 1834. & & $1,943,252$ & $1,943,252$ & 1896. & 4,422 & 342,179 & $2,806,601$ \\
\hline 1835. & & $1,209,867$ & $1,209,867$ & 1897. & 0,691 & 341,503 & $2,842,195$ \\
\hline 1836. & & $1,912,858$ & $1,912,858$ & 1898. & 4,924 & 428,456 & $2,473,381$ \\
\hline 1837. & & $2,167,287$ & $2,167,287$ & 1899. & $2,089,982$ & 412,591 & $2,502,572$ \\
\hline 1838 & & 5,033 & $2,575,033$ & 1900. & 804 & 337,948 & 751 \\
\hline 183 & & 718 & 718 & 1901. & 251 & 374,842 & 093 \\
\hline & & 2,305 & 2,305 & 1902. &, 579 & 183,176 & 755 \\
\hline 1841. & 47 & $3,120,520$ & $3,340,767$ & 1903. & 7,424 & 95,801 & $1,933,225$ \\
\hline 1842 & & $2,128,882$ & $2,291,903$ & 1904 & 299 & 135,090 & $1,743,389$ \\
\hline & & 2,8 & $3,127,507$ & 19 & 424 & & 424 \\
\hline 44 & & 134 & $4,003,552$ & 1906. & $2,554,055$ & 135,240 & 295 \\
\hline 18 & &, 903 & $3,762,358$ & 1907. & 893 & 69,821 & 714 \\
\hline 18 & 705 & $3,507,146$ & $3,838,851$ & 1908. & $2,603,036$ & & $2,603,036$ \\
\hline 18 & 262,879 & $3,688,476$ & $3,951,355$ & 1909. & $2,568,485$ & & $2,568,485$ \\
\hline 1848. & & 4,629 & $4,737,126$ & 1910 & $2,341,750$ & & $2,341,750$ \\
\hline & & 5,834 & 3,569 & 191 & $2,177,071$ & & $2,177,071$ \\
\hline & & 187 & $4,268,919$ & 191 & $1,484,071$ & .. & $1,484,071$ \\
\hline & & 150 & & 191 & $2,184,773$ & & $2,184,773$ \\
\hline 1852 . & & 938 & $4,922,533$ & 191 & 1,29 & & $1,297,250$ \\
\hline 1853. & 47 & $4,826,577$ & $5,404,524$ & 191 & $1,777,821$ & & $1,777,821$ \\
\hline & & $5,068,873$ & $5,803,347$ & 191 & $1,248,643$ & & $1,249,643$. \\
\hline $185 \overline{5}$ & 24 & 4,761 & $6,082,855$ & 1917. & 672,429 & & 672,429 \\
\hline & 709,391 & $5,257,419$ & $5,966,810$ & & & & \\
\hline 18 & 481,280 & $3,830,846$ & $4,312,12 \hat{\jmath}$ & & $39,262,746$ & $271,416,742$ & $410,679,488$ \\
\hline & $1,514,554$ & $5,518,665$ & $7,033,219$ & & & & \\
\hline
\end{tabular}

The total of $410,679,488$ bushels of salt, equivalent to $82,135,894$ barrels, or $11,499,025$ short tons, produced from the springs of this reservation during the 121 years for which records are available is of especial interest, as this is the only district in New York where the natural brine is produced, the other districts producing either rock salt or brine made by dissolving salt with water forced into the deposits of rock salt. The total output for these 121 years is more than one and four-fifths times the present yearly production of salt 
in the entire country. While the State controlled these springs, the expense of building and repairing the tanks from which the brine was delivered to the lessee was borne by the State, and for every bushel of salt made the State received at first (1797), 4 cents in lieu of rent. In 1805, 3 cents a bushel was paid; in 1812, $12 \frac{1}{2}$ cents; in 1834,6 cents; and in 1846, 1 cent, the last rate being continued for the remaining years. The output of the springs was made into fine salt for 43 years, from 1797 to 1840 , when solar salt also began to be marketed. The producing of fine salt was gradually discontinued, until now the product is practically all solar salt.

\section{EARIY PRODUCTION IN MICHIGAN.}

Salt was first made in Michigan in 1860. The production from 1860 to 1868 , inclusive, according to a report made by the first inspector, appointed in 1869, was as follows:

Salt produced in Michigan, 1S60-1S68, in barrels of 280 pounds.

\begin{tabular}{|c|c|c|c|}
\hline Year. & Production. & Year. & Production. \\
\hline 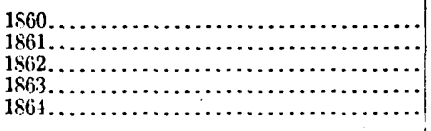 & $\begin{array}{r}4,000 \\
125,000 \\
243,000 \\
466,000 \\
529,073\end{array}$ & 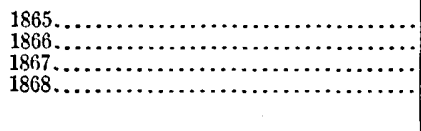 & $\begin{array}{l}477,200 \\
407,997 \\
474,721 \\
55 ;, 690\end{array}$ \\
\hline
\end{tabular}

The production as reported by the State inspector from 1869 to 1889 , inclusive, was as follows:

Salt produced in Wichigan, 1869-1889, in barrels of 280 pounds.

\begin{tabular}{|c|c|c|c|}
\hline Yenr. & Production. & year. & Production. \\
\hline 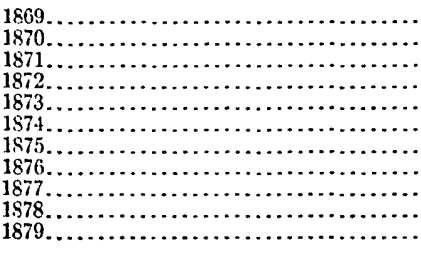 & $\begin{array}{r}561,288 \\
621,352 \\
728,175 \\
721,481 \\
823,346 \\
1,026,979 \\
1,081,865 \\
1,462,729 \\
1,660,997 \\
1,885,884 \\
2,058,040\end{array}$ & 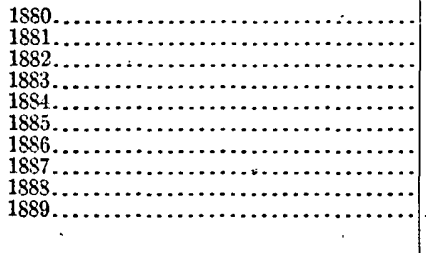 & $\begin{array}{l}2,6 \$ 5,5 \$ 8 \\
2,750,299 \\
3,037,317 \\
2,894,672 \\
3,161,806 \\
3,297,403 \\
3,677,257 \\
3,944,309 \\
3,866,228 \\
3,846,979\end{array}$ \\
\hline
\end{tabular}

The figures used by the United States Geological Survey for compiling the statistics of production since 1889 have been reported by the producers in Michigan. The annual State totals thus obtained differ from those of the Michigan salt inspector because the Survey collects data for the quantity sold whereas the State inspector reports the quantity of salt made and inspected; the Survey also includes in its figures the salt content of the brine pumped and used by chemical manufacturers in the State, whereas the State inspector does not. 


\section{EARLY PRODUCTION IN WEST VIRGINIA.}

Dr. J. P. Hale, of Charleston, W. Va.,; gives the following figures of production of salt in the State from 1797 to 1882, inclusive.

Salt produced in West Virginia, 1797-1882, in bushels of 56 pounds.

\begin{tabular}{|c|c|c|c|c|}
\hline $1797 \ldots \ldots \ldots$ & (') & 1838. & $1,811,076$ & $1,493,548$ \\
\hline $1798-1807$. & No record. & 1839. & $1,593,217$ & $1,264,049$ \\
\hline 1808. & $\left({ }^{2}\right)$ & 1840. & $1,419,205$ & $1,266,749$ \\
\hline $1809-1813$. & No record. & 1841. & $1,443,645$ & No record. \\
\hline 1814. & 600,000 & 1842. & $1,919,389$ & $1,300,991$ \\
\hline $181 \tilde{0}-1$ & No record. & 1843. & $2,197,887$ & 861,973 \\
\hline 1827. & 787,000 & 1844 & $1,874,919$ & $1,275,017$ \\
\hline 823 . & $863,54.2$ & 1845. & $2,578,499$ & 1867. \\
\hline 1829 . & 989,758 & $1846 \ldots$ & $3,224,786$ & 1868 \\
\hline 830 . & 906,132 & 1847. & $2,690,087$ & $1,822,430$ \\
\hline 1831. & 956,814 & 1848. & $2,876,010$ & $1,721,963$ \\
\hline 1832. & $1,029,207$ & 1849 & $2,951,492$ & $1871-1874$. \\
\hline 1833. & $1,288,873$ & 1850 & $3,142,100$ & $967,46 \overline{5}$ \\
\hline 1834. & $1,702,956$ & 1851. & $2,862,676$ & No record. \\
\hline 1835. & $1,960,583$ & 1852. & $2,741,570$ & $2,679,435$ \\
\hline 1836 & $1,762,410$ & 1853. & $2,729,910$ & No record. \\
\hline 1837. & $1,880,415$ & 1854. & $2,233,863$ & $2,000,000$ \\
\hline
\end{tabular}

\section{EXPORTS.}

The following figures, compiled from reports of the Bureau of Foreign and Domestic Commerce, Department of Commerce, show the exports of salt from the United States from 1790 to 1917. The export trade has fluctuated greatly, but it has increased about 400 per cent in quantity and about 355 per cent in value during the last ten years, the figures for 1917 being the greatest ever recorded in the history of the export trade. 
Salt of domestic production exported from the Unitcd Siates, $1 \% 90-101 \%$.

\begin{tabular}{|c|c|c|c|c|c|}
\hline Jear cnding- & Quantity. & Valuc. & Year ending- & Quantity. & Value. \\
\hline 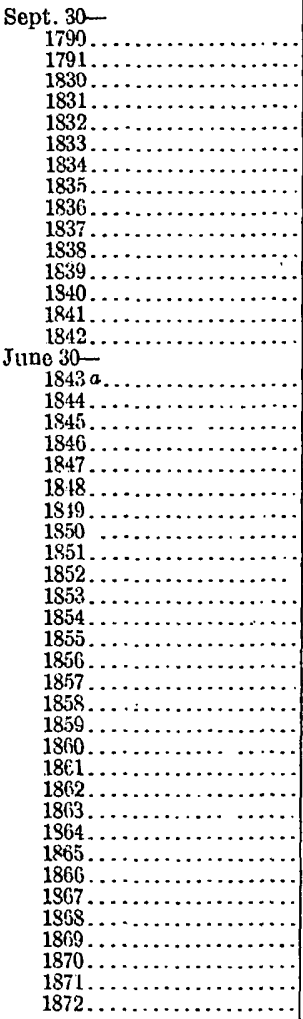 & $\begin{array}{r}\text { Bushels. } \\
31,935 \\
4,208 \\
47,488 \\
45,847 \\
45,072 \\
25,069 \\
89,064 \\
126,230 \\
49,917 \\
99,133 \\
114,155 \\
264,337 \\
92,145 \\
215,034 \\
110,400 \\
40,678 \\
157,529 \\
131,500 \\
117,627 \\
202,244 \\
219,115 \\
312,063 \\
319,175 \\
344,061 \\
1,467,676 \\
515,857 \\
548,185 \\
536,073 \\
638,458 \\
576,151 \\
533,100 \\
717,257 \\
475,445 \\
537,401 \\
397,506 \\
584,901 \\
635,519 \\
589,537 \\
70,644 \\
605,825 \\
624,970 \\
442,947 \\
298,142 \\
120,156 \\
42,603 \\
\end{array}$ & $\begin{array}{r}88,230 \\
1,052 \\
22,078 \\
26,948 \\
27,914 \\
18,211 \\
54,007 \\
46,483 \\
31,943 \\
58,472 \\
67,707 \\
64,272 \\
42,246 \\
62,765 \\
39,064 \\
10,262 \\
47,755 \\
45,151 \\
39,520 \\
42,333 \\
73,274 \\
82,072 \\
75,103 \\
61,424 \\
89,316 \\
119,729 \\
159,020 \\
156,879 \\
311,495 \\
190,699 \\
162,(i 50 \\
212,710 \\
129,717 \\
144,046 \\
228,109 \\
277,838 \\
296,085 \\
358,109 \\
300,980 \\
304,030 \\
289,936 \\
190,076 \\
119,582 \\
47,151 \\
19,978\end{array}$ & 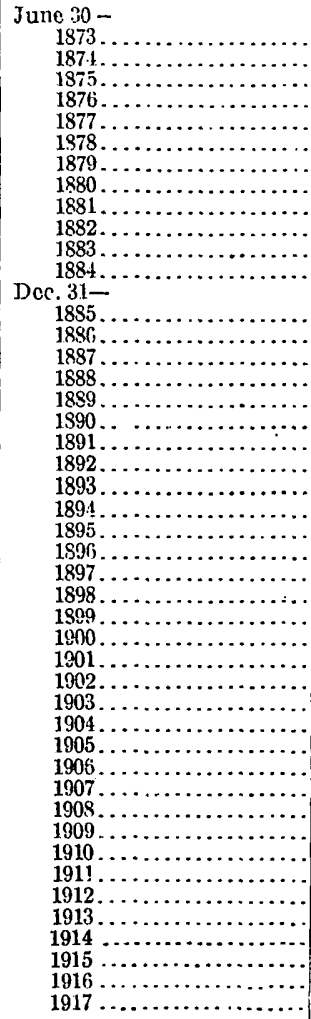 & $\begin{array}{r}\text { Bushcls. } \\
73,323 \\
31,657 \\
47,094 \\
51,014 \\
65,771 \\
72,427 \\
43,710 \\
22,179 \\
45,455 \\
42,085 \\
54,147 \\
70,014 \\
P 024718 \\
4,101,587 \\
4,828,863 \\
4,685,080 \\
5,359,237 \\
5,378,450 \\
4,927,022 \\
4,448,846 \\
5,208,935 \\
5,792,207 \\
10,853,759 \\
7,203,024 \\
11,711,314 \\
11,593,321 \\
17,290,193 \\
25,200,191 \\
15,021,861 \\
18,865,247 \\
10,188,771 \\
21,499,630 \\
27,928,089 \\
68,47 ., 356 \\
67,976,581 \\
61,603,422 \\
53,253,739 \\
80,306,820 \\
98,026,369 \\
97,745,833 \\
124,819,713 \\
140,578,092 \\
164,589,012 \\
160,948,389 \\
168,129,201 \\
227,985,222\end{array}$ & $\begin{array}{r}\$ 43,777 \\
15,701 \\
16,273 \\
18,378 \\
20,133 \\
24,968 \\
13,612 \\
6,613 \\
14,752 \\
18,265 \\
17,321 \\
26,007 \\
\\
26,488 \\
29,580 \\
27,177 \\
32,986 \\
31,405 \\
30,079 \\
23,771 \\
23,399 \\
38,375 \\
46,730 \\
30,939 \\
43,202 \\
52,320 \\
63,624 \\
86,465 \\
65,410 \\
86,414 \\
55,432 \\
95,570 \\
113,625 \\
239,223 \\
274,627 \\
232,895 \\
202,33 \times \\
269,273 \\
320,921 \\
325,255 \\
413,525 \\
515,194 \\
586,055 \\
613,850 \\
567,441 \\
1,000,773\end{array}$ \\
\hline
\end{tabular}

a Nine months.

\section{IMPORTS.}

Import figures for salt have been collected since 1867 by the Bureau of Foreign and Domestic Commerce, Department of Commerce. The following table compiled from reports of this bureau shows the quantity and value of salt imported and entered for consumption in the United States from 1867 to 1917, according to the condition and use of the salt. 


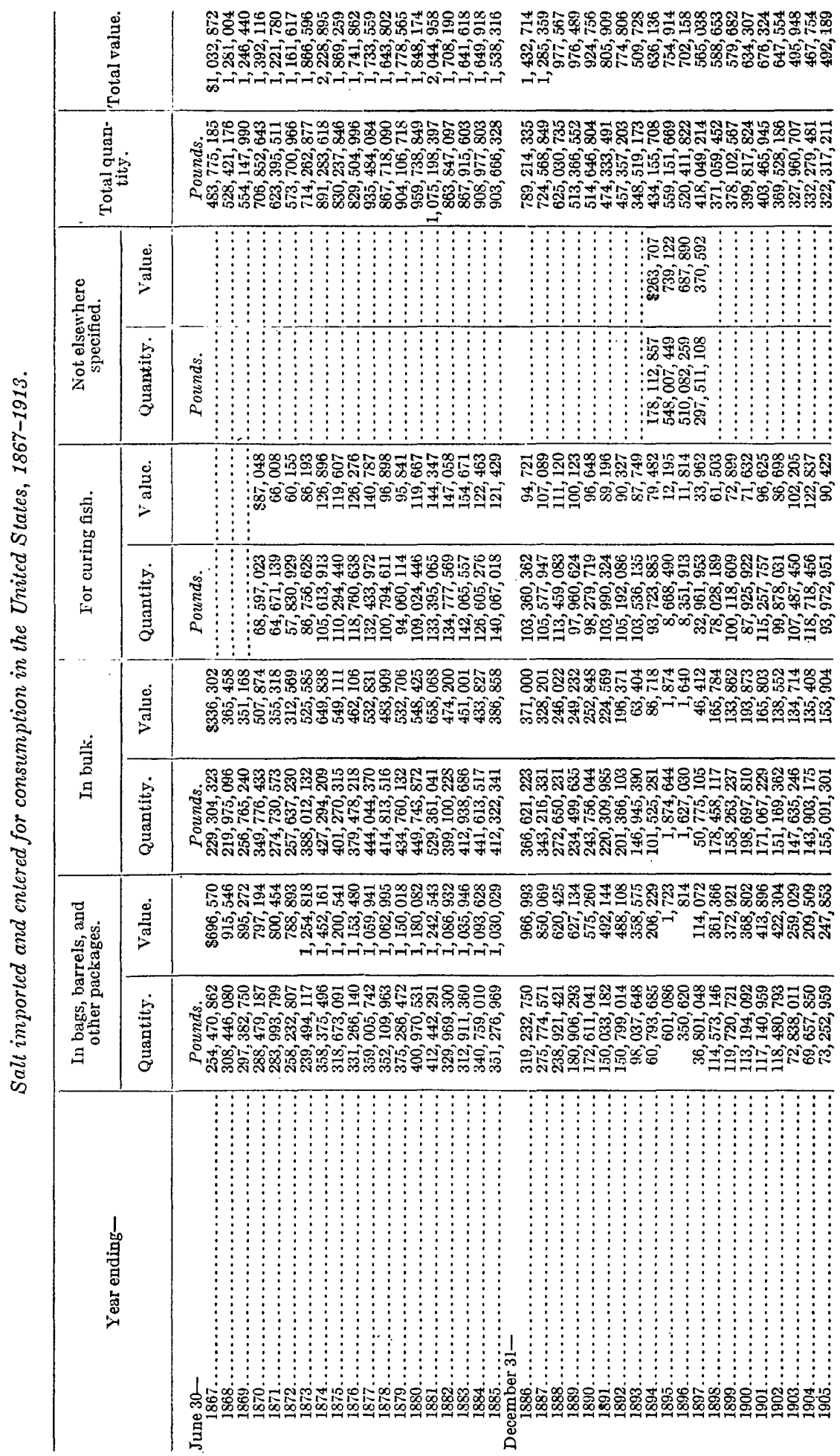




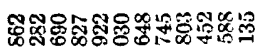

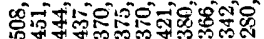

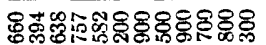

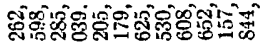

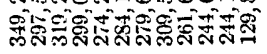

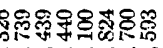

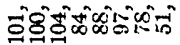

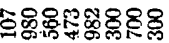

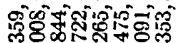

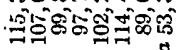

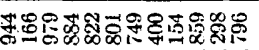

जoํำ

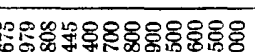

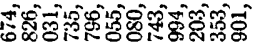

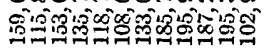

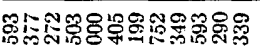

ลิ่

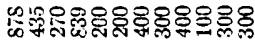

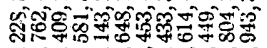

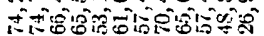

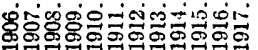




\section{TARIFF REGULATIONS ON SALT.}

As the tariff acts of different years have had considerable influence on the importations of salt, a brief statement of the various Acts of Congress regulating imports of salt has been compiled. ${ }^{1}$

Act of July 4, 1789: Six cents per bushel on all salt imported.

Act of August 10, 1790: Twelve cents per bushel on all salt imported.

Act of July 8, 1797: That from and after the thirtieth day of September next, there shall be levied, collected, and paid upon all salt imported into the United States, in ships or vessels of the United States, in addition to the duty of twelve cents now payable by law, eight cents per bushel, and on all salt which, after the said thirtieth day of September, shall be imported in to the United States, in ships or vessels not of the United States, the like additional duty of eight cents, and ten per centum thereon; further, that all drawbacks and allowances now authorized by law, in relation to the existing duty on salt imported into the United States, shall apply to the additional duty laid by this act, and that in addition thereto, there shall be allowed and paid upon provisions salted within the United States, except upon dried fish, upon the exportation thereof to any foreign port or place as follows, viz: On pickled fish at the rate of twelve cents per barrel, and on other provisions at the rate of ten cents per barrel; and from and after the first day of January next there shall be an addition of thirty-three and a third per centum to the allowances now respectively granted to ships or vessels employed in the bank or other cod fisheries, and the terms provided by an act entitled "An act concerning certain fisheries of the United States and for the regulation and government of the fishermen employed therein," and during the continuance of the said act; and further, that this act shall continue in force for two years, and from thence until the end of the next session of Congress, and no longer.

Act of May 2, 1792: From June 30, the bushel shall contain fifty-six pounds.

Act of May 7, 1800: That an act passed on the eighth day of July, one thousand seven hundred and ninety-seven, entitled "An act laying an additional duty on salt imported into the United States, and for other purposes," shall be, and the same is hereby, continued in force for and during the term of ten years from the third day of March, one thousand eight hundred, and from thence to the end of the next session of Congress thereafter and no longer. Repealed March 3, 1807.

Act of July 29, 1813: That from and after the first day of January next (1814), a duty of twenty cents per bushel shall be laid, imposed, and collected, upon all salt imported from any foreign port or place into the United States. In calculating the said duty, every fifty-six pounds of salt shall be computed as equal to one bushel.

Act of April 27, 1816: Twenty cents per bushel on all salt imported.

Act of May 29, 1830: Fifteen cents from December 31, 1830, to December 31, 1831; after that, ten cents.

Act of July 14, 1832: Ten cents per bushel on all salt imported.

Act of August 30, 1842: Eight cents per bushel on all salt imported.

Act of March 2, 1861: Salt imported in bulk, four cents per bushel; in bags, sacts, barrels, or other packages, six cents per bushel.

Act of August 15, 1861: Salt imported in bulk, twelve cents per one hundred pounds; in bags, sacks, barrels, or other packages, eighteen cents per one hundred pounds.

Act of July 14, 1862: Salt imported in bulk, six cents per one hundred pounds; in bags, sacks, barrels, or other packages, six cents per one hundred pounds.

Act of June 30, 1864: Salt imported in bulk, eighteen cents per one hundred pounds; in bags, sacks, barrels, or other packages, twenty-four cents per one hundred pounds.

Act of July 28, 1866: Vessels licensed to engage in fisheries may take on board imported salt in bond to be used in curing fish, under such regulations as the Secretary 
of the Treasury shall prescribe, and upon proof that said salt has been lised in curing fish, the duties on same shall be remitted.

Act of June 6, 1872: Salt imported in bulk, eight cents per one hundred pounds; in bags, sacks, barrels, or other packages, twelve cents per one hundred pounds.

Act of March 3, 1883: Salt in bags, sacks, barrels, or other packages, twelve cents per one hundred pounds; in bulk, eight cents per one hundred pounds, Provided that exporters of meate, whether packed or smoked, which have been cured in the United States with imported salt, shall, upon satisfactory proof, under such regulations as the Secretary of the Treasury shall prescribe, that such meats have been cured with imported salt; have refunded to them from the Treasury, the duties paid on the salt so used in curing such exported meats, in amounts not less than one hundred dollars, and Provided further, that imported salt in bond may be used in curing fish taken by vessels licensed to engage in the fisheries, and in curing fish on the shores of the navigable waters of the United States, under such regulations as the Secretary of the Treasury shall prescribe, and upon proof that the salt has been used for either of the purposes stated in this proviso, the duties on the same shall be remitted.

Act of October 1, 1890: Salt imported in bags, sacks, barrels, or other packages, twelve cents per one hundred pounds; in bulk, eight cents per one hundred pounds; Provided that imported salt in bond may be used in curing fish taken by vessels - licensed to engage in the fisheries, and in curing fish on the shores of the navigable waters of the United States, under such regulations as the Secretary of the Treasury shall prescribe, and upon proof that the salt has been used for either of the purposes stated in this proviso, the duties on the same shall be remitted, and Provided further, that exporters of meats, whether packed or smoked, which have been cured in the United States with imported salt, shall upon satisfactory proof, under such regulations as the Secretary of the Treasury shall prescribe, that such meats have been cured with imported salt, have refunded to them from the Treasury the duties paid on the salt so used in curing such exported meats, in amounts not less than one hundred dollars.

Act of August 27, 1894: On the free list: Salt in bulk and salt in bags, sacks, barrels, or' other packages, but the coverings shall pay the same rate of duty as if imported separately: Provided, That if salt is imported from any country whether independent or dependency which imposes a duty upon salt exported from the United States, then there shall be levied, paid, and collected upon such salt the rate of duty existing prior to the passage of this Act.

Act of July 24, 1897: Salt in bags, sacks, barrels, or other packages, twelve cents per one hundred pounds; in bulk, eight cents per one hundred pounds: Provided, that imported salt in bond may be used in curing fish taken by vessels licensed to cngage in the fisheries, and in curing fish on the shores of the navigable waters of the United States, uncier such regulations as the Secretary of the Treasury shall prescribe, and upon proof that the salt has been used for either of the purposes stated in this proviso, the duties of the same shall be remitted: Provided further, that exporters of meats, whether packed or smoked, which have been cured in the United States with im ported salt, shall, upon satisfactory proof, under such regulations as the Secretary of the Treasury shall prescribe, that such meats have been cured with imported salt, have refunded to them from the Treasury the duties paid on the salt so used in curing such exported meats, in amounts not less than one hundred dollars.

Act of August 5, 1909: Salt in bags, sacks, barrels, or other packages, eleven cents per one hundred pounds; in bulk, seven cents per one hundred pounds: Provided, that imported salt in bond may be used in curing fish taken by vessels licensed to engaged in the fisheries, and in curing fish on the shores of the navigable waters of the United States under such regulations as the Secretary of the Treasury shall prescribe, and upon proof that the salt has been used for either of the purposes stated in this proviso the duties on the same shall be remitted: Provided further, that exporters of meats, 
whether packed or smoked, which have been cured in the United States with imported salt, shall, upon satisfactory proof, under such regulations as the Secretary of the Treasury shall prescribe, that such meats have been cured with imported salt, have refunded to them from the Treasury the duties paid on the salt so used in curing such exported meats, in amounts not less than one hundred dollars.

Act of October 3, 1913: Salt placed on the free list.

\section{DOMESTIC CONSUMPTION.}

The consumption of salt in the United States from 1880 to 1917 is given in the following table. The annual domestic consumption increased very rapidly from about $10,000,000$ barrels in 1890 to more than $20,000,000$ barrels in 1899 , and it has continued to increase till it has exceeded $49,000,000$ barrels. The quantity of salt imported annually dropped markedly between 1885 and 1893, and after marked increases up to 1897 has irregularly decreased to less than 500,000 barrels in 1917 . The exports rose from a little more than 4,000 barrels in 1880 to 20,000 barrels in 1893, and then jumped to slightly more than 63,000 barrels in 1896 and to more than 800,000 barrels in 1917. The steady increase in domestic production has rendered the market for foreign salt in the United States less and less important. The percentage of imports to total consumption decreased steadily from 38.3 per cent in 1881 to 9.49 per cent in 1893 and was less than 1 per cent in 1917. The United States, therefore, now supplies more than 99 per cent of the salt it consumes . during the year. This country is not dependent on any foreign country for any portion of its salt supply, as the capacity of its active mines and manufacturing plants is greatly in excess of the present output.

Salt consumed in the Cnited States, 18S0-1917, in barrels of 280 pounds.

\begin{tabular}{|c|c|c|c|c|}
\hline Sourcc. & 1880 & 1881 & 1882 & 1883 \\
\hline $\begin{array}{l}\text { Domestic production.... } \\
\text { Imports................. }\end{array}$ & $\begin{array}{l}5,961,060 \\
3,427,639\end{array}$ & $\begin{array}{r}a 6,200,000 \\
\cdot 3,839,994\end{array}$ & $\begin{array}{l}6,412,373 \\
3.085,168\end{array}$ & $\begin{array}{l}6,192,231 \\
3,099,698\end{array}$ \\
\hline Exports... & $\begin{array}{r}8,388,699 \\
4,436\end{array}$ & $\begin{array}{r}10,039,994 \\
9,091\end{array}$ & $\begin{array}{r}9,497,541 \\
8,417\end{array}$ & $\begin{array}{r}9,291,929 \\
10,829\end{array}$ \\
\hline 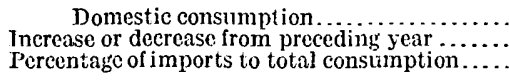 & $\begin{array}{r}9,384,263 \\
36.5\end{array}$ & $\begin{array}{r}10,030,903 \\
+646,640 \\
38.3\end{array}$ & $\begin{array}{r}9,489,124 \\
-341,779 \\
32.5\end{array}$ & $\begin{array}{r}9,281,100 \\
-208,024 \\
33.4\end{array}$ \\
\hline Source. & $18 S .1$ & $1 S S 5$ & 1886 & 1887 \\
\hline 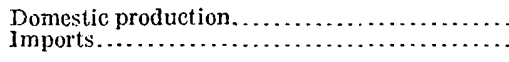 & $\begin{array}{l}6,514,937 \\
3,246,349\end{array}$ & $\begin{array}{l}7,038,653 \\
3,227,380\end{array}$ & $\begin{array}{l}7,707,081 \\
2,818,623\end{array}$ & $\begin{array}{l}8,003,962 \\
2,587,745\end{array}$ \\
\hline Exports.. & $\begin{array}{r}9,761,286 \\
14,003 \\
\end{array}$ & $\begin{array}{r}10,266,033 \\
14,649 \\
\end{array}$ & $\begin{array}{r}10,525,704 \\
17,246 \\
\end{array}$ & $\begin{array}{r}10,591,707 \\
16,732 \\
\end{array}$ \\
\hline $\begin{array}{l}\text { Domestic consumption...................... } \\
\text { Increase or decrease from preceding year } \\
\text { Percentage of imports to total constimption.. }\end{array}$ & $\begin{array}{r}9,747,283 \\
+466,183 \\
33.3\end{array}$ & $\begin{array}{r}10,251,384 \\
+504,101 \\
31.5\end{array}$ & $\begin{array}{r}10,508,458 \\
+257,074 \\
. \quad 26.8\end{array}$ & $\begin{array}{r}10,574,975 \\
+66,517 \\
24.5\end{array}$ \\
\hline
\end{tabular}

a Estimated. 
Salt consumed in the United States, 1850-191\%, in barrels of :SO pounds--Continued.

\begin{tabular}{|c|c|c|c|c|c|c|c|}
\hline \multicolumn{2}{|l|}{ Source. } & \multicolumn{2}{|c|}{1888} & \multicolumn{2}{|r|}{1880} & 1890 & 1891 \\
\hline \multicolumn{3}{|c|}{ 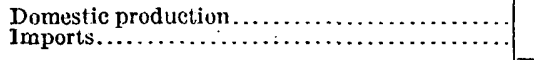 } & $\begin{array}{l}8,055,881 \\
2,232,253\end{array}$ & \multicolumn{2}{|c|}{$\begin{array}{l}8,055,565 \\
1,833,452\end{array}$} & $\begin{array}{l}8,876,991 \\
1,838,024\end{array}$ & $\begin{array}{l}9,9 \times 7,945 \\
1,694,048\end{array}$ \\
\hline \multicolumn{2}{|l|}{ Exports.. } & \multicolumn{2}{|c|}{$\begin{array}{r}10,288,13.4 \\
19,140\end{array}$} & \multicolumn{2}{|c|}{$\begin{array}{r}9,889,017 \\
19,209\end{array}$} & $\begin{array}{r}10,715,015 \\
17,597\end{array}$ & $\begin{array}{r}11,681,993 \\
15,880\end{array}$ \\
\hline \multicolumn{2}{|c|}{ 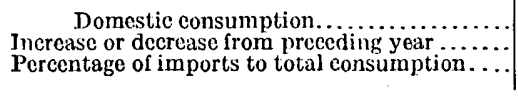 } & \multicolumn{2}{|c|}{$\begin{array}{r}10,268,994 \\
-305,981 \\
21.7\end{array}$} & \multicolumn{2}{|c|}{$\begin{array}{r}9,869,808 \\
-399,186 \\
18.5\end{array}$} & $\begin{array}{r}10,697,418 \\
+827,610 \\
17.2\end{array}$ & $\begin{array}{r}11,666,104 \\
+968,686 \\
14.5\end{array}$ \\
\hline \multicolumn{2}{|l|}{ Source. } & \multicolumn{2}{|c|}{1892} & \multicolumn{2}{|r|}{1893} & 1894 & 1895 \\
\hline \multicolumn{3}{|c|}{ 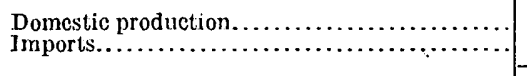 } & $\begin{array}{r}11,698,830 \\
1,633,419 \\
\end{array}$ & \multicolumn{2}{|c|}{$\begin{array}{r}11,897,208 \\
1,244,711 \\
\end{array}$} & $\begin{array}{r}12,968,417 \\
1,550,555\end{array}$ & $\begin{array}{r}13,669,649 \\
1,99 t, 970\end{array}$ \\
\hline \multirow{2}{*}{\multicolumn{2}{|c|}{ 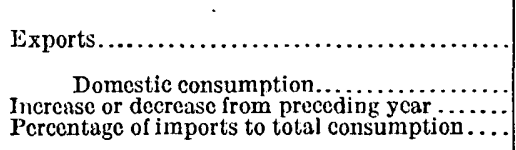 }} & \multicolumn{2}{|c|}{$\begin{array}{r}13,332,309 \\
18,603\end{array}$} & \multicolumn{2}{|c|}{$\begin{array}{r}13,141,919 \\
20,686\end{array}$} & $\begin{array}{r}14,518,972 \\
38,763\end{array}$ & $\begin{array}{r}15,660,619 \\
36,855\end{array}$ \\
\hline & & \multicolumn{2}{|c|}{$\begin{array}{r}13,313,706 \\
+1,647,602 \\
12.3\end{array}$} & \multicolumn{2}{|c|}{$\begin{array}{r}13,121,233 \\
-192,473 \\
0.49\end{array}$} & $\begin{array}{r}1.4,480,209 \\
+1,358,976 \\
10.71\end{array}$ & $\begin{array}{r}15,629,704 \\
+1,149,555 \\
12.78\end{array}$ \\
\hline \multicolumn{2}{|l|}{ Source. } & \multicolumn{2}{|c|}{1896} & \multicolumn{2}{|r|}{$1 S 97$} & 1893 & 1899 \\
\hline \multicolumn{2}{|c|}{ 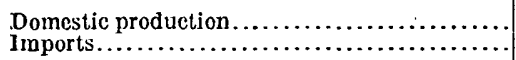 } & \multicolumn{2}{|c|}{$\begin{array}{r}13,850,726 \\
1,858,614\end{array}$} & \multicolumn{2}{|c|}{$\begin{array}{r}15,973,202 \\
1,493,033\end{array}$} & $\begin{array}{r}17,612,6344 \\
1,325,212\end{array}$ & $\begin{array}{r}19,708,614 \\
1,350,366\end{array}$ \\
\hline Exports.. & & \multicolumn{2}{|c|}{$\begin{array}{r}15,709,340 \\
63,391\end{array}$} & \multicolumn{2}{|c|}{$\begin{array}{r}17,466,235 \\
54,195\end{array}$} & $\begin{array}{r}18,937,846 \\
61,715\end{array}$ & $\begin{array}{r}21,058,980 \\
90,000\end{array}$ \\
\hline \multicolumn{2}{|c|}{$\begin{array}{l}\text { Domestic consumption.................... } \\
\text { Increase or decrease from preceding year ....... } \\
\text { Percentage of imports to total consumption.... }\end{array}$} & \multicolumn{2}{|c|}{$\begin{array}{r}15,645,949 \\
+16,185 \\
11.88\end{array}$} & \multicolumn{2}{|c|}{$\begin{array}{r}17,412,040 \\
+1,766,091 \\
\text { \&. } 57\end{array}$} & $\begin{array}{r}18,876,131 \\
+1,464,091 \\
7.02\end{array}$ & $\begin{array}{r}20,968,980 \\
+2,092,849 \\
6.4\end{array}$ \\
\hline Source. & 1900 & 1901 & 19 & & 1903 & 1904 & 1905 \\
\hline $\begin{array}{l}\text { Domestic production........... } \\
\text { Imports................... }\end{array}$ & $\begin{array}{r}20,869,342 \\
1,427,921\end{array}$ & $\begin{array}{r}20,566,661 \\
1,440,950\end{array}$ & $\begin{array}{r}23,84 \\
1,31\end{array}$ & & $\begin{array}{r}18,368,089 \\
1,185,578\end{array}$ & $\begin{array}{r}22,030,002 \\
1,186,712\end{array}$ & $\begin{array}{r}25,966,122 \\
1,151,133\end{array}$ \\
\hline Exp & $\begin{array}{r}22,297,263 \\
53,650 \\
\end{array}$ & $\begin{array}{r}22,007,611 \\
67,376\end{array}$ & $\begin{array}{r}25,16 \\
3\end{array}$ & & $\begin{array}{r}20,153,667 \\
91,070\end{array}$ & $\begin{array}{r}23,216,714 \\
99,743\end{array}$ & $\begin{array}{r}27,117,255 \\
244,555\end{array}$ \\
\hline $\begin{array}{l}\text { Domestic consumption. } \\
\text { Incrcase or decrease from pre- } \\
\text { ceding year.................. } \\
\text { Percentage of imports to total } \\
\text { consumption................. }\end{array}$ & $\begin{array}{r}22,243,613 \\
+1,274,633 \\
6.4\end{array}$ & $\begin{array}{r}21,940,235 \\
-303,378 \\
6.6\end{array}$ & $\begin{array}{r}25,13 \\
+-3,10\end{array}$ & $\begin{array}{l}589 \\
554 \\
5.3\end{array}$ & $\begin{array}{r}20,062,597 \\
-5,069,992 \\
5.9\end{array}$ & $\begin{array}{r}23,116,971 \\
+3,054,374 \\
5.1\end{array}$ & $\begin{array}{r}26,872,700 \\
+3,755,729 \\
4.3\end{array}$ \\
\hline Source. & 1906 & 1907 & 19 & & 1909 & 1910 & 1911 \\
\hline $\begin{array}{l}\text { Domestie production ............ } \\
\text { Imports..................... }\end{array}$ & $\begin{array}{r}28,172,380 \\
1,247,367\end{array}$ & $\begin{array}{r}29,704,128 \\
1,062,851\end{array}$ & $\begin{array}{r}28,82 \\
1,14\end{array}$ & $\begin{array}{l}062 \\
306\end{array}$ & $\begin{array}{r}30,107,646 \\
1,067,999\end{array}$ & $\begin{array}{r}30,305,656 \\
979,30 j\end{array}$ & $\begin{array}{r}31,183,968 \\
1,014,926\end{array}$ \\
\hline Exports & $\begin{array}{r}29,419,747 \\
242,774 \\
\end{array}$ & $\begin{array}{r}30,766,979 \\
-\quad 220,012 \\
\end{array}$ & $\begin{array}{r}29,96 \\
19 \\
\end{array}$ & $\begin{array}{l}368 \\
192 \\
\end{array}$ & $\begin{array}{r}31,175,645 \\
28 i, ;, 810 \\
\end{array}$ & $\begin{array}{r}31,281,961 \\
350,094 \\
\end{array}$ & $\begin{array}{r}32,198,894 \\
349,092 \\
\end{array}$ \\
\hline $\begin{array}{l}\text { Domestic consumption. } \\
\text { Increase or decrease from pre- } \\
\text { ceding year .................. } \\
\text { Fercentage of imports to total } \\
\text { consumiption................. }\end{array}$ & $\begin{array}{r}29,176,973 \\
+2,304,273 \\
4.3\end{array}$ & $\begin{array}{r}30,546,967 \\
+1,369,994 \\
3.4\end{array}$ & $\begin{array}{r}29,77 \\
-77\end{array}$ & $\begin{array}{l}176 \\
791 \\
3.8\end{array}$ & $\begin{array}{r}30,888,835 \\
+1,116,659 \\
3.4\end{array}$ & $\begin{array}{r}30,931,867 \\
+46,032 \\
3.2\end{array}$ & $\begin{array}{r}31,849,802 \\
+914,935 \\
3.2\end{array}$ \\
\hline
\end{tabular}

$40104^{\circ}-18-$ Bull. $669-18$ 
Salt consumed in the Urited States, 1880-191\%, in barrels of 280 pounds-Continued.

\begin{tabular}{|c|c|c|c|c|c|c|}
\hline Source. & 1912 & 1913 & 1914 & 1915 & 1916 & 1917 \\
\hline $\begin{array}{l}\text { Domesti. production... } \\
\text { Imports ............... }\end{array}$ & $\begin{array}{r}33,324,808 \\
998,664\end{array}$ & $\begin{array}{r}34,399,298 \\
1,105,466\end{array}$ & $\begin{array}{r}34,804,683 \\
934,319\end{array}$ & $\begin{array}{r}38,231,496 \\
873,760 \\
\end{array}$ & $\begin{array}{r}45,449,329 \\
871,992 \\
\end{array}$ & $\begin{array}{r}49,844,121 \\
463,730\end{array}$ \\
\hline Exports & $\begin{array}{r}34,323,472 \\
445,785 \\
\end{array}$ & $\begin{array}{r}35,504,764 \\
502,065\end{array}$ & $\begin{array}{r}35,739,002 \\
587,818\end{array}$ & $\begin{array}{r}39,105,256 \\
574,816\end{array}$ & $\begin{array}{r}46,321,321 \\
600,461 \\
\end{array}$ & $\begin{array}{r}50,307,851 \\
814,233\end{array}$ \\
\hline $\begin{array}{l}\text { Domestic consumption. } \\
\text { Increase or decrease from pre- }\end{array}$ & $\begin{array}{r}33,877,687 \\
+2,027,885\end{array}$ & & & $\begin{array}{r}38,531,440 \\
+3,380,256\end{array}$ & & $\begin{array}{r}49,493,618 \\
+3,770,758\end{array}$ \\
\hline 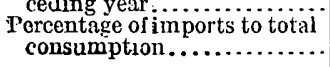 & $\begin{array}{r}785 \\
2.9\end{array}$ & $\begin{array}{r}1,125,012 \\
3.2\end{array}$ & $\begin{array}{r}+148,485 \\
2.7\end{array}$ & $\begin{array}{r}+3,3 \times 0,256 \\
2.3\end{array}$ & $\begin{array}{r}+7,189,420 \\
1.9\end{array}$ & $\begin{array}{r}+3,772,758 \\
.9\end{array}$ \\
\hline
\end{tabular}

\section{USEFUL TABLES AND FACTORS.}

Conversion table for salt solutions.

[Computed by F. E. Englehardt.a]

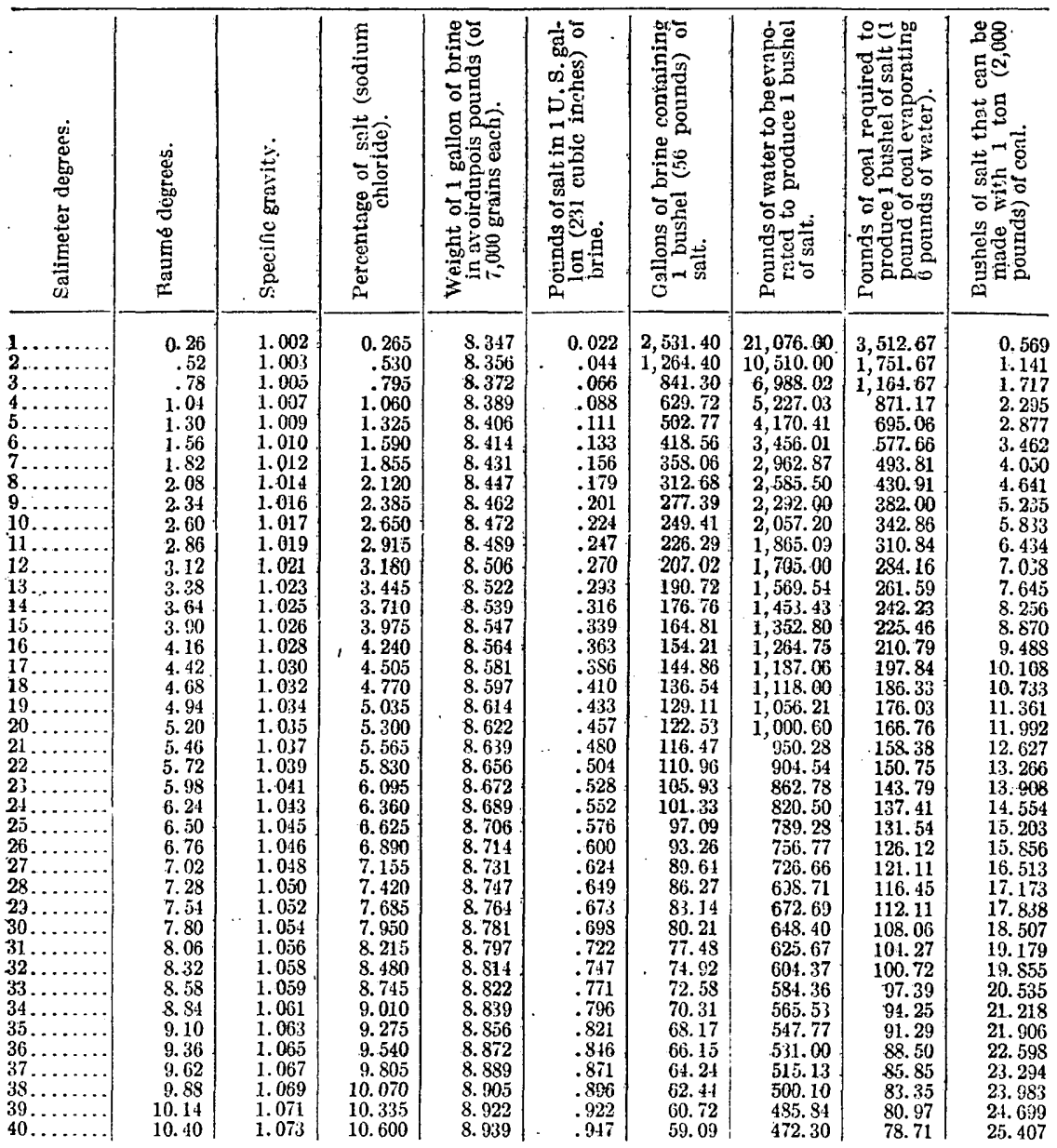

a Superintendent Onondaga Salt Springs, N. Y., Rept. for 1883, pp. 36-37, 1884. Theoretical values apparently based on a pure solution of sodium chloride. 
USEFUL TABLES AND FACTORS.

Conversion table for salt solutions-Continued.

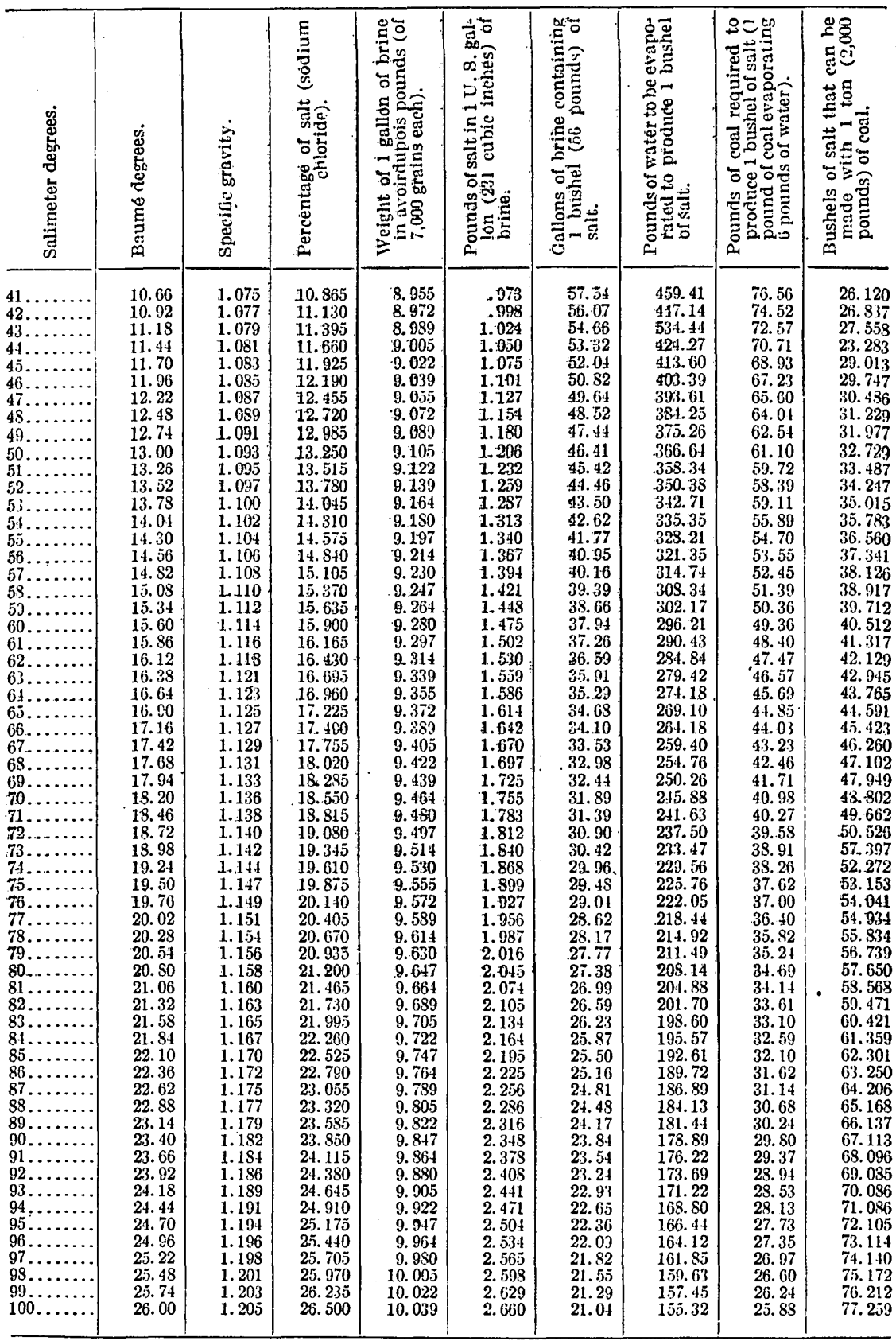


Chlorine content, salinity, and specific gravity of sca water at various concentrations. ${ }^{a}$

\begin{tabular}{|c|c|c|c|c|c|}
\hline Chlorine. & Salinity. & $\begin{array}{c}\text { Specific } \\
\text { gravity } \\
\left(\frac{0}{4}^{\circ}\right) .\end{array}$ & Chlorine. & Salinity. & $\begin{array}{c}\text { Specific } \\
\text { graijty } \\
\left(\frac{\circ}{6}^{\circ}\right) .\end{array}$ \\
\hline $\begin{array}{c}\text { Grams per } \\
\text { kilogram. } \\
1.00 \\
2.00 \\
3.00 \\
4.00 \\
5.00 \\
6.00 \\
7.00 \\
8.00 \\
9.00 \\
10.00 \\
11.00 \\
12.00 \\
13.00 \\
14.00 \\
15.00 \\
16.00 \\
17.00 \\
18.00 \\
19.00 \\
19.10 \\
19.20 \\
19.30 \\
19.40 \\
19.50\end{array}$ & \begin{tabular}{|c|} 
Grams pcr \\
kilogram. \\
1.84 \\
3.64 \\
5.45 \\
7.25 \\
9.06 \\
10.86 \\
12.67 \\
14.47 \\
16.28 \\
18.08 \\
19.89 \\
21.69 \\
23.50 \\
25.30 \\
27.11 \\
28.91 \\
30.72 \\
32.52 \\
34.33 \\
34.51 \\
34.69 \\
34.87 \\
35.05 \\
35.23
\end{tabular} & $\begin{array}{l}1.00140 \\
1.00287 \\
1.00433 \\
1.00579 \\
1.00725 \\
1.00871 \\
1.01016 \\
1.01162 \\
1.01307 \\
1.01452 \\
1.01597 \\
1.01742 \\
1.01887 \\
1.02032 \\
1.02177 \\
1.02322 \\
1.02468 \\
1.02613 \\
1.02758 \\
1.02773 \\
1.02787 \\
1.02802 \\
1.02816 \\
1.02831\end{array}$ & \begin{tabular}{|c} 
Grams per \\
kilogramn \\
19.60 \\
19.65 \\
19.70 \\
19.75 \\
19.80 \\
19.85 \\
19.90 \\
19.95 \\
20.00 \\
20.10 \\
20.20 \\
20.30 \\
20.40 \\
20.50 \\
20.60 \\
20.70 \\
20.80 \\
20.90 \\
21.00 \\
21.50 \\
22.00 \\
22.50 \\
23.00
\end{tabular} & \begin{tabular}{|c|} 
Grams per \\
kilogram. \\
35.41 \\
35.50 \\
35.59 \\
35.68 \\
35.77 \\
35.86 \\
35.95 \\
36.04 \\
36.13 \\
36.31 \\
36.49 \\
36.67 \\
36.85 \\
37.03 \\
37.21 \\
37.39 \\
37.57 \\
37.75 \\
37.94 \\
38.84 \\
39.74 \\
40.64 \\
41.55
\end{tabular} & $\begin{array}{l}1.02846 \\
1.02853 \\
1.02860 \\
1.02867 \\
1.02875 \\
1.02882 \\
1.02889 \\
1.02896 \\
1.02904 \\
1.02918 \\
1.02933 \\
1.02947 \\
1.02962 \\
1.02977 \\
1.02991 \\
1.03006 \\
1.03020 \\
1.03035 \\
1.03049 \\
1.03122 \\
1.03195 \\
1.03268 \\
1.03341\end{array}$ \\
\hline
\end{tabular}

a Knudsen, Martin, Hydrographische Tabellen, Copenhagen, 1901.

Atomic wcight of elements common in saline solutions. ${ }^{a}$

\begin{tabular}{|c|c|c|c|c|c|}
\hline Element. & Symbol. & $\begin{array}{l}\text { Atomic } \\
\text { weight. }\end{array}$ & Element. & Symbol. & $\begin{array}{l}\text { Atomic } \\
\text { weight. }\end{array}$ \\
\hline 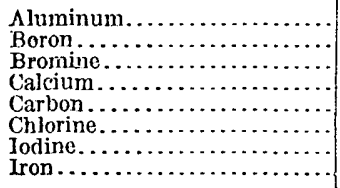 & $\begin{array}{l}\mathrm{Al} \\
\mathrm{B} \\
\mathrm{Br} \\
\mathrm{Ca} \\
\mathrm{C} \\
\mathrm{Cl} \\
\mathrm{I} \\
\mathrm{Fe}\end{array}$ & \begin{tabular}{r|}
27.1 \\
11.0 \\
79.92 \\
40.07 \\
12.00 \\
35.46 \\
126.92 \\
55.84
\end{tabular} & 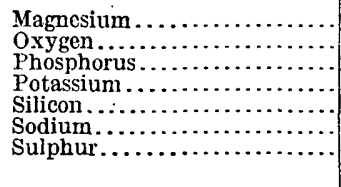 & $\begin{array}{c}\mathrm{Mg} \\
\mathrm{O} \\
\mathrm{P} \\
\mathrm{K} \\
\mathrm{Si} \\
\mathrm{Na} \\
\mathrm{S}\end{array}$ & $\begin{array}{l}24.32 \\
16.00 \\
31.04 \\
39.10 \\
28.3 \\
23.00 \\
32.07\end{array}$ \\
\hline
\end{tabular}

a Report of the international committee on atomic weights, 1915: Am. Chem. Soc. Jour., vol. 36, pp. 15851589,1914 . 
Factors for converting radicles to compounds. ${ }^{a}$

\begin{tabular}{|c|c|c|c|c|c|}
\hline Radicle. & Compound. & Factor. & Radicle. & Compound. & Factor. \\
\hline $\mathbf{K} \ldots \ldots \ldots \ldots \ldots \ldots$ & 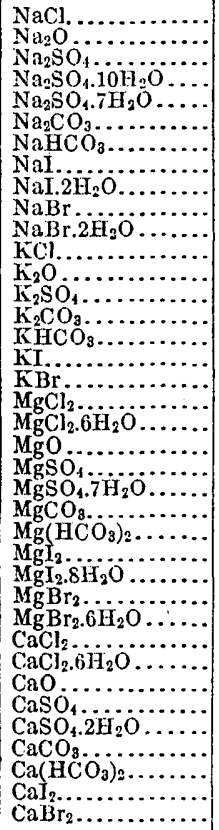 & $\begin{array}{r}2.538 \\
1.347 \\
3.054 \\
6.992 \\
5.820 \\
2.301 \\
3.647 \\
6.502 \\
8.066 \\
4.469 \\
6.036 \\
1.906 \\
1.204 \\
2.228 \\
1.767 \\
2.560 \\
4.243 \\
3.044 \\
3.920 \\
8.376 \\
1.659 \\
4.958 \\
10.151 \\
3.471 \\
6.028 \\
11.449 \\
17.385 \\
7.586 \\
12.035 \\
2.769 \\
5.467 \\
1.399 \\
3.398 \\
4.297 \\
2.498 \\
4.045 \\
7.331 \\
4.990\end{array}$ & $\begin{array}{c}\text { Br. } \ldots \ldots \ldots \ldots \ldots \ldots \ldots \\
\text { I. } \ldots \ldots \ldots \ldots \ldots \ldots \ldots\end{array}$ & 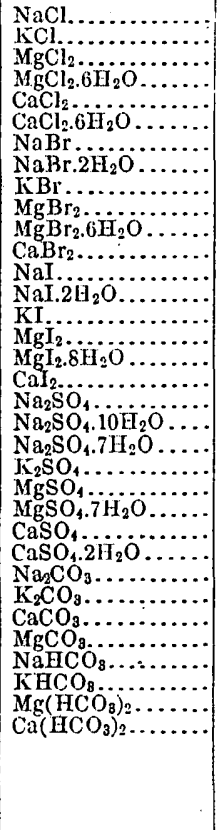 & $\begin{array}{l}1.650 \\
2.103 \\
1.342 \\
2.867 \\
1.565 \\
3.090 \\
1.288 \\
1.739 \\
1.489 \\
1.152 \\
1.828 \\
1.251 \\
1.182 \\
1.466 \\
1.308 \\
1.096 \\
1.664 \\
1.158 \\
1.480 \\
3.355 \\
2.792 \\
1.814 \\
1.253 \\
2.565 \\
1.417 \\
1.792 \\
1.768 \\
2.304 \\
1.668 \\
1.405 \\
1.378 \\
1.641 \\
1.199 \\
1.328\end{array}$ \\
\hline
\end{tabular}

a Calculated by R. B. Dole, U. S. Gcological Survey, from atomic wcights of 1597 , which differ little from those of $191 \bar{j}$. 

A.

Abert Jake, Oreg., description of ,

Acknowledgments for aid.

Actno Springs, Cal , salt in .

Alfalfa County salt plain, Okla., description of Alhambra Mineral Springs, Cal., salt in..... Alkali Lake, Oreg., description of.

Allen Spring, Cal., salt in.

Alpena, Mich $\log$ of well at .

Alsace, potask deposits in.

Alum Spring, Cal., sall in......................

Aluminum, estimation of, in brines...........

Amargosa River, Nex.Cal., description of... salts carried by $185-186,18$

Amboy, Cal., salt beds near................ 185

$\Lambda$ nalysis of brines, calculation of results of . . 215 method of .......................... 211-215

Andersons Springs, Cal., salt in............. 192

Anse-la-Butte, La., description of........... 107-108

Anthony, Kans., log of well at............. 100-101

Arizona, bibliography of salt in............. 155 rock salt and brine in............... 154-155

Atomic weights of elements common in saline solutious................. 276

$\Lambda$ ttica, N. Y., $\log$ of well at................ 26

Aurora, N. Y., $\log$ of well at................. 38

Axawatz Moumtains, Cal., rock salt in..... 156-187

Avawatz Salt \& Gypsum Co., property of, plates showing ............... 1506,186

Avery Island, La., see Petite Anse, La.

Azule Spring, Cal., salt in.

B.

Bailey, G. E., analysis by................. 163

Bailey, R. K., acknowledgment to......... 12 analyses by.................... 163, 181, 188

Bar theory of Ochsenits, statement of..... 196-198

Batavia, N. X., log of well at............... 25

Batson, Tex., rock salt reported at.......... 117

Bay City, Mich., log of well at.............. 64-65

Beaver, Utah, salt deposit at............. 159

Beckham County, Okla., salt plain, description of ................... 128-129

Belen, N. Afex., salt spring west of.......... 153

Belle Isle, Ia., deseription of ........... 103-105

log of shaft at........................ 104

log of well at........................ 105

Beris Rock Salt Co.'s mine, stratined shale and salt in, plate showing .......

Big Hill, Tex., salt brine at............... 117

Big Salt Plain, Okla., description of....... 127

Bishop, I. P., cited...................... 23-38

Bitter Springs, Cal., salts in . .............. 189

Bitterns, composition oi........... 223, 22t, 240-248

Blaine County salt plain, Okla., description of..............................

Bliss, N. Y., $\log$ of well at................. 30
Page.

Blodgett Spring, Cal., salt in ............ 192

Bloedite, occurrence of.................. 1;il

Borax, occurrence of.................. 15, $140,141,1 \cdot 12,167,169,189,191$

Borax Lake, Cal., salt in ................. 191

Bradford, $\mathrm{Pa}$, log of well at............... st

Brines, artificial, definition of .............. 221

natural, definition of................. 221

Sce also under the several States.

naturalsurface, composition of ........ 21i-22!

natural and artificial underground com-

position of ...................... 221-23!

Bromine, determination of, in brine i. . ... 214-21 occurrence of . .................. 227,230-231

Brooks saline, Tex., description of......... 121

Browns Valley, Cal., see Indian Wells Valley.

Buffalo, Rochestei \& Pittsburgh $R_{y}$., junc-

tion of, in Genesee County, N. ${ }^{2}$.

$10 \mathrm{~g}$ of well at..................

Buffalo Springs, Nev., Salt Works, opera-

tion of............................ 115-1.10

\section{C.}

Calaveras County, Cal., salt springs in....... 191

Calcium, deternination of, in brines........ 212-213

Calcium carbonate, deposition of............ 196

Calcium chloride, analyses of .............. 2t3

Calculation of results of analysis........... 215

Caledonia, N. Y., log of well at............. 30

Califormia, anal yses of bitterns from . . ..... 217-2 tS

bibliography of salt in ............... 192

localities of salt production in........... 161

oocurrence of salt in ................ 160-161

Calistoga Springs, Cal., salt in ............... . . 192

Cameron Lake, Cal., salt deposited by....... 1s2

Canada, analysis of brine from ............. 227

Cardiff, N. Y., log of well ati.............. 40

Carlsbad, N. Mex., brine lake southeast of... 153

Carnallite, uses of name................... $\quad 209$

Castac Lake, Cal., salt deposited by........ 182

Castile, N. Y., $\log$ of wellat............... 30

Cedarville, Cal., salt near................. 192

Celestite, deposits of, plates showini........ 180

Chaney Salt Plain, Okla., description of ..... 127

Chatard, T. M., analyses by............. 163,183

Chemical composition of saline materials... 210-249

Chicot, La., probability of salt at.......... 108

Chile, potash deposit in................. 201

Chins Lake, location of ................. 167

Clear Lake, Cal., salt in................... 191

Clear Lake, Utah, salt deposits at.......... 158

Cleveland, Ohio, logs of wells at........... 73,74

Clifton Springs, N. Y., log of well at.........

Colorado, Tex., rock salt at............... 125

Columbus Marsh, Nev., search for potash in.. $\quad 112$

Compounds, factors for converting radicfesto 277 
Page.

Confidence Spring, Cal., salt in . . . . . . . . . 181-182

Congress Spring, Cal., salt in............... 191

Consumption of salt, $1880-1917 \ldots \ldots . . \ldots .272-274$

Continental theory of the origin of rock salt. 201-202

Contra Costa County, Cal., saltsprings in ..... 191

Conversion tablefor saltsolutions......... 274-275

Cooney, James, acknowledgments to........ 39, 40

Coons, $A$. T., Production of salt in the United States.................... 25!-274

Cortland, Ohio, log of well near............ 68

Cote Blanche, La., description of .......... 106

Cote Carline, J.a., description of . ........... 106-107 sections of wells in.................. 107

Crystallization of salts from brines, process of ........................ 193-195

Crystals, salt, form of..

salt, plate showing.

Cuylerville, N. Y., $\log$ of well at............ 34

D.

Daggett, Cal., salt deposits uear.

189

Damon Mound, Tex, rock salt in...

Danby, Cal., salt bods southeast of......... 187

Dansville, N. Y., $\log$ of well at............. $\quad 36$

Dayton Hill, Tex., rock salt at........... 117

Dead Sea, salts in water of.............. 202-203

Death Valley, Cal., borings for potash in... 178-179 salts in, analyses of ................. 178 sources of...................... 176

Delaware, Lackawanna \& Western R. R., junction of, in Genesee County, N. Y., $\log$ of well at. ........... 25

Deposition of salts from brines, process of .. 193-197 Desiert basins, potash in ............... 175-182

Desiccation theory of salt deposits......... 198-201

Detroit, Mich., $\log$ of well at. .

Distribution of salt.................. 12-13,14-15

Dittmar, W., analyses by.............. 217, 219

Dixie Salt Marsh, Nev., description of ...... 140-141

Dolc, R. B., acknowledgment to........... 12 cited............................ 143 table computed by .................. $\quad 277$

Domes, salt, structure and origin of......... 109,

$$
\text { E. }
$$

$112,200-201$

liagle Salt Works, Leete, Nev., process employed at.

Fast A urora, N. Y., log of well at............ 24

East Lake, Mich., $\operatorname{logs}$ of wells at........... 52, 53

Eckel, E. C., on Virginia salt beds........... $85-86$

Ecorse, Mich., log of well at............... $\quad 61$

Eden Valley, N. Y., log of well at......... 24

El Paso del Róbles, Cal., salt springs near.. 190-191

Elko County, Nev., salines in............. 145

linglehardt, F. E., table computed by ..... 274-275

Erie County, N. Y., salt in ................ Is

Estancia Valley, N. Mex., salines in ...... 149-150

Eureka County, Nev., salines in........... 145

Fureka Springs, Cal., salt in.............. 191

Exports of salt, $1790-1917 \ldots \ldots \ldots \ldots \ldots \ldots .266-267$

F.

Federal Company, development of salt wells by.
Ferguson, Okla., salt plain near.

Page.

128

Field work, extent of..................... 12

Folds, strata of salt in, plate showing....... 114

Friedrich Franz, Germany, potash deposit at.........................

G.

Gale, Hoyt S., acknowledgment to ........ 12 cited ............................ 176 on the composition of salt froin the Salduro salt marsh, Utah........ 15\&-1.59 on the history and salts of Scarles Lake, Cal........................ 164-174

on the salts in Owens Lakc, Cal....... 162-164

on the Virgin River salt beds, Nev..... 146

Galicia, potash deposits in............... 201

Garden Spring, Cal., salt in............... 101

Gardenville, N. Y., Jog of well at........... 24

Genesee River Valley, N. Y., beginning of salt industry in.................. 16

Goderich, Ontario, Canada, $\log$ of well at.... 64

Gowanda, N. Y., log of well at............. 23

Grabau, A. W., and Sherzer, W. H., on the origin of rock salt . . . . . . . . 201-202

Grand Saline, Tex., geology and development of..................... 118-120

logs of wells at........................ 119

Grande Cote, La., geology of ............. 113-115 location of ........................... 112

Myles salt mine at, plates showing...... 114

Great Salt Lake, Utah, analyses of water of. 220-221 changes in salinity of ................. 221 localities of salt production on .......... 156

Green Point, N. Y., log of well at............ 41

Greigsville, N. Y., logs of wclls at........... 33, 34

Gunnison, Utah., salt mining at........... 156

salt mining at, plate showing........... 156

Gypsum, deposits of; in San Barnardino

County, Cal., plates showing... 156, 180 occurrence of, in the Salina formation.. 20-21,22

\section{H.}

Hackberry Island, Ia., indications of salt at.. 109 Halite, properties and oceurrence of ........ 13

Haskell, Tcx., potash and nitrate ncar....... 123

Hartford, W. Va., log of well at............. 72

Haworth, Erasmus, cited.................. 91

Herrick, C. L., cited...................... 151

Hicks, W. B., analyses by ............... 14, 103

High Island, Tex, rock salt at............ 117

Hot Borate Spring, Cal., salt in............ 191

Howard Spring, Cal., salt in............. 191

Howell, E. E., cited ................... 156-157

Humble, Tex., salt brinc at ................. 117

Humboldt County, Cal., salt springs in..... 191 Hutchinson, Kans., logs of wells at....... $\$ 7, \$ 8,99$ Huxley, Nov., saline at.................. $\quad 140$

\section{I.}

Idaho, salt deposits in, bibliography of:....... 137 salt deposits in, composition of ....... 136-137 geology and origin of............. 132-136 location of..................... 131-132

Illinois, analysis of brine from ............. $\quad 239$

Ilssenitz, Germany, potash deposit at......... 204

15 Imperial County, Cal., salt deposit in....... 1S4-185 
Page.

Imports of salt, 1867-1917

tariff regulations on.

Indian Wells Valley, Cal., location an:l history of.................... 166-167

Information, sources of ................. 11-12

Iron, estimation of, in hrines............. 212

Iron Spring, Cal., salt in................. 191

Islands, salt, of Louisiana, use of term....... 109

Ithaca, N. Y., logs of wells at and nenr...... $\quad 39$

test well bored at.................... 16

J.

Jackson County, Okla., sait plains, description of .......................

Jamesville, N. Y., $\log$ of well at............. Jefferson Island, sce Cote Cariine, La.

Jordan Ri ver, salts carried by .

\section{K.}

Kalusz, Galicia, potash deposit at...........

Kane Lake, Cal., salt deposited hy ..........

Kanopolis, Kans., log of shaft at............ $\log$ of wells at...

Kansas, analyses of brines from analyses of bitterns from .............. 240 bibliography of salt in ............... 101 middle, map of, showing locations of salt. $\quad 88$ salt beds of, area of ................... so geologic sections across............. 90 geology of ..................... 90-91 salt marshes of ....................... 90

Karaboghaz Gulf, salts deposited in........ 203 Kenmore, Ohio, logs of wells at........... 75-78 Kentucky, analysis of brine from ........... 239 Kern County, Cal., salines in ............. 182-183 Kindle, E. M., cited................... 37 Kingman, Kans., log of well north of ....... 100 Kiser Salt Plain, Okla., description of...... 127 Kisers Hill, Tex., rock salt reported at......

\section{I.}

Laguna del Perro, N. Mex., salt deposit in.. Laguna Salina, N. Mex., salt deposit in..... J ake County, Cal., salt lakes and springs in.. Lake Hachinhama, Cal., salt in............. Lake Lahontan, Nev.-Cal., deposition of salts by $\ldots \ldots \ldots \ldots \ldots \ldots \ldots \ldots \ldots . .199-200$

Lakeville, N. Y., $\log$ of well at............ 35

Lane, A. C., cited .................... 46-47,50

Leete, Nev., salt works at .............. 13\$-139

Lehigh, N. Y., $\log$ of well at................. 24

Le Roy, N. Y.; logs of wells at ............ 25

Little River, Kans., log of shaft at.......... 95 log of well at ..................... 96

I.ittle Salt Creek, Cal., salt in............. 192

Litt!e Salt Lake, Utah; salt on ........... 159

Ijttle Salt Plain, Okla., deseription of...... 127

Livonia, N. Y., logs of wells and shait at.... 35,36 " mixed salt" in salt mine at, plate showing.

I.oew, Oscar, analysis by ...........163, 178, 189

Los Angeles County, Cal., salt springs in.... 191

Louisiana, analyses of brines from .......... 235 bjbliography of salt in ................ 116 localities producing salt in........... 112-116 rage.

Louisiana, salines of northern part of, history

of ....................... 102

salines of northern part of, location

of $\ldots \ldots \ldots \ldots \ldots \ldots \ldots \ldots \ldots 101-102$

map showing..................... 100

stratigraphy of ................. 103

salines of southern part of, dessriptions

of ........................ 103-109

Inoations of ..................... 103

stratigraphy of ................ 109

structure and origin of ........... 103-112

Lubtheen, Gormany, potash deposit at..... 20.4

Ludington, Mich., logs of wells at..... 49, 53, 5. , ,55

Lunge, George, analysis by............... 103

cited ............................ 173-174

Lyons, Kans., $\log$ of shaft at............... $\quad 34$ stratified shale and salt at, plate showing. 204

M.

Magnesium, determination of, in brincs.... 212-213

Malpais in New Mexico, salt spring in...... 1 ī3

Manistee, Mich., logs of wells at and near. 51, 52,53

Manufacture of salt, publication on.......... 11

Map, geologic, of the lower peninsula of

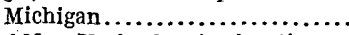

of central New York, showing locations of salt......................... 18

of middle Kansas, showing locations of salt

of northern Louisiana, showing locations of salines..................... showing general location of Owens-Searles Panamint lake system, Cal...... 162

showing location of salt plants in the United States................ 12

Marine City, Mich., logs of weils at............. 57-60 Marshall sandstonc, description of, in Michigan .......................... 50-51

Merrill, F. J. H., cited....................... 23-41

Meyers, N. Y., logs of wells near............ 39,40

Michigan, analyses of brines from........ 225-228

analyses of bitterns from .............. 241-2i3

bibliography of salt in............... 67

columnar section of strata in........... 44

geologic map of the lower peninsula of... 10

production of salt in, $1860-1889 \ldots \ldots \ldots . . .265$

rock salt in, depth to................. 48-50

localities of ..................... 44

origin of ...................... 201-202

stratigraphy and structure of ....... 44-51

well records in........................ 51-67

Midland, Mich., logs of wells at............ 66

Mincralogy of salt...................... 13

Mines in rock salt, plates showing........ 11.4, 156

Miscellaneous substances, analyses of ..... 248-249

Mississippi embayment, structure of........ 111

"Mixed salt" at Livonia, N. Y., plate show-

ing......................... 204

Modoc County, Cal., salt in................ 192

Mohave River, Cal., salts carried by ....... 187-1s9

Mono Lake, Cal., salts in water of........ 1\$3-184

Monroc group, description and salt beds of, in

Michigan................... 45-50

Morrisville, N. Y.. lng of well at............ 41

Mount Morris, N. Y., logs of welts at......... 34

Mount Pleasant, Mich., logs of wells at..... 50,67. 
Mud Spring, Cal., salt in . ................ 190

Muttonville, N. Y., $\log$ oi well at ........... 36

Myles salt mine, Weeks Island, La., plates showing

N.

Napa County., Cal., salt in

Nephi, Utah, salt beds and springs near... 158

Nevada, bibliography of salt in........... 148 salt marshes in ................... 137-148

New Almaden Spring, Cal., salt in......... 192

New Liverpool Salt Co., well bored by... 184-185

New Mexico, bibliography of salt in....... 154 salt deposits in . .................... 148-154

New York, analyses of briues from. . . . . ... 222-224 analyses of bitterns from .............. $\quad 240$ bibliography of salt in ................. 42-44 central, map of, showing locations of salt. 18 history of the salt industry in......... 15-17 location of salt field in . . . . . . . . . . . . 17-19 records of salt wells and shaits in ..... 23-41 rock salt $m$, origin of.............. 201-202 - sections showing deptlus to ....... $\quad 22$ stratigraphy of . . . . . . . . . . . . . 20 20-23 Newburg, Ohio, log of well at............ 74 Northfield Township, Ohio, logs of wells in. . 78,79 Nunda, N. Y., log of well at............ 36

\section{O.}

Oatka Rizer valley, N. Y., beginning of salt industry in ..............................

Occurrence of salt, modes of .

Ochsenius, C., bar theory of........... 196-198

Ohio, analyses of brines from . .......... 228-233

analyses of bitterns from ............ 244-245

bibliography of salt in ............. 80

natural brines in, nature of ........... $72-73$

sources of..................... $71-72$

northeastern, salt deposits in, extent of. 68-70

salt deposits in, stratigraphy of..... $70-71$

salt in, sources of . . . . . . . . . . . . . . .67-68

southeastern, brine horizon in ........71-73

Oklahoma, analyses of brines from . . . . 23 2 -238

bibliography of salt in ............. 129

location of salt plains in . ............. 126

Onondaga limestone, sections showing depths of rock salt below, in New York..

Onondaga Sait Springs Reservation, establishment of...

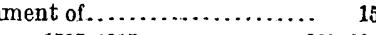

1797-1917............. 263-265

Ontario, Canada, origin of rock salt in. . . . 201-202

Oregon, bibliography of salt in......... 131

rock salt in ........................ 130

salt brines in . . . . . . . . . . . . . . . . . 129-131

Owens Lake, Cal., overflow from.......... 166

salts dissolved in................ 162-161

Owens River, content of salts in water of.... 162

Owens-Searles-Panamint lake system, Cal., map.showing location of........

Owl Spring district, Cal., saits in .

P.

Pacific Congress Springs, Cal., salt in...... 192

Palestine saline, Tex., description of. . . . . . 120-121

Palmer, Chase, analyses by............. 136-137

Panamint Valley, Cal., ancient lalke in...... 174
Panamint Valley, Cal., ancient lake in, man showing location of............. : 162 possibility 0 : saline deposit in. ... . . . . . . 174-175

Parran, Nev., salt deposit at................ 140

Pavilion, N. Y., logs of wells at.......... 25, 26

Pearl Creek, N. Y., logs of wells at and near. 26

Pennsylvania, brines in ... . . ............ 81-82

brines in, analyses of ................. 233

Perry, N. Y., log of well.at. ............ 20

Petite Anse, La., location and geology of . 115-116 sections of wells at . . . . . . . . . . . . . . 115

Petrolia, Ontario, Canada, log of well at.... 03

Phillips, J. Arthur, analysis by . . . . . . . . 153

Piffard, N. Y., logs of wells at........... 31,32

Pittsburgh, Pa., log of well at............ 8 ?

Placer County, Cal., salt springs in....... 192

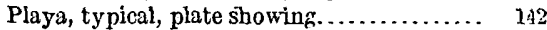

Pomeroy, Ohio, $\log$ of well near......... 71

Port Huron, Mich., logs of wells at........ 5ij-50

Port Lambton, Ontario, Canada, log of well at........................ 64

Potash, absence of, from the Salina beds.... 202 bibliography of . . . . . . . . . . . . . . . . 250-251 chief deposits of . .................. 201 conitent of, in sea water.............. 23.9 from brines and bitterns, pessibilities of . 249 in the water of Owens Leke........... 164 miner German deposits of.............. 204 occurrence of. . ............... 121-123,

$130-131,138,141,144-145,229$ prospects for, in California ........... 175-192 seareh for ......................... 249 tests of saline material for. . . . . . . . . . . 239 Potassium, determination of, in brines... . . 213-214 Prairie Mainou, La., description of. ........ 108 Price, Thomas, analysis by .............. 190 Prices of salt per barrel. . . . . . . . . . . . . . $\quad 252$ per ton......................... 263 Production of salt by grades, $1893-1917 \ldots . .254-257$ by States, 1880-1917 . . . . . . . . . . 257-262 by years, $1880-1917 \ldots \ldots \ldots \ldots . . . \ldots 252-254$ rank of States in, 1915-1917 . . . . . . . 262-263 reliability of statistics on ............. 251

Properties of salt. .................... 13

R.

Radicles, factors for converting, to compounds................... 277

Railroad Valley, Nev., saline in ......... 144-14j

"Red Beds," salt in...... 126, 127, 148-149, 153-154

Redding, Cal., salt deposit east of........... 192

Redmond, Utah, salt mïning at........... 156 surface mine in rock salt near, plave showing.................. 156

Retsoi, N. Y., log of shaft at............... 33 Rhodes Marsh, Nev., description of...... . . 141-142 Richardson, G. B., cited............... 157 Rio Salada, N. Mex., salt spring on........ 153 Rittman, Ohio, logs of wells at.......... 79 Riverside County, Cel., salt deposit in. . . . 184-185 Rock G!en, N. Y., $\log$ of well at........... 29 Rock.salt, analyses of................. 216 discovery of, in New York........... 15-17 increased production of .............. 254 origin of . ............... 196-198, 201-202 plate showing . ..................... 14 Ross, W. H., analysis by ............. 171-172 
Page.

Royal Oak, Mich., log of well at'........... 60 Rüdersdorf, Germany, potash deposit at... 204 Rundio, Frank, acknowledgment to........ 33 Russell, I. C., cited.................... 139, 109-200

s.

Salduro salt marsh, Utah, salt deposit on.. 158-159 Salina, Utah, salt mining at.. Salina formation in Michigan, description and salt beds of ................... 45-50

in New York, outcrop of ............. 17-18 outcrop of, map showing........... 18 stratigraphy of . ................ 12-20 structure of......................... 29-23

origin of salt beds in . .............. 201-202

Saline deposits, age of ...................... 193

Saline Valley, Cal., salt deposit in ........ 179-181

Salt Basin, Tex., location of ............... 124

salt deposit of . ...................... 124-125

Salt River valley, Ariz., salt in............. 154

Salt Springs, San Bernardino County, Cal., salt in........................ 189

Salt Wolls Valley, Cal., hustory of ......... 16t-168

Salton Salt Plain, Okla., description of...... 127

Salton Sink, Cal., salt irod under......... 184-185

Saltus, Cal., salt beds near............... 18;

Saltvale, N. Y., $\log$ of well at............. 27

Saltville, Va., logs of wolls at and near...... si-ss

open valley at, plate showing........... si

Samples of salt, collection of............... 211

San Benito County, Cal., salt springs in..... 192

San Bernardino County, Cal., gypsum and salt bods in, plates showing... 156,186

salt deposits in .................... 18j-190

San Luis Obispo, Cal., salt spring near..... 191

San Luis Obispo County, Cal., salt deposits in ...................... 190-191

Sand Sprung, Cal., sait in ................ 191

Sand Springs, Nev., description of . ....... 137-13S

Sandusky, Ohio, log of well at............. 70

Santa Clara County, Cal., salt springs in..... 192

Santa Rosa Spring, Cal., salt in . .......... 192

Saratoga, Tex., salt brine at.............. 117

Saratoga Springs, Cal., salts near........... 189

Sea water, analyses of . . . . . . . . . . . 217-219

analyses of bitterns from . . .......... 24i-248

chlorine content, salinity, and spesific gravity of, at various concentrations.....

276

salts cantained in ................. 10t-195

Searles lake, Cal., losation and history of... 16t$166,168,185$

location of, map showing ............... 162

salt deposits of . ................... 168-170

chemical composition of ........... 170-170

red color in .................... 173-174

Sevier River valley, Utah, geology of the salt beds in.................. 156-15i

Shale, salt stratified with, at Lyons, Kins., plate showing .................

Shasta County, Cal., salt deposit in......... 192

Sherzer, W. H., Grabau, A. W., and, on the origin of rock salt ........... 201-202

Siegler Spring, Cal., salt in ................ 191

Silver Lake, Cal., salt springs near .......... ' 191
Silver Peak Marsh, Nev., deseription of . ... 14:-144

plate showing...................... 142

Silver Springs, N., Y., logs of wells at...........

Siskiyou County, Cal., salt brine in......... 192

Skaggs Springs, Cal., salt in ................ 192

Slate Range Marsh, see Searles I.ate.

Sludge, analyses of . . . . . . . . . . . . . . . . . 2.19

Smoky Creek Desert, Ner., salines in........ 145-1+6

Snake Valley, Utah, salt marshes in ........ 159

Soda, occurrence of ................ 130-131, 141

Soda Lake, Cal., salts deposited liy. . 18:-189, 130-191

Sodn Spring, Cal., salt in ................. 191

Sodium, determination of, in brines. ...... 213-211

Solano County, Cal., salt springs in ......... 102

Solubility of salts.................... 10;-196

Solutions of salt, couversion talle for . ...... 274-27j

Solvay Process C $0 ., 801 t$ wells drilted i, ...... 17

Sonoma Clounty, Cal., salt springs in......... 192

Sour Lake, Tex., rock salt at ............... 117

Spain, potash deposit in .................. 2 in

Sperenberg, German $y$, potash deposit at...... 20!

Spindletop, Tex., roek salt at.............. 117

Spur, Tex., salt brine ai................... 121-123

Stassfurt salt deposits, disposit ion of i,ittern of 208 extent and development of . .......... 203-80t formation of . . . . . . . . . . . . $197-108,201$ investigations of .................... 210 minerals of . ....................... $203-209$

potash-bearing .................. 20i, 209

secondary alteration of . . . . . . . . . 208-203

seetion of . . . . . . . . . . . . . . . . 204-20ti

Stebnik, Galicia, potash depositat .......... 201

Steen saline, Tex., description oî.......... 121

Steiger, George, analyses lyy........... 178, 181)

Sterling, Kans., logs of wells at . . ............ 96,07

Stone, C. H., analyses 1 y................. 16.3

Stose, G. W., on Virginis salt beds........... $\quad$ Si

Sulphate, determination of, in trintes........ 213

Sulphur Spring, Cal., salt ia. . ........... 190-191

Summer Lake, Oreg., description of . ....... 130-131

Sycanore Spring, Cal., salt in ............. 191

Sylvite, mixtures containing............., $\quad 209$

Syracuse, N. Y., log of well at ............. 40

T.

Tables and factors.................... $2 \pi \mathbb{i}-2 ; 7$

Tariff regulations on salt . . . . . . . . . . . . . $270-272$

Taylor, F. W., analyses by................. 139, 146

Tecopa, Cal., salt beds at ................ 181

Tehama Count $y$, Cal., salt springs in. ....... 192

Tennessec, analysis of brine from ........... 239

Texas, analyses of brincs from .............. 236

analysis of bittcrn from............... 247

bibliography of salt in ................. 128

coast lagoons of, salt in .............. 126

northwestem, salt in ............ 121-124, 125

salines of ......................... 118-121

salt domes of ..................... 116-113

western, salt in ...................... 124-125

Tolenas Springs, Cal., salt in............. 192

Tularosa Basin, ‥ Mex., salines in....... 150-152

Tully, N. Y. log of well at............... 4.1

Turrentine, J. W., on the method used for analysis of lurines............. 211-215

Tuscan Springs, Cal., sạlt in.............. 192 
U.

Udden, J. A., cited...................... 122-123

Uses of salt............................ 13-14

Utah, analysis of bittern from............ 247 analysis of brine from.................. 239

bibliography of salt in ................ 159

production of salt in................ 155-159

V.

Valley Springs, Cal., salts in 189-190

Van Winkle, Walton, analyses by .......... 171

Verde River valley, Ariz., salt in.......... $\quad 155$

Vincent, N. Y., discovery of salt at.......... 16

Vinton, La., indications of salt at.......... 109

Virgin River, Nev.-Ariz., rock salt on and near................. 146-148, 154-155

rock salt on and near, plates showing ... 146

Virginia, analysis of brine from............ 239

bibliography of salt in ................ 89

salt beds in, location and geology of..... $85-86$ origin of. 201

W.

Walther, J., theory of, for the formation of the Stassfurt deposits........... 198

Warsaw, N. Y., drilling of salt well at....... 16

logs of wells at..................... 27,28

Watkins, N. Y., logs of wells at............ 37,38

Weeks Island, La., see Grande Cote, La.
Page.

Welsh, La., evidence of salt at............. 108

West Saginaw, Mich., log of well at......... 65

West Virginia, analyses of brines from.... 230-233 analyses of bitterns from............... 245

bibliography of salt in ................ 81

natural brines in, localities of........... so so

production of salt in, $1797-1 £ \delta 2 \ldots \ldots \ldots . .266$

White Plains, Nev., saline at............. 140

White Sand Plains, N. Mex., salines in .... 150-152

White Sulphur Springs, Cal., salt in ...... 191,192

Willards Lake, Cal., salts deposited by...... 190

Wilson, Kans., $\log$ of well at................ 91

Woodward, R. W., analysis by........... 140-141

Worrell, S. H., analyses of salt $b y . . . . . \ldots . .125$ analysis of brine by................. 121-122

Wrinkle, Noah, analysis by.............. 163

Wyandotte, Mich., logs of wells at......... 62-63

Wyoming, salt deposits in, bibliography of.. $\quad 137$ salt deposits in, composition of....... 136-137 geology and origin of ............ 132-136 location of ..................... 131-132

Wyoming, N. Y., discovery of salt at....... 16 logs of wells near................. 26,27

\section{$\mathrm{Y}$}

York, N. Y., $\log$ of well at............... $\quad 30$

Yrcka, Cal., salt well near................. 192

\section{$\mathrm{Z}$.}

Zechstein deposits, section of ............ 204-206 Zuni salt deposits, N. Mex., description of.. 152-153

\begin{tabular}{c}
\hline ADDITIONAL COPIES \\
OF THIS PUBLICATION MAY BE PROCURED FROM \\
THE SUPERINTENDENT OF DOCUMENTS \\
GOVERNMENT PRINTING OFFICE \\
WASHINGTON, D. C. \\
AT T CENTS PER COPY \\
$\nabla 5$
\end{tabular}

